\section{Pacific Northwest}

National Laboratory

Operated by Battelle for the

U.S. Department of Energy

\title{
Hanford Site National Environmental Policy Act (NEPA) Characterization
}
D. A. Neitzel
D. G. Horton
A. L. Bunn
G. V. Last
S. D. Cannon
T. M. Poston
J. P. Duncan
E. L. Prendergast-Kennedy
R. A. Fowler
S. P. Reidel
B. G. Fritz
A. C. Rohay
D. W. Harvey
M. J. Scott
P. L. Hendrickson
P. D. Thorne
D. J. Hoitink

September 2004

Prepared for the U.S. Department of Energy under Contract DE-AC06-76RL01830 


\title{
DISCLAIMER
}

This report was prepared as an account of work sponsored by an agency of the United States Government. Neither the United States Government nor any agency thereof, nor Battelle Memorial Institute, nor any of their employees, makes any warranty, express or implied, or assumes any legal liability or responsibility for the accuracy, completeness, or usefulness of any information, apparatus, product, or process disclosed, or represents that its use would not infringe privately owned rights. Reference herein to any specific commercial product, process, or service by trade name, trademark, manufacturer, or otherwise does not necessarily constitute or imply its endorsement, recommendation, or favoring by the United States Government or any agency thereof, or Battelle Memorial Institute. The views and opinions of authors expressed herein do not necessarily state or reflect those of the United States Government or any agency thereof.

\author{
PACIFIC NORTHWEST NATIONAL LABORATORY \\ operated by \\ BATTELLE \\ for the \\ UNITED STATES DEPARTMENT OF ENERGY \\ under Contract DE-AC06-76RL01830
}

This document was printed on recycled paper. 


\title{
Hanford Site National Environmental Policy Act (NEPA) Characterization
}

\author{
D. A. Neitzel, Editor
}
A. L. Bunn
S. D. Cannon
J. P. Duncan
R. A. Fowler
B. G. Fritz
D. W. Harvey
P. L. Hendrickson
D. J. Hoitink
D. G. Horton
G. V. Last
T. M. Poston
E. L. Prendergast-Kennedy
S. P. Reidel
A. C. Rohay
M. J. Scott
P. D. Thorne

September 2004

Prepared for

the U.S. Department of Energy

under Contract DE-AC06-76RL01830

Pacific Northwest National Laboratory

Richland, Washington 99352 
This page intentionally left blank 


\section{Preface}

This document describes the U.S. Department of Energy’s (DOE) Hanford Site environment. It is updated each year and is intended to provide a consistent description of the Hanford Site environment for the many environmental documents being prepared by DOE contractors concerning the National Environmental Policy Act (NEPA). No statements of significance or environmental consequences are provided. This year's report is the sixteenth revision of the original document published in 1988 and is (until replaced by the seventeenth revision) the only version that is relevant for use in the preparation of Hanford NEPA, State Environmental Policy Act (SEPA), and Comprehensive Environmental Response, Compensation, and Liability Act (CERCLA) documents.

The two chapters included in this document (Chapters 4 and 6) are numbered to correspond to the chapters where such information is typically presented in environmental impact statements (EISs) and other Hanford Site NEPA or CERCLA documentation. Chapter 4.0 (Affected Environment) describes Hanford Site climate and meteorology; geology; hydrology; ecology; cultural, archaeological, and historical resources; socioeconomics; noise; and occupational health and safety. Sources for extensive tabular data related to these topics are provided in the chapter. Most subjects are divided into a general description of the characteristics of the Hanford Site, followed by site-specific information, where available, of the 100, 200, 300, and other areas. This division allows the reader to go directly to those sections of particular interest. When specific information on each of these separate areas is not complete or available, the general Hanford Site description should be used.

Chapter 6.0 (Statutory and Regulatory Requirements) describes federal and state laws and regulations, DOE directives and permits, and presidential executive orders that are applicable to the NEPA documents prepared for Hanford Site activities. Information in Chapter 6 of this document can be adapted and supplemented with specific information for a chapter covering statutory and regulatory requirements in an environmental assessment or environmental impact statement (EIS).

When preparing environmental assessments and EISs, authors should also be cognizant of the document titled Recommendations for the Preparation of Environmental Assessments and Environmental Impact Statements published by the DOE Office of NEPA Oversight (DOE 1993a) which is currently being revised. Additional guidance on preparing DOE NEPA documents can be found at http://tis.eh.doe.gov/nepa/guidance.html.

Any interested individual seeking baseline data on the Hanford Site and its past activities may also use the information contained in this document to evaluate projected activities and their impacts.

For this 2004 revision, all sections of the document were reviewed by the authors and updated with the best available information through May 2004.

Pacific Northwest National Laboratory (PNNL) staff prepared individual sections of this document, with input from other Hanford Site contractors. More detailed data are available from reference sources cited or from the authors. The following personnel are responsible for the various sections of this document and can be contacted with questions: 


\begin{tabular}{|c|c|c|c|}
\hline Document Editor & D.A. Neitzel & (509) 376-0602 & duane.neitzel@pnl.gov \\
\hline Introduction & A.L. Bunn & (509) 376-6300 & amoret.bunn@pnl.gov \\
\hline $\begin{array}{l}\text { Climate and Meteorology/ } \\
\text { Air Quality }\end{array}$ & $\begin{array}{l}\text { D.J. Hoitink } \\
\text { B.G. Fritz }\end{array}$ & $\begin{array}{l}\text { (509) } 372-6414 \\
\text { (509) } 376-0535\end{array}$ & $\begin{array}{l}\text { dana.j.hoitink@pnl.gov } \\
\text { bradley.fritz@pnl.gov }\end{array}$ \\
\hline Geology & $\begin{array}{l}\text { S.P. Reidel } \\
\text { A.C. Rohay }\end{array}$ & $\begin{array}{l}\text { (509) 376-9932 } \\
\text { (509) } 376-6925\end{array}$ & $\begin{array}{l}\text { sp.reidel@pnl.gov } \\
\text { alan.rohay@pnl.gov }\end{array}$ \\
\hline Hydrology & $\begin{array}{l}\text { P.D. Thorne } \\
\text { D.G. Horton } \\
\text { G.V. Last }\end{array}$ & $\begin{array}{l}\text { (509) } 372-4482 \\
(509) 376-6868 \\
(509) 376-3961\end{array}$ & $\begin{array}{l}\text { paul.thorne@pnl.gov } \\
\text { dg.horton@pnl.gov } \\
\text { george.last@pnl.gov }\end{array}$ \\
\hline Ecology & T.M. Poston & (509) 376-5678 & ted.poston@pnl.gov \\
\hline $\begin{array}{l}\text { Cultural, Archaeological, } \\
\text { and Historical Resources }\end{array}$ & $\begin{array}{l}\text { D.W. Harvey } \\
\text { E.L. Prendergast- } \\
\text { Kennedy }\end{array}$ & $\begin{array}{l}\text { (509) 373-2945 } \\
\text { (509) 376-4626 }\end{array}$ & $\begin{array}{l}\text { david.harvey@pnl.gov } \\
\text { ellen.prendergast@pnl.gov }\end{array}$ \\
\hline Socioeconomics & $\begin{array}{l}\text { R.A. Fowler } \\
\text { M.J. Scott }\end{array}$ & $\begin{array}{l}\text { (509) 372-4332 } \\
\text { (509) } 372-4273\end{array}$ & $\begin{array}{l}\text { richard.fowler@pnl.gov } \\
\text { michael.scott@pnl.gov }\end{array}$ \\
\hline Noise & B.G. Fritz & (509) 376-5678 & bradley.fritz@pnl.gov \\
\hline Occupational Safety & J.P. Duncan & (509) 376-7899 & joanne.duncan@pnl.gov \\
\hline $\begin{array}{l}\text { Statutory and Regulatory } \\
\text { Requirements }\end{array}$ & P.L. Hendrickson & (509) 372-4294 & paul.hendrickson@pnl.gov \\
\hline
\end{tabular}

The suggested citation for this document is Neitzel, D. A., ed. 2004. Hanford Site National Environmental Policy Act (NEPA) Characterization. PNL-6415, Rev. 16. Pacific Northwest National Laboratory, Richland, Washington.

A copy of the document is available, upon request, from Duane A. Neitzel at (509) 376-0602. The document is also available electronically at http://www.pnl.gov/nepa. 


\title{
Acknowledgments
}

As the editor of Revision 16, I hope you find this document useful in preparing Hanford Site NEPA documents or as a useful source of information about the Hanford environment. Many people are responsible for the years of work that went into preparing this description of the Hanford Site. The authors of the individual sections took great care to accurately describe their work. PNNL, DOE, and other Hanford contractor personnel reviewed the document. Their comments and suggestions are important to preparing Revision 16. This year's reviewers include Kathy Rhoads, Charles Brandt, Paul Dunigan, Douglas Hildebrand, Michael Galgoul, Amanda Stegen, Clifford Clark, Janelle Downs, Thomas Ferns, Regan Weeks, Barbara Williamson, Dana Ward, Bruce Bjornstad, Katherine Cort, Robert

Carosino, and Theresa Gilbride. Special thanks go to Paul Dunigan and Annabelle Rodriguez with DOE for their help and support. Most importantly, I thank Joanne Duncan and Amoret Bunn for all their work in making sure Revision 16 was completed on time and presented in a way that is useful to everyone needing an up-to-date description of the Hanford environment. Joanne Duncan also maintains the electronic copy of the document throughout the year.

\author{
D. A. Neitzel
}


This page intentionally left blank 


\section{Acronyms, Abbreviations, and Symbols}

\begin{tabular}{|c|c|}
\hline AADT & Annual average daily traffic \\
\hline AAS & Associate in applied science \\
\hline ACL & Administrative Control Level \\
\hline AEA & Atomic Energy Act \\
\hline AMH & Advance Med Hanford \\
\hline ARAR & Applicable or Relevant and Appropriate Requirements \\
\hline ARPA & Archaeological Resources Protection Act \\
\hline BCAA & Benton Clean Air Authority \\
\hline BCRFD & Benton County Rural Fire Department \\
\hline BFCOG & Benton Franklin Council of Governments \\
\hline BFT & Benton Franklin Transit \\
\hline BLS & Bureau of Labor Statistics \\
\hline BNI & Bechtel National Inc. \\
\hline BNSF & Burlington Northern \& Santa Fe Railway \\
\hline BPA & Bonneville Power Administration \\
\hline CAA & Clean Air Act \\
\hline CBC & Columbia Basin College \\
\hline ССР & Comprehensive Conservation Plan \\
\hline CEQ & Council on Environmental Quality \\
\hline CERCLA & Comprehensive Environmental Response, Compensation, and Liability Act \\
\hline CFR & Code of Federal Regulations \\
\hline Corps & U.S. Army Corps of Engineers \\
\hline CREHST & Columbia River Exhibition of History, Science and Technology \\
\hline CWA & Clean Water Act \\
\hline $\mathrm{dB}$ & Decibels \\
\hline dBA & A-weighted sound level \\
\hline DCG & Derived concentration guides \\
\hline DOC & U.S. Department of Commerce \\
\hline DOE & U.S. Department of Energy \\
\hline DOE-ORP & U.S. Department of Energy Office of River Protection \\
\hline $\mathrm{DOE} / \mathrm{RL}$ & U.S. Department of Energy, Richland Operations Office \\
\hline $\mathrm{DOH}$ & Washington State Department of Health \\
\hline DOI & U.S. Department of the Interior \\
\hline DOL & U.S. Department of Labor \\
\hline DWS & Drinking water standards \\
\hline $\mathrm{E} / \mathrm{Q}$ & Atmospheric dispersion estimates \\
\hline EA & Environmental assessment \\
\hline EC & Environmental concern \\
\hline Ecology & Washington State Department of Ecology \\
\hline EDNA & Environmental designation for noise abatement \\
\hline EIS & Environmental Impact Statement \\
\hline EJ & Environmental justice \\
\hline EMC & Ecological Monitoring and Compliance \\
\hline EMT & Emergency medical technician \\
\hline EO & Environmental Objections \\
\hline E.O. & Executive Order \\
\hline
\end{tabular}




\section{Acronyms, Abbreviations, and Symbols (cont'd.)}

EPA
EPCRA
ESA
ESU
EU
FEMA
FFTF
FR
FY
GENII
GIS
HABS
HAER
HAMMER
HCP-EIS
HCRL
HEHF
Historic District
HMS
Hz
I
JOA
kWh
Leq
LIGO
LLWPA
LMEA
LO
LOS
LWC
LWD
MCL
MEI
MMI
MW
NAAQS
National Register
NEPA
NESHAP
NHPA
NPDES
NPL
NPR
NRC
NWPA
NWPPA
OFM

U.S. Environmental Protection Agency

Emergency Planning and Community Right-To-Know Act

Endangered Species Act

Evolutionary significant units

Environmentally unsatisfactory

Federal Emergency Management Agency

Fast Flux Test Facility

Federal Register

Fiscal Year

Generation II Model for Environmental Dose Calculations

Geographic Information System

Historic American Buildings Survey

Historic American Engineering Record

Hazardous Materials Management and Emergency Response

Hanford Comprehensive Land-Use Plan Environmental Impact Statement

Hanford Cultural Resources Laboratory

Hanford Environmental Health Foundation

Hanford Site Manhattan Project and Cold War Era Historic District

Hanford Meteorology Station

Hertz

Interstate

Joint Operating Agency

Kilowatt-hour

Equivalent sound level

Laser Interferometer Gravitational Wave Observatory

Low-Level Radioactive Waste Policy Act

Labor Market and Economic Analysis

Lack of objections

Level of service

Lost workday cases

Lost workdays

Maximum contaminant levels

Maximally exposed individual

Modified Mercalli intensity

Megawatt

National Ambient Air Quality Standards

National Register of Historic Places

National Environmental Policy Act

National Emission Standards for Hazardous Air Pollutants

National Historic Preservation Act

National Pollutant Discharge Elimination System

National Priorities List

New Production Reactor

U.S. Nuclear Regulatory Commission

Nuclear Waste Policy Act

Northwest Public Power Association

Office of Financial Management (Washington State) 


\section{Acronyms, Abbreviations, and Symbols (cont'd.)}

\begin{tabular}{|c|c|}
\hline ORP & Office of River Protection (Department of Energy) \\
\hline OSHA & Occupational Safety and Health Administration \\
\hline OTED & Washington State Office of Trade and Economic Development \\
\hline PCB & Polychlorinated biphenyls \\
\hline PFP & Plutonium Finishing Plant \\
\hline PL & Public law \\
\hline $\mathrm{PM}_{2.5}$ & Particulate matter (2.5 $\mu \mathrm{m}$ or less) \\
\hline $\mathrm{PM}_{10}$ & Particulate matter (10 $\mu \mathrm{m}$ or less) \\
\hline PNNL & Pacific Northwest National Laboratory \\
\hline PSD & Prevention of significant deterioration \\
\hline PUREX & Plutonium-uranium extraction \\
\hline RCRA & Resource Conservation and Recovery Act \\
\hline RCW & Revised Code of Washington \\
\hline REIS & Regional Economic Information System \\
\hline RL & Richland Operations Office (Department of Energy) \\
\hline $\mathrm{RM}$ & River mile \\
\hline ROD & Record of Decision \\
\hline SALDS & State-approved land disposal structure \\
\hline SARA & Superfund Amendments and Reauthorization Act \\
\hline SDWA & Safe Drinking Water Act \\
\hline SEPA & State Environmental Policy Act $\quad$ (Washington) \\
\hline SESP & Surface Environmental Surveillance Project \\
\hline SIP & State Implementation Plan \\
\hline SR & State route \\
\hline TCP & Traditional Cultural Place \\
\hline TEDE & Total effective dose equivalent \\
\hline TEDF & Treated Effluent Disposal Facility \\
\hline TRC & Total recordable cases \\
\hline Tri-Cities & Kennewick, Pasco, and Richland, Washington \\
\hline Tri-Party Agreement & Hanford Federal Facility Agreement and Consent Order \\
\hline TSCA & Toxic Substances Control Act \\
\hline TSD & Treatment, storage, and/or disposal \\
\hline $\mathrm{UO}_{3}$ & Uranium trioxide \\
\hline USC & Unisted States Code \\
\hline USFWS & U.S. Fish and Wildlife Service \\
\hline USGS & U.S. Geological Survey \\
\hline WAC & Washington Administrative Code \\
\hline WDFW & Washington State Department of Fish and Wildlife \\
\hline WNP & Washington nuclear plant \\
\hline WSU-TC & Washington State University, Tri-Cities \\
\hline$X / Q^{\prime}$ & Atmospheric dispersion coefficient \\
\hline
\end{tabular}




\section{Acronyms, Abbreviations, and Symbols (cont'd.)}

Names and Symbols for Units of Measure, Radioactivity, Time, and Mathematical Terms

\begin{tabular}{|c|c|c|c|}
\hline $\begin{array}{ll} & \text { Length } \\
\mathrm{cm} & \text { centimeter } \\
\mathrm{ft} & \text { foot } \\
\mathrm{in} . & \text { inch } \\
\mathrm{km} & \text { kilometer } \\
\mathrm{m} & \text { meter } \\
\mathrm{mi} & \text { mile } \\
\mathrm{mm} & \text { millimeter }\end{array}$ & \begin{tabular}{ll} 
& \multicolumn{1}{c}{ Area } \\
$\mathrm{km}^{2}$ & square \\
kilometer $^{2}$ & \\
$\mathrm{mi}^{2}$ & square mile \\
$\mathrm{ac}$ & acre \\
ha & hectare
\end{tabular} & \begin{tabular}{ll} 
& \multicolumn{1}{c}{ Volume } \\
$\mathrm{m}^{3}$ & cubic meter \\
gal & gallon \\
$\mathrm{L}$ & liter
\end{tabular} & $\begin{array}{ll} & \text { Time/Speed } \\
\mathrm{s} & \text { second } \\
\mathrm{hr} & \text { hour } \\
\mathrm{yr} & \text { year } \\
\mathrm{mph} & \text { miles per hour } \\
\mathrm{m} / \mathrm{s} & \text { meters per } \\
& \text { second } \\
\mathrm{g} & \text { acceleration of } \\
& \text { gravity } \\
\end{array}$ \\
\hline \multirow{2}{*}{\begin{tabular}{ll}
\multicolumn{2}{l}{ Radioactivity/ } \\
Radiation Dose \\
$\mathrm{Ci}$ & curie \\
$\mathrm{pCi}$ & picocurie \\
mrem & millirem \\
$\mathrm{Bq}$ & becquerel \\
$\mathrm{Sv}$ & sievert \\
$\mathrm{Gy}$ & gray
\end{tabular}} & $\begin{array}{l}\text { Temperature } \\
\text { degrees Celsius } \\
\text { degrees Fahrenheit }\end{array}$ & \multirow{2}{*}{$\begin{array}{ll} & \text { Mathematical } \\
> & \text { greater than } \\
\geq & \text { greater than or equal to } \\
< & \text { less than } \\
\leq & \text { less than or equal to } \\
\sim & \text { approximately } \\
\text { avg } & \text { average } \\
\text { max } & \text { maximum } \\
\min & \text { minimum }\end{array}$} & \begin{tabular}{ll} 
& \multicolumn{1}{c}{ Mass } \\
$\mathrm{g}$ & gram \\
$\mathrm{kg}$ & kilogram \\
$\mathrm{mg}$ & milligram \\
$\mu \mathrm{g}$ & microgram
\end{tabular} \\
\hline & $\begin{array}{l}\text { Chemical } \\
\text { molar }\end{array}$ & & $\begin{array}{c}\text { Concentration } \\
\text { ppm parts per million }\end{array}$ \\
\hline
\end{tabular}




\section{Table of Contents}

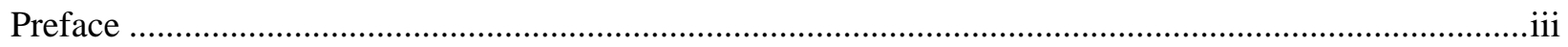

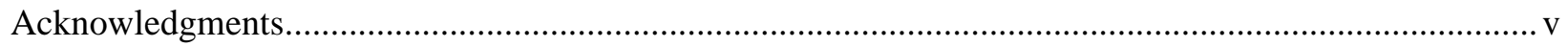

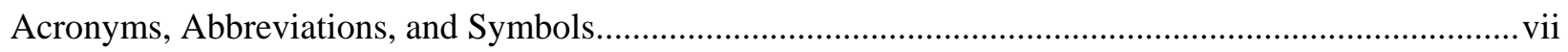

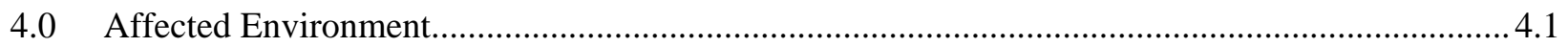

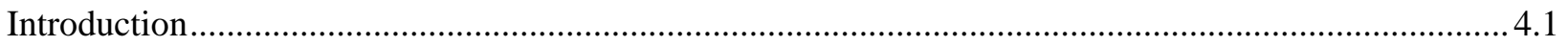

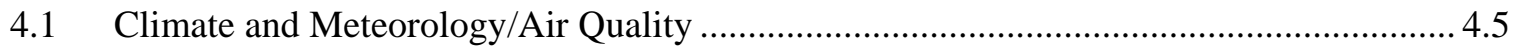

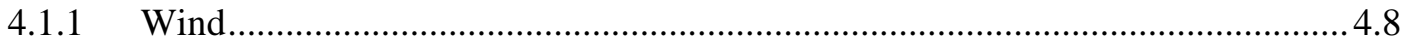

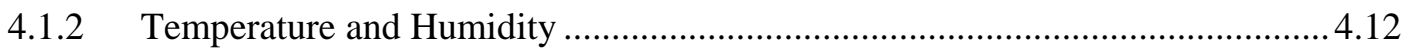

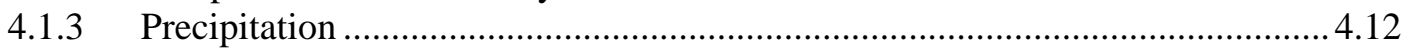

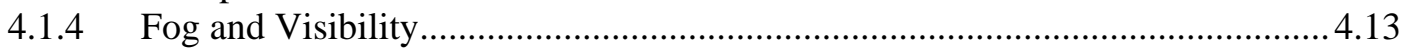

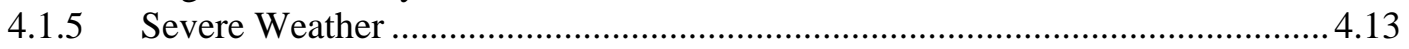

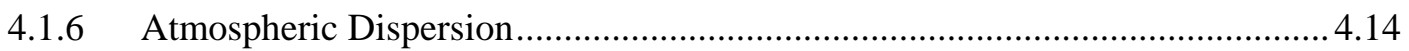

4.1.7 Nonradiological Air Quality ........................................................................... 4.

4.1.7.1 Prevention of Significant Deterioration .....................................................18

4.1.7.2 Emissions of Nonradiological Pollutants...................................................18

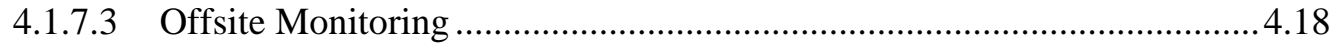

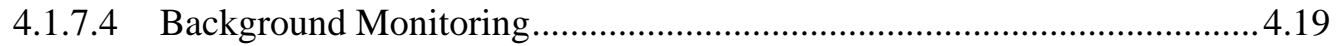

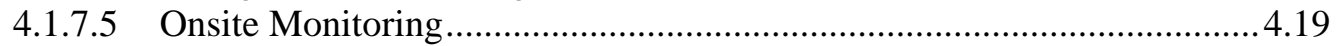

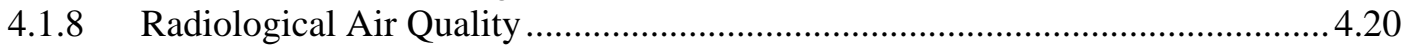

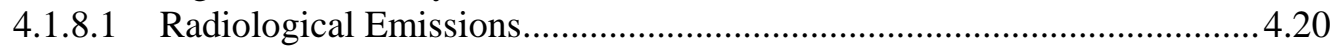

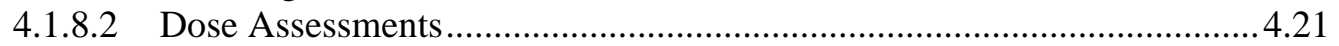

4.1.8.3 Environmental Monitoring ....................................................................2. 4.22

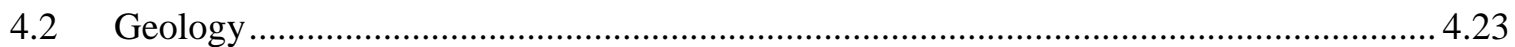

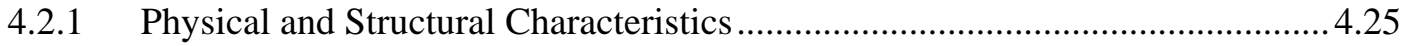

4.2.2 Strata and Structure of Sediment and Rock ........................................................2. 4.28

4.2.2.1 Columbia River Basalt Group..................................................................28.28

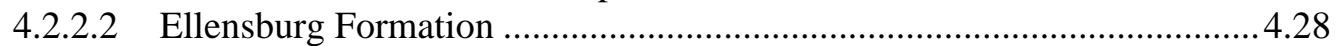

4.2.2.3 Hanford Formation, Cold Creek Unit, and Ringold Formation.................4.28

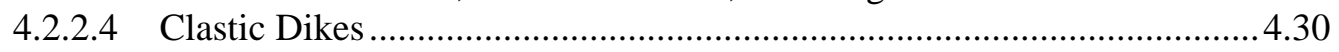

4.2.2.5 100 Areas Strata and Structure ...............................................................31

4.2.2.6 200 Areas Strata and Structure ...................................................................31

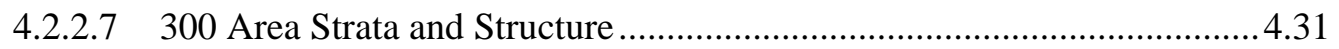

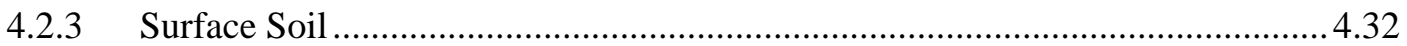

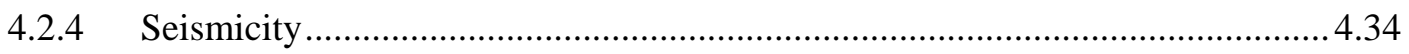

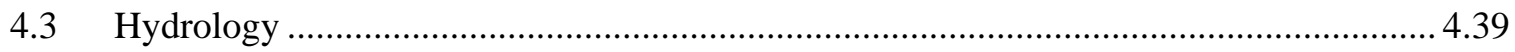

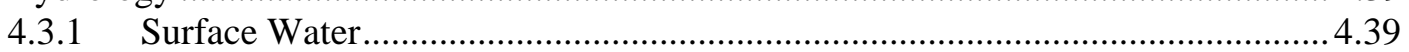

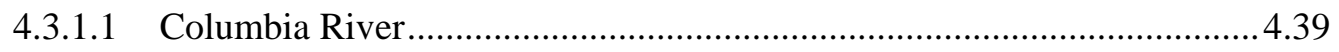

4.3.1.2 Water Quality of the Columbia River...................................................4.41

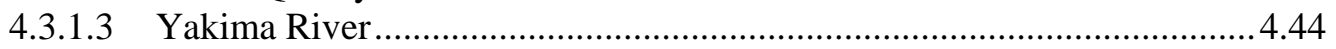

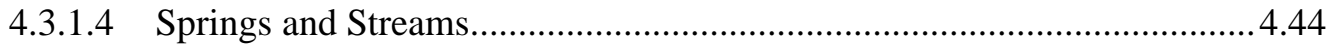




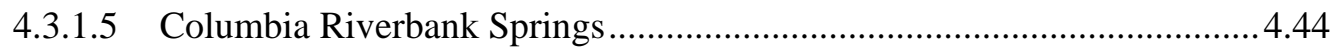

4.3.1.6 Runoff and Net Infiltration .................................................................4.46

4.3.1.7 Flooding ............................................................................................4. 4.4

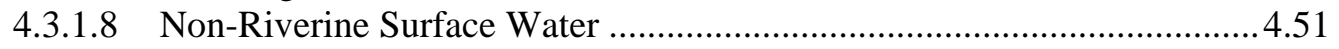

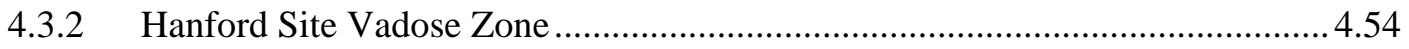

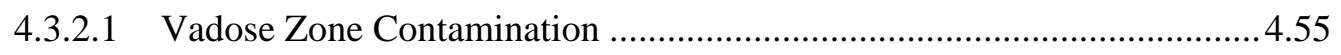

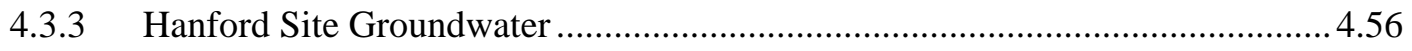

4.3.3.1 Basalt-Confined Aquifer System .........................................................5.5

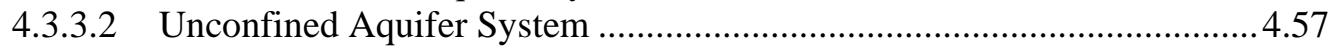

4.3.3.3 Limitations of Hydrogeologic Information.............................................4.59

4.3.3.4 Groundwater Travel Times ......................................................................5. 4.59

4.3.3.5 Groundwater East and North of the Columbia River.................................4.60

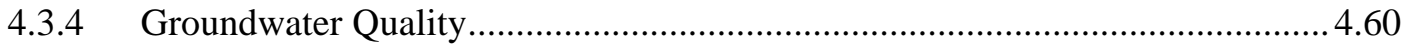

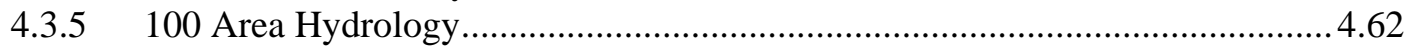

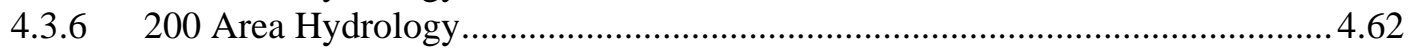

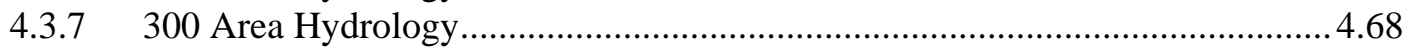

4.3.8 Richland North Area Hydrology ......................................................................68

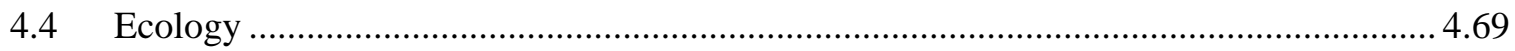

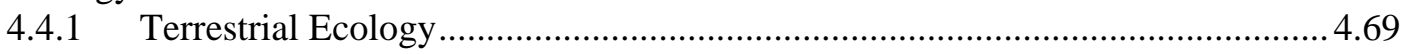

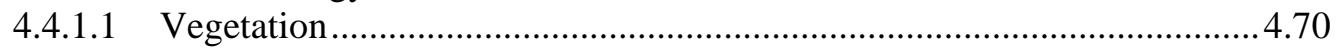

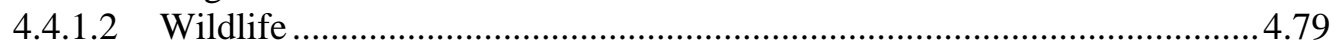

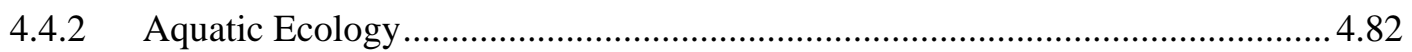

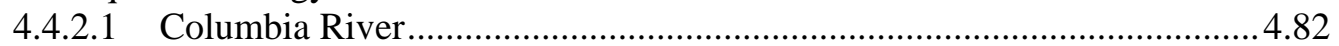

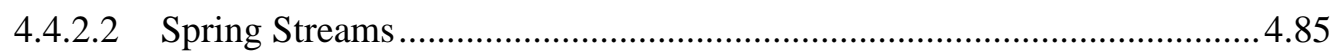

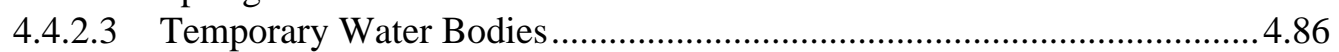

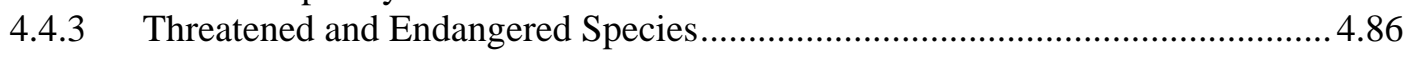

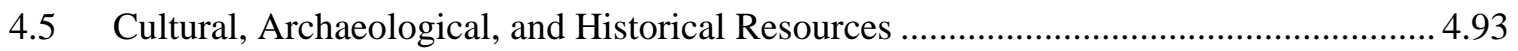

4.5.1 Native American Cultural Landscape .............................................................96

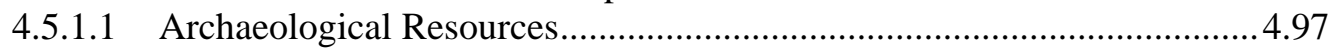

4.5.1.2 Traditional Cultural Places ..................................................................4.97

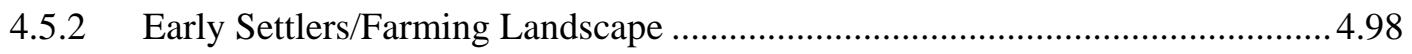

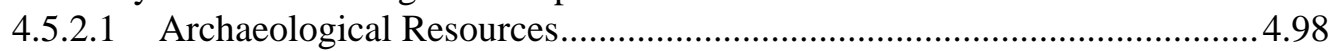

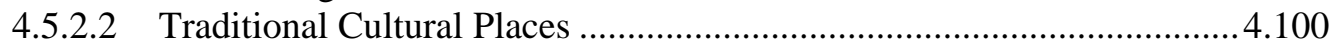

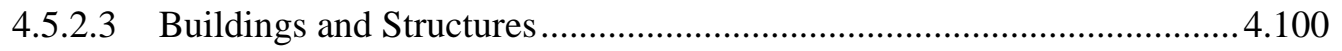

4.5.3 Manhattan Project and Cold War Cultural Landscape ...................................... 4.100

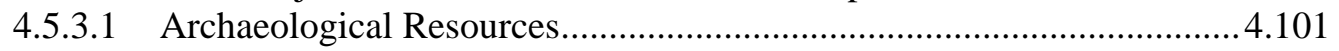

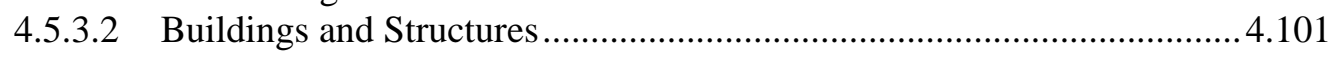

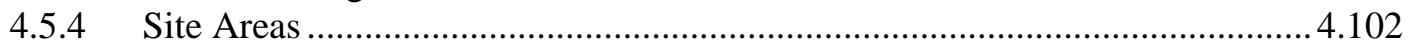

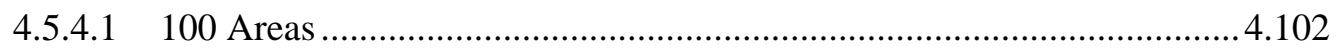

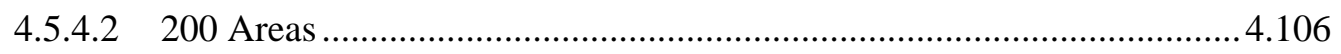

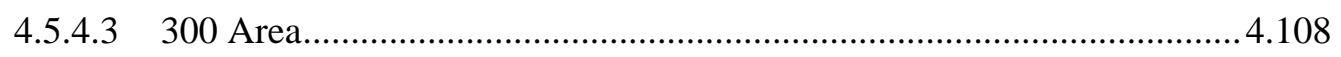

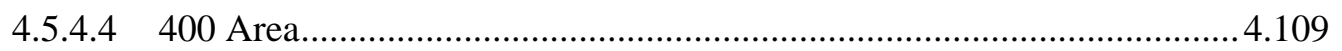

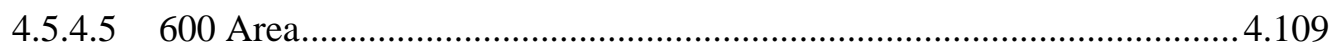

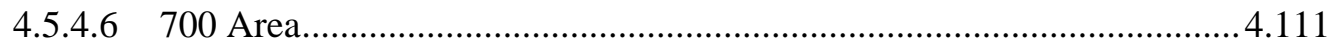

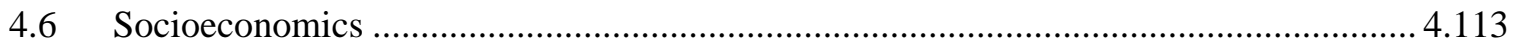

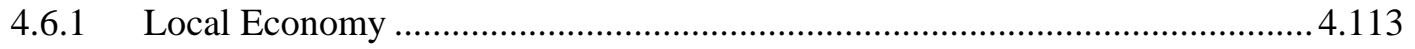

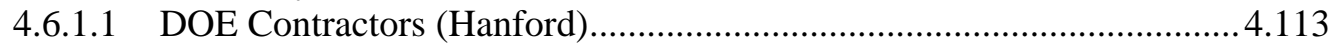

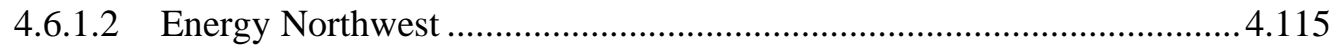




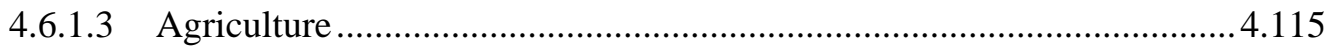

4.6.1.4 Other Major Employers ….................................................................4.116

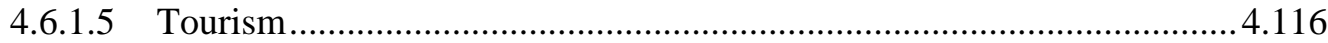

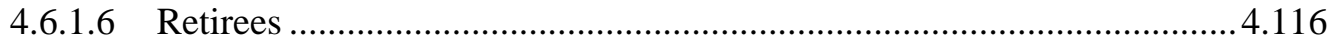

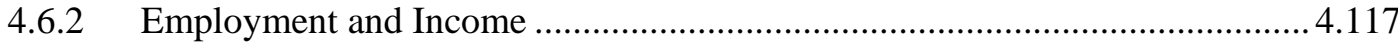

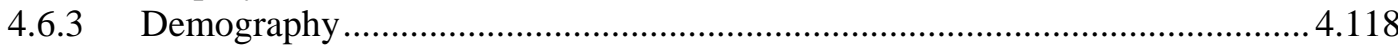

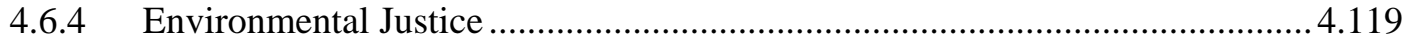

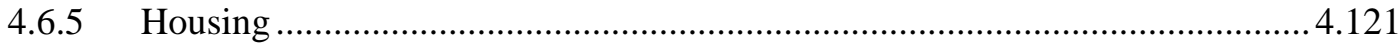

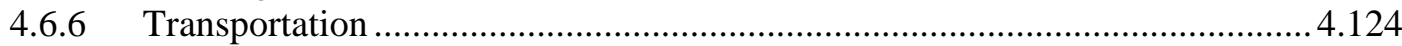

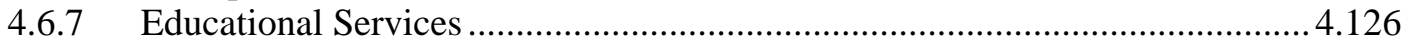

4.6.8 Health Care and Human Services ............................................................... 4.127

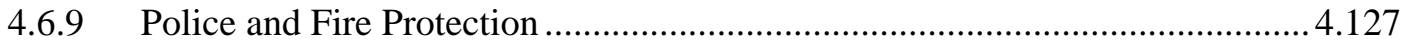

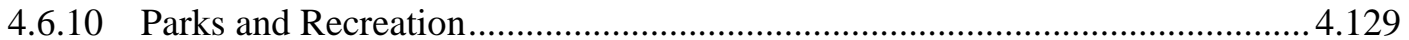

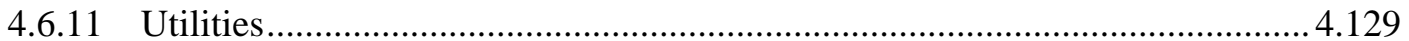

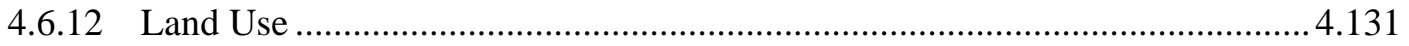

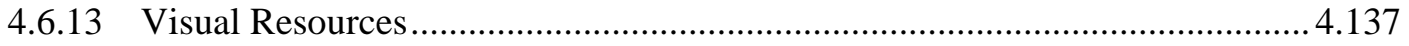

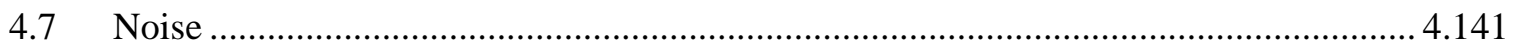

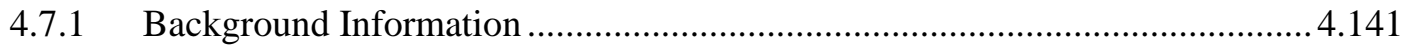

4.7.2 Environmental Noise Regulations...........................................................141

4.7.3 Hanford Site Sound Levels ......................................................................... 4.142

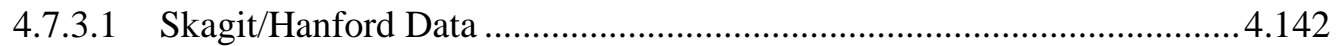

4.7.3.2 Basalt Waste Isolation Project (BWIP) Data ....................................... 4.142

4.7.3.3 New Production Reactor (NPR) EIS...................................................... 4.144

4.7.3.4 Noise Levels of Hanford Field Activities .............................................. 4.144

4.8 Occupational Health and Safety ............................................................................. 4.147

4.8.1 Industrial Illness and Injury Experience at the Hanford Site .......................... 4.147

4.8.2 Occupational Radiation Exposure at the Hanford Site.................................... 4.150

References.

4.153

Appendix A. Atmospheric Dispersion Tables .............................................................................. A.1

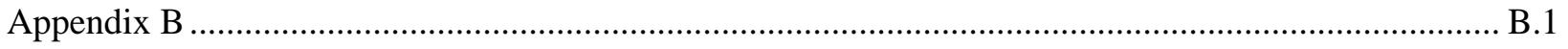

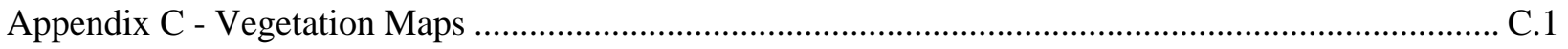

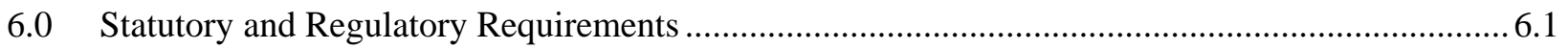

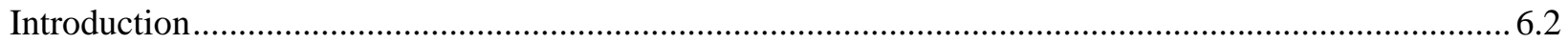

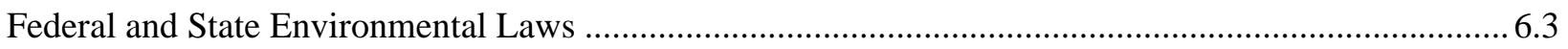

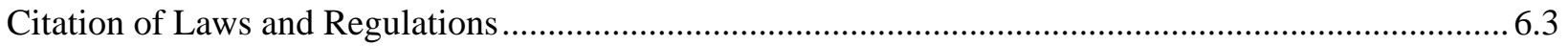

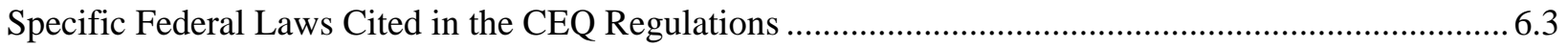

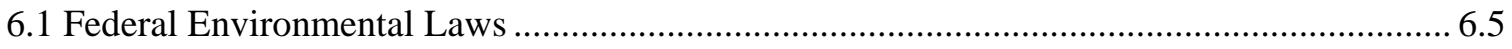

6.2 Federal and State Environmental Regulations .................................................................... 6.7 


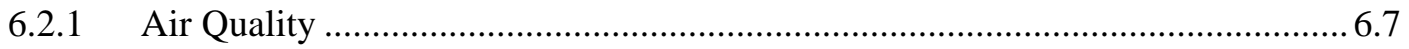

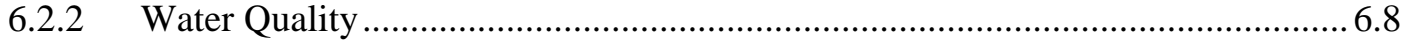

6.2.3 Hazardous Waste Management ........................................................................... 6.10

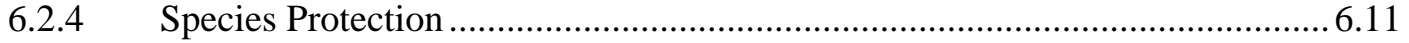

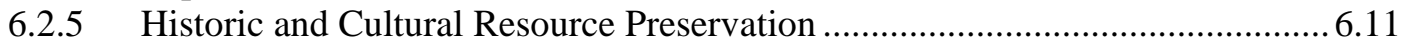

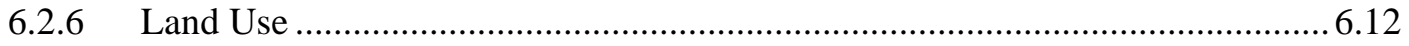

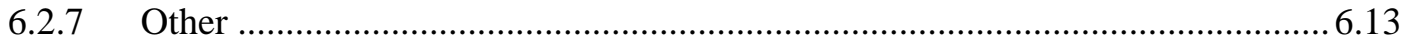

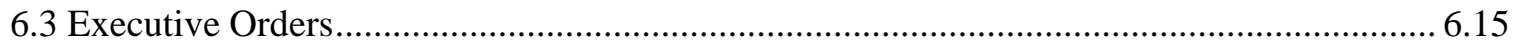

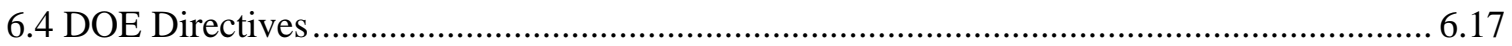

6.5 Treaties, Statutes, and Policies Relating to Indian Tribes of the Hanford Region................ 6.19

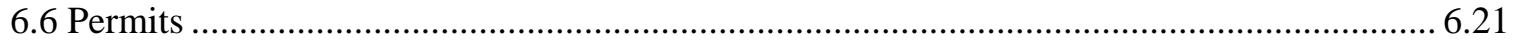




\section{Figures}

Figure 4.0-1. U.S. Department of Energy's Hanford Site, Washington...................................... 4.2

Figure 4.1-1. Hanford Meteorological Monitoring Network, Hanford Site, Washington .............. 4.6

Figure 4.1-2. Wind Roses at the $9.1 \mathrm{~m}$ (30 ft) Level of the Hanford Meteorological Monitoring Network, Washington, 1982 to 2003 (after Hoitink et al. 2004) ........... 4.9

Figure 4.1-3. Wind Roses at the $60 \mathrm{~m}(197 \mathrm{ft})$ Level of the Hanford Meteorological Monitoring Network, Washington, 1986 to 2003

Figure 4.1-4. $\quad$ 24-hr Average Concentrations for Particulate Matter with a Diameter of 10 $\mu \mathrm{m}$ or less at the Hanford Meteorological Station, Washington, 2003

Figure 4.2-1. Geologic Elements of the Pasco Basin Portion of the Columbia Basin, Washington

Figure 4.2-2. White Bluffs at the Hanford Site, Washington, Display River and Lake Deposits Left from the Ancestral Columbia River.

Figure 4.2-3. Conceptualization of an Ice-Age Flood in the Vicinity of the Hanford Site, Washington, which Occurred Intermittently between 18,000-13,000 years ago

Figure 4-2.4. Physical and Structural Geology of the Hanford Site, Washington 4.27

Figure 4.2-5. Strata of Rocks and Sediment at the Hanford Site, Washington

Figure 4.2-6. $\quad$ Map of Soil Types at the Hanford Site, Washington

Figure 4.2-7. Historical Earthquake Activity of the Columbia Basin, Washington, and Surrounding Areas Showing All Earthquakes between 1850 and March 20, 1969, with a Modified Mercalli Intensity of V or Larger and/or a Richter Magnitude of 4 or Larger....

Figure 4.2-8. Earthquake Activity of the Columbia Basin, Washington, and Surrounding Areas as Measured by Seismographs from March 20, 1969, to December 31, 2000, with Richter Magnitude 3 or Larger.

Figure 4.3-1. Surface Water Features on the Hanford Site, Washington, including Rivers, Ponds, Major Springs, and Ephemeral Streams

Figure 4.3-2. Average Daily Flow for the Columbia River downstream of Priest Rapids Dam, Washington, from January 1993 through April 2004.

Figure 4.3-3. Average Daily Flow for the Columbia River during Calendar Year 2003 4.42 
Figure 4.3-4. Surface Water and Sediment Monitoring Locations, Hanford Site, Washington

Figure 4.3-5. Average Daily Flow for the Yakima River, Washington, from 1993 through April 2004.

Figure 4.3-6. Locations of Principal Dams within the Columbia Plateau, Washington and Oregon......

Figure 4.3-7. Flood Area on the Hanford Site, Washington, during the 1894 Flood Modeled Based on Topographic Cross Sections.

Figure 4.3-8. $\quad$ Flood Area on the Hanford Site, Washington, for the Probable Maximum Flood

Figure 4.3-9. $\quad$ Flood Area from a 100-Year Flood of the Yakima River near the Hanford Site, Washington .....

Figure 4.3-10. Extent of Probable Maximum Flood in Cold Creek Area, Hanford Site, Washington, delineated using the U.S. Army Corps of Engineers' HEC-2 Water Surface Profiles model

Figure 4.3-11. Water Table Elevations in Meters $(1 \mathrm{~m}=3.28 \mathrm{ft})$ and Inferred Groundwater Flow Directions for the Unconfined Aquifer at Hanford, Washington, March 2003.

Figure 4.3-12. Distribution of Radionuclides in Groundwater on the Hanford Site, Washington, at Concentrations above the Maximum Contaminant Level or Interim Drinking Water Standard during Fiscal Year 2003.

Figure 4.3-13. Distribution of Hazardous Chemicals in Groundwater on the Hanford Site, Washington, at Concentrations above the Maximum Contaminant Level or Interim Drinking Water Standard during Fiscal Year 2003 .................................. 4.66

Figure 4.4-1. Distribution of Vegetation Types and Land Use Areas on the Hanford Site, Washington, before the Year 2000 Fire

Figure 4.4-2. Area of Hanford Site, Washington, Burned as a Result of the June 27 - July 2, 2000, Wildfire

Figure 4.4-3. Columbia River Islands in the Vicinity of the Hanford Site, Washington.............. 4.78

Figure 4.5-1. Areas Surveyed for Cultural Resources on the Hanford Site, Washington............. 4.94

Figure 4.5-2. $\quad$ Map of the Hanford Site, Washington, showing towns, ferries and prominent features associated with the Early Settlers landscape ......

Figure 4.6-1. Hanford Site, Washington, and Surrounding Communities 4.114

Figure 4.6-2. Location of Minority Populations Near the Hanford Site, Washington, based on 2000 Census. 
Figure 4.6-3. Location of Low-Income Populations Near the Hanford Site, Washington, based on 2000 Census.

Figure 4.6-4. DOE's Preferred Alternative for Land Use on the Hanford Site, Washington..... 4.132

Figure 4.6-5. Geographic Study Areas for the Hanford Site, Washington ................................ 4.134

Figure 4.6-6. Viewshed from Gable Mountain on the Hanford Site, Washington .................... 4.138

Figure 4.7-1. Location of Background Noise Measurements Collected for the Basalt Waste Isolation Project, Hanford Site, Washington

Figure 4.8-1. Occupational Injury and Illness Total Recordable Case Rates at the Hanford Site, Washington, Compared to Department of Energy and Private Industry. .... 4.148

Figure 4.8-2. Average Measureable Dose (mrem/yr) to Hanford Site, Washington, 19992003

Figure 4.8-3. Collective Operational Dose (person-mrem/yr) at the Hanford Site, Washington, 1999-2003.

Figure C-1. Vegetation/Land Coverage Map for the 100-B/C Area, Hanford Site, Washington

Figure C-2. Vegetation/Land Coverage Map for the 100-D Area, Hanford Site, Washington

Figure C-3. Vegetation/Land Coverage Map for the White Bluffs Boat Launch Vicinity, Hanford Site, Washington

Figure C-4. Vegetation/Land Coverage Map for the 100-F Area, Hanford Site, Washington

Figure C-5. Vegetation/Land Coverage Map for the 100-H Area, Hanford Site, Washington

Figure C-6. Vegetation/Land Coverage Map for the 100-K Area, Hanford Site, Washington

Figure C-7. Vegetation/Land Coverage Map for the 100-N Area, Hanford Site, Washington

Figure C-8. Vegetation/Land Coverage Map for the Hanford Townsite Vicinity, Hanford Site, Washington C.10

Figure C-9. Vegetation/Land Coverage Map for the 300 Area, Hanford Site, Washington .... C.11 
This page intentionally left blank 


\section{Tables}

Table 4.1-1. Station Numbers, Names, and Meteorological Data Measured at each Station in the Hanford Meteorological Monitoring Network, Washington.

Table 4.1-2. Monthly and Annual Prevailing Wind Directions, Average Speeds, and Peak Gusts at 15-m (50-ft) Level, 1945 through 2003, Hanford Meteorology

Station, Washington

Table 4.1-3. Number of Days with Peak Gusts above Specific Thresholds at 15-m (50-ft)

Level, 1945 through 2003, Hanford Meteorology Station, Washington

Table 4.1-4. N N N N $\quad$ Dumber of Days with Fog by Season, Hanford Site, Washington

Table 4.1-5. Estimate of the Probability of Extreme Winds Associated with Tornadoes

Striking a Point at Hanford, Washington

Table 4.1-6. Estimates of Extreme Winds at the Hanford Site, Washington

Table 4.1-7. Percent Probabilities for Extended Periods of Surface-Based Inversions, Hanford Site, Washington.

Table 4.1-8. $\quad$ U.S. Environmental Protection Agency (EPA) and Washington State

Ambient Air Quality Standards.

Table 4.1-9. Nonradioactive Constituents Discharged to the Atmosphere during 2003,

Hanford Site, Washington.

Table 4.1-10. Radionuclides Discharged to the Atmosphere at the Hanford Site,

Washington, 2003

Table 4.3-1. Regulatory Drinking Water Standards for Groundwater 4.46

Table 4.3-2. Maximum Concentrations of Selected Groundwater Contaminants in Fiscal Year 2003.

Table 4.4.1. Federal or Washington State Threatened and Endangered Species on the Hanford Site.

Table 4.4-2. Washington State Candidate and Sensitive Animal Species on the Hanford Site .

Table 4.4-3. Washington State Plant Species of Concern on the Hanford Site.

Table 4.5-1. Historic Buildings, Archaeological Sites, and Districts Listed in the National Register of Historic Places on the Hanford Site, Washington 
Table 4.5-2. Historic Buildings, Archaeological Sites, and Districts Determined Eligible for Listing in the National Register of Historic Places on the Hanford Site, Washington

Table 4.5-3. Archaeological Sites and Districts Listed in the Washington Heritage

Register on the Hanford Site, Washington.

Table 4.6-1. Federal Government Transfer Payments in Benton County and Franklin

County, Washington, 2002.

Table 4.6-2. Nonagricultural Wage and Salary Workers in Benton County and Franklin

County, Washington, 2002 and 2003.

Table 4.6-3. Population Estimates and Percentages by Race and Hispanic Origin within each County in Washington State and the 80-km (50 mi) Radius of Hanford as Determined by the 2000 Census

Table 4.6-4. Police Personnel in the Tri-Cities, Washington, 2004

Table 4.6-5. Fire Protection Personnel in the Tri-Cities, Washington, 2003 4.128

Table 4.6-6. Examples of Physical Recreational Facilities Available in the Tri-Cities,

Washington

Table 4.6-7 Definitions and Descriptions of DOE's Preferred Alternative Land Use Designations for the Hanford Site, Washington

Table 4.6-8. Key Areas of the Hanford Site, Washington, Outgranted/Released to Date.

Table 4.7-1. Applicable State Noise Limitations for the Hanford Site, Washington, Based on Source and Receptor EDNA Designation .

Table 4.7-2 Estimated Noise Resulting from Automobile Traffic at Hanford, Washington, with the New Production Reactor Environmental Impact Statement.

Table 4.7-3. Monitored Levels of Noise Propagated from Outdoor Activities at the Hanford Site, Washington

Table 4.8-1. Occupational Injury and Illness Incidence Rates, and Fatality Counts for Department of Energy Facilities and Private Industry.

Table 4.8-2. Radiation Exposure Data for the Hanford Site, Washington, 1999-2003 152

Table A1. Joint Frequency Distributions of Atmospheric Stability, Wind Speed, and Transport Direction for the 100 Area at $9.1 \mathrm{~m}$ (30 ft) above Ground Level, Hanford Site, Washington.

Table A2. Joint Frequency Distributions of Atmospheric Stability, Wind Speed, and Transport Direction for the 100 Area at $60 \mathrm{~m}$ (197 ft) above Ground Level, Hanford Site, Washington. 
Table A3. Joint Frequency Distributions of Atmospheric Stability, Wind Speed, and Transport Direction for the 200 Areas at $9.1 \mathrm{~m}$ (30 ft) above Ground Level, Hanford Site, Washington.

Table A4. Joint Frequency Distributions of Atmospheric Stability, Wind Speed, and Transport Direction for the 200 Areas at $60 \mathrm{~m}(197 \mathrm{ft})$ above Ground Level, Hanford Site, Washington.

Table A5. Joint Frequency Distributions of Atmospheric Stability, Wind Speed, and Transport Direction for the 300 Area at $9.1 \mathrm{~m}$ (30 ft) above Ground Level, Hanford Site, Washington.

Table A6. Joint Frequency Distributions of Atmospheric Stability, Wind Speed, and Transport Direction for the 300 Area at $60 \mathrm{~m}(197 \mathrm{ft})$ above Ground Level, Hanford Site, Washington.

Table A7. Joint Frequency Distributions of Atmospheric Stability, Wind Speed, and Transport Direction for the 400 Area at $9.1 \mathrm{~m}$ (30 ft) above Ground Level, Hanford Site, Washington.

Table A8. Joint Frequency Distributions of Atmospheric Stability, Wind Speed, and Transport Direction for the 400 Area at $60 \mathrm{~m}(197 \mathrm{ft})$ above Ground Level, Hanford Site, Washington.

Table A9. $\quad X / \mathrm{Q}^{\prime}$ Values $\left(\mathrm{s} \mathrm{m}^{-3}\right.$ ) for Chronic Ground-Level Releases from 100-N Area Based on 1983 through 2002 Meteorological Information, Hanford Site, Washington

Table A10. $\quad$ X/Q' Values $\left(\mathrm{s} \mathrm{m}^{-3}\right)$ for Chronic 60-m Stack Releases from 100-N Area Based on 1986 through 2002 Meteorological Information, Hanford Site, Washington

Table A11. $\quad X / \mathrm{Q}^{\prime}$ Values $\left(\mathrm{s} \mathrm{m}^{-3}\right)$ for Chronic Ground-Level Releases from 200 Areas Based on 1983 through 2002 Meteorological Information, Hanford Site, Washington

Table A12. $\quad X / Q^{\prime}$ Values $\left(\mathrm{s} \mathrm{m}^{-3}\right)$ for Chronic 60-m Stack Releases from 200 Areas Based on 1983 through 2002 Meteorological Information, Hanford Site, Washington

Table A13. $\quad X / Q^{\prime}$ Values $\left(\mathrm{s} \mathrm{m}^{-3}\right)$ for Chronic Ground-Level Releases from 300 Area Based on 1983 through 2002 Meteorological Information, Hanford Site, Washington

Table A14. $\quad X / Q^{\prime}$ Values $\left(\mathrm{s} \mathrm{m}^{-3}\right)$ for Chronic 60-m Stack Releases from 300 Area Based on 1986 through 2002 Meteorological Information, Hanford Site, Washington 
Table A15. $\quad X / \mathrm{Q}^{\prime}$ Values $\left(\mathrm{s} \mathrm{m}^{-3}\right)$ for Chronic Ground-Level Releases from 400 Area Based on 1983 through 2002 Meteorological Information, Hanford Site, Washington

Table A16. $\quad X / Q^{\prime}$ Values $\left(\mathrm{s} \mathrm{m}^{-3}\right)$ for Chronic 60-m Stack Releases from 400 Area Based on 1986 through 2002 Meteorological Information, Hanford Site,

Washington

Table A17. 95th Percentile E/Q Values $\left(\mathrm{s} \mathrm{m}^{-3}\right)$ for Acute Ground Level Releases from 100-N Area Based on 1983 through 2002 Meteorological Information, Hanford Site, Washington.

Table A18. 95th Percentile E/Q Values $\left(\mathrm{s} \mathrm{m}^{-3}\right)$ for Acute 60-m Stack Releases from 100N Area Based on 1986 through 2002 Meteorological Information, Hanford Site, Washington

Table A19. 95th Percentile E/Q Values $\left(\mathrm{s} \mathrm{m}^{-3}\right)$ for Acute Ground-Level Releases from 200 Areas Based on 1983 through 2002 Meteorological Information, Hanford Site, Washington.

Table A20. 95th Percentile E/Q Values $\left(\mathrm{s} \mathrm{m}^{-3}\right)$ for Acute 60-m Stack Releases from 200 Areas Based on 1983 through 2002 Meteorological Information, Hanford Site, Washington

Table A21. 95th Percentile E/Q Values $\left(\mathrm{s} \mathrm{m}^{-3}\right)$ for Acute Ground-Level Releases from 300 Area Based on 1983 through 2002 Meteorological Information, Hanford Site, Washington

Table A22. 95th Percentile E/Q Values $\left(\mathrm{s} \mathrm{m}^{-3}\right)$ for Acute 60-m Stack Releases from 300 Area Based on 1986 through 2002 Meteorological Information, Hanford Site, Washington

Table A23. 95th Percentile E/Q Values $\left(\mathrm{s} \mathrm{m}^{-3}\right)$ for Acute Ground-Level Releases from 400 Area Based on 1983 through 2002 Meteorological Information, Hanford Site, Washington

Table A24. 95th Percentile E/Q Values $\left(\mathrm{s} \mathrm{m}^{-3}\right)$ for Acute 60-m Stack Releases from 400 Area Based on 1986 through 2002 Meteorological Information, Hanford Site, Washington A.20

Table B-1. Common Vascular Plants on the Hanford Site, Washington B.3

Table B-2. Mammals that Have Been Observed on the Hanford Site, Washington B.6

Table B-3. Common Bird Species Known to Occur on the Hanford Site, Washington B.7

Table B-4. Reptiles and Amphibians Found on the Hanford Site, Washington. B.12

Table B-5. Fish Species in the Hanford Reach, Washington, Region of the Columbia River. 


\subsection{Affected Environment}

\section{Introduction}

\section{A.L. Bunn}

The U.S. Department of Energy (DOE) Hanford Site lies within the semiarid Pasco Basin of the Columbia Plateau in southcentral Washington State (Figure 4.0-1). The Hanford Site occupies an area of about $1517 \mathrm{~km}^{2}$ (about $586 \mathrm{mi}^{2}$ ) ${ }^{\text {(a) }}$ north of the confluence of the Yakima River with the Columbia River. The Hanford Site is about $50 \mathrm{~km}$ (30 mi) north to south and $40 \mathrm{~km}(24 \mathrm{mi})$ east to west. This land, with restricted public access, provides a buffer for the smaller areas currently used for storage of nuclear materials, waste treatment, and waste storage and/or disposal. The Columbia River flows through the northern part of the Hanford Site and, turning south, forms part of the Site's eastern boundary. The Yakima River runs near the southern boundary of the Hanford Site and joins the Columbia River at the city of Richland, which bounds the Hanford Site on the southeast. Rattlesnake Mountain, Yakima Ridge, and Umtanum Ridge form the southwestern and western boundaries. Saddle Mountain forms the northern boundary of the Hanford Site. Two small east-west ridges, Gable Butte and Gable Mountain, rise above the plateau of the central part of the Hanford Site. Adjoining lands to the west, north, and east are principally range and agricultural land. The cities of Kennewick, Pasco, and Richland (the Tri-Cities), and the city of West Richland constitute the nearest population centers and are located south-southeast of the Hanford Site.

The Hanford Site was established in 1943 to produce plutonium for nuclear weapons; it was the first nuclear production facility in the world. The U.S. Army Corps of Engineers selected the Hanford Site because it was remote from major populated areas and had ample electrical power from Grand Coulee Dam, a functional railroad, clean water available from the Columbia River, and plenty of sand and gravel available onsite for construction. The Hanford Site was divided into a number of operational areas (e.g., 100, 200, 300, and 400 Areas) (DOE 1998a, b).

From the early 1940s to the present, most research and development activities were carried out in the 300 Area located just north of Richland. The 300 Area was also the location of nuclear fuel fabrication. Nuclear fuel in the form of pipe-like cylinders (fuel slugs) was fabricated from purified uranium shipped in from offsite production facilities. The fabricated fuel slugs were shipped by rail from the 300 Area to the nuclear reactors in the100 Area, located at the northern portion of the Site on the shore of the Columbia River, where up to nine nuclear reactors were in operation. The first eight reactors were constructed between 1944 and 1955. The ninth reactor, N Reactor, was completed in 1963. The irradiated fuel produced in the 100 Area reactors was transported by rail to the 200 Areas, where the plutonium was recovered.

The 200 East and 200 West Areas are located on a plateau about 11 and 8 km (7 and $5 \mathrm{mi}$ ), respectively, south of the Columbia River. These areas housed facilities called separations plants that received and dissolved irradiated fuel and then separated out the plutonium. Wastes were neutralized and stored in large underground tanks. Wastes containing fission products, activation products, and nitrate

(a) This figure is based on the newest geographical information system (GIS) interpolation of the Hanford Site legal boundary. Historically, the Site area was reported as $1450 \mathrm{~km}^{2}\left(560 \mathrm{mi}^{2}\right)$, calculated by the addition of sections and subunits based on surveys from the 1800s. Included in the Site is $36.42 \mathrm{~km}^{2}\left(14.1 \mathrm{mi}^{2}\right)$ of Columbia River surface water and $2.6 \mathrm{~km}^{2}\left(1 \mathrm{mi}^{2}\right)$ of Washington State land (DOE 1999a). 


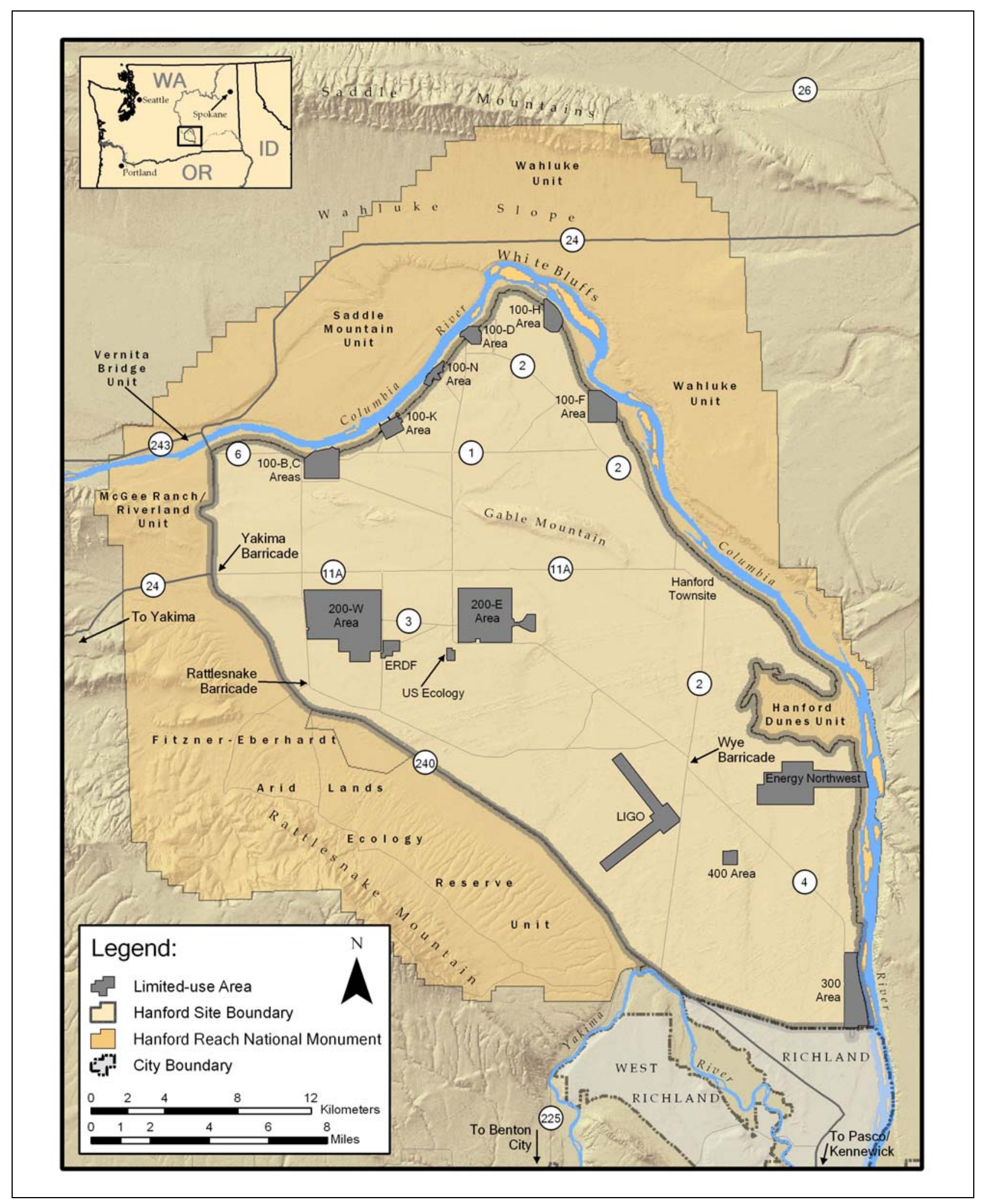

Figure 4.0-1. U.S. Department of Energy's Hanford Site, Washington 
were discharged to cribs. Low-level wastes and cooling water from the plants were distributed by open ditch to surface ponds for evaporation and percolation into the ground.

Other areas on the Hanford Site include the 400 and 600 Areas. The Fast Flux Test Facility (FFTF) located in the 400 Area was a special nuclear reactor designed to test various types of nuclear fuel, produce medical and industrial isotopes, and conduct cooperative international research. The facility operated for about ten years and has been shut down since 1993. The 600 Area includes all the land between the designated areas of the Site.

The 700 and 1100 Areas, near north Richland, provided Hanford Site support services. The 700 Area was the original location for administrative activities for the Hanford Site, and was located where the Federal Building is located today (DOE 1997a). The 1100 Area was the location of general stores and transportation maintenance facilities for the Hanford Site. Operations at the transportation maintenance facility resulted in ground contamination from several chemicals, oils, and greases. The 1100 Area was located about $1.8 \mathrm{~km}(1.1 \mathrm{mi})$ west of the Columbia River and contiguous to the 600 Area. In September 1996, the 1100 Area was declared remediated and the Environmental Protection Agency issued a delisting from the National Priorities List (DOE 1998a). No radioactive waste was discharged to the ground in the 1100 Area. Most of the 1100 Area has been incorporated into the city of Richland and is no longer a part of the Hanford Site (DOE 2002a).

At the Hanford Site several areas, totaling $665 \mathrm{~km}$ (257 mi), have been set aside for special uses. The Fitzner-Eberhardt Arid Lands Ecology Reserve Unit, used for ecological research, was established in 1967 on land between the southern boundary of the Hanford Site and State Route 240. On the north end of the site is the Saddle Mountain National Wildlife Refuge Unit. Operations and activities on the Hanford Site, not under the auspices of DOE include: a commercial power production reactor by Energy Northwest (near the 400 Area); a scientific observatory for measuring gravity waves at extremely tiny levels, called the Laser Interferometer Gravitational Wave Observatory (LIGO) project (near the 400 Area); and a commercial low-level radioactive waste burial ground at a site leased and licensed by the State of Washington and operated by U.S. Ecology (near the 200 Areas). Offsite, but near the southern boundary of the Hanford Site in North Richland, Framatome ANP (an AREVA and Siemens company) operates a commercial nuclear fuel fabrication facility and Pacific EcoSolutions LLC operates a low-level radioactive waste decontamination, super-compaction, and packaging disposal facility.

The Hanford Site encompasses more than 2700 waste management units and groundwater contamination plumes. These waste sites have been grouped into 74 operable units. Each operable unit has complementary characteristics such as geography, waste content, type of facility, and relationship of contaminant plumes. The grouping into operable units allows for economies of scale to reduce the cost and number of characterization investigations and remedial actions required to complete environmental cleanup (WHC 1989). The 74 operable units are located in four areas: 17 in the 100 Area, 51 in the 200 Areas, two in the 300 Area, and four in the former 1100 Area (DOE 2002a). Those persons contemplating National Environmental Policy Act (NEPA)-related activities on the Hanford Site should be aware of the existence and location of the operable units. Detailed information concerning the operable units and current maps showing the locations of the operable units can be obtained from Hanford Site Waste Management Units Report (DOE 2002a).

A portion of the Hanford Site was designated the Hanford Reach National Monument (65 FR 37253) during 2000. As established, the Monument totals $792.6 \mathrm{~km}^{2}\left(306 \mathrm{mi}^{2}\right)$ and includes Fitzner-Eberhardt Arid Lands Ecology Reserve Unit, Saddle Mountain Wildlife Refuge Unit, McGee Ranch/Riverlands Unit, and land $0.40 \mathrm{~km}(0.25 \mathrm{mi})$ inland from the mean high-water mark on the south and west shores of the $82 \mathrm{~km}(51 \mathrm{mi})$ long Hanford Reach of the Columbia River. It also includes the federally owned islands in the Hanford Reach and the sand dune area northwest of the Energy Northwest Site. This 
designation establishes the protection and management of the lands within the region of the monument. Also, a letter from President Clinton to the Secretary of Energy directs the Secretary of Energy to consult with the Secretary of the Interior regarding the incorporation of additional Hanford Site lands into the Monument as the land is remediated. The U.S. Fish and Wildlife Service (USFWS) is the lead agency in producing a Comprehensive Conservation Plan (CCP) Environmental Impact Statement (EIS) for management of the Hanford Reach National Monument. Knowledge of the objectives within this Plan may be important in the preparation of NEPA documents for activities on the Hanford Site. 


\subsection{Climate and Meteorology/Air Quality}

\section{D.J. Hoitink and B.G. Fritz}

The Hanford Site lies within the semiarid shrub-steppe Pasco Basin of the Columbia Plateau in southcentral Washington State. The region's climate is greatly influenced by the Pacific Ocean, the Cascade Mountain Range to the west, and other mountain ranges located to the north and east. The Pacific Ocean moderates temperatures throughout the Pacific Northwest and the Cascade Range generates a rain shadow that limits rain and snowfall in the eastern half of Washington State. The Cascade Range also serves as a source of cold air drainage, which has a considerable effect on the wind regime on the Hanford Site. Mountain ranges to the north and east of the region shield the area from the severe winter storms and frigid air masses that move southward across Canada.

Climatological data for the Hanford Site are compiled at the Hanford Meteorology Station (HMS). The HMS is located on the Hanford Site's Central Plateau, just outside the northeast corner of the 200 West Area and about $4 \mathrm{~km}(3 \mathrm{mi})$ west of the 200 East Area. Meteorological measurements have been made at the HMS since late 1944. Prior to the establishment of the HMS, local meteorological observations were made at the Old Hanford Townsite (1912 through late 1943) and in Richland (19431944). A climatological summary for Hanford is provided in Hoitink et al. (2004). ${ }^{\text {(a) }}$

Data from the HMS capture the general climatic conditions for the region and describe the specific climate of Hanford's Central Plateau. The size of the Hanford Site and its topography give rise to substantial spatial variations in wind, precipitation, temperature, and other meteorological characteristics. This is observed for the differences in the annual distribution of wind directions and speeds measured at the HMS and at the 300 Area. To accurately characterize meteorological differences across the Hanford Site, the HMS operates a network of monitoring stations. These stations, which currently number 30, are located throughout the Site and in neighboring areas (Figure 4.1-1). A 124-m (408-ft) instrumented meteorological tower operates at the HMS. A 61-m (200-ft) instrumented tower operates at each of the $100-\mathrm{N}, 300$, and 400 area meteorology-monitoring sites. Most of the other network stations use

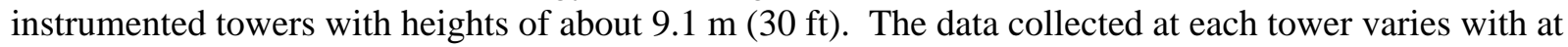
least three variables collected at all towers and up to seven characteristics collected at some (Table 4.1-1). Data are collected and processed at each station, and information is transmitted to the HMS every 15 minutes. This monitoring network has been in full operation since the early 1980s.

For the following descriptions in this section the seasons are defined as follows: Winter - December through February; spring - March through May; summer - June through August; and autumn September through November.

\footnotetext{
(a) Hanford climatological data summaries have been updated annually since 1995. Earlier climatological reports that have been extensively cited include Glantz et al. (1990) and Stone et al. (1983).
} 


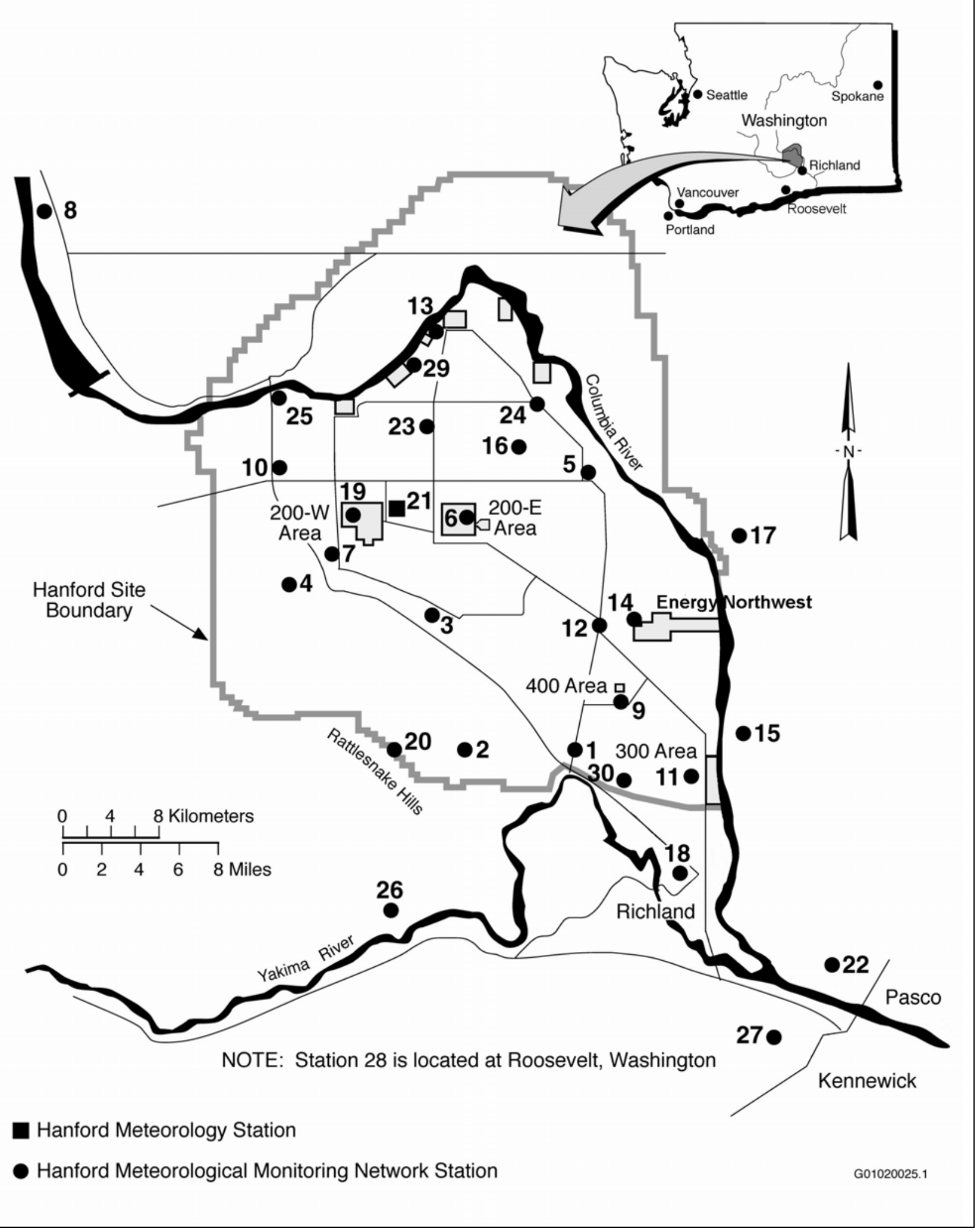

Figure 4.1-1. Hanford Meteorological Monitoring Network, Hanford Site, Washington 
Table 4.1-1. Station Numbers, Names, and Meteorological Data Measured at each Station in the Hanford Meteorological Monitoring Network, Washington

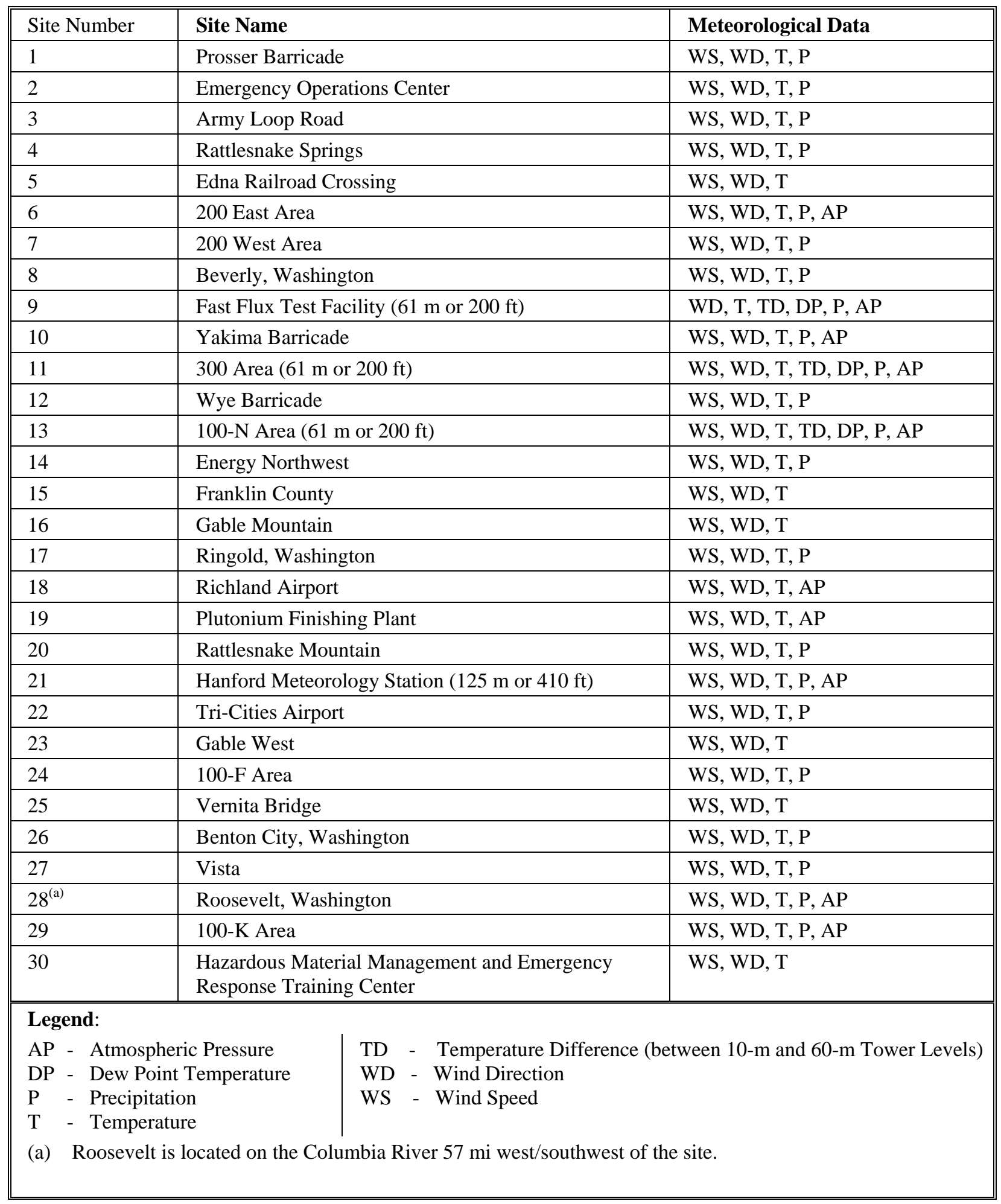




\subsubsection{Wind}

Wind data at the HMS are collected at $2.1 \mathrm{~m}(7 \mathrm{ft})$ above the ground and at the 15.2-, 61.0-, and 121.9-m (50-, 200-, and 400-ft) levels on the 124-m (408-ft) tower. Each of the three $61-\mathrm{m}(200-\mathrm{ft})$ towers has wind-measuring instrumentation at the 10-, 25-, and 60-m (33-, 82-, and 197-ft) levels. The short towers measure winds at $9.1 \mathrm{~m}(30 \mathrm{ft})$ above ground level.

The prevailing surface winds on Hanford's Central Plateau are from the northwest (Figure 4.1-2). Winds from the northwest occur most frequently during the winter and summer. Winds from the southwest also have a high frequency of occurrence on the Central Plateau. During the spring and fall, there is an increase in the frequency of winds from the southwest and a corresponding decrease in winds from the northwest.

In the southeastern portion of the Hanford Site (including the 300 [Station 11] and 400 [Station 9] Areas), the prevailing wind direction near the surface is from the southwest during most months; winds from the northwest are much less common (Figure 4.1-2). In the 100 Area and along the Columbia River, local winds are strongly influenced by the topography near the river. At the 100-K (Station 29) and 100$\mathrm{N}$ (Station 13) Areas, the prevailing wind direction is from the west. At the 100-F (Station 24) Area and near the Old Hanford Townsite (Edna Railroad crossing [Station 5]), winds often have a northwesterly or southeasterly component.

Stations that are relatively close together can exhibit significant differences in wind patterns. For example, the stations at Rattlesnake Springs (Station 4) and the 200 West Area (Station 7) are separated by about $5 \mathrm{~km}$ (3 mi), yet the wind patterns at the two stations are very different (Figure 4.1-2). Care should be taken when assessing the appropriateness of the wind data used in estimating environmental impacts. When possible, wind data from the closest representative station should be used for estimating local dispersion conditions.

Monthly and annual joint-frequency distributions of wind direction versus wind speed for the HMS are reported in Hoitink et al. (2004). Monthly average wind speeds at $15.2 \mathrm{~m}$ (50 ft) above the ground are lower during the winter months, averaging 2.7 to $3.1 \mathrm{~m} / \mathrm{s}$ (6 to $7 \mathrm{mph}$ ), and faster during the summer, averaging 3.6 to $4.0 \mathrm{~m} / \mathrm{s}$ (8 to $9 \mathrm{mph}$ ) (Table $4.1-2)$. The fastest wind speeds at the HMS are usually associated with flow from the southwest (Table 4.1-2). However, the summertime drainage winds from the northwest frequently exceed speeds of $13 \mathrm{~m} / \mathrm{s}(30 \mathrm{mph})$. The maximum speed of the drainage winds (and their frequency of occurrence) tends to decrease as one moves toward the southeast across the Hanford Site. The HMS averages 156 days per year with peak wind gusts greater or equal to $11 \mathrm{~m} / \mathrm{s}$ (25 mph) (ranging from a low of about 7 in January to high of nearly 20 in June and July), and 56 days with peak gusts greater or equal to $16 \mathrm{~m} / \mathrm{s}$ (35 mph) (from a low of about 3 days in September and October to a high of about 6 during the months April through July) (Table 4.1-3).

Surface features have less influence on winds aloft than winds near the surface. However, substantial spatial variations are found in the wind distributions across Hanford at $60 \mathrm{~m}(197 \mathrm{ft})$ above ground level (Figure 4.1-3). For releases at greater heights, the most representative data may come from the closest representative 61-m (200-ft) tower rather than the nearest 9.1-m (30-ft) tower. 


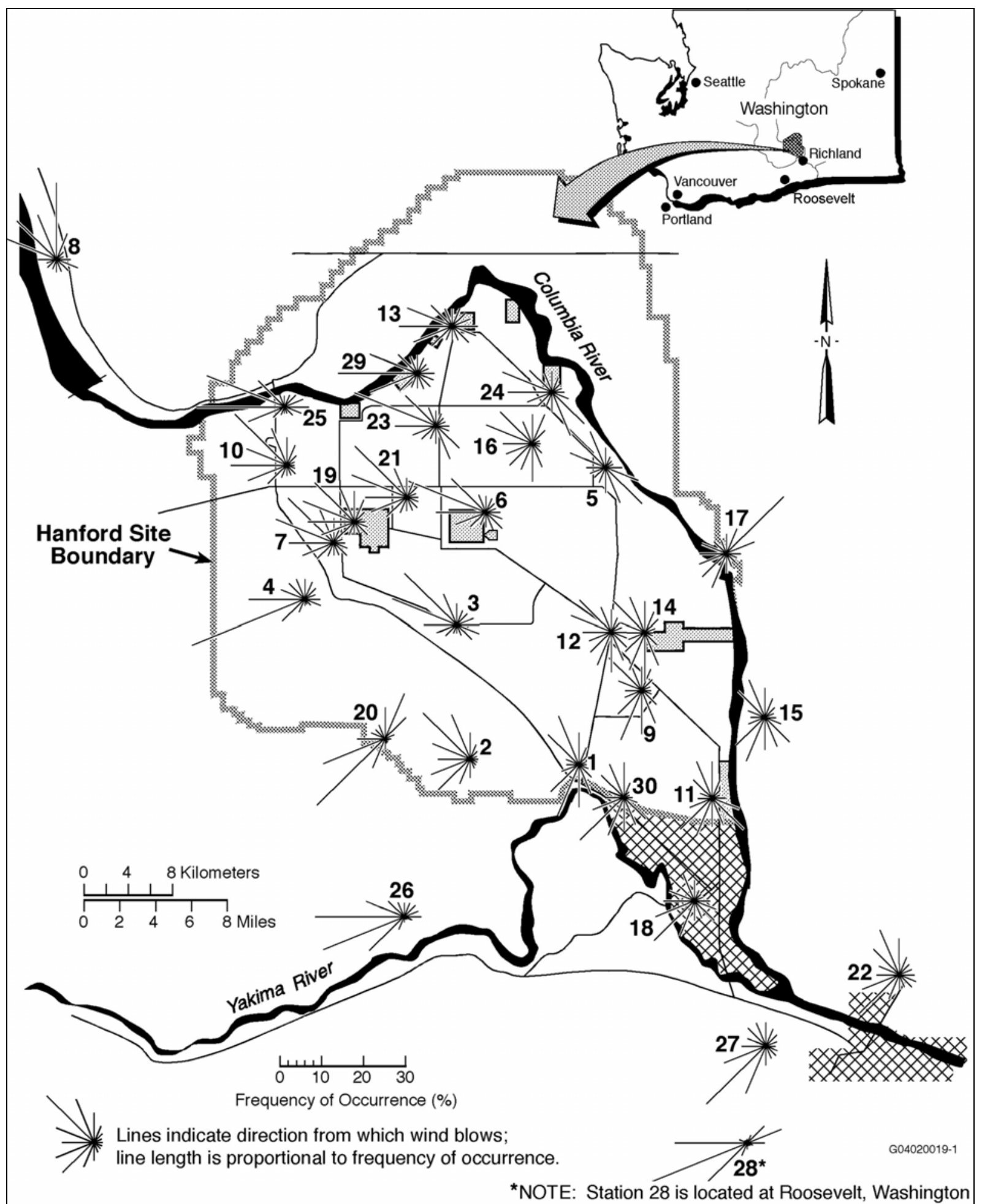

Figure 4.1-2. Wind Roses at the $9.1 \mathrm{~m}$ (30 ft) Level of the Hanford Meteorological Monitoring Network, Washington, 1982 to 2003 (after Hoitink et al. 2004) 
Table 4.1-2. Monthly and Annual Prevailing Wind Directions, Average Speeds, and Peak Gusts at 15-m (50-ft) Level, 1945 through 2003, Hanford Meteorology Station, Washington (Hoitink et al. 2004)

\begin{tabular}{|c|c|c|c|c|c|c|c|c|c|}
\hline \multirow[b]{2}{*}{ Month } & \multirow[b]{2}{*}{$\begin{array}{l}\text { Prevailing } \\
\text { Direction }\end{array}$} & \multirow[b]{2}{*}{$\begin{array}{c}\text { Average } \\
\text { Speed } \\
\text { (mph) }\end{array}$} & \multirow[b]{2}{*}{$\begin{array}{c}\text { Highest } \\
\text { Average } \\
\text { (mph) }\end{array}$} & \multirow[b]{2}{*}{ Year } & \multirow[b]{2}{*}{$\begin{array}{c}\text { Lowest } \\
\text { Average } \\
\text { (mph) }\end{array}$} & \multirow[b]{2}{*}{ Year } & \multicolumn{3}{|c|}{ Peak Gusts } \\
\hline & & & & & & & $\begin{array}{l}\text { Speed } \\
(\mathrm{mph})\end{array}$ & Direction & Year \\
\hline January & NW & 6.3 & 10.3 & 1972 & 2.9 & 1985 & 80 & SW & 1972 \\
\hline February & NW & 7.1 & 11.1 & 1999 & 4.6 & 1963 & 65 & SW & 1971 \\
\hline March & WNW & 8.2 & 10.7 & $1977^{(\mathrm{a})}$ & 5.9 & 1958 & 70 & SW & 1956 \\
\hline April & WNW & 8.8 & 11.1 & $1972^{(a)}$ & 7.4 & $1989^{(a)}$ & 73 & SSW & 1972 \\
\hline May & WNW & 8.8 & 10.7 & 1983 & 5.8 & 1957 & 71 & SSW & 1948 \\
\hline June & NW & 9.1 & 10.7 & $1983^{(a)}$ & 7.7 & $1950^{(a)}$ & 72 & SW & 1957 \\
\hline July & NW & 8.6 & 10.7 & 1983 & 6.8 & 1955 & 69 & WSW & 1979 \\
\hline August & WNW & 8.0 & 9.5 & 1996 & 6.0 & 1956 & 66 & SW & 1961 \\
\hline September & WNW & 7.5 & 9.2 & 1961 & 5.4 & 1957 & 65 & SSW & 1953 \\
\hline October & NW & 6.6 & 9.1 & 1946 & 4.4 & 1952 & 72 & SW & 1997 \\
\hline November & NW & 6.4 & 10.0 & 1990 & 2.9 & 1956 & 67 & WSW & 1993 \\
\hline December & NW & 6.0 & 8.3 & 1968 & 3.3 & 1985 & 71 & SW & 1955 \\
\hline Annual & NW & 7.6 & 8.8 & 1999 & 6.2 & 1989 & 80 & SW & $\begin{array}{c}\text { Jan- } \\
72 \\
\end{array}$ \\
\hline
\end{tabular}

Table 4.1-3. Number of Days with Peak Gusts above Specific Thresholds at 15-m (50-ft) Level, 1945 through 2003, Hanford Meteorology Station, Washington (Hoitink et al. 2004)

\begin{tabular}{|c|c|c|c|c|c|c|c|c|c|c|}
\hline \multicolumn{6}{|c|}{ Days with Peak Gusts $\geq 11 \mathrm{~m} / \mathrm{s}$ (25 mph) } & \multicolumn{5}{|c|}{ Days with Peak Gusts $\geq 16 \mathrm{~m} / \mathrm{s}(35 \mathrm{mph})$} \\
\hline Month & Avg & Max & Year & Min & Year & Avg & Max & Year & Min & Year \\
\hline January & 7.6 & 21 & 1953 & 0 & $1985^{(a)}$ & 4.0 & 14 & 1953 & 0 & $1985^{(a)}$ \\
\hline February & 8.6 & 17 & $1976^{(\mathrm{a})}$ & 2 & $1952^{(\mathrm{a})}$ & 3.8 & 14 & 1976 & 0 & $2001^{(a)}$ \\
\hline March & 13.2 & 21 & 1977 & 4 & 1992 & 5.5 & 14 & 1997 & 0 & 1992 \\
\hline April & 17.0 & 26 & 1954 & 8 & 1946 & 6.3 & 12 & 1972 & 1 & 1967 \\
\hline May & 18.8 & 26 & 1978 & 9 & 1945 & 6.2 & 13 & 2002 & 0 & 1957 \\
\hline June & 19.7 & 26 & 1963 & 11 & $1950^{(\mathrm{a})}$ & 6.3 & 12 & $2002^{(a)}$ & 1 & 1982 \\
\hline July & 19.5 & 26 & 1995 & 11 & 1955 & 5.6 & 11 & $1994^{(\mathrm{a})}$ & 1 & $1982^{\text {(a) }}$ \\
\hline August & 15.9 & 24 & 2000 & 7 & 1945 & 4.2 & 12 & 1996 & 0 & $1978^{(\mathrm{a})}$ \\
\hline September & 11.3 & 17 & $2002^{(a)}$ & 7 & $1975^{(\mathrm{a})}$ & 3.4 & 7 & $2003^{(a)}$ & 0 & 1975 \\
\hline October & 9.0 & 19 & 2003 & 3 & $1987^{(\mathrm{a})}$ & 3.4 & 11 & 1997 & 0 & $1993^{(a)}$ \\
\hline November & 8.3 & 16 & 1990 & 0 & 1979 & 3.8 & 10 & 1998 & 0 & $1997^{(a)}$ \\
\hline December & 7.4 & 15 & 1968 & 0 & 1985 & 4.2 & 11 & 1957 & 0 & $1985^{(a)}$ \\
\hline Annual & 156.6 & 192 & 1999 & 123 & 1952 & 56.7 & 86 & 2002 & 31 & 1978 \\
\hline
\end{tabular}




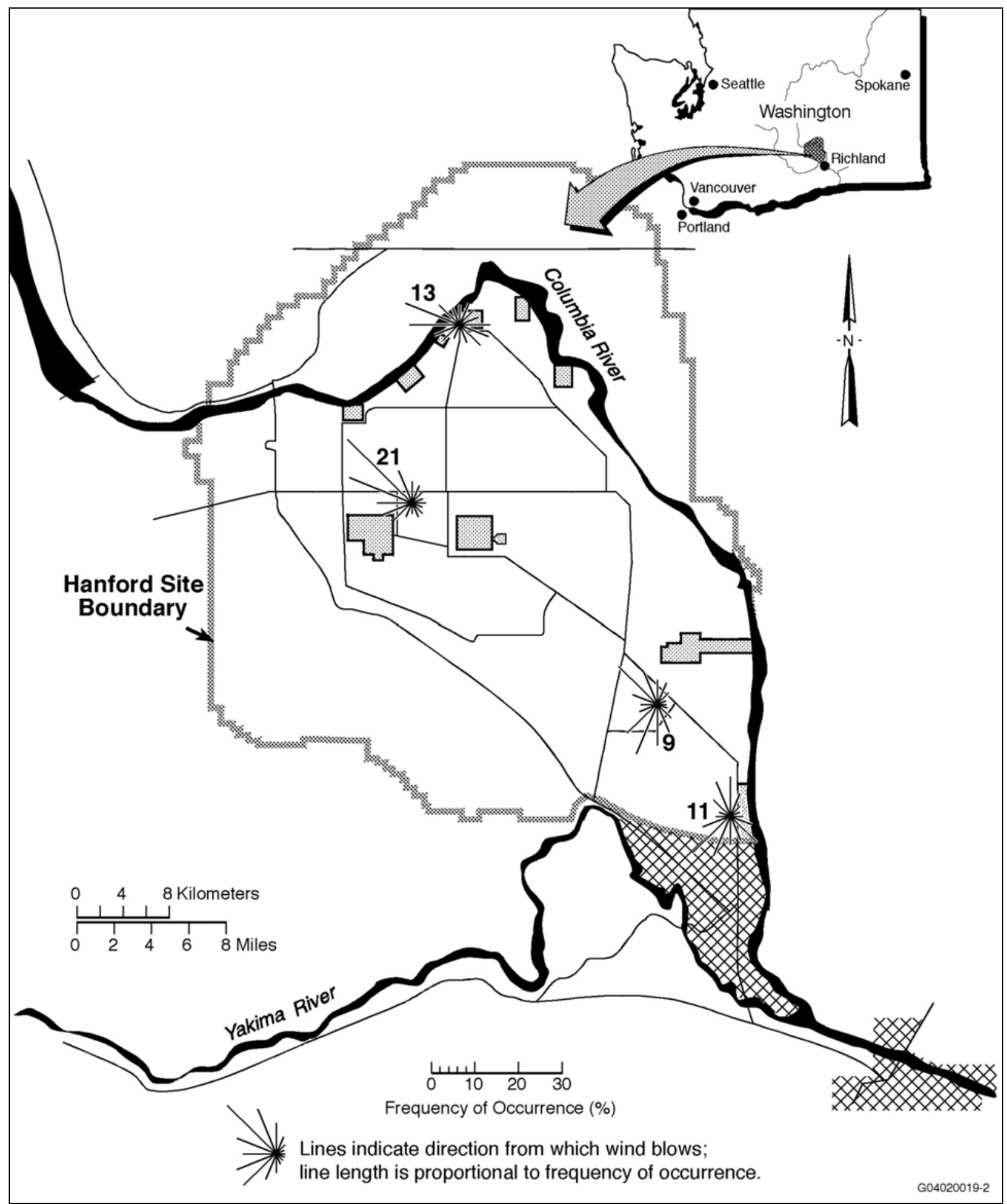

Figure 4.1-3. Wind Roses at the $60 \mathrm{~m}$ (197 ft) Level of the Hanford Meteorological Monitoring Network, Washington, 1986 to 2003 (after Hoitink et al. 2004) 


\subsubsection{Temperature and Humidity}

The 124-m (408-ft) tower at the HMS has temperature-measuring instrumentation at the following levels: $0.9,9.1,15.2,30.5,61.0,76.2,91.4$, and $121.9 \mathrm{~m} \mathrm{(3,} \mathrm{30,} \mathrm{50,} \mathrm{100,} \mathrm{200,} \mathrm{250,} \mathrm{300,} \mathrm{and} 400 \mathrm{ft})$. The three $61-\mathrm{m}(200-\mathrm{ft})$ towers have temperature-measuring instrumentation at the following levels: 2,10 , and $60 \mathrm{~m}$ ( 6.5, 33, and $197 \mathrm{ft})$. Temperatures are measured at the 2-m ( 6.5-ft) level on the 9-m (30-ft) towers. Relative humidity/dew point temperature measurements are made at the HMS and at the three 61-m (200-ft) tower locations.

Monthly averages and extremes of temperature, dew point, and humidity are presented in Hoitink et al. (2004). Based on data collected from 1946 through 2003, the average monthly temperatures at the HMS range from a low of $-0.7^{\circ} \mathrm{C}\left(31^{\circ} \mathrm{F}\right)$ in January to a high of $24.7^{\circ} \mathrm{C}\left(76^{\circ} \mathrm{F}\right)$ in July. The highest winter monthly average temperatures were $6.9^{\circ} \mathrm{C}\left(44^{\circ} \mathrm{F}\right)$ in February 1958 and February 1991, and the lowest average monthly temperature was $-11.1^{\circ} \mathrm{C}\left(12^{\circ} \mathrm{F}\right)$ in January 1950 . The highest monthly average temperature was $27.9^{\circ} \mathrm{C}\left(82^{\circ} \mathrm{F}\right)$ in July 1985 and the lowest summer monthly average temperature was $17.2^{\circ} \mathrm{C}\left(63^{\circ} \mathrm{F}\right)$ in June 1953.

Daily maximum temperatures at the HMS vary from an average of $2^{\circ} \mathrm{C}\left(35^{\circ} \mathrm{F}\right)$ in late December and early January to $36^{\circ} \mathrm{C}\left(96^{\circ} \mathrm{F}\right)$ in late July. There are, on average, 52 days during the summer months with maximum temperatures $\geq 32^{\circ} \mathrm{C}\left(90^{\circ} \mathrm{F}\right)$ and 12 days with maxima greater than or equal to $38^{\circ} \mathrm{C}\left(100^{\circ} \mathrm{F}\right)$. The greatest number of consecutive days on record with maximum daily temperatures $\geq 32^{\circ} \mathrm{C}\left(90^{\circ} \mathrm{F}\right)$ is 32 days. The record maximum temperature, $45^{\circ} \mathrm{C}\left(113^{\circ} \mathrm{F}\right)$ occurred at the HMS on July 13, 2002 and August 4, 1961.

From mid-November through early March, the average daily minimum temperature is below freezing; the daily minimum in late December and early January is $-6^{\circ} \mathrm{C}\left(21^{\circ} \mathrm{F}\right)$. On average, the daily minimum temperature of $\leq-18^{\circ} \mathrm{C}\left(\sim 0^{\circ} \mathrm{F}\right)$ occurs only 3 days per year; however, only about one winter in two experiences such low temperatures. The greatest number of consecutive days on record with minimum daily temperatures of $\leq-18^{\circ} \mathrm{C}\left(\sim 0^{\circ} \mathrm{F}\right)$ is 11 days. The record minimum temperature, $-31^{\circ} \mathrm{C}\left(-23^{\circ} \mathrm{F}\right)$ occurred on both February 1 and 3, 1950.

The annual average relative humidity at the HMS is 55\%. It is highest during the winter months, averaging about $76 \%$, and lowest during the summer, averaging about $36 \%$. The annual average dewpoint temperature at the $\mathrm{HMS}$ is $1^{\circ} \mathrm{C}\left(34^{\circ} \mathrm{F}\right)$. In the winter, the dewpoint temperature averages about $-3^{\circ} \mathrm{C}\left(27^{\circ} \mathrm{F}\right)$, and in the summer it averages about $6^{\circ} \mathrm{C}\left(43^{\circ} \mathrm{F}\right)$.

\subsubsection{Precipitation}

Average annual precipitation at the HMS is $17 \mathrm{~cm}$ (6.8 in.). During 1995, the wettest year on record, $31.3 \mathrm{~cm}$ (12.3 in.) of precipitation was measured; during 1976, the driest year, only $7.6 \mathrm{~cm}$ (3 in.) was measured. The wettest season on record was the winter of 1996-1997 with $14.1 \mathrm{~cm}$ (5.4 in.) of precipitation; the driest season was the summer of 1973 when only $0.1 \mathrm{~cm}(0.03 \mathrm{in}$.) of precipitation was measured. Most precipitation occurs during the late autumn and winter, with more than half of the annual amount occurring from November through February. Days with $>1.3 \mathrm{~cm}$ (0.50 in.) precipitation occur on average less than one time each year.

Average snowfall ranges from $0.25 \mathrm{~cm}(0.1 \mathrm{in}$.) during October to a maximum of $13.2 \mathrm{~cm}(5.2 \mathrm{in})$. during December and decreases to $1.3 \mathrm{~cm}$ (0.5 in.) during March. The record monthly snowfall of 59.4 cm (23.4 in.) occurred during January 1950. The seasonal record snowfall of $142.5 \mathrm{~cm}$ (56.1 in.) 
occurred during the winter of 1992-1993. Snowfall accounts for about 38\% of all precipitation from December through February.

\subsubsection{Fog and Visibility}

Fog has been recorded during every month of the year at the HMS; however, 89\% of the occurrences are from November through February, with less than 3\% from April through September (Table 4.1-4). The average number of days per year with fog (visibility $\leq 9.6 \mathrm{~km}[6 \mathrm{mi}]$ ) is 48 , while those with dense fog (visibility $\leq 0.4 \mathrm{~km}[0.25 \mathrm{mi}]$ ) are 25 . The greatest number of days with fog was 84 days during 19851986, and the least was 22 during 1948-1949. The greatest number of days with dense fog was 42 days during 1950-1951, and the least was 9 days during 1948-1949. The greatest persistence of fog was 114 hours (December 1985) and the greatest persistence of dense fog was 47 hours (December 1957).

Other phenomena causing restrictions to visibility (i.e., visibility $<9.6 \mathrm{~km}$ [6 mi]) include dust, blowing dust, and smoke from field burning. There are few such days; an average of 5 days per year have dust or blowing dust, and less than 1 day per year, on average, has reduced visibility from smoke.

Table 4.1-4. Number of Days with Fog by Season, Hanford Site, Washington

\begin{tabular}{|lccccc|}
\hline Category & Winter & Spring & Summer & Autumn & Total \\
\hline fog & 32 & 3 & $\leq 1$ & 12 & 48 \\
dense fog & 17 & 1 & $\leq 1$ & 7 & 25 \\
\hline
\end{tabular}

\subsubsection{Severe Weather}

Concerns about severe weather usually center on hurricanes, tornadoes, and thunderstorms. Fortunately, Washington does not experience hurricanes. In addition, tornadoes are infrequent and generally small in the northwestern portion of the United States. The National Climatic Data Center maintains a database that provides information on the incidence of tornados reported in each county in the United States. (This database can be accessed via the Internet at http://www.ncdc.noaa.gov/ol/climate/severeweather/extremes.html).

This database reports that in the ten counties closest to the Hanford Site (Benton, Franklin, Grant, Adams, Yakima, Klickitat, Kittitas, and Walla Walla counties in Washington and Umatilla and Morrow counties in Oregon), there have been only 18 tornadoes recorded from 1950 through March 2001. Of these, 12 tornadoes had maximum wind speeds estimated to be in the range of 18 to $32 \mathrm{~m} / \mathrm{s}$ (40 to 72 $\mathrm{mph}$ ), three had maximum wind speeds in the range of 33 to $50 \mathrm{~m} / \mathrm{s}$ (73 to $112 \mathrm{mph}$ ), and three had maximum wind speeds in the range of 51 to $71 \mathrm{~m} / \mathrm{s}$ (113 to $157 \mathrm{mph}$ ). There were no deaths or substantial property damage (in excess of $\$ 50,000$ ) associated with any of these tornadoes.

Ramsdell and Andrews (1986) report that for the $5^{\circ}$ block centered at $117.5^{\circ}$ west longitude and $47.5^{\circ}$ north latitude (the area in which the Hanford Site is located), the expected path length of a tornado is $7.6 \mathrm{~km}(5 \mathrm{mi})$, the expected width is $95 \mathrm{~m}$ (312 ft), and the expected area is about $1.5 \mathrm{~km}^{2}\left(1 \mathrm{mi}^{2}\right)$. The estimated probability of a tornado striking a point on the Hanford Site is $9.6 \times 10^{-6} / \mathrm{yr}$ (Ramsdell and Andrews 1986). The probabilities of extreme winds associated with tornadoes striking a point can be estimated using the distribution of tornado intensities for the region (Table 4.1-5). 
Table 4.1-5. Estimate of the Probability of Extreme Winds Associated with Tornadoes Striking a Point at Hanford, Washington (after Ramsdell and Andrews 1986)

\begin{tabular}{|ccc|}
\hline \multicolumn{2}{|c|}{ Wind Speed } & Probability Per Year \\
$(\mathbf{m} / \mathbf{s})$ & $(\mathbf{m p h})$ & \\
\hline 28 & 62 & $2.6 \times 10^{-6}$ \\
56 & 124 & $6.5 \times 10^{-7}$ \\
83 & 186 & $1.6 \times 10^{-7}$ \\
111 & 249 & $3.9 \times 10^{-8}$ \\
\hline
\end{tabular}

The average occurrence of thunderstorms in the vicinity of the HMS is 10 per year. They are most frequent during the summer; however, they have occurred in every month. Thunderstorms can generate high-speed winds and hail. Using the National Weather Service criteria for classifying a thunderstorm as "severe" (i.e., hail with a diameter $\geq 19 \mathrm{~mm}$ [3/4 in.] or wind gusts of $\geq 25.9 \mathrm{~m} / \mathrm{s}$ [58 mph]), only $1.9 \%$ of all thunderstorm events surveyed at the HMS have been "severe" storms, and all met the criteria based on their wind gusts. High-speed winds at Hanford are more commonly associated with strong cold frontal passages. In rare cases, intense low-pressure systems can generate winds of near hurricane force (Table 4.1-6).

Table 4.1-6. Estimates of Extreme Winds at the Hanford Site, Washington (Hoitink et al. 2004)

\begin{tabular}{|ccccc|}
\hline \multicolumn{5}{c|}{ Peak Gusts } \\
$\begin{array}{c}\text { Return } \\
\text { Period (yr) }\end{array}$ & $\begin{array}{c}\text { 15.2 m (50 ft) } \\
\text { above Ground } \\
\text { (m/s) }\end{array}$ & $\begin{array}{c}\text { 61 m m (200 ft) } \\
\text { above Ground } \\
\text { (m/s) }\end{array}$ & (mph) \\
\hline & & & & \\
2 & 27 & 60 & 30 & 67 \\
10 & 32 & 71 & 36 & 80 \\
100 & 38 & 85 & 43 & 96 \\
1000 & 44 & 98 & 50 & 111 \\
\hline
\end{tabular}

\subsubsection{Atmospheric Dispersion}

Atmospheric dispersion (the transport and diffusion of gases and particles within the atmosphere) is a function of wind speed, duration and direction of wind, intensity of atmospheric turbulence, and mixing depth. Atmospheric turbulence is not directly measured at the Hanford Site; instead, the impact of turbulence on atmospheric dispersion is characterized using atmospheric stability. Atmospheric stability describes the thermal stratification or vertical temperature structure of the atmosphere. Generally, six or seven different classes of atmospheric stability are used to describe the atmosphere. These classes range from extremely unstable (when atmospheric turbulence is greatest) to extremely stable (when atmospheric mixing is at a minimum and wind speeds are low). When the atmosphere is unstable, pollutants can rapidly diffuse through a large volume of the atmosphere. When the atmosphere is stable, pollutants will diffuse much more slowly in a vertical direction. Horizontal dispersion may be limited during stable 
conditions; however, plumes may also fan out horizontally during stable conditions, particularly when the wind speed is low. Most major pollutant incidents have been associated with stable conditions when inversions can trap pollutants near the ground.

Conditions likely to increase dispersion are most common in the summer when neutral and unstable stratification exists, about $56 \%$ of the time (Stone et al. 1983). Conditions less likely to promote dispersion are most common during the winter when moderately to extremely stable stratification exists, about $66 \%$ of the time (Stone et al. 1983). Less favorable conditions also occur periodically for surface and low-level releases in all seasons from about sunset to about an hour after sunrise as a result of ground-based temperature inversions and shallow mixing layers. Occasionally, there are extended periods of poor dispersion conditions associated with stagnant air in stationary high-pressure systems. These instances tend to occur during the winter months (Stone et al. 1983).

Stone et al. (1972) estimated the probability of extended periods of poor dispersion conditions. The probability of an inversion once established persisting more than $12 \mathrm{hr}$ varies from a low of about $10 \%$ in May and June to a high of about 64\% in September and October. These probabilities decrease rapidly for durations of $>12 \mathrm{hr}$ and are associated with extended surface-based inversions (Table 4.1-7).

Table 4.1-7. Percent Probabilities for Extended Periods of Surface-Based Inversions, Hanford Site, Washington (after Stone et al. 1972)

\begin{tabular}{|lrrr|}
\hline \multirow{2}{*}{ Months } & \multicolumn{3}{c|}{ Inversion Duration } \\
\cline { 2 - 4 } & 12-hr & 24-hr & 48-hr \\
\hline January-February & 54.0 & 2.5 & 0.28 \\
March-April & 50.0 & $<0.1$ & $<0.1$ \\
May-June & 10.0 & $<0.1$ & $<0.1$ \\
July-August & 18.0 & $<0.1$ & $<0.1$ \\
September-October & 64.0 & 0.11 & $<0.1$ \\
November-December & 50.0 & 1.2 & 0.13 \\
\hline
\end{tabular}

Many simple dispersion models use the joint frequency distribution of atmospheric stability, wind speed, and wind direction to compute diffusion factors for both chronic and acute releases. Joint frequency distributions for atmospheric stability, wind speed, and transport direction have been estimated for the data collected at the 100-N, 200, 300, and 400 Areas from two different release heights $(9.1 \mathrm{~m}$ and $60 \mathrm{~m}$ [30 ft and $197 \mathrm{ft}$ ]) (Tables A1 through A8, Appendix A). For each station, the joint frequency

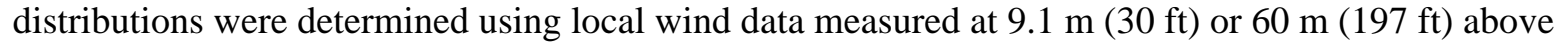
ground level, and atmospheric stability measurements made at the HMS.

The annual sector-average atmospheric dispersion coefficient (X/Q') where $\mathrm{X}$ is the air concentration $\left(\mathrm{Ci} / \mathrm{m}^{3}\right)$ and $\mathrm{Q}^{\prime}$ is the emission rate $(\mathrm{Ci} / \mathrm{s})$ were estimated for ground level and $60 \mathrm{~m}(197 \mathrm{ft})$ releases (Tables A9 through A16, Appendix A). The 95\% centerline atmospheric dispersion estimates (E/Q') for the four major Hanford operating areas (100, 200, 300, and 400 Areas) were estimated from atmospheric data (Tables A17 through A24, Appendix A). These dispersion factors are presented as a function of direction and distance from the release point and are based on meteorological data collected during the years 1983 through 2002. 


\subsubsection{Nonradiological Air Quality}

The Clean Air Act (CAA) is the basis for federal regulation of air quality in the United States (42 USC 7401). The CAA was first passed during 1967 and had comprehensive amendments during 1970, 1977, and 1990. Section 108 of the CAA calls for the U.S. Environmental Protection Agency (EPA) to promulgate a list of air pollutants that are emitted by numerous or diverse sources and whose presence in the atmosphere may reasonably be anticipated to endanger public health or welfare. In response to this mandate, EPA has issued regulations in 40 CFR 50 setting national ambient air quality standards. These standards are not directly enforceable, but other enforceable regulations are based on these standards. The states have primary responsibility for ensuring that air quality within the state meets the national ambient air quality standards through state implementation plans that are approved by EPA. Areas that meet ambient air quality standards are said to be "in attainment." Areas that do not meet one or more ambient air standards are designated as "nonattainment areas." The CAA also establishes a permitting program for construction or modification of large sources of air pollutants in both attainment and nonattainment areas and an operating permit program. In 2003, Washington State Department of Ecology completed the Columbia Plateau Windblown Dust Natural Events Action Plan (Ecology 2003).

Section 176 of the CAA states that federal agencies are not to engage in, support in any way, provide financial assistance for, license, permit, or approve any activity that does not conform to an applicable state implementation plan. The DOE has guidance (DOE 2000a) on how to apply the CAA conformity requirements and associated EPA regulations in a NEPA document and how to coordinate the CAA and NEPA public participation requirements.

Ambient air quality standards define levels of air quality that are necessary, with an adequate margin of safety, to protect the public health (primary standards) and the public welfare (secondary standards). "Ambient air" is that portion of the atmosphere, external to buildings, to which the general public has access (40 CFR 50.1). EPA has issued ambient air standards for sulfur oxides (measured as sulfur dioxide), nitrogen dioxide, carbon monoxide, lead, ozone, and $\mathrm{PM}_{10} . \mathrm{PM}_{10}$ is an air pollutant consisting of small particles with an aerodynamic diameter less than or equal to 10 micrometers. The standards specify the maximum pollutant concentrations and frequencies of occurrence that are allowed for specific averaging periods. The averaging periods vary from 1 hour to 1 year, depending on the pollutant.

State and local governments have the authority to impose standards for ambient air quality that are stricter than the national standards (Table 4.1-8). Washington State has established more stringent standards for sulfur dioxide. In addition, Washington has established standards for total suspended particulates (WAC 173-470) and fluorides (WAC 173-481) that are not covered by national standards. The state standards for carbon monoxide, nitrogen dioxide, $\mathrm{PM}_{10}$, and lead are identical to the national standards. Benton County, and subsequently the Hanford Site, is "in attainment" for all standards outlined in Table 4.1-8.

July 18, 1997, EPA issued new air quality standards for particulate matter with a diameter of $2.5 \mu \mathrm{m}$ or less $\left(\mathrm{PM}_{2.5}\right)$ and an 8-hr ozone standard. Decisions on violations of the new particulate matter and ozone standard were to be delayed for 5 to 8 years to give states time to set up monitoring networks and obtain 3 years of data (Ecology 1997). 
Table 4.1-8. U.S. Environmental Protection Agency (EPA) and Washington State Ambient Air Quality Standards ${ }^{(a)}$

\begin{tabular}{|c|c|c|c|}
\hline Pollutant & EPA Primary & EPA Secondary & Washington State \\
\hline \multicolumn{4}{|l|}{\begin{tabular}{|l} 
Total Suspended \\
Particulates
\end{tabular}} \\
\hline annual geometric mean & $\mathrm{NS}^{(\mathrm{b})}$ & NS & $60 \mu \mathrm{g} / \mathrm{m}^{3}$ \\
\hline 24-hr average & NS & NS & $150 \mu \mathrm{g} / \mathrm{m}^{3}$ \\
\hline \multicolumn{4}{|l|}{$\mathbf{P M}_{-10}{ }^{(\mathrm{c})}$} \\
\hline annual arithmetic mean & $50 \mu \mathrm{g} / \mathrm{m}^{3}$ & $50 \mu \mathrm{g} / \mathrm{m}^{3}$ & $50 \mu \mathrm{g} / \mathrm{m}^{3}$ \\
\hline 24-hr average & $150 \mu \mathrm{g} / \mathrm{m}^{3}$ & $150 \mu \mathrm{g} / \mathrm{m}^{3}$ & $150 \mu \mathrm{g} / \mathrm{m}^{3}$ \\
\hline \\
\hline 24-hr average & $65 \mu \mathrm{g} / \mathrm{m}^{3}$ & $65 \mu \mathrm{g} / \mathrm{m}^{3}$ & \\
\hline \multicolumn{4}{|l|}{ Sulfur Dioxide } \\
\hline annual average & $0.03 \mathrm{ppm}\left(\cong 80 \mu \mathrm{g} / \mathrm{m}^{3}\right)$ & NS & $0.02 \mathrm{ppm}\left(\cong 50 \mu \mathrm{g} / \mathrm{m}^{3}\right)$ \\
\hline 24-hr average & $0.14 \mathrm{ppm}\left(\cong 365 \mu \mathrm{g} / \mathrm{m}^{3}\right)$ & NS & $0.10 \mathrm{ppm}\left(\cong 260 \mu \mathrm{g} / \mathrm{m}^{3}\right)$ \\
\hline 3-hr average & NS & $0.50 \mathrm{ppm}\left(\cong 1.3 \mathrm{mg} / \mathrm{m}^{3}\right)$ & NS \\
\hline 1-hr average & NS & NS & $0.40 \mathrm{ppm}\left(\cong 1.0 \mathrm{mg} / \mathrm{m}^{3}\right)^{(\mathrm{e})}$ \\
\hline \multicolumn{4}{|l|}{ Carbon Monoxide } \\
\hline 8-hr average & $9 \mathrm{ppm}\left(\cong 10 \mathrm{mg} / \mathrm{m}^{3}\right)$ & $9 \mathrm{ppm}\left(\cong 10 \mathrm{mg} / \mathrm{m}^{3}\right)$ & $9 \mathrm{ppm}\left(\cong 10 \mathrm{mg} / \mathrm{m}^{3}\right)$ \\
\hline 1-hr average & $35 \mathrm{ppm}\left(\cong 40 \mathrm{mg} / \mathrm{m}^{3}\right)$ & $35 \mathrm{ppm}\left(\cong 40 \mathrm{mg} / \mathrm{m}^{3}\right)$ & $35 \mathrm{ppm}\left(\cong 40 \mathrm{mg} / \mathrm{m}^{3}\right)$ \\
\hline \multicolumn{4}{|l|}{ Ozone } \\
\hline 8-hr average & $0.08 \mathrm{ppm}\left(\sim 157 \mu \mathrm{g} / \mathrm{m}^{3}\right)$ & $0.08 \mathrm{ppm}\left(\sim 157 \mu \mathrm{g} / \mathrm{m}^{3}\right)$ & NS \\
\hline 1-hr average & $0.12 \mathrm{ppm}\left(\cong 235 \mu \mathrm{g} / \mathrm{m}^{3}\right)$ & $0.12 \mathrm{ppm}\left(\cong 235 \mu \mathrm{g} / \mathrm{m}^{3}\right)$ & $0.12 \mathrm{ppm}\left(\cong 235 \mu \mathrm{g} / \mathrm{m}^{3}\right)$ \\
\hline $\begin{array}{l}\text { Nitrogen Dioxide } \\
\text { annual average }\end{array}$ & $0.053 \mathrm{ppm}\left(\cong 100 \mu \mathrm{g} / \mathrm{m}^{3}\right)$ & $0.053 \mathrm{ppm}\left(\cong 100 \mu \mathrm{g} / \mathrm{m}^{3}\right)$ & $0.053 \mathrm{ppm}\left(\cong 100 \mu \mathrm{g} / \mathrm{m}^{3}\right)$ \\
\hline quarterly average & $1.5 \mu \mathrm{g} / \mathrm{m}^{3}$ & $1.5 \mu \mathrm{g} / \mathrm{m}^{3}$ & $1.5 \mu \mathrm{g} / \mathrm{m}^{3}$ \\
\hline Radionuclides & NS & NS & (f) \\
\hline \multicolumn{4}{|l|}{ Fluorides } \\
\hline 12-hr average & NS & NS & $3.7 \mu \mathrm{g} / \mathrm{m}^{3}$ \\
\hline 24-hr average & & & $2.9 \mu \mathrm{g} / \mathrm{m}^{3}$ \\
\hline 7 day average & & & $1.7 \mu \mathrm{g} / \mathrm{m}^{3}$ \\
\hline 30 day average & & & $0.84 \mu \mathrm{g} / \mathrm{m}^{3}$ \\
\hline \multicolumn{4}{|c|}{$\begin{array}{l}\text { Abbreviations: } \mathrm{ppm}=\text { parts per million; } \mu \mathrm{g} / \mathrm{m}^{3}=\text { micrograms per cubic meter; } \mathrm{mg} / \mathrm{m}^{3}=\text { milligrams per cubic meter. } \\
\text { (a) Source: } 40 \mathrm{CFR} 50 \text { and WAC } 173-470-173-481 \text {. Annual standards are never to be exceeded; short-term standards are not to be exceeded more } \\
\text { than once per year unless otherwise noted. Particulate pollutants are in micrograms per cubic meter. Gaseous pollutants are in parts per million } \\
\text { and equivalent micrograms (or milligrams) per cubic meter. }\end{array}$} \\
\hline (b) NS = no standard. & & & \\
\hline (c) $\mathrm{PM}_{10}$ - small particles in $\mathrm{tl}$ & th an aerodynamic diameter less $t$ & an or equal to 10 micrometers. & \\
\hline $\begin{array}{l}\text { (d) } \mathrm{PM}_{2.5} \text { - small particles in } \mathrm{t} \\
\text { enforced by the EPA. }\end{array}$ & ith an aerodynamic diameter less & an or equal to 2.5 micrometers. C & ently the $\mathrm{PM}_{2.5}$ standard is not \\
\hline (e) $0.25 \mathrm{ppm}$ not to be exceed & than twice in any 7 consecutive $d$ & & \\
\hline $\begin{array}{l}\text { (f) Emissions of radionuclide } \\
\text { mrem/yr to a critical orga } \\
\text { from these limits. }\end{array}$ & $\begin{array}{l}\text { ir shall not cause a maximum acc } \\
\text { member of the public. Doses due }\end{array}$ & $\begin{array}{l}\text { mulated dose equivalent of more } t \\
\text { o radon-220, radon-222, and their }\end{array}$ & $\begin{array}{l}25 \mathrm{mrem} / \mathrm{yr} \text { to the whole body or } 75 \\
\text { ppective decay products are excluded }\end{array}$ \\
\hline
\end{tabular}




\subsubsection{Prevention of Significant Deterioration}

Prevention of significant deterioration permits are issued to large sources of pollutants subject to ambient air standards in attainment areas. The Plutonium-Uranium Extraction (PUREX) and Uranium Trioxide $\left(\mathrm{UO}_{3}\right)$ facilities were issued a prevention of significant deterioration permit for nitrogen oxide emissions during 1980. These facilities were permanently shut down in the late 1980s and deactivated in the 1990s. None of the currently operating Hanford facilities have nonradiological emissions of sufficient magnitude to warrant consideration under prevention of significant deterioration regulations.

\subsubsection{Emissions of Nonradiological Pollutants}

Nonradiological pollutants are mainly emitted from power-generating and chemical-processing facilities located in the 200 and 300 Areas on the Hanford Site (Table 4.1-9). The 100, 400, and 600 Areas do not have any nonradiological emission sources of concern (Poston et al. 2004).

Table 4.1-9. Nonradioactive Constituents Discharged to the Atmosphere during 2003, Hanford Site, Washington (Poston et al. 2004)

\begin{tabular}{|l|c|}
\hline Constituent & Release, kg (lb) \\
\hline & \\
particulate matter & $1,800(3,900)$ \\
nitrogen oxides & $16,000(34,000)$ \\
sulfur oxides & $3,800(8,300)$ \\
carbon monoxide & $17,000(38,000)$ \\
lead & $0.64(1.4)$ \\
volatile organic compounds ${ }^{\text {(a,b) }}$ & $11,000(25,000)$ \\
ammonia ${ }^{\text {(c) }}$ & $16,000(36,000)$ \\
other toxic air pollutants & (d) \\
\hline (a) The estimate of volatile organic compound emissions does not include emissions from certain \\
laboratory operations. \\
(b) Produced from burning fossil fuel for steam and electrical generators, calculated estimates from \\
the 200 East and 200 West Areas tank farms, and operation of the 242-A evaporator and the 200 \\
Area Effluent Treatment Facility. \\
(c) Estimated ammonia releases are from the 200 East Area and 200 West Area tank farms, and \\
operation of the 242-A Evaporator and the 200 Areas Effluent Treatment Facility. \\
(d) Releases are a composite of calculated estimates of toxic air pollutants, excluding ammonia, \\
from the 200 East Area and 200 West Area tank farms, and operation of the 242-A Evaporator \\
and the 200 Areas Effluent Treatment Facility. \\
\hline
\end{tabular}

\subsubsection{Offsite Monitoring}

During 1998, the Washington State Department of Ecology (Ecology) conducted offsite monitoring near the Hanford Site for $\mathrm{PM}_{10}$ (Ecology 1999, 2000). $\mathrm{PM}_{10}$ was monitored at one location in Benton County, the Tri-Tech Vocational Center near the Hanford network's Vista Field meteorological monitoring site in Kennewick. The Benton Clean Air Authority currently conducts particulate monitoring at Tri-Tech Vocational Center to demonstrate compliance with EPA and Washington State standards (Table 4.1-8). During 2003, the maximum measured $\mathrm{PM}_{10}$ concentration was $138 \mu \mathrm{g} / \mathrm{m}^{3}$, while the second highest measured concentration was $126 \mu \mathrm{g} / \mathrm{m}^{3}$ (EPA 2004). The annual average $\mathrm{PM}_{10}$ concentration reported for Benton County was $24 \mu \mathrm{g} / \mathrm{m}^{3}$ (EPA 2004). The maximum measured $\mathrm{PM}_{2.5}$ concentration for Benton County during 2003 was $19 \mu \mathrm{g} / \mathrm{m}^{3}$, while the 2003 annual average $\mathrm{PM}_{2.5}$ 
concentration was $6.3 \mu \mathrm{g} / \mathrm{m}^{3}$ (EPA 2004). These 2003 measured concentrations were less than EPA and Washington State standards.

\subsubsection{Background Monitoring}

During the last 10 years, carbon monoxide, sulfur dioxide, and nitrogen dioxide have been monitored periodically in communities and commercial areas southeast of Hanford. These urban measurements are typically used to estimate the maximum background pollutant concentrations for the Hanford Site because of the lack of specific onsite monitoring.

Particulate concentrations can reach relatively high levels in eastern Washington because of exceptional natural events (i.e., dust storms and large brushfires) that occur in the region. During June 1996, EPA adopted the policy that allows dust storms to be treated as uncontrollable natural events (EPA 1996). This means that EPA will not designate areas affected by dust storms as nonattainment. However, states are required to develop and implement a natural events action plan.

Areas that require more strict controls on air quality impacts are regions that have been determined to be nonattainment areas by the EPA. Federal Class I areas include certain national parks and wilderness areas. Actions on the Hanford Site are unlikely to have any impacts on these types of areas. The nearest nonattainment area to the Hanford Site is the Wallula area (located approximately $30 \mathrm{~km} \mathrm{[20} \mathrm{mi]}$ southeast of the Site), which is a nonattainment area for PM $\mathrm{PM}_{10}$ (40 CFR 81.348, 66 FR 9663). The major source of $\mathrm{PM}_{10}$ in the Wallula area is from windblown dust. In making the nonattainment determination, EPA found that even if some of the data from the Wallula monitoring site are considered uncontrollable natural events and excluded from consideration in determining the air quality status of the area, the remaining data still show that the Wallula area has not attained the $\mathrm{PM}_{10}$ national ambient air quality standard (66 FR 9663).

The nearest Federal Class I areas to the Hanford Site are Mount Rainer National Park, located $160 \mathrm{~km}$ (100 mi) west of the Site; Goat Rocks Wilderness Area, located approximately $145 \mathrm{~km}$ (90 mi) west of the Site; Mount Adams Wilderness Area, located approximately $150 \mathrm{~km}$ (95 mi) southwest of the Site; and Alpine Lakes Wilderness Area, located approximately $175 \mathrm{~km}$ (110 mi) northwest of the Site (40 CFR 81.434). Operations at the Hanford Site should have no discernable effects on these areas because of their distance from the Site and because topography and prevailing winds tend to prevent Hanford emissions from reaching these Class I areas.

\subsubsection{Onsite Monitoring}

Monitoring of particulate matter mass concentrations in air on the Hanford Site began during February 2001. $\mathrm{PM}_{10}$ data have been collected at the Hanford Meteorological Station since February 2001, while $\mathrm{PM}_{2.5}$ data collection began at the Hanford Meteorological Station during October 2001. The observed annual average $\mathrm{PM}_{10}$ concentration at the Hanford Meteorological Station during 2003 was $14 \mu \mathrm{g} / \mathrm{m}^{3}$. Daily average $\mathrm{PM}_{10}$ concentrations on the Hanford Site were greater than the EPA standard on two days (Figure 4.1-4). The Benton Clean Air Authority conducts air monitoring that is responsible for determining Benton County's compliance with the EPA National Ambient Air Quality Standards (NAAQS), so concentrations on the Hanford Site that are higher than the EPA standard for $\mathrm{PM}_{10}$ are not considered for determining compliance with the EPA NAAQS. All of the elevated $\mathrm{PM}_{10}$ concentrations observed on the Hanford Site during 2003 were associated with high winds. The measured annual average $\mathrm{PM}_{2.5}$ concentration at the Hanford Meteorological Station during 2003 was $6 \mu \mathrm{g} / \mathrm{m}^{3}$, while the highest 24-hr average concentration observed was $29 \mu \mathrm{g} / \mathrm{m}^{3}$. Both of these concentrations were less than EPA standards of $15 \mu \mathrm{g} / \mathrm{m}^{3}$ and $65 \mu \mathrm{g} / \mathrm{m}^{3}$, respectively (Table $4.1-8$ ). 


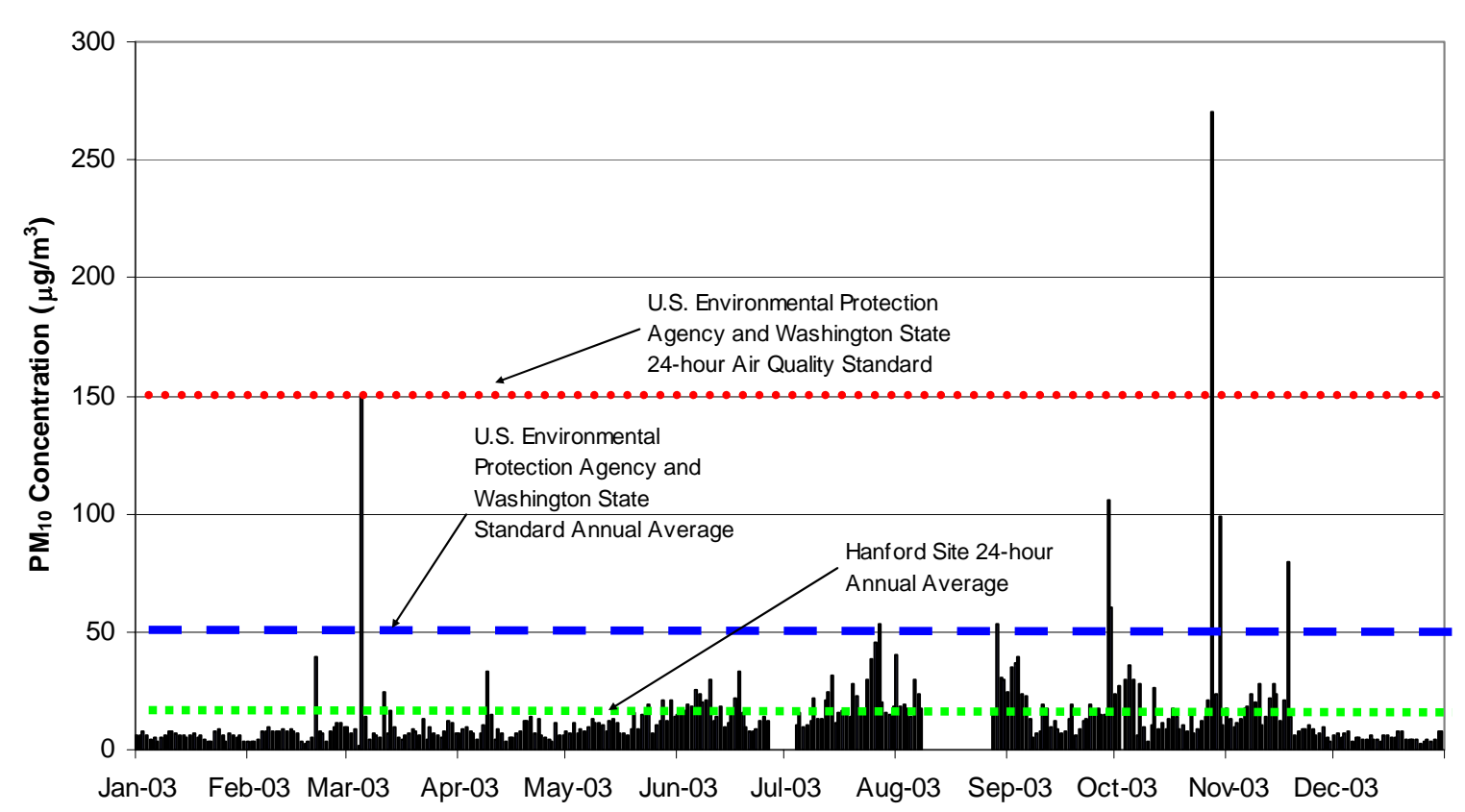

Figure 4.1-4. 24-hr Average Concentrations for Particulate Matter with a Diameter of $10 \mu \mathrm{m}$ or less at the Hanford Meteorological Station, Washington, 2003

\subsubsection{Radiological Air Quality}

Airborne effluents that may contain radioactive constituents are continually monitored at the Hanford Site. Samples are analyzed for gross alpha and gross beta activity as well as selected radionuclides. Radioactive emissions during 2002 originated in the 100, 200, 300, and 400 Areas. 100 Area emissions originated from the K Basins (irradiated fuel stored in two water-filled storage basins) and the Cold Vacuum Drying Facility, where fuel from the K Basins was prepared for storage. 200 Area emissions originated from the PUREX Plant, the Waste Encapsulation and Storage Facility, the Plutonium Finishing Plant, T Plant, 222-S Laboratory, underground storage tanks, and waste evaporators. Emissions from the 300 Area originated from the 324 Waste Technology Engineering Laboratory, 325 Radiochemical Processing Laboratory, 327 Post-Irradiation Laboratory, and 340 Vault and Tanks. 400 Area emissions originated at the Fast Flux Test Facility (FFTF) and Maintenance and Storage Facility (Rokkan et al. 2003).

\subsubsection{Radiological Emissions}

Standards for emissions of radionuclides from DOE facilities have been established by EPA (40 CFR Part 61) and Washington State (WAC 173-480 and WAC 246-247). Emissions may not exceed quantities that would result in a dose of 10 mrem in a year to a maximally exposed individual (MEI) of the public. Dose to a MEI is calculated through computer modeling that uses radiological emissions to the atmosphere as one input parameter (Table 4.1-10). 
Table 4.1-10. Radionuclides Discharged to the Atmosphere at the Hanford Site, Washington, 2003 (Poston et al. 2004)

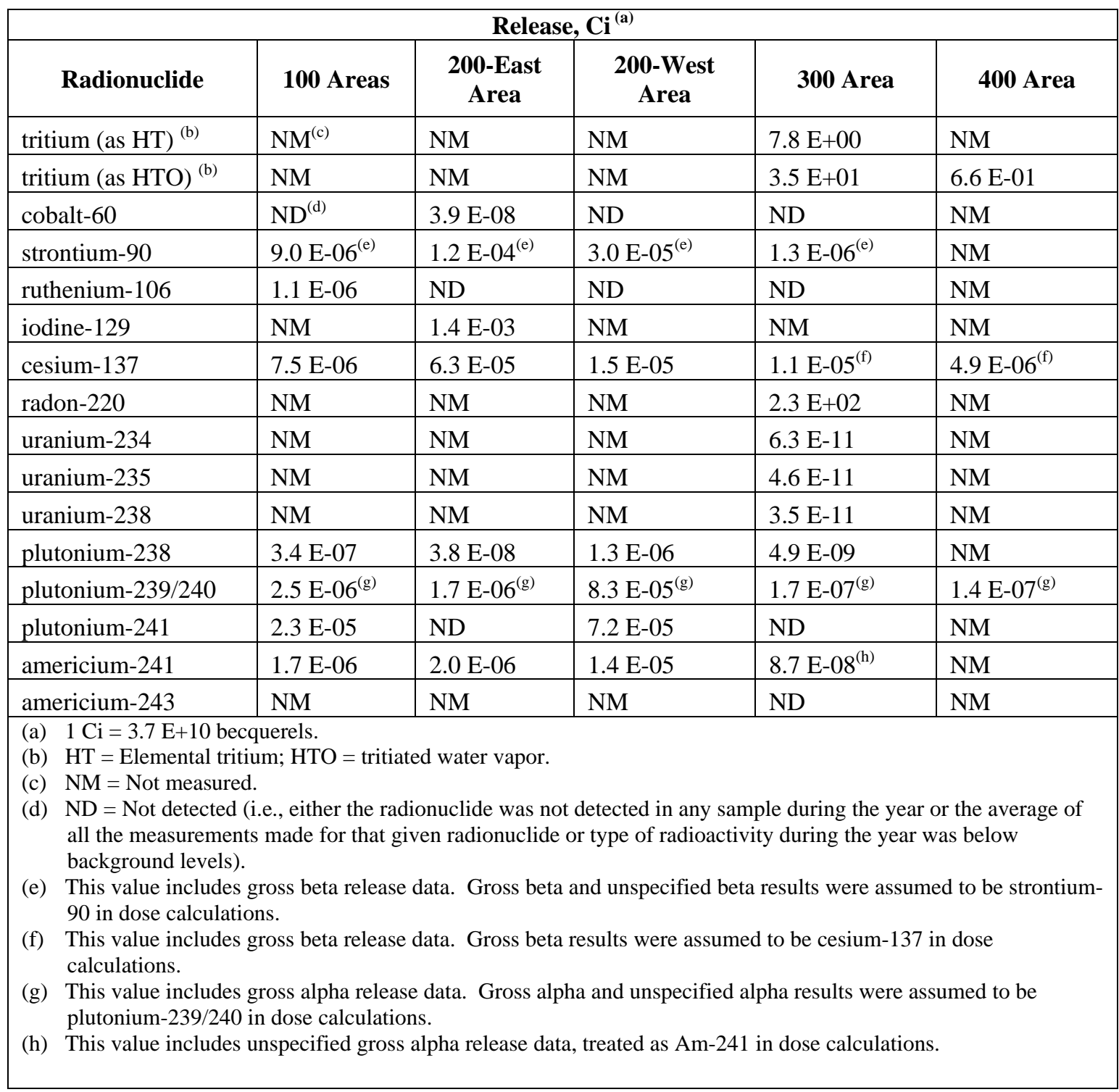

\subsubsection{Dose Assessments}

In order to comply with the Clean Air Act (40 CFR 61, Subpart H), dose assessments are required to assure that no member of the public receives a dose greater than 10 mrem in a year. EPA requires the use of a computer model approved by the EPA to calculate doses. During 2003, the estimated annual dose to an offsite member of the public from all pathways (inhalation, ingestion, and absorption) due to radionuclide emissions to a hypothetical MEI was $0.023 \mathrm{mrem}(0.23 \mu \mathrm{Sv})$. This calculated MEI scenario was determined using the EPA-approved CAP88-PC model (EPA 2000). Model results were calculated using established standard parameters for the Hanford Site (Rokkan et al. 2003). Inhalation dose to an offsite MEI was also calculated. This calculation used environmental measurements to estimate 
maximum air concentrations and the resulting dose. For 2003, the maximum annual dose to a member of the public from inhalation of air at the site perimeter was $0.02 \mathrm{mrem}(0.2 \mu \mathrm{Sv})$.

Another maximally exposed individual dose is estimated annually to comply with DOE Order 5400.5 (DOE 1993b). This dose assessment uses a multi-media pathway assessment computer model known as GENII (Napier et al. 1998). During 2003, the annual dose to a hypothetical maximally exposed individual was estimated to be $0.06 \mathrm{mrem}(0.6 \mu \mathrm{Sv})$ (Poston et al. 2004). The average individual dose to the population living within $80 \mathrm{~km}(50 \mathrm{mi})$ of Hanford was calculated to be 0.001 mrem $(0.01 \mu \mathrm{Sv})$ (Poston et al. 2004).

\subsubsection{Environmental Monitoring}

Both the Surface Environmental Surveillance Project (SESP) and the near-facility environmental monitoring project conduct Hanford Site environmental monitoring. The SESP conducts monitoring at locations across the Hanford Site, as well as at upwind and downwind locations. The near-facility monitoring project primarily collects samples near known effluent sources. Summaries of the 2003 monitoring data from both of these projects are available in the annual Hanford Site Environmental Report (Poston et al. 2004). The spatial coverage of these two monitoring networks is sufficient to identify some Hanford sources. However, the amount of radiological materials in air is so small that there is no difference between upwind and downwind samples for most radionuclides. Atmospheric dispersion reduces Hanford atmospheric emissions to background levels before those emissions leave the site (Poston et al. 2004). 


\subsection{Geology}

\section{S.D. Cannon, S.P Reidel, A.C. Rohay}

The Hanford Site contains all the main geologic characteristics of the Columbia Basin (DOE 1988). The Columbia Basin is the area bounded by the Cascade Range to the west, the Rocky Mountains to the northeast, and the Blue Mountains to the southeast (Figure 4.2-1). Four major geologic processes occurring over millions of years formed the soil, rocks, and geologic features (ridges and valleys) in the Columbia Basin and therefore the Hanford Site. The area was flooded with numerous basaltic lava flows between 17 and 6 million years ago, as tectonic forces folded the basalt. In this landscape, the ancestral Columbia River flowed across the area leaving behind layers of sediment called the Ringold Formation. Between 1-2 million and 12,000 years ago the area was inundated by a series of Ice-Age floods (including the Missoula floods), which deposited more sediment in what is referred to informally as the Hanford formation.

Lava Flows. Lava flows erupted over a period of time from 17 to 6 million years ago. Under the Hanford Site, basaltic lava deposits (Columbia River Basalt Group) are over 4 km (13,000 ft) thick (Reidel and Hooper 1989), spreading over portions of Idaho, Oregon, and Washington. The Columbia Basin encloses the Columbia River Basalt Group. A depression in the south-central part of the Columbia Basin is referred to as the Pasco Basin. The Pasco Basin is bounded by the Saddle Mountains to the north, Naneum Ridge to the west, Rattlesnake Hills to the south, and the Palouse Slope to the eastgenerally the area north and east of where the Snake River flows into the Columbia River. Geographically, the ridges surrounding the Hanford Site and vicinity define the Pasco Basin, which contains Ringold Formation sediment from the ancestral Columbia River and sediment deposited by the Ice-Age floods.

Crustal Folding. During and after the eruption of the lava flows, the Earth's tectonic forces buckled and folded the basalt in the western Columbia Basin into generally east-west trending, long, narrow ridges (anticlines) and intervening valleys (synclines). Collectively, this is identified as the Yakima Fold Belt.

Ancestral Columbia River Deposits. The Columbia River within the Pasco Basin changed its course over the past 15 million years, depositing gravel, sand, silt, and clay (Tallman et al. 1981, Fecht et al. 1987, DOE 1988, Reidel et al. 1994, Lindsey 1996). Uplifting basalt ridges diverted the course of the Columbia River from a southerly direction (toward Goldendale) to the east (toward Wallula Gap) and left behind the sediment called the Ringold Formation (Fecht et al. 1987). Later regional uplift associated with the Cascade Mountains caused the river to cut through its own earlier deposits (the Ringold Formation) exposing the White Bluffs (Figure 4.2-2). The Columbia River continues to erode the White Bluffs. Groundwater seepage from irrigation along the bluffs also makes them unstable. Consequently, the White Bluffs are landsliding and sloughing into the Columbia River along the shoreline (Hays and Schuster 1987, USBR 2002).

Ice-Age Floods. The Ice-Age floods began as early as 2.5 million years ago (Bjornstad et al. 2001) with the most recent occurring 18,000 to 12,000 years ago. During the freezes and thaws that occurred in the Ice-Age, an ice dam across the Clark Fork River along the Montana-Idaho border formed and failed many times, each time releasing a wall of water that surged southwest through the Columbia Basin, inundating the area that is now the Hanford Site. As the water moved across eastern Washington, it eroded the basalt, forming channels of barren rocky land referred to as the Channeled Scabland. At other localities the water deposited bars of gravel and sand. The waste management facilities in the 200 Areas of the Hanford Site are located on one prominent flood bar of sand and gravel, the Cold Creek bar (Bretz et al. 1956, DOE 1988). Where the waters back-flooded up tributary valleys, they left behind deposits of 


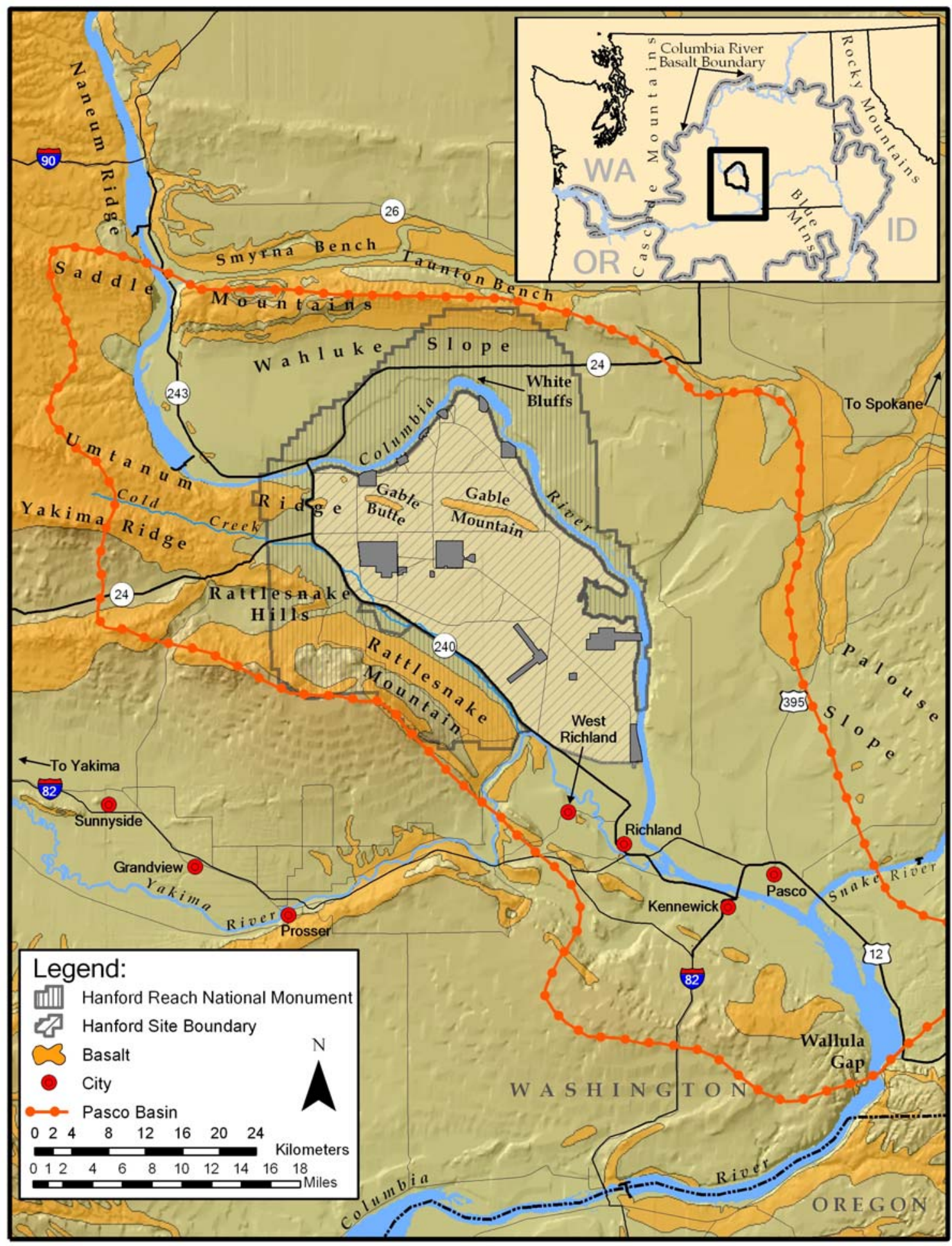

Figure 4.2-1. Geologic Elements of the Pasco Basin Portion of the Columbia Basin, Washington 


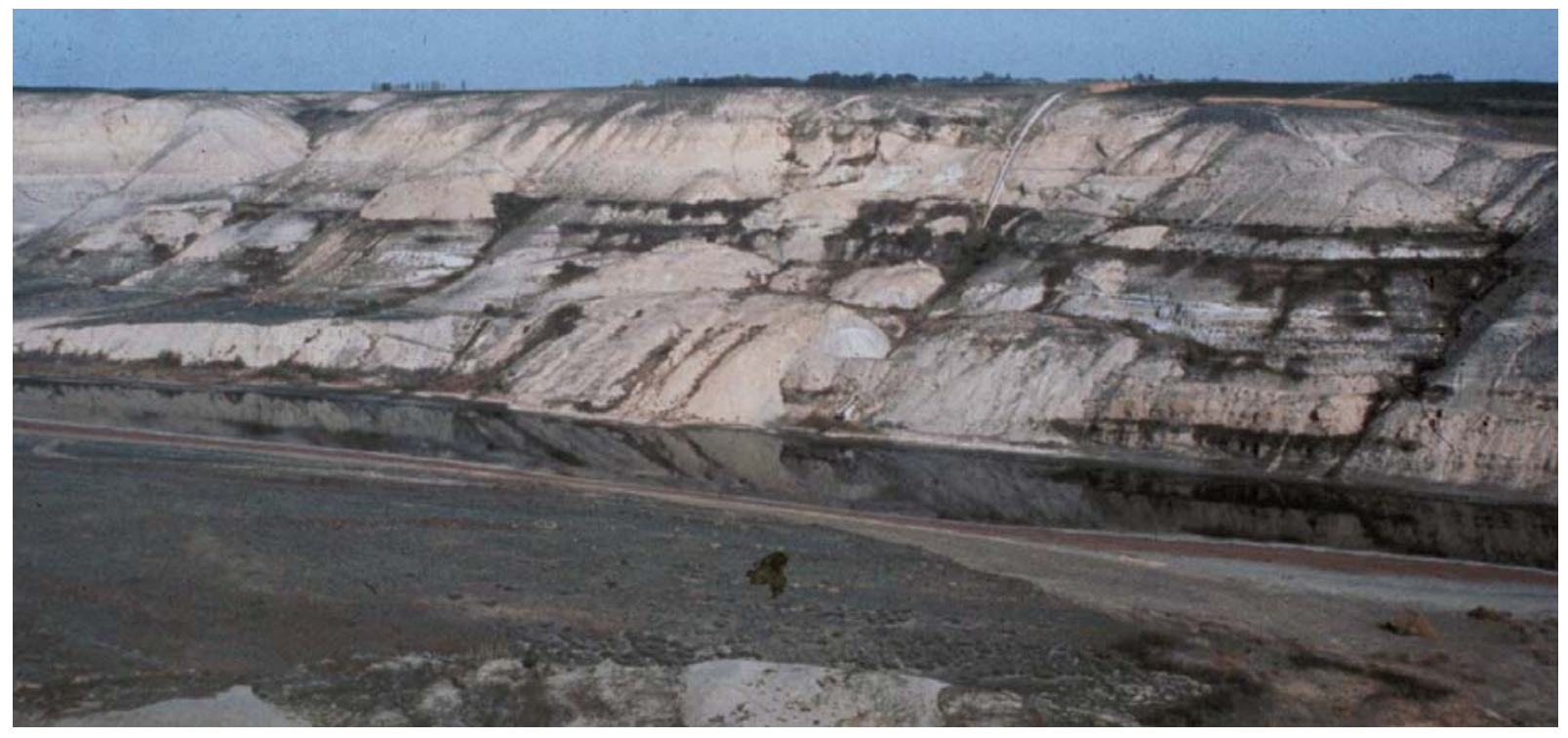

Figure 4.2-2. White Bluffs at the Hanford Site, Washington, Display River and Lake Deposits Left from the Ancestral Columbia River

sand and silt known as the Touchet Beds. Touchet Bed silt deposits lie beneath the southern/central plateau of the Hanford Site.

During the largest Ice-Age floods, most of the southern Pasco Basin was under water (Figure 4.2-3). Ice-Age floods became hydraulically dammed behind Wallula Gap, forming Lake Lewis, which probably lasted a week or less. The largest and most frequent floods came from glacial Lake Missoula in northwestern Montana. Other floods probably escaped down-valley from glacial lakes Clark and Columbia along the northern margin of the Columbia Plateau (Waitt 1980, Baker and Bunker 1985) or down the Snake River from glacial Lake Bonneville (Malde 1968, O’Connor 1993) or from subglacial outbursts (Shaw et al. 1999).

Since the end of the Ice-Age floods, winds have reworked the deposits of sand and silt, shifting them into dune sands in the lower elevations and loess (windblown fine sand and silt) around the margins of the Pasco Basin. Anchoring vegetation has stabilized many sand dunes. Where human activity has disturbed this vegetation, dunes have been reactivated. Most recently, many dunes were reactivated by the removal of vegetation resulting from the June-July 2000 fire at the Hanford Site.

The Hanford Site today is a composite of what the lava flows, earth's tectonic forces, river changes, and Ice-Age floods of long ago left behind and the winds since then have reshaped. The resulting landmass elements that affect and are affected by activities at the Hanford Site are its physical and structural characteristics, and the strata and structure of its rocks.

\subsubsection{Physical and Structural Characteristics}

The physical characteristics of the Hanford Site include the mountains, valleys, and riverbeds. These are the landmarks that usually have recognizable names on topographical maps.

The structural geology of the Hanford Site demonstrates pressure effects on the landmass, which have produced many of the landmarks (Figure 4.2-4). The Earth's internal forces continually push and press the landmass into a variety of shapes: ridges (anticlines) and valleys (synclines) and associated faults 


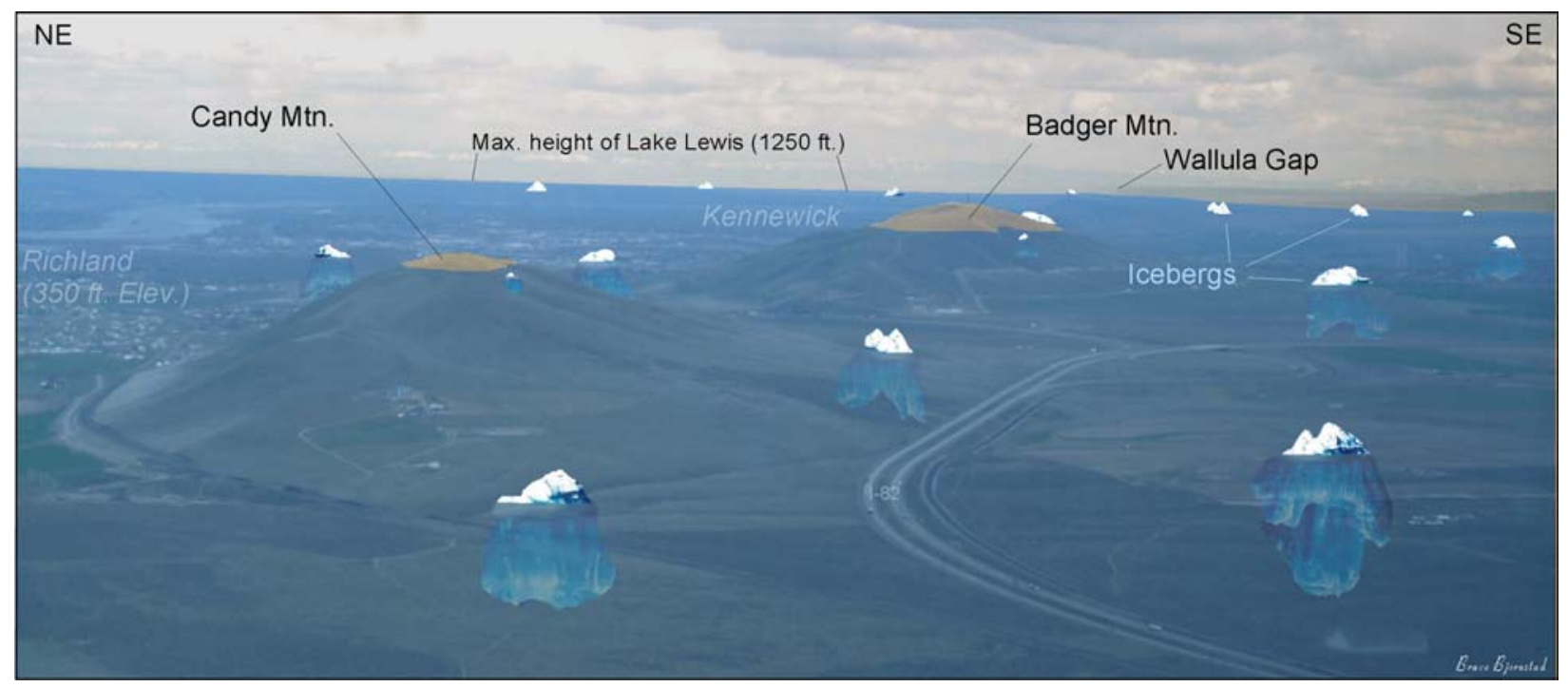

Figure 4.2-3. Conceptualization of an Ice-Age Flood in the Vicinity of the Hanford Site, Washington, which Occurred Intermittently between 18,000-13,000 years ago

Unlike the physical characteristics which define the landscape, structural geology defines the fabric of a landmass.

The fabric of the Hanford Site is defined by the Palouse Slope and Yakima Fold Belt (DOE 1988). The underlying basalt of the Palouse Slope dips toward the central Columbia Basin and exhibits some structural deformation. A wedge of Columbia River basalt underlies the Palouse Slope thinning gradually toward the east and north and lapping onto the adjacent highlands. The Yakima Fold Belt is the name collectively given to all the ridges formed from the folded basaltic lava flows that are found within the central and western parts of the Columbia Basin (DOE 1988).

The main ridges and valleys on the Hanford Site area are as follows:

- Saddle Mountains form the ridge that is the northern boundary of the Pasco Basin and Hanford Site. The Saddle Mountains are an east-west ridge about $110 \mathrm{~km}(68 \mathrm{mi})$ long and 5 km (3 mi) wide.

- Wahluke Slope is on the north side of the Columbia River. The Wahluke Slope is a portion of the synclinal valley of basalt between the Saddle Mountains and Umtanum Ridge.

- Umtanum Ridge makes up the southern boundary of the Wahluke Syncline. Gable Butte and Gable Mountain are the parts of this ridge that lie between the 100 and 200 Areas. Gable Butte and Gable Mountain are folded layers of rock that are the high points along the Umtanum anticlinal ridge, which is buried in places by the Ringold Formation and Hanford formation. The valley north of the Umtanum Ridge is the Wahluke Syncline and the valley south is Cold Creek.

- Rattlesnake Hills, southwest of the Hanford Site, are also the result of folded rock layers. Rattlesnake Mountain, the highest of the Rattlesnake Hills, reaches an elevation of $1110 \mathrm{~m}$ (3660 ft) above mean sea level, the highest elevation in the area. 


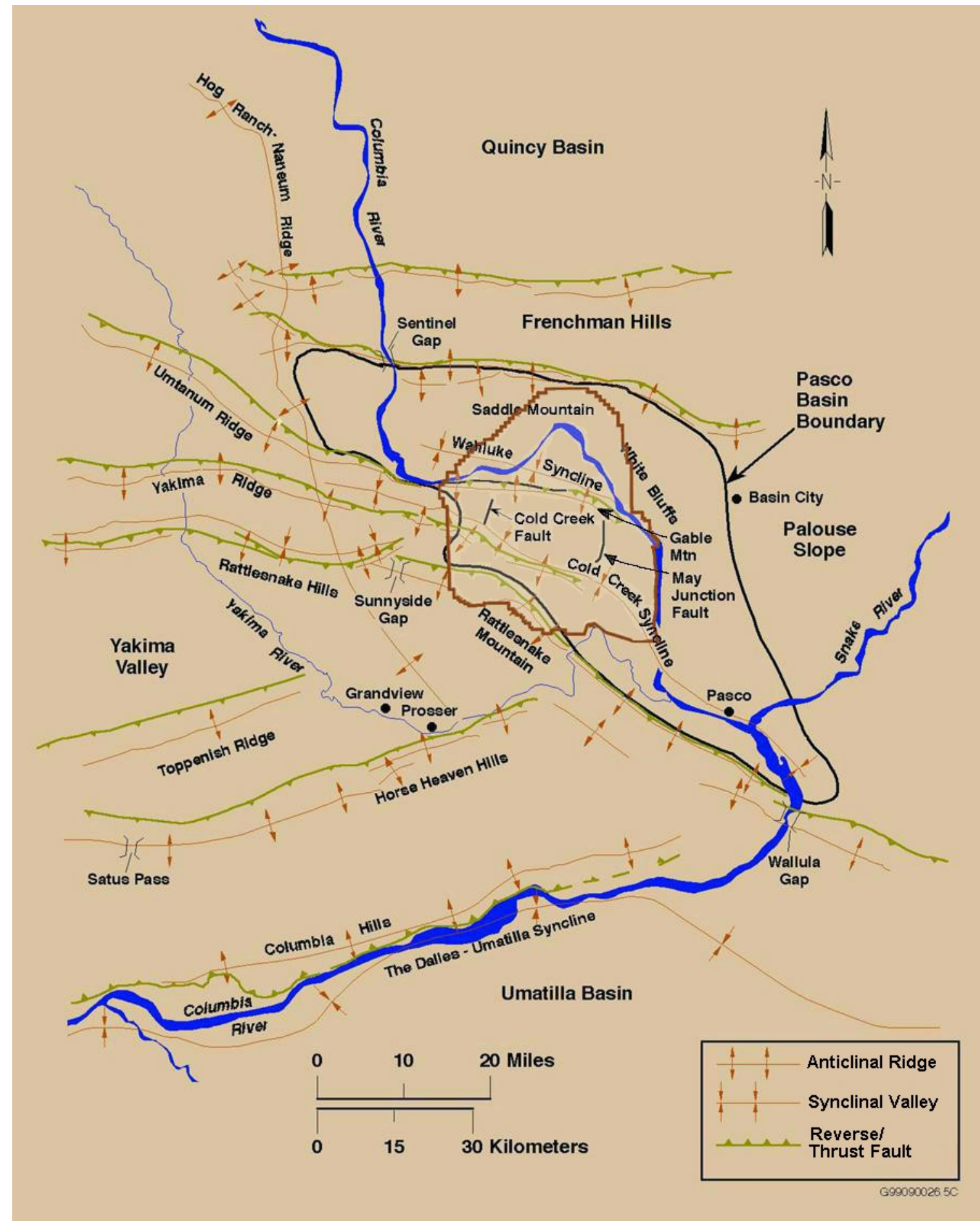

Figure 4-2.4. Physical and Structural Geology of the Hanford Site, Washington (Hartshorn et al. 2002) 
- Cold Creek is a valley of rock and sediment that lies between Umtanum Ridge and Yakima Ridge. Yakima Ridge is one of the anticlinal ridges of the Yakima Fold Belt. The Cold Creek bar, a deposit of Ice-Age flood sediment, lies in this area.

\subsubsection{Strata and Structure of Sediment and Rock}

The strata and structure of the sediment and rocks (Figure 4.2-5) are important characteristics of the Hanford Site (DOE 1988).

\subsubsection{Columbia River Basalt Group}

The bedrock of the Hanford Site is basalt. Beneath the Hanford Site lay a minimum of 100 basalt flows with a maximum combined thickness of more than $4 \mathrm{~km}(\sim 13,000 \mathrm{ft})$ (DOE 1988), all part of the Columbia River Basalt Group.

To organize the many basalt deposits into a consistent nomenclature, geologists have named and grouped them based on their physical and chemical properties. The basalt deposit closest to the surface at the Hanford Site, and therefore most often referred to, is Saddle Mountains Basalt (Figure 4.2-5). Saddle Mountains Basalt consists of ten distinct basaltic lava deposits (members). The most recent basalt flow underlying most of the Hanford Site is the Elephant Mountain Member of the Saddle Mountains Basalt. A younger basalt flow, the Ice Harbor Member, is found in the southern portion of the site near the 300 Area (DOE 1988).

In addition to basalt, the Hanford Site has sedimentary formations. Some of the sediment at the Hanford Site is found between the basaltic lavas and is called the Ellensburg Formation. The majority of the sediment is above the basalt with the Ringold Formation overlain by the Cold Creek unit, and topped with the Hanford formation (Figure 4.2-5). Understanding the formations, along with clastic dikes and the soil of the Hanford Site, contributes to our understanding of how, for example, contaminants might travel in the 100, 200, and 300 Areas.

\subsubsection{Ellensburg Formation}

The Ellensburg Formation is the sediment found interbedded with the Columbia River Basalt Group. The Ellensburg Formation formed as early as 17 million years ago, although the youngest portion on the Hanford Site may have formed as recently as 8 million years ago (DOE 1988). The Ellensburg Formation was created when volcanic rock and sediment from uplands surrounding the Columbia Plateau interfingered with the basalt of the Columbia River Basalt Group (Swanson et al. 1979a, b). The thickest accumulations of the Ellensburg Formation lie along the western margin of the Columbia Basin. While deposition along the western margin was primarily from volcanic debris flows and related stream and sheet floods, no volcanic debris flows have been identified at the Hanford Site (Reidel et al. 1994). Volcanic ash known as tuff is the dominant material in the Hanford Site portion of the Ellensburg Formation. The Ellensburg Formation is commonly exposed between basalt flows along the ridges of the Yakima Fold Belt.

\subsubsection{Hanford Formation, Cold Creek Unit, and Ringold Formation}

Sediments overlying basalt in the Pasco Basin and Hanford Site include the Ringold Formation, Cold Creek unit, and the Hanford formation. These formations are primarily exposed in the lower elevation areas around the Hanford Site, including White Bluffs. 


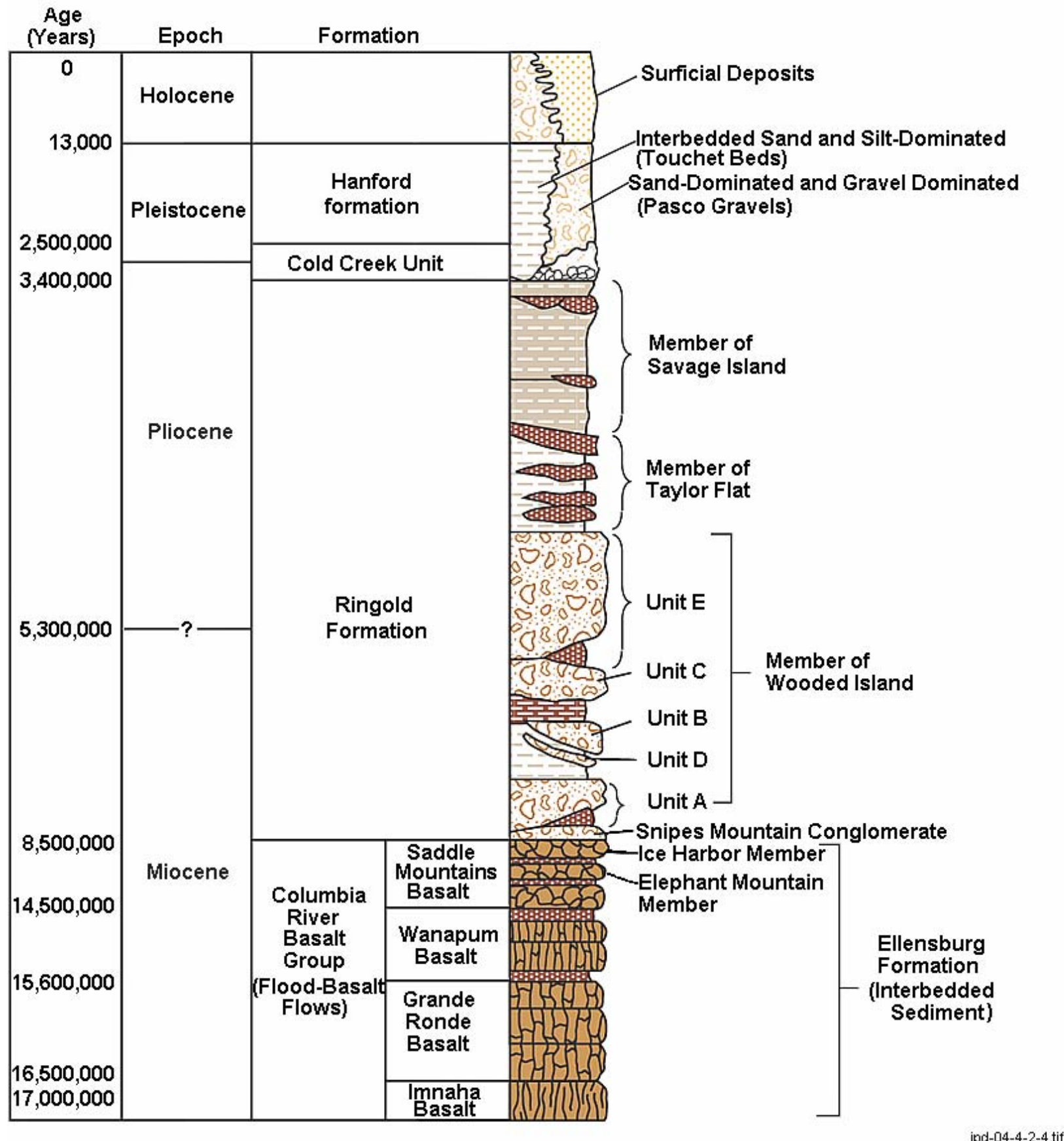

Figure 4.2-5. Strata of Rocks and Sediment at the Hanford Site, Washington 
Ringold Formation. The Ringold Formation formed between 8.5 and about 3.0 million years ago and consists of gravel, sand, silt, and clay deposited across portions of the Columbia Basin by the ancestral Columbia River (Tallman et al. 1981, DOE 1988, Lindsey 1996). For detailed descriptions of the Ringold Formation see DOE (1988) and Lindsey $(1995,1996)$. Although exposures of the Ringold Formation are limited to White Bluffs within the central Pasco Basin and to Smyrna and Taunton Benches along the Saddle Mountains north of the Pasco Basin, extensive data on the Ringold Formation are available from boreholes. The Ringold Formation at the Hanford Site is up to $185 \mathrm{~m}(600 \mathrm{ft})$ thick. Erosion removed the upper 300 feet of the Ringold Formation over most of the Hanford Site. Along White Bluffs, the Ringold Formation is up to 285 m (900 ft) thick (DOE 1988).

Cold Creek unit. The Cold Creek unit (DOE 2002b) includes all material underlying the Hanford formation, overlying the Ringold Formation in the vicinity of 200 West, and may extend over most of the central Pasco Basin. The Cold Creek unit distinguishes itself from the Hanford and Ringold formations because it was formed when the Ringold Formation was eroding and relatively little was being deposited at the Hanford Site. This subunit is found locally in the subsurface of the Cold Creek synclinal valley. Distribution of the Cold Creek unit depends in part on erosion and weathering of the underlying Ringold Formation and post-depositional erosion by the Ice-Age floods (Slate 1996). The thickness of the Cold Creek deposit ranges from 0-20 m (0-66 ft). Locally the Cold Creek unit contains very hard rock that formed during soil development as precipitation evaporated and left behind minerals forming what geologists call caliche or hardpan. This layer can influence contaminant migration by slowing its rate of downward movement and potentially diverting contaminants laterally (Slate 1996). The thin, fine-grained layers in the Hanford formation also cause lateral migration (Serne et al. 2002).

Hanford formation. The Hanford formation is the informal name for the strata that lie on top of Cold Creek unit above the Ringold Formation. The Ice-Age floods inundated the Hanford Site a number of times beginning as early as 1-2 million years ago (Bjornstad et al. 2001). The last major flood sequence occurred about 12,000 years ago. When the Ice-Age floodwaters entered the Pasco Basin, they quickly became impounded behind Wallula Gap, which was too restrictive for the volume of water

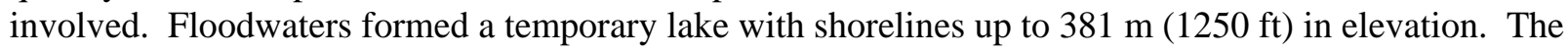
lake only lasted a few days (O’Connor and Baker 1992). After the floodwater receded, the Hanford formation deposits were left in the low-lying areas over most of the Hanford Site.

On the Hanford Site the Hanford formation is thickest in the vicinity of the 200 Areas where it is up to $100 \mathrm{~m}$ (300 ft) thick (DOE 2002b). Gravel, sand, and silt (Touchet Beds) dominate the Hanford formation (Reidel et al. 1992). The different sediment types of the Hanford formation commonly interfinger laterally. The relative proportion of each sediment type at any given location is related to its distance from main high-energy flows at the time of deposition (DOE 2002b). Generally, gravel was deposited in the center of the Pasco Basin, while finer grained sand and silt were deposited along the margins of the basin.

\subsubsection{Clastic Dikes}

Clastic dikes are fissures filled with sand, silt, clay, and coarser debris. They are commonly associated with, but not restricted to, Ice-Age flood deposits in the Columbia Basin. Many dikes occur as sharp-walled, near-vertical tabular bodies filled with multiple layers of unconsolidated sediment. Thin clay/silt linings separate the margins of dikes and internal layers (Fecht et al. 1999). Dikes vary in width from less than $1 \mathrm{~mm}(0.039 \mathrm{in}$.) to greater than $2 \mathrm{~m}(6.5 \mathrm{ft})$. Vertical extents range from less than $1 \mathrm{~m}$

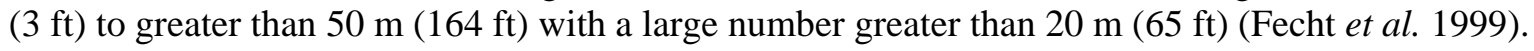


Clastic dikes are complex natural structures that may facilitate or retard the migration of contaminants. Where large leaks have occurred, clastic dikes may also act as barriers, limiting the extensive lateral spreading of contaminants caused by horizontal layers of Hanford sediment (Murray et al. 2002, 2003; Ward et al. 2002a, 2002b).

\subsubsection{100 Areas Strata and Structure}

The 100 Areas are located along the Columbia River in the northern portion of the Hanford Site (Figure 4.0-1). With the exception of the 100-B/C Area, the 100 Areas lie on the north limb of the Wahluke synclinal valley. The 100-B/C Area lies over the axis of the synclinal valley. The top of the basalt in the 100 Areas ranges in elevation from $46 \mathrm{~m}(150 \mathrm{ft})$ near the $100-\mathrm{H}$ Area to $-64 \mathrm{~m}(-210 \mathrm{ft})$ below sea level near the 100-B/C Area. The Ringold Formation and Hanford formation occur throughout this area. The Cold Creek unit deposits have not been identified in the 100 Areas.

The Ringold Formation shows a marked west-to-east variation in the 100 Areas (Lindsey 1992). The main channel of the ancestral Columbia River flowed along Umtanum Ridge and through the 100-B/C and 100-K Areas before turning south to flow along Gable Mountain and/or through the Gable MountainGable Butte gap. This main channel deposited coarse-grained sand and gravel of the Ringold Formation. Farther to the north and east, however, the Ringold sediment is gradually dominated by the fine-grained silt deposits and associated ancient soil with the 100-H Area showing almost no gravel.

\subsubsection{200 Areas Strata and Structure}

The geology in the 200 West Area is notably different from that in the 200 East Area even though they are separated by a distance of only $6 \mathrm{~km}$ (4 mi) (DOE 1988) (Figure 4.0-1). The 200 West Area has sections containing all three formations including most of the Ringold Formation as well as the Cold Creek unit and the Hanford formation (DOE 1988).

In the 200 East Area, some Ringold Formation is present in the southern portion but has been completely eroded in the northern part. On the north side of the 200 East Area, the Hanford formation rests directly on the basalt, and no Ringold sediment is present. Erosion by the ancestral Columbia River and Ice-Age flooding are believed to have removed the Ringold Formation from this area. Material of questionable origin overlies basalt within the B-BX-BY Waste Management Area (Wood et al. 2000). This material may be equivalent or partially equivalent to the Cold Creek unit or it may represent the earliest ice-age flood deposits overlain by a locally thick sequence of fine-grained non-flood deposits. This unit is referred to informally as Hanford-Cold Creek deposits.

\subsubsection{300 Area Strata and Structure}

The 300 Area is located in the southeastern portion of the Hanford Site (Figure 4.0-1). The 300 Area lies next to the Columbia River and sits on the Hanford formation, which in turn overlies the Ringold Formation and Columbia River Basalt Group. The Columbia River Basalt Group and Ringold Formation beneath the 300 Area are folded into the Cold Creek synclinal valley that lies near the intersection of the Yakima Fold Belt and the un-deformed Palouse Slope (Figure 4.2-3) (DOE 1988). Over most of the Hanford Site, the uppermost basalt flows belong to the Elephant Mountain Member, but near the 300 Area younger flows belonging to the Ice Harbor Member of the Saddle Mountains Basalt are present, causing the overlying sediment layers to be relatively thin (Schalla et al. 1988). Both Ringold Formation and Hanford formation sediment is found in the 300 Area. 


\subsubsection{Surface Soil}

Hajek (1966) ${ }^{(a)}$ describes 15 different surface soil types on the Hanford Site, varying from sand to silty and sandy loam (Figure 4.2-6). Various classifications, including land use, are also given in Hajek (1966).

Soil types found on the Hanford Site include the following:

Ritzville Silt Loam. Ritzville silt loam, a dark-colored silt loam soil, is found midway up the slopes of the Rattlesnake Hills. It was formed under bunch grass from silty wind-laid deposits mixed with small amounts of volcanic ash. Characteristically greater than $150 \mathrm{~cm}$ (60 in.) deep, Ritzville silt loam may be separated by bedrock that occurs between 75 and $150 \mathrm{~cm}$ (30 and $60 \mathrm{in}$.).

Rupert Sand. Rupert sand, brown-to grayish-brown coarse sand grading to dark grayish-brown at a depth of $90 \mathrm{~cm}$ (35 in.), is one of the most extensive soil types on the Hanford Site. Rupert sand developed under grass, sagebrush, and hopsage in coarse sandy alluvial deposits that were mantled by wind-blown sand and formed hummocky terraces and dune-like ridges.

Hezel Sand. Hezel sand, similar to Rupert sands, is laminated grayish-brown strongly calcareous silt loam subsoil usually encountered within $100 \mathrm{~cm}$ (39 in.) of the surface. When found as surface soil it is very dark brown. Hezel sand was formed in wind-blown sands that mantled lake-laid sediment.

Koehler Sand. Koehler sand is similar to other sandy soil found on the Hanford Site, differing in that it mantles a lime-silica cemented hardpan layer. It was developed in a wind-blown sand mantle and exhibits a very dark grayish-brown surface layer and is somewhat darker than Rupert sand. Its calcareous subsoil is usually dark grayish-brown at about $45 \mathrm{~cm}$ (18 in.).

Burbank Loamy Sand. Burbank loamy sand is a dark-colored, coarse-textured soil underlain by gravel. Its surface soil is usually about $40 \mathrm{~cm}$ (16 in.) thick but may be as much as $75 \mathrm{~cm}$ (30 in.) thick. The gravel content of its subsoil ranges from 20 percent to 80 percent.

Ephrata Sandy Loam. Ephrata sandy loam is found on level topography on the Hanford Site. Its surface is darkly colored and its subsoil is dark grayish-brown medium-textured soil underlain by gravelly material that may continue for many feet.

Lickskillet Silt Loam. Lickskillet silt loam occupies the ridge slopes of Rattlesnake Hills and slopes greater than $765 \mathrm{~m}$ (2509 ft) elevation. It is similar to Kiona silt loam except the surface soil is darker. Lickskillet silt loam is shallow over basalt bedrock and exhibits numerous basalt fragments throughout the profile.

Ephrata Stony Loam. Ephrata stony loam is similar to Ephrata sandy loam. It differs in that many large hummocky ridges are made up of debris released from melting glaciers. Areas of Ephrata stony loam located between hummocks contain many boulders several feet in diameter.

Pasco Silt Loam. Pasco silt loam is poorly drained very dark grayish-brown soil formed in recent alluvial material. Its subsoil is variable, consisting of stratified layers. Only small areas of Pasco silt loam are found on the Hanford Site, located in low areas adjacent to the Columbia River.

(a) The soil classifications given in Hajek (1966) have not been updated to reflect current reinterpretations of soil classifications. Until the surface soil on the Hanford Site is resurveyed, the descriptions presented in Hajek (1966) will continue to be used. 


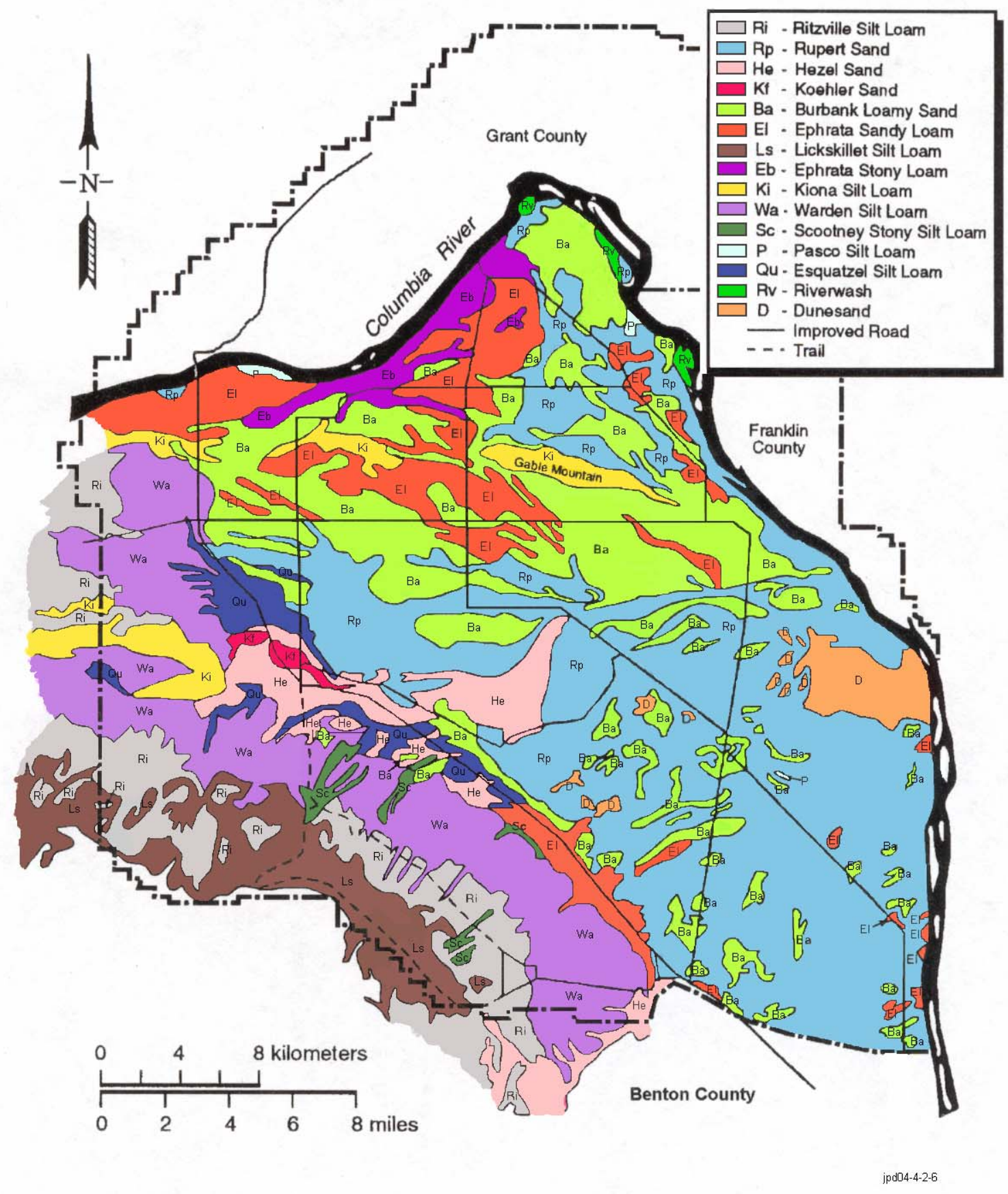

Figure 4.2-6. Map of Soil Types at the Hanford Site, Washington (based on Hajek 1966) 
Kiona Silt Loam. Kiona silt loam occupies steep slopes and ridges. Its surface soil is very dark grayish-brown and about $10 \mathrm{~cm}$ (4 in.) thick and has dark-brown subsoil containing basalt fragments 30 cm (12 in.) and larger in diameter. Many basalt fragments are found in its surface layer and basalt rock outcrops are often present. Kiona silt loam is a shallow stony soil normally occurring in association with Ritzville and Warden soil.

Warden Silt Loam. Warden silt loam is dark grayish-brown soil with a surface layer usually $23 \mathrm{~cm}$ (9 in.) thick. Its silt loam subsoil becomes strongly calcareous at about $50 \mathrm{~cm}$ (20 in.) and becomes lighter colored. Granitic boulders are found in many areas. Warden silt loam is usually greater than $150 \mathrm{~cm}$ (60 in.) deep.

Scootney Stony Silt Loam. Scootney stony silt loam developed along the north slope of the Rattlesnake Hills and is usually confined to floors of narrow draws or small fan-shaped areas where draws open onto plains. It is severely eroded with numerous basaltic boulders and fragments exposed and surface soil is usually dark grayish-brown grading to grayish-brown within the subsoil.

Esquatzel Silt Loam. Esquatzel silt loam is a deep dark-brown soil formed in recent alluvium derived from loess and lake sediment. Its subsoil grades to dark grayish-brown in many areas, but the color and texture of the subsoil are variable because of the stratified nature of the alluvial deposits.

Riverwash. Riverwash is wet, periodically flooded areas of sand, gravel, and boulder deposits that make up overflowed islands in the Columbia River and adjacent land.

Dunesand. Dunesand is a miscellaneous land type that consists of hills or ridges of sand-sized particles drifted and piled up by wind. They are either actively shifted or so recently fixed or stabilized that no soil layers have developed.

\subsubsection{Seismicity}

The historic record of earthquakes in the Pacific Northwest dates from about 1840. The early part of this record is based on newspaper reports of human perception of shaking and structural damage as classified using the Modified Mercalli Intensity (MMI) scale; the early record is probably incomplete because the region was sparsely populated. The historical record appears to be complete since 1905 for MMI V and since 1890 for MMI VI (Rohay 1989). Seismograph networks did not start providing earthquake locations and magnitudes of earthquakes in the Pacific Northwest until about 1960. A comprehensive network of seismic stations that provides accurate locating information for most earthquakes of magnitude $>2.5$ was installed in eastern Washington during 1969. DOE (1988) provides a summary of the seismicity of the Pacific Northwest, a detailed review of the seismicity in the Columbia Plateau region and the Hanford Site, and a description of the seismic networks used to collect the data.

Large earthquakes (magnitude $M \geq 7$ ) in the Pacific Northwest have occurred near Puget Sound, Washington, and near the Rocky Mountains in eastern Idaho and western Montana. Two large earthquakes occurred beneath Vancouver Island. The first occurred during 1918 and had a maximum MMI VII (estimated magnitude M 7.0). The second earthquake occurred in 1946 and had a maximum MMI VII (over a wider area) and magnitude $\mathrm{M}=7.3$. The depth of these early, large earthquakes beneath Vancouver Island is uncertain. Another large earthquake occurred at a depth of $53 \mathrm{~km}$ (33 mi) near Olympia, Washington, in 1949 that had a maximum MMI VIII and a magnitude $\mathrm{M}=7.1$. A smaller ( $M=6.5$ ), deep (63 km [39 mi]) earthquake occurred during 1965 between Seattle and Tacoma. These events may all be related to deformation within the subducting Juan de Fuca Plate at depth beneath the Vancouver Island/Puget Sound region. 
Two large events occurred on the eastern boundary of the Pacific Northwest, in the Rocky Mountains. These were the 1959 Hebgen Lake earthquake in western Montana, which had a Richter magnitude of 7.5 and an MMI X, and the 1983 Borah Peak earthquake in eastern Idaho, which had a Richter magnitude of 7.3 and an MMI IX.

Closer to the Hanford Site, a significant large earthquake of uncertain location occurred in northcentral Washington in 1872. This event had an estimated maximum MMI ranging from VIII to IX and an estimated Richter magnitude of approximately 7.4. The distribution of intensities suggests a location within a broad region between Lake Chelan, Washington, and the British Columbia border. Evidence of landslides near Lake Chelan suggests a location near there.

On February 28, 2001, there was a moderate $(\mathrm{M}<7)$, deep earthquake near Olympia (termed the Nisqually earthquake). This earthquake was located at a depth of $52 \mathrm{~km}$ (32 mi) and had a magnitude of 6.8; reported ground shaking effects reached MMI VIII. This event is similar to those in 1949 and 1965 described above. Actual ground motions from this earthquake measured at the Hanford Site are reported at the end of this section.

Seismicity of the Columbia Plateau, as determined by the rate of earthquakes per area and the historical magnitude of these events, is relatively low when compared with other regions of the Pacific Northwest, the Puget Sound area, and western Montana/eastern Idaho. The largest known earthquake in the Columbia Plateau occurred in 1936 near Milton-Freewater, Oregon. This earthquake had a Richter magnitude of 5.75 and a maximum MMI of VII, and was followed by a number of aftershocks indicating a northeast-trending fault plane.

Other earthquakes with Richter magnitudes $\geq 5$ and/or MMIs of VI occurred along the boundaries of the Columbia Plateau in a cluster near Lake Chelan in 1872 extending into the northern Cascade Range, in northern Idaho and Washington, and along the boundary between the western Columbia Plateau and the Cascade Range. Three MMI VI earthquakes have occurred within the Columbia Plateau, including one event in the Milton-Freewater, Oregon, region in 1921; one near Yakima, Washington, in 1892; and one near Umatilla, Oregon, in 1893 (Figure 4.2-7). In the central portion of the Columbia Plateau, the largest earthquakes near the Hanford Site are two earthquakes that occurred during 1918 and 1973. These two events were magnitude 4.4 and intensity V and were located north of the Hanford Site near Othello.

Earthquakes often occur in spatial and temporal clusters in the central Columbia Plateau and are termed "earthquake swarms." The region north and east of the Hanford Site is a region of concentrated earthquake swarm activity, but earthquake swarms have also occurred in several locations within the Hanford Site. The frequency of earthquakes in a swarm tends to gradually increase and decay with no one outstanding large event within the sequence. Roughly $90 \%$ of the earthquakes in swarms have Richter magnitudes of 2 or less. These earthquake swarms generally occur at shallow depths, with 75\% of the events located at depths $<4 \mathrm{~km}(2.5 \mathrm{mi})$. Each earthquake swarm typically lasts several weeks to months, consists of several to 100 or more earthquakes, and the locations are clustered in an area 5 to $10 \mathrm{~km}$ (3 to $6 \mathrm{mi}$ ) in lateral dimension. Often, the longest dimension of the swarm area is elongated in an east-west direction. However, detailed locations of swarm earthquakes indicate that the events occur on fault planes of variable orientation and not on a single, through-going fault plane.

Earthquakes in the central Columbia Plateau also occur to depths of about $30 \mathrm{~km}$ (18.6 mi). These deeper earthquakes are less clustered and occur more often as single, isolated events. Based on seismic 


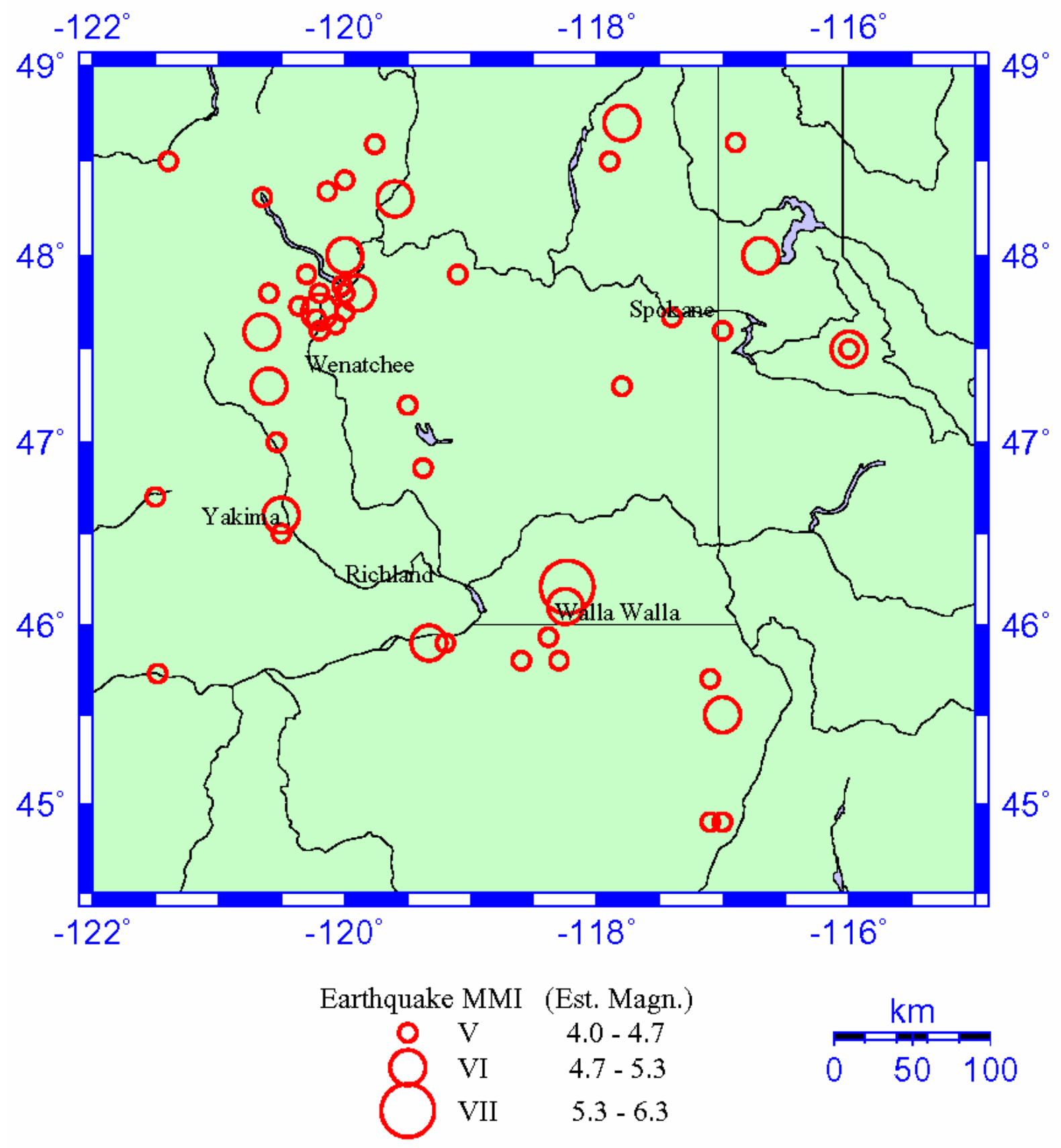

Figure 4.2-7. Historical Earthquake Activity of the Columbia Basin, Washington, and Surrounding Areas Showing All Earthquakes between 1850 and March 20, 1969, with a Modified Mercalli Intensity of V or Larger and/or a Richter Magnitude of 4 or Larger (Rohay 1989) 
refraction surveys in the region, the shallow earthquake swarms are occurring in the Columbia River Basalts and the deeper earthquakes are occurring in crustal layers below the basalts.

The spatial pattern of seismicity in the central Columbia Plateau suggests an association of the shallow swarm activity with the east-west oriented Saddle Mountain anticline. However, this association is complex, and the earthquakes do not delineate a throughgoing fault plane that would be consistent with the faulting observed on this structure.

Earthquake focal mechanisms in the central Columbia Plateau generally indicate reverse faulting on east-west planes, consistent with a north-south-directed maximum compressive stress and with the formation of the east-west oriented anticlinal folds of the Yakima Fold Belt (Rohay 1987). However, earthquake focal mechanisms indicate faulting on a variety of fault plane orientations.

Earthquake focal mechanisms along the western margin of the Columbia Plateau also indicate northsouth compression, but here the minimum compressive stress is oriented east to west, resulting in strikeslip faulting (Rohay 1987). Geologic studies indicate an increased component of strike-slip faulting in the western portion of the Yakima Fold Belt. Earthquake focal mechanisms in the Milton-Freewater region to the southeast indicate a different stress field, one with maximum compression directed east-west instead of north-south.

Estimates for earthquake potential of structures and zones in the central Columbia Plateau have been developed during the licensing of nuclear power plants at the Hanford Site. In reviewing the operating license application for the Washington Public Power Supply System Washington Nuclear Plant (WNP)-2 (now Energy Northwest Columbia Generating Station), the U.S. Nuclear Regulatory Commission (NRC) concluded that four earthquake sources should be considered for seismic design: the Rattlesnake-Wallula alignment, Gable Mountain, a floating earthquake in the tectonic province, and a swarm area (NRC 1982).

For the Rattlesnake-Wallula alignment, which passes along the southwest boundary of the Hanford Site, the NRC estimated a maximum Richter magnitude of 6.5; for Gable Mountain, an east-west structure that passes through the northern portion of the Hanford Site, a maximum Richter magnitude of 5.0 was estimated. These estimates were based upon the inferred sense of slip, the fault length, and/or the fault area. The floating earthquake for the tectonic province was developed from the largest event located in the Columbia Plateau, the Richter magnitude 5.75 Milton-Freewater earthquake. The maximum swarm earthquake for the purpose of Columbia Generating Station seismic design was a Richter magnitude 4.0 event, based on the maximum swarm earthquake in 1973 (Figure 4.2-8). (The NRC concluded that the actual magnitude of this event was smaller than estimated previously.)

Probabilistic seismic hazard analyses have been used to determine the seismic ground motions expected from multiple earthquake sources, and these are used to design or evaluate facilities on the Hanford Site. The most recent Hanford Site-specific hazard analysis (Geomatrix 1994, 1996) estimated that $0.10 \mathrm{~g}$ ( $1 \mathrm{~g}$ is the acceleration of gravity) horizontal acceleration would be experienced on average every $500 \mathrm{yr}$ (or with a $10 \%$ chance every $50 \mathrm{yr}$ ). This study also estimated that $0.2 \mathrm{~g}$ would be experienced on average every $2500 \mathrm{yr}$ (or with a $2 \%$ chance in $50 \mathrm{yr}$ ). These estimates are in approximate agreement with the results of national seismic hazard maps produced by the U.S. Geological Survey (USGS 1996).

The February 28, 2001, Nisqually earthquake in Puget Sound was recorded by a network of strong motion accelerographs at the Hanford Site. Peak horizontal accelerations measured ranged from 0.0016 to $0.0055 \mathrm{~g}$. These levels of ground shaking are considerably less than the design and evaluation values described above (PNNL Seismic Monitoring Team 2001). 


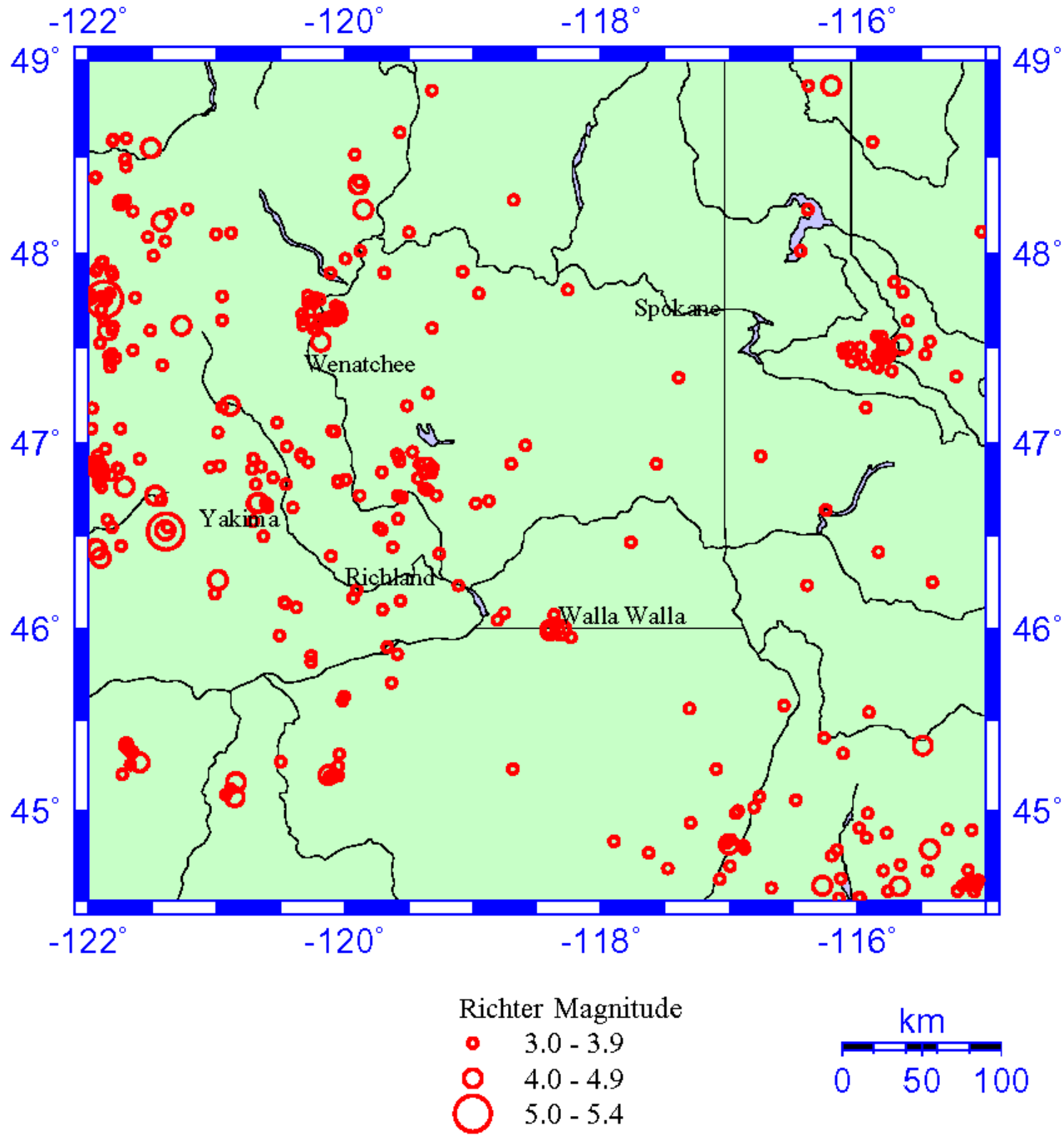

Figure 4.2-8. Earthquake Activity of the Columbia Basin, Washington, and Surrounding Areas as Measured by Seismographs from March 20, 1969, to December 31, 2000, with Richter Magnitude 3 or Larger (UWGP 2001, CNSS 2001) 


\subsection{Hydrology}

\section{P.D. Thorne, D G. Horton, and G.V. Last}

Characterization of hydrology at the Hanford Site includes surface water, the vadose zone, and groundwater. The vadose zone is the unsaturated or partially saturated region between the ground surface and the saturated zone. Water in the vadose zone is called soil moisture. Groundwater refers to water within the saturated zone. Permeable saturated units in the subsurface are called aquifers.

\subsubsection{Surface Water}

Surface water at Hanford includes the Columbia River, springs, and ponds. Intermittent surface streams, such as Cold Creek, may also contain water after large precipitation or snowmelt events. In addition, the Yakima River flows along a short section of the southern boundary of the Hanford Site (Figure 4.3-1), and there is surface water associated with irrigation east and north of the Site.

\subsubsection{Columbia River}

The Columbia River is the second largest river in the contiguous United States in terms of total flow and is the dominant surface-water body on the Hanford Site. The original selection of the Hanford Site for plutonium production and processing was based, in part, on the abundant water provided by the Columbia River. The existence of the Hanford Site has precluded development of this section of the river for hydroelectric production and barge transportation.

Originating in the Canadian Rockies of southeastern British Columbia, Canada, the Columbia River drains a total area of approximately $680,000 \mathrm{~km}^{2}\left(262,480 \mathrm{mi}^{2}\right)$ en route to the Pacific Ocean. Most of the Columbia River is impounded by 11 dams within the United States: 7 upstream and 4 downstream of the Hanford Site. Priest Rapids is the nearest upstream dam, and McNary is the nearest downstream dam. Lake Wallula, the impoundment created by McNary Dam, extends upstream past Richland, Washington, to the southern part of the Hanford Site. Except for the Columbia River estuary, the only unimpounded stretch of the river in the United States is the Hanford Reach, which extends from Priest Rapids Dam downstream approximately $82 \mathrm{~km}$ (51 mi) to Lake Wallula, north of Richland, Washington. The Hanford Reach of the Columbia River was recently incorporated into the land area established as the Hanford Reach National Monument.

Flows through the Hanford Reach fluctuate significantly and are controlled primarily by releases from three upstream storage dams: Grand Coulee in the United States, and Mica and Keenleyside in Canada. Storage dams on tributaries of the Columbia River also affect flows. Flows in the Hanford Reach are directly affected by releases from Priest Rapids Dam; however, Priest Rapids operates as a run-of-theriver dam rather than a storage dam. Flows are controlled for purposes of power generation and to promote salmon egg and embryo survival ${ }^{(a)}$. Columbia River flow rates near Priest Rapids during the 83year period from 1917 to 2000 averaged nearly $3360 \mathrm{~m}^{3} / \mathrm{s}\left(120,000 \mathrm{ft}^{3} / \mathrm{s}\right)$. Daily average flows during this period ranged from 570 to $19,500 \mathrm{~m}^{3} / \mathrm{s}\left(20,000\right.$ to $\left.690,000 \mathrm{ft}^{3} / \mathrm{s}\right)$. The lowest and highest flows occurred before the construction of upstream dams. During the 10-year period from 1991 through 2000, the average flow rate was also about $3360 \mathrm{~m}^{3} / \mathrm{s}\left(120,000 \mathrm{ft}^{3} / \mathrm{s}\right)$. Daily average flows for 1993 through April 2004 are plotted in Figure 4.3-2.

\footnotetext{
(a) The Vernita Bar Agreement (signed June 16, 1988, by the U.S. Department of Energy, federal and state agencies, Tribal governments, and public utility districts in Grant, Chelan, and Douglas counties) was created to prevent redds (salmon nests) from being left high and dry when river flows fluctuate to meet peak power demands.
} 


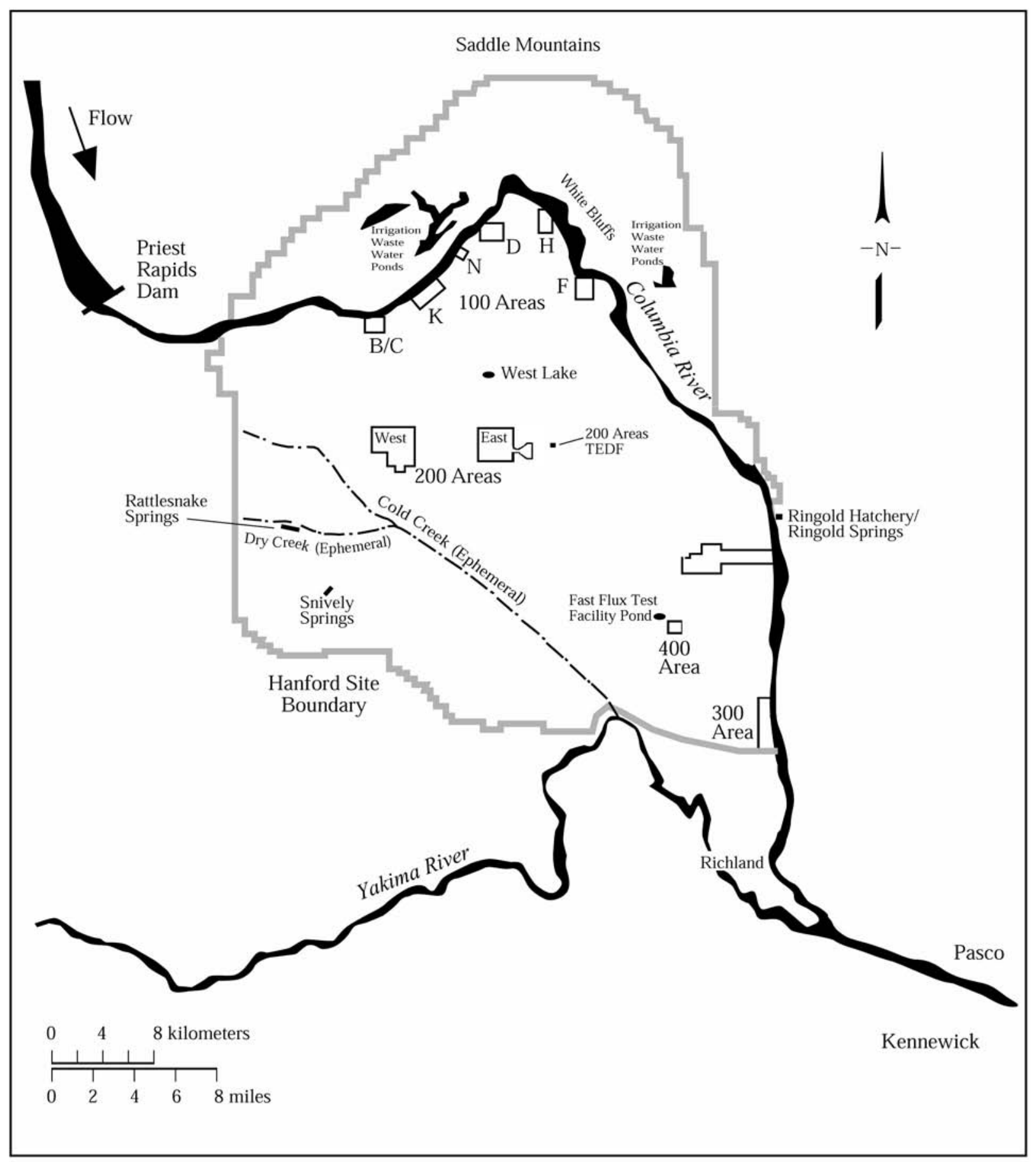

Figure 4.3-1. Surface Water Features on the Hanford Site, Washington, including Rivers, Ponds, Major Springs, and Ephemeral Streams 


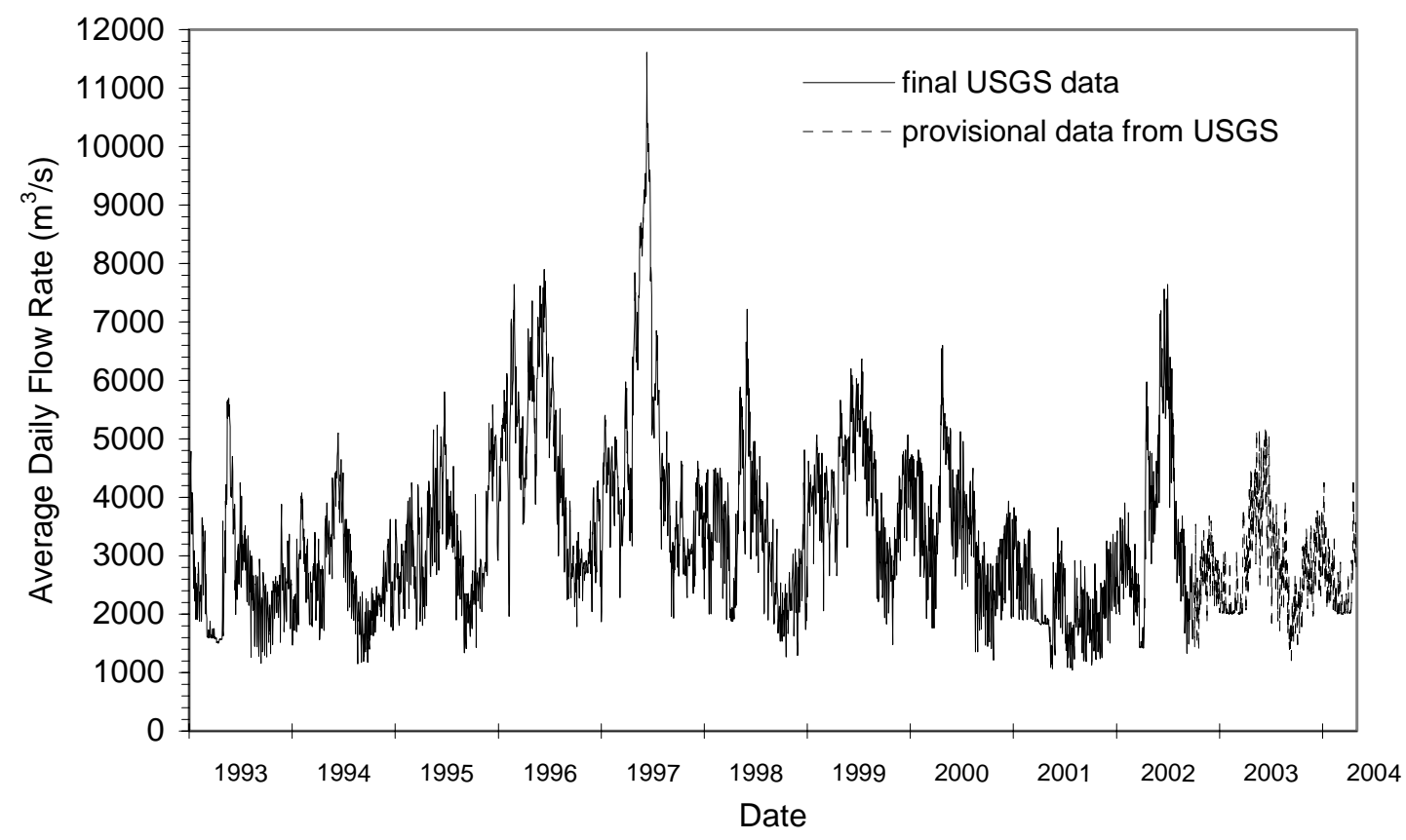

Figure 4.3-2. Average Daily Flow for the Columbia River downstream of Priest Rapids Dam, Washington, from January 1993 through April 2004 (data from USGS 2004, provisional data not yet reviewed and subject to change) $\left(1 \mathrm{~m}^{3} / \mathrm{s}=35.3 \mathrm{ft}^{3} / \mathrm{s}\right)$

During 1996 and 1997, exceptionally high spring runoff resulted from larger than normal snowpacks. The highest daily average flow rate during 1997 was nearly $11,750 \mathrm{~m}^{3} / \mathrm{s}\left(415,000 \mathrm{ft}^{3} / \mathrm{s}\right)$ (USGS 2004). Peak daily average flow during 2003 was $5154 \mathrm{~m}^{3} / \mathrm{s}\left(182,000 \mathrm{ft}^{3} / \mathrm{s}\right.$ ) (Figure 4.3-3). Columbia River flows typically peak from April through June during spring runoff from snowmelt and are lowest from September through October. As a result of daily discharge fluctuations from upstream dams, the depth of

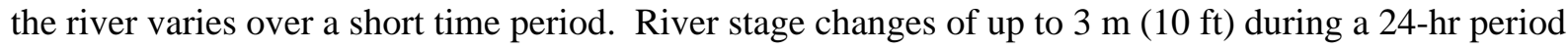
may occur along the Hanford Reach (Poston et al. 2003). The width of the river varies from approximately $300 \mathrm{~m}$ (1000 ft) to $1000 \mathrm{~m}$ (3300 ft) within the Hanford Reach. The width also varies with the flow rate, which causes repeated wetting and drying of an area along the shoreline.

The primary uses of the Columbia River include the production of hydroelectric power, irrigation of cropland in the Columbia Basin, and transportation of materials by barge. The Hanford Reach is the upstream limit of barge traffic on the mainstem Columbia River. Barges are used to transport reactor vessels from decommissioned nuclear submarines to Hanford for disposal. Several communities located along the Columbia River rely on the river as their source of drinking water. The Columbia River is also used as a source of both drinking water and industrial water for several Hanford Site facilities (Poston $e t$ al. 2003). In addition, the Columbia River is used extensively for recreation, including fishing, hunting, boating, sailing, water-skiing, diving, and swimming.

\subsubsection{Water Quality of the Columbia River}

The water quality of the Columbia River from Grand Coulee Dam to the Washington-Oregon border, which includes the Hanford Reach, has been designated as Class A, Excellent (WAC 173-201A) by Washington State (Poston et al. 2003). Class A waters are suitable for essentially all uses, including raw 


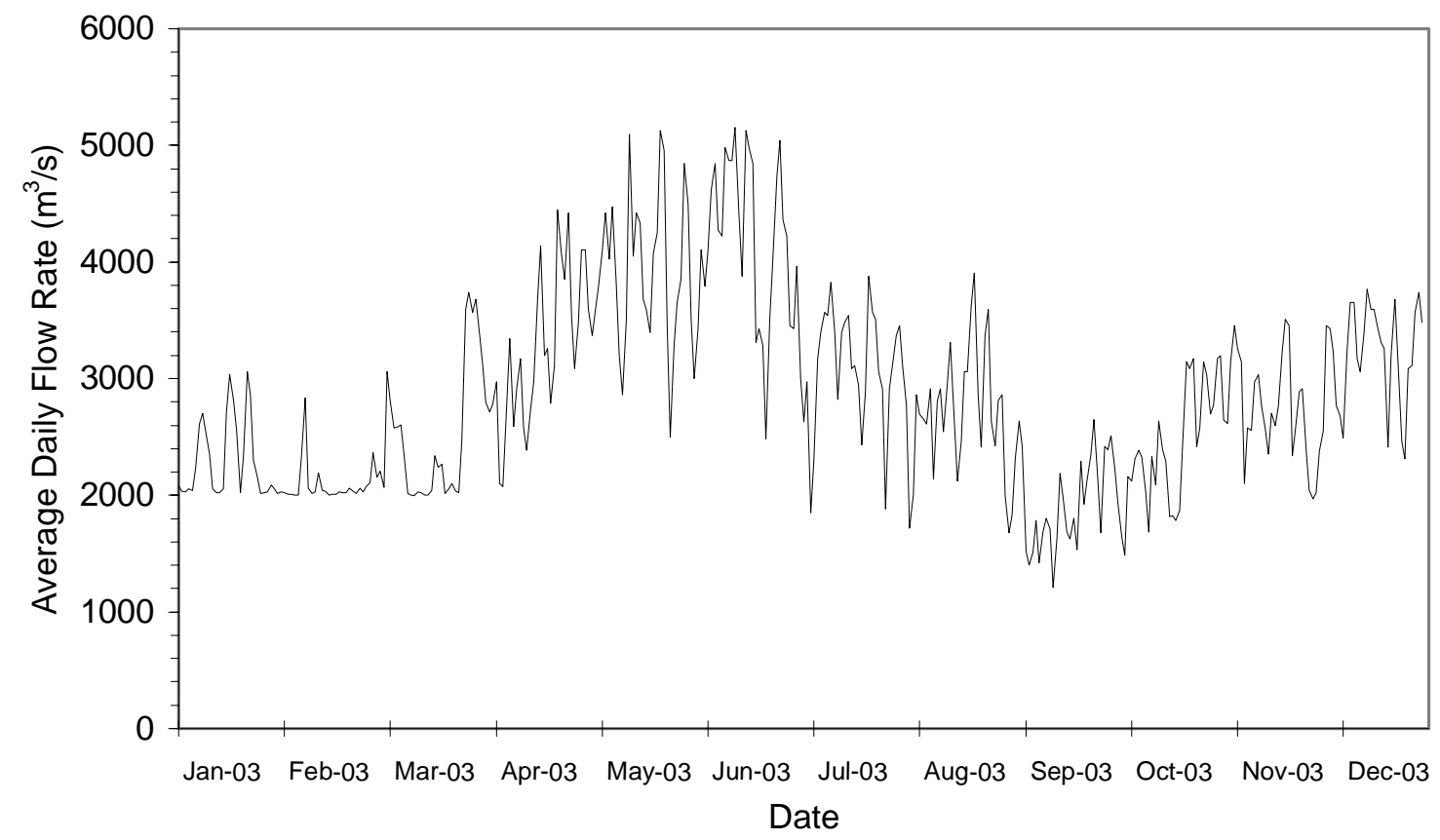

Figure 4.3-3. Average Daily Flow for the Columbia River during Calendar Year 2003 (data from USGS 2004, provisional data not yet reviewed and subject to change) $\left(1 \mathrm{~m}^{3} / \mathrm{s}=35.3 \mathrm{ft}^{3} / \mathrm{s}\right)$

drinking water, recreation, and wildlife habitat. State and federal drinking water standards apply to the Columbia River (Section 6.2.2).

During 2002, the USGS measured several water quality parameters at the Vernita Bridge, upstream of Hanford Site operations areas, and at the Richland pumphouse, which is downstream of the Hanford Site (Figure 4.3-4). Total dissolved solids measured near the Hanford Site during 2002 ranged from 71 to $99 \mathrm{mg} / \mathrm{L}$ and total dissolved nitrogen ranged from 0.16 to $0.37 \mathrm{mg} / \mathrm{L}$. Dissolved oxygen ranged from 10 to $14 \mathrm{mg} / \mathrm{L}$ and $\mathrm{pH}$ was 7.7 to 8.2. There were no statistically significant differences between upstream and downstream samples for these parameters (Poston et al. 2003).

PNNL measured both radiological and nonradiological constituents in Columbia River water during 2002 as part of a continuing environmental monitoring program (Poston et al. 2003). Cumulative water samples are collected at Priest Rapids Dam and at the Richland pumphouse (Figure 4.3-4). Additional samples were taken at transects of the river and at near-shore locations at the Vernita Bridge, 100-F Area, 100-N Area, the Hanford Townsite, and the 300 Area (Figure 4.3-4). These water samples were collected at frequencies varying from quarterly to annually. Results are presented in Bisping (2003) and summarized in Poston et al. (2003). These data show a statistical increase in tritium, nitrate, uranium, and iodine-129 along the Hanford Reach. All these constituents are known to be entering the river from contaminated groundwater beneath the Hanford Site (Section 4.3.4). Measurements of strontium-90 at the Richland pumphouse were not statistically higher than those at the Vernita Bridge even though strontium-90 is known to enter the river through groundwater inflow at 100-N Area. Measurements of tritium along transects showed higher concentrations near the shoreline relative to mid-river for samples from the 100-N Area, the Hanford Townsite, the 300 Area, and the Richland pumphouse. 


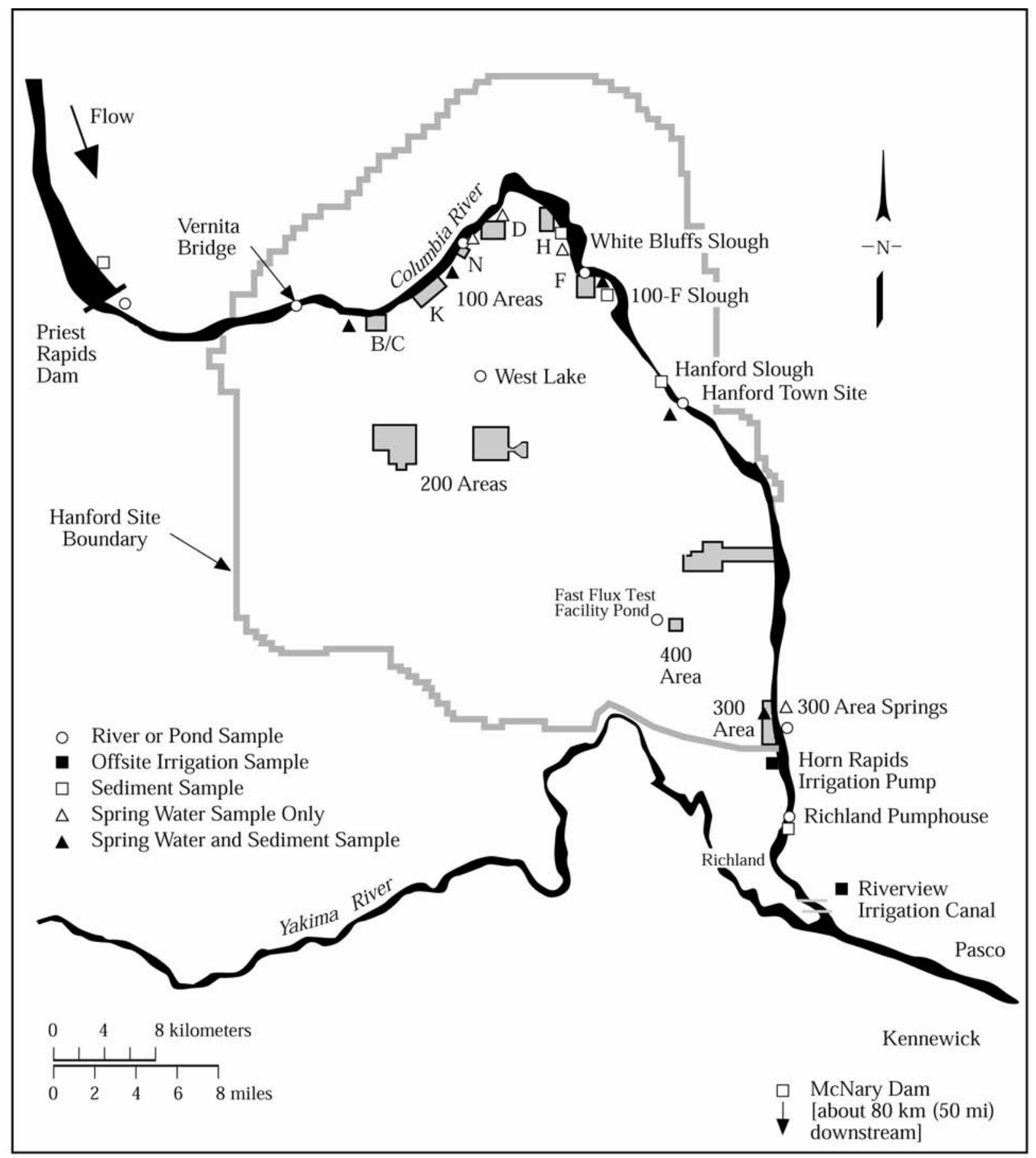

Figure 4.3-4. Surface Water and Sediment Monitoring Locations, Hanford Site, Washington (Poston et al. 2003) 
Other sources of pollutants entering the river are irrigation return flows and groundwater seepage associated with irrigated agriculture. The USGS (1995) documented nitrate groundwater contamination in Franklin County, which also seeps into the river along the Hanford Reach. However, in spite of pollutants introduced from both the Hanford Site and other sources, dilution in the river results in contaminant concentrations that are below drinking water standards (Poston et al. 2003).

\subsubsection{Yakima River}

The Yakima River follows a portion of the southwestern boundary of the Hanford Site and has much lower flows than the Columbia River. The average flow, based on 70 years of daily flow records (USGS 2004), is about $100 \mathrm{~m}^{3} / \mathrm{s}\left(3530 \mathrm{ft}^{3} / \mathrm{s}\right)$, with an average monthly maximum of $497 \mathrm{~m}^{3} / \mathrm{s}\left(17,550 \mathrm{ft}^{3} / \mathrm{s}\right)$ and minimum of $4.6 \mathrm{~m}^{3} / \mathrm{s}\left(165 \mathrm{ft}^{3} / \mathrm{s}\right)$. Exceptionally high flows were observed during 1996 and 1997 (Figure 4.3-5). The highest average daily flow rate during 1997 was nearly $1300 \mathrm{~m}^{3} / \mathrm{s}\left(45,900 \mathrm{ft}^{3} / \mathrm{s}\right)$. Average daily flow during 2000 was $89.9 \mathrm{~m}^{3} / \mathrm{s}\left(3176 \mathrm{ft}^{3} / \mathrm{s}\right)$. Average daily flow during 2003 was $89.3 \mathrm{~m}^{3} / \mathrm{s}$ $\left(3150 \mathrm{ft}^{3} / \mathrm{s}\right)$ (USGS 2004). The Yakima River System drains surface runoff from approximately one-third of the Hanford Site. Groundwater is expected to flow from the Yakima River into the aquifer underlying the Site rather than from the aquifer into the river because, based on well water-level measurements, the elevation of the river surface is higher than the adjacent water table (Thorne et al. 1994). Therefore, groundwater contaminants from the Hanford Site do not reach the Yakima River.

\subsubsection{Springs and Streams}

Springs are found on the slopes of the Rattlesnake Hills along the western edge of the Hanford Site (DOE 1988). There is also an alkaline spring at the east end of Umtanum Ridge (Hall 1998). Rattlesnake and Snively springs form small surface streams. Water discharged from Rattlesnake Springs flows in Dry Creek for about $3 \mathrm{~km}$ (1.6 mi) before disappearing into the ground (Figure 4.3-1). Cold Creek and its tributary Dry Creek, are ephemeral streams within the Yakima River drainage system in the southwestern portion of the Hanford Site. These streams drain areas to the west of the Hanford Site and cross the southwestern part of the Site toward the Yakima River. When surface flow occurs, it infiltrates rapidly and disappears into the surface sediments in the western part of the Site. The quality of water in these springs and streams varies depending on the source. However, they are upgradient of Hanford waste sites and groundwater contamination plumes.

\subsubsection{Columbia Riverbank Springs}

Riverbank springs were documented along the Hanford Reach long before Hanford operations began (Jenkins 1922). During the early 1980s, researchers identified 115 springs along the Benton County shoreline of the Hanford Reach (McCormack and Carlile 1984). Seepage occurs both below the river surface and on the exposed riverbank, particularly at low-river stage. Riverbank springs flow intermittently, apparently influenced primarily by changes in river level. In many areas, water flows from the river into the aquifer at high river stage and then returns to the river at low river stage. This "bankstorage” phenomenon has been numerically modeled for the 100-H Area (Peterson and Connelly 2001).

In areas of contaminated groundwater, riverbank springs are also generally contaminated. However, the concentrations in seeping water along the riverbank may be lower than groundwater because of the bank-storage phenomenon. Contaminants have been detected in near shore samples downstream from riverbank springs (Poston et al. 2003). Riverbank springs are monitored for radionuclides at the 100-N Area, the Hanford Townsite, and the 300 Area (Figure 4.3-4). Hanford-origin contaminants occur in some of these springs (Peterson and Johnson 1992, Poston et al. 2003). Detected radionuclides include strontium-90, technetium-99, iodine-129, uranium-234, -235, and -238, and tritium. Other detected 


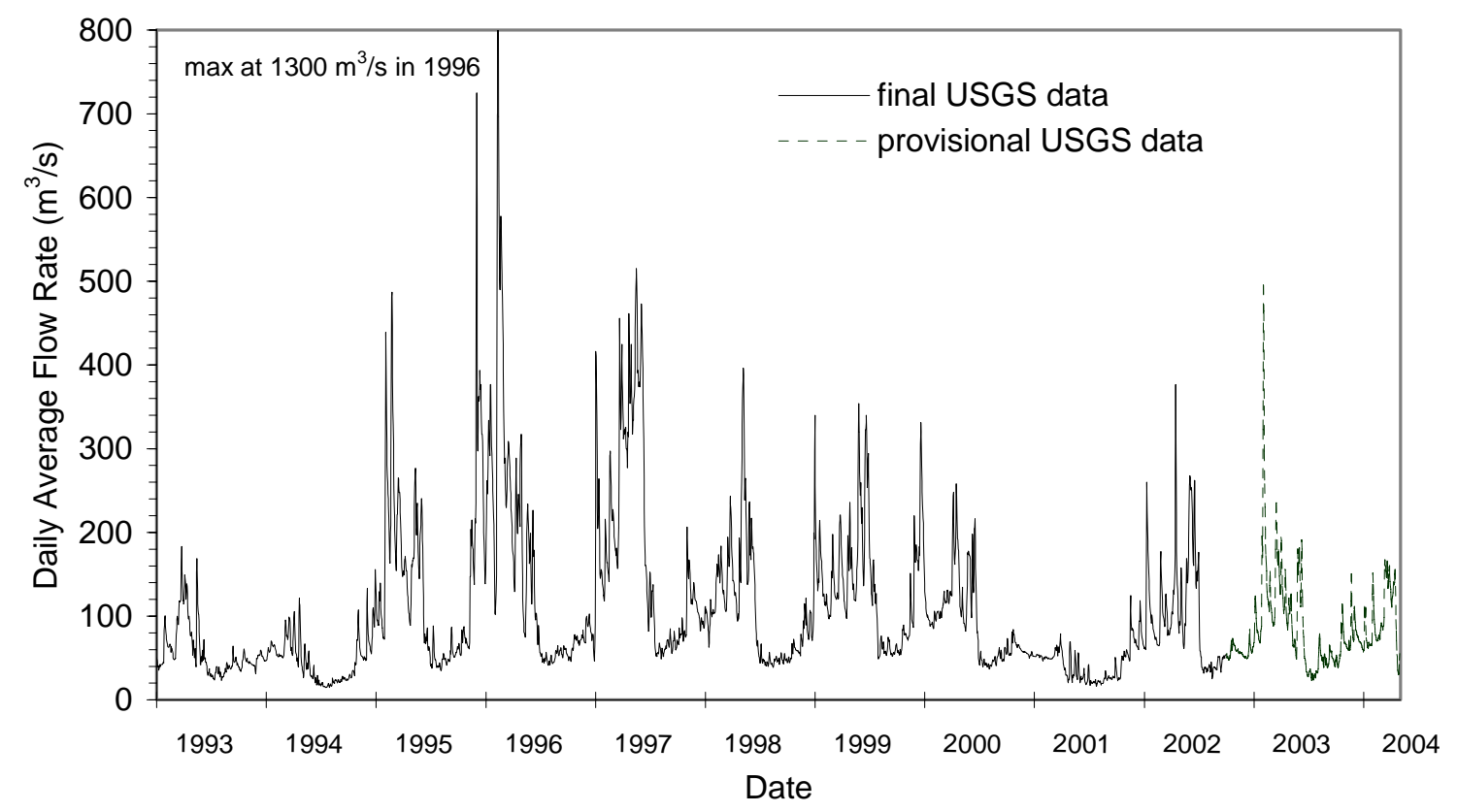

Figure 4.3-5. Average Daily Flow for the Yakima River, Washington, from 1993 through April 2004 (data from USGS 2004, provisional data not yet reviewed and subject to change) $\left(1 \mathrm{~m}^{3} / \mathrm{s}=35.3 \mathrm{ft}^{3} / \mathrm{s}\right)$

contaminants include arsenic, chromium, chloride, fluoride, nitrate, and sulfate. Volatile organic compounds were below detection limits. Analyses results for riverbank spring samples are listed in Bisping (2003) and summarized in Poston et al. (2003). For a listing of the regulatory standards for groundwater, refer to Table 4.3-1.

The highest strontium-90 concentration detected in riverbank springs during 2002 was $3.3 \mathrm{pCi} / \mathrm{L}$ $(0.12 \mathrm{~Bq} / \mathrm{L})$ at the $100-\mathrm{N}$ Area. A spring in this area previously had a reported strontium-90 concentration higher than $1000 \mathrm{pCi} / \mathrm{L}(37.34 \mathrm{~Bq} / \mathrm{L})$. However, because of decreased groundwater elevations, no flow has been observed at this spring during the past six years (Poston et al. 2003). Tritium concentrations in riverbank springs varied widely with location. The highest tritium concentration detected in riverbank springs during 2002 was 58,000 pCi/L $(2,100 \mathrm{~Bq} / \mathrm{L})$ at the Hanford Townsite. The highest iodine- 129 concentration of $0.19 \mathrm{pCi} / \mathrm{L}(0.007 \mathrm{~Bq} / \mathrm{L})$ was also found in a Hanford Townsite spring. Concentrations of radionuclides including tritium, technetium-99, and iodine-129 in riverbank springs near the Hanford Townsite have generally been increasing since 1994. This is an area where a major groundwater plume from the 200 East Area intercepts the river. However, tritium concentration has declined since 1997. This decline may be due to the effects of radioactive decay and/or less wastewater disposal, resulting in the groundwater tritium plume moving at a slower velocity. 
Table 4.3-1. Regulatory Drinking Water Standards for Groundwater

\begin{tabular}{|c|c|c|c|}
\hline Contaminant, units & $\begin{array}{c}\text { Drinking } \\
\text { Water } \\
\text { Standard } \\
\end{array}$ & Contaminant, units & $\begin{array}{c}\text { Drinking } \\
\text { Water } \\
\text { Standard } \\
\end{array}$ \\
\hline arsenic (filtered), $\mu \mathrm{g} / \mathrm{L}$ & 10 & & \\
\hline cadmium (filtered), $\mu \mathrm{g} / \mathrm{L}$ & 5 & gross beta, $\mathrm{pCi} / \mathrm{L}$ & 50 \\
\hline carbon tetrachloride, $\mu \mathrm{g} / \mathrm{L}$ & 5 & iodine-129, pCi/L & 1 \\
\hline carbon-14, pCi/L & 2,000 & nickel (filtered), $\mu \mathrm{g} / \mathrm{L}$ & 100 \\
\hline cesium-137, pCi/L & 200 & nitrate, mg/L & 45 \\
\hline chloroform, $\mu \mathrm{g} / \mathrm{L}$ & 100 & nitrite, mg/L & 3.3 \\
\hline chromium (dissolved), $\mu \mathrm{g} / \mathrm{L}$ & 100 & plutonium-239/240, pCi/L & not applicable \\
\hline cis-1,2-dichloroethene, $\mu \mathrm{g} / \mathrm{L}$ & 70 & strontium-90, pCi/L & 8 \\
\hline cobalt-60, pCi/L & 100 & technetium-99, pCi/L & 900 \\
\hline cyanide, $\mu \mathrm{g} / \mathrm{L}$ & 200 & trichloroethene, $\mu \mathrm{g} / \mathrm{L}$ & 5 \\
\hline fluoride, mg/L & 4 & tritium, $\mathrm{pCi} / \mathrm{L}$ & 20,000 \\
\hline gross alpha, pCi/L & 15 & uranium, $\mu \mathrm{g} / \mathrm{L}$ & 30 \\
\hline
\end{tabular}

\subsubsection{Runoff and Net Infiltration}

Total estimated precipitation over the Pasco Basin is about $9 \times 10^{8} \mathrm{~m}^{3}\left(3.2 \times 10^{10} \mathrm{ft}^{3}\right)$ annually (DOE 1988). This was calculated by multiplying the average annual precipitation averaged over the Pasco Basin by the $4900 \mathrm{~km}^{2}\left(1900 \mathrm{mi}^{2}\right)$ basin area. Precipitation varies both spatially and temporally with higher amounts generally falling at higher elevations. Annual precipitation measured at the Hanford Meteorology Station (HMS) has varied from $7.6 \mathrm{~cm}$ (3 in.) to $31.3 \mathrm{~cm}$ (12.3 in.) since 1945. Most precipitation occurs during the late autumn and winter, with more than half of the annual amount occurring from November through February. Mean annual runoff from the Pasco Basin is estimated at $3.1 \times 10^{7} \mathrm{~m}^{3} / \mathrm{yr}\left(1.1 \times 10^{9} \mathrm{ft}^{3} / \mathrm{yr}\right)$, or approximately $3 \%$ of the total precipitation (DOE 1988). Most of the remaining precipitation is lost through evapotranspiration. However, a portion of the precipitation that infiltrates the soil is not lost to evaporation or transpiration and eventually recharges the groundwater flow system. The amount of recharge varies spatially based primarily on soil texture and vegetation (Gee et al. 1992, Fayer and Walters 1995). Recharge also varies temporally with the majority occurring in the winter and spring. There is some evidence that the most significant recharge events are associated with rapid melting of relatively large snowpacks, which may only occur a few times in a decade (Fayer and Szecsody 2004).

\subsubsection{Flooding}

Large Columbia River floods have occurred in the past (DOE 1987), but the likelihood of recurrence of large-scale flooding has been reduced by the construction of several flood control/water-storage dams upstream of the Hanford Site (Figure 4.3-6). Major floods on the Columbia River are typically the result of rapid melting of the winter snowpack over a wide area augmented by above-normal precipitation. The maximum historical flood on record occurred June 7, 1894, with a peak discharge at the Hanford Site of $21,000 \mathrm{~m}^{3} / \mathrm{s}\left(742,000 \mathrm{ft}^{3} / \mathrm{s}\right)$. The floodplain associated with the 1894 flood was modeled based on topographic cross-sections of the river channel (ERDA 1976) (Figure 4.3-7). The largest recent flood 


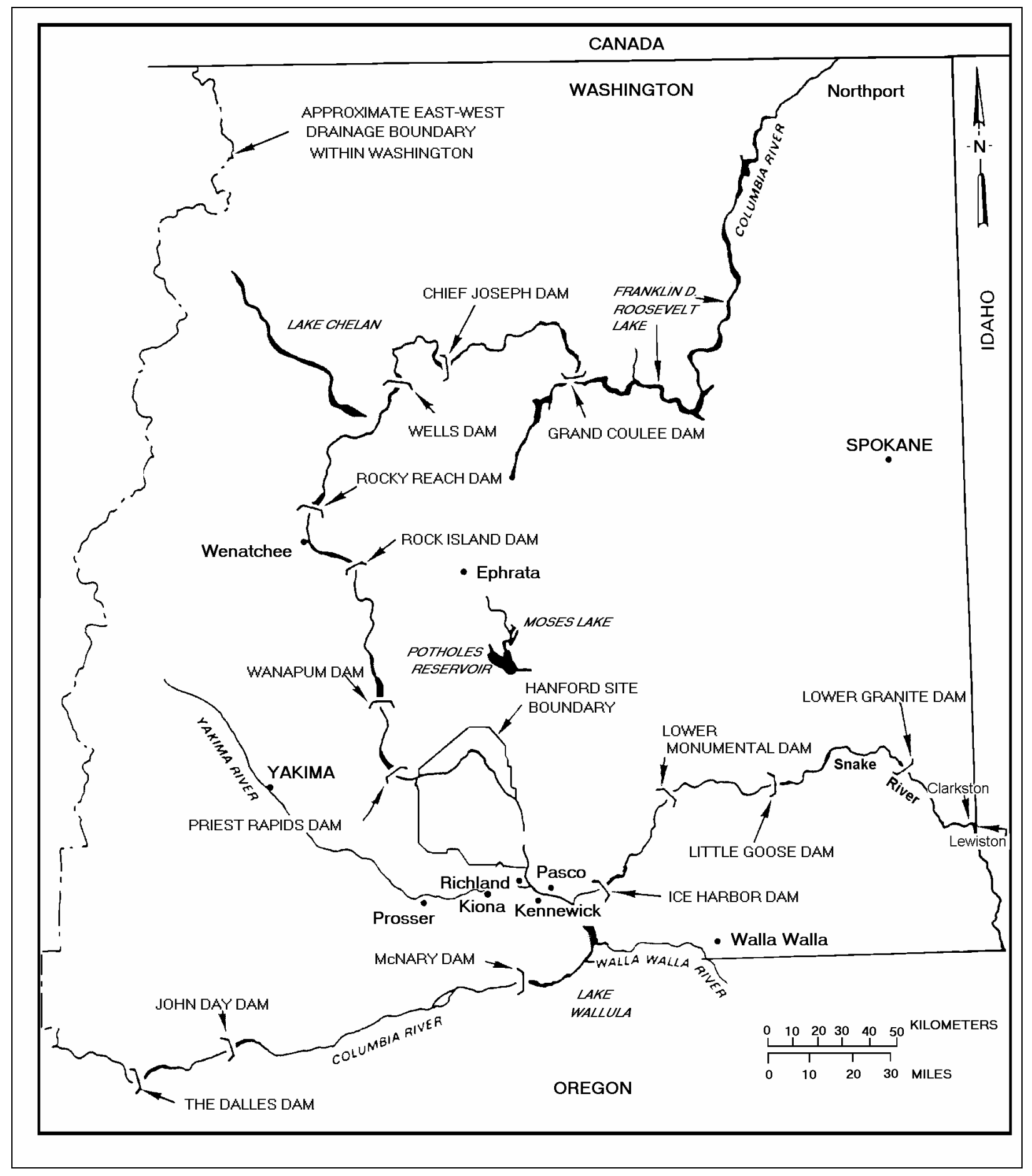

Figure 4.3-6. Locations of Principal Dams within the Columbia Plateau, Washington and Oregon (DOE 1988) 


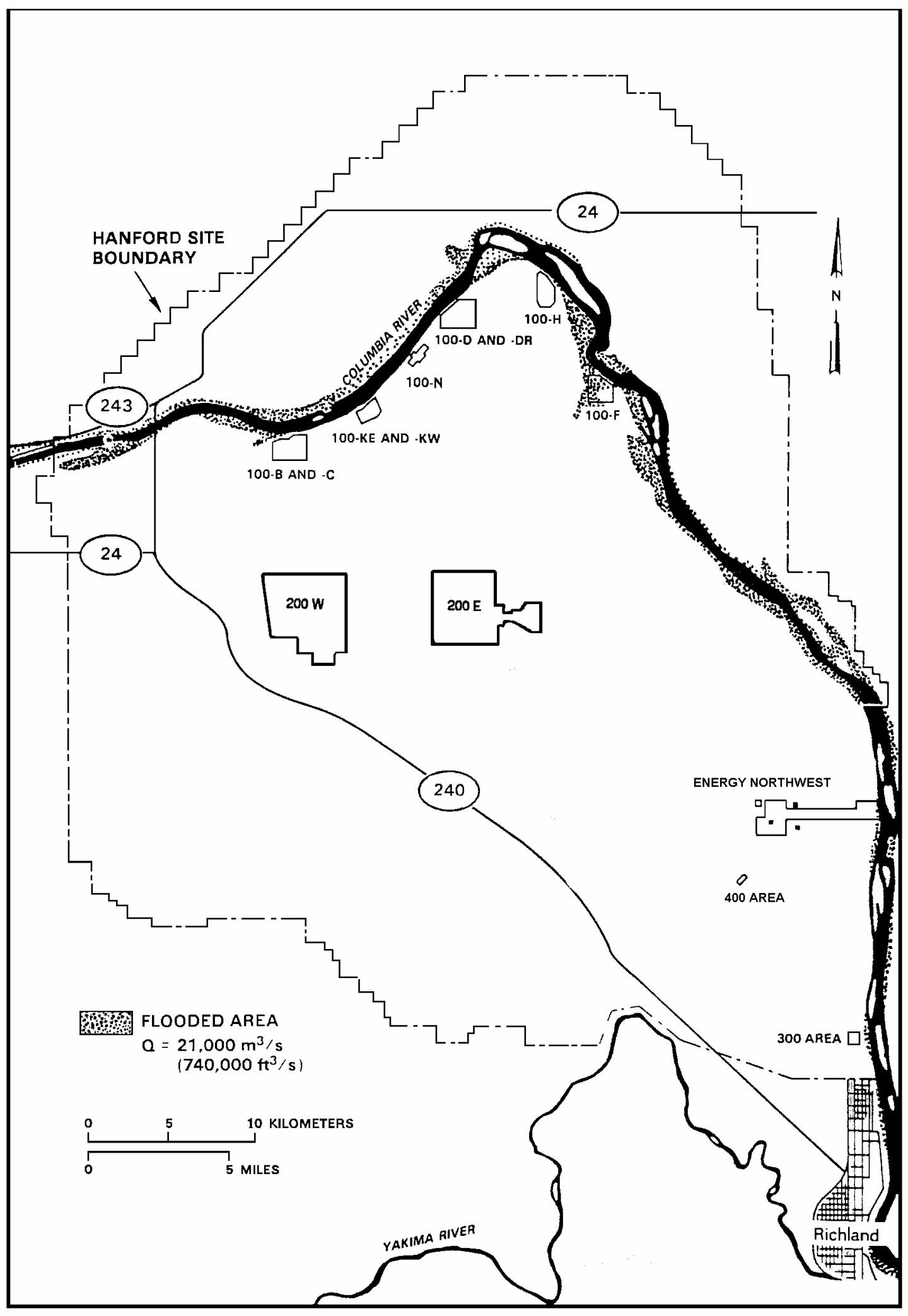

Figure 4.3-7. Flood Area on the Hanford Site, Washington, during the 1894 Flood Modeled Based on Topographic Cross Sections (DOE 1986) 
took place during 1948 with an observed peak discharge of 20,000 $\mathrm{m}^{3} / \mathrm{s}\left(700,000 \mathrm{ft}^{3} / \mathrm{s}\right)$ at the Hanford Site. The exceptionally high runoff during the spring of 1996 resulted in a maximum discharge of nearly $11,750 \mathrm{~m}^{3} / \mathrm{s}$ (415,000 $\mathrm{ft}^{3} / \mathrm{s}$ ) (USGS 2002). There are no Federal Emergency Management Agency (FEMA) floodplain maps for the Hanford Reach of the Columbia River. FEMA only maps developing areas, and the Hanford Reach has been specifically excluded because the adjacent land is primarily under federal control.

Evaluation of flood potential is conducted in part through the concept of the probable maximum flood, which is determined from the upper limit of precipitation falling on a drainage area and other hydrologic factors, such as antecedent moisture conditions, snowmelt, and tributary conditions that could result in maximum runoff. The probable maximum flood for the Columbia River downstream of Priest Rapids Dam has been calculated to be $40,000 \mathrm{~m}^{3} / \mathrm{s}\left(1.4\right.$ million $\left.\mathrm{ft}^{3} / \mathrm{s}\right)$ and is greater than the 500 -year flood (Figure 4.3-8). This flood would inundate parts of the 100 Area located adjacent to the Columbia River, but the central portion of the Hanford Site would remain unaffected (DOE 1986).

The U.S. Army Corps of Engineers (Corps) (1989) has derived the Standard Project Flood with both regulated and unregulated peak discharges given for the Columbia River downstream of Priest Rapids Dam. Frequency curves for both unregulated and regulated peak discharges are also given for the same portion of the Columbia River. The regulated Standard Project Flood for this part of the river is given as $15,200 \mathrm{~m}^{3} / \mathrm{s}\left(54,000 \mathrm{ft}^{3} / \mathrm{s}\right)$ and the 100 -year regulated flood as $12,400 \mathrm{~m}^{3} / \mathrm{s}\left(440,000 \mathrm{ft}^{3} / \mathrm{s}\right)$ (DOE 1998c). Impacts to the Hanford Site are negligible and would be less than the probable maximum flood (Figure 4.3-8).

Potential dam failures on the Columbia River have been evaluated. Upstream failures could arise from a number of causes, with the magnitude of the resulting flood depending on the degree of breaching at the dam. The Corps evaluated a number of scenarios on the effects of failures of Grand Coulee Dam, assuming flow conditions of $11,000 \mathrm{~m}^{3} / \mathrm{s}\left(400,000 \mathrm{ft}^{3} / \mathrm{s}\right)$. For emergency planning, they hypothesized that $25 \%$ and $50 \%$ breaches, the "instantaneous" disappearance of $25 \%$ or $50 \%$ of the center section of the dam, could result from the detonation of explosives. The discharge or floodwave resulting from such an instantaneous $50 \%$ breach at the outfall of the Grand Coulee Dam was determined to be $600,000 \mathrm{~m}^{3} / \mathrm{s}$ (21 million $\mathrm{ft}^{3} / \mathrm{s}$ ). In addition to the areas inundated by the probable maximum flood (Figure 4.3-8), the remainder of the 100 Area, the 300 Area, and nearly all of Richland, Washington, would be flooded (DOE 1986, ERDA 1976). No determinations were made for failures of dams upstream, for associated failures downstream of Grand Coulee, or for breaches greater than 50\% of Grand Coulee Dam. The 50\% scenario was believed to represent the largest realistically conceivable flow resulting from either a natural or human-induced breach (DOE 1986). It was also assumed that a scenario such as the $50 \%$ breach would occur only as the result of direct explosive detonation, and not because of a natural event such as an earthquake, and that even a 50\% breach under these conditions would indicate an emergency situation in which there might be other overriding major concerns.

The possibility of a landslide resulting in river blockage and flooding along the Columbia River has been examined for an area bordering the east side of the river upstream of the city of Richland. The possible landslide area considered was the 75-m- (250-ft-) high bluff generally known as White Bluffs. Calculations were made for an $8 \times 10^{5} \mathrm{~m}^{3}\left(1 \times 10^{6} \mathrm{yd}^{3}\right)$ landslide volume with a concurrent flood flow of

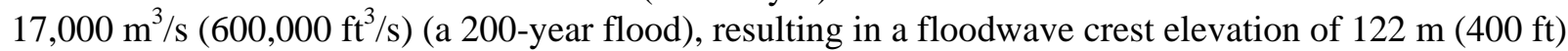
above mean sea level. Areas inundated upstream of such a landslide event would be similar to those occurring during the probable maximum flood (DOE 1986). 


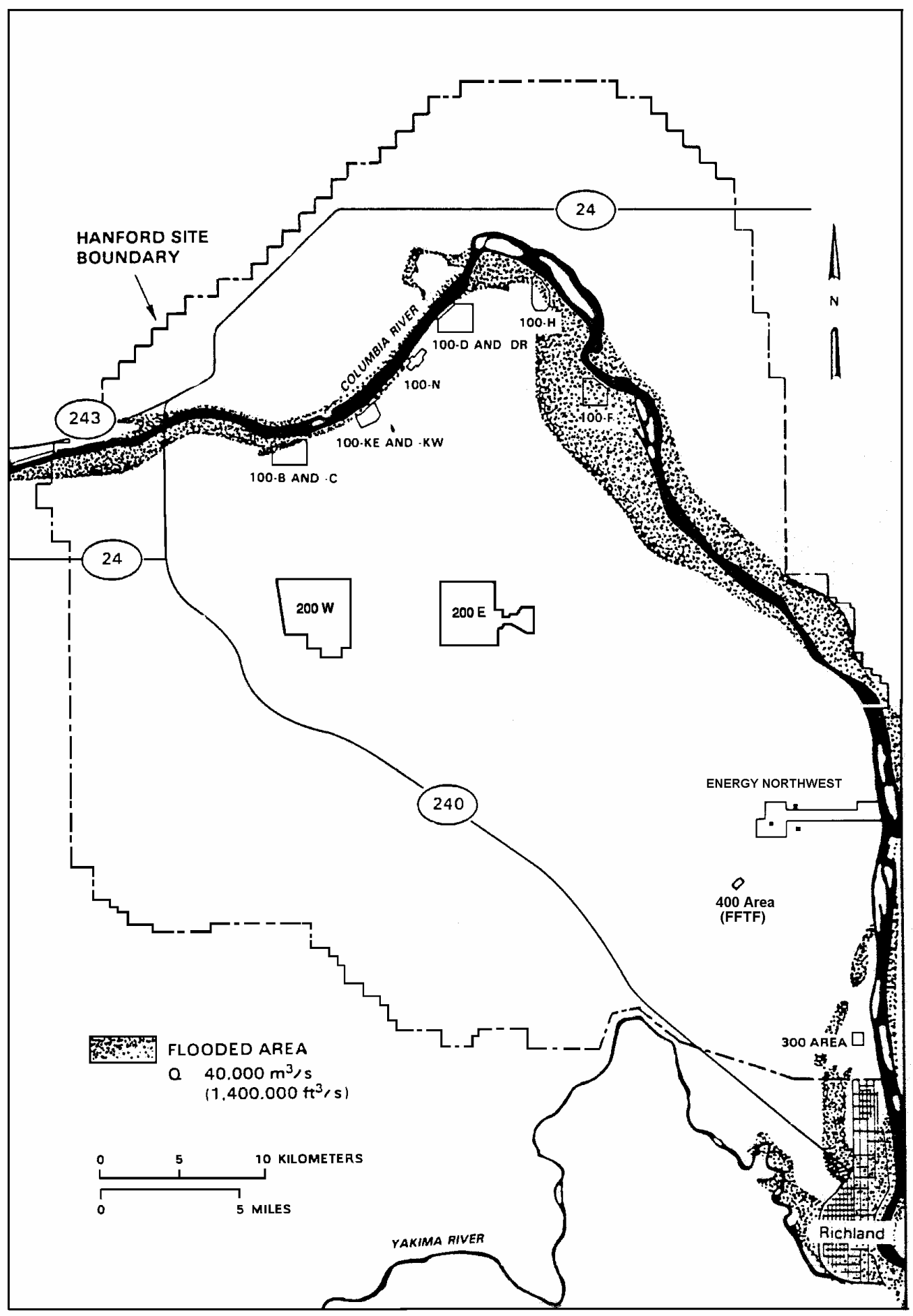

Figure 4.3-8. Flood Area on the Hanford Site, Washington, for the Probable Maximum Flood (DOE 1986) 
There have been fewer than 20 major floods on the Yakima River since 1862 (DOE 1986). The most severe occurred during November 1906, December 1933, May 1948, and February 1996; discharge magnitudes at Kiona, Washington, were $1870 \mathrm{~m}^{3} / \mathrm{s}\left(66,000 \mathrm{ft}^{3} / \mathrm{s}\right), 1900 \mathrm{~m}^{3} / \mathrm{s}\left(67,000 \mathrm{ft}^{3} / \mathrm{s}\right), 1050 \mathrm{~m}^{3} / \mathrm{s}$ $\left(37,000 \mathrm{ft}^{3} / \mathrm{s}\right)$, and $1300 \mathrm{~m}^{3} / \mathrm{s}\left(45,900 \mathrm{ft}^{3} / \mathrm{s}\right)$, respectively. The average flow of the Yakima River is $104 \mathrm{~m}^{3} / \mathrm{s}\left(165 \mathrm{ft}^{3} / \mathrm{s}\right)$, and the average monthly maximum is $490 \mathrm{~m}^{3} / \mathrm{s}\left(17,500 \mathrm{ft}^{3} / \mathrm{s}\right)$. The recurrence intervals for the 1933 and 1948 floods are estimated at 170 and 33 years, respectively. The development of irrigation reservoirs within the Yakima River Basin has considerably reduced the flood potential of the river. The southern border of the Hanford Site could be susceptible to a 100-year flood on the Yakima River (Figure 4.3-9).

During 1980, a flood risk analysis of Cold Creek was conducted as part of the characterization of a basaltic geologic repository for high-level radioactive waste. Such design work is usually done according to the criteria of Standard Project Flood or probable maximum flood, rather than the worst-case or 100year flood scenario. Therefore, in lieu of 100- and 500-year floodplain studies, a probable maximum flood evaluation was performed (Skaggs and Walters 1981). The probable maximum flood discharge rate for the lower Cold Creek Valley was $2265 \mathrm{~m}^{3} / \mathrm{s}\left(80,000 \mathrm{ft}^{3} / \mathrm{s}\right)$ compared to $564 \mathrm{~m}^{3} / \mathrm{s}\left(19,900 \mathrm{ft}^{3} / \mathrm{s}\right)$ for the 100-year flood. Modeling indicated that State Route (SR) 240 along the Site's southwestern and western areas would not be usable (Figure 4.3-10).

\subsubsection{Non-Riverine Surface Water}

Active ponds on the Hanford Site include West Lake and the 200 Area Treated Effluent Disposal Facility (TEDF) disposal ponds (Figure 4.3-1). West Lake is north of the 200 East Area and is a natural feature recharged from groundwater (Gephart et al. 1976, Poston et al. 1991). West Lake has not received direct effluent discharges from Site facilities; rather, its existence is caused by the intersection of the elevated water table with the land surface in the topographically low area. Water levels of West Lake fluctuate with water table elevation, which is influenced by wastewater discharge in the 200 Area. The water level and size of the lake has been decreasing over the past several years because of reduced wastewater discharge (Section 4.3.3.1). There is unsubstantiated information that sewage sludge may have been dumped in the vicinity of West Lake during the 1940s, and this has been cited as the reason for elevated dissolved solids and nitrate in the lake water (Emery and McShane 1978, Meinhardt and Frostenson 1979). However, it is possible that the concentration of salts resulted from evaporation of groundwater at the lake, which has no outlet. Total dissolved solids are approximately 15,000 mg/L and $\mathrm{pH}$ is greater than 9. Nitrate and ammonia concentrations of about 1.8 and $2.6 \mathrm{mg} / \mathrm{L}$, respectively, have been reported, which are greater than freshwater lakes, but lower than other alkaline lakes in Washington such as Soap Lake and Lake Lenore. West Lake contains relatively high levels of uranium that are thought to be from natural sources concentrated by evaporation in the lake (Poston et al. 1991, 2003).

TEDF is east of the 200 East Area and consists of two disposal ponds. These ponds are each $0.02 \mathrm{~km}^{2}\left(0.008 \mathrm{mi}^{2}\right)$ in size and receive industrial wastewater permitted in accordance with Ecology's State Waste Discharge Permit Program (WAC 173-216). The wastewater evaporates into the air or percolates into the ground from the disposal ponds.

There are several naturally occurring vernal ponds near Gable Mountain and Gable Butte (Hall 1998). These ponds appear to occur where a depression is present in a relatively shallow buried basalt surface. Water collects within the depression over the winter resulting in a shallow pond that dries during the summer months. The formation of these ponds in any particular year depends on the amount and temporal distribution of precipitation and snowmelt events. The vernal ponds range in size from about $20 \mathrm{ft} \times 20 \mathrm{ft}$ to $150 \mathrm{ft} \times 100 \mathrm{ft}(6.1 \mathrm{~m} \times 6.1 \mathrm{~m}$ to $45.73 \mathrm{~m} \times 30.5 \mathrm{~m})$, and were found in three clusters. Approximately 10 were documented at the eastern end of Umtanum Ridge, 7 were observed in the central part of Gable Butte, and 3 were found at the eastern end of Gable Mountain (Figure 4.0-1). 


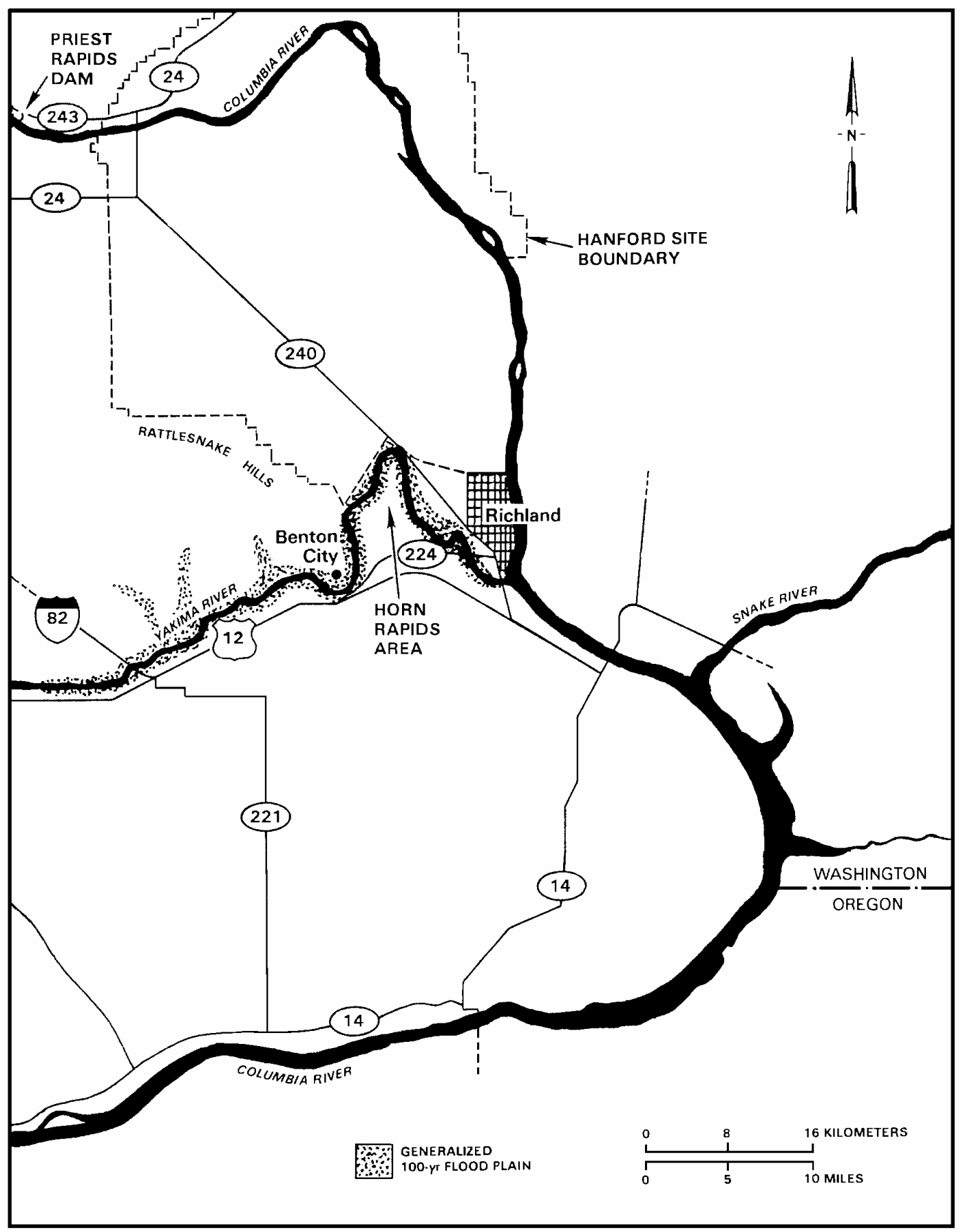

Figure 4.3-9. Flood Area from a 100-Year Flood of the Yakima River near the Hanford Site, Washington (DOE 1986) 


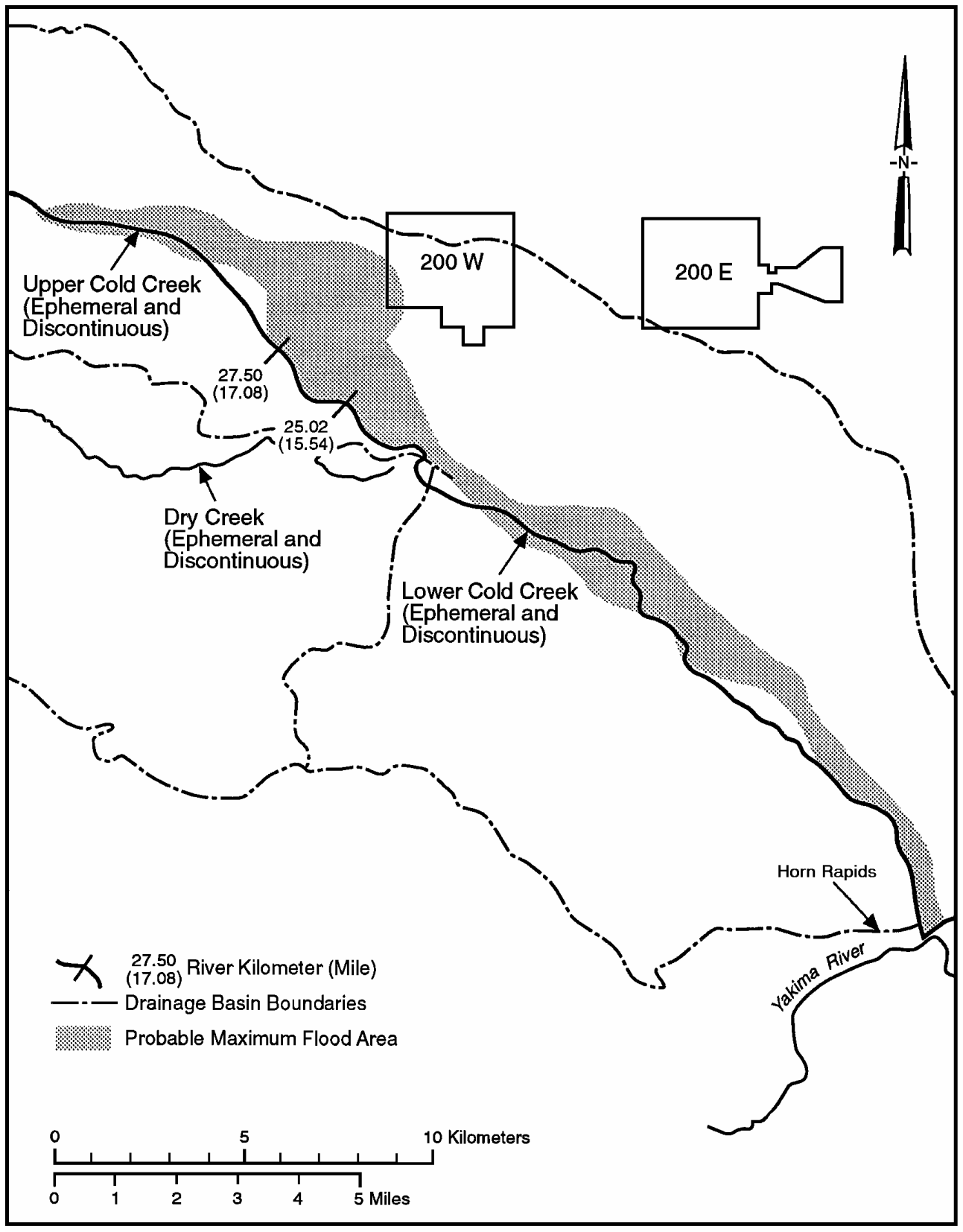

Figure 4.3-10. Extent of Probable Maximum Flood in Cold Creek Area, Hanford Site, Washington, delineated using the U.S. Army Corps of Engineers' HEC-2 Water Surface Profiles model (Skaggs and Walters 1981) 
Other than rivers and springs, there are no naturally occurring bodies of surface water adjacent to the Hanford Site. There are wetlands caused by irrigation, on the east and west sides of the Wahluke Slope, which lies north of the Columbia River and on the White Bluffs east of the Columbia River (Figure 4.31). Hatcheries and irrigation canals constitute the only other surface water in the Hanford Site vicinity. The Ringold Hatchery is located just south of the Hanford Site boundary on the east side of the Columbia River (Figure 4.3-1).

\subsubsection{Hanford Site Vadose Zone}

The vadose zone is that part of the geologic media which extends from the earth's surface to the water table. At the Hanford Site, the thickness of the vadose zone ranges from $0 \mathrm{~m}(0 \mathrm{ft})$ near the Columbia River to greater than $100 \mathrm{~m}$ (328 ft) beneath parts of the central plateau (Hartman 2000). Unconsolidated glacio-fluvial sands and gravels of the Hanford formation make up most of the vadose zone. In some areas, such as most of the 200 West Area and in some of the 100 Areas, the fluvial-lacustrine sediments of the Ringold Formation make up the lower part of the vadose zone. The Cold Creek unit also makes up part of the vadose zone. The integrated knowledge obtained from previous and on-going studies provides a good conceptual understanding of the geologic, hydraulic, and geochemical environment and its controls on the distribution and movement of contaminants within the vadose zone (DOE 1999b; Last et al. 2004).

Moisture movement through the vadose zone is important because it is the driving force for migration of most contaminants to the groundwater. Radioactive and hazardous wastes in the soil column from liquid-waste disposals, unplanned leaks, solid waste burial, and underground tank storage are potential sources of continuing and future vadose zone and groundwater contamination. Contaminants may continue to move downward for long periods (tens to hundreds of years depending on recharge rates and the distribution coefficient of the contaminant) after termination of liquid waste disposal.

Except for the State Approved Land Disposal Site (SALDS), the 200 Area TEDF ponds (Figure 4.31), and septic drain fields, liquid discharges to the vadose zone ended during the mid-1990s. Currently, the major source of moisture to the vadose zone is precipitation. Infiltration and deep drainage of meteoric water in the vadose zone causes older preexisting water to be displaced downward by newly infiltrated water. The amount of deep drainage (below the root zone) at any particular site is dependent on the total amount of water available at the time of the event, soil type, and the presence of vegetation. Usually, vegetation reduces the amount of deep drainage through the biological process of transpiration.

The vadose-zone stratigraphy influences the movement of liquid through the soil column. Where conditions are favorable, lateral spreading of liquid effluent and/or local perched water zones may develop. Lateral spreading can occur along any strata with contrasting conductivity. Perched water zones form where downward moving moisture accumulates on top of less-permeable soil lenses or highly cemented horizons. Even in relatively uniform sediments the influence of grain orientation is important and can give rise to anisotropic hydraulic properties, causing significant lateral movement of contaminant plumes (Ward et al. 2002a, b; Zhang et al. 2003). Lateral spreading can delay the arrival of contaminants at the water table but may cause mixing of the subsurface plume at one site with that of an adjacent site. Spreading may also require increasing the area of surface barriers to cover wider plumes.

Preferential flow may also occur along discontinuities, such as clastic dikes and fractures. Clastic dikes are a common geologic feature in the suprabasalt sediments at the Hanford Site. Their most important feature is their potential to either enhance or inhibit vertical and lateral movement of contaminants in the subsurface, depending on textural relationships (Fecht et al. 1998). 


\subsubsection{Vadose Zone Contamination}

The Hanford Site has more than 800 past-practice liquid-disposal facilities. Radioactive liquid waste was discharged to the vadose zone through reverse (injection) wells, French drains, cribs, ponds, trenches, and ditches. From 1944 through the late 1980s, 1.5 to 1.7 billion $\mathrm{m}^{3}$ (396 to 449 billion gal) of effluent were disposed to the soils (Gephart 1999). Most effluent was released in the 200 Areas. The major groundwater contaminant plumes emanating from the 200 Areas are those of tritium and nitrate. The major source for both was discharges from chemical processing of irradiated nuclear fuel rods.

Also present are technetium-99 and iodine-129 which, like tritium and nitrate, are mobile in both the vadose zone and groundwater. The major sources of technetium-99 and iodine-129 were discharges to liquid disposal facilities. Vadose zone sources for these contaminants remain beneath many past-practice disposal facilities. However, other than physical sampling and laboratory analysis, there are few direct ways to monitor tritium, nitrate, technetium-99, and iodine-129 in the vadose zone.

Liquid wastes generated during plutonium recovery processes at Z Plant in the 200 West Area contained carbon tetrachloride. These wastes were discharged to nearby subsurface liquid waste disposal facilities from 1955 to 1973 (Rohay et al. 1994, Swanson et al. 1999). Soil vapor extraction is being used to remove carbon tetrachloride from the vadose zone in the 200 West Area (Hartman et al. 2004).

Approximately 280 unplanned releases in the 200 Areas also contributed contaminants to the vadose zone (DOE 1997b). Many of these were from underground tanks and have contributed significant contamination to the vadose zone. In addition, approximately 50 active and inactive septic tanks and drain fields and numerous radioactive and non-radioactive landfills and dumps have impacted the vadose zone (DOE 1997b). The landfills are and were used to dispose of solid wastes, which, in most instances, are easier to locate, retrieve, and remediate than are liquid wastes.

One hundred and forty-nine single-shell tanks and 28 double-shell tanks have been used to store highlevel radioactive and mixed wastes in the 200 Areas. The wastes resulted from uranium and plutonium recovery processes and, to a lesser extent, from strontium and cesium recovery processes. Sixty-seven of the single-shell tanks are assumed to have leaked an estimated total of 2839 to $3975 \mathrm{~m}^{3}$ (750,000 to $1,050,000$ gal) of contaminated liquid to the vadose zone (Hanlon 2001). The three largest tank leaks were 435,320 L (115,000 gal), 37,850 to 1,048,560 L (10,000 to 277,000 gal), and 265,980 L (70,365 gal). The average tank leak was between 41,640 and 60,565 L (11,000 and 16,000 gal) (Hanlon 2001).

In addition to removing pumpable liquids from the single-shell tanks, interim measures have been taken to reduce the movement of tank farm contaminants in the vadose zone. Infiltration of water has been identified as the primary means by which contaminants are displaced beneath the farms. Surface water controls have been constructed to reduce surface water run-on from major meteorological events and from breaks in water lines. Also, waterlines that were determined unnecessary have been isolated, cut, and capped. Water lines that were found to be necessary for continued operations are being leak tested and any lines found to be leaking will be replaced.

Cooling water from the single-pass reactors along the Columbia River was routinely routed to retention basins in the 100 Areas prior to return to the river. Thermal shock from the hot cooling water cracked the basins so that much of the cooling water leaked into the vadose zone. In addition, trenches were used for disposal of cooling water from 100-KE, 100-KW, and 100-N Reactors. The disposed cooling waters contained fission and neutron activation products and some chemicals and actinides. Tritium, strontium-90, nitrate, and chromium migrate through the vadose zone to groundwater, and ultimately, to the Columbia River in the 100 Areas. Chromium is actively being remediated at the $100-\mathrm{K}$ 
and 100-H Areas by pump-and-treat methods and in the 100-D/DR Area by pump-and-treat and in situ redox methods (Hartman et al. 2004).

Contaminated cooling water that had contacted broken fuel rods was routed to trenches rather than being directly returned to the river. These fluids contained large quantities of fission and neutron activation products. In addition, leakage from fuel-storage basins in the 100-K Area also contributed quantities of fission products, transuranics, and carbon-14 to the soil column (Johnson et al. 1995). Thus, both past-practice sites and fuel-storage basin leakage are potential vadose zone sources of contaminants in the 100 Areas. Groundwater monitoring data from wells near the 100-KE and 100-KW basins do not show any indication of current leakage from either basin.

The amount of contamination remaining in the vadose zone is uncertain. Several compilations of vadose zone contamination have been formulated through the past years. DOE (1997b), Kincaid et al. (1998, 2001), and Simpson et al. (2001) contain the most recent inventories of contaminants disposed to past-practice liquid disposal facilities in the 200 Areas. Dorian and Richards (1978) list contaminant inventories disposed to most 100 Area past-practice facilities. Agnew (1997) and Anderson (1990) list inventories of effluents sent to single-shell tanks and Simpson et al. (2001) list the compositions of fluids leaked from single-shell tanks. Most recently, the Hanford Tank Farm Vadose Zone Project has issued a series of reports that estimate the curies of gamma-emitting radionuclides and the volumes of contaminated soil associated with each single-shell tank farm (http://www.gjo.doe.gov/programs/hanf/).

Further information on vadose zone characterization and monitoring activities on the Hanford Site is available online at http://vadose.pnl.gov and http://www.hanford.gov/cp/gpp/ as well as in the yearly updated Hanford Site groundwater monitoring report (i.e., Hartman et al. 2004).

\subsubsection{Hanford Site Groundwater}

Groundwater at the Hanford Site originated as either recharge from rain and snowmelt, or from excess irrigation, canal seepage, and wastewater disposal. Most of this groundwater will eventually discharge to the Columbia River. Some will be brought to the surface through wells, or excavations, or through evaporation or transpiration in shallow water table areas.

Groundwater beneath the Hanford Site is found in both an upper unconfined aquifer system and deeper basalt-confined aquifers. The unconfined aquifer system is also referred to as the suprabasalt aquifer system because it is within the sediments that overlie the basalt bedrock (Figure 4.2-4). Portions of the suprabasalt aquifer system are locally confined. However, because the entire suprabasalt aquifer system is interconnected on a site-wide scale, it is referred to in this report as the Hanford unconfined aquifer system.

\subsubsection{Basalt-Confined Aquifer System}

Relatively permeable sedimentary interbeds and the more porous tops and bottoms of basalt flows provide the confined aquifers within the Columbia River Basalts. The horizontal hydraulic conductivities of most of these aquifers fall in the range of $10^{-10}$ to $10^{-4} \mathrm{~m} / \mathrm{s}\left(3 \times 10^{-10}\right.$ to $\left.3 \times 10^{-4} \mathrm{ft} / \mathrm{s}\right)$. Saturated but relatively impermeable dense interior sections of the basalt flows have horizontal hydraulic conductivities ranging from $10^{-15}$ to $10^{-9} \mathrm{~m} / \mathrm{s}\left(3 \times 10^{-15}\right.$ to $\left.3 \times 10^{-9} \mathrm{ft} / \mathrm{s}\right)$, about five orders of magnitude lower than some of the confined aquifers that lie between these basalt flows (DOE 1988). Hydraulic-head information indicates that groundwater in the basalt-confined aquifers generally flows toward the Columbia River and, in some places, toward areas of enhanced vertical interaquifer flow with the unconfined aquifer system (Hartman et al. 2004, DOE 1988, Spane 1987). The basalt-confined aquifer system is important because 
there is a potential for significant groundwater movement between the two systems. Head relationships presented in previous reports (DOE 1988) demonstrate the potential for such interaquifer flow. In addition, limited water chemistry data indicate that interaquifer flow has occurred in an area near the Gable Mountain anticlinal structure, north of the 200 East Area (Graham et al. 1984, Jensen 1987).

\subsubsection{Unconfined Aquifer System}

The unconfined aquifer system is composed primarily of the Ringold Formation and overlying Hanford formation (Section 4.2). In some areas, the coarse-grained multilithic facies of the Cold Creek unit (pre-Missoula gravels) lie between these formations and below the water table. The other subunits of the Cold Creek unit are generally above the water table.

Water table elevations (Figure 4.3-11) show that groundwater in the unconfined aquifer at Hanford generally flows from recharge areas in the elevated region near the western boundary of the Hanford Site toward the Columbia River on the eastern and northern boundaries. The Columbia River is the primary discharge area for the unconfined aquifer. The Yakima River borders the Hanford Site on the southwest and is generally regarded as a source of recharge. Along the Columbia River shoreline, daily river level fluctuations may result in water table elevation changes of up to $3 \mathrm{~m}(10 \mathrm{ft})$. During the high river stage periods of 1996 and 1997, some wells near the Columbia River showed water level changes of more than $3 \mathrm{~m} \mathrm{(10} \mathrm{ft).} \mathrm{As} \mathrm{the} \mathrm{river} \mathrm{stage} \mathrm{rises,} \mathrm{a} \mathrm{pressure} \mathrm{wave} \mathrm{is} \mathrm{transmitted} \mathrm{inland} \mathrm{through} \mathrm{the} \mathrm{groundwater.} \mathrm{The}$ longer the duration of the higher river stage, the farther inland the effect is propagated. The pressure wave is observed farther inland than the water actually moves. For the river water to flow inland, the river level must be higher than the groundwater surface and must remain high long enough for the water to flow through the sediments. Typically, this inland flow of river water is restricted to within several hundred feet of the shoreline (McMahon and Peterson 1992).

Gee et al. (1992) and Fayer et al. (1996) estimate that recharge rates from precipitation across the Hanford Site range from near zero to over $100 \mathrm{~mm} / \mathrm{year}$ (3.94 in./yr). Recharge is variable both spatially and temporally. It is greatest for coarse-textured soils bare of deep-rooted vegetation and in years with rapid snowmelt events and precipitation during cool months. The magnitude of recharge at a particular location is influenced by five main factors: climate, soils, vegetation, topography, and springs and streams. Events such as the fire that burned vegetation from a large portion of the Hanford Site during the summer of 2000 also affect recharge rates. Fayer et al. (1996) used several types of field data and computer modeling to estimate the areal distribution of mean recharge rates for the soil and vegetation conditions at the Hanford Site, including any disturbance by Hanford operations.

Between 1944 and the mid-1990s, the volume of artificial recharge from Hanford wastewater disposal was significantly greater than recharge from precipitation. An estimated $1.68 \times 10^{12} \mathrm{~L}\left(4.44 \times 10^{11}\right.$ gal $)$ of liquid was discharged to disposal ponds, trenches, and cribs during this period. Wastewater discharge has decreased since 1984 and currently contributes a volume of recharge in the same range as the estimated natural recharge from precipitation. Because of the reduction in discharges, groundwater levels are falling, particularly around the operational areas (Hartman et al. 2004).

After the beginning of Hanford operations during 1943, the water table rose about $27 \mathrm{~m}$ (89 ft) under the U Pond disposal area (Figure 4.3-11) in the 200 West Area and about $9.1 \mathrm{~m}$ (30 ft) under disposal ponds near the 200 East Area. The volume of water that was discharged to the ground at the 200 West Area was actually less than that discharged at the 200 East Area. However, the lower hydraulic conductivity of the aquifer near the 200 West Area inhibited groundwater movement in this area resulting in a higher groundwater mound. The presence of the groundwater mounds locally affected the direction of groundwater movement, causing radial flow from the discharge areas. Zimmerman et al. (1986) documented changes in water table elevations between 1950 and 1980. Until about 1980, the edge 


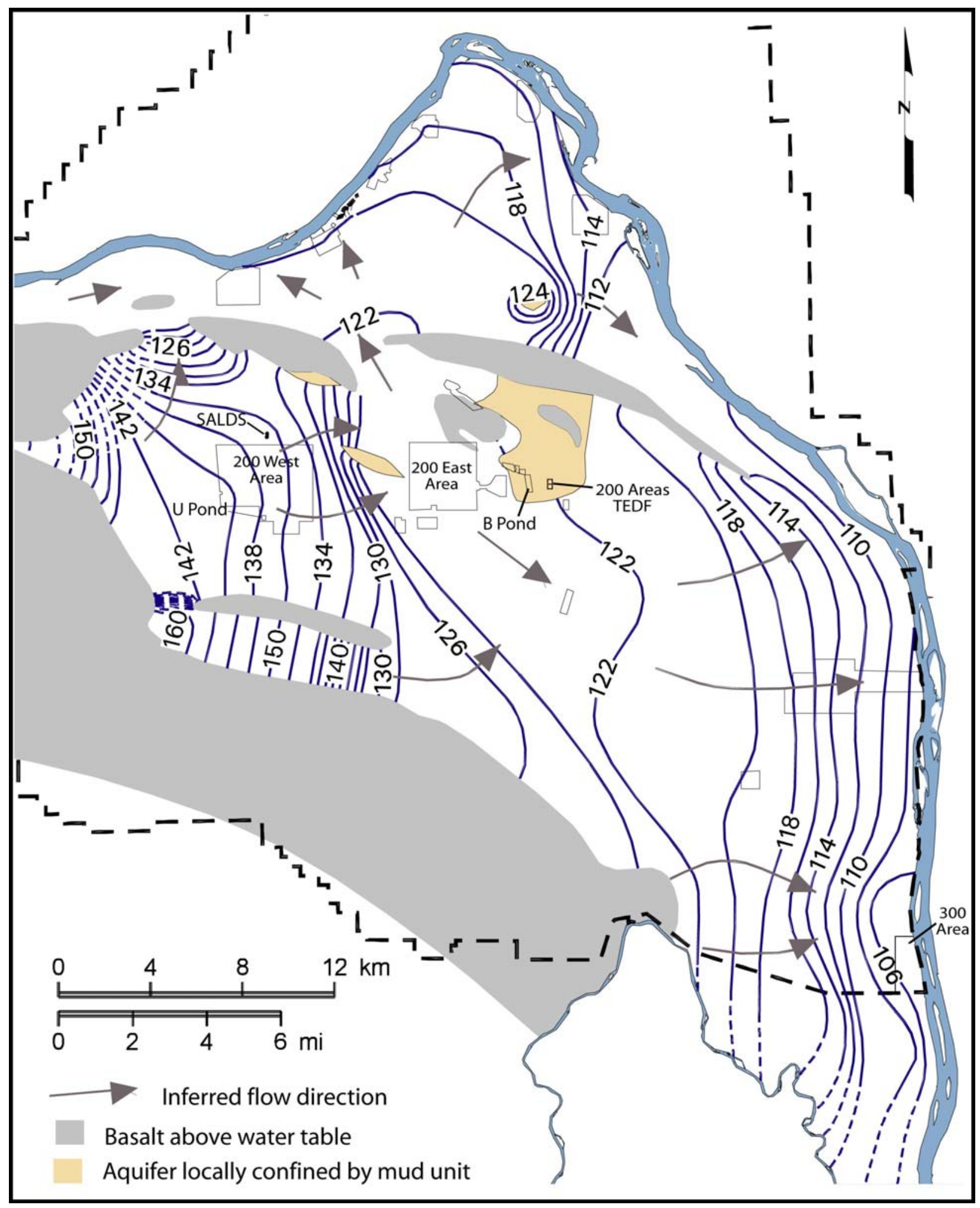

Figure 4.3-11. Water Table Elevations in Meters $(1 \mathrm{~m}=3.28 \mathrm{ft})$ and Inferred Groundwater Flow Directions for the Unconfined Aquifer at Hanford, Washington, March 2003 (Hartman et al. 2004) 
of the mounds migrated outward from the sources over time. Groundwater levels have declined over most of the Hanford Site since 1984 because of decreased wastewater discharges (Hartman et al. 2004). Although the reduction of wastewater discharges has caused water levels to drop significantly, a residual groundwater mound beneath the 200 West Area is still shown by the curved water table contours near this area and small groundwater mounds exist near the 200 Area Treated Effluent Disposal Facility (TEDF) and SALDS wastewater disposal sites (Figure 4.3-11).

Horizontal hydraulic conductivities of sand and gravel facies within the Ringold Formation generally range from about 1 to $100 \mathrm{~m} / \mathrm{d}$ ( 3 to $330 \mathrm{ft} / \mathrm{d}$ ), compared to 10 to $3000 \mathrm{~m} / \mathrm{d}$ (33 to 10,000 ft/d) for the Hanford formation and the coarse-grained multilithic facies of the Cold Creek unit (pre-Missoula gravels) (DOE 1988, Cole et al. 2001, Thorne and Newcomer 2002). Because the Ringold Formation sediments are more consolidated and partially cemented, they are about 10 to 100 times less permeable than the sediments of the overlying Hanford formation. Before wastewater disposal operations at the Hanford Site, the uppermost aquifer was mainly within the Ringold Formation, and the water table extended into the Hanford formation at only a few locations (Newcomb et al. 1972). However, wastewater discharges raised the water table elevation across the Site. The general increase in groundwater elevation caused the unconfined aquifer to extend upward into the Hanford formation over a larger area, particularly near the 200 East Area. This resulted in an increase in groundwater velocity because of both the greater volume of groundwater and the higher permeability of the newly saturated Hanford formation sediments.

\subsubsection{Limitations of Hydrogeologic Information}

The sedimentary architecture of the unconfined aquifer is very complex because of repeated deposition and erosion. Although hundreds of wells have been drilled on the Hanford Site, many penetrate only a small percentage of the total unconfined aquifer thickness, and there are a limited number of wells that can be used for defining the deeper sediment facies. A number of relatively deep wells were drilled in the early 1980s as part of a study for a proposed nuclear power plant (PSPL 1982), and these data are helpful in defining facies architecture. For most of the thinner and less extensive sedimentary units, correlation between wells is either not possible or uncertain. Major sand and gravel units of the Ringold Formation (e.g., Units A, B, C, D, and E) are separated by mud-dominated units (Figure 4.2-4). In some places the mud units act as aquitards that locally confine groundwater in deeper permeable sediments.

A limited amount of hydraulic property data is available from testing of wells. Hydraulic test results from wells on the Hanford Site have been compiled for the Hanford Groundwater Monitoring Project and for environmental restoration efforts (Kipp and Mudd 1973; Connelly et al. 1992 (a,b); Thorne and Newcomer 1992, 2002; Spane and Thorne 1995, 2000; Spane et al. 2001(a,b); Spane et al. 2002). Most

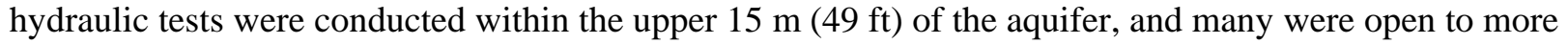
than one geologic unit. In some cases, changes in water table elevation may have significantly changed the unconfined aquifer transmissivity at a well since the time of the hydraulic test. Few hydraulic tests within the Hanford Site unconfined aquifer system have yielded accurate estimates of aquifer-specific yield.

\subsubsection{Groundwater Travel Times}

Tritium and carbon-14 measurements indicate that groundwater residence time (time that ground water has been in the subsurface) is up to thousands of years for the unconfined aquifer and more than 10,000 years for groundwater in the shallow confined aquifer (Johnson et al. 1992). Chlorine-36 and noble gas isotope data suggest groundwater ages greater than 100,000 years in the deeper confined systems (Johnson et al. 1992). These relatively long residence times are consistent with semiarid-site 
recharge conditions. However, groundwater travel time from the 200 East Area to the Columbia River has been shown to be much faster, in the range of 10 to 30 years (USGS 1987, Freshley and Graham 1988). This is because of large volumes of recharge from wastewater that was disposed in the 200 Area between 1944 and the mid-1990s and the relatively high permeability of Hanford formation sediments, which are below the water table between the 200 East Area and the Columbia River. Travel time from the 200 West Area is greater because of the lower permeability of Ringold Formation sediments. Plume monitoring indicates that groundwater from the 200 West Area has moved about $6 \mathrm{~km}$ (3.7 mi) during the past 50 years. Groundwater travel times from the 200 Area to the Columbia River are expected to decrease because of diminishing wastewater recharge in the 200 Area and the resulting reduction of the hydraulic gradient.

\subsubsection{Groundwater East and North of the Columbia River}

The Hanford Site boundary extends east and north of the Columbia River. Hanford Site activities in these areas have not impacted the groundwater. However, the groundwater in this area is impacted by high recharge from irrigation and canal leakage. The South Columbia Basin Irrigation District manages surface water used to irrigate land east and north of the Columbia River. Recharge from irrigation water has increased water table elevations in large areas of the Pasco Basin, in some places by as much as $92 \mathrm{~m}$ (300 ft) (Drost et al. 1989).

There are two general hydrologic areas that impinge upon the Hanford Site boundaries to the east and north of the river. The eastern area extends from north to south between the lower slope of Saddle Mountain and the Esquatzel Diversion canal and includes the Ringold Coulee, White Bluffs area, and Esquatzel Coulee. The water table occurs in the Pasco gravels of the Hanford formation in both Ringold and Esquatzel Coulees. Brown (1979) reported that runoff from spring discharge at the mouth of Ringold Coulee is greater than $0.631 \mathrm{~m}^{3} / \mathrm{s}\left(22.3 \mathrm{ft}^{3} / \mathrm{s}\right)$. Elsewhere in this area, the unconfined aquifer is in the lesstransmissive Ringold Formation. Irrigation has also created perched aquifers and resulted in a series of springs issuing from perched water along the White Bluffs. The increased hydraulic pressure in these sediments has caused subsequent slumping and landslides (Brown 1979, Newcomer et al. 1991).

The other principal irrigated area is the northern part of the Pasco Basin on the Wahluke Slope, which lies between the Columbia River and the Saddle Mountain anticline. Irrigation return waste-water paths off of the Wahluke Slope have created ponds and springs in the Saddle Mountain Wildlife Refuge. The direction of unconfined groundwater flow is southward from the basalt ridges toward the Columbia River. Bauer et al. (1985) reported that lateral water table gradients are essentially equal to or slightly less than the structural gradients on the flanks of the anticlinal fold mountains where the basalt dips steeply.

\subsubsection{Groundwater Quality}

The quality of groundwater at the Hanford Site, uncontaminated by Hanford activities, varies depending on the aquifer system and depth, which generally is related to residence time in the aquifer (DOE 1992a, 1997c; Hartman et al. 2004). The DOE (1997c) study involved examination of historical data and new data from wells in areas not affected by Hanford Site contaminants.

Groundwater chemistry in the basalt-confined aquifers displays a range depending on depth and residence time (DOE 1988). The chemical type varies from calcium- and magnesium-carbonate water to sodium- and chloride-carbonate water. Some of the shallower basalt-confined aquifers in the region (e.g., the Wanapum basalt aquifer) have exceptionally good water quality characteristics: less than $300 \mathrm{mg} / \mathrm{L}$

dissolved solids; less than $0.1 \mathrm{mg} / \mathrm{L}$ iron and magnesium; less than $20 \mathrm{mg} / \mathrm{L}$ sodium, sulfate, and chloride; and less than 10 ppb heavy metals (Johnson et al. 1992). However, deeper basalt-confined aquifers 
typically have high dissolved solids content and some have fluoride concentrations greater than the drinking water standard of $5 \mathrm{mg} / \mathrm{L}$ (DOE 1988).

Groundwater beneath large areas of the Hanford Site has been contaminated by radiological and chemical constituents resulting from past Hanford Site operations. These contaminants were primarily introduced through wastewater discharged to cribs, ditches, injection wells, trenches, and ponds (Kincaid et al. 1998). Additional contaminants from spills, leaking waste tanks, and burial grounds (landfills) have also entered groundwater in some areas. Contaminant concentrations in the existing groundwater plumes are expected to decline through radioactive decay, mineral adsorption, chemical degradation, and dispersion. However, contaminants also exist within the vadose zone beneath waste sites (Section 4.3.2) as well as in waste storage and disposal facilities. These contaminants have a potential to continue to move downward into the aquifer.

Some contaminants, including tritium and chloride, move at the same velocity as groundwater. The movement of other contaminants is slower because they react with or are sorbed on the surface of minerals within the aquifer or the vadose zone. The factor by which the velocity of a constituent is reduced compared to average groundwater flow velocity is called the "retardation factor." Therefore, tritium in groundwater will move 10 times faster than a contaminant with a retardation factor of 10 . For Hanford sediments, it has been estimated that technetium and chromium have small retardation factors and move at nearly the same velocity as groundwater (Thorne 2004). Iodine, nitrate, uranium, and carbon tetrachloride were estimated to have median retardation factors between 3 and 12. Strontium, cesium, and plutonium were estimated to have median retardation factors between 290 and 27,000. Cantrell et al. (2002) and Serne and Kaplan (2000) offer additional information on retardation of chemicals transported in groundwater.

Groundwater contamination is being actively remediated through pump-and-treat operations at the 200-West Area, 100-F Area and 100-K Area. These operations are summarized in Hartman et al. (2004). At the 100-N Area, pump-and-treat remediation has been terminated and a passive treatment barrier is being used to reduce contaminant migration.

Monitoring of radiological and chemical constituents in groundwater at the Hanford Site is performed to characterize physical and chemical trends in the flow system, establish groundwater quality baselines, assess groundwater remediation, and identify new or existing groundwater problems. Groundwater monitoring is also performed to verify compliance with applicable environmental laws and regulations. Samples were collected from 710 wells and 79 shoreline aquifer sampling tubes during FY 2003 to determine the distributions of radiological and chemical constituents in Hanford Site groundwater (Hartman et al. 2004).

To assess the quality of groundwater, concentrations measured in samples were compared with maximum contaminant levels (MCL) or interim Drinking Water Standards (DWS) and DOE's Derived Concentration Guides (DCG). The MCL or DWS standards are legal limits for contaminant concentrations in public drinking water supplies enforceable by the Washington State Department of Health or EPA. Although these standards are only applicable at the point of consumption of the water, they provide a useful indicator of negative impacts to the groundwater resource. The DCG applies only to radionuclides and is based on the concentration that would result in a dose exposure of $1 \mathrm{mSv} /$ year (100mrem/year) effective dose equivalent, a calculation of dose that assumes ingestion under specified intake scenarios.

Radiological constituents including carbon-14, iodine-129, strontium-90, technetium-99, gross alpha, gross beta, tritium, and uranium were detected at levels greater than the DWS in one or more onsite wells. Concentrations of strontium-90, tritium, and uranium were detected at levels greater than DOE's DCG. 
Certain nonradioactive chemicals regulated by EPA and the State of Washington (nitrate, fluoride, chromium, cyanide, carbon tetrachloride, chloroform, trichloroethylene, and tetrachloroethylene) were also present in Hanford Site groundwater during fiscal year 2003 (Table 4.3-2). The extent of radiological and non-radiological contamination in Hanford Site groundwater above the applicable DWS is determined annually (Figures 4.3-12 and 4.3-13). The area of contaminant plumes on the Hanford Site with concentrations exceeding drinking water standards was estimated to be $190 \mathrm{~km}^{2}\left(89.2 \mathrm{mi}^{2}\right)$ during fiscal year 2004.

\subsubsection{Area Hydrology}

The hydrology of the 100 Area is affected by its location adjacent to the Columbia River. The water table ranges in depth from near $0 \mathrm{~m}(0 \mathrm{ft})$ at the river edge to $30 \mathrm{~m}(107 \mathrm{ft})$. The groundwater flow direction is generally toward the river. However, during high river stage, the flow direction may reverse immediately adjacent to the river. The unconfined aquifer in the 100 Area is composed of either the Ringold Unit E gravels or a combination of the Unit E gravels and the Hanford formation (Figure 4.2-5). There are two large areas where the water table is within the Ringold Formation (Lindsey 1992), and the Hanford formation is unsaturated (Figure 4.3-14). In the 100-H and 100-F Areas, the Ringold Unit E gravels are missing, and the Hanford formation lies directly over the fine-grained Ringold lower-mud unit. In most of the 100 Area, the lower Ringold mud forms an aquitard, and the Ringold gravels below the mud are locally confined. Additional information on the hydrology of the 100 Area is available in Hartman and Peterson (1992) and Peterson et al. (1996). A number of studies of various sites in the 100 Area present specific hydrologic information. These include: 100-B/C Area - Lindberg (1993a); 100-D Area - Lindsey and Jaeger (1993); 100-F Area - Lindsey (1992), Peterson (1992); 100-H Area - Liikala et al. (1988), Lindsey and Jaeger (1993); 100-K Area - Lindberg (1993b); and 100-N Area - Gilmore et al. (1992), Hartman and Lindsey (1993).

\subsubsection{Area Hydrology}

In the 200 West Area, the water table occurs almost entirely in the Ringold Unit E gravels, while in the 200 East Area, it occurs primarily in the Hanford formation and in the Ringold Unit A gravels (Figure 4.2-5). Along the southern edge of the 200 East Area, the water table is in the Ringold Unit E gravels. The upper Ringold facies were eroded in most of the 200 East Area by the ancestral Columbia River and, in some places, by the Missoula floods that subsequently deposited Hanford gravels and sands on what was left of the Ringold Formation (DOE 2002b). Because the Hanford formation and possibly the Cold Creek unit sand and gravel deposits are much more permeable than the Ringold gravels, the water table is relatively flat in the 200 East Area, but groundwater flow velocities are higher. On the north side of the 200 East Area, there is evidence of erosional channels that may allow interaquifer flow between the unconfined and uppermost basalt-confined aquifer (Graham et al. 1984, Jensen 1987).

The hydrology of the 200 Area has been strongly influenced by the discharge of large quantities of wastewater to the ground during a 50-year period. The discharges caused elevated groundwater levels across much of the Hanford Site resulting in a large groundwater mound beneath the former U Pond (Figure 4.3-11) in the 200 West Area and a smaller mound beneath the former B Pond, east of the 200 East Area. Water table changes beneath the 200 West Area have been greatest because of the lower transmissivity of the aquifer in this area (Cole et al. 2001). Discharges of water to the ground have been greatly reduced, and corresponding decreases in the elevation of the water table have been observed. 
Table 4.3-2. Maximum Concentrations of Selected Groundwater Contaminants in Fiscal Year 2003 (modified from Hartman et al. 2004)

\begin{tabular}{|c|c|c|c|c|c|c|c|c|c|c|c|c|}
\hline \multirow[b]{2}{*}{$\begin{array}{l}\text { Contaminant, units } \\
\text { (alphabetical order) }\end{array}$} & \multirow[b]{2}{*}{ DWS(a) } & \multicolumn{2}{|c|}{ 100-BC-5 } & \multicolumn{2}{|c|}{ 100-KR-4 } & \multirow{2}{*}{$\begin{array}{c}\text { 100-NR-2 } \\
\text { Wells } \\
\end{array}$} & \multicolumn{2}{|c|}{ 100-HR-3-D } & \multicolumn{2}{|c|}{ 100-HR-3-H } & \multicolumn{2}{|c|}{ 100-FR-3 } \\
\hline & & Wells & $\begin{array}{c}\text { Aquifer } \\
\text { Tubes }\end{array}$ & Wells & $\begin{array}{c}\text { Aquifer } \\
\text { Tubes }\end{array}$ & & Wells & $\begin{array}{c}\text { Aquifer } \\
\text { Tubes }\end{array}$ & Wells & $\begin{array}{c}\text { Aquifer } \\
\text { Tubes }\end{array}$ & Wells & $\begin{array}{c}\text { Aquifer } \\
\text { Tubes }\end{array}$ \\
\hline arsenic (filtered), $\mu \mathrm{g} / \mathrm{L}$ & 10 & & & & & & & & & & & \\
\hline cadmium (filtered), $\mu \mathrm{g} / \mathrm{L}$ & 5 & 3.3 & & & & 3.1 & 3.4 & & & & 3.9 & \\
\hline carbon tetrachloride, $\mu \mathrm{g} / \mathrm{L}$ & 5 & & & & & & & & & & & \\
\hline carbon-14, pCi/L & 2,000 & & & 20,900 & 67.2 & 15.4 & & & & & & \\
\hline cesium-137, pCi/L & 200 & & & & & ND & & & & & & \\
\hline chloroform, $\mu \mathrm{g} / \mathrm{L}$ & 100 & & & 1 & & 7.2 & & & & & 1.1 & \\
\hline chromium (dissolved), $\mu \mathrm{g} / \mathrm{L}$ & 100 & 46 & 38 & 542 & 52 & 168 & 5,440 & 295 & 154 & 43 & 90 & \\
\hline cis-1,2-dichloroethene, $\mu \mathrm{g} / \mathrm{L}$ & 70 & & & & & & & & & & & \\
\hline cobalt-60, pCi/L & 100 & & & & & ND & & & & & & \\
\hline cyanide, $\mu \mathrm{g} / \mathrm{L}$ & 200 & & & & & & & & & & & \\
\hline fluoride, mg/L & 4 & 0.51 & & 0.49 & & 1 & 0.45 & & 0.45 & & 0.72 & \\
\hline gross alpha, $\mathrm{pCi} / \mathrm{L}$ & 15 & 2.99 & & 7.14 & & 3.07 & 3.94 & & 72.4 & & 10.1 & \\
\hline gross beta, $\mathrm{pCi} / \mathrm{L}$ & 50 & 221 & & 3,590 & & 16,000 & 466 & & 183 & & 51.1 & \\
\hline iodine-129, pCi/L & 1 & & & & & & & & & & & \\
\hline nickel (filtered), $\mu \mathrm{g} / \mathrm{L}$ & 100 & & & 28.8 & & 17 & 416 & & 21.6 & & & \\
\hline nitrate, $\mathrm{mg} / \mathrm{L}$ & 45 & 27.9 & & 195 & 3.6 & 228 & 107 & & 474 & & 177 & \\
\hline nitrite, mg/L & 3.3 & & & 0.135 & & 0.299 & 7.55 & & & & & \\
\hline plutonium-239/240, pCi/L & $\mathrm{NA}(\mathrm{b})$ & & & & & & & & & & & \\
\hline strontium-90, pCi/L & 8 & 98.9 & 15 & 2,440 & ND & 8,000 & 7.06 & & 23.2 & & 27.8 & \\
\hline technetium-99, pCi/L & 900 & 46.7 & & 85.4 & & & & & 986 & ND & & \\
\hline trichloroethene, $\mu \mathrm{g} / \mathrm{L}$ & 5 & & & 11 & & & & & & & 9.8 & \\
\hline tritium, $\mathrm{pCi} / \mathrm{L}$ & 20,000 & 21,900 & 32,200 & $1,270,000$ & ND & 31,400 & 23,700 & 29,700 & 6,210 & & 11,500 & \\
\hline uranium, $\mu \mathrm{g} / \mathrm{L}$ & 30 & & & & & & 3.58 & & 119 & & & \\
\hline $\begin{array}{l}\text { Note: Table lists highest mea } \\
\text { indicates the constituent not } 0 \\
\text { (a) DWS = Drinking water } \\
\text { (b) There is no drinking wat } \\
\text { Conversion: } 27 \mathrm{pCi} / \mathrm{L}=1 \mathrm{~Bq} \\
\mathrm{NA}=\text { Not applicable }\end{array}$ & $\begin{array}{l}\text { concentrati } \\
\text { cern in the g } \\
\text { rd or U.S. E } \\
\text { ndard for pl } \\
\text { Not detected }\end{array}$ & $\begin{array}{l}\text { fiscal yea } \\
\text { ea. } \\
\text { mental } \mathrm{PI} \\
\text { n-239/24 }\end{array}$ & $\begin{array}{l}2003 \text { in ea } \\
\text { tection Ag } \\
\text { The Dep }\end{array}$ & $\begin{array}{l}\text { groundwa } \\
\text { ncy maxim } \\
\text { tment of En }\end{array}$ & $\begin{array}{l}\text { er interest } \\
\text { m contam } \\
\text { rgy Deriv }\end{array}$ & $\begin{array}{l}\text { ea. Concen } \\
\text { Concentrat }\end{array}$ & $\begin{array}{l}\text { ations in } \\
\text { L) if ther } \\
\text { n Guide }\end{array}$ & $\begin{array}{l}\text { old exceed } \\
\text { is no DWS } \\
30 \mathrm{pCi} / \mathrm{L}\end{array}$ & $\begin{array}{l}\text { inking w } \\
1 \mathrm{~Bq} / \mathrm{L})\end{array}$ & ater stand & s. Blan & \\
\hline
\end{tabular}

Table 4.3-1. (cont'd) 


\begin{tabular}{|c|c|c|c|c|c|c|c|}
\hline $\begin{array}{l}\text { Contaminant, units } \\
\text { (alphabetical order) }\end{array}$ & DWS(a) & $\begin{array}{c}\text { 200-ZP-1 } \\
\text { Wells }\end{array}$ & $\begin{array}{c}\text { 200-UP-1 } \\
\text { Wells }\end{array}$ & $\begin{array}{c}\text { 200-BP-5 } \\
\text { Wells }\end{array}$ & $\begin{array}{c}\text { 200-PO-1 } \\
\text { Wells }\end{array}$ & $\begin{array}{c}\text { 300-FF-5 } \\
\text { Wells }\end{array}$ & $\begin{array}{c}\text { 1100-EM-1 } \\
\text { Wells }\end{array}$ \\
\hline arsenic (filtered), $\mu \mathrm{g} / \mathrm{L}$ & 10 & 4.1 & 8.7 & 7.6 & 9.2 & & \\
\hline cadmium (filtered), $\mu \mathrm{g} / \mathrm{L}$ & 5 & 3.2 & 3.1 & 4.6 & 3.3 & & \\
\hline carbon tetrachloride, $\mu \mathrm{g} / \mathrm{L}$ & 5 & 6,200 & 690 & & 0.29 & 0.35 & \\
\hline carbon-14, pCi/L & 2,000 & & & & & & \\
\hline cesium-137, pCi/L & 200 & & & 1,170 & & & \\
\hline chloroform, $\mu \mathrm{g} / \mathrm{L}$ & 100 & 31 & 20 & & 0.46 & 3 & 4.4 \\
\hline chromium (dissolved), $\mu \mathrm{g} / \mathrm{L}$ & 100 & 592 & 209 & 54.9 & 6,250 & 7.3 & \\
\hline cis-1,2-dichloroethene, $\mu g / L$ & 70 & 0.09 & & & & 160 & 48 \\
\hline cobalt-60, pCi/L & 100 & & & 48.4 & & & \\
\hline cyanide, $\mu \mathrm{g} / \mathrm{L}$ & 200 & 6.4 & & 275 & & & \\
\hline fluoride, mg/L & 4 & 4.3 & 0.7 & 0.98 & 1.3 & 0.52 & 4.3 \\
\hline gross alpha, pCi/L & 15 & 6.73 & 13.9 & 324 & 10.7 & 43.9 & 77 \\
\hline gross beta, $\mathrm{pCi} / \mathrm{L}$ & 50 & 4,390 & 71,200 & 12,100 & 79.7 & 97.5 & 34.7 \\
\hline iodine-129, pCi/L & 1 & 36.7 & 35.3 & 3.65 & 11.9 & & \\
\hline nickel (filtered), $\mu \mathrm{g} / \mathrm{L}$ & 100 & 328 & 120 & 133 & 864 & 41.6 & \\
\hline nitrate, $\mathrm{mg} / \mathrm{L}$ & 45 & 2,160 & 1,930 & 735 & 170 & 134 & 261 \\
\hline nitrite, mg/L & 3.3 & 0.361 & 0.46 & 1.12 & 0.233 & 0.069 & 0.043 \\
\hline plutonium-239/240, pCi/L & $\mathrm{NA}(\mathrm{b})$ & & & 74.8 & & & \\
\hline strontium-90, pCi/L & 8 & 1.29 & 53.6 & 5,680 & 21.4 & 4.03 & \\
\hline technetium-99, pCi/L & 900 & 11,117 & 188,000 & 10,600 & 287 & 319 & 27 \\
\hline trichloroethene, $\mu \mathrm{g} / \mathrm{L}$ & 5 & 18 & 11 & & 0.88 & 7.2 & 27 \\
\hline tritium, pCi/L & 20,000 & $2,170,000$ & 634,000 & 27,600 & $5,570,000$ & $3,670,000$ & 251 \\
\hline uranium, $\mu \mathrm{g} / \mathrm{L}$ & 30 & 367 & 1,190 & 554 & 7.19 & 235 & 18 \\
\hline \multicolumn{8}{|c|}{$\begin{array}{l}\text { Note: Table lists highest measured concentration for fiscal year } 2003 \text { in each groundwater interest area. Concentrations in bold exceed drinking water standards. Blank space } \\
\text { indicates the constituent was not of concern in the given area.. } \\
\text { (a) DWS = Drinking water standard or U.S. Environmental Protection Agency maximum contaminant level (MCL) if there is no DWS } \\
\text { (b) There is no drinking water standard for plutonium-239/240. The Department of Energy Derived Concentration Guide is } 30 \mathrm{pCi} / \mathrm{L}(1.1 \mathrm{~Bq} / \mathrm{L}) \\
\text { Conversion: } 27 \mathrm{pCi} / \mathrm{L}=1 \mathrm{~Bq} / \mathrm{L} \\
\mathrm{NA}=\text { Not anplicable }\end{array}$} \\
\hline
\end{tabular}




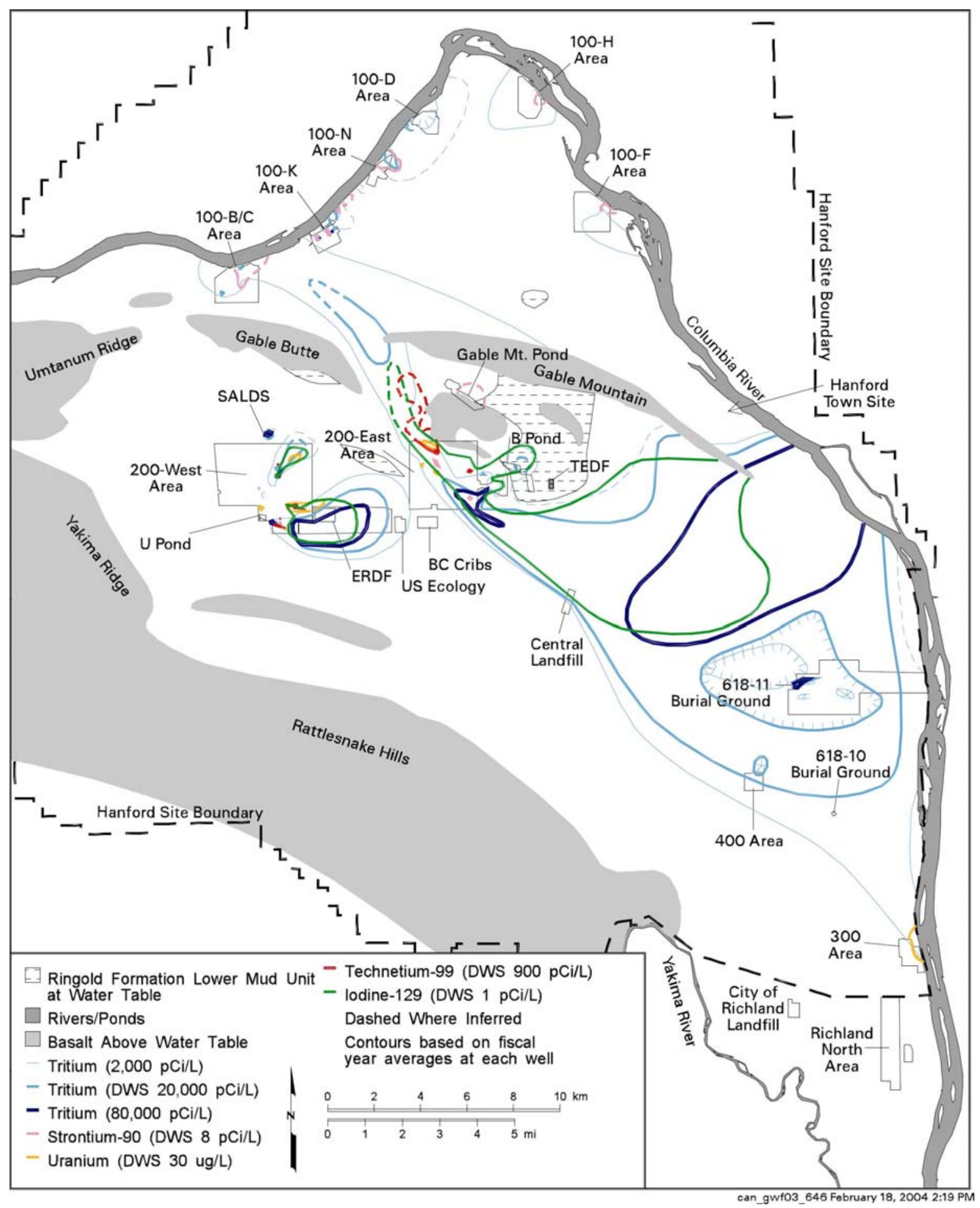

Figure 4.3-12. Distribution of Radionuclides in Groundwater on the Hanford Site, Washington, at Concentrations above the Maximum Contaminant Level or Interim Drinking Water Standard during Fiscal Year 2003 (Hartman et al. 2004) $(27$ pCi/L = $1 \mathrm{~Bq} / \mathrm{L})$ 


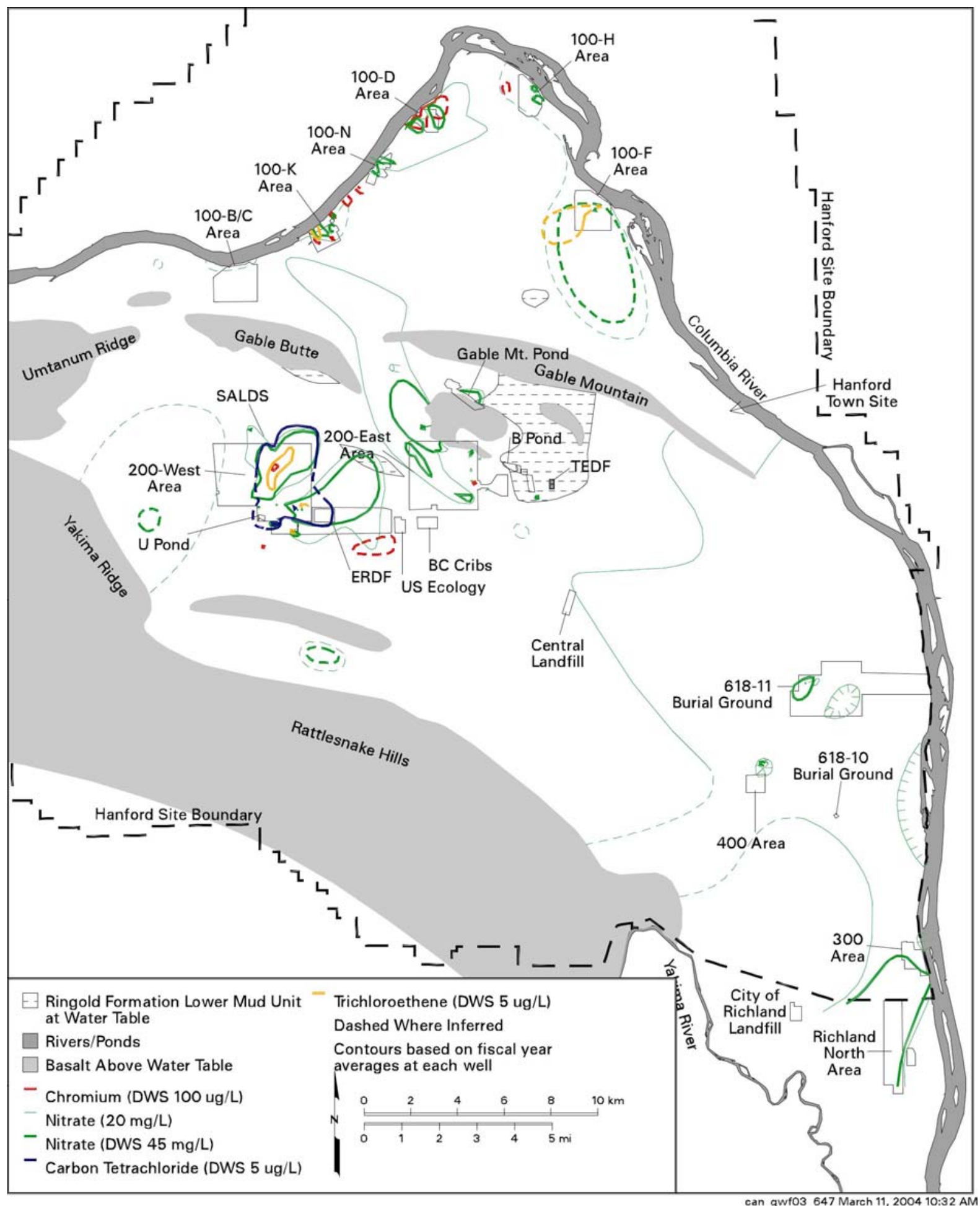

Figure 4.3-13. Distribution of Hazardous Chemicals in Groundwater on the Hanford Site, Washington, at Concentrations above the Maximum Contaminant Level or Interim Drinking Water Standard during Fiscal Year 2003 (Hartman et al. 2004) 


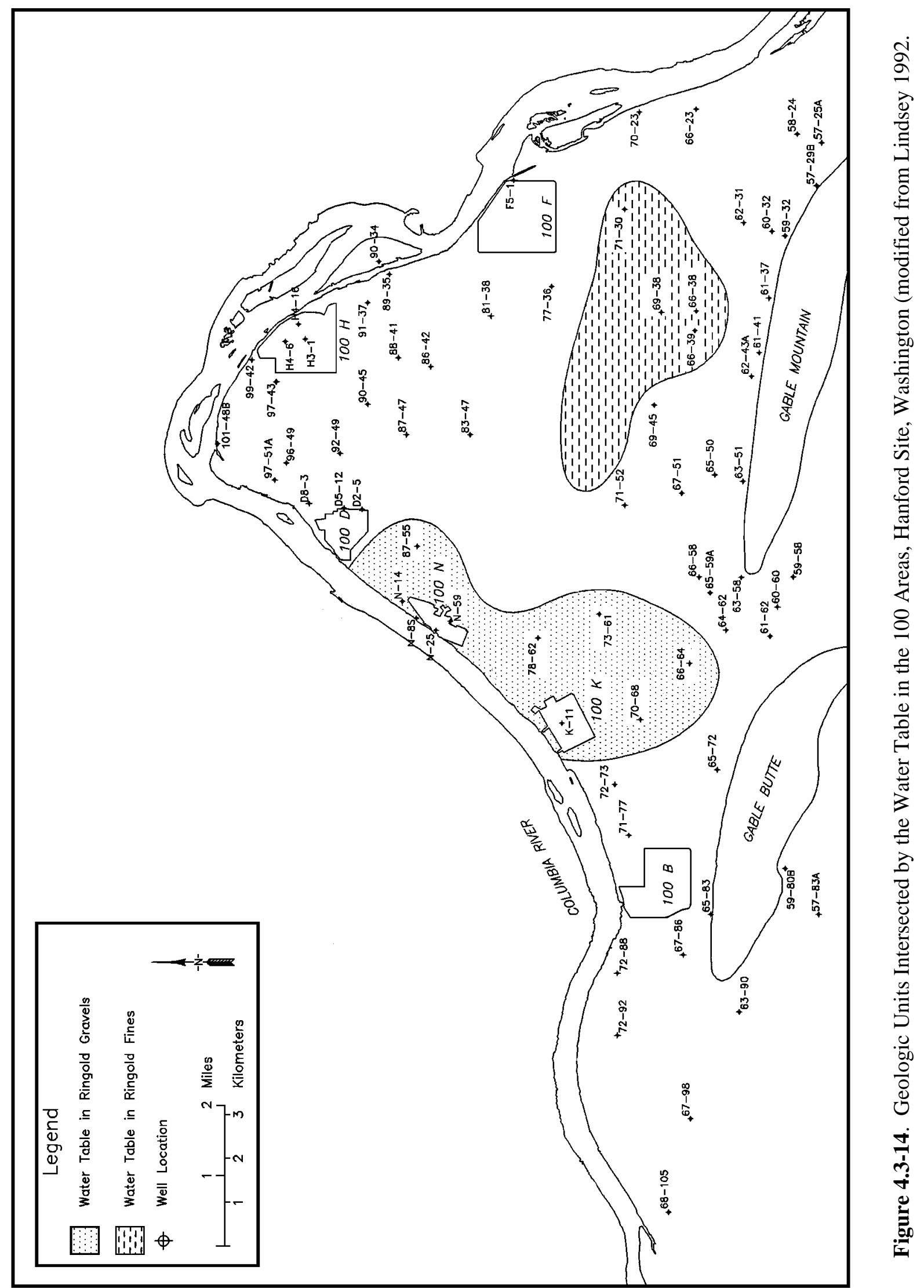




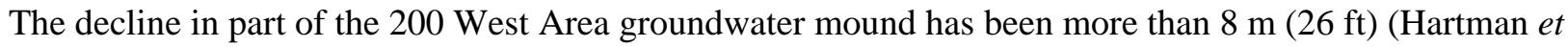
al. 2004). Water levels are expected to continue to decrease as the unconfined groundwater system reaches equilibrium with the new level of artificial recharge (Wurstner and Freshley 1994).

A number of reports dealing with the hydrogeology of the 200 Area have been released including Williams et al. (2000, 2002), Graham et al. (1981), Last et al. (1989), and Connelly et al. (1992a,b).

\subsubsection{Area Hydrology}

The unconfined aquifer water table in the 300 Area (Figure 4.3-11) is found in both the Hanford formation and the Ringold Formation. It is 0 to $19 \mathrm{~m}$ (0 to $62 \mathrm{ft}$ ) below ground surface depending on location. Elevation of the Columbia River stage strongly affects the groundwater levels and flow near the river in the 300 Area. Water table contours in the vicinity of the 300 Area are somewhat concentric, showing that there is a groundwater discharge area for the unconfined aquifer system in the area of convergence. Groundwater flows from the northwest, west, and even the southwest to discharge into the Columbia River near the 300 Area. Schalla et al. (1988), Swanson (1992), and Hartman et al. (2004) have provided more detailed information on the hydrogeology of the 300 Area.

\subsubsection{Richland North Area Hydrology}

The Richland North Area (Figure 4.3-13) is located in the southern part of the Hanford Site and includes the former 1100 Area, ${ }^{(a)}$ which was transferred from the DOE to the Port of Benton on October 1 , 1998. The groundwater in this area is influenced by artificial recharge associated with the North Richland recharge basins and nearby irrigated farming (Liikala 1994). Water is pumped from the Columbia River to the recharge basins and subsequently pumped from nearby wells. This system is used by the City of Richland as a backup filtration system for city water. Because an excess of water is pumped into the recharge basins, a mound has been created in the water table, which helps to reduce the potential for groundwater flow from the Hanford Site into this area (Hartman et al. 2004). The river stage elevation of the Yakima River, which flows just west of the area, is high enough such that the river also acts as a recharge source for the groundwater system. However, a study of water levels in wells adjacent to the river showed that flow between the Yakima River and aquifer may be inhibited in some areas by mud deposited along the river bed (Thorne et al. 1993).

The southern portion of the tritium plume from the 200 East Area extends to the 300 Area. However, tritium concentrations decrease from greater than $10,000 \mathrm{pCi} / \mathrm{L}(373.4 \mathrm{~Bq} / \mathrm{L})$ to less than $100 \mathrm{pCi} / \mathrm{L}$ (3.734 Bq/L) across the 300 Area and the distribution across this area has changed little since fiscal year 1999 (Hartman et al. 2004). A few wells south of the 300 Area, in the vicinity of Richland's recharge ponds, have shown slightly elevated tritium levels compared to expected background levels for the groundwater. However, the observed tritium levels are consistent with tritium concentrations in the Columbia River water that is pumped into the ponds (Hartman et al. 2004). Nitrate contamination is also found in the Richland North Area. This is the result of industrial and agricultural sources off the Hanford Site. The nitrate plume is migrating eastward and entering the Columbia River. Concentrations above the 45-mg/L maximum contaminant level are found over most of the Richland North Area (Figure 4.3-13) (Hartman et al. 2004).

\footnotetext{
(a) The 1100 Area was the location of general stores and transportation maintenance facilities at the Hanford Site. The 1100 Area was declared clean by the regulatory agencies during September 1996.
} 


\subsection{Ecology}

\section{T.M. Poston and M.R. Sackschewsky}

Ecology is an integrating discipline that defines the relationships between organisms and their environment. Ecological evaluations are organized by broad habitat type and include terrestrial and aquatic ecosystems. Terrestrial ecosystems include upland and riparian/wetland habitat.

The Columbia River crosses the Hanford Site entering at the northwest corner of the site, traveling eastward and then turning south, forming the eastern boundary of the site. The Columbia River and associated riparian zones provide habitat for numerous wildlife and plant species. The area known as the Hanford Reach, the Columbia River from Priest Rapids Dam (river mile (RM) 397) to McNary Pool (RM 346) is the last free-flowing, non-tidal segment of the Columbia River in the United States. Several small intermittent spring/streams are also found on the site and, with their unique riparian habitat, provide a break in the vast expanses of shrub-steppe habitat that dominate the Hanford Site.

Other descriptions of the ecology of the Hanford Site can be found in Cadwell (1994), Downs et al. (1993), ERDA (1975), Jamison (1982), Landeen (1996), Rogers and Rickard (1977), Sackschewsky and Downs (2001), Watson et al. (1984), Weiss and Mitchell (1992), and Poston et al. (2004).

The remainder of this section addresses the habitat, flora, and fauna found in terrestrial (Section 4.4.1) and aquatic ecosystems (Section 4.4.2). A third section addresses species formally listed as threatened, endangered, or special status by federal and state agencies (Section 4.4.3).

\subsubsection{Terrestrial Ecology}

The Hanford Site encompasses about $1517 \mathrm{~km}^{2}$ (about $586 \mathrm{mi}^{2}$ ) of predominantly shrub-steppe habitat located within the Columbia Basin (Plateau) Ecoregion (Stroms et al. 1997). Shrub-steppe ecosystems are typified by a shrub overstory and a grass and forb understory (Daubenmire 1970). Lichens and mosses, often times referred to as "microbiotic or cryptogamic crust," provide a soil stabilizing growth on undisturbed soils in the shrub-steppe ecosystem. The Columbia Basin (Plateau) Ecoregion historically included over 6 million hectares (14.8 million acres) of steppe and shrub-steppe vegetation across most of central and southeastern Washington, as well as portions of north-central Oregon. Much of this land has been developed for agriculture, industrial, and other developments. Terrestrial ecosystems basically include upland and riparian/wetland habitat. Upland habitat at Hanford is influenced by arid climate and characterized by vegetation and wildlife adapted to hot summers, cold winters, and low precipitation. Riparian habitat occurs along bodies of water and is inhabited by plants requiring more water than that provided by precipitation. Wetlands are areas where some open water is present and soils and associated vegetation reflect the presence of water.

In the early 1800s, the dominant vascular plants in the area were big sagebrush underlain by perennial bunchgrasses and forbs. With the advent of Euro-American settlement, livestock grazing and agricultural production contributed to colonization by non-native plant species that currently dominate portions of the landscape. Agriculture and livestock production were the primary subsistence activities at the turn of the $20^{\text {th }}$ century. Although these activities ceased when the Hanford Site was created in January 1943, remnants of past agricultural practices are still evident. Many places on the Hanford Site are relatively free of non-native species and are extensive enough to retain characteristic populations of shrub-steppe plants and animals that are absent or scarce in developed or fire-impacted areas of the ecoregion. Because of its location, the Hanford Site provides important connectivity with other undeveloped portions of the ecoregion. 
Large areas of the Hanford Site have experienced recent range fires that influence the vegetation composition and distribution of wildlife. In 1984, a major fire burned across $800 \mathrm{~km}^{2}\left(310 \mathrm{mi}^{2}\right)$ of the Hanford Site (Price et al. 1986). During 2000, a range fire burned across the Hanford Site consuming most of the shrub-steppe habitat on the Fitzner-Eberhardt Arid Lands Ecology Reserve Unit, a small section of the McGee-Riverlands Unit, and other southwestern portions of the Site. The fire burned a total of $655 \mathrm{~km}^{2}\left(250 \mathrm{mi}^{2}\right)$ of federal, state, and private lands before it was controlled (BAER 2000).

These fires have altered the composition of the shrub-steppe habitat. Much of the year 2000 burn was considered to be low severity. Low severity refers to a burn that leaves the soil structure and seed bank intact. The belowground portions of most perennial plants were unharmed and have returned. Much of the burned area is in various stages of recovery. Sagebrush may take considerably longer to recover than perennial bunchgrass areas depending on the availability of seed in the soil, severity of the burn, and the distance to other seed sources. Re-establishment of mature sagebrush stands is likely to take 5 to 10 years. Some of the burned areas continue to be invaded by non-indigenous plant species such as Russian thistle (Salsola tragus, formerly kali) and tumble mustard (Sisymbrium altissimum). In some areas, efforts have been taken to re-establish big sagebrush (Artemesia tridentata).

\subsubsection{Vegetation}

The Hanford Site contains some of the highest quality shrub-steppe habitat in the State of Washington and the larger ecoregions in the Northwest. In some areas, unique and rare communities exist in spite of past wildfires and the presence of non-native species introduced by man. Because of the diversity of habitats on the Hanford Site, including a relatively large elevation range of $1000 \mathrm{~m}$, the riparian corridor, sand dunes, and other special habitats, there is a high number of plant species on site. A total of 727 species representing 90 families of vascular plants are recorded for the Hanford Site (Sackschewsky and Downs 2001). Of this total, 179 are non-native species. Cheatgrass (Bromus tectorum) is the dominant non-native species. It is an aggressive colonizer and has become well established across the Hanford Site (Rickard and Rogers 1983). Hanford Site plants are adapted to low annual precipitation (17 cm [6.8 in.]), low water-holding capacity of the rooting substrate (sand), dry summers, and cold winters.

Microbiotic crusts are an important component of the shrub-steppe communities found at Hanford. The microbiotic (or cryptogamic) crusts generally occur in the top 1 to $4 \mathrm{~mm}$ (0.04 to $0.16 \mathrm{in}$.) of soil and are composed of primarily algae, lichens, and mosses. These crusts are formed by organisms and their by-products, creating a consolidated layer of soil particles bound together by organic materials.

Microbiotic crusts are common in the semi-arid Columbia Basin, where the dominant organism tends to be green algae (Johansen et al. 1993). The functions of microbiotic crusts include soil stability and protection from erosion; fixation of atmospheric nitrogen; nutrient contribution to plants influencing soilplant water relations; and increasing water infiltration, seedling germination, and plant growth. The ecological roles of microbiotic crusts depend on the relative cover of various crustal components. Carbon inputs are higher when mosses and lichens are present than when the crust is dominated by cyanobacteria. Nitrogen inputs are higher with greater water infiltration. Soil surface stability is related to cyanobacterial biomass as well as total moss and lichen cover (Belnap et al. 2001). The lichen and mosses of the Hanford Site were surveyed and evaluated by Link et al. (2000). They found 29 soil lichens in 19 genera and 6 moss species in 4 genera. Twelve (41 percent) lichen species are of the crustose growth form (flat and firmly attached to the substrate), eight (28 percent) are squamulose (having small, flat scales that do not adhere tightly to substrate), seven (24 percent) are foliose (having leaf-like lobes, attached in the center to substrate by clusters of rhizomes), and two (7 percent) are fruticose (plant-like growth attached at one point). More recent surveys have found a total of 120 taxa of lichens and mosses on the Hanford Monument lands surrounding the central portion of the Hanford Site (Evans et al. 2003). 
Soll et al. (1999) conducted plant surveys on Fitzner-Eberhardt Arid Lands Ecology Reserve Unit, the Wahluke Slope, central Hanford, and riparian communities along the Columbia River shoreline from 1994 through 1997. These surveys tentatively identified 30 "potential” terrestrial plant communities. Designation as a potential community indicates a type of community that would exist in an area if it were free of disturbance. In addition to characterizing potential plant communities, Soll et al. (1999) found 112 populations/occurrences of 28 rare plant taxa on the Hanford Site. Rare plant taxa are defined by the Washington Natural Heritage Program as plants that are followed because of loss of habitat and dwindling populations. When combined with observations preceding the 1994-1999 inventory, a total of 127 populations of 30 rare plant taxa have been documented on the Hanford Site (Figure 4.4-1). A more general description of the vegetation cover types found on Hanford, including shrublands, grasslands, microbiotic crust, tree zones, and riparian habitat, follows.

Shrublands. Shrublands occupy the largest area in terms of acreage and comprise seven of the nine major plant communities on the Hanford Site (Sackschewsky and Downs 2001). Of the shrubland types, sagebrush-dominated communities are predominant, with other shrub communities varying with changes in soil and elevation. About $287 \mathrm{~km}^{2}\left(111 \mathrm{mi}^{2}\right)$ of shrub habitat dominated by big sagebrush was destroyed in the year 2000 fire and is in various stages of shrub recovery.

Of the vegetation types found on the Hanford Site (Figure 4.4-1), those with a shrub component (i.e., big sagebrush, threetip sagebrush [Artemisia tripartita], bitterbrush [Purshia tridentata], gray rabbitbrush [Ericameria nauseousa previously Chrysothamnus nauseosus], green rabbitbrush [Chrysothamnus viscidiflorus], black greasewood [Sarcobatus vermiculatus], winterfat [Krascheninnikovia (Ceratoides) lanata], snow buckwheat [Eriogonum niveum], and spiny hopsage [Grayia (Atriplex) spinosa]) are considered shrub-steppe. These stands typically have an understory dominated by bunchgrasses such as bluebunch wheatgrass (Pseudoroegnaria spicata previously Agropyron spicatum), Sandberg's bluegrass (Poa sandbergii [secunda]), needle-and-thread grass (Hesperostipa comata previously Stipa comata), Indian ricegrass (Achnatherum hymenoides previously Oryzopsis hymenoides), bottlebrush squirreltail (Elymus elymoides previously Sitanion hysterix), and prairie junegrass (Koeleria cristata) as well as a number of broad-leaf forbs. Areas that have been heavily grazed or disturbed often have an understory dominated by cheatgrass. Heterogeneity of species composition varies with soil, slope, and elevation. Vegetation types with a significant cheatgrass component are generally of lower habitat quality than those with bunchgrass understories. A list of common plant species in Hanford areas is presented in Appendix B, Table B-1 and Sackschewsky and Downs (2001).

Grasslands. Most grasses occur as understory in shrub-dominated plant communities. Because shrubs have been removed by fire in many areas, there are large areas of grass-dominated communities on the Hanford Site. Cheatgrass has replaced many native perennial grass species and is well established in many low-elevation (less than $244 \mathrm{~m}$ [800 ft]) and/or disturbed areas (Rickard and Rogers 1983, Soll et al. 1999). Of the native grasses that occur on the Hanford Site, bluebunch wheatgrass occurs at higher elevations. Sandberg's bluegrass is widely distributed throughout the Columbia Basin and the intermountain west. Needle-and-thread grass, Indian ricegrass, and thickspike wheatgrass (Elymus macrourus previously Agropyron dasytachyum) occur in sandy soils and dune habitats. Species preferring more moist locations include streambank or riparian wheatgrass (Elymus lanceolatus previously Agropyron dasystachyum var. smithii), bentgrass (Agrostis spp.), bluegrass (Poa spp.), meadow foxtail (Alopecurus aequalis), lovegrasses (Eragrostis spp.), and reed canarygrass (Phalaris arundinacea) (DOE 2001a). A list of common plant species in grassland areas is presented in Appendix B, Table B-1.

Trees. Within the past few hundred years, the Hanford Site upland landscape had few trees and the 


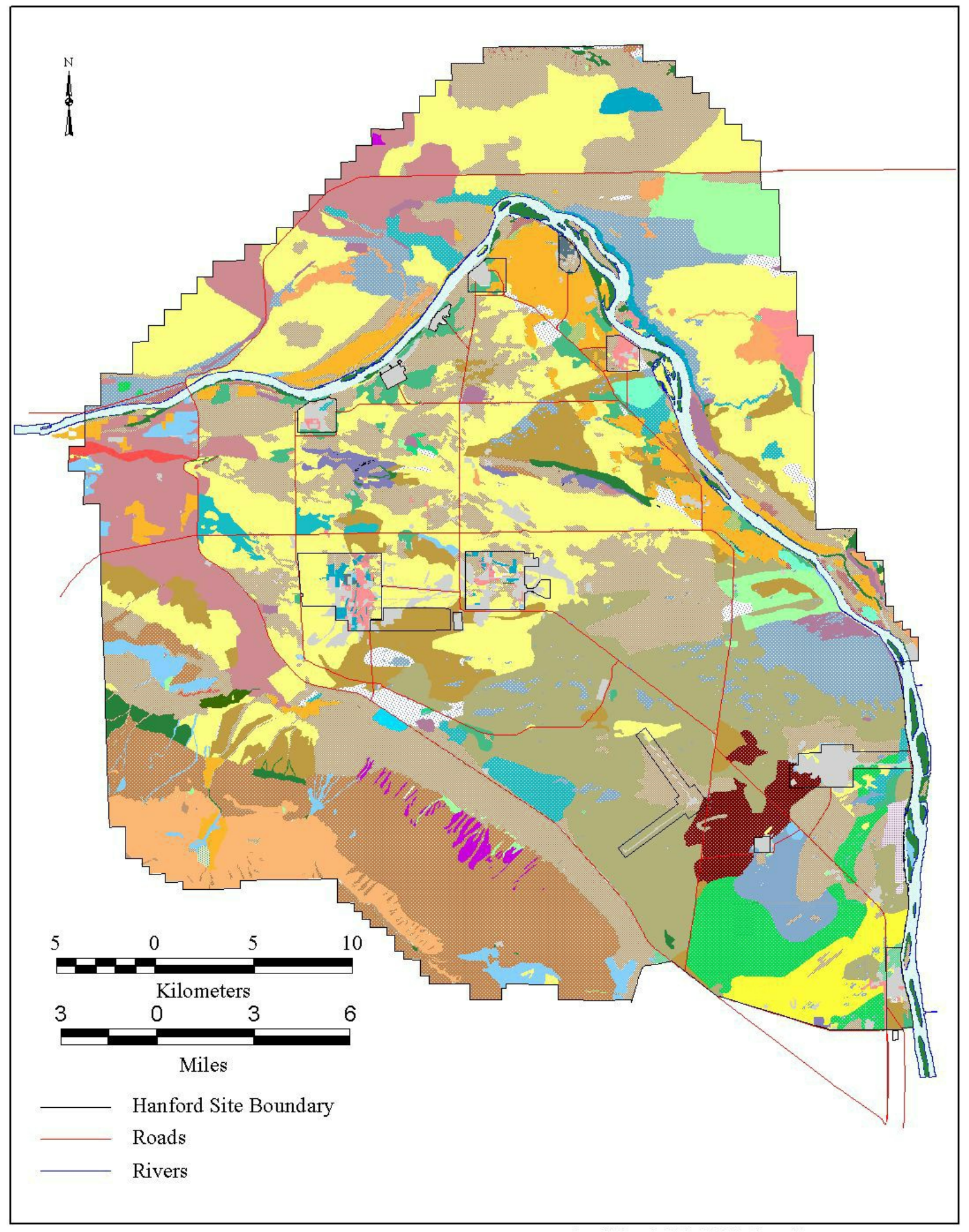

Figure 4.4-1. Distribution of Vegetation Types and Land Use Areas on the Hanford Site, Washington, before the Year 2000 Fire 


\section{LEGEND}

Abandoned Old Agricultural Fields

Alkali Saltgrass - Cheatgrass

Big Sagebrush - Bitterbrush / Bunchgrass

Big Sagebrush - Bitterbrush / Needle-and-Thread Grass

Big Sagebrush - Bitterbrush / Sandberg's Bluegrass

Big Sagebrush - Rigid Sagebrush / Bunchgrass

Big Sagebrush - Rock Buckwheat / Bunchgrass

Big Sagebrush - Spiny Hopsage / Bunchgrass

Big Sagebrush - Spiny Hopsage / Sandberg's Bluegrass - Cheatgrass

Big Sagebrush / Bluebunch Wheatgrass

Big Sagebrush / Bunchgrass

Big Sagebrush / Needle-and-Thread Grass

Big Sagebrush / Sand Dropseed

Big Sagebrush / Sandberg's Bluegrass - Cheatgrass

Bitterbrush / Bunchgrass

Bitterbrush / Indian Ricegrass

Bitterbrush / Needle-and-Thread Grass

Black Greasewood / Alkali Saltgrass

Bluebunch Wheatgrass - Needle-and-Thread Grass

Bluebunch Wheatgrass - Sandberg's Bluegrass

Bunchgrass - Cheatgrass

Crested Wheatgrass

Disturbed

Gray Rabbitbrush - Snow Buckwheat / Bunchgrass

Gray Rabbitbrush / Bunchgrass

Gray Rabbitbrush / Cheatgrass

Gray Rabbitbrush / Needle-and-Thread Grass

Gray Rabbitbrush / Sand Dropseed

Gray Rabbitbrush / Sandberg's Bluegrass - Cheatgrass

Needle-and-Thread Grass - Indian Ricegrass

Needle-and-Thread Grass -Sandberg's Bluegrass

Non-Riverine Wetlands and Associated Deepwater Habitats

Rabbitbrush / Bunchgrass

Rigid Sagebrush / Sandberg's Bluegrass

Riparian

Riverine Wetlands and Associated Deepwater Habitats

Sand Dropseed - Sandberg's Bluegrass - Cheatgrass

Sandberg's Bluegrass - Cheatgrass

Snow Buckwheat - Bitterbrush / Bunchgrass

Snow Buckwheat / Bunchgrass

Snow Buckwheat / Sandberg's Bluegrass - Cheatgrass

Spiny Hopsage / Sandberg's Bluegrass - Cheatgrass

Talus

Threetip Sagebrush / Bunchgrass

Thymeleaf Buckwheat / Sandberg's Bluegrass

Vernal Pool

White Bluffs

Winterfat / Bunchgrass

Figure 4.4-1. (cont'd) 
Columbia River shoreline supported a few scattered cottonwood (Populus spp.) or willows (Salix spp.). Homesteaders and Manhattan Project construction workers planted trees in association with agricultural areas and housing camps. Shade and ornamental trees were planted in the 1950s around former military installations and industrial areas on the Hanford Site. Currently, approximately 23 species of trees occur on the Site. The most commonly occurring species are black locust (Robinia pseudo-acacia), Russian olive (Eleagnus angustifolia), cottonwood (Populus trichocarpa), mulberry (Morus alba), sycamore (Platanus occidentalis), and poplar (Populus spp.). Many of these non-indigenous species are aggressive colonizers and have become established along the Columbia River (e.g., mulberry, poplar, Russian olive), serving as a functional component of the riparian zone (DOE 2001a). Trees provide nesting habitat and cover for many species of mammals and birds.

The 100 Area upland region consists of old agricultural fields dominated by cheatgrass and tumble mustard. Scattered big sagebrush and gray rabbitbrush also occur throughout the 100 Areas (Landeen et al. 1993). An area of natural big sagebrush habitat near the 100-D Area experienced a significant and apparently natural decline during the mid 1990s (Cardenas et al. 1997). A total area encompassing $17.8 \mathrm{~km}^{2}\left(6.9 \mathrm{mi}^{2}\right)$ was affected, and a central core area of $2.8 \mathrm{~km}^{2}\left(1.1 \mathrm{mi}^{2}\right)$ experienced more than $80 \%$ mortality of sagebrush.

Waste management areas, reactors, and crib sites are generally either barren or vegetated by invasive species, including Russian thistle, tumble mustard, and cheatgrass. Most of the waste disposal and storage sites are covered with non-native vegetation such as crested wheatgrass or are kept in a vegetation-free condition with the use of herbicides to prevent plant root intrusion to waste constituents. Russian thistle and gray rabbitbrush that occur in these areas are deep rooted and have this potential to function as a pathway to other parts of the ecosystem (Landeen et al. 1993).

The undisturbed portions of the 200 Areas are characterized as sagebrush/cheatgrass or sagebrush/Sandberg's bluegrass communities. The dominant plants on the 200 Area Plateau are big sagebrush, rabbitbrush, cheatgrass, and Sandberg's bluegrass (Sackschewsky and Downs 2001, Sackschewsky et al. 2001). Most of the waste disposal and storage sites are planted with crested or Siberian wheatgrass to stabilize surface soil, control soil moisture, or displace more invasive deep-rooted species like Russian thistle.

Vegetation surveys were conducted at the 300-FF-5 Operable Unit located north of the 300 Area during 1992. The shrub-steppe vegetation community in the unit is characterized as antelope bitterbrush/Sandberg's bluegrass with an overstory of bitterbrush and big sagebrush and an understory of cheatgrass and Sandberg's bluegrass (Brandt et al. 1993).

Riparian and Wetland Areas. Riparian areas are vegetated wetlands, especially associated with rivers and streams, and include shoreline areas along sloughs and backwaters. Wetlands also include the shorelines of lakes, ponds, vernal pools temporarily formed by melting snow in basalt outcrops, industrialized ponds, and irrigation wasteways and ponds on the Wahluke Slope.

Riparian habitat that occurs in association with the Columbia River includes riffles, gravel bars, backwater sloughs, and cobble shorelines. These habitats occur infrequently along the Hanford Reach and have acquired greater significance because of the net loss of wetland habitat elsewhere within the region. Vegetation that occurs along the river shoreline includes water smartweed (Polygonum amphibium), sedges (Carex spp.), reed canary grass (Phalaris arundinacea), bulbous bluegrass (Poa bulbosa), common witchgrass (Panicum capillare), and large barnyard grass (Echinochloa crusgalli). Rushes and sedges occur along the shorelines of the Columbia River and at several sloughs along the Hanford Reach. Trees include willow (Salix spp.), mulberry (Morus alba), and Siberian elm (Ulmus pumila). A list of common Hanford Site riparian plants is provided in Appendix B, Table B-1. 
Noxious weeds are also becoming established along the riparian zones of the Hanford Reach. Purple loosestrife (Lythrum salicaria), tamarisk (Tamarix parviflora), yellow nutsedge (Cyperus esculentus), reed canary grass, knapweed (Centaurea spp.), and yellow star thistle (Centaurea solstitialis) are some of the more common species found near or on wetlands on the Hanford Site. The Department of Energy and the USFWS have an ongoing program to control populations of noxious weeds with aerial applications of herbicides.

Some wetland habitat exists in the riparian zones of some of the larger spring streams on the FitznerEberhardt Arid Lands Ecology Reserve Unit. These are not extensive and usually amount to less than $0.01 \mathrm{~km}^{2}\left(0.004 \mathrm{mi}^{2}\right)$ in size, although the riparian zone along Rattlesnake Springs is probably about $2 \mathrm{~km}$ (1.2 mi) in length and consists of peach leaf willows, cattails, and other non-indigenous plants.

Rattlesnake and Snively Springs support highly diverse biological communities (Cushing and Wolf 1984) that include bulrush (Scirpus spp.), spike rush (Eleocharis spp.), and cattail (Typha latifolia). Watercress (Rorippa nasturtium-aquaticum), which persists at these sites, is also abundant for a large portion of the year. In the past 30 years, introduced trees and shrubs have become established in the riparian zone along these springs. The riparian transects associated with Snively and Rattlesnake Springs were greatly impacted by the year 2000 fire (BAER 2000) (Figure 4.4-2).

Other wetland habitats can be found within the Saddle Mountain National Wildlife Refuge Unit and the Wahluke Unit. These two areas encompass all the lands extending from the north bank of the Columbia River northward to the Hanford Site boundary and east of the Columbia River from Ringold Springs north to Highway 24 in Adams County. Wetland habitat in these areas consists of fairly large pond habitat resulting from irrigation runoff. These ponds have extensive stands of cattails and other emergent aquatic vegetation surrounding the open-water regions (Figure 4.3-1). They are extensively used as nesting sites by waterfowl and support populations of warm water fish that have been introduced by the irrigation network.

Other Habitats. Basalt outcrops, river bluffs, dunes, and islands occur on the Hanford Site and their unique qualities create habitat for a distinct assemblage of vegetation (DOE 2001a). The top of Rattlesnake Mountain, Umtanum Ridge, Gable Butte, and Gable Mountain include rock outcrops and have thin rocky soils. Plant communities dominated by thyme buckwheat (Eriogonum thymoides) and Sandberg's bluegrass most often occupy these basalt outcrops.

The White Bluffs border the Columbia River along the northern shoreline from RM 376 downstream to RM 356 presenting a steep environment with sparse and patchy vegetation. Dense patches of Indian ricegrass occupy the top of the bluff area. Primary shrubs found on the slopes of the bluff are greasewood and spiny hopsage. Bluff areas provide habitat for sensitive species (e.g., Hoover's desert parsley [Lomatium tuberosum] and the White Bluffs bladderpod [Lesquerella tuplashensis], a Washington State endangered plant).

Bitterbrush and Indian ricegrass dominate a large dune area north of the Energy Northwest complex along the Columbia River shoreline (Figure 4.4-1). The terrain of the dune habitat rises and falls between 3 and $5 \mathrm{~m}$ (10 and $16 \mathrm{ft}$ ) above ground level, creating areas that range from 2.5 to several hundred acres in size (U.S. Department of the Army 1990). The dunes vegetation consists of a mosaic of shrubs and grasses, primarily bitterbrush and gray and green rabbitbrush with understory forbs and grasses that include scurfpea (Psoralea lanceolata), needle-and-thread grass, and thickspike wheatgrass. Smaller dunes containing basalt grains that impart a dark color to the sand are found near the 100-F Area and westward across the Site north of Gable Mountain. As a result of the fire that occurred in 2000, temporary dunes have formed along State Route 240 east to the 200 West Area and Army Loop Road. These burnt areas are in various stages of recovery. 


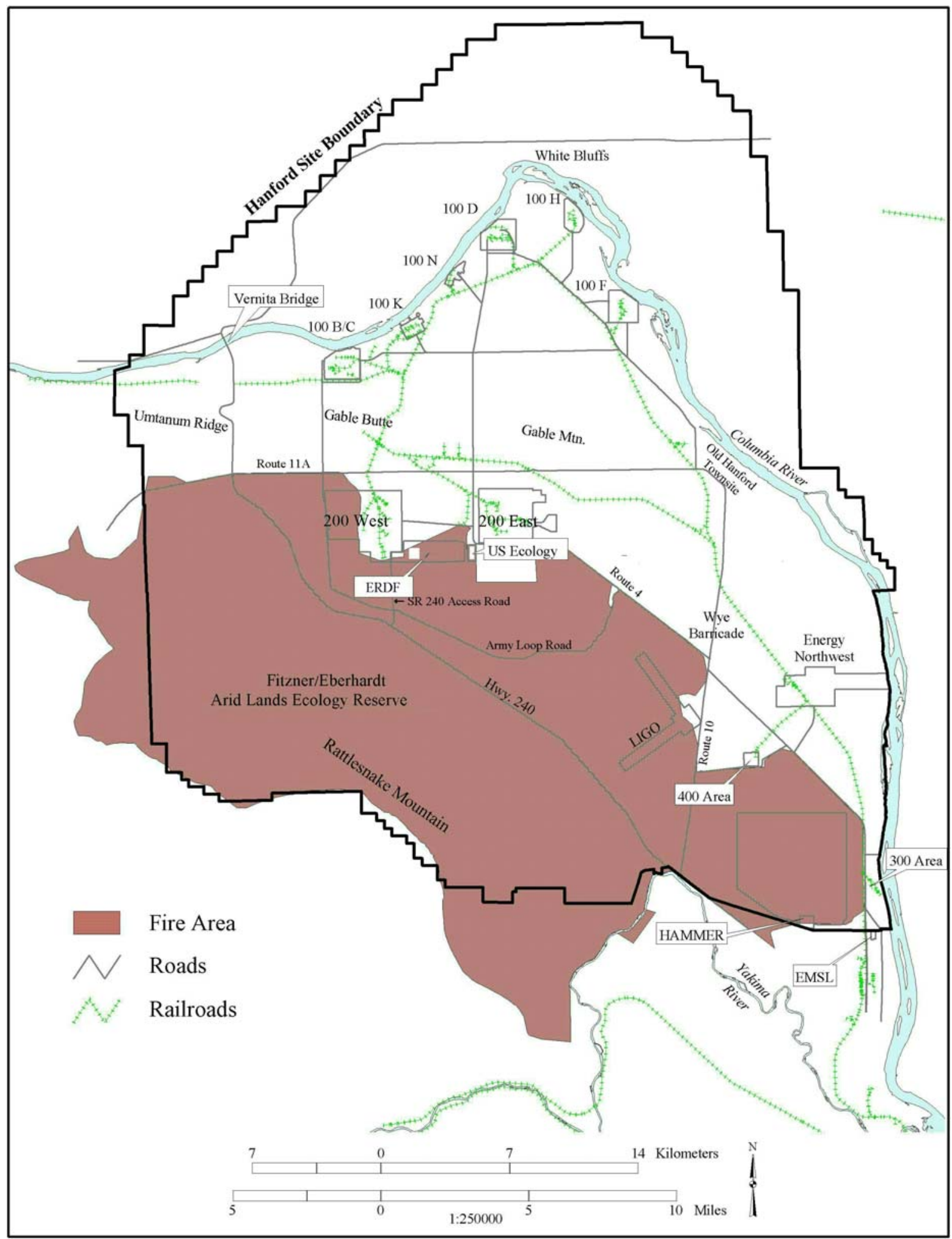

Figure 4.4-2. Area of Hanford Site, Washington, Burned as a Result of the June 27 - July 2, 2000, Wildfire 
Island habitat accounts for approximately $4.74 \mathrm{~km}^{2}\left(1.8 \mathrm{mi}^{2}\right)$ (Hanson and Browning 1959) and $64.3 \mathrm{~km}$ (39.9 mi) of river shoreline within the main channel of the Hanford Reach (Figure 4.4-3). ${ }^{\text {(a) }}$ DOE owns and administers the upland portions of Locke Island (RM 371-373.5) and Wooded Island (RM 348351). The Washington State Department of Natural Resources manages the shorelines of Locke and Wooded islands. Landslides caused by rotational slumping in the White Bluffs area caused accelerated erosion of Locke Island by the Columbia River. Shoreline riparian vegetation on the islands includes willow, poplar, Russian olive, and mulberry. Before regulation of river flows by dams, trees were generally not found along river shoreline habitat, with the exception of small willows and a few juniper trees near the 100-B/C Area and Riverlands. The most common tree to establish itself along the shoreline is mulberry. Species occurring on the island interior include buckwheat, lupine, mugwort, thickspike wheatgrass, giant wildrye, yarrow, and cheatgrass (Warren 1980).

West Lake and its immediate basin represent a habitat that is characterized by highly saline conditions (Poston et al. 1991). These conditions occur most likely from the evaporation of water from the pond and the accumulation of dissolved solids during the early years of operations on the Hanford Site. West Lake is now classified as a waste site under the Comprehensive Environmental Restoration, Compensation, and Liability Act of 1980 (CERCLA) (42 USC 9601, et seq.). Water levels of the pond fluctuate with wastewater discharge levels in the 200 Areas. Predominant plants at West Lake include salt grass, plantain, and rattle box. Three-spine bulrush grows along the shoreline; however, the water in the lake is too saline to support aquatic macrophytes. Following the decrease in water discharged to the ground in the 200 Areas in the early 1990s, the water level of West Lake has dropped, exposing large sections of saline mud flats and salt deposits along the shoreline.

A series of vegetation/land cover maps (Appendix C) were prepared to provide information on available habitat in support of a review of ecological data for clean-up activities along the Columbia River shoreline (Poston et al. 2004). These maps represent the best available information on vegetation cover types and plant associations located in specific areas at the time the data were collected (from 1997 to the present). Vegetation communities are subject to change depending on climatic conditions, physical disturbance, progress with clean-up, and natural recruitment and succession at the sites. For descriptions of upland vegetation the reader is referred Sackschewsky and Downs (2001); for descriptions of riparian vegetation, see Section 8.0 of the Hanford Site Annual Environmental Report (Poston et al. 2004).

The maps in Appendix $\mathrm{C}$ are subsets of maps originally constructed using aerial photography and limited ground surveys and should be appropriate for use in project planning. Maps are updated as information becomes available. However, the extent and boundaries of the vegetation cover types may change over time and the accuracy of the boundaries is further limited by the resolution of the source data used for mapping (usually +/- 20 to $30 \mathrm{~m}$ [66 to $98 \mathrm{ft}$ ] depending on the source). Reference to these maps cannot be used in place of project-specific site biological surveys for compliance. To access the most recent vegetation maps maintained for the areas of the Hanford Site, visit the PNNL project web site for the Ecological Monitoring and Compliance (EMC) Project (http://www.pnl.gov/ecomon) or request updated maps from the EMC Project at PNNL.

\footnotetext{
(a) Management of these islands is the responsibility of the island owners, which include DOE, USFWS, and the U.S. Bureau of Land Management. Island ownership descriptions pertain to status prior to national monument designation and are subject to change with agreements among the agencies.
} 


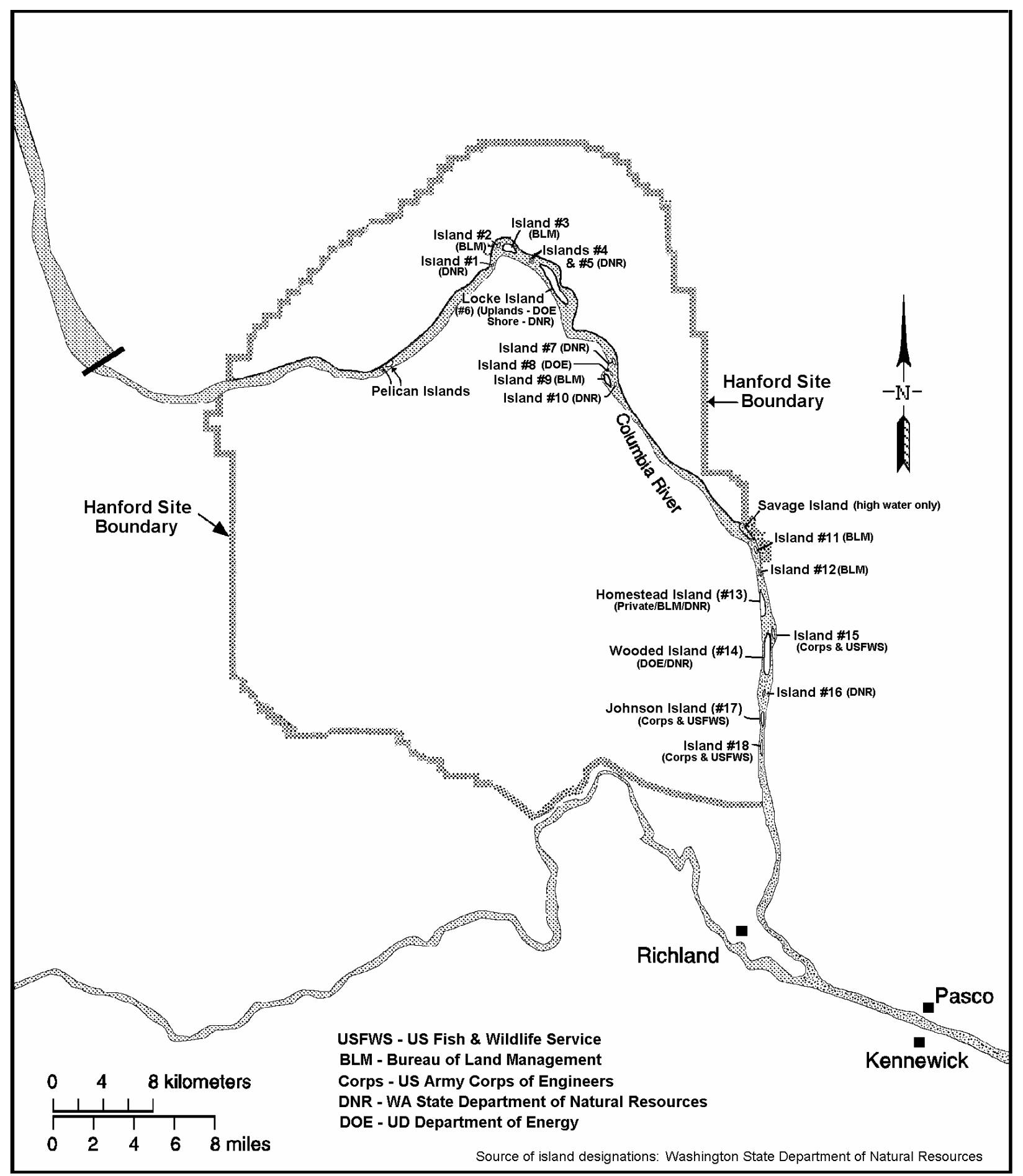

Figure 4.4-3. Columbia River Islands in the Vicinity of the Hanford Site, Washington 


\subsubsection{Wildlife}

The characterization of Hanford Site wildlife includes descriptions of mammals, birds, reptiles, amphibians, and insects. Approximately 300 species of terrestrial vertebrates have been observed on the Hanford Site. The species list includes approximately 42 species of mammals (Appendix B, Table B-2), 246 species of birds (Appendix B, Table B-3), 5 species of amphibians, and 12 species of reptiles (Appendix B, Table B- 4) (Soll and Soper 1996, Brandt et al. 1993). From 1991 to 1993, surveys for birds, mammals, insects, and vegetation were conducted at several of the 100 and 300 Area operable units (Brandt et al. 1993, Landeen et al. 1993). Soll et al. (1999) recently summarized its observations of birds and mammal surveys. These surveys did not account for all of the species that have been documented historically on the Hanford Site. For example, 221 species of birds were observed in the bird surveys of The Nature Conservancy's biodiversity 4-year effort (Soll et al. 1999). This number falls short of the 238 species identified historically (Landeen et al. 1992). By combining the 1994-1999 list of The Nature Conservancy with the site list (Landeen et al. 1992), a total of 258 species of birds have been documented on the Hanford Site (Soll et al. 1999). There are 144 bird species considered common to the Hanford Site (Appendix B, Table B 3). Site wildlife communities are generally associated with specific vegetation communities. Recent surveys have been performed by the EMC and USFWS, but are not available in published form.

Shrub-steppe and Grassland Wildlife. The shrub and grassland habitat of the Hanford Site supports many groups of terrestrial wildlife. Species include large animals like Rocky Mountain elk (Cervus elaphus) and mule deer (Odocoileus hemionus); predators such as coyote (Canis latrans), bobcat (Lynx rufus), and badger (Taxidea taxus); and herbivores including deer mice (Peromyscus maniculatus), harvest mice (Riethrodontonomys megalotis), ground squirrels (Spermophilus spp.), voles (Lagurus spp., Microtus spp.), and black-tailed jackrabbits (Lepus californicus). The most abundant mammal on the Hanford Site is the Great Basin pocket mouse (Perognathus parvus). Many of the rodent species and some predators (badgers) construct burrows on the site. Other non-borrowing animals including cottontails (Sylvilagus nutalli), jackrabbits, snakes, and burrowing owls (Athene cunicularia) may utilize abandoned burrows of other animals.

There was a reported sighting of a cougar (Felis concolor) on Fitzner-Eberhardt Arid Lands Ecology Reserve Unit by experienced biologists during the elk relocation effort in March 2000, supplementing anecdotal accounts of other observations of the presence of cougars at the Hanford Site.

Mule deer rely mainly on shoreline vegetation and bitterbrush shrubs for browse (Tiller et al. 1997). Elk, which are more dependent on open grasslands for forage, seek the cover of sagebrush and other shrub species during the summer months. Elk first appeared on the Hanford Site in 1972 (Fitzner and Gray 1991), and have increased from approximately 8 animals observed in 1975 to approximately 900 in 1999. The Rattlesnake Hills herd of elk that inhabits the Hanford Site primarily occupies FitznerEberhardt Arid Lands Ecology Reserve Unit and private lands that adjoin the reserve to the south and west. They are occasionally seen on the 200 Area Plateau and have been sighted at the White Bluffs boat launch on the Hanford Site proper. The herd tends to congregate on Fitzner-Eberhardt Arid Lands Ecology Reserve Unit in the winter and disperses during the summer months to higher elevations on the reserve, private land to the west, and the Yakima Training Center. Efforts were taken in March 2000 to remove and relocate about 200 elk from the Fitzner-Eberhardt Arid Lands Ecology Reserve Unit and another 31 elk were removed during 2002. Special hunts adjacent to the Hanford Site in 2000 accounted for the removal of 207 additional elk. The fire in June 2000 temporarily destroyed nearly all the elk forage on Fitzner-Eberhardt Arid Lands Ecology Reserve Unit. The herd moved onto unburned private land west of the site, to unburned areas on central Hanford, and along the Columbia River near the 100$\mathrm{B} / \mathrm{C}$ and $100-\mathrm{K}$ Areas. Elk have returned to burned areas as the vegetation recovered. 
Shrub-steppe and grassland provide nesting and foraging habitat for many passerine (i.e., perching) bird species. Surveys conducted during 1993 (Cadwell 1994) reported the occurrence of western meadowlarks (Sturnella neglecta) and horned larks (Eremophila alpestris) more frequently in shrubsteppe habitats than in other habitats on the Hanford Site. Soll et al. (1999) reported a total of 41 species that are considered steppe or shrub-steppe habitat dependent. Long-billed curlews (Numenius americanus) and vesper sparrows (Pooecetes gramineus) were also noted as commonly occurring species in shrub-steppe habitat. Species that are dependent on undisturbed shrub habitat include sage sparrow (Amphispiza belli), sage thrasher (Oreoscoptes montanus), and loggerhead shrike (Lanius ludovicianus). Both the sage sparrow and loggerhead shrike tend to roost and nest in sagebrush or bitterbrush that occurs at lower elevations (DOE 2001a). Ground-nesting species that occur in grass-covered uplands include long-billed curlews, western meadowlark, and burrowing owls.

Common upland gamebird species that occur in shrub and grassland habitat include chukar (Alectoris chukar), partridge (Perdix perdix), California quail (Callipepla californica), and ring-necked pheasant (Phasianus colchicus). Chukars are most numerous in the Rattlesnake Hills, Yakima Ridge, Umtanum Ridge, Saddle Mountain, and Gable Mountain areas of the Hanford Site. Less common species include greater sage grouse (Centrocercus urophasianus), and scaled quail (Callipepla squamata). Greater sage grouse were historically abundant on the Hanford Site; however, populations have declined since the early 1800s because of the conversion of sagebrush-steppe habitat to farmland, hunting, and destruction of habitat by range fires. Surveys conducted by the Washington Department of Fish and Wildlife and PNNL during 1993 and biodiversity inventories conducted in 1997 (Soll et al. 1999) did not observe greater sage grouse in the sagebrush-steppe habitat at Fitzner-Eberhardt Arid Lands Ecology Reserve Unit. Greater sage grouse were observed on Fitzner-Eberhardt Arid Lands Ecology Reserve Unit in 1999 and 2000. ${ }^{\text {(a) }}$ A greater sage grouse was killed by an automobile near the 100-F area in the spring of 2003; however, this is considered an abnormal occurrence for this part of the Hanford Site. The fire in June 2000 destroyed potential greater sage grouse habitat, and it is unlikely that greater sage grouse will return until the vegetation has recovered to a point where it can support them.

Among the more common raptor species that use shrub and grassland habitat are the ferruginous hawk (Buteo regalis), Swainson's hawk (B. swainsoni), and red-tailed hawk (B. jamaicensis). Northern harriers (Circus cyaneus), sharp-shinned hawks (Accipiter striatus), rough-legged hawks (B. lagopus), and golden eagles (Aquila chrysaetos) also occur in this habitat, although infrequently. In 1994, nesting by red-tailed, Swainson's, and ferruginous hawks was known to occur in 41 nests located across the Hanford Site on high voltage transmission towers, trees, cliffs, and basalt outcrops. Since the mid-1990s, the number of breeding ferruginous hawks (a Washington State threatened species) on the Hanford Site has increased, due, in part, to their use of steel powerline towers for nesting in the open grass and shrubsteppe habitats.

The side-blotched lizard (Uta stansburiana) is the most abundant reptile species occurring on the Hanford Site. Short-horned (Phrynosoma douglassii) and sagebrush (Sceloporus graciosus) lizards are also found on the Hanford Site, but occur infrequently. The most common snake species include gopher snake (Pituophis melanoleucus), yellow-bellied racer (Coluber constrictor), and western rattlesnake (Crotalus viridis).

Many species of insects occur throughout all habitats on the Hanford Site. Butterflies, grasshoppers, and darkling beetles are among the most conspicuous of the about 1500 species of insects that have been identified from specimens collected on the Hanford Site (Soll et al. 1999). The actual number of insect species occurring on the Hanford Site may reach as high as 15,500. A total of 1509 species-level identifications were completed in 1999 and 500 more are expected. Recent surveys included the

(a) Source: Personal communication between T. M. Poston and L.L. Cadwell, PNNL, April 2002. 
collection of 40,000 specimens and have resulted in the identification of 43 new taxa and 142 new findings in the state of Washington (Soll et al. 1999). The high diversity of insect species on the Hanford Site reflects the size, complexity, and relatively undisturbed quality of the shrub-steppe habitat.

Riparian Wildlife. Riparian areas provide nesting and foraging habitat and escape cover for many species of birds and mammals. Shoreline riparian communities are seasonally important for a variety of species. Willows trap food for waterfowl (e.g., Canada geese [Branta canadensis]) and birds that use shoreline habitat (e.g., Forster's tern [Sterna forsteri]) as well as providing nesting habitat for passerines (e.g., mourning doves [Zenaida macroura]). Terrestrial and aquatic insects are abundant in emergent grasses and provide food for fish, waterfowl, and shorebirds.

Mammals occurring primarily in riparian areas include rodents, bats, furbearers (e.g., mink [Mustela vison] and weasel [Mustela spp.]), porcupine (Erithizon dorsatum), raccoon (Procyon lotor), skunk (Mephitis mephitis), and mule deer. Beavers (Castor canadensis) rely on shoreline habitat for dens and foraging. River otters (Lutra canadensis) have been observed infrequently in the Hanford Reach. During the summer, mule deer rely on riparian vegetation for foraging. Mule deer use Columbia River islands for fawning and nursery areas. Beaver and muskrat (Ondatra zibethica) rely on shoreline habitat for dens and foraging. The Columbia River and Rattlesnake Springs provide foraging habitat for bats including Yuma myotis (Myotis yumanensis), small-footed myotis (Myotis subulatus), silver-haired bats (Lasionycteris octivagans), and pallid bats (Antrozous pallidus), all of which feed on emergent aquatic insects (Becker 1993).

Common bird species that occur in riparian habitats include red-winged blackbird (Agelaius phoeniceus), American robin (Turdus migratorius), black-billed magpie (Pica pica), song sparrow (Melospiza melodia), and dark-eyed junco (Junco hyemalis) (Cadwell 1994). Upland gamebirds that use this habitat include ring-necked pheasants and California quail. Predatory birds include common barn owl (Tyto alba) and great horned owl (Bubo virginianus). Burrowing owls have been observed on some of the islands in the Columbia River. Species known or expected to nest in riparian habitat are Brewer's blackbird (Euphagus cyanocephalus), mourning dove, black-billed magpie, northern oriole (Icterus galbula), lazuli bunting (Passerina amoena), eastern kingbird (Tyrannus tyrannus), western kingbird (Tyrannus verticalis), and western wood peewee (Contopus sordidulus). Bald eagles (Haliaeetus leucocephalus) have wintered on the Hanford Site since 1960. Great blue herons (Ardea herodias) and black-crowned night herons (Nycticorax nycticorax) are associated with trees in riparian habitat along the Columbia River and use groves or individual trees for perching and nesting. On occasion, great blue herons have constructed nests in the large metal powerline towers that are present on the shores of the Columbia River.

The Hanford Site is located in the Pacific Flyway, and the Hanford Reach serves as a resting area for neotropical migrant birds, migratory waterfowl, and shorebirds (Soll et al. 1999). During the fall and winter months, ducks (primarily mallards) and Canada geese rest on the shorelines and islands along the Hanford Reach. The area between the Old Hanford Townsite and Vernita Bridge is closed to recreational hunting, and large numbers of migratory waterfowl find refuge in this portion of the river. Other species observed during this period include American white pelicans (Pelecanus erythrorhynchos), egrets (Casmerodius albus), double-crested cormorants (Phalacrocorax auritus), coots (Fulica americana), and common loons (Gavia immer).

Along with the reptiles and insects identified in the grasslands discussion, five amphibians have been identified on the site. The Great Basin spadefoot toad (Scaphiopus intermontanus), Woodhouse's toad (Bufo woodhousei), Pacific tree frog (Hyla regilla), tiger salamander (Ambystoma tigrinum), and bullfrog (Rana catesbeiana) are the only amphibians found in close proximity to water on the Hanford Site (Soll et al. 1999, Brandt et al. 1993). 
Wildlife Occurring in Other Hanford Site Habitats. Bluffs provide perching, nesting, and escape habitat for several bird species on the Hanford Site. The White Bluffs and Umtanum Ridge provide nesting habitat for prairie falcons (Falco mexicanus), red-tailed hawks, cliff swallows (Hirundo pyrrhonota), bank swallows (Riparia riparia), and rough-winged swallows (Stelgidopteryx serripennis). In the 1970s and '80s, Canada geese used the lower elevations of the White Bluffs for nesting and brooding. Bald eagles use the White Bluffs for roosting. Bluff areas provide habitat for sensitive species (e.g., peregrine falcon [Falco peregrinus]) that otherwise may be subject to impact from frequent or repeated disturbance. Trees that do not normally occur in arid steppe habitat supply nesting, perching, and roosting sites for many birds. Consequently, herons and raptors, such as ferruginous and Swainson's hawks, can use trees for breeding in areas that previously did not support breeding populations.

Ferruginous hawks also nest on electrical transmission line towers. These occurrences of raptor nesting in non-native trees occur in upland areas as well as riparian zones along the Hanford Reach.

Dune habitat is unusual in its association with the surrounding shrub-steppe vegetation type. The individuality of the dunes is noted in its vegetation component as well as its geologic formation. The Hanford dunes, located on the eastern border of the Site, provide habitat for mule deer, burrowing owls, and coyotes as well as many transient species. In contrast, the dunes in west central Hanford, formed as a result of the fire in June 2000, may be temporary and could disappear once vegetation is re-established.

Islands provide resting, nesting, and escape habitat for waterfowl and shorebirds. Use of islands for nesting by Canada geese has been monitored since 1950. The suitability of habitat for nesting Canada geese is attributed to restricted human use of islands during the nesting season, suitable substrate, and adequate forage and cover for broods (Eberhardt et al. 1989). The nesting population fluctuates annually. Since the early 1990s, geese have used the downstream islands in the Hanford Reach for nesting as a result of coyote predation in the upper Reach islands. Islands also accommodate colonial nesting species including California gulls (Larus californicus), ring-billed gulls (Larus delawarensis), and Forster's terns (Sterna forsteri). Island areas ranging from 0.1 to $0.2 \mathrm{~km}^{2}\left(0.05\right.$ to $\left.0.08 \mathrm{mi}^{2}\right)$ accommodate colonial nesting species that may range in population size up to 2000 individuals.

\subsubsection{Aquatic Ecology}

Aquatic resources on the Hanford Site are primarily associated with the Columbia River. The river crosses the Hanford Site entering at the northwest corner of the site, traveling eastward and then turning south, forming the eastern boundary of the site. The Columbia River and associated riparian zones provide habitat for numerous wildlife and plant species. The area known as the Hanford Reach, the Columbia River from Priest Rapids Dam (river mile [RM] 397) to McNary Pool (RM 346) is the last freeflowing, non-tidal segment of the Columbia River in the United States. Several small intermittent spring/streams are also found on the site and, with their unique riparian habitat, provide a break in the vast expanses of shrub-steppe habitat that dominate the Hanford Site.

\subsubsection{Columbia River}

The Columbia River is the dominant aquatic ecosystem on the Hanford Site and supports a large and diverse community of plankton, benthic and lotic invertebrates, fish, and other communities. Large rivers, like the Columbia River with its series of large reservoirs, contain significant populations of primary energy producers (e.g., algae and plants) that contribute to the biota's basic energy requirements.

Phytoplankton (free-floating algae) and periphyton (sessile algae) are abundant in the Columbia River and provide food for herbivores such as immature insects. Plankton populations in the Hanford Reach are 
influenced by communities that develop in the reservoirs of upstream dams, particularly Priest Rapids Reservoir, and by the manipulation of water levels by dam operations in upstream and downstream reservoirs. Phytoplankton and zooplankton populations at the Hanford Site are largely transient, flowing from one reservoir to another. With the relatively rapid flow of the Columbia River, there is generally insufficient time for characteristic endemic groups of phytoplankton and zooplankton to develop in the Hanford Reach.

Phytoplankton. Phytoplankton species identified from the Hanford Reach include diatoms, golden or yellow-brown algae, green algae, blue-green algae, red algae, and dinoflagellates. Studies show diatoms are the dominant algae in the Columbia River phytoplankton, usually representing more than $90 \%$ of the populations. The main genera include Asterionella, Cyclotella, Fragilaria, Melosira, Stephanodiscus, and Synedra (Neitzel et al. 1982a). These are typical of those forms found in lakes and ponds and originate in upstream reservoirs. A number of algae found as free-floating species in the Hanford Reach of the Columbia River are actually derived from the periphyton; they were detached and suspended by currents and frequent fluctuations of the water level.

Cushing (1967a) found peak concentrations of phytoplankton occurred in April and May, with a secondary peak in late summer/early autumn. The spring pulse in phytoplankton density was probably related to increasing light and water temperature rather than to availability of nutrients, as phosphate and nitrate nutrient concentrations are never limiting. Minimum numbers were present in December and January. Green algae (Chlorophyta) and blue-green algae (Cyanophyta) occur in phytoplankton communities during warmer months but in substantially fewer numbers than diatoms. Diversity indices, carbon uptake, and chlorophyll concentrations for the phytoplankton show similar seasonal trends (Neitzel et al. 1982a, Wolf et al. 1976).

Periphyton. Communities of periphytic species or "benthic microflora" develop on suitable solid substrate wherever there is sufficient light for photosynthesis and adequate currents to prevent sediment from covering the colonies. Operation of Priest Rapids Dam results in frequent river level fluctuations. These fluctuations result in exposed shoreline areas that do not allow for the establishment of viable and persistent periphyton communities in shoreline areas inundated by water at flows greater than $1310 \mathrm{~m}^{3} / \mathrm{s}$ (46,300 cfs) (Tiller and Downs 2004). Cushing (1967b) observed peaks of production to occur in spring and late summer. Dominant genera are the diatoms Achnanthes, Asterionella, Cocconeis, Fragilaria, Gomphonema, Melosira, Nitzchia, Stephanodiscus, and Synedra (Beak Consultants Inc. 1980, Neitzel et al. 1982a, Page and Neitzel 1978, Page et al. 1979).

Macrophytes. Macrophytes are sparse in the Columbia River because of strong currents, rocky bottom, and frequently fluctuating water levels. Rushes (Juncus spp.) and sedges (Carex spp.) occur along shorelines of the slack-water areas such as White Bluffs Slough below the 100-H Area, the slough area downstream of the 100-F Area, and the Hanford Slough. Reed canary grass (Phalaris arundinacea) is a common non-native species found along shoreline areas. Macrophytes are also present along gently sloping shorelines that are subject to flooding during the spring freshet and daily fluctuating river levels (downsteam of Coyote Rapids and the 100-D Area). Commonly found plants include duckweed (Lemna sp.) and the native rooted pond weeds (Potamogeton sp. and Elodea canadensis). Where they exist, macrophytes have considerable ecological value. They provide food and shelter for juvenile fish and spawning areas for some species of warm-water game fish. Eurasian milfoil (Myriophyllum spicatum), an introduced macrophyte, has increased to nuisance levels since the late 1980s and may encourage increased sedimentation of fine particulate matter.

Zooplankton. The zooplankton populations in the Hanford Reach of the Columbia River are generally sparse. Studies by Neitzel et al. (1982b) indicate crustacean zooplankters were dominant in the open-water regions. Dominant genera were Bosmina, Diaptomus, and Cyclops. Densities were lowest in 
winter and highest in the summer, with summer peaks dominated by Bosmina, ranging up to 160,650 organisms $/ \mathrm{m}^{3}$ (4500 organisms $\left./ \mathrm{ft}^{3}\right)$. Winter densities were generally $<1785$ organisms $/ \mathrm{m}^{3}(<50$ organisms $/ \mathrm{ft}^{3}$ ). Diaptomus and Cyclops dominated in winter and spring, respectively (Neitzel et al. 1982b).

Benthic Organisms. Benthic organisms are found either attached to or closely associated with the substratum. All major freshwater benthic taxa are represented in the Columbia River. Insect larvae such as caddisflies (Trichoptera), midge flies (Chironomidae), and black flies (Simuliidae) are dominant. Dominant caddisfly species are Hydropsyche cockerelli, Cheumatopsyche campyla, and C. enonis. Other benthic organisms include clams (Corbicula spp., Anodontia spp.), limpets (Fisherola spp.), snails (Physa spp.), sponges (Spongilla spp.), and crayfish (Astacus trowbridgii). Operation of Priest Rapids Dam results in frequent river level fluctuations. These fluctuations result in exposed shoreline areas during low-flow periods that do not allow for the establishment of persistent benthic communities. Clams and crayfish have difficulty in establishing populations in stranded shoreline areas that are frequently left dewatered by river level fluctuations. Species with rapid life cycles are less likely to be impacted by river fluctuations.

Early Hanford studies found crayfish numbers in shallow water areas ranged from 0.2 to 1.1 individuals $/ \mathrm{ft}^{2}$ (0.02 to 0.10 individuals $/ \mathrm{m}^{2}$ ) of river bottom, with a diet primarily of vegetation (Coopey 1953), while insect larvae numbers were sometimes as high as $2000 / \mathrm{ft}^{2}\left(185.8 / \mathrm{m}^{2}\right)$ (Davis and Cooper 1951). Peak larval insect densities are found in late fall and winter, and the major emergence is in spring and summer (Wolf 1976). Stomach contents of fish collected in the Hanford Reach from June 1973 through March 1980 revealed that benthic invertebrates were important food items for nearly all juvenile and adult fish. There was a correlation between food organisms in the stomach contents and those in the benthic and invertebrate drift communities. A recent survey by Soll et al. (1999) identified 21 new taxa of aquatic invertebrates from the Hanford Reach bringing the total number of aquatic invertebrate taxa at Hanford to 151.

Fish. Gray and Dauble (1977) listed 43 species of fish in the Hanford Reach of the Columbia River. The brown bullhead (Ictalurus nebulosus), collected since 1977, and the blue catfish (Ictalurus furcatus) listed by Washington Department of Fish and Game, brings the total number of fish species identified in the Hanford Reach to 45 (Appendix B, Table B-5). Sixteen of these 45 species are introduced (Wydoski and Whitney 1979). Of these species, Chinook salmon (Oncorhynchus tshawytscha), sockeye salmon (Oncorhynchus nerka), coho salmon (Oncorhynchus kisutch), and steelhead trout (Oncorhynchus mykiss) use the river as a migration route to and from upstream spawning areas and are of the greatest economic importance. Additionally, fall Chinook salmon and steelhead trout spawn in the Hanford Reach. The relative contribution of up-river bright stocks to fall Chinook salmon runs in the Columbia River increased from about $24 \%$ of the total in the early 1980 s, to $50 \%$ to $60 \%$ of the total by 1988 (Dauble and Watson 1990). Inundation of other mainstream Columbia spawning grounds by dams has increased the relative importance of the Hanford Reach to fall Chinook salmon production in the Columbia and Snake rivers (Watson 1970, 1973; Dauble and Watson 1997). Operation of Priest Rapids Dam, however, can result in frequent river level fluctuations exposing shoreline and cobble bars during low-flow periods. In recent years, Priest Rapids Dam has operated with an objective to stabilize fall river levels to prevent salmon from spawning in areas that will be exposed at low river flow during the winter, thus protecting salmon redds from desiccation and temperature extremes.

The steelhead fishery in the Hanford Reach (Highway 395 Bridge to Priest Rapids Dam) consists almost exclusively of summer-run fish. The Washington State Department of Fish and Wildlife (WDFW) estimates steelhead sport catch for the 2002 season at 1100 fish. The majority of these fish were marked hatchery fish. In recent years the return of fall Chinook salmon has been high and the harvest during 2002 was 7550 adults and about 1000 jacks (precocious males). 
American shad (Alosa sapidissima), an introduced anadromous species, may also spawn in the Hanford Reach. The upstream range of the shad has been increasing since 1956 when less than 10 adult shad passed McNary Dam. Since then, the number of shad ascending Priest Rapids Dam has risen to many thousands each year, and young-of-the-year have been collected in the Hanford Reach. Shad are not dependent on the same conditions that are required by salmonids for spawning and apparently have found favorable conditions for reproduction.

Other fish of importance to sport fishermen are the native mountain whitefish (Prosopium williamsoni) and white sturgeon (Acipenser transmontanus). Introduced species like smallmouth bass (Micropterus dolomieui), crappie (Pomoxis nigromaculatus), catfish (Ictalurus punctatus), walleye (Stizostedion vitreum), and yellow perch (Perca flavescens) are also popular. Large populations of rough fish are also present, including introduced carp (Cyprinus carpio) and native species such as redside shiner (Richardsonius balteatus), suckers (Catostomus macrocheilus), and northern pikeminnow (Ptychocheilus oregonensis). Because northern pikeminnow feed on juvenile salmon, WDFW has established a bounty program on adult pikeminnow to bolster salmon runs. Northern pikeminnow removed from the Hanford Reach are usually turned in at bounty stations located at Columbia Point in Richland and at the Vernita Bridge rest stop.

\subsubsection{Spring Streams}

Small interrupted streams, such as Rattlesnake, Bobcat, and Snively springs located on FitznerEberhardt Arid Lands Ecology Reserve Unit, contain diverse biotic communities and are extremely productive (Cushing and Wolf 1984). Dense blooms of watercress arise and are lost when flash floods occur. Aquatic insect production is fairly high as compared with mountain streams (Gaines 1987). The macrobenthic biota varies from site to site and is related to the proximity of colonizing insects and other factors. The fire of 2000 has had little direct impact on the stream ecology, even though the riparian transect along the lower two-thirds of the stream was heavily damaged by the fire (BAER 2000).

Rattlesnake Springs, on the western side of the Hanford Site, forms a small surface stream that flows for about $2.5 \mathrm{~km}(1.6 \mathrm{mi})$ before disappearing into the ground as a result of seepage and evapotranspiration. Base flow of this stream is about $0.01 \mathrm{~m}^{3} / \mathrm{s}\left(0.4 \mathrm{ft}^{3} / \mathrm{s}\right)$ (Cushing and Wolf 1982). Water temperature ranges from $2^{\circ}$ to $22^{\circ} \mathrm{C}\left(36^{\circ}\right.$ to $\left.72^{\circ} \mathrm{F}\right)$. Mean annual total alkalinity (as $\left.\mathrm{CaCO}_{3}\right)$, nitrate nitrogen, phosphate phosphorus, and total dissolved solids are 127, 0.3, 0.18, and $217 \mathrm{mg} / \mathrm{L}$, respectively (Cushing and Wolf 1982, Cushing et al. 1980). The sodium content of the spring water is about $7 \mathrm{ppm}$ (Brown 1970). Rattlesnake Springs is of ecological importance because it provides a source of water to terrestrial animals in an otherwise arid part of the Hanford Site. Snively Springs, located west of and at a higher elevation than Rattlesnake Springs, is another source of drinking water for terrestrial animals. Both springs provide a valuable source of drinking water for the Rattlesnake Hills elk herd. The major rooted aquatic plant, which in places may cover the entire width of the stream, is watercress. Isolated patches of bulrush, spike rush, and cattail occupy less than $5 \%$ of the streambed.

Primary productivity at Rattlesnake Springs is greatest during the spring and coincident with the maximum periphyton standing crop. Net primary productivity averaged $0.9 \mathrm{~g} / \mathrm{cm}^{2} / \mathrm{d}$ organic matter during 1969 and 1970; the spring maximum was $2.2 \mathrm{~g} / \mathrm{cm}^{2} / \mathrm{d}$. Seasonal productivity and respiration rates are within the ranges reported for arid region streams. Although Rattlesnake Springs is a net exporter of organic matter during much of the growing season, it is subject to flash floods and severe scouring and denuding of the streambed during winter and early spring, making it an importer of organic materials on an annual basis (Cushing and Wolf 1984). 
Secondary production is dominated by detritus-feeding collector-gatherer insects (mostly Chironomidae and Simuliidae) that have multiple cohorts and short generation times (Gaines et al. 1992). Overall production is not high and is likely related to the low diversity found in these systems related to the winter spates that scour the spring streams. Total secondary production in Rattlesnake and Snively springs is 16,356 and $14,154 \mathrm{~g}$ dry weight $/ \mathrm{m}^{2} / \mathrm{yr}$, respectively. There is an indication that insects in these spring-streams depend on both autochthonous (originating within the stream) and allochthonous (originating outside the stream) primary production as an energy source, despite significant shading by exotic species of trees and shrubs (Mize 1993).

Invertebrate surveys on the Fitzner-Eberhardt Arid Lands Ecology Reserve Unit identified 30 new taxa at Rattlesnake Springs and 12 new taxa at Snively Springs (Soll et al. 1999). These recent findings bring the total number of taxa at each spring to 43 and 24, respectively.

There are other springs occurring on the Rattlesnake Hills (Schwab et al. 1979). Limited physical and chemical data are reported for each site.

\subsubsection{Temporary Water Bodies}

West Lake is a small saline pond created by a rise in the water table in the 200 Areas and is not fed by surface flow. Evaporation of groundwater and possible disposal of sewage during the early Hanford years created highly saline and alkaline conditions that greatly restricted the complement of biota in West Lake (Poston et al. 1991).

Several artificial water bodies, both ponds and ditches, were formed as a result of wastewater disposal practices associated with operation of the reactors and separation facilities. Most of these have been taken out of service and have been backfilled with the cessation of activities. When present, however, they formed established aquatic ecosystems complete with representative flora and fauna (Emery and McShane 1980). The temporary wastewater ponds and ditches existed for as long as two decades and covered fairly large areas. Rickard et al. (1981) discusses the ecology of Gable Mountain Pond, one of the former major lentic sites at Hanford. Emery and McShane (1980) present ecological characteristics of all the temporary water bodies. The ponds developed luxuriant riparian communities and became quite attractive to autumn and spring migrating birds. Several species have nested near the ponds. Section 4.3.1.8 describes those water bodies still active. These former sites have been decommissioned and are now covered with overburden and planted with grasses for stabilization.

\subsubsection{Threatened and Endangered Species}

There are a number of species of plants and animals on the Hanford Site that are considered to be rare and of management concern. Species are listed as endangered, threatened, candidate, or species of concern by the federal government under the Endangered Species Act (ESA) (see 50 CFR 17) and listed as endangered, threatened, or candidate by the State of Washington (Washington Natural Heritage Program 2004, Washington Department of Fish and Wildlife 2004) (Table 4.4.1). There are no federal or state-listed endangered or threatened mammals, reptiles, amphibians, or invertebrates on the Hanford Site.

There are two species of plants on the Hanford Site that are candidates for protection under the federal ESA: Umtanum desert buckwheat which occurs in localized small populations on Umtanum Ridge, and the White Bluffs bladderpod which occurs on White Bluffs. Several of these threatened and endangered State-listed plant species (awned halfchaff sedge, grand redstem, lowland toothcup, and persistent sepal yellowcress) are restricted to wetlands in the riparian zone of the Columbia River. 
Table 4.4.1. Federal or Washington State Threatened and Endangered Species on the Hanford Site

\begin{tabular}{|c|c|c|c|}
\hline Common Name & Scientific Name & Federal $^{(\mathbf{a})}$ & State $^{(\mathrm{a})}$ \\
\hline \multicolumn{4}{|c|}{ Plants } \\
\hline awned halfchaff sedge & Lipocarpha (= Hemicarpha) aristulata & & $\mathrm{T}$ \\
\hline desert dodder & Cuscuta denticulata & & $\mathrm{T}$ \\
\hline Geyer's milkvetch & Astragalus geyeri & & $\mathrm{T}$ \\
\hline grand redstem & Ammannia robusta & & $\mathrm{T}$ \\
\hline loeflingia & Loeflingia squarrosa var. squarrosa & & $\mathrm{T}$ \\
\hline lowland toothcup & Rotala ramosior & & $\mathrm{T}$ \\
\hline persistent sepal yellowcress & Rorippa columbiae & SC & $\mathrm{E}$ \\
\hline rosy pussypaws & Calyptridium roseum & & $\mathrm{T}$ \\
\hline Umtanum desert buckwheat & Eriogonum codium & $\mathrm{C}$ & $\mathrm{E}$ \\
\hline White Bluffs bladderpod & Lesquerella tuplashensis & $\mathrm{C}$ & $\mathrm{T}$ \\
\hline white eatonella & Eatonella nivea & & $\mathrm{T}$ \\
\hline \multicolumn{4}{|c|}{ Fish } \\
\hline bull trout & Salvelinus confluentus & $\mathrm{T}$ & $\mathrm{C}$ \\
\hline spring-run chinook & Oncorhynchus tshawytscha & $\mathrm{E}$ & $\mathrm{C}$ \\
\hline steelhead & Oncorhynchus mykiss & $\mathrm{E}$ & $\mathrm{C}$ \\
\hline \multicolumn{4}{|c|}{ Birds } \\
\hline American white pelican & Pelecanus erythrorhychos & & $\mathrm{E}$ \\
\hline bald eagle $^{(\mathrm{b})}$ & Haliaeetus leucocephalus & $\mathrm{T}$ & $\mathrm{T}$ \\
\hline ferruginous hawk & Buteo regalis & SC & $\mathrm{T}$ \\
\hline sandhill crane & Grus canadensis & & $\mathrm{E}$ \\
\hline western sage grouse & Centrocercus urophasianus phaios & $\mathrm{C}$ & $\mathrm{T}$ \\
\hline \multicolumn{4}{|c|}{$\begin{aligned} \text { (a) } \mathrm{E}= & \text { Endangered (species in danger of extinction within all or a significant portion or its range). } \\
\mathrm{T}= & \text { Threatened (species likely to become endangered in the foreseeable future). } \\
\mathrm{C}= & \text { Candidate (species that are believed to qualify for threatened or endangered species status, but for } \\
& \text { which listing proposals have not been prepared) } \\
\mathrm{SC}= & \text { Species of concern }- \text { species that are not currently listed or candidates under the ESA, but are of } \\
& \text { conservation concern within specific USFWS regions. }\end{aligned}$} \\
\hline
\end{tabular}


Loeflingia and rosy pussypaws, both State threatened species, are small annuals that have been found in relatively undisturbed sagebrush areas around Gable Mountain. The remaining three State-listed plant species (Geyer's milkvetch, white eatonella, and desert dodder) have been found at various sites on the Wahluke slope.

State threatened, endangered, or species of concern that occur within the 100 Area include persistent sepal yellowcress (Rorippa columbiae), false pimpernel (Lindernia dubia anagallidea), shining flatsedge (Cyperus bipartitus [rivularis]), and gray cryptantha (Cryptantha leucophaea) (Landeen et al. 1993, Soll et al. 1999). Persistent sepal yellowcress has also been identified at 18 locations north of the 300 Area.

There are 3 species of fish and 5 species of birds listed as threatened or endangered on the Site. Of the 3 species of listed fish, only the upper Columbia River steelhead trout spawns in the Hanford Reach, although the extent of natural spawning is not known. The EMC Project monitors springtime steelhead trout spawning in the Hanford Reach. Upper Columbia River spring Chinook salmon do not spawn in the Hanford Reach, but pass through while migrating to spawning grounds and as the juveniles migrate toward the ocean. The Hanford Reach is utilized as a migration corridor and as a nursery area for migrating juvenile upriver spring Chinook salmon. The bull trout (Salvelinus confluentus) primarily inhabits smaller streams, usually at higher elevations. Bull trout have been observed in the Hanford Reach on very rare occasions, usually associated with the spring freshets. Bull trout are not considered to be residents of the Hanford Site, although the Hanford Reach is part of the proposed critical habitat for this species.

The bald eagle is a relatively common winter resident, and occasionally attempts to nest on the Hanford Site. However, bald eagles have not successfully nested on the Hanford Site. Bald eagle roosting and nesting sites are protected by site employee access controls that are in place between November and March of each year. The EMC Project monitors wintering bald eagles in the Hanford Reach.

Ferruginous hawks have successfully nested on site, especially on several steel transmission line towers. The white pelican is relatively common along the Hanford Reach, but does not appear to nest or reproduce there. The sandhill crane migrates over the site, but on occasion is observed on the shore or islands of the Hanford Reach. The western sage grouse was formerly more common on the Hanford Site, especially on Fitzner-Eberhardt Arid Lands Ecology Reserve Unit. It disappeared for a number of years following several large fires in the 1980s. Since the late 1990s there have been scattered observations of western sage grouse on Fitzner-Eberhardt Arid Lands Ecology Reserve Unit, and in 2003 a dead individual was found near 100-F Area.

The Washington ground squirrel (Spermophilus washingtoni), listed as a candidate species by both the state and federal governments, is most likely to occur in the Franklin or Grant county portions of the Hanford Site.

In addition to the species listed by the state or federal resource agencies as threatened or endangered, there are numerous species listed by the State of Washington as state level candidates, as sensitive species, or as review and watch list plants (Tables 4.4-2 and 4.4-3). The common loon is the only Washington State sensitive species on the Hanford Site. Several species (loggerhead shrike, burrowing owl, sagebrush lizard, peregrine falcon, goshawk, Columbia River spire snail) are considered to be species of concern by the USFWS. These species are not protected under federal law, but are considered to be vulnerable and of special management concern. Three of these species, Columbia milkvetch, Hoover's desert parsley, and gray cryptantha, are considered by USFWS to be species of concern in the mid-Columbia Basin. More information about the species listed in Table 4.4-3 can be found in Sackschewsky and Downs (2001). 
The USFWS indicates that four additional federally listed threatened, endangered, or candidate species may be present in Benton, Franklin, or Grant counties (USFWS 2004). The pygmy rabbit (Brachylagus idahoensis) is a federal and state endangered species that is restricted to a few small populations north of the Hanford Site in Grant and Adams counties. This species has been searched for on the Hanford Site, but has never been conclusively observed on site. Ute Ladies tresses (Spiranthes diluvialis) is a threatened orchid that potentially could be found along the Columbia River, but has never been observed near the site and is documented in Chelan and Okanogan counties (WNHP 2004). The yellow-billed cuckoo (Coccyzus americanus) is a candidate species that has been rarely been observed in southeast Washington. It normally requires relatively large, forested wetland areas for successful breeding. Such habitat is not available on the Hanford Site, and the species has not been observed on the Hanford Site. The northern wormwood (Artemisia campestris var wormskioldii) is a federal candidate and State endangered species that occurs along the Columbia River near Wanapum Dam. Extensive surveys along the shore of the Hanford Reach have failed to locate this species on the Hanford Site. The USFWS (2004) also list a number of additional species of concern for Benton, Franklin, and Grant Counties, including a number of bat species that may occur on the Hanford Site; most of these have no State-level status designation. 
Table 4.4-2. Washington State Candidate and Sensitive Animal Species on the Hanford Site

\begin{tabular}{|c|c|}
\hline Common Name & Scientific Name \\
\hline \multicolumn{2}{|l|}{ Molluscs } \\
\hline giant Columbia River limpet & Fisherola (= Lanx) nuttalli \\
\hline giant Columbia River spire snail $^{(\mathrm{a})}$ & Fluminicola (= Lithoglyphus) columbiana \\
\hline \multicolumn{2}{|l|}{ Fish } \\
\hline bull trout $^{(\mathrm{c}, \mathrm{f})}$ & Salvelinus confluentus \\
\hline mountain sucker ${ }^{(\mathrm{f})}$ & Catastomus platyrhynchus \\
\hline leopard dace ${ }^{(\mathrm{f})}$ & Rhinichthys flacatus \\
\hline river lamprey ${ }^{(\mathrm{f})}$ & Lampetra ayresi \\
\hline spring-run chinook ${ }^{(b)}$ & Oncorhynchus tshawytscha \\
\hline steelhead $^{(\mathrm{b})}$ & Oncorhynchus mykiss \\
\hline \multicolumn{2}{|l|}{ Insects } \\
\hline Columbia River tiger beetle $\mathrm{e}^{(\mathrm{e})}$ & Cicindela columbica \\
\hline \multicolumn{2}{|l|}{ Birds } \\
\hline burrowing owl ${ }^{(\mathrm{a})}$ & Athene cunicularia \\
\hline common loon ${ }^{(\mathrm{g})}$ & Gavia immer \\
\hline flamulated owl ${ }^{(\mathrm{f})}$ & Otus flammeolus \\
\hline golden eagle & Aquila chrysaetos \\
\hline Lewis’ woodpecker $^{(\mathrm{f})}$ & Melanerpes lewisii \\
\hline loggerhead shrike ${ }^{(a)}$ & Lanius ludovicianus \\
\hline peregrine falcon $^{(\mathrm{a}, \mathrm{g})}$ & Falco peregrinus \\
\hline merlin & Falco columbarius \\
\hline northern goshawk ${ }^{(\mathrm{a}, \mathrm{f})}$ & Accipter gentilis \\
\hline sage sparrow & Amphispiza belli \\
\hline sage thrasher & Oreoscoptes montanus \\
\hline western grebe & Aechmorus occidentalis \\
\hline Reptiles & \\
\hline sagebrush lizard $^{(\mathrm{a})}$ & Sceloporus graciosus \\
\hline striped whipsnake & Masticophis taeniatus \\
\hline Mammals & \\
\hline black-tailed jackrabbit & Lepus californicus \\
\hline Merriam’s shrew & Sorex merriami \\
\hline Townsend's ground squirrel & Spermophilus townsendii \\
\hline Washington ground squirrel ${ }^{(\mathrm{d}, \mathrm{f})}$ & Spermophilus washingtoni \\
\hline white-tailed jackrabbit & Lepus townsendii \\
\hline $\begin{array}{l}\text { (a) } \\
\text { (b) } \\
\text { (c) } \\
\text { Federal species of endangered. } \\
\text { (d) } \\
\text { (e) } \\
\text { (ederal candidate. } \\
\text { Probable, but not observed, on the Hanford Site. }\end{array}$ & $\begin{array}{l}\text { (f) Reported, but seldom observed, on the } \\
\text { Hanford Site. } \\
\text { State Sensitive (i.e., taxa vulnerable or } \\
\text { declining) and could become endangered or } \\
\text { threatened without active management or } \\
\text { removal of threats. }\end{array}$ \\
\hline
\end{tabular}


Table 4.4-3. Washington State Plant Species of Concern on the Hanford Site

\begin{tabular}{|c|c|c|}
\hline Common Name & Scientific Name & State Listing $^{(\mathrm{a})}$ \\
\hline annual paintbrush & Castilleja exilis & $\mathrm{W}$ \\
\hline annual sandwort & Minuartia pusilla var. pusilla & R1 \\
\hline basalt milk-vetch & Astragalus conjunctus var. rickardii & W \\
\hline beaked spike-rush & Eleocharis rostellata & $\mathrm{S}$ \\
\hline bristly combseed & Pectocarya setosa & $\mathrm{W}$ \\
\hline brittle prickly pear & Opuntia fragilis & $\mathrm{R} 1$ \\
\hline Canadian St. John’s wort & Hypericum majus & $\mathrm{S}$ \\
\hline chaffweed & Centunculus minimus & $\mathrm{R} 1$ \\
\hline Columbia milkvetch & Astragalus columbianus & $\mathrm{S}^{(\mathrm{b})}$ \\
\hline Columbia River mugwort & Artemesia lindleyana & $\mathrm{W}$ \\
\hline coyote tobacco & Nicotiana attenuata & S \\
\hline crouching milkvetch & Astragalus succumbens & $\mathrm{W}$ \\
\hline desert evening-primrose & Oenothera caespitosa & $\mathrm{S}$ \\
\hline dwarf evening primrose & Camissonia (= Oenothera) pygmaea & $\mathrm{S}$ \\
\hline false pimpernel & Lindernia dubia anagallidea & $\mathrm{W}$ \\
\hline fuzzytongue penstemon & Penstemon eriantherus whitedii & $\mathrm{S}$ \\
\hline giant helleborine & Epipactis gigantea & $\mathrm{W}$ \\
\hline gray cryptantha & Cryptantha leucophaea & $\mathrm{S}^{(\mathrm{b})}$ \\
\hline Great Basin gilia & Gilia leptomeria & $S$ \\
\hline hedge hog cactus & Pediocactus simpsonii var. robustior & $\mathrm{R} 1$ \\
\hline Hoover's desert parsley & Lomatium tuberosum & $S^{(b)}$ \\
\hline Kittitas larkspur & Delphinium multiplex & $\mathrm{W}$ \\
\hline medic milkvetch & Astragalus speirocarpus & $\mathrm{W}$ \\
\hline miner's candle & Cryptantha scoparia & $\mathrm{S}$ \\
\hline mousetail & Myosurus clavicaulis & $\mathrm{S}$ \\
\hline Piper’s daisy & Erigeron piperianus & S \\
\hline porcupine sedge & Carex hystericina & $\mathrm{W}$ \\
\hline Robinson's onion & Allium robinsonii & $\mathrm{W}$ \\
\hline rosy balsamroot & Balsamorhiza rosea & $\mathrm{W}$ \\
\hline scilla onion & Allium scilloides & $\mathrm{W}$ \\
\hline shining flatsedge & Cyperus bipartitus (rivularis) & $\mathrm{S}$ \\
\hline small-flowered evening-primrose & Camissonia (= Oenothera) minor & $\mathrm{S}$ \\
\hline small-flowered nama & Nama densum var. parviflorum & $\mathrm{W}$ \\
\hline smooth cliffbrake & Pellaea glabella simplex & $\mathrm{W}$ \\
\hline Snake River cryptantha & Cryptantha spiculifera (= C. interrupta) & S \\
\hline southern mudwort & Limosella acaulis & $\mathrm{W}$ \\
\hline stalked-pod milkvetch & Astragalus sclerocarpus & $\mathrm{W}$ \\
\hline
\end{tabular}




\begin{tabular}{|l|l|c|}
\hline \multicolumn{1}{|c|}{ Common Name } & \multicolumn{1}{c|}{ Scientific Name } & State Listing $^{(\mathrm{a})}$ \\
\hline Suksdorf's monkey flower & Mimulus suksdorfii & S \\
\hline Thompson's sandwort & Arenaria franklinii thompsonii & R2 \\
\hline winged combseed & Pectocarya penicillata & W \\
\hline
\end{tabular}

(a) $\mathrm{S}=$ Sensitive (i.e., taxa vulnerable or declining) and could become endangered or threatened without active management or removal of threats.

R1 = Review List 1 - Taxa for which there are insufficient data available to support listing as threatened, endangered, or sensitive.

R2 = Review List 2 - Taxa with unresolved taxonomic questions

$\mathrm{W}=$ Watch List - Taxa that are more abundant and/or less threatened than previously assumed.

(b) USFWS Columbia Basin federal species of concern 


\subsection{Cultural, Archaeological, and Historical Resources}

\section{E.L. Prendergast-Kennedy and D.W. Harvey}

The following section represents a summary of cultural, archaeological, and historical resources that are known to be located on the Hanford Site. The inventory is based on a summary of archaeological, historical, and ethnographic data collected from archival records, archaeological surveys, and ethnographic interviews. It does not reflect a complete inventory as presently 24 percent of the Hanford Site has been surveyed for archaeological resources (Figure 4.5-1).

The Hanford Site is one of the richest cultural resource areas remaining in the western Columbia Plateau. The Hanford Site comprises a series of cultural landscapes that have been documented and evaluated containing the cumulative record of multiple occupations by both Native and non-Native Americans. For management and interpretive purposes, these cultural landscapes have been divided into the Native American landscape, the Early Settlers/Farming landscape, and the Manhattan Project and Cold War landscape. These landscapes contain numerous well-preserved archaeological and aboveground resources representing pre-contact, ethnographic, and historic periods. Period resources include sites with cultural materials that are thousands of years old, traditional cultural places, and buildings and structures from the pre-Hanford, Manhattan Project, and Cold War eras (DOE 1997a). Site-wide management of Hanford's cultural resources follows the Hanford Cultural Resources Management Plan (DOE 2003).

Approximately 1447 cultural resources sites and isolated finds, and 531 buildings and structures have been documented since 1926 on the Hanford Site. Early archaeological reconnaissance projects dating from 1926 to 1968 (Drucker 1948; Krieger 1928; Rice 1968a,b) and more recent National Historic Preservation Act, Section 110 and 106, archaeological surveys conducted between 1987 and 2004 have resulted in formal recording of these resources on archaeological site and isolate forms and Washington State Historic Property Inventory Forms. The DOE Hanford Cultural Resources Laboratory holds these records.

Of the 127 sites that have been evaluated for listing in the National Register of Historic Places (National Register), 49 have been listed (Table 4.5-1). Except for B-Reactor, which is associated with the Manhattan Project and Cold War Period, the other listed sites are associated with the Native American Landscape. Most of these are part of six Archaeological Districts and with the exception of the Rattlesnake Springs Sites and the Snively Canyon Archaeological District, are situated on the shores and islands of the Columbia River. ${ }^{\text {(a) }}$

Eleven individual archaeological sites and three historic districts comprising 59 archaeological sites and 530 buildings or structures have also been determined to be eligible for listing in the National Register (Table 4.5-2). These sites are dispersed throughout the Hanford Site and represent the three cultural landscapes found on the Hanford Site. In addition to the National Register sites and districts, 47 of Hanford's cultural resource sites (46 in three districts and one site) are listed in the Washington Heritage Register (Table 4.5-3). These are associated with the Native American cultural landscape and are located predominantly along the Columbia River.

\footnotetext{
(a)In order to protect resources, the National Historic Preservation Act (16 USC 470) Section 304, and Archaeological Resources Protection Act (16 USC 470aa) Section 9 requires agencies to withhold from public disclosure information on the location and character of cultural resources.
} 


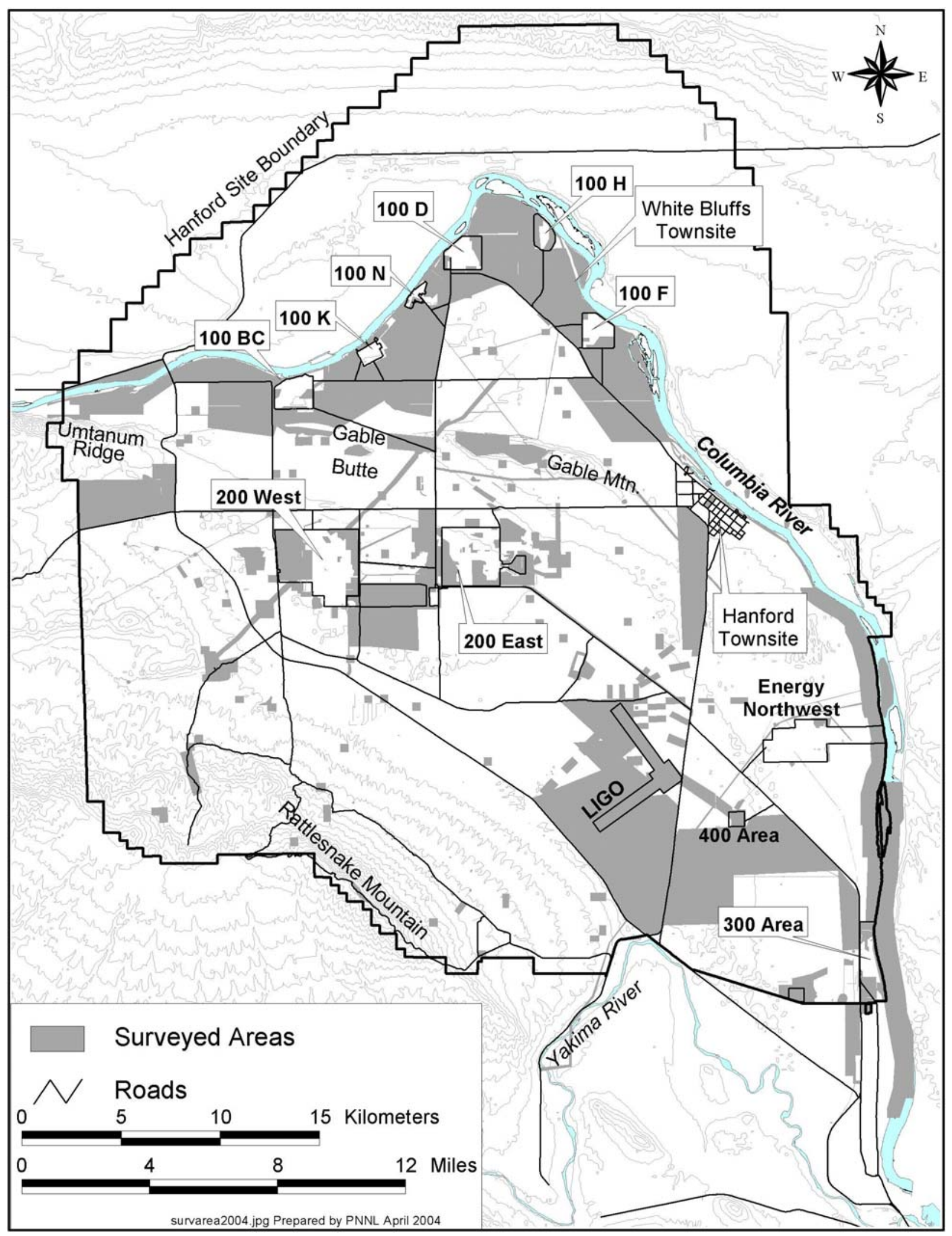

Figure 4.5-1. Areas Surveyed for Cultural Resources on the Hanford Site, Washington 
Table 4.5-1. Historic Buildings, Archaeological Sites, and Districts Listed in the National Register of Historic Places on the Hanford Site, Washington

\begin{tabular}{|lll|}
\hline \multicolumn{1}{|c}{ Property Name } & \multicolumn{1}{c|}{ General Location } & Landscape Association \\
\hline Districts: & & \\
Hanford North Archaeological District & $100-\mathrm{F}$ & Native American \\
Locke Island Archaeological District & $100-\mathrm{H}$ & Native American \\
Ryegrass Archaeological District & $100-\mathrm{K}$ & Native American \\
Savage Island Archaeological District & Energy Northwest & Native American \\
Snively Canyon Archaeological District & Rattlesnake Hills & Native American \\
Wooded Island Archaeological District & 300 Area & Native American \\
Sites: & & \\
Hanford Island Archaeological Site & Hanford Townsite & Native American \\
Paris Archaeological Site & Vernita Bridge & Native American \\
Rattlesnake Springs Sites & Rattlesnake Mountain. & Native American \\
Building: & & \\
105-B Reactor & 100-B/C Area & Manhattan Project \\
\hline
\end{tabular}

Table 4.5-2. Historic Buildings, Archaeological Sites, and Districts Determined Eligible for Listing in the National Register of Historic Places on the Hanford Site, Washington

\begin{tabular}{|c|c|}
\hline Property Name & General Location \\
\hline \multicolumn{2}{|l|}{ Native American: } \\
\hline Wanawish fishing village & 600 Area \\
\hline Gable Mountain/Gable Butte Cultural District & 200 East Area \\
\hline $45 \mathrm{BN} 423^{\text {(a) }}$ & 100-K Area \\
\hline 45BN434 & 100-K Area \\
\hline 45BN446 & 100-B/C Area \\
\hline 45BN606 & 100-F Area \\
\hline 45BN888 & 100-D Area \\
\hline \multicolumn{2}{|l|}{ Early Settlers: } \\
\hline Midway-Benton Transmission line & 600 Area \\
\hline McGee Ranch/Cold Creek Valley District & Cold Creek Valley \\
\hline Fry and Conforth Farm & 100-B/C Area \\
\hline White Bluffs Road & 200 West to White Bluffs town site \\
\hline First Bank of White Bluffs & White Bluffs town site \\
\hline Bruggemann’s Warehouse & 100-B/C Area \\
\hline Hanford Electrical Substation-Switching Station & Hanford Townsite \\
\hline Hanford High School & Hanford Townsite \\
\hline Coyote Rapids Hydroelectric Pumping Plant & 100-B/C Area \\
\hline \multicolumn{2}{|l|}{ Manhattan Project/Cold War: } \\
\hline Hanford Site Manhattan Project and Cold War & 100, $200 \mathrm{E}$ and W, 300, 400, 600, 700, and \\
\hline Era Historic District & 1100 Areas \\
\hline Five Anti-Aircraft Artillery Sites & 600 Area \\
\hline Hanford Atmospheric Dispersion Test Facility & 600 Area \\
\hline
\end{tabular}


Table 4.5-3. Archaeological Sites and Districts Listed in the Washington Heritage Register on the Hanford Site, Washington

\begin{tabular}{|ll|}
\hline Property Name & General Location \\
\hline Districts: & \\
Coyote Rapids Archaeological District & $100-$ K Area \\
Hanford South Archaeological District & 300 Area \\
Wahluke Archaeological District & $100-\mathrm{D}$ Area \\
Site: & \\
Gable Mountain Archaeological Site & 600 Area, North of 200 East \\
\hline
\end{tabular}

DOE identified a National Register-eligible Hanford Site Manhattan Project and Cold War Era Historic District (Historic District) that serves to organize and delineate the evaluation and mitigation of Hanford's plutonium production built environment (Table 4.5-2). Standards for evaluating and mitigating the built environment were established in accordance with National Register criteria, as well as historic contexts and themes associated with nuclear technology for national defense and non-military purposes, energy production, and human health and environmental protection. DOE completed a programmatic agreement that addresses management of the built environment (buildings and structures) constructed during the Manhattan Project and Cold War periods. The Federal Advisory Council on Historic Preservation and the Washington State Historic Preservation Officer accepted this programmatic agreement during 1996 (DOE 1996a).

Establishment of the Historic District resulted in the selection of 190 buildings, structures, and complexes as contributing properties within the historic district recommended for individual documentation. Certain property types, such as mobile trailers, modular buildings, storage tanks, towers, wells, and structures with minimal or no visible surface manifestations, were exempt from the identification and evaluation requirements.

Approximately 900 buildings and structures were identified as either contributing properties with no individual documentation requirement (not selected for mitigation) or as non-contributing/exempt properties (DOE 1998b).

Hanford Site projects that entail transfer or lease of property, disturbing ground, and/or altering or demolishing existing structures result in cultural resource reviews. These reviews ensure that archeological sites, traditional cultural places, and buildings and structures listed in or eligible for the National Register are considered before impacts by proposed projects.

\subsubsection{Native American Cultural Landscape}

For thousands of years American Indians have utilized the lands both within and around the Hanford Site (Relander 1956, Spier 1936, Walker 1998). When Euro-American explorers arrived in the early 1800s, peoples presently referred to as the Wanapum were observed inhabiting numerous villages and fishing camps scattered throughout this segment of the mid-Columbia River. Neighboring groups known today as the Yakama, Umatilla, Cayuse, Walla Walla, Palus, Nez Perce, and Middle Columbia Salish frequented the area to trade, gather resources, and conduct other activities. Many descendants of these 
tribes and bands are affiliated with the Wanapum, Confederated Tribes and Bands of the Yakama Nation, Confederated Tribes of the Umatilla Reservation, Nez Perce Tribe of Idaho, or the Confederated Tribes of the Colville Reservation, and they retain traditional, cultural, and religious ties to Hanford's places and resources. The record of Native American use and history is reflected in the archaeological sites and traditional cultural places that are located across the Hanford Site.

\subsubsection{Archaeological Resources}

More than 8000 years of pre-contact human activity in the largely arid environment of the midColumbia River region have left extensive archaeological deposits along the river shores (DOE 2003, Greengo 1982, Leonhardy and Rice 1970). Well-watered areas inland from the river also show evidence of concentrated human activity (Chatters 1982, DOE 2003, Daugherty 1952, Greene 1975, Leonhardy and Rice 1970, Rice 1980a) and recent research (Woody 2003) has indicated ephemeral use of arid lowlands for hunting and other resource procurement activities. Throughout most of the region, hydroelectric development, agricultural activities, and domestic and industrial construction have destroyed or covered many of these deposits. Amateur artifact collectors have impacted numerous sites. Because the areas included in the Hanford Site were restricted to public access, archaeological deposits found in the Hanford Reach of the Columbia River and on adjacent plateaus and mountains are more protected than many other areas.

Approximately 720 archaeological sites and isolated finds associated with the pre-contact period have been recorded on the Hanford Site; of these, 80 contain historic components as well. Pre-contact period sites common to the Hanford Site include pit house villages, various types of open campsites, spirit quest monuments (rock cairns), hunting camps, game drive complexes, and quarries in nearby mountains and rocky bluffs (Rice 1968a, b; Rice 1980a); hunting/kill sites in lowland stabilized dunes; and small temporary camps near perennial sources of water located away from the river (Rice 1968b).

A historic context for the pre-contact period of the Hanford Site has been prepared as part of a National Register Multiple Property Documentation form to assist with the evaluation of the National Register eligibility of pre-contact archaeological resources (DOE 1997a).

\subsubsection{Traditional Cultural Places}

In 1990, the National Park Service formalized the concept of traditional cultural property or traditional cultural place (TCP) as a means to identify and protect cultural landscapes, places, and objects that have special cultural significance to American Indians and other ethnic groups (Parker and King 1990). A TCP eligible for the National Register is associated with "cultural practices or beliefs of a living community that are rooted in that community's history and are important in maintaining the continuing cultural identity of the community” (Parker and King 1990).

The Hanford Reach and the greater Hanford Site, a geographic center for regional American Indian religious activities, is central to the practice of Indian religion of the region, and many believe the Creator made the first people here (DOI 1994). Indian religious leaders such as Smoholla, a prophet of Priest Rapids who brought the Washani religion to the Wanapum and others during the late $19^{\text {th }}$ century, began their teachings here. Native plant and animal foods, some of which can be found on the Hanford Site, are used in the ceremonies performed by tribal members. Based on consultation with affected tribal members and interviews with tribal elders, it is known that prominent landforms such as Rattlesnake Mountain, Gable Mountain, and Gable Butte, as well as various sites along and including the Columbia River, remain sacred to them. 
American Indian traditional cultural places within the Hanford Site include, but are not limited to, a wide variety of places and landscapes: archaeological sites, cemeteries, trails and pathways, campsites and villages, fisheries, hunting grounds, plant gathering areas, holy lands, landmarks, important places in Indian history and culture, places of persistence and resistance, and landscapes of the heart (Bard 1997). Because affected tribal members consider these places sacred, many traditional cultural sites remain unidentified. The DOE and HCRL continue to consult with Hanford Tribes for input on these locations, as their importance is determined through methods that are mutually agreed upon by DOE and the American Indian community.

A historic context for the Ethnographic/Contact Periods of the Hanford Site has been prepared as part of a National Register Multiple Property Documentation form to assist with the evaluation of the National Register eligibility of American Indian ethnographic resources (DOE 1997a).

\subsubsection{Early Settlers/Farming Landscape}

The Early Settlers/Farming landscape is comprised of those areas on the Hanford Site where people, mainly of European descent, and some of other ethnicity, settled in the Columbia River Plateau prior to the start of the Manhattan Project during 1943. Non-Native American presence in the mid-Columbia began during 1805 with the arrival of the Lewis and Clark Expedition. It was not until the late $19^{\text {th }}$ and early $20^{\text {th }}$ centuries, however, that non-Native American peoples began intensive settlement on the Hanford Site. A record of their activities and use is present in the archaeological sites, traditional cultural places, and buildings and structures that are located throughout the Hanford Site.

A historic context for the Euro-American resettlement period (pre-Hanford era) has been prepared as part of a National Register Multiple Property Documentation form to assist with the evaluation of the National Register eligibility of historic archaeological resources, traditional cultural places, and historic structures (DOE 1997a).

\subsubsection{Archaeological Resources}

The first Euro-Americans to pass near the Hanford Site were part of the Lewis and Clark expedition, which traveled along the Columbia and Snake rivers during their 1803 to 1806 exploration of the Louisiana Territory. The first European explorer to cross the Hanford Site was David Thompson, who traveled along the Columbia River from Canada during his 1811 exploration of the Columbia River. Other visitors included fur trappers, military units, and miners who traveled through the Hanford Site on their way to lands up and down the Columbia River and across the Columbia Basin. It was not until the 1860s that merchants set up stores, a freight depot, and the White Bluffs Ferry on the Hanford Reach. Chinese miners began to work the gravel bars for gold during the 1860s. Cattle ranches were established in the 1880s and farmers followed during the next two decades. Agricultural development, irrigation districts, and roads were established in the eastern portion of the central Hanford Site. Several small towns, including Hanford, White Bluffs, Richland, and Ringold, grew up along the riverbanks during the early $20^{\text {th }}$ century. The communities' accessibility to outside markets expanded with the arrival during 1913 of the Chicago, Milwaukee, St. Paul and Pacific Railroad branch line (Priest Rapids-Hanford Line) from Beverly, Washington. Ferries were established at Richland, Hanford, Wahluke, and Vernita (Figure 4.5-2). The towns and nearly all other structures were razed in the years after the U.S. Government acquired the land for the Hanford Engineer Works during 1943 (DOE 2003, ERTEC 1981, Rice 1980a). 


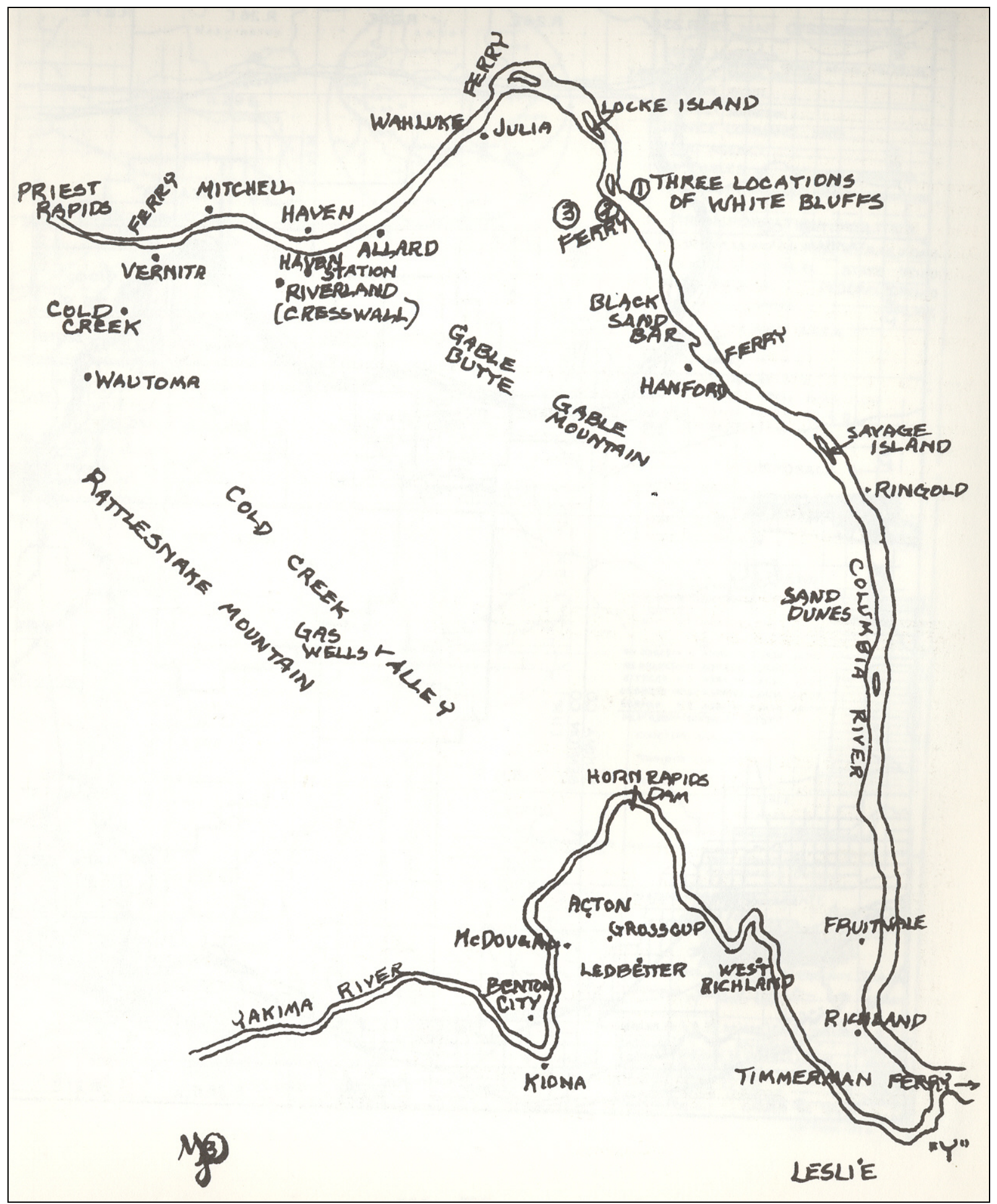

Figure 4.5-2. Map of the Hanford Site, Washington, showing towns, ferries and prominent features associated with the Early Settlers landscape (Parker 1986) 
Approximately 650 historic archaeological sites associated with the Early Settlers/Farming landscape including an assortment of towns, farmsteads, corrals and domestic debris are recorded by the HCRL since 1987. Approximately 80 of these sites contain pre-contact components as well. Archaeological resources from the Early Settlers/Farming period are scattered over the entire Hanford Site and include numerous areas of gold mining features along the riverbanks of the Columbia and remains of homesteads, building foundations, agricultural equipment and fields, ranches, and irrigation features. Archaeological properties from this period include the Hanford Irrigation Canal; Hanford Townsite; Wahluke Ferry; White Bluffs town site; Vernita Ferry; White Bluffs Road; and Chicago, Milwaukee, St. Paul and Pacific Railroad (Priest Rapids-Hanford Line) and associated stops.

\subsubsection{Traditional Cultural Places}

Traditional cultural places associated with the Early Settlers/Farming landscape that are located on the Hanford Site include structures and places that are important to descendants of pre-1943 settlers in the region. These places are deeply rooted in the memories of local residents and include but are not limited to numerous home sites and town sites, orchards, fields, and places of former community activities, e.g., swimming holes and town square. Previous residents of the region and their descendents visit their homes annually with friends and family.

\subsubsection{Buildings and Structures}

Although most of the Early Settlers/Farming structures were demolished by the U.S. Government to build infrastructure for the Hanford Engineer Works during 1943 (DOE 2003, ERTEC 1981, Rice 1980a), a small number of buildings associated with the Early Settlers/Farming landscape remain standing today. They include the Hanford Irrigation and Power Company's pumping plant at Coyote Rapids, the high school and the electrical substation at the Hanford Townsite, First Bank of White Bluffs, Bruggemann's fruit warehouse, and the blacksmith cabin at the East White Bluffs ferry landing. These structures are located near the Columbia River.

\subsubsection{Manhattan Project and Cold War Cultural Landscape}

The Manhattan Project and Cold War era landscape is comprised of cultural resources associated with plutonium production, military operations, research and development, waste management, and environmental monitoring activities that took place beginning with the establishment of the Hanford Site (Hanford Engineer Works) during 1943 to the end of the Cold War during 1990.

The Hanford Site built environment is an industrial landscape that consists of buildings and structures constructed during the Manhattan Project and Cold War period. This industrial landscape makes up the Hanford Site Manhattan Project and Cold War Era Historic District. The DOE Richland Operations Office, the State Historic Preservation Officer, and the Federal Advisory Council on Historic Preservation, through a programmatic agreement to manage the Manhattan Project and Cold War built environment, determined that a historic district afforded the best means to inventory, assess, and mitigate the most significant buildings and structures constructed during the Manhattan Project and Cold War. Industrial, scientific, administrative, environmental monitoring, waste management, infrastructure, and military facilities constructed during the Manhattan Project and Cold War era can be found in all of the Site areas.

While buildings and structures representing this era are located throughout the site, evidence of military operations consists mostly of archaeological remains. Military operations in various forms took place on the Site from World War II to the early 1960s. Most of the military operations, however, took 
place beginning with the establishment of Camp Hanford by the U.S. Army during 1950-51 until its closure in 1961. Camp Hanford was a military outpost, with the main cantonment located in North Richland and forward positions situated throughout the Site consisting of anti-aircraft artillery sites and Nike missile installations.

Historic contexts were completed for the Manhattan Project and Cold War eras as part of a National Register Multiple Property Documentation Form prepared for the Hanford Site to assist with the evaluation of National Register eligibility of buildings and structures site wide (DOE 1997a).

Additionally, historical narratives and individual building documentations have been completed for the History of the Plutonium Production Facilities at the Hanford Site Historic District, 1943-1990 (DOE 2002c). Five hundred twenty-eight Manhattan Project and Cold War era buildings/structures and complexes are eligible for the National Register as contributing properties within the Historic District. Of that number, 190 are recommended for individual documentation. DOE/RL is undertaking an assessment of the contents of the contributing buildings and structures to locate and identify any Manhattan Project and Cold War era artifacts that may have interpretive or educational value for museum exhibit purposes (DOE 1998b).

\subsubsection{Archaeological Resources}

Archaeological remains of military sites associated with the Manhattan Project and Cold War landscape are scattered throughout the Hanford Site's 600 Area. These archaeological resources are mainly located within the former Camp Hanford forward positions, the 16 anti-aircraft artillery sites that encircled the 100 and 200 Areas, and the three Nike missile installations on Wahluke Slope. (A fourth Nike position, in relatively intact condition, is located at the base of Rattlesnake Mountain on FitznerEberhardt Arid Lands Ecology Reserve Unit.) The Nike position on the reserve is eligible for inclusion in the National Register as a contributing property within the Hanford Site Manhattan Project and Cold War Era Historic District. Five of the 16 anti-aircraft artillery sites are eligible for the National Register.

The anti-aircraft artillery and Nike sites were strategic components in Camp Hanford's military defense of the Site's plutonium production facilities during the 1950s. Potential archeological resources at these sites include former gun emplacements, launch and radar sites, concrete foundations and pads, pathways/sidewalks, associated dumpsites, small arms firing ranges, and ammunition caches.

The archaeological remains of the Atmospheric Dispersion Test Facility Grid are located in the Hanford Site east of the 200 West Area. The facility was used for monitoring airborne waste dispersions during the operation of the plutonium production facilities on the Hanford Site.

\subsubsection{Buildings and Structures}

Historic built resources documented from the Manhattan Project and Cold War eras include buildings and structures found in the 100, 200, 300, 400, 600, 700, and 1100 Areas. The most significant of these are the plutonium production and test reactors, chemical separation and plutonium finishing buildings, and fuel fabrication/manufacturing facilities. The first reactors, 105-B, 105-D, and 105-F, were constructed during the Manhattan Project. Plutonium for the first atomic explosion and the bomb dropped on Nagasaki, Japan, at the end of World War II were produced at the Hanford Site. Additional reactors and processing facilities were constructed after World War II during the Cold War period. All reactor containment buildings still stand, although many ancillary structures have been removed, and C, DR, and F Reactors have been considerably modified. 
DOE/RL will consider the retention of National Register-eligible buildings and structures that may qualify for adaptive reuse as interpretive centers, museums, industrial, or manufacturing facilities (DOE 1996a).

\subsubsection{Site Areas}

Archaeological sites, traditional cultural places, buildings, and structures are found in each of several areas on the Hanford Site, including the 100, 200, 300, 400, 600, and 700 Areas. Since it was the Manhattan Project that established these areas as geographical locations on the Hanford Site, many cultural resources located within these areas are associated with that landscape. Many of these areas were developed over the top of existing cultural resources from the Native American and Early Settlers/Farming landscape. Hence, these earlier landscapes were changed; however, many resources remain as they were prior to 1943. A brief synopsis of known resources found in these areas is presented in the following subsections.

\subsubsection{100 Areas}

Field surveys were completed in the 100 Area from 1991 to 1995 (Andrefsky et al. 1996, Chatters et al. 1992, Wright 1993). Much of the surface area within the 100 Area operable units has been disturbed by the industrial activities that have taken place during the past 50 years. However, these areas still contain many cultural resources.

Each of the three landscapes is represented in the 100 Area by the presence of archaeological sites, traditional cultural properties, and reactor facilities. Most of these resources reflect past use of river resources such as open camps, fishing sites, farmsteads, pump houses, gold mining pits, and water intake and outtake structures.

Plutonium production reactors and their ancillary and support facilities were located in the 100 Area. The production reactors functioned to irradiate uranium fuel elements, the essential second step in the plutonium production process. A complete inventory of 100 Area buildings and structures was completed during FY 1995, and a National Register evaluation for each was finalized during 1996. To date, 146 buildings/structures have been inventoried in the 100 Area. Of that number, 55 have been determined eligible for the National Register as contributing properties within the Historic District recommended for individual documentation (DOE 1998b). As remediation continues in the 100 Areas, the potential exists for inadvertent discoveries of archaeological resources. To understand impacts to cultural resources and to reduce the need to perform extensive reviews on highly disturbed areas, disturbance maps and reports have been completed for 100-B/C, 100-D/DR, and 100-F Areas.

\section{0-B/C Area}

Archaeological Resources. There is a high density of archaeological resources associated with the Native American cultural landscape in the 100-B/C Area. Three are located partially within the 100-B/C Area (Rice 1968a, Rice 1980a, b), and 35 have been recorded within the immediate vicinity of the B/C Area during archaeological surveys completed during 1995.

Historic archaeological resources include the remains of Haven Station, a small stop on the former Chicago, Milwaukee, St. Paul and Pacific Railroad, located to the west of the 100-B/C Area. One archaeological site and the remains of the small community of Haven lie on the opposite bank of the Columbia River. 
Two archaeological sites (45BN447 and 45BN446 ${ }^{(\mathrm{a})}$ ) located near 100-B/C have been investigated. Test excavations conducted during 1991 at archaeological site 45BN447 revealed large quantities of deer and mountain sheep bone, and projectile points dating from 500 to 1500 years ago. The second archaeological site, 45BN446, is considered to be eligible for listing in the National Register, in part, because it may contain new information about the Frenchman Springs and Cayuse Phases of midColumbia prehistory.

Traditional Cultural Places. Many sites related to hunting and religious activities are located at the west end of Gable Butte. These sites are associated with the Gable Mountain Cultural District.

Buildings and Structures. The only structure associated with the Early Settlers/Farming landscape in the $100-\mathrm{B} / \mathrm{C}$ Area is the Hanford Irrigation and Power Company pumping plant built at Coyote Rapids during 1908. It is located east of the 100-B/C Area and the 105-B Reactor.

The 105-B Reactor was the world's first full-scale plutonium production reactor and is designated as a National Historic Mechanical Engineering Landmark. It is also listed in the National Register, is a National Civil Engineering Landmark, and was given the Nuclear Historic Landmark Award. Historic American Engineering Record (HAER) documentation of B Reactor was completed during 1999 (DOE 2001b). A total of 14 buildings and structures within the reactor area have been recorded on historic property inventory forms. Of that number, 10 properties are eligible for the National Register as contributing properties within the Historic District recommended for individual documentation. These include 105-B Reactor, 181-B River Pump house, 104-B-1 Tritium Vault, 104-B-2 Tritium Laboratory, 105-B-Rod Tip Cave, 116-B Reactor Exhaust Stack, 117-B Exhaust Air Filter Building, 118-B-1 Solid Waste Burial Trench, and 182-B Reservoir and Pump house (DOE 1998b).

An assessment of the contents of the 105-B Reactor was conducted to locate and identify Manhattan Project and Cold War era artifacts that may have interpretive or educational value in potential exhibits. Thirty-nine industrial artifacts were identified and tagged, with many on display as interpretive exhibits in the reactor. Tagged artifacts from 105-D and F Reactors were transferred to B Reactor to be displayed as interpretive exhibits.

\section{0-D/DR Area}

Archaeological Resources. Twenty-three known archaeological sites lie within $1 \mathrm{~km}(0.6 \mathrm{mi})$ of the 100-D/DR Area: three on the northern bank and the remainder on the southern bank of the Columbia River. The Wahluke Archaeological District is located north of the reactor area. Most remaining sites represent early Euro-American settlement activities. The former community of Wahluke, which was at the landing of a ferry of the same name, is situated on the river's north bank. Remains of historic farmsteads are scattered throughout the nearby area. An archaeological excavation was completed in 2001 of 45BN888, a camp site associated with the Native American cultural landscape adjacent to the reactor area.

Traditional Cultural Places. Twenty-seven individual rock cairns located south of the reactor area are associated with an area known to have traditional cultural importance to affected tribes.

\footnotetext{
(a) Smithsonian Trinomial numbers are the standard designation for archaeological sites in the United States. 45 represents the state of Washington. BN, GR and FR represent Benton, Grant and Franklin counties. The number that follows indicates that the site was the $\mathrm{n}^{\text {th }}$ archaeological site to be recorded in that county.
} 
Buildings and Structures. All the buildings and structures in the 100-D/DR Area were built during the Manhattan Project and Cold War eras. Twenty buildings/structures have been inventoried, including the 105-D and 105-DR Reactor buildings. Both reactors are eligible for the National Register as contributing properties within the Historic District, but are not recommended for individual documentation. An assessment of the contents of 105-D and 105-DR was conducted to locate and identify Manhattan Project and Cold War era artifacts that may have interpretive or educational value in potential exhibits. Twenty-four industrial artifacts were identified and tagged in 105-D, including control panels, a reactor curtain, lunch tables, benches, tools, and signs. All the tagged artifacts in 105-D were transferred to B Rector. Ten industrial artifacts were identified and tagged on 105-DR, including a radiological worker procedures poster, an instrument ladder, three metal signs, a lead sampling chamber "pig," a control panel, vintage ceiling lights, and graphite blocks. The 185/189-D buildings and adjoining facilities, all part of the 190-D complex, are eligible for the National Register and were documented to HAER standards (DOE 1998b). The 190-D Complex has been demolished.

\section{0-F Area}

Archaeological Resources. The 100-F Area is situated on the shore of the Columbia River and contains many cultural sites associated with the Native American cultural landscape. According to Relander (1956), a nearly continuous string of camps and villages of the Wanapum extended from the Hanford Townsite upstream to the White Bluffs Townsite. Sixty-seven archaeological sites have been recorded within $1 \mathrm{~km}(0.6 \mathrm{mi})$ of the $100-\mathrm{F}$ Area. Sites of particular importance include a site that is eligible to the National Register (45BN606) and an historic Wanapum cemetery.

The principal site associated with the Early Settlers/Farming landscape near 100-F is the White Bluffs Townsite and ferry landing. This location was the upriver terminus of shipping during the mid- $19^{\text {th }}$ century. It was at this point that supplies for trappers, traders, and miners were off-loaded, and commodities from the interior were transferred from pack trains and wagons to riverboats. The first store and ferry of the mid-Columbia region were located at the ferry landing (ERTEC 1981). A log cabin, thought to have been a blacksmith shop built during the late $19^{\text {th }}$ century, still stands there. Test excavations conducted at the cabin by the University of Idaho revealed historic and pre-contact cultural materials. The structure was recorded according to standards of the Historic American Buildings Survey (Rice 1976). Stabilization of the structure was carried out by the USFWS during 2001. The only remaining structure associated with the White Bluffs town site (near the railroad) is the First Bank of White Bluffs.

Traditional Cultural Places. Cemeteries associated with the Native American landscape are known to be in the vicinity of the 100-F Area.

Buildings and Structures. Three Manhattan Project/Cold War era buildings/structures have been inventoried in this area, including the 105-F Reactor building. An assessment of the contents of 105-F was conducted to identify any artifacts that may have value as potential museum exhibits. Eleven industrial artifacts were identified and tagged, including a fuel scale, elevator control panel, two shop signs, four safety signs, a hardhat, graphite blocks, and vintage ceiling lights. All tagged artifacts were transferred to either B Reactor or the Columbia River Exhibition of History, Science and Technology (CREHST) museum in Richland, Washington, for inclusion into the Hanford Collection.

\section{0-H Area}

Archaeological Resources. As of 2004, there have been 31 archaeological sites recorded within $1 \mathrm{~km}(0.6 \mathrm{mi})$ of the $100-\mathrm{H}$ Area. Included in this group are two historic Wanapum cemeteries, six camps, and three house pit villages. The largest village contains approximately 100 house pits and 
numerous storage caches. It appears to have been occupied consistently from 2500 years ago to 1943 (Rice 1968a). The cemeteries, camps, and villages are included in the Locke Island Archaeological District.

Archaeological sites associated with the Early Settlers/Farming landscape in 100-H include several $20^{\text {th }}$ century farmsteads and associated domestic debris. None of these sites have yet been evaluated for eligibility to the National Register. Remains of military encampments associated with the Manhattan Project and Cold War landscape are also located near the 100-H Area.

Traditional Cultural Places. Wanapum cemeteries are known to be located in the vicinity of the 100-H Area.

Buildings and Structures. Four Cold War era buildings/structures were inventoried in the $100-\mathrm{H}$ Area. Of that number, only the 105-H Reactor is eligible for the National Register as a contributing property within the Historic District. The reactor, however, was not recommended for individual documentation (DOE 1998b). An assessment of the contents of $105-\mathrm{H}$ was conducted to locate and identify Cold War era artifacts that may have interpretive or educational value in potential exhibits. No items were tagged.

\section{0-K Area}

Archaeological Resources. An archaeological survey of the 100-K Area during 1991 revealed five previously unrecorded archaeological sites. Archaeological surveys conducted in the 100-K Area during 1995 resulted in documentation of 31 additional pre-contact and historic sites. Two of these sites (45BN423 and 45BN434) are believed to date to the Cascade Phase 8000 to 4000 years ago and are eligible for listing in the National Register. The Coyote Rapids Archaeological District and the Ryegrass Archaeological District are located near the 100-K Area.

The Hanford Irrigation Canal and the former Chicago, Milwaukee, St. Paul and Pacific Railroad, two important linear features associated with the Early Settlers/Farming landscape, are also present in the 100K Area. Archaeological remains of the Early Settlers/Farming community at Coyote Rapids and a number of historic farmstead sites are located west of the 100-K Area.

Traditional Cultural Places. Events took place at this locale during the mid-19 ${ }^{\text {th }}$ century that are important to American Indian people of the interior Northwest (Relander 1956). The Washani religion (also known as Seven Drums or Dreamer religion) was first practiced here, eventually spreading to many neighboring tribes. A group of pit houses with an associated long house and sweat lodge have been identified that may have been the site of the Wanapum religious leader Smohalla's first Washat dance. An area located a short distance upstream is also recognized as a traditional cultural place because of its association with Wanapum history and traditional cultural beliefs (Relander 1956).

Buildings and Structures. Thirty-eight buildings and structures have been inventoried in the $100-\mathrm{K}$ Area, including the 105-KE and KW Reactor buildings. Of that number, 13 are eligible for the National Register as contributing properties within the Historic District recommended for individual documentation. These include the 105-KW Reactor, 190-KW Main Pump house, 107-KW Retention Basin, 183-KW Filter Plant, and 181-KW River Pump house (DOE 1998b).

An assessment of the contents of 105-KE and KW was conducted to identify any artifacts that may have educational or interpretive value as potential museum exhibits. Twenty-two industrial artifacts were identified and tagged in 105-KE Reactor, including tools, signage, radiation monitoring equipment, and furniture. Nine artifacts were identified and tagged from 105-KW Reactor, including furniture, a 
measurement scale, tools, and a floodlight. An assessment of the contents of the other historic buildings in the 100-K Area resulted in 23 additional artifacts being identified and tagged.

\section{0-N Area}

Archaeological Resources. Twenty archaeological sites associated with the Native American cultural landscape have been recorded within $1 \mathrm{~km}(0.6 \mathrm{mi})$ of the $100-\mathrm{N}$ Area perimeter. Three sites (two house pit villages, 45BN150 and 45BN180, and one cemetery, 45BN151) comprise the Ryegrass Archaeological District. Site 45BN179, once considered for a National Register nomination as the Hanford Generating Plant Site, has been found to be part of 45BN149, which is already listed in the National Register. Extant knowledge about the archaeology of the 100-N Area is based largely on reconnaissance-level archaeological surveys conducted during the late 1960s to late 1970s (Rice 1968b; Rice 1980a, b), which do not purport to produce complete inventories of the areas covered.

The most common evidence of activities associated with the Early Settlers/Farming landscape found near the 100-N Area consists of the archaeological remains of farmhouses and agricultural fields. The historic Hanford Irrigation Canal is adjacent to and south of the 100-N Area.

Traditional Cultural Places. Three places near the 100-N Area are known to have been of importance to the Wanapum. Cataclysmic flooding at the end of the Pleistocene formed the numerous small rolling hills known as Mooli Mooli, which means Little Stacked Hills. Gable Mountain (called Nookshai or Otter) and Gable Butte,which lie to the south of the river, are highly significant to affect tribes. According to Relander (1956) these are places where Wanapum youths would go on overnight vigils seeking guardian spirits. Rock cairns located in these areas indicate ethnographic use of these areas. Sites of religious importance may also exist near the 100-N Area.

Buildings and Structures. The 100-N Reactor, completed during 1963, was the last of the plutonium production, graphite-moderated reactors. The design of N Reactor differed from the previous eight reactors in several ways to afford greater safety and to enable co-generation of electricity. Sixty-six Cold War era buildings and structures were inventoried in the 100-N Area. Thirty 100-N Area buildings/structures are eligible for the National Register as contributing properties within the Historic District recommended for individual documentation (DOE 1998b). These include the 105-N Reactor, 109-N Heat Exchanger Building, 181-N River Water Pump house, 183-N Water Filter Plant, 184-N Plant Service Powerhouse, 185-N Export Powerhouse, and the 1112-N Guard Station (DOE 1997d).

An assessment of the contents of $185-\mathrm{N}$ was conducted to locate and identify Cold War era artifacts that may have interpretive or educational value in potential exhibits. Six artifacts were identified and tagged, including control room panels, phone booths, a "hear-here” phone, metal cart, and a safety sign. All the artifacts were photographed and transferred to CREHST Museum in Richland, Washington, for inclusion in the Hanford Collection. Building 185-N was recently demolished.

\subsubsection{200 Areas}

Much of the 200 Areas has been altered by Hanford operations. The Hanford Cultural Resources Laboratory conducted a comprehensive archaeological resources survey of the fenced portions of the 200 Areas during 1987 and 1988 (Chatters and Cadoret 1990). The results indicate that evidence of cultural resources associated with the Native American cultural landscape and the Early Settlers/Farming landscape is minimal. Archaeological surveys conducted since that time have revealed much the same pattern. 
Archaeological Resources. The most significant archaeological resource located in the 200 Area is an extensive linear feature known as the White Bluffs Road, a portion of which passes diagonally southwest to northeast through the 200 West Area. This road, in its entirety, is eligible for listing in the National Register, except for non-contributing segments of the White Bluffs Road that are located in the 200 West Area. Non-contributing segments of the White Bluffs Road are those sections that have been so considerably altered that they lack historic integrity, but retain evidence of its contiguous bearing. Originally a trail used by area tribes, it played a role in Euro-American immigration, development, agriculture, and Hanford Site operations. The survey conducted in 2000 on the White Bluffs Road recorded an additional 54 historic isolated finds and 2 pre-contact isolated finds, as well as six can dump features.

Traditional Cultural Places. Many sites related to hunting and religious activities are located on Gable Mountain and Gable Butte north of the 200 West and 200 East Areas. These sites are associated with the Gable Mountain/Gable Butte Cultural District.

Buildings and Structures. The 200 Areas contain many significant buildings and structures associated with the Manhattan Project and Cold War landscape. They were formerly used as chemical separations (processing) plants and ancillary and support facilities. The plants functioned to dissolve the irradiated fuel elements to separate out the plutonium, the essential third step in plutonium production. Historic property inventory forms have been completed for 72 buildings/structures in the 200 Area. Of that number, 58 buildings are eligible for the National Register as contributing properties within the Historic District recommended for individual documentation. These include the 202-A Purex Plant, 212N Lag Storage Facility, 221-T Plant, 222-S Redox Plant, 225-B Encapsulation Building, 231-Z Plutonium Metallurgical Laboratory, 234-5Z Plutonium Finishing Plant, 236-Z Plutonium Reclamation Facility, 242-Z Water Treatment Facility, 282-E Pump house and Reservoir Building, 283-E Water Filtration Plant, and the 284-W Powerhouse and Steam Plant. The 232-Z Waste Incinerator Facility and the 233-S Plutonium Concentration Building are also eligible for the National Register and along with 221-T Plant, have been documented to HAER standards (DOE 1998b). The 233-S building was recently demolished.

An assessment of the contents of nine facilities in the Plutonium Finishing Plant (PFP) complex was conducted during 1998 and 2002, and a letter report was completed entitled "Interpretive and Curation Plan for the Deactivation and Decommissioning of Historic Buildings at the PFP Complex". These buildings and structures included the 234-5Z PFP, 291-Z Exhaust Stack, 232-Z Waste Recovery Facility, 236-Z Plutonium Reclamation Facility, 2704-Z Safeguards and Security Building, the 2736-Z, ZA, and ZB Plutonium Storage Facilities, and 2736-ZC (non-historic) Cargo Restraint Transport Facility. Because of security/radiological exposure concerns, Buildings 2701-ZA and 242-Z were not accessible for walkthroughs. In 234-5Z, the entire Remote Mechanical C line (glove boxes) and control room, and the Remote Mechanical A line (glove boxes) and control room were identified and tagged. Ten additional Cold War era artifacts were identified and tagged as a result of a walkthrough of the Analytical Laboratories in 234-5Z. The assessment of the 2704-Z Building resulted in two tagged artifacts: a typology of "cans" poster and demonstration training cans. A third artifact, the classified documents vault, was identified but not tagged. The non-historic 2736-ZA building contains historic metal pedestals and a wooden mockup pedestal that were tagged.

Thirty-two industrial artifacts were identified and tagged in chemical separations buildings located in the 200 Area. The following buildings were inspected for artifacts during the walkthroughs: 202-A, 202S, 221-T, 221-U, 224-U, 224-B, and 271-U. Types of artifacts selected included electrical equipment, control panels, tools, vintage lights, health and safety items, signage, and communications equipment. 


\subsubsection{300 Area}

Much of the 300 Area has been used for industrial activities associated with the Manhattan Project and Cold War cultural landscape. Prior to the Manhattan Project during 1943, the 300 Area was used by Native Americans as a camp location and by early settlers who developed a farming community known as Fruitvale. Due to its proximity to the Columbia River, many archaeological resources associated with both these landscapes are located along the river shore outside of the 300 Area fence. Subsurface archaeological deposits are likely to be located underneath existing 300 Area facilities in pockets of undisturbed ground.

Archaeological Resources. Five recorded archaeological sites, including campsites, house pits, and a historic trash scatter, are located at least partially within the 300 Area. Many more may be located in subsurface deposits. Twenty-three archaeological sites and 10 isolated artifacts have been recorded within $1 \mathrm{~km}(0.6 \mathrm{mi})$ of the 300 Area fence. Archaeological site 45BN162 has been determined eligible for listing in the National Register. Several archaeological sites in this area are in the Hanford South Archaeological District, which is listed in the Washington Heritage Register. Archaeological sites associated with the Early Setters/Farming cultural landscape in the 300 Area are comprised mainly of domestic debris scatters and roadbeds associated with farmsteads.

Traditional Cultural Places. A documented historic Wanapum cemetery is located near the 300 Area.

Buildings and Structures. The 300 Area, the location of the uranium fuel fabrication plants that manufactured fuel rods to be irradiated in the Hanford Site reactors, provided the first essential step in the plutonium production process. The 300 Area was also the location of most of the Hanford Site's research and development laboratories. One hundred fifty-nine buildings/structures in the 300 Area have been documented on historic property inventory forms. Of that number, 47 buildings/structures are eligible for the National Register as contributing properties within the Historic District recommended for individual documentation. This total includes the 305 Test Pile, 313 Fuels Fabrication Facility, 314 Metal Press/Extrusion Building, 318 High Temperature Lattice Test Reactor, 321 Separation Building, 325 Radiochemistry Laboratory, 333 Fuel Cladding Facility, 3706 Radiochemistry Laboratory, and the 3760 (former) Hanford Technical Library (DOE 1998b).

Assessments/walkthroughs of the contents of former fuel manufacturing and reactor operations facilities in the 300 Area have been conducted including the 303-A Magazine Product Storage Building, 305 Test Pile, 305-B Engineers Development Lab Annex, 306-W Materials Development Laboratory, 306-E Fabrication Test Lab, 308 Plutonium Fabrication Pilot Plant, 309 Plutonium Recycle Test Reactor, 313 Fuels Fabrication Facility/Metal Fabrication Building, 314 Press Building, and the 333 Fuel Cladding Facility. The 27 Manhattan Project/Cold War era artifacts that were identified and tagged are mainly industrial in nature associated with the fuel manufacturing processes and reactor operations. A second walkthrough of Building 333 resulted in an additional 12 artifacts being identified including a selection of safety signs/posters, a control panel, a safety shower, protective worker clothes, and a sample uranium fuel element.

Other 300 Area buildings assessed include the 303-K Fresh Metal Storage Building, 304 Uranium Scrap Concentration Storage Facility, 324 Chemical Engineering Laboratory, 325 Radiochemistry Laboratory, 327 Post Irradiation Test Laboratory, 329 Biophysics Laboratory, 334 Chemical Handling Facility, 334-A Acid Pump house, 3701-D (former) Hanford Patrol Building, 3707-G Change House, 3716 Fuels Manufacturing Storage/Automotive Repair Shop, 3727 Classified Storage Facility, 3746 Radiological Physics Building, 3762 Technical Safety Building, the 340 Waste Neutralization 
Complex, 3745-B Positive Ion Accelerator Building, 3708 Radiochemical Lab, 3706 Radiochemistry Lab, 326 Physics Lab, 3707-D Patrol Headquarters, 384 Power House, 328 Engineering Services Building, 3720 Environmental Sciences Laboratory, 3745-A Electron Accelerator Building, 3722 Area Shop, and the 3713 Storeroom. Approximately 75 to 80 Manhattan Project/Cold War era artifacts were identified and tagged in these buildings.

\subsubsection{400 Area}

Most of the 400 Area has been so altered by construction activities that archaeologists surveying the site during 1978 were able to find only $0.12 \mathrm{~km}^{2}\left(0.047 \mathrm{mi}^{2}\right)$ of land that was undisturbed (Rice et al. 1978). They found no cultural resources in this area. No archaeological sites are known to be located within $1 \mathrm{~km}(0.6 \mathrm{mi})$ of the 400 Area.

The 400 Area consists of the Fast Flux Test Facility (FFTF) complex. The 405 Reactor Containment Building includes a 400-megawatt, sodium-cooled test reactor designed primarily to test fuels and materials for advanced nuclear power plants. All the buildings and structures in the 400 Area were constructed during the Cold War era. Twenty-one building/structures have been recorded on historic property inventory forms. Of that number, six have been determined eligible for the National Register as contributing properties within the Historic District recommended for individual documentation. These include the 405 Reactor Containment Building, 436 Training Facility, 4621-W Auxiliary Equipment Facility, 4703 FFTF Control Building, 4710 Operation Support Building, and the 4790 Patrol Headquarters (DOE 1998b). In response to the production of a Curation Plan for the Deactivation and Decommissioning of Historic Buildings at the FFTF, walkthroughs were conducted of the contributing properties requiring mitigation except for the 4790 patrol headquarters. In addition, walkthroughs were also conducted of 16 contributing properties at FFTF where no individual documentation was required. Operations carried out in these facilities were closely related to the work conducted in the five contributing buildings that required mitigation. Thirty artifacts were identified and tagged in 8 of the 21 historic buildings: 405, 4703, 436, 403, 4621-W, 4621-E, 4710, and 4701-A. Two of the identified artifacts are located in Building 4732-C, a non-historic building. The types of artifacts included industrial equipment and machinery, photographs, publications, control room panels, and models.

An assessment of the contents of Building 427 was also conducted to locate and identify Cold War era artifacts that may have interpretive or educational value in potential exhibits. Four artifacts were identified and tagged, including fuel assembly components.

\subsubsection{600 Area}

The 600 Area includes all of the Hanford Site not occupied by the 100, 200, 300, and 400 Areas. Project-driven surveys have been conducted throughout the area, but much of the 600 Area has not been surveyed. Based on what is known, the 600 Area contains cultural resources associated with all three cultural landscapes that exist on the Hanford Site. Representing a full range of human activity across the Hanford Site, the activities are best characterized for the Native American cultural landscape by the gathering of inland resources (quarry sites, hunting sites, religious use sites, plant gathering sites) and riverine resources (fishing sites, open camp sites, root gathering). The Early Settlers/Farming landscape is present in the 600 Area, mainly consisting of the archaeological remains of former farmsteads, ranches, and pre-1943 transportation routes. Evidence of cultural resources associated with the Manhattan Project and Cold War Era landscape consists of anti-aircraft artillery sites, meteorological towers, and roads located in the 600 Area. 
Archaeological Resources. Numerous National Register Districts associated with the Native American landscape are located within the 600 Area including the Hanford Archaeological Site, Hanford North Archaeological District, the Paris Archaeological Site (45GR317), Rattlesnake Springs Sites (45BN170 and 45BN171), Savage Island Archaeological District, Snively Basin Archaeological District, and Wooded Island Archaeological District.

Archaeological properties associated with the Early Settlers/Farming landscape in the 600 Area include the Hanford Townsite; the White Bluffs town site and ferry landing; the Chicago, Milwaukee, St. Paul and Pacific Railroad line and associated whistle stops; early settler's farmsteads; and the Hanford Irrigation Canal and associated irrigation features. The McGee Ranch/Cold Creek Valley District is located in the 600 Area and is eligible for listing in the National Register.

Cold War era archaeological resources that are located in the 600 Area include five National Registereligible anti-aircraft artillery sites associated with Camp Hanford's defense of the Hanford Site during the 1950s. The Hanford Atmospheric Dispersion Test Facility is a contributing property within the Historic District and is recommended for individual documentation. Numerous artifacts in the facility were identified as having interpretive or educational value in potential exhibits. A selected representative number of artifacts were removed from the facility and curated into the Hanford Collection.

Traditional Cultural Places. Areas of traditional cultural importance include Rattlesnake Mountain and foothills, the Columbia River, Gable Mountain, Gable Butte, and National Register-eligible Wanawish. Cemeteries associated with the Native American cultural landscape are also dispersed throughout the 600 Area.

Buildings and Structures. There are several structures associated with the Early Settlers/Farming landscape that are located in the 600 Area. The Bruggemann Warehouse, located approximately $1.6 \mathrm{~km}$ (3 mi) east of 100-B/C, is eligible for listing in the National Register. During 2002, the Hanford Electrical Substation-Switching Station, the Hanford Townsite high school, the Coyote Rapids Pumping Plant, and the First Bank of White Bluffs are eligible for listing in the National Register.

Fifteen Cold War era buildings/structures, including the former underground missile storage facility, have been inventoried at the former 6652 Nike launch and control center in the Fitzner-Eberhardt Arid Lands Ecology Reserve Unit. The 622 Meteorological Complex, located near 200 West, includes seven inventoried properties. Both complexes are eligible for the National Register as contributing properties within the Historic District and recommended for mitigation. An assessment of the contents of 622-F and the 6652 Nike site were conducted. No artifacts of interpretive or educational value were identified.

Five other 600 Area properties, the 604 Yakima Patrol Checking Station, 604-A Sentry House, 607 Batch Plant, 618-10 Solid Waste Burial Trench, and Hanford Site Railroad System are eligible for the National Register as contributing properties within the Historic District recommended for individual documentation. Twenty-five railcars located at the 212-N rail spur were designated Register-eligible as contributing features of the Hanford Site Railroad and recommended for mitigation. Documentation/ mitigation of the 25 railcars was completed as an addendum to the Expanded Historic Property Inventory Form of the Hanford Site Railroad System. Due to their high contamination levels, most of the railcars have been removed from the Hanford Site.

The former Central Shops complex located in the 600 Area north of the 200 Areas is not eligible for the National Register (DOE 1997a).

Buildings 623 (Gable Mountain Relay Station) and 213 (Magazine/Waste Storage Vault) are contributing properties within the Historic District recommended for individual documentation. 


\subsubsection{700 Area}

The 700 Area was the location of the administrative functions of the early Hanford Site period. Most of the 700 Area was altered by industrial and demolition activities. Of the seven Manhattan Project and Cold War era buildings/structures identified in this area, the 703 Administrative Building, 712

Records/Printing/Mail Office Facility, and the 748 Emergency Decontamination Facility are eligible for listing in the National Register as contributing properties within the Historic District and recommended for individual documentation (DOE 1998b). 
This page intentionally left blank 


\subsection{Socioeconomics}

\section{R.A. Fowler and M.J. Scott}

Activity on the Hanford Site plays a dominant role in the socioeconomics of the Tri-Cities and other parts of Benton and Franklin counties (Figure 4.6-1). The agricultural community also has a significant effect on the local economy. Any major changes in Hanford activity would potentially affect the TriCities and other areas of Benton and Franklin counties. Unless otherwise specifically cited, data in this section are collected from interviews with the referenced organization.

\subsubsection{Local Economy}

Three major sectors have been the principal driving forces of the economy in the Tri-Cities since the early 1970s: 1) DOE and its contractors operating the Hanford Site; 2) Energy Northwest (formerly the Washington Public Power Supply System) in its construction and operation of nuclear power plants; and 3) the agricultural community, including a substantial food-processing component. With the exception of a minor amount of agricultural commodities sold to local-area consumers, the goods and services produced by these sectors are exported outside the Tri-Cities. In addition to the direct employment and payrolls, these major sectors also support a sizable number of jobs in the local economy through their procurement of equipment, supplies, and business services.

In addition to these three major employment sectors, three other components can be readily identified as contributors to the economic base of the Tri-Cities. The first of these, loosely termed "other major employers," includes the five major non-Hanford employers in the region (discussed in more detail in section 4.6.1.4). The second component is tourism. The Tri-Cities area has increased its convention business substantially in recent years as well as recreational travel. The third component in the economic base relates to the local purchasing power generated not from current employees, but from retired former employees. Government transfer payments, specifically retirement and disability insurance benefit payments constitute a significant proportion of total spendable income in the local economy.

\subsubsection{DOE Contractors (Hanford)}

DOE contractors comprise the largest single source of employment in the Tri-Cities. During fiscal year (FY) 2003, an average of 10,650 employees were employed by DOE Office of River Protection (ORP) and its prime contractor CH2M Hill Hanford Group, Inc.; DOE-Richland Operations Office (RL) and its prime contractor Fluor Hanford, Inc.; Battelle Memorial Institute which operates Pacific Northwest National Laboratory for the DOE Office of Science's Pacific Northwest Site Office; Bechtel Hanford, Inc. (since replaced by the Washington Group, International); and the Hanford Environmental Health Foundation (since replaced by AdvanceMed Hanford [AMH]). Fiscal year 2003 year-end employment for all DOE contractors was 10,288, down from 10,938 during FY 2002. In addition to these totals, Bechtel National, Inc. (BNI) and its prime subcontractor Washington Group International employed 2045 at the end of FY 2003, down from 3013 at the end of FY 2002. (Bechtel Hanford is a subsidiary of Bechtel National. In 2003 Bechtel Hanford was the Environmental Restoration Contractor for the Hanford Site, planning, managing, and executing a full range of activities to clean up contaminated soils and inactive nuclear facilities under DOE's Environmental Restoration Project.) During December 2000, ORP directly awarded a contract to BNI to design, build, and start up waste treatment facilities for the glassification of liquid radioactive waste. According to the Washington State Labor Market and Economic Analysis (LMEA) establishment the annual average number of employees at Hanford is down by more than 5000 from a peak of 19,200 during FY 1994, but still represents 13\% of the 96,400 total jobs in the economy (LMEA 2004a). 


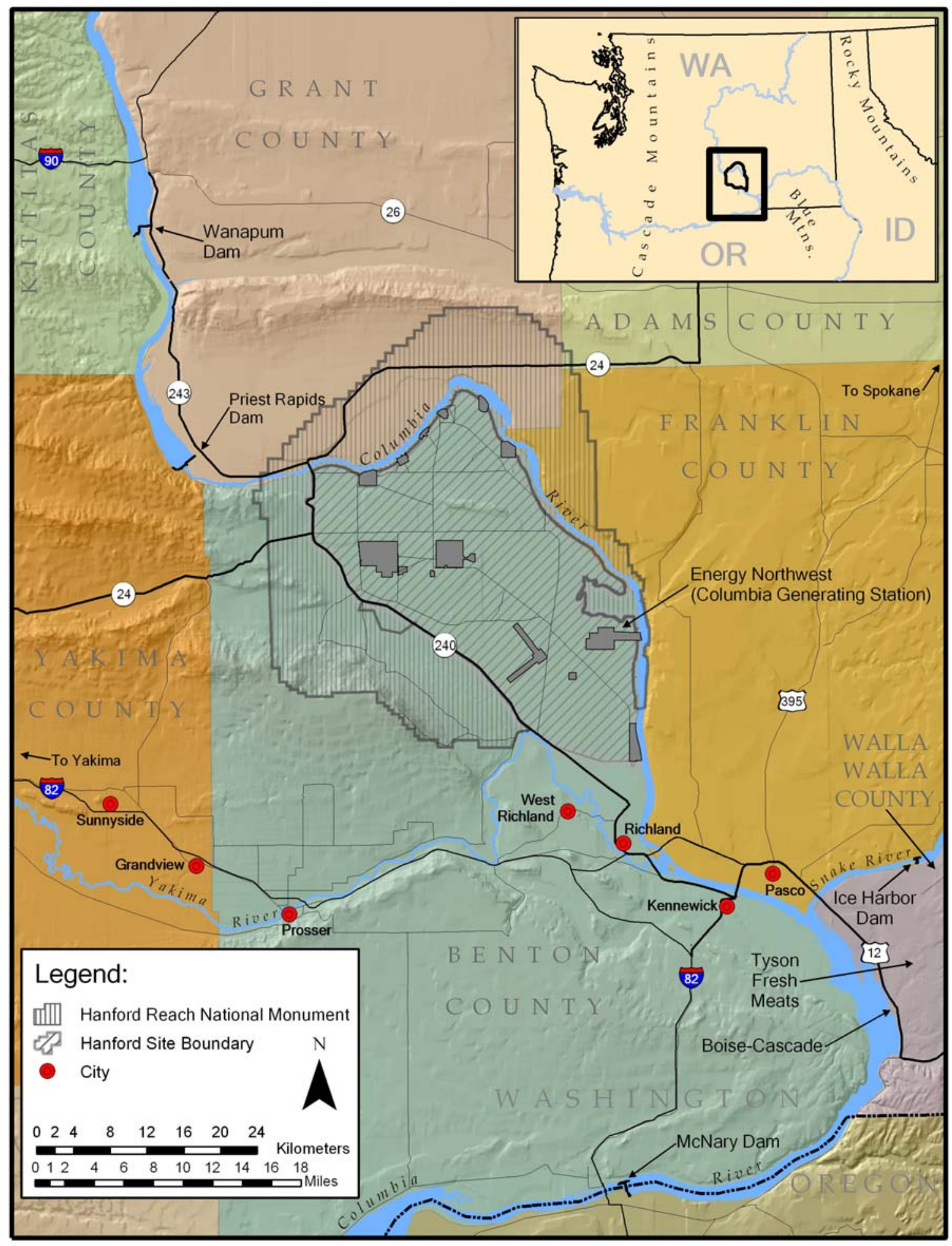

Figure 4.6-1. Hanford Site, Washington, and Surrounding Communities 
Based on employee residence records as of April 2004, 91\% of the direct employees of Hanford live in Benton and Franklin counties. Approximately 73\% of Hanford employees reside in Richland, Pasco, or Kennewick. More than 36\% are Richland residents, 10\% are Pasco residents, and 27\% live in Kennewick. Residents of other areas of Benton and Franklin counties, including West Richland, Benton City, and Prosser, account for about $18 \%$ of total Hanford Site employment.

\subsubsection{Energy Northwest}

Energy Northwest is a joint operating agency (JOA) comprised of 19 member public utilities from across the state of Washington. They provide electricity, at cost, to public utilities and municipalities in the Northwest and operate four electricity generating stations: Columbia Generating Station, Packwood Lake Hydroelectric Project, Nine Canyon Wind Project, and the White Bluffs Solar Station. Although activity related to commercial nuclear power plant construction ceased with the completion of the 1157megawatt (MW) WNP-2 nuclear reactor during 1983 (now named Columbia Generating Station), Energy Northwest continues to be a major employer in the Tri-Cities area. Headquarters personnel based in Richland oversee the operation of the Columbia Generating Station. Decommissioning of mothballed nuclear power plants (WNP-1 and WNP-3), which were never completed, began during 1995. Since 2000, Energy Northwest has maintained an average of 20 employees at WNP-1, which is located near the Columbia Generating Station. As part of an effort to reduce electricity production costs, Energy Northwest headquarters decreased the size of its total workforce from over 1900 during 1994 to 1016 at the end of 1999. At the end of calendar year 2003, employment was 1261 personnel.

\subsubsection{Agriculture}

In 2003, over 11 percent of workers in Benton and Franklin counties were employed in agriculture. The total agricultural employment was 10,920, which was an increase from the 2002 total of 10,640 (LMEA 2004b). Seasonal farm workers are not included in that total but are estimated by the U.S. Department of Labor (DOL) for the agricultural areas in the state of Washington. During 2003, there was an average of 5005 seasonal farm workers per month in Benton, Franklin, and Walla Walla counties, ranging from 778 workers during the winter pruning season to 10,922 workers at the peak of harvest. An estimated average of 4197 seasonal workers were classified as local (ranging from 778 to 7956 ); an average of 24 were classified as intrastate (ranging from 0 to 129), and an average of 504 were classified as interstate (ranging from 0 to 2075). The weighted seasonal wage for 2003 ranged from \$7.01/hr to $\$ 7.34 / \mathrm{hr}$, with an average wage of \$7.16/hr (DOL 2004).

According to the U.S. Department of Commerce's Regional Economic Information System (REIS), 2467 people were classified as farm proprietors in Benton and Franklin counties during 2002. Total farm proprietors' income, according to this same source, was estimated to be \$32.8 million (DOC 2004).

The area's farms and ranches generate a sizable number of jobs in supporting activities, such as agricultural services (e.g., application of pesticides and fertilizers and irrigation system development) and wholesale trade (e.g., farm supply and equipment sales and fruit packing). Although formally classified as a manufacturing activity, food processing is a natural extension of the farm sector. As of May, 2004, 52 processors in Benton and Franklin counties produce such items as potato products, canned fruits and vegetables, wine, and animal feed. In 2003, food manufacturing jobs accounted for $53 \%$ of all the manufacturing jobs in the area. 


\subsubsection{Other Major Employers}

During 2003, the five largest non-Hanford and non-government employers employed approximately 6522 people in Benton and Franklin counties. These companies include 1) ConAgra/ Lamb Weston, which employed 3063; 2) Tyson Fresh Meats (formerly Iowa Beef Processing Inc.), which employed 1450; 3) Boise Cascade Corporation Paper and Corrugated Container Divisions, which employed 862; 4) Framatome ANP, Richland Inc. (formerly Siemens Power Corporation), which employed 747; and 5) Wal-Mart (two stores), which employed 700. Both Boise Cascade and Iowa Beef are located in western Walla Walla County, but most of their workforce resides in Benton and Franklin counties. Four of the largest agriculture growers and processors in the area, AgriNorthwest, Broetje Orchards, J.R. Simplot Company, and Twin City Foods, Inc., employed approximately 2278 people during 2003; however, a large portion of the workers were seasonal (BFCOG 2003).

Other area employers include three major school districts: Richland, Kennewick, and Pasco, which employed a total of 4043; the three major health care facilities: Kadlec Medical Center, Kennewick General Hospital, and Lourdes Health Network, which employed a total of 2294; local government offices: Benton and Franklin county and Richland, Kennewick and Pasco city offices, which employed 1833, and the Tri-Cities Airport which employed 400.

\subsubsection{Tourism}

A significant rise in the number of visitors to the Tri-Cities over the last several years has resulted in tourism playing an increasing role in helping to diversify and stabilize the area economy. The Tri-Cities Visitors and Convention Bureau reported that 106,995 people attended meetings, conventions, sporting and group events, spending an estimated \$35.3 million in the mid-Columbia during 2003, down from 112,810 and $\$ 37.3$ million during 2002. The number of people attending conventions and group events has more than doubled from 1995 to 2002 and has more than tripled since 1991.

The importance of tourism is evidenced by the amount of money spent on local goods and services. Overall tourism expenditures in the Tri-Cities were over \$247 million during 2002, up from \$238 million during 2001. Travel-generated employment in Benton and Franklin counties was about 3660 with an estimated \$63.8 million in payroll, down from an estimated 4250 employed and up from a \$60.6 million payroll during 2001. In addition, tourism generated \$4.6 million in local taxes and \$17.7 million in state taxes during 2002 (OTED 2004a).

\subsubsection{Retirees}

In the Tri-Cities, as in many other places, retirees are a major source of consumer spending. Although Benton and Franklin counties have a relatively young population (approximately 52\% under the age of 35), 20,228 people over the age of 65 resided in Benton and Franklin counties during 2003. Washington State Office of Financial Management (OFM) reports the portion of the total population 65 years and older in Benton and Franklin counties accounts for $9.9 \%$ of the total population, which is below the $11.3 \%$ for the state of Washington (OFM 2004a). This segment of the population supports the local economy through income received from government transfer payments and pensions, private pension benefits, and prior individual savings. Although the retirees are not employed, their income affects the local economy in much the same way as local spending on salaries by the federal government and the area's private sector employers.

Although information on private pensions and savings is not available, data are available regarding the magnitude of government transfer payments. REIS has estimated transfer payments by various programs 
at the county level. Estimated major government transfer payments received by the residents of Benton and Franklin counties during 2002 totals greater than \$816 million (Table 4.6-1). Nearly 40\% of the payments are for retirement and disability insurance benefit payments, which provide over \$321 million of spendable income to the local economy.

\subsubsection{Employment and Income}

Nonagricultural employment in the Tri-Cities grew steadily from 1988 to 1994 . The total annual average employment fell during 1995 and 1996, but has grown every year since. During 2003, nonagricultural employment rose 3.2\% (Table 4.6-2). There was an average of 83,200 non-agricultural jobs in the Tri-Cities during 2003, up approximately 2600 from 2002. The bulk of the gains were in the manufacturing and the trade, transportation, and utilities sectors. Modest gains were seen in the finance, insurance, real estate, services, and government sectors, while the information sector remained the same (LMEA 2004c).

Three measures of area income are presented in this section: total personal income, per capita income, and median household income. Total personal income comprises all forms of income received by the populace, including wages, dividends, and other revenues. Per capita income is equivalent to total personal income divided by the number of people residing in the area. Median household income is the point at which half of the households have incomes greater than the median and half have less.

During 2002, the total personal income was $\$ 4.4$ billion for Benton County and $\$ 1.1$ billion for Franklin County, compared to the State of Washington’s total of $\$ 198.0$ billion. Per capita income during 2002 was \$29,086 for Benton County, \$20,715 for Franklin County, and \$32,638 for Washington State (DOC 2004). The preliminary estimate of median household income during 2002 for Benton County is $\$ 52,515$; for Franklin County is estimated at $\$ 42,634$, and for Washington is estimated at $\$ 49,725$ (OFM 2004b).

Table 4.6-1. Federal Government Transfer Payments in Benton County and Franklin County, Washington, $2002^{\text {(a) }}$

\begin{tabular}{|lrrr|}
\hline Government Payments to Individuals & $\begin{array}{c}\text { Benton } \\
\text { County } \mathbf{\$ M}\end{array}$ & $\begin{array}{c}\text { Franklin } \\
\text { County \$M }\end{array}$ & Total \$M \\
\hline retirement \& disability insurance payments & & & \\
medical payments & 257.0 & 64.2 & 321.2 \\
income maintenance benefit payments & 212.2 & 110.2 & 322.4 \\
unemployment insurance benefit payments & 51.8 & 30.2 & 82.0 \\
veterans benefit payments & 47.8 & 21.4 & 69.2 \\
federal education \& training assistance payments & 12.6 & 2.9 & 15.5 \\
other payments to individuals & 1.2 & 4.1 & 5.3 \\
Total & 0.8 & 0.3 & 1.1 \\
& $\mathbf{5 8 3 . 4}$ & $\mathbf{2 3 3 . 3}$ & $\mathbf{8 1 6 . 7 0}$ \\
\hline (a) DOC 2004. & & & \\
\hline
\end{tabular}


Table 4.6-2. Nonagricultural Wage and Salary Workers in Benton County and Franklin County, Washington, 2002 and $2003^{(a)}$

\begin{tabular}{|lccc|}
\hline \multicolumn{1}{|c}{ Industry } & $\begin{array}{c}\text { 2002 Annual } \\
\text { Average } \\
\text { (Revised) }\end{array}$ & $\begin{array}{c}\text { 2003 Annual } \\
\text { Average } \\
\text { (Preliminary) }\end{array}$ & $\begin{array}{c}\text { Change } \\
\text { 2002-2003 (\%) }\end{array}$ \\
\hline manufacturing & 5,000 & 5,700 & 14.0 \\
construction, nat. resources \& & 4,500 & 4,900 & 8.9 \\
mining & 13,100 & 13,800 & 5.3 \\
trade, transportation and utilities & 1,000 & 1,000 & 0.0 \\
information & 3,000 & 3100 & 3.3 \\
finance, insurance, and real & 38,600 & 39,100 & 1.3 \\
estate & 15,400 & 15,600 & $\mathbf{3 . 2}$ \\
services & & $\mathbf{8 3 , 2 0 0}$ & \\
government & $\mathbf{8 0 , 6 0 0}$ & & \\
Total nonagricultural wage & & \\
and salary workers & & \\
\hline (a) Source: Washington State Employment Security Department (LMEA 2004c). & \\
\hline
\end{tabular}

\subsubsection{Demography}

An estimated total of 151,600 people lived in Benton County and 53,600 lived in Franklin County during 2003, for a total of 205,200, which is up almost 7\% from the Census 2000 figure (OFM 2004c). According to the 2000 Census, population totals for Benton and Franklin counties were 142,475 and 49,347, respectively (Census 2001a). Both Benton and Franklin counties grew at a faster pace than Washington as a whole during the 1990s. The population of Benton County grew $26.6 \%$, up from 112,560 during 1990. The population of Franklin County grew 31.7\%, up from 37,473 during 1990 (Census 2001a).

The distribution of the 2003 Tri-Cities population by city is as follows: Richland 41,650, Pasco 37,580, and Kennewick 57,900. The combined populations of Benton City, Prosser, and West Richland totaled 17,085 during 2003. The unincorporated population of Benton County was 34,965. In Franklin County, incorporated areas other than Pasco had a total population of 3845. The unincorporated population of Franklin County was 12,175 (OFM 2004c).

During 2003, Benton and Franklin counties accounted for 3.4\% of Washington's population. The population demographics of Benton and Franklin counties are quite similar to those found within Washington. In general, the population of Benton and Franklin counties is somewhat younger than that of Washington. The 0 - to 14 -year old age group accounts for $24.8 \%$ of the total bi-county population as compared to $20.6 \%$ for Washington. The population in Benton and Franklin counties under the age of 35 is $52.2 \%$, compared to $48.5 \%$ for Washington State (OFM 2004c).

The 2000 population figures by race and Hispanic origin indicate that in Benton and Franklin counties, Asians represent a lower proportion, and individuals of Hispanic origin represent a higher proportion of the population than in the state of Washington as a whole. Table 4.6-3 represents population 
estimates and percentages by race and Hispanic origin for Benton, Franklin, Grant, Adams, and Yakima counties, and the $80-\mathrm{km}(50-\mathrm{mi})$ radius of the Hanford Site.

\subsubsection{Environmental Justice}

Executive Order 12898, "Federal Actions to Address Environmental Justice in Minority Populations and Low-income Populations," (59 FR 7629), directs federal agencies in the Executive Branch to consider environmental justice so that their programs will not have "disproportionately high and adverse human health or environmental effects” on minority and low-income populations. Executive Order 12898 further directs federal agencies to consider effects to "populations with differential patterns of subsistence consumption of fish and wildlife.” The Executive Branch agencies also were directed to develop plans for carrying out the order. The Council on Environmental Quality (CEQ) later provided additional guidance for integrating environmental justice (EJ) into the National Environmental Policy Act process in a December 1997 document, Environmental Justice Guidance under the National Environmental Policy Act (CEQ 1997).

Minority populations are defined as all nonwhite individuals, plus all white individuals of Hispanic origin, as reported in the 2000 Census (Census 2001b). Low-income persons are defined as living in households that report an annual income less than the United States' official poverty level, as reported by the Census Bureau. The poverty level varies by size and relationship of the members of the household. The year 2000 poverty level was $\$ 17,761$ for a family of four (Census 2000, 2001a). Nationally, during 1999, $29.9 \%$ of all persons were minorities, and $11.8 \%$ of all persons lived in households that had incomes less than the poverty level (which was $\$ 17,029$ for a family of four during that year) (Census 2000, 2001a). The 2000 Census reports that $10.6 \%$ of Washington's population lived in poverty during 1999, while $10.3 \%$ of Benton County persons and 19.2\% of Franklin County persons were below the poverty level (Census 2003a).

Based on the 2000 census (Census 2001b,c), the 80-km (50-mi) radius area surrounding the Hanford Site had a total population of 482,300 and a minority population of 178,500 . $^{(a)}$ The ethnic composition of the minority population is primarily White Hispanic (24 percent), self-designated "other and multiple" races (63 percent), and Native American (6 percent). Asians and Pacific Islanders (4 percent) and African Americans (3 percent) make up the rest. The Hispanic population resides predominantly in Franklin, Yakima, Grant, and Adams counties. Native Americans within the 80-km (50-mi) area reside primarily on the Yakama Reservation and upstream of the Hanford Site near the town of Beverly, Washington.

The low-income population during 2000 was approximately 80,800, or 17 percent of the total population residing in the $80-\mathrm{km}(50-\mathrm{mi})$ radius of the Hanford Meteorological Station at the center of the Hanford Site (Census 2002 a, b), about the same percentage as the 1990 Census. The majority of these households were located to the southwest and northwest of the Site (Yakima and Grant counties) and in the cities of Pasco and Kennewick.

(a) The Hanford Site National Environmental Policy Act (NEPA) Characterization Rev.14 (2002) shows the total population "within" $80 \mathrm{~km}$ as 511,500, which was estimated by a geographical information system from the populations of individual census block groups, the smallest geographic area for which both minority and poverty status were estimated in the 2000 Census. The higher number resulted because the total population of a census block group was previously assigned to the $80-\mathrm{km}$ area if any part of the block group lay within $80 \mathrm{~km}$ of the Hanford Meteorological Station in the middle of the Hanford Site. The new estimate splits boundary block groups to include only those portions within $80 \mathrm{~km}$, which should result in a lower and more accurate estimate. 
Table 4.6-3. Population Estimates and Percentages by Race and Hispanic Origin within each County in Washington State and the 80-km (50 mi) Radius of Hanford as Determined by the 2000 Census (Census 2003b)

\begin{tabular}{|c|c|c|c|c|c|c|c|c|c|c|}
\hline Subject & WA State & Percent & $\begin{array}{c}\text { Benton/Franklin/ } \\
\text { Grant/Adams/ } \\
\text { Yakima } \\
\end{array}$ & Percent & $\begin{array}{l}\text { Benton } \\
\text { County }\end{array}$ & $\begin{array}{c}\text { Franklin } \\
\text { County }\end{array}$ & $\begin{array}{c}\text { Grant } \\
\text { County }\end{array}$ & $\begin{array}{l}\text { Adams } \\
\text { County }\end{array}$ & $\begin{array}{l}\text { Yakima } \\
\text { County }\end{array}$ & $\begin{array}{c}\text { 80-km (50-mi) } \\
\text { Radius of } \\
\text { Hanford }^{(\mathrm{a})} \\
\end{array}$ \\
\hline Total population & $5,894,121$ & 100 & 505,529 & 100 & 142,475 & 49,347 & 74,698 & 16,428 & 222,581 & 482,280 \\
\hline Single race & $5,680,602$ & $96.4 \%$ & 489,206 & $96.8 \%$ & 138,646 & 47,302 & 72,451 & 15,977 & 214,830 & 466,626 \\
\hline White & $4,821,823$ & $81.8 \%$ & 367,283 & $72.7 \%$ & 122,879 & 30,553 & 57,174 & 10,672 & 146,005 & 347,047 \\
\hline $\begin{array}{r}\text { Black or African } \\
\text { American } \\
\end{array}$ & 190,267 & $3.2 \%$ & 5,494 & $1.1 \%$ & 1,319 & 1,230 & 742 & 46 & 2,157 & 5,507 \\
\hline $\begin{array}{r}\text { American } \\
\text { Indian/Alaska } \\
\text { Native } \\
\end{array}$ & 93,301 & $1.6 \%$ & 12,468 & $2.5 \%$ & 1,165 & 362 & 863 & 112 & 9,966 & 10,288 \\
\hline Asian & 322,335 & $5.5 \%$ & 6,809 & $1.3 \%$ & 3,134 & 800 & 652 & 99 & 2,124 & 6,681 \\
\hline \begin{tabular}{|r|} 
Native \\
Hawaiian/Pacific \\
Islander \\
\end{tabular} & 23,953 & $0.4 \%$ & 482 & $0.1 \%$ & 163 & 57 & 53 & 6 & 203 & 479 \\
\hline Other race & 228,923 & $3.9 \%$ & 96,670 & $19.1 \%$ & 9,986 & 14,300 & 12,967 & 5,042 & 54,375 & 96,625 \\
\hline $\begin{array}{c}\text { Two or more } \\
\text { races }\end{array}$ & 213,519 & $3.6 \%$ & 16,323 & $3.2 \%$ & 3,829 & 2,045 & 2,247 & 451 & 7,751 & 15,654 \\
\hline $\begin{array}{l}\text { Hispanic origin } \\
\text { (of any race) }^{(\mathrm{b})}\end{array}$ & 441,509 & $7.5 \%$ & 150,951 & $29.9 \%$ & 17,806 & 23,032 & 22,476 & 7,732 & 79,905 & 149,588 \\
\hline $\begin{array}{l}\text { (a) Includes } \\
\text { (b) Hispanic } \\
\text { or person } \\
\text { the racial }\end{array}$ & $\begin{array}{l}\text { portion of Or } \\
\text { origin is not a } \\
\text { s parents or an }\end{array}$ & $\begin{array}{l}\text { egon } \\
\text { racial cate } \\
\text { cestors bc } \\
\text { wn. }\end{array}$ & $\begin{array}{l}\text { gory. It may be vi } \\
\text { fore arrival in the }\end{array}$ & $\begin{array}{l}\text { red as the } \\
\text { ited State }\end{array}$ & $\begin{array}{l}\text { ancestry, } \\
\text { es. Persor }\end{array}$ & $\begin{array}{l}\text { hationality } \\
\text { of Hispar }\end{array}$ & $\begin{array}{l}\text { roup, lineas } \\
\text { c origin ma }\end{array}$ & $\begin{array}{l}\text { ge, or coun } \\
\text { y be of any }\end{array}$ & $\begin{array}{l}\text { try of birt } \\
\text { race and }\end{array}$ & $\begin{array}{l}\text { th of the person } \\
\text { l are counted in }\end{array}$ \\
\hline
\end{tabular}


Figure 4.6-2 shows the location of Census block groups from the 2000 Census that had either a majority of residents who were members of a minority group (racial minority or Hispanic), or whose percentage of residents belonging to any minority group was at least 20 percentage points greater than the corresponding percentage of the state population (Census 2001a,b,c).

Figure 4.6-3 shows the location of Census block groups from the 2000 Census that had either a majority of residents who were low income (members of a household below the national poverty level), or a percentage of low-income residents at least 20 percentage points greater than the corresponding percentage of the state population (Census $2002 \mathrm{a}, \mathrm{b}$ ).

The CEQ guidance for identifying potential disproportionate impacts on minority and low-income populations recognizes that some minority and low-income groups may be more reliant than the majority population on subsistence hunting, fishing, and gathering activities (sometimes for species unlike those consumed by the majority population), or may be dependent on water supplies or other resources that are atypical or used at different rates than other groups. These differential patterns of resource use are to be identified "where practical and appropriate". While no hunting and gathering activities currently occur on the Hanford Site, some Native Americans of various tribal affiliations who live in the greater Columbia Basin do participate in tribal fishing for salmon and resident fish that utilize the Hanford Reach for habitat.

Fishing access rights for Native Americans is guaranteed by federal treaty. For example, The Treaty of 1855 with the Confederated Tribes and Bands of the Yakama Nation (Yakama 1855) secured to the Yakamas, "the right of taking fish at all usual and accustomed places, in common with the citizens of the Territory [now the state of Washington] and of erecting temporary buildings for curing them; together with the privilege of hunting, gathering roots and berries, and pasturing their horses and cattle upon open and unclaimed lands” ceded to the government. Some of this ceded territory is located on the Hanford Site. Similar guarantees were extended to the Umatilla, Nez Perce, and Warm Springs groups. The Wanapum, a non-treaty tribe, historically lived along the Columbia River and continue to live upstream of the Hanford Site. They fish on the Columbia River and gather food resources near the Hanford Site. The Confederated Tribes of the Colville Reservation established by the Executive Order of April 9, 1872, traditionally fished and gathered food resources in the Hanford area. They also are recognized as having cultural and religious ties to the Hanford Site.

The Walker Research Group (Walker and Pritchard 1999) discussed the historical location of Native fishing sites, the level and productivity of fishing effort, estimates from several studies of fish consumption in traditional Native American diets (Hewes 1947, 1973; Hunn and Bruneau 1989; Walker 1967), and possible exposure levels to radionuclides. According to the fish consumption studies, annual rates of fish consumption by Native Americans in the region before European contact ranged from $23 \mathrm{~kg}$ (50 lbs) to as much as $438 \mathrm{~kg}$ (900 lbs). Estimates of contemporary fish consumption (CRITFC 1994, Harris and Harper 1997) tend to be somewhat lower, but still indicate a heavy reliance on fish among Native Americans following a traditional diet.

\subsubsection{Housing}

During FY 2003, 2927 houses were sold in the Tri-Cities at an average price of \$160,611, compared to 2603 houses sold at an average price of \$151,902 during 2002 (TCAR 2004). During FY 2003, 1750 single-family houses were built, up 43\% from the 1227 that were built during 2002. The FY 2003 total had surpassed the previous annual peak of 1117 during 1994 (WCRER 2004a). 


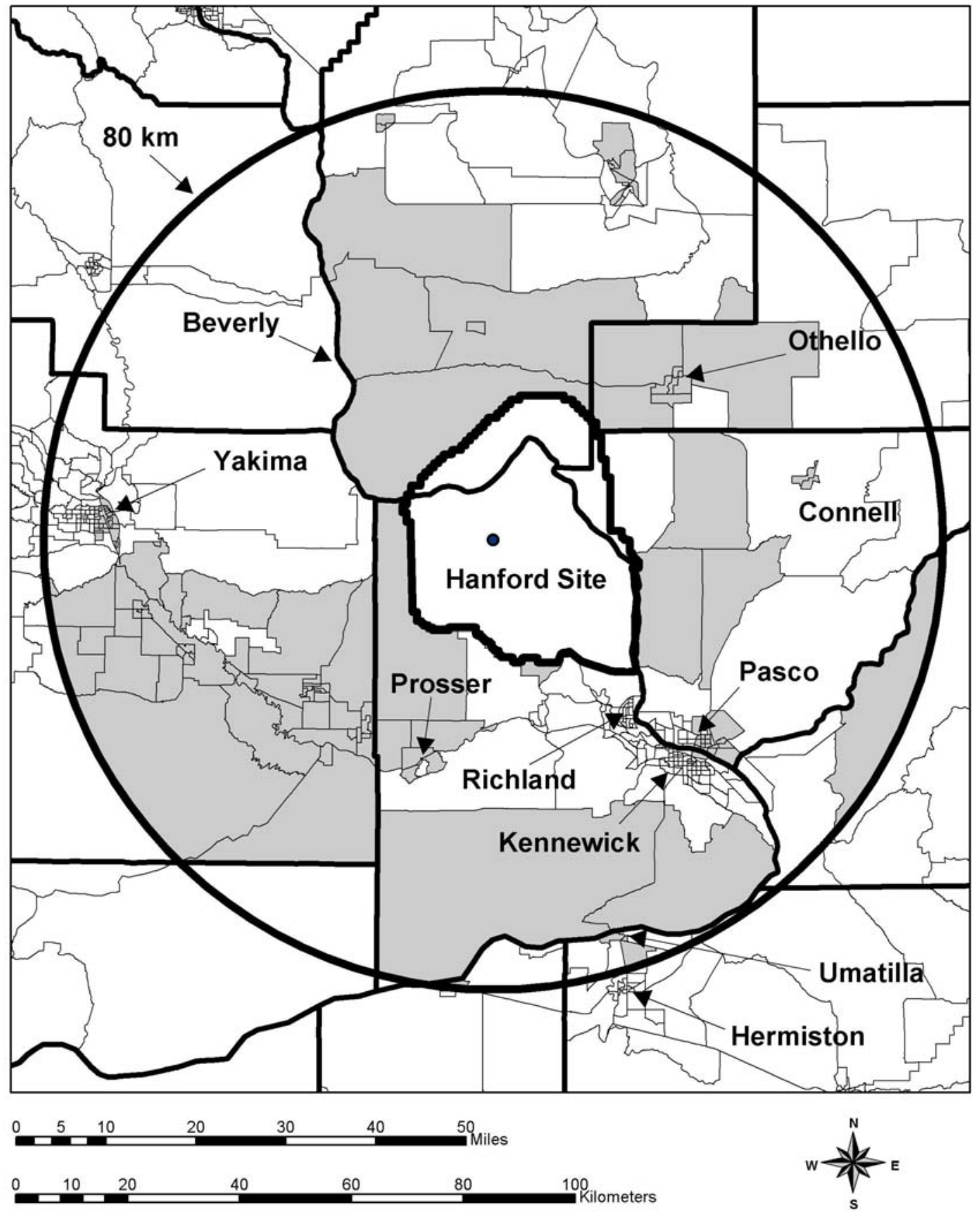

Figure 4.6-2. Location of Minority Populations Near the Hanford Site, Washington, based on 2000 Census. Shaded areas indicate regions that have a majority of residents who are members of a minority group, or for which the percentage of minority population is 20 percentage points greater than the statewide average. Minority groups include all non-white individuals, plus Hispanic whites. 


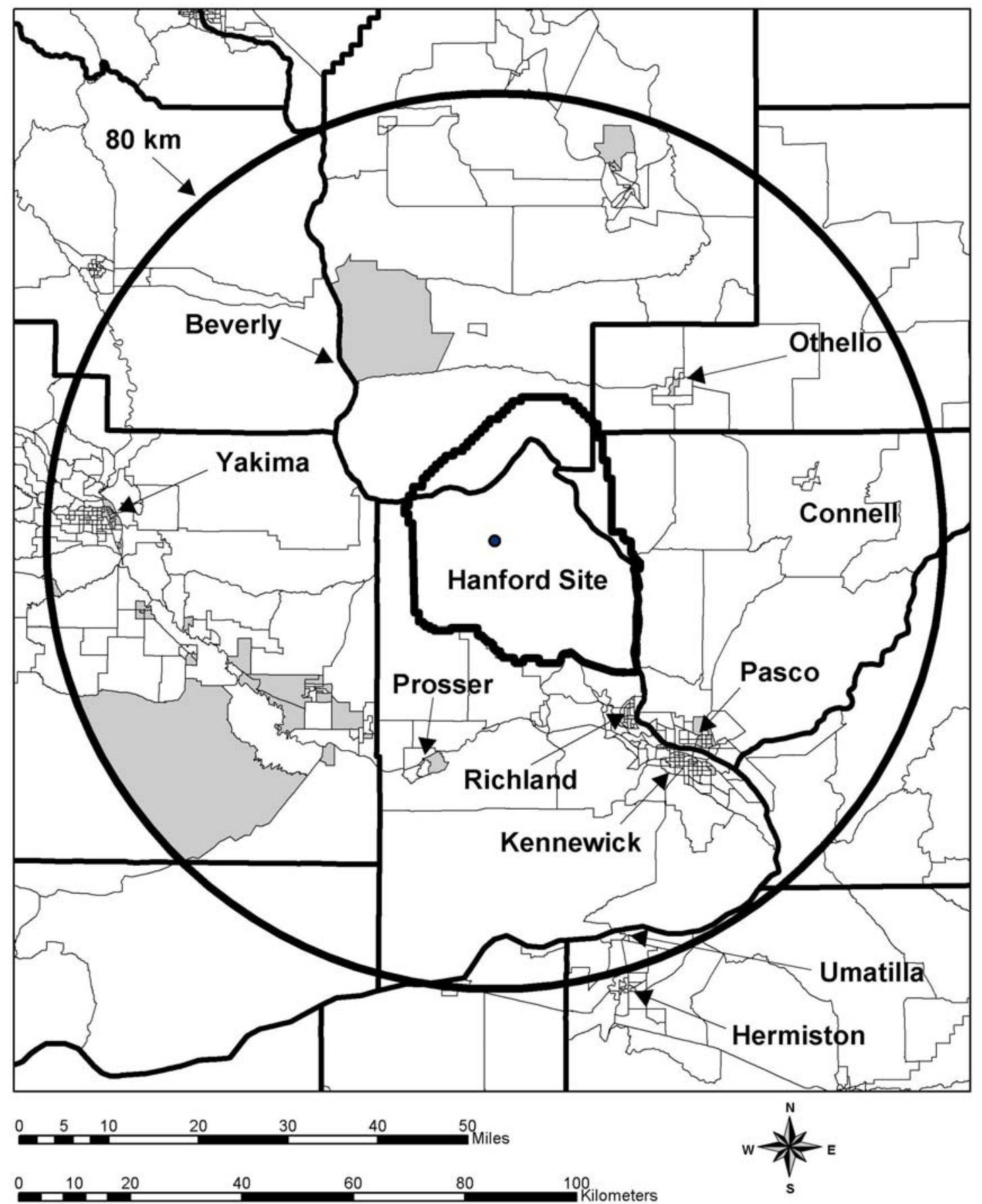

Figure 4.6-3. Location of Low-Income Populations Near the Hanford Site, Washington, based on 2000 Census. Shaded areas indicate regions that have a majority of lowincome residents, or for which the percentage of low-income population is 20 percentage points greater than the statewide average. Low-income persons live in households with incomes that fall below the official U.S. poverty level ( $\$ 17,761$ for a family of four in the year 2000). 
As of April 1, 2003, there were an estimated 77,521 housing units in Benton and Franklin counties, which is 32.4\% more than the 58,541 during 1990 (OFM 2004d). The number of apartments has increased from 8225 during 1990 to 10,936 during 2003. The vacancy rate of apartments in Benton and Franklin counties during September 2003 was 5.5\%, and the average rent was \$606 per month. These figures are up from the $2.7 \%$ vacancy rate but down from the $\$ 611$ average rent during 2002 (WCRER 2004b).

\subsubsection{Transportation}

The Tri-Cities serves as a regional transportation and distribution center with major air, land, and river connections. The Burlington Northern and Santa Fe Railway (BNSF) and Union Pacific Railroad provide direct rail service. Union Pacific Railroad operates the largest fleet of refrigerated rail cars in the United States and is essential to food processors, which ship frozen food from this area. Passenger rail service is provided by Amtrak, which has a station in Pasco. Rail service on the Hanford Site is maintained and operated by the Tri-City and Olympia Railroad Company.

Docking facilities at the Ports of Benton, Kennewick, and Pasco are important aspects of this region's infrastructure. These facilities are located on the 525-km- (325.5-mi-) long commercial waterway, which includes the Snake and Columbia rivers, that extends from the Ports of Lewiston-Clarkston in Idaho to the deep-water ports of Portland, Oregon, and Vancouver, Washington (see Figure 4.3-7).

Daily air passenger and freight services connect the area with most major cities through the Tri-Cities Airport, located in Pasco. This modern commercial airport links the Tri-Cities to major hubs and provides access to destinations anywhere in the world. There are two runways, a main runway and a minor runway for use during crosswinds. The main runway is equipped for precision instrumentation landings and takeoffs. Each runway is $2347 \mathrm{~m}$ (7700 ft) long and $46 \mathrm{~m}(150 \mathrm{ft})$ wide, and can accommodate landings and takeoffs by medium-range commercial aircraft, such as the Boeing 727-200 and Douglas DC-9.

During 2003, Delta Airlines, Skywest, and Horizon Air provided daily connections to domestic and international flights through Salt Lake City, Seattle, Denver, Spokane, and Portland. There were 203,729 enplanements at the Tri-Cities Airport during 2003, which was down from 210,351 enplanements during 2002, which was a record for the airport. From 1995 to 2002, the number of annual passenger increased 25 percent. Projections indicate that the terminal can serve almost 300,000 passengers annually.

The Tri-Cities region has three general aviation airports that serve private aircraft. The Richland Airport, owned by the Port of Benton, is located northwest of the Richland central business district, adjacent to the Richland by-pass highway (SR-240). Vista Field Airport, owned by the Port of Kennewick, is located at the intersection of Columbia Center Boulevard and Canal Drive, with easy access to SR-240, I-82, and I-182. The Prosser Airport, owned by the Port of Benton, is located $1.61 \mathrm{~km}$ (1 mi) northwest of the business district of Prosser and is adjacent to US-12. Airfreight shippers that service the region include Airborne from Richland, United Parcel Service from Kennewick, and Federal Express from the Tri-Cities Airport in Pasco.

Mass transit within the Tri-Cities is provided by the Ben Franklin Transit system. The system covers more than $1523 \mathrm{~km}^{2}\left(588 \mathrm{mi}^{2}\right)$ and provides frequent service to all four local communities (Richland, Kennewick, Pasco, and West Richland). As of the end of 2003 the Ben Franklin fleet consists of 71 buses, 57 Dial-a-Ride para-transit vehicles, and $162 \mathrm{VanPool}$ vans. The total number of boardings in 2003 was 3,790,146, a 3.4\% increase from 2002 (BFT 2003). Two local taxi companies provide radiodispatched taxicab service 24 hours per day: A-1 Tri-Cities Taxi and Tri-City Cab. 
The regional transportation network in the Hanford vicinity includes the areas in Benton and Franklin counties from which most of the commuter traffic associated with the Site originates. Interstate highways that serve the area are I-82 and I-182. I-82 is $8 \mathrm{~km}(5 \mathrm{mi})$ south-southwest of the Site. I-182, a 24-km (15-mi)-long urban connector route, located $8 \mathrm{~km}$ (5 mi) south-southeast of the Site, provides an east-west corridor linking I-82 to the Tri-Cities area. I-90, located north of the Site, is the major link to Seattle and Spokane and extends to the East Coast. I-82 serves as a primary link between Hanford and I-90, as well as I-84. I-84, located south of the Site in Oregon, is a major corridor leading to Portland, Oregon. SR 224 (Van Giesen Street), also south of the Site, serves as a 16-km (10-mi) link between I-82 and SR 240. SR 24 enters the Site from the west, continues eastward across the northernmost portion of the Site, and intersects SR 17 approximately $24 \mathrm{~km} \mathrm{(15} \mathrm{mi)} \mathrm{east} \mathrm{of} \mathrm{the}$ Site boundary. SR 17 is a north-south route that links I-90 to the Tri-Cities and joins U.S. Route 395, continuing south through the Tri-Cities. U.S. Route 395 north also provides direct access to I-90. SR 240 and SR 24 traverse the Site and are maintained by Washington State.

A DOE-maintained road network within the Hanford Site consists of $607 \mathrm{~km}$ (377 mi) of asphaltpaved road and provides access to the various work centers. Primary access roads to the industrial areas of the Hanford Site are Routes 1, 2, 3, 5, 6, 10, 11, and Beloit Avenue (Figure 4.0-1). Public access to the 200 Areas and interior locations of the Hanford Site has been restricted by guarded gates at the Wye Barricade (at the intersection of Routes 10 and 4), the Yakima Barricade (at the intersection of SR 240 and Route 11A), and Rattlesnake Barricade south of the 200 West Area. None of those roadways have experienced any substantial congestion except Route 4 (WHC 1994).

Access to the Hanford Site is via four main routes: Hanford Route 4S from Stevens Drive in the City of Richland, Route 10 from SR 240 near its intersection with SR 225, Beloit Avenue from SR 240, or Route 11A from SR 240 near its intersection with SR 24. Another route, through the Rattlesnake Barricade, is located $35 \mathrm{~km}$ (22 mi) northwest of Stevens Drive and is for passenger vehicle access only. The estimated total number of commuters to this area is 3100 . Approximately 87 percent of the workers commuting to the 200 Areas are from the Tri-Cities, West Richland, Benton City, and Prosser (Perteet $e t$ al. 2001). The remaining workers commute from the surrounding counties of Yakima, Adams, Grant, and Walla Walla.

The portion of SR 240 most affected by 200 Area commuters is between U.S. 395 in Kennewick and Stevens Drive. Portions of this roadway currently operate below the minimum level of service established by the Regional Transportation Planning Organization. Peak annual average daily traffic (AADT) on the section from Columbia Center Boulevard to I-182 is 54,000 (Perteet et al. 2001).

I-182 has peak traffic counts of 35,000 AADT in the vicinity of SR 240 in Richland. I-182 deficiencies at the interchanges with Queensgate Drive and $20^{\text {th }}$ Avenue. SR 224 (Van Giesen Street) transports most of the commuters from West Richland and Benton City to SR 240. The intersection of SR 224 and SR 240 is the only section of SR 224 with current level of service (LOS) deficiencies. LOS is a qualitative measure of a roadway's ability to accommodate vehicular traffic, ranging from free-flow conditions (LOS A) to extreme congestion (LOS F). LOS D is considered the lower end of acceptable LOS (Perteet et al. 2001).

Stevens Drive (in and north of Richland) has peak traffic counts of 8300 AADT at Horn Rapids Road and 22,000 AADT just north of its intersection with SR 240 (Bypass Highway). Currently this roadway experiences LOS deficiencies. George Washington Way is the principal north-south arterial through Richland. AADT at the entrance of the Hanford Site on George Washington Way is 1800. Counts north of McMurray are 18,000 AADT and counts on George Washington Way just north of I-182 are 43,000 
AADT. George Washington Way has LOS deficiencies between I-182 and Swift Boulevard (Perteet et al. 2001).

Private vehicles account for 91 percent of the person trips to the Hanford Site. The remaining person trips are by forms of high occupancy vehicles (mostly Ben-Franklin Vanpools). Of the 91 percent of private vehicles only 3 percent are by carpool with the remaining 88 percent being single-occupancy vehicles. The Draft Regional Transportation Plan identifies 11,468 employees working at Hanford. Based on 88 percent of the trips carrying a single person to Hanford, 10,092 single occupancy trips are made daily or an AADT of 10,184 (Perteet et al. 2001). Several local highway construction projects are underway to reduce some of the traffic bottlenecks.

The Hanford Site rail system originally consisted of approximately $210 \mathrm{~km}$ (130 mi) of track. It connected to the Union Pacific Railroad commercial track at the Richland Junction (at Columbia Center in Kennewick) and to a now abandoned commercial right-of-way (Chicago, Milwaukee, St. Paul and Pacific Railroad) near Vernita Bridge in the northwest section of the Site. Prior to 1990, annual railcar movements numbered about 1400 sitewide, transporting materials including coal, fuel, hazardous process chemicals, and radioactive materials and equipment (DOE 1996b). During October 1998, 26 km (16 mi) of track from Columbia Center to Horn Rapids Road were transferred to the Port of Benton and are currently operated by the Tri-City and Olympia Railroad. The Port of Benton has been granted the right to operate portions of the railroad on the Hanford Site.

\subsubsection{Educational Services}

Most of the primary and secondary students in the Tri-Cities area are served by the Richland, Pasco, Kennewick, and Kiona-Benton (Benton City) school districts. The total 2003 fall enrollment for all districts in Benton and Franklin counties was 42,759 students, an increase of 1.8\% from the 2002 total of 41,999 students. The 2003 totals include 9790 students from the Richland School District, down from 9800 during 2002; 10,477 students from the Pasco School District, up from 9785 during 2002; 14,981 students from the Kennewick School District, up from 14,698 during 2002; and 1459 from the KionaBenton School District, down from 1664 during 2002 (OSPI 2004).

There are fourteen private elementary and secondary schools in the Tri-Cities, including Bethlehem Lutheran (K-8), Calvary Christian (K-5), and St. Joseph's (K-8) in Kennewick; Christ the King (K-8) and Liberty Christian (K-12) in Richland; and Kingspoint Christian (K-12), Country Haven Academy, St. Patrick's (K-8), Tri-City Junior Academy (K-10), and Tri-Cities Prep Catholic High School in Pasco. Fall 2003 enrollment at these schools totaled 2292 students, slightly lower than from the 2002 total of 2300 (OSPI 2004).

Post-secondary education in the Tri-Cities area is provided by Columbia Basin College (CBC), City University, and Washington State University, Tri-Cities branch campus (WSU-TC). The 2001 fall/winter enrollment was 7750 at CBC, 300 at City University, and 1200 at WSU-TC. Many of the programs offered by these three institutions are geared toward the vocational and technical needs of the area. During 2002-03, CBC offered 22 Associate in Applied Science (AAS) degree programs. City University offers three undergraduate and four graduate programs, plus access to several more programs through distance learning. WSU-TC offers 16 undergraduate and 14 graduate programs, as well as access to graduate programs via satellite. 


\subsubsection{Health Care and Human Services}

The Tri-Cities has three major hospitals and five minor emergency centers. All three hospitals offer general medical services and include a 24-hr emergency room, basic surgical services, intensive care, and neonatal care.

Kadlec Medical Center, located in Richland, has 153 beds and functioned at $66.8 \%$ capacity with 8489 total admissions during 2003. Non-Medicare/Medicaid patients accounted for $41 \%$ of Kadlec's admissions during 2003. An average stay of 4.27 days per admission was reported for 2003.

Kennewick General Hospital maintained a 39\% occupancy rate of its 101 beds with 4612 total admissions during 2003. Non-Medicare/Medicaid patients represented $41 \%$ of its total admissions. An average stay of 3.1 days per admission was reported during 2003.

Our Lady of Lourdes Hospital operates a 132-bed Health Center, located in Pasco, providing acute, sub-acute, skilled nursing and rehabilitation, and alcohol and chemical dependency services. Our Lady of Lourdes operates the Carondolet Psychiatric Care Center, a 32-bed psychiatric hospital located in Richland. They also provide a significant amount of outpatient and home health services. For calendar year 2003, Our Lady of Lourdes had a total of 4022 admissions, 21\% of which were non-

Medicare/Medicaid. Lourdes had an average acute care length of stay of 5.6 days, and the occupancy rate was 34\% during 2003.

The Tri-Cities offers a broad range of social services. State human service offices in the Tri-Cities include the Job Service Center within the Employment Security Department; food stamp offices; Developmental Disabilities Division; financial and medical assistance; Child Protective Service; emergency medical service; a senior companion program; and vocational rehabilitation.

The Tri-Cities is also served by a large number of private agencies and voluntary human service organizations. The United Way, an umbrella fund-raising organization, incorporated 19 Community Impact Partners and 7 Community Solutions Partners during 2003. The Community Impact budget was $\$ 27.6$ million, which funded 34 programs during 2003. The Community Solutions budget was \$2.0 million, which funded 8 programs during 2003. The number of organizations receiving donor designations was 497.

\subsubsection{Police and Fire Protection}

Benton and Franklin counties' sheriff departments, local municipal police departments, and the Washington State Patrol Division, with headquarters in Kennewick, provide police protection in Benton and Franklin counties, for a total of 347 officers (commissioned and reserved) in the Tri-Cities (Table 4.64). The Kennewick Municipal Police Department maintains the largest staff of commissioned officers with 87.

Fire protection is provided by the fire departments of the cities of Kennewick, Pasco, and Richland, and by Benton County Rural Fire Departments \#1, \#2, and \#4. A total of 357 fire fighting personnel (187 paid and 170 volunteer) are on staff in the Tri-Cities.

In addition, the Hanford Fire Department, a highly trained and professional career industrial fire department with 145 members, provides fire protection on the Hanford Site and nearby areas. There are four fire stations strategically located on the Hanford Site. From these stations four pumper crews, staffed 
Table 4.6-4. Police Personnel in the Tri-Cities, Washington, 2004

\begin{tabular}{|lcrc|}
\hline Area & $\begin{array}{c}\text { Commissioned } \\
\text { Officers }\end{array}$ & Reserve Officers & Patrol Cars \\
\hline Kennewick Municipal & 87 & 6 & 20 \\
Pasco Municipal & 54 & 14 & 21 \\
Richland Municipal & 53 & 7 & 13 \\
West Richland Municipal & 12 & 7 & 14 \\
Benton County Sheriff & 56 & 10 & 56 \\
Franklin County Sheriff & $\underline{23}$ & $\underline{8}$ & $\underline{\mathbf{4 4}}$ \\
Tri-Cities total & $\mathbf{2 8 5}$ & & \\
\hline
\end{tabular}

with at least three firefighters each, provide suppression response. Four ambulance crews (one in each fire station), staffed with two firefighters (Emergency Medical Technicians [EMT] - or paramedictrained), provide emergency medical services $24 \mathrm{hr}$ /day, 7 days/week. A total of 40 emergency response vehicles, representing diverse capabilities, are maintained at the four fire stations. Some emergency equipment is specifically intended to control situations exclusive to the Hanford Site.

The Hanford Fire Department provides coverage to the entire Hanford Site and to SR 240 and SR 24. Coverage on the highways extends from the Vernita Bridge to the Silver Dollar Cafe on SR 24 and along SR 240 from the Yakima Barricade to the intersection with SR 225. Additionally, the Hanford Fire Department responds to mutual aid requests from 10 surrounding fire districts.

Table 4.6-5. Fire Protection Personnel in the Tri-Cities, Washington, 2003

\begin{tabular}{|lccrl|}
\hline \multicolumn{1}{|c}{$\begin{array}{c}\text { Fire } \\
\text { Department }\end{array}$} & $\begin{array}{c}\text { Fire Fighting } \\
\text { Personnel }\end{array}$ & Volunteers & Total & Service Area \\
\hline Hanford & 145 & 0 & 145 & Hanford Site \\
Kennewick & 69 & 0 & 69 & City of Kennewick \\
Pasco & 45 & 0 & 45 & City of Pasco \\
Richland & 56 & 0 & 56 & City of Richland \\
BCRFD $^{(\text {a) }}$ 1 & 7 & 100 & 107 & Kennewick Area \\
BCRFD 2 $^{\text {BCRFD 4 }}$ & 5 & 30 & 35 & Benton City \\
Tri-Cities total & $\underline{5}$ & $\underline{40}$ & $\underline{45}$ & West Richland \\
& $\mathbf{3 3 2}$ & $\mathbf{1 7 0}$ & $\mathbf{5 0 2}$ & \\
\hline (a) BCRFD = Benton County Rural Fire Department. & & \\
\hline
\end{tabular}




\subsubsection{Parks and Recreation}

The convergence of the Columbia, Snake, and Yakima rivers offers residents of the Tri-Cities a variety of recreational opportunities. The Lower Snake River Project includes Ice Harbor, Lower Monumental, Little Goose, and Lower Granite locks and dams, and a levee system and parkway at Clarkston and Lewiston (see Figure 4.3-7). Although navigation capabilities and the electrical output are the major benefits of this project, recreational benefits have also resulted. The Lower Snake River Project provides boating, camping, and picnicking facilities in nearly a dozen areas along the Snake River. During FY 2003, 1.8 million people visited the area and participated in activities along the river.

Similarly, the Columbia River provides ample water recreational opportunities on the lakes formed by the dams. Lake Wallula, formed by McNary Dam, offers a large variety of parks and activities that attracted more than 4.4 million visitors during FY 2003. The Columbia River Basin is also a popular area for migratory waterfowl and upland game bird hunting.

Other opportunities for recreational activities in the Tri-Cities are accommodated by indoor and outdoor facilities including numerous tennis courts, ball fields, and golf courses which offer outdoor recreation to residents and tourists (see Table 4.6-6). Several privately owned health clubs in the area offer indoor tennis and racquetball courts, pools, and exercise programs. Bowling lanes and skating rinks also serve the Tri-Cities.

\subsubsection{Utilities}

The principal source of water in the Tri-Cities and the Hanford Site is the Columbia River. The water systems of Richland, Pasco, and Kennewick drew a large portion of the 51.5-billion L (13.6-billion gal) used during 2003 from the Columbia River. Each city operates its own supply and treatment system. The Richland water supply system derives about $82 \%$ of its water directly from the Columbia River, while the remainder is split between a well field in North Richland (that is recharged from the river) and groundwater wells. The city of Richland's total usage during 2003 was 23.5 billion L (6.2 billion gal). The city of Pasco system also draws from the Columbia River for its water needs. During 2003, Pasco consumed 14.01 billion L (3.7 billion gal). The Kennewick system uses two wells and the Columbia River for its supply. These wells serve as the sole source of water between November and March and can provide approximately $40 \%$ of the total maximum supply of 30 billion L ( 8 billion gal). Total 2003 usage in Kennewick was 14.01 billion L (3.7 billion gal). A significant part of Kennewick's residents (about 15,000 residential customers) draw irrigation water from the Kennewick Irrigation District, which has the Yakima River as its source (Tri-City Herald 2001).

The major incorporated areas of Benton and Franklin counties are served by municipal wastewater treatment systems, whereas the unincorporated areas are served by onsite septic systems. Richland's wastewater treatment system processed an average flow of 22.3 million L/d (5.8 million gal/d) during 2003 and is designed to treat 43.1 million L/d (11.4 million gal/d). Kennewick's waste treatment system processed an average 21.6 million L/d (5.7 million gal/d) during 2003. Their system is capable of treating about 46.1 million L/d (12.2 million gal/d). Pasco's waste treatment system processed an average 11.0 million L/d (2.9 million gal/d) and is capable of treating 16.1 million L/d (4.25 million gal/d).

The Benton County Public Utility District, Franklin County Public Utility District, and City of Richland Energy Services Department provide electricity to the Tri-Cities and surrounding areas. Nearly all the power these utilities provide in the local area is purchased from the Bonneville Power Administration (BPA), a federal power-marketing agency. These three utilities served nearly 83,000 
Table 4.6-6. Examples of Physical Recreational Facilities Available in the Tri-Cities, Washington

\begin{tabular}{|c|c|}
\hline Activity & Facilities \\
\hline team sports & $\begin{array}{l}\text { Baseball fields and basketball courts are located throughout the Tri-Cities. } \\
\text { Soccer and football fields are also located in various areas. Spectator sports } \\
\text { include minor league baseball and junior professional hockey. }\end{array}$ \\
\hline bowling & $\begin{array}{l}\text { Lanes in each city, including Fiesta Bowling Center, Celebrity Bowl, and Go- } \\
\text { Bowl. }\end{array}$ \\
\hline camping & $\begin{array}{l}\text { Several hundred campsites within driving distance from the Tri-Cities area, } \\
\text { including Fishhook Park and Sun Lakes. }\end{array}$ \\
\hline fishing & $\begin{array}{l}\text { Steelhead, sturgeon, trout, walleye, bass, and crappie fishing in the lakes and } \\
\text { rivers near the Tri-Cities. }\end{array}$ \\
\hline golf & $\begin{array}{l}\text { Several public courses including Sun Willows, Columbia Park, Canyon Lakes, } \\
\text { Columbia Point, Buckskin, and West Richland Municipal, two semi-private } \\
\text { courses, two private courses, and a number of driving ranges and pro shops. }\end{array}$ \\
\hline hunting & $\begin{array}{l}\text { Duck, geese, pheasant, and quail hunting. Deer and elk hunting in the Blue } \\
\text { Mountains and the Cascade Range. }\end{array}$ \\
\hline skating & $\begin{array}{l}\text { Roller-skating in Richland, Kennewick, and Prosser; recreational ice skating in } \\
\text { Kennewick; junior professional ice hockey arena available to the public in } \\
\text { Kennewick. }\end{array}$ \\
\hline water sports & $\begin{array}{l}\text { Public swimming pools in Pasco, Kennewick, and Richland, plus numerous } \\
\text { private club pools. Boating, sailing, windsurfing, diving, water-skiing, } \\
\text { swimming, etc. on the Columbia River, with } 31 \text { boat ramps in the Tri-Cities. }\end{array}$ \\
\hline tennis & $\begin{array}{l}\text { Several outdoor city courts in each city, with additional outdoor courts located at } \\
\text { area schools. Two private health clubs have indoor courts available. }\end{array}$ \\
\hline walking/bicycling & Over 30 miles of paved bike/hike paths and 5600 acres of parks. \\
\hline
\end{tabular}

customers and had 3.03 billion kilowatt-hour $(\mathrm{kWh})$ total sales during 2003. The average rate for residential customers was approximately $\$ 0.0647 / \mathrm{kWh}$ during 2003, up slightly from $\$ 0.0646$ during 2002. The Benton Rural Electrical Association serves portions of the rural areas of Benton and adjacent counties.

Electrical power for the Hanford Site is purchased wholesale from BPA, which provided $92 \%$ of the electricity consumed on the Hanford Site during 2003. Energy requirements for the Hanford Site during FY 2003 were over 250 million $\mathrm{kWh}$ for a total cost of \$8.6 million. Additionally, the Site spends about $\$ 0.024 / \mathrm{kWh}$ for electrical transportation and distribution within the Hanford Site.

Natural gas, provided by the Cascade Natural Gas Corporation, serves a small portion of local residents, with 11,261 residential customers served in 2003. The average annual gas bill for residential customers is approximately $\$ 1100$. The Cascade Natural Gas Corporation also serves the Hanford Site 300 Area.

Wind energy is a new but growing component of the mix of Pacific Northwest generating resources, and is quite visible in the Tri-Cities area. Phase I of FPL Energy's Stateline wind generation project (180 megawatt [MW]) entered service during December 2001 near Walla Walla, and Energy Northwest's Nine 
Mile Canyon Wind Farm (48 MW) entered service during October 2002 near Kennewick (American Wind Energy Association 2003). A number of other wind power projects (including a 40 MW Phase II for Stateline) have been proposed for the Northwest, although many have been put on hold because of low electricity demand, declining wholesale electricity prices and reduced economic activity due to recession. At prices of 4.0 to 6.0 cents per $\mathrm{kWh}$, wind energy is close to competitive with other sources, despite relatively high costs per installed kWh and capacity factors of around 35 percent (OTED 2004b). A capacity factor is the net electricity generated, for the period of time considered, to the energy that could have been generated at continuous full-power operation during the same period. For comparison, the average capacity factor for nuclear plants in the United States in 2002 was 90 percent (EIA 2004).

\subsubsection{Land Use}

The DOE completed a Hanford Comprehensive Land-Use Plan EIS (HCP-EIS) during September 1999 (DOE 1999a), and a Record of Decision (ROD) was issued on November 2, 1999 (64 FR 61615). The purpose of this land-use plan and its implementing policies and procedures is to facilitate decisionmaking about the Hanford Site's uses and facilities over at least the next 50 years. The DOE Preferred Alternative addresses future and existing use. Proposed future uses include nine land-use designations defining permissible uses of the Hanford Site (Figure 4.6-4 and Table 4.6-7).

For analysis purposes the HCP-EIS used existing land use activities presented on a map that divided the Hanford Site into five geographical areas - Wahluke Slope, Columbia River Corridor, Central Plateau, All Other Areas of the Site, and the Fitzner-Eberhardt Arid Lands Ecology Reserve Unit (Figure 4.6-5).

The key features of the Hanford Site that formed the basis of analysis of the five geographic areas used in the environmental impact analysis and land-use plans were as follows:

- The Wahluke Slope. The area north of the Columbia River and the Hanford Site proper encompassed approximately $357 \mathrm{~km}^{2}\left(138 \mathrm{mi}^{2}\right)$ and was designated as part of the Hanford Reach National Monument by President Clinton. This is an area of relatively undisturbed or recovering shrub-steppe habitat managed by the USFWS for the DOE. These lands consisted of two wildlife management units within the Hanford Reach National Monument/Saddle Mountain National Wildlife Refuge: the $130 \mathrm{~km}^{2}\left(50 \mathrm{mi}^{2}\right)$ Saddle Mountain Unit, and the $225 \mathrm{~km}^{2}\left(87 \mathrm{mi}^{2}\right)$ Wahluke Unit. Portions of the Saddle Mountain Unit, which are closed to public access, still serve as buffer areas for the Hanford Site. The Wahluke Unit was open to public recreational access. A small strip of land approximately $1.62 \mathrm{~km}^{2}\left(0.63 \mathrm{mi}^{2}\right)$ located between SR 243 and the Columbia River west of SR 24 is still managed by the Washington State Department of Fish and Wildlife under DOE permit and retains public access.

- Columbia River Corridor. The $111.6 \mathrm{~km}^{2}\left(43.1 \mathrm{mi}^{2}\right)$ Columbia River Corridor was placed into the Hanford Reach National Monument by President Clinton. Adjacent to and running through the Hanford Site, it is used for boating, water skiing, fishing, and hunting of upland game birds and migratory waterfowl. Although public access is allowed on certain islands below the high water mark, access to other islands and adjacent areas is restricted because of distinctive habitats and the presence of cultural resources.

Along the southern shoreline of the Columbia River Corridor, the 100 Areas occupy approximately $68 \mathrm{~km}^{2}\left(26 \mathrm{mi}^{2}\right)$. The facilities in the 100 Areas included nine retired plutonium production reactors, associated facilities, and structures. Resource Conservation and Recovery Act of 1976 (RCRA) (42 USC 6901 et seq.) closure permit restrictions have been placed in the vicinity of the 100-H Area, which is associated with the 183-H Solar Evaporation Basins and the 


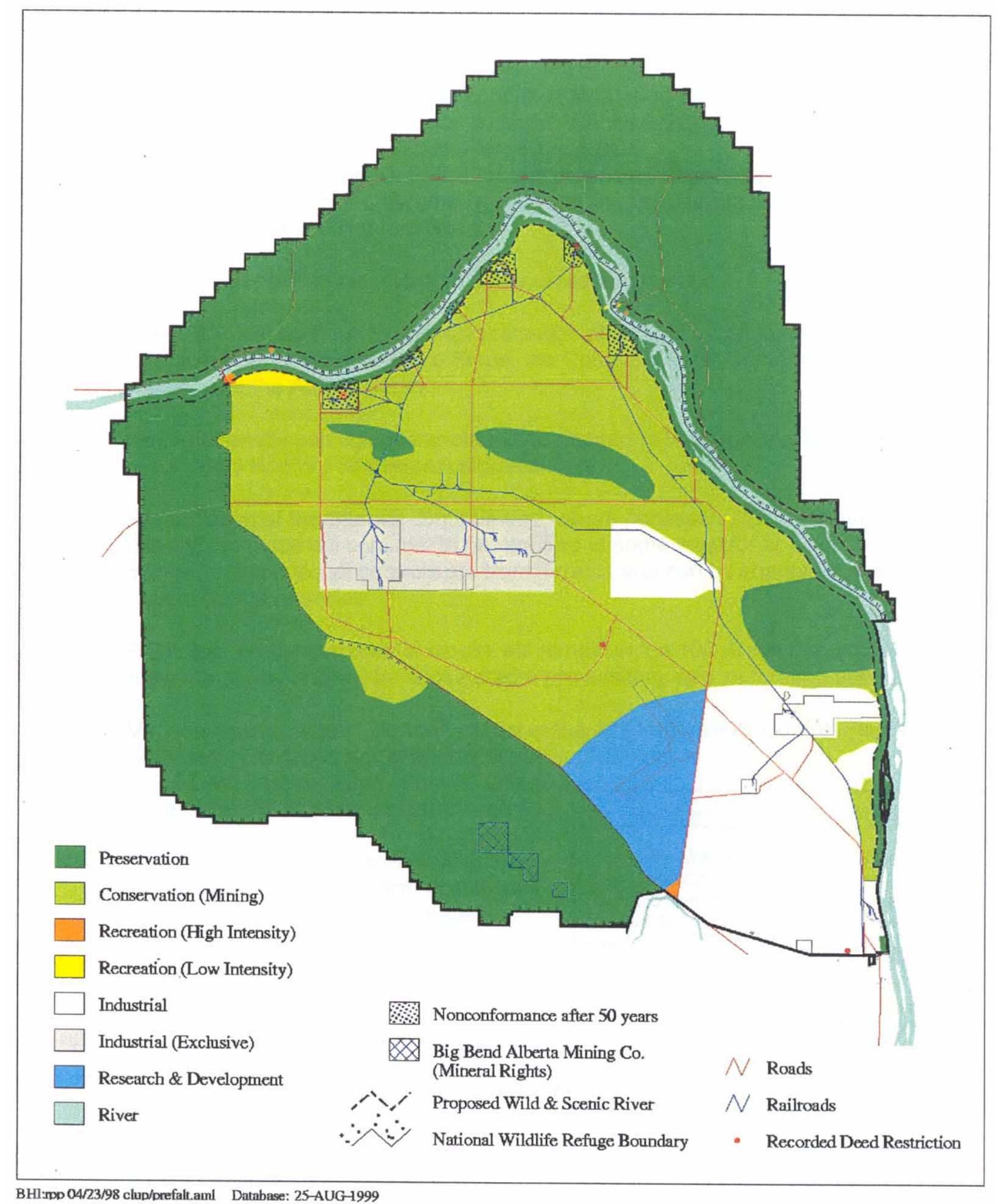

Figure 4.6-4. DOE's Preferred Alternative for Land Use on the Hanford Site, Washington (DOE 1999a) 
Table 4.6-7 Definitions and Descriptions of DOE's Preferred Alternative Land Use Designations for the Hanford Site, Washington (DOE 1999a)

\begin{tabular}{|c|c|}
\hline $\begin{array}{c}\text { Land-Use } \\
\text { Designation } \\
\end{array}$ & Definition \\
\hline $\begin{array}{l}\text { Industrial- } \\
\text { Exclusive }\end{array}$ & $\begin{array}{l}\text { An area suitable and desirable for treatment, storage, and disposal of hazardous, dangerous, } \\
\text { radioactive, and nonradioactive wastes. Includes related activities consistent with Industrial- } \\
\text { Exclusive uses. }\end{array}$ \\
\hline Industrial & $\begin{array}{l}\text { An area suitable and desirable for activities such as reactor operations, rail, barge transport } \\
\text { facilities, mining, manufacturing, food processing, assembly, warehouse, and distribution } \\
\text { operations. Includes related activities consistent with Industrial uses. }\end{array}$ \\
\hline Agricultural & $\begin{array}{l}\text { An area designated for the tilling of soil, raising of crops and livestock, and horticulture for } \\
\text { commercial purposes along with all those activities normally and routinely involved in } \\
\text { horticulture and the production of crops and livestock. Includes related activities consistent with } \\
\text { Agricultural uses. }\end{array}$ \\
\hline $\begin{array}{l}\text { Research and } \\
\text { Development }\end{array}$ & $\begin{array}{l}\text { An area designated for conducting basic or applied research that requires the use of a large-scale } \\
\text { or isolated facility or smaller-scale time-limited research conducted in the field or in facilities } \\
\text { that consume limited resources. Includes scientific, engineering, technology development, } \\
\text { technology transfer, and technology deployment activities to meet regional and national needs. } \\
\text { Includes related activities consistent with Research and Development. }\end{array}$ \\
\hline $\begin{array}{l}\text { High-Intensity } \\
\text { Recreation }\end{array}$ & $\begin{array}{l}\text { An area allocated for high-intensity, visitor-serving activities and facilities (commercial and } \\
\text { governmental), such as golf courses, recreational vehicle parks, boat launching facilities, Tribal } \\
\text { fishing facilities, destination resorts, cultural centers, and museums. Includes related activities } \\
\text { consistent with High-Intensity Recreation. }\end{array}$ \\
\hline $\begin{array}{l}\text { Low-Intensity } \\
\text { Recreation }\end{array}$ & $\begin{array}{l}\text { An area allocated for low-intensity, visitor-serving activities and facilities, such as improved } \\
\text { recreational trails, primitive boat launching facilities, and permitted campgrounds. Includes } \\
\text { related activities consistent with Low-Intensity Recreation. }\end{array}$ \\
\hline $\begin{array}{l}\text { Conservation } \\
\text { (Mining and } \\
\text { Grazing) }\end{array}$ & $\begin{array}{l}\text { An area reserved for the management and protection of archeological, cultural, ecological, and } \\
\text { natural resources. Limited and managed mining (e.g. quarrying for sand, gravel, basalt, and } \\
\text { topsoil for governmental purposes only), and grazing could occur as a special use (i.e. a permit } \\
\text { would be required) within appropriate areas. Limited public access would be consistent with } \\
\text { resource conservation. Includes activities related to Conservation (Mining and Grazing) } \\
\text { consistent with the protection of archeological, cultural, ecological, and natural resources. }\end{array}$ \\
\hline $\begin{array}{l}\text { Conservation } \\
\text { (Mining) }\end{array}$ & $\begin{array}{l}\text { An area reserved for the management and protection of archeological, cultural, ecological, and } \\
\text { natural resources. Limited and managed mining (e.g. quarrying for sand, gravel, basalt, and } \\
\text { topsoil for governmental purposes only), and grazing could occur as a special use (i.e. a permit } \\
\text { would be required) within appropriate areas. Limited public access would be consistent with } \\
\text { resource conservation. Includes activities related to Conservation (Mining) consistent with the } \\
\text { protection of archeological, cultural, ecological, and natural resources. }\end{array}$ \\
\hline Preservation & $\begin{array}{l}\text { An area managed for the preservation of archeological, cultural, ecological, and natural } \\
\text { resources. No new consumptive uses (i.e. mining or extraction of non-renewable resources) } \\
\text { would be allowed within this area. Limited public access would be consistent with resource } \\
\text { conservation. Includes activities related to Preservation uses. }\end{array}$ \\
\hline
\end{tabular}




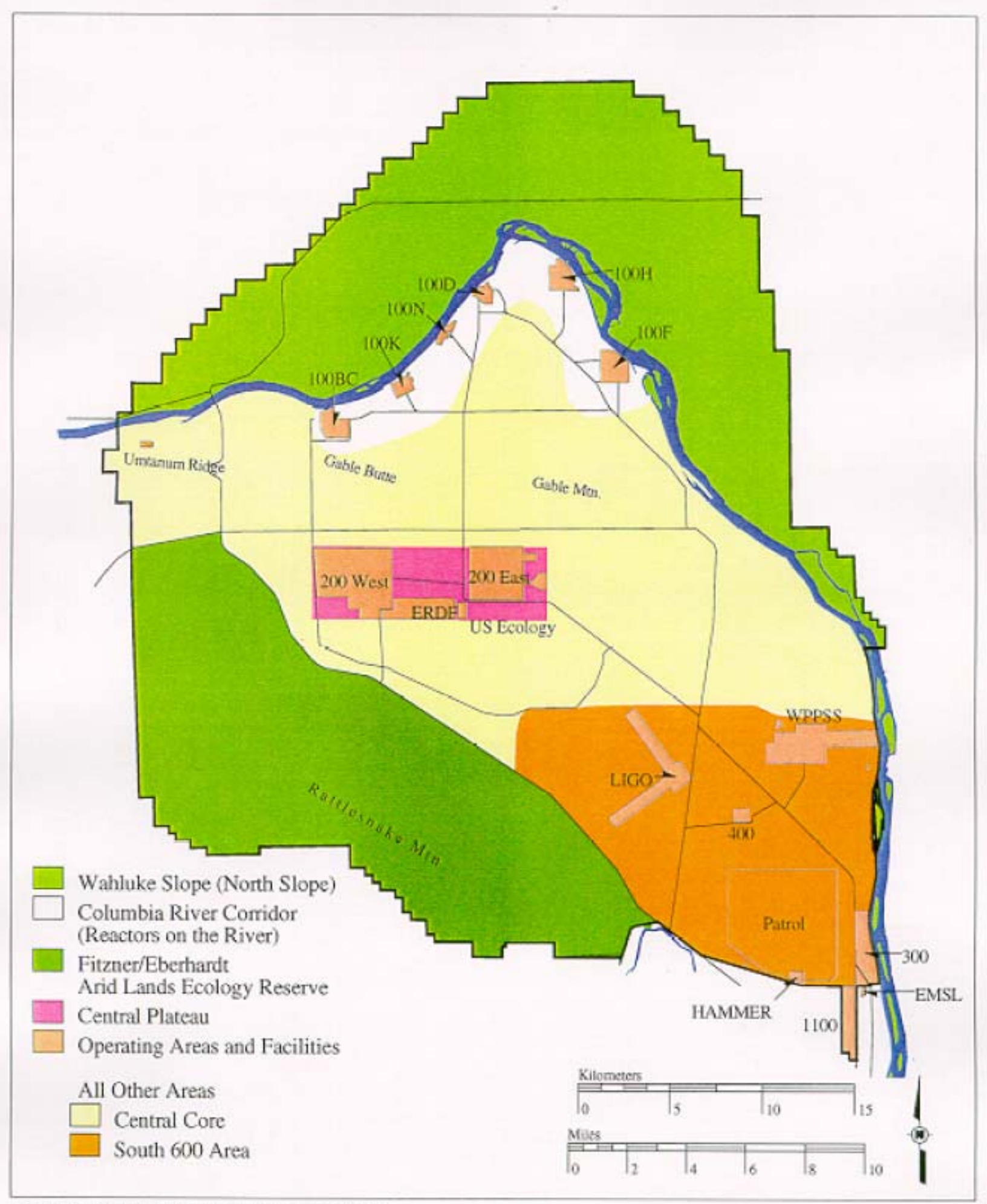

BHITP 04/23/96 cluplgeogareaclant Darabse: 03-DEC-1998

Figure 4.6-5. Geographic Study Areas for the Hanford Site, Washington (DOE 1999a) 
$\mathrm{N}$ Reactor cribs. Additional deed restrictions or covenants for activities that potentially extend

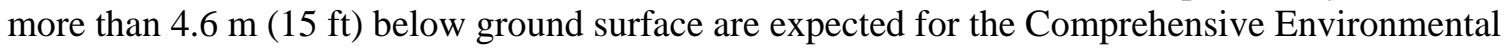
Restoration, Compensation, and Liability Act of 1980 (CERCLA) (42 USC 9601, et seq.) remediation areas.

The area within the Columbia River Corridor known as the Hanford Reach includes a $402 \mathrm{~m}$ (1320 ft) strip of public land on either side of the Columbia River.

- Central Plateau. The 200 East and 200 West Areas occupy approximately $51 \mathrm{~km}^{2}\left(19.5 \mathrm{mi}^{2}\right)$ in the Central Plateau of the Hanford Site. Facilities located in the Central Plateau were built to process irradiated fuel from the plutonium production reactors. The operation of these facilities resulted in the treatment, storage, disposal, and unplanned release of radioactive and nonradioactive waste. The Environmental Restoration Disposal Facility for CERCLA cleanup wastes is located in the Central Plateau as will be the Integrated Disposal Facility as authorized by the Hanford Solid Waste EIS ROD.

A commercial low-level radioactive waste disposal facility, licensed by the State of Washington and run by U.S. Ecology, Inc., currently operates on $0.4 \mathrm{~km} 2(0.16 \mathrm{mi} 2)$ of the Central Plateau.

- All Other Areas. All Other Areas comprise $689 \mathrm{~km}^{2}$ (266 mi ${ }^{2}$ ) and contain the 300, 400, and 1100 Areas, Energy Northwest facilities, and a section of land currently owned by the State of Washington for the disposal of hazardous substances.

The Hanford 1100 Area and the Hanford railroad southern connection (from Horn Rapids Road to Columbia Center) have been transferred from DOE ownership to Port of Benton ownership to support future economic development. Although the 1100 Area is no longer under DOE control, it was included in the HCP EIS to support the local governments with their State Environmental Policy Act (SEPA) EIS analyses of the Hanford sub-area of Benton County under the State of Washington's Growth Management Act.

The 300 Area is located just north of the city of Richland and covers $1.5 \mathrm{~km}^{2}\left(0.6 \mathrm{mi}^{2}\right)$. The 300 Area is the site of former reactor fuel fabrication facilities and was also the principal location of nuclear research and development facilities serving the Hanford Site.

The 400 Area, located southeast of the 200 East Area, is the site primarily of the Fast Flux Test Facility (FFTF), a 400-megawatt (thermal) liquid metal (sodium) fast neutron flux nuclear test reactor. The construction of the FFTF was completed in 1978 and its initial operation began in 1980. From 1982 to 1992, the FFTF operated as a national research facility to test advanced nuclear fuels, materials, components, nuclear power plant operations and maintenance protocols, and reactor safety designs. During this time, the FFTF also produced a wide variety of medical and industrial isotopes, made tritium for the U.S. fusion research program, and conducted cooperative international research work. Since 2001, major FFTF deactivation activities underway at this time consist of, but are not limited to, dry cask storage of irradiated fuel, dry storage of unirradiated and sodium-bonded fuel, sodium drain and storage, and deactivation of the auxiliary plant systems.

Energy Northwest currently operates the Columbia Generating Station on leased land approximately $10 \mathrm{~km}(6 \mathrm{mi})$ north of Richland. Originally leased for the operation of three nuclear power plants, construction of two of the plants was halted; other industrial options are currently being considered. 
During 1980, the federal government sold a $2.59 \mathrm{~km}^{2}\left(1 \mathrm{mi}^{2}\right)$ section of land (known as Section 1) south of the 200 East Area, near SR 240, to the State of Washington for the purpose of nonradioactive hazardous waste disposal. To date, this parcel has not been used for hazardous waste disposal, and it is undeveloped and uncontaminated (although the underlying groundwater might be contaminated). The deed requires that if it were used for any purpose other than hazardous waste disposal, ownership would revert to the federal government.

Additional activities in All Other Areas include:

- $\quad$ A specialized training center: The Hazardous Materials Management and Emergency Response (HAMMER) Volpentest Training and Education Center is used to train hazardous materials response personnel and operating personnel for the Waste Treatment Plant. It is located north of the former 1100 Area and covers about $0.3 \mathrm{~km}^{2}\left(0.12 \mathrm{mi}^{2}\right)$.

- A regional law-enforcement training facility: The Hanford Patrol Training Academy provides a range of training environments including classrooms, library resources, practice shoot houses, an exercise gym, and an obstacle course.

- A national research facility: The Laser Interferometer Gravitational Wave Observatory (LIGO), built by the National Science Foundation for scientific research, is designed to detect cosmic gravitational waves. The facility consists of two optical tube arms, each $4 \mathrm{~km}$ (2.5 mi) long, arrayed in an "L" shape, which are extremely sensitive to vibrations.

- A national utilities training center: The National Utility Training Services facility in Richland, Washington, will help continue to develop curriculum for the state-of-theart training facility located adjacent to the Volpentest HAMMER Training Center for emergency workers at the U.S. Department of Energy's Hanford facility. National Utility Training Services is a facility designed to provide the best in electric utility hands-on, performance-based training. Originally a project of the Northwest Public Power Association (NWPPA), National Utility Training Services is now a non-profit educational 501(c)3 organization, and works in conjunction with NWPPA to provide hands-on performance-based training to the west's electric utility employees.

- A national counter-drug center: National Counternarcotics Center pilot. The drug interdiction prototype will support future interest and funding for a permanent multijurisdictional counternarcotics program involving federal and local agencies.

- Fitzner-Eberhardt Arid Lands Ecology Reserve Unit. The $308.7 \mathrm{~km}^{2}\left(119.2 \mathrm{mi}^{2}\right)$ FitznerEberhardt Arid Lands Ecology Reserve Unit is part of the Hanford Reach National Monument and is managed by the USFWS for the DOE. The Unit is located in the southwestern portion of the Hanford Site and is managed as a wildlife reserve. The public is currently restricted from the site.

The Hanford Site facilities and activities are consolidated within operating areas that occupy about 6 percent of the total available area of the Site (DOE 1999a). Some of the Hanford Site that is not involved with the current mission has been leased, disposed, or permitted to federal or state agencies, or private entities (Table 4.6-8). 
Table 4.6-8. Key Areas of the Hanford Site, Washington, Outgranted/Released to Date ${ }^{\text {(a) }}$

\begin{tabular}{|c|c|c|c|c|}
\hline Area & Management & Use & Year & Controls \\
\hline $\begin{array}{l}\text { US Ecology Low- } \\
\text { Level Radioactive } \\
\text { Waste Disposal } \\
\text { Facility }\end{array}$ & $\begin{array}{l}\text { State of } \\
\text { Washington }\end{array}$ & $\begin{array}{l}\text { Commercial } \\
\text { Radioactive } \\
\text { Waste } \\
\text { Disposal }\end{array}$ & 1964 & Leased \\
\hline Vernita Rest Area ${ }^{(b)}$ & $\begin{array}{l}\text { Washington } \\
\text { State } \\
\text { Department of } \\
\text { Transportation }\end{array}$ & $\begin{array}{l}\text { Highway } \\
\text { Rest Area }\end{array}$ & 1966 & Washington State Highway Patrol \\
\hline $\begin{array}{l}\text { Columbia } \\
\text { Generating Station }\end{array}$ & $\begin{array}{l}\text { Energy } \\
\text { Northwest }\end{array}$ & $\begin{array}{l}\text { Power } \\
\text { Production }\end{array}$ & 1971 & Leased \\
\hline $\begin{array}{l}\text { West End of } \\
\text { Wahluke Slope } \\
\text { (Saddle Mountain } \\
\text { National Wildlife } \\
\text { Refuge) } \\
\text { (b) } \\
\text { (Superseded) }\end{array}$ & $\begin{array}{l}\text { U.S. Fish and } \\
\text { Wildlife } \\
\text { Service }\end{array}$ & $\begin{array}{l}\text { Wildlife } \\
\text { Refuge }\end{array}$ & 1971 & $\begin{array}{l}\text { Permitted with the following } \\
\text { controls: } \\
\text { - } \quad \text { No overnight camping } \\
\text { - } \quad \text { Access control plans required } \\
\text { - } \quad \text { No drilling of wells for } \\
\quad \text { residential water }\end{array}$ \\
\hline $\begin{array}{l}\text { East End of } \\
\text { Wahluke Slope } \\
\text { (b) } \\
\text { (Superseded) }\end{array}$ & $\begin{array}{l}\text { WA State } \\
\text { Department of } \\
\text { Fish and } \\
\text { Wildlife }\end{array}$ & $\begin{array}{l}\text { Wildlife \& } \\
\text { Recreational } \\
\text { Reserve } \\
\end{array}$ & $\begin{array}{l}1971- \\
1999 \\
\end{array}$ & $\begin{array}{l}\text { Permitted with same controls as } \\
\text { mentioned for Wahluke Slope } \\
\text { above. }\end{array}$ \\
\hline $\begin{array}{l}\text { Township } 11 \text { Range } \\
\text { 26, Section } 1\end{array}$ & $\begin{array}{l}\text { State of } \\
\text { Washington }\end{array}$ & $\begin{array}{l}\text { Hazardous } \\
\text { Waste } \\
\text { Disposal }\end{array}$ & 1980 & Disposed (Title Transfer) \\
\hline 3000 Area & Port of Benton & $\begin{array}{l}\text { Economic } \\
\text { Development }\end{array}$ & 1996 & Disposed (Title Transfer) \\
\hline $\begin{array}{l}\text { Fitzner-Eberhardt } \\
\text { Arid Lands Ecology } \\
\text { Reserve Unit }{ }^{(b)}\end{array}$ & $\begin{array}{l}\text { U.S. Fish and } \\
\text { Wildlife } \\
\text { Service }\end{array}$ & $\begin{array}{l}\text { Wildlife } \\
\text { Reserve }\end{array}$ & 1998 & $\begin{array}{l}\text { Permitted with same controls as } \\
\text { mentioned for Wahluke Slope } \\
\text { above. }\end{array}$ \\
\hline $\begin{array}{l}\text { Laser Interferometer } \\
\text { Gravitational Wave } \\
\text { Observatory (LIGO) } \\
\end{array}$ & $\begin{array}{l}\text { The National } \\
\text { Science } \\
\text { Foundation }\end{array}$ & Research & 1998 & Permitted \\
\hline 1100 Area & Port of Benton & $\begin{array}{l}\text { Economic } \\
\text { Development }\end{array}$ & 1998 & Disposed (Title Transfer) \\
\hline $\begin{array}{l}\text { Wahluke Slope }{ }^{(b)} \\
\text { (Remainder/all) }^{\text {Rem de }}\end{array}$ & $\begin{array}{l}\text { U.S. Fish and } \\
\text { Wildlife } \\
\text { Service } \\
\end{array}$ & $\begin{array}{l}\text { Wildlife } \\
\text { Refuge }\end{array}$ & 1999 & $\begin{array}{l}\text { Permitted with same controls as } \\
\text { mentioned for Wahluke Slope } \\
\text { above. }\end{array}$ \\
\hline \multicolumn{5}{|c|}{$\begin{array}{l}\text { (a) Does not include release of lands within the Richland City, lease of the City itself, leased facilities on } \\
\text { the Hanford Site, or lands released before } 1964 . \\
\text { (b) Included in Hanford Reach National Monument, established June 9, } 2000 \text { (65 FR 37253). }\end{array}$} \\
\hline
\end{tabular}

\subsubsection{Visual Resources}

With the exception of Rattlesnake Mountain, the land near the Hanford Site is generally flat with little relief. Rattlesnake Mountain, rising to $1060 \mathrm{~m}$ (3477 ft) above mean sea level forms the western boundary of the Hanford Site, and Gable Mountain and Gable Butte are the highest landforms within the Site (Figure 4.6-6). The view toward Rattlesnake Mountain is visually pleasing, especially during the 


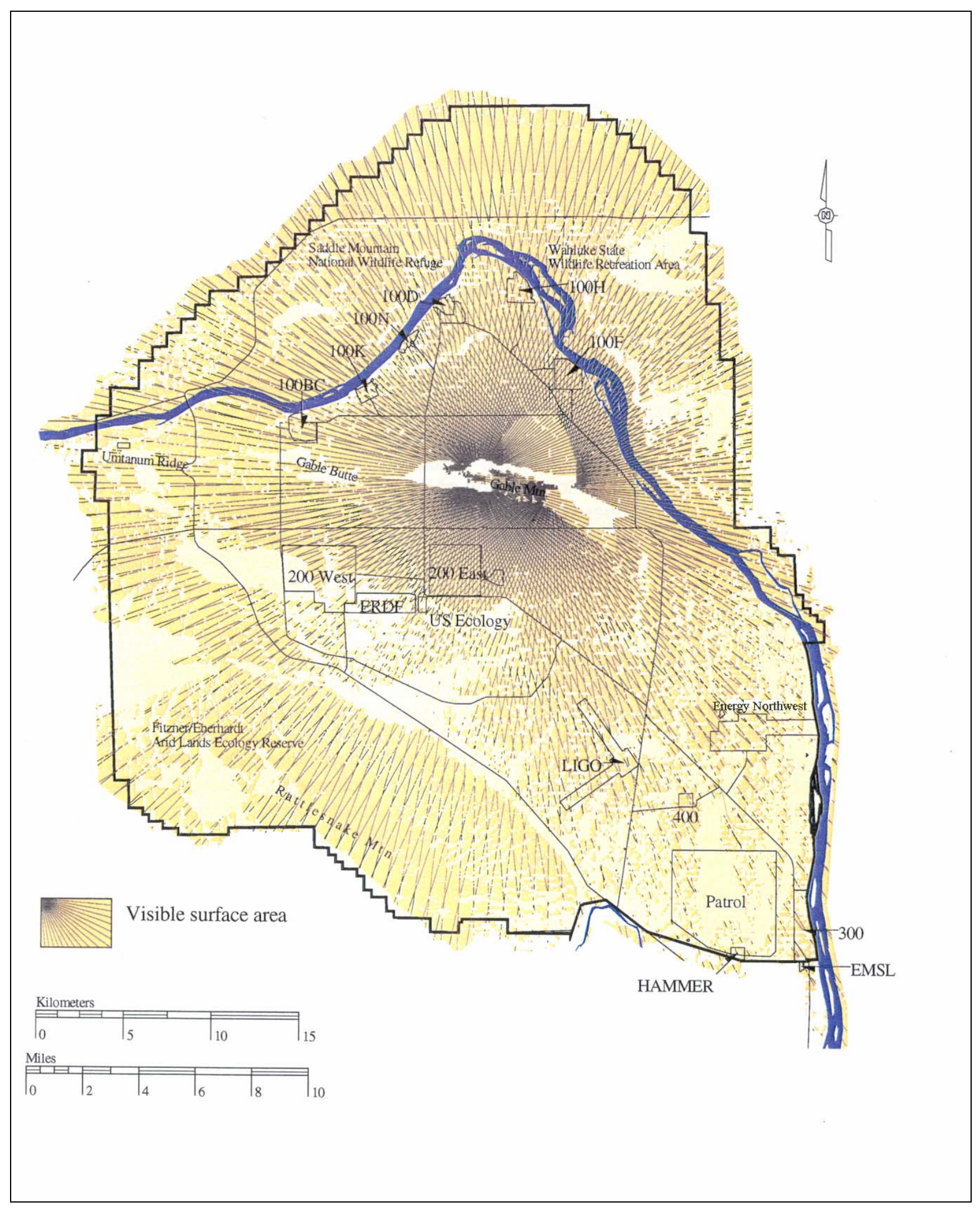

Figure 4.6-6. Viewshed from Gable Mountain on the Hanford Site, Washington (modified from DOE 1999a) 
springtime when wildflowers are in bloom. Large rolling hills are located to the west and far north. The Columbia River, flowing across the northern part of the Hanford Site and forming the eastern boundary, is generally considered scenic, with its contrasting blue against a background of brown basaltic rocks and sagebrush (DOE 1999a). The White Bluffs, steep whitish-brown bluffs adjacent to the Columbia River and above the northern boundary of the river in this region, are a major feature of the landscape.

Traditional Native American religion is manifest in the earth, water, sky, and all animate or inanimate beings that inhabit a given location. The National Historic Preservation Act (16 USC 470, et seq.), the Native American Graves Protection and Repatriation Act (25 USC 3001, et seq.), the Archaeological Resources Protection Act (16 USC 470aa, et seq.), and DOE's American Indian Policy (DOE 1992b), among other legislation and guidelines, all require the identification and protection of areas and resources of concern to Native Americans. The acquisition of spiritual guidance and assistance through personal vision quests is a religious practice of the Native Americans that lived near the Hanford Site. High spots were selected as sacred sites in part because they afforded extensive views of the landscape and seclusion for meditation, and the Gable Butte Block Survey in 2001 determined that Gable Butte and Gable Mountain likely were used for vision quests (Hale and Harvey 2002). Many Hanford facilities that clearly are not part of the "natural" landscape are easily seen from these sites. 
This page intentionally left blank 


\subsection{Noise}

\section{B.G. Fritz}

Noise is technically defined as the intensity, duration, and character of sounds from any and all sources (RCW 70.107). Sound waves are characterized by frequency, measured in Hertz (Hz), and sound pressure expressed as decibels $(\mathrm{dB})$. Humans have a perceptible hearing range of 31 to 20,000 $\mathrm{Hz}$. The decibel is a value equal to 10 times the logarithm of the ratio of a sound pressure squared to a standard reference sound-pressure level (20 micropascals) squared (Harris 1991). The threshold of audibility ranges from about $60 \mathrm{~dB}$ at a frequency of $31 \mathrm{~Hz}$ to less than about $1 \mathrm{~dB}$ between 900 and $8000 \mathrm{~Hz}$. (For regulatory purposes, noise levels for perceptible frequencies are weighted to provide an A-weighted sound level [dBA] that correlates highly with individual community response to noise.) Sound levels outside the range of human hearing are not considered noise in a regulatory sense, even though wildlife may hear at these frequencies.

Noise levels are often reported as the equivalent sound level $\left(\mathrm{L}_{\mathrm{eq}}\right)$. The $\mathrm{L}_{\mathrm{eq}}$ is expressed in dBA over a specified period of time, usually 1 or $24 \mathrm{hr}$. The $\mathrm{L}_{\mathrm{eq}}$ is the equivalent steady sound level that, if continuous during a specified time period, would contain the same total energy as the actual time-varying sound over the monitored or modeled time period (Harris 1991).

\subsubsection{Background Information}

Studies of the propagation of noise at Hanford have been concerned primarily with occupational noise at work sites. Environmental noise levels have not been extensively evaluated because of the remoteness of most Hanford activities and isolation from receptors that are covered by federal or state statutes. This discussion focuses on what few environmental noise data are available. The majority of available information consists of model predictions, which in many cases have not been verified because the predictions indicate that the potential to violate federal or state standards is remote or unrealistic.

\subsubsection{Environmental Noise Regulations}

The Noise Control Act of 1972 and its subsequent amendments (Quiet Communities Act of 1978 and 40 CFR 201-211) direct the regulation of environmental noise to the state. The State of Washington has adopted Revised Code of Washington (RCW) 70.107, which authorizes Ecology to implement rules consistent with federal noise control legislation. RCW 70.107 and the implementing regulations embodied in WAC 173-60 through 173-70 define the regulation of environmental noise levels. Maximum noise levels are defined for the zoning of the area in accord with the environmental designation for noise abatement (EDNA). The Hanford Site is classified as a Class C EDNA on the basis of industrial activities. Unoccupied areas are also classified as Class $C$ areas by default because they are neither Class A (residential) nor Class B (commercial). Maximum noise levels are established based on the EDNA classification of the receiving area and the source area (Table 4.7-1). 
Table 4.7-1. Applicable State Noise Limitations for the Hanford Site, Washington, Based on Source and Receptor EDNA Designation

\begin{tabular}{|l|ccc|}
\hline \multirow{2}{*}{$\begin{array}{c}\text { Source Hanford } \\
\text { Site }\end{array}$} & $\begin{array}{c}\text { Class A } \\
\text { Residential } \\
\text { (dBA) }\end{array}$ & $\begin{array}{c}\text { Receptor } \\
\text { Commercial } \\
\text { (dBA) }\end{array}$ & $\begin{array}{c}\text { Class C } \\
\text { Industrial } \\
\text { (dBA) }\end{array}$ \\
\hline Class C - day & 60 & 65 & 70 \\
night & 50 & -- & -- \\
\hline
\end{tabular}

\subsubsection{Hanford Site Sound Levels}

Most industrial facilities on the Hanford Site are located far enough away from the Site boundary that noise levels at the boundary are not measurable or are barely distinguishable from background noise levels. Modeling of environmental noises has been performed for commercial reactors and SR 240 through the Hanford Site. These data are not concerned with background levels of noise and are not reviewed here. There have been two studies measuring environmental noise at Hanford: during a 1981 site characterization for the Skagit/Hanford Nuclear Power Plant Site (NRC 1982) and when the Hanford Site was considered for a geologic waste repository (Basalt Waste Isolation Project) for spent commercial nuclear fuel and other high-level nuclear waste. Hanford Site characterization studies performed during 1987 included measurement of background environmental noise levels at five locations (Figure 4.7-1). Additionally, certain activities such as well drilling and sampling have the potential for producing noise in the field apart from major permanent facilities.

\subsubsection{Skagit/Hanford Data}

Measurements of environmental noise were collected during June 1981 on the Hanford Site during site characterization prior to the construction of the Skagit/Hanford Nuclear Power Plant (NRC 1982). Fifteen sites were monitored and noise levels ranged from 30 to $61 \mathrm{dBA}\left(\mathrm{L}_{\mathrm{eq}}\right)$. The values for isolated areas ranged from 30 to $39 \mathrm{dBA}$. Measurements taken around the sites where Energy Northwest was constructing nuclear power plants (WNP-1, WNP-2 (now the Columbia Generating Station), and WNP-4) ranged from 51 to $64 \mathrm{dBA}$. Measurements taken along the Columbia River near the intake structures for the Columbia Generating Station were 48 and $52 \mathrm{dBA}$ compared with more remote river noise levels of $46 \mathrm{dBA}$ (measured about $4.8 \mathrm{~km}$ [3 mi] upstream of the intake structures). Community noise levels in North Richland (Horn Rapids Road and SR 240) were 61 dBA.

\subsubsection{Basalt Waste Isolation Project (BWIP) Data}

Background noise levels were measured at five locations within the Hanford Site boundary (Figure 4.7-1). Noise levels are expressed as $\mathrm{L}_{\mathrm{eq}}$ for $24 \mathrm{hr}\left(\mathrm{L}_{\mathrm{eq}-24}\right)$. Wind was identified as the primary contributor to background noise levels, with winds exceeding $19 \mathrm{~km} / \mathrm{hr}(12 \mathrm{mi} / \mathrm{hr})$ having a significant effect on noise levels. Background noise levels $\left(\mathrm{L}_{\mathrm{eq}-24}\right)$ in undeveloped areas around the Hanford Site were observed to range between 24 to $36 \mathrm{dBA}$. Periods of high wind, which normally occur in the spring, would elevate background noise levels. 


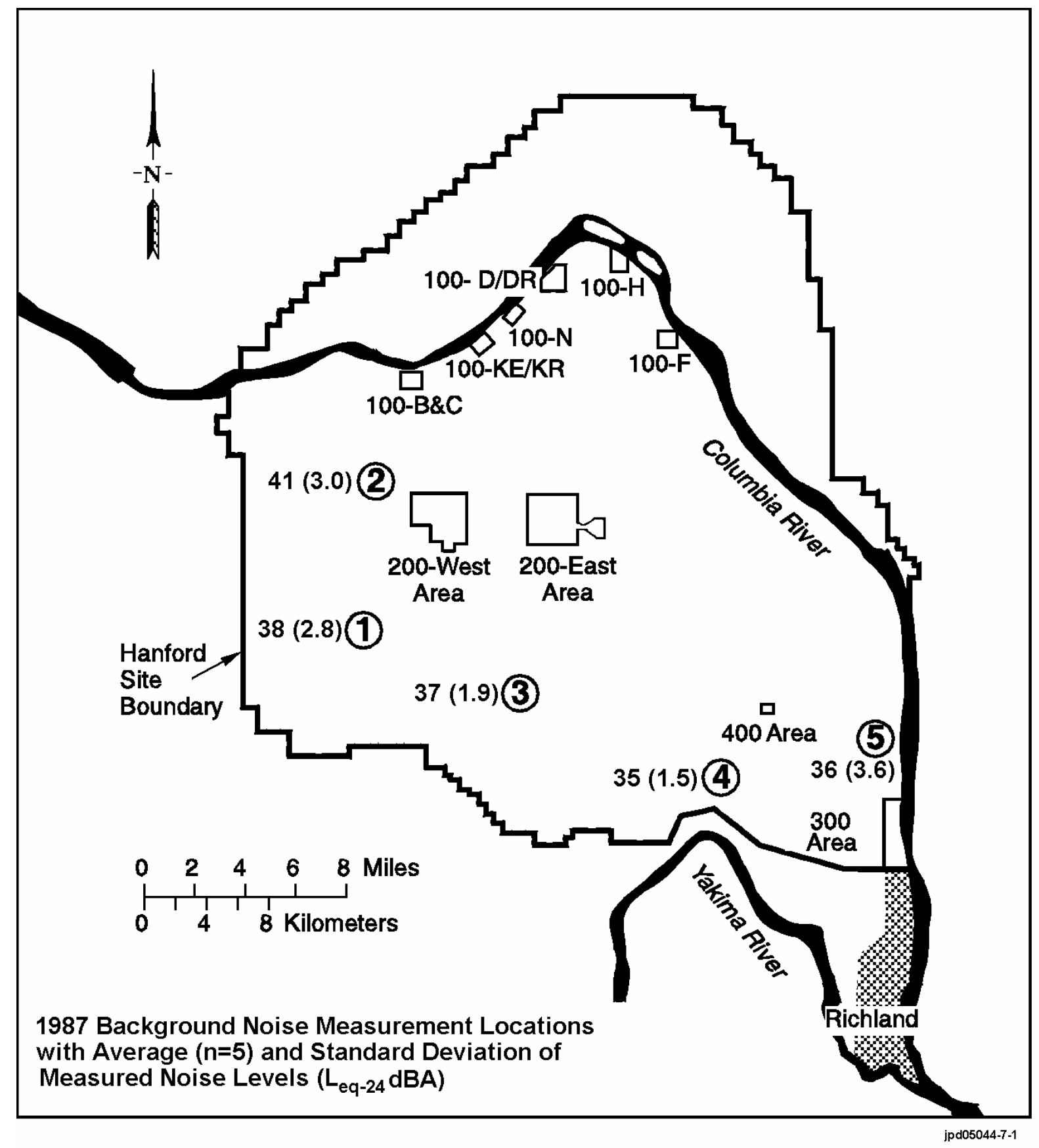

Figure 4.7-1. Location of Background Noise Measurements Collected for the Basalt Waste Isolation Project, Hanford Site, Washington 


\subsubsection{New Production Reactor (NPR) EIS}

Baseline noise estimates were determined for two locations: SR 24, leading from the Hanford Site west to Yakima, and SR 240, south of the Hanford Site and west of Richland where it handles maximum traffic volume (DOE 1991). Traffic volumes were predicted based on an operational work force and a construction work force. Both peak (rush hour) and off-peak hours were estimated. Noise levels were

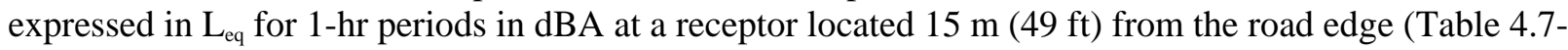
2). Adverse responses would not be expected at increases of $5 \mathrm{dBA}$ over background noise levels.

Table 4.7-2 Estimated Noise Resulting from Automobile Traffic at Hanford, Washington, with the New Production Reactor Environmental Impact Statement (DOE 1991) ${ }^{(a)}$

\begin{tabular}{|c|c|c|c|c|c|c|}
\hline \multirow[b]{2}{*}{ Location $^{(\mathbf{b})}$} & \multirow[b]{2}{*}{ Scenario } & \multicolumn{2}{|c|}{$\begin{array}{l}\text { Traffic flow } \\
\text { (Vehicles/hr) }\end{array}$} & \multicolumn{2}{|c|}{$\begin{array}{c}\text { Noise levels } \\
\left(L_{e q}-1 \text { hr in dBA }\right)\end{array}$} & \multirow[b]{2}{*}{$\begin{array}{c}\text { Maximum } \\
\text { Increase } \\
\text { (dBA) }\end{array}$} \\
\hline & & Baseline & Maximum $^{(c)}$ & $\begin{array}{c}\text { Baseline } \\
\text { Noise } \\
\text { Levels } \\
\end{array}$ & $\begin{array}{c}\text { Estimated } \\
\text { Noise } \\
\text { Levels }^{(c)} \\
\end{array}$ & \\
\hline \multicolumn{7}{|l|}{$\begin{array}{l}\text { Construction } \\
\text { phase }\end{array}$} \\
\hline SR 24 & $\begin{array}{l}\text { Off- } \\
\text { Peak } \\
\text { Peak }\end{array}$ & $\begin{array}{l}91 \\
91\end{array}$ & $\begin{array}{r}91 \\
343\end{array}$ & $\begin{array}{l}62.0 \\
62.0\end{array}$ & 62.0 & 0.0 \\
\hline SR 240 & $\begin{array}{l}\text { Off- } \\
\text { Peak } \\
\text { Peak }\end{array}$ & $\begin{array}{l}571 \\
571\end{array}$ & $\begin{array}{r}579 \\
2839\end{array}$ & $\begin{array}{l}70.2 \\
70.2\end{array}$ & $\begin{array}{l}70.6 \\
73.5\end{array}$ & $\begin{array}{l}0.4 \\
3.3\end{array}$ \\
\hline \multicolumn{7}{|l|}{ Operation phase } \\
\hline SR 24 & $\begin{array}{l}\text { Off- } \\
\text { Peak } \\
\text { Peak }\end{array}$ & $\begin{array}{r}91 \\
300\end{array}$ & $\begin{array}{r}91 \\
386\end{array}$ & $\begin{array}{l}62.0 \\
65.7\end{array}$ & $\begin{array}{l}62.0 \\
66.2\end{array}$ & $\begin{array}{l}0.0 \\
1.5\end{array}$ \\
\hline SR 240 & $\begin{array}{l}\text { Off- } \\
\text { Peak } \\
\text { Peak }\end{array}$ & $\begin{array}{r}571 \\
2239\end{array}$ & $\begin{array}{r}582 \\
3009\end{array}$ & $\begin{array}{l}70.2 \\
74.1\end{array}$ & $\begin{array}{l}70.5 \\
74.7\end{array}$ & $\begin{array}{l}0.3 \\
0.6\end{array}$ \\
\hline $\begin{array}{l}\text { (a) Measured } 15 \\
\text { (b) SR } 24 \text { leads to } \\
\text { (c) Traffic flow a } \\
\text { techniques a }\end{array}$ & $\begin{array}{l}9 \mathrm{ft} \text { ) from th } \\
\text { kima; SR } 24 \\
\text { oise estimate } \\
\text { lown here. }\end{array}$ & $\begin{array}{l}\text { e road edge } \\
0 \text { leads to th } \\
\text { s varied wit }\end{array}$ & $\begin{array}{l}\text { e Tri-Cities area } \\
\text { h NPR technolog }\end{array}$ & ; the maxi & Im impacts frc & three NPR \\
\hline
\end{tabular}

\subsubsection{Noise Levels of Hanford Field Activities}

In the interest of protecting Hanford workers and complying with Occupational Safety and Health Administration (OSHA) standards for noise in the workplace, the Hanford Environmental Health Foundation (HEHF) has monitored noise levels resulting from several routine operations performed at Hanford (Table 4.7-3). These operations have the potential to disturb wildlife when conducted in remote locations. For the activities monitored, well drilling and the operation of a pile driver produce the highest levels of noise. For an activity with a noise level of $120 \mathrm{dBA}$, the noise will be attenuated to $100 \mathrm{dBA}$ $145 \mathrm{~m}$ from the source, and will be attenuated to $80 \mathrm{dBA} 1350 \mathrm{~m}$ from the source. 
Table 4.7-3. Monitored Levels of Noise Propagated from Outdoor Activities at the Hanford Site, Washington

\begin{tabular}{|c|c|c|c|c|}
\hline Activity & $\begin{array}{l}\text { Average } \\
\text { Noise } \\
\text { Level } \\
\text { (dBA) }\end{array}$ & $\begin{array}{l}\text { Maximum } \\
\text { Noise Level }\end{array}$ & $\begin{array}{c}\text { Year } \\
\text { Measured }\end{array}$ & Distance \\
\hline Water wagon operation ${ }^{(a)}$ & 104.5 & 111.9 & 1984 & On staff member \\
\hline Well sampling ${ }^{(a)}$ & $74.8-78.2$ & & 1987 & On staff member \\
\hline Truck $^{(a)}$ & $78-83$ & & 1989 & On staff member \\
\hline Compressor ${ }^{(b)}$ & $88-90$ & & & $0.3 \mathrm{~m}(1 \mathrm{ft})$ from truck \\
\hline Generator $^{(\mathrm{b})}$ & $93-95$ & & & $0.3 \mathrm{~m}(1 \mathrm{ft})$ from truck \\
\hline Well drilling, Well 32-2(a) & $98-102$ & 102 & 1987 & $23 \mathrm{~m}(75 \mathrm{ft})$ \\
\hline Well drilling, Well 32-3 ${ }^{(a)}$ & $105-11$ & $120-125$ & 1987 & $15 \mathrm{~m}(49 \mathrm{ft})$ \\
\hline Well drilling, Well 33-29(a) & $89-91$ & & 1987 & $15 \mathrm{~m}(49 \mathrm{ft})$ \\
\hline Pile driver $^{(a)}$ & $118-119$ & & 1981 & $1.5 \mathrm{~m}(5 \mathrm{ft})$ \\
\hline Tank farm filter building ${ }^{(a)}$ & 86 & & 1976 & $9.0 \mathrm{~m}(30 \mathrm{ft})$ \\
\hline
\end{tabular}


This page intentionally left blank 


\subsection{Occupational Health and Safety}

\section{J.P. Duncan}

This section describes worker health and safety experience at the Hanford Site, for use in comparing and estimating projected effects of proposed activities evaluated in NEPA documents. Information is presented on industrial accident and illness experience as well as worker exposure to radiation.

\subsubsection{Industrial Illness and Injury Experience at the Hanford Site}

Total occupational work hours at the Hanford Site for the 5-year period, 1999-2003, were 135,087,857 hours, or about 78,000 worker-years, based on 1735 hours of project-related labor per DOE worker-year. The DOE records occupational injuries and illnesses in four categories pertinent to National Environmental Policy Act analysis. Total Recordable Cases (TRC) are work-related deaths, illnesses, or injuries resulting in loss of consciousness, restriction of work or motion, transfer to another job, or requiring medical treatment beyond first aid. Lost Workday Cases (LWC) represent the number cases recorded resulting in days away from work or days of restricted work activity, or both, for affected employees. Lost Workdays (LWD) are the total number of workdays (consecutive or not), after the day of injury or onset of illness, during which employees were away from work or limited to restricted work activity because of an occupational injury or illness. Fatalities are the number of occupationally related deaths (DOE 2004a).

Occupational injury and illness incidence rates for the Hanford Site Office of River Protection showed an increase from 1999 through 2000, with rates ranging from 2.6 cases per 200,000 worker hours (100 worker years) during 1999 to 3.1 cases during 2000 (Figure 4.8-1). Rates dropped to 1.7 cases per 200,000 worker hours in 2001. Due to recordkeeping requirement changes, 2002 and 2003 data are not directly comparable to previous years (DOE 2004a). Data for 2002 and 2003 indicate the occupational injury and illness incidence rates for the Office of River Protection dropped from 1.7 to 1.1 cases per 200,000 worker hours. 


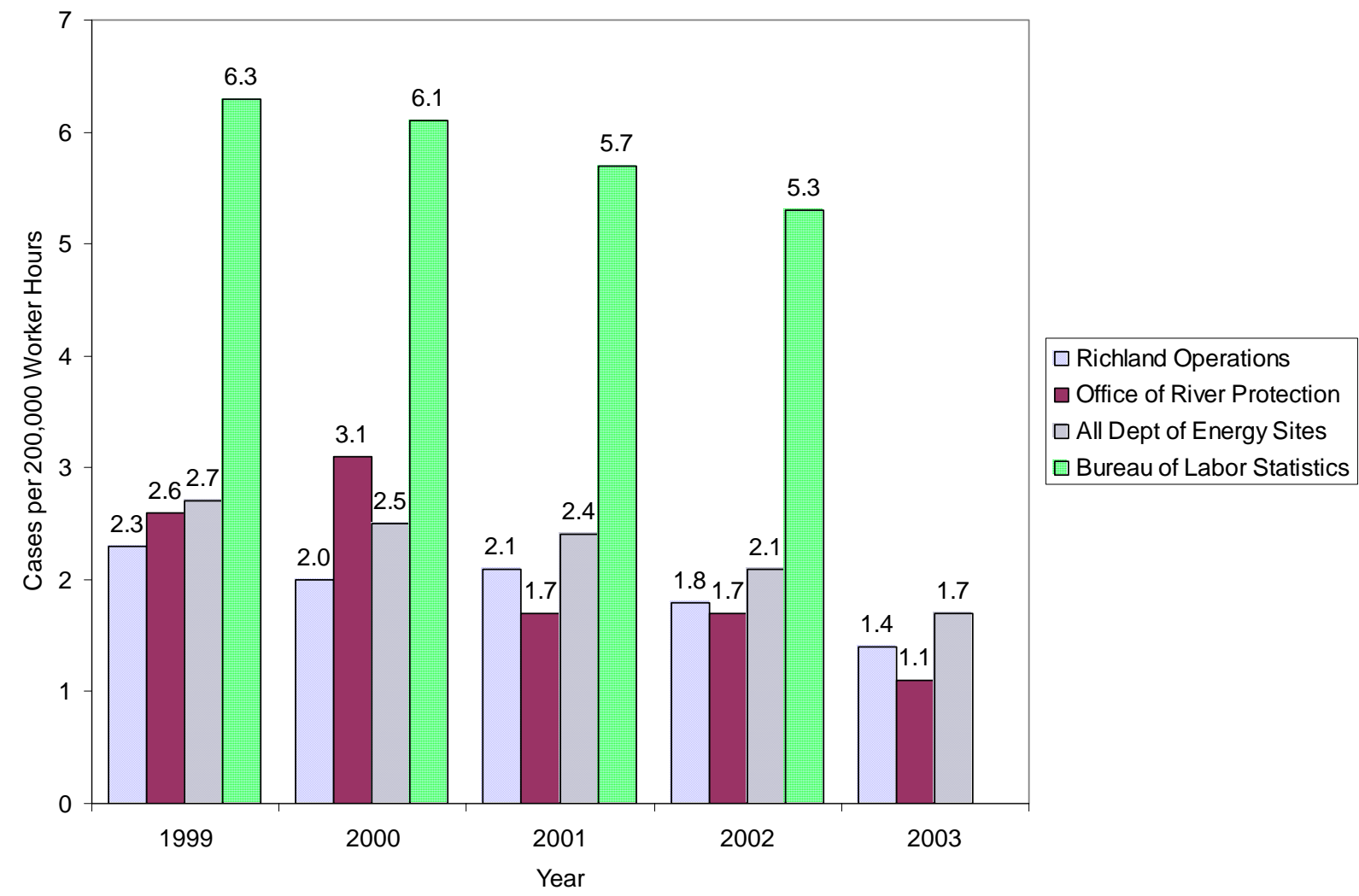

Figure 4.8-1. Occupational Injury and Illness Total Recordable Case Rates at the Hanford Site, Washington, Compared to Department of Energy and Private Industry (Note: Due to recordkeeping requirement changes, 2002 and 2003 data are not comparable to prior years) (DOE 2004a).

Occupational injury and illness incidence rates for Richland Operations declined from 2.3 cases per 200,000 worker hours during 1999 to 2.0 cases in 2000, increasing slightly during 2001 to 2.1 cases. Rates for 2002 and 2003 decreased from 1.8 to 1.4 cases per 200,000 worker hours (DOE 2004a).

Occupational injury and illness incidence rates for all DOE sites demonstrate similar annual decreases, ranging from 2.7 cases per 200,000 worker hours during 1999 to 2.4 cases in 2001. Data for 2002 and 2003 decreased from 2.1 to 1.7 cases per 200,000 worker hours (DOE 2004a).

Over the 5-yr period from 1999 to 2003 rates on the Hanford Site averaged 2.0 cases per 200,000 worker hours, whereas the incidence rate for all DOE sites averaged slightly higher, at 2.3 cases per 200,000 worker hours (DOE 2004a). Both the Hanford Site and DOE-wide average TRC rates were well below the Bureau of Labor Statistics (BLS) rates for U.S. private industry of 5.9 cases per 200,000 worker hours during the same period (BLS 2004).

During the 5-yr period from 1999-2003, Hanford Site TRC and LWC rates were somewhat lower than those for all DOE sites, whereas the private sector was consistently higher (Table 4.8-1). Average LWD rates for Hanford's Office of River Protection for the 1999 to 2003 period were higher than Richland Operations and DOE-wide rates. There were no fatalities at the Hanford Site during the 1999 to 2003 period (DOE 2004a). 
Table 4.8-1. Occupational Injury and Illness Incidence Rates, and Fatality Counts for Department of Energy Facilities and Private Industry. ${ }^{\text {(a) }}$ (Note: Due to recordkeeping requirement changes, 2002 and 2003 data are not comparable to prior years) (DOE 2004a and BLS 2004).

\begin{tabular}{|c|c|c|c|c|c|c|c|c|c|c|c|c|c|c|c|c|c|c|c|c|}
\hline & \multicolumn{5}{|c|}{ Total Recordable Cases } & \multicolumn{5}{|c|}{ Lost Work Cases } & \multicolumn{5}{|c|}{ Lost Work Days } & \multicolumn{5}{|c|}{ Fatalities } \\
\hline & 1999 & 2000 & 2001 & 2002 & 2003 & 1999 & 2000 & 2001 & 2002 & 2003 & 1999 & 2000 & 2001 & 2002 & 2003 & 1999 & 2000 & 2001 & 2002 & 2003 \\
\hline $\begin{array}{l}\text { Bureau of } \\
\text { Labor } \\
\text { Statistics }\end{array}$ & 6.3 & 6.1 & 5.7 & 5.3 & NA & 3.0 & 3.0 & 2.8 & 2.8 & NA & NA & NA & NA & NA & NA & 5488 & 5347 & 5281 & 4970 & NA \\
\hline $\begin{array}{l}\text { 1999-2002 } \\
\text { average }\end{array}$ & \multicolumn{5}{|c|}{5.9} & \multicolumn{5}{|c|}{2.9} & \multicolumn{5}{|c|}{ NA } & \multicolumn{5}{|c|}{5272} \\
\hline $\begin{array}{l}\text { U.S. } \\
\text { Department of } \\
\text { Energy }\end{array}$ & 2.7 & 2.5 & 2.4 & 2.1 & 1.7 & 1.2 & 1.1 & 1.0 & 1.0 & 0.7 & 45.1 & 36.0 & 27.5 & 40.4 & 25.6 & 1 & 4 & 0 & 1 & 0 \\
\hline $\begin{array}{l}\text { 1999-2003 } \\
\text { average }\end{array}$ & \multicolumn{5}{|c|}{2.3} & \multicolumn{5}{|c|}{1} & \multicolumn{5}{|c|}{34.9} & \multicolumn{5}{|c|}{1.2} \\
\hline $\begin{array}{l}\text { DOE Office of } \\
\text { River } \\
\text { Protection, } \\
\text { Hanford Site }\end{array}$ & 2.6 & 3.1 & 1.7 & 1.7 & 1.1 & 1.1 & 1.1 & 0.5 & 0.8 & 0.7 & 68.7 & 55.5 & 10.1 & 53.9 & 32.3 & 0 & 0 & 0 & 0 & 0 \\
\hline $\begin{array}{l}\text { 1999-2003 } \\
\text { average }\end{array}$ & \multicolumn{5}{|c|}{2.0} & \multicolumn{5}{|c|}{0.8} & \multicolumn{5}{|c|}{44.1} & \multicolumn{5}{|c|}{0} \\
\hline $\begin{array}{l}\text { DOE Richland } \\
\text { Operations } \\
\text { Office, } \\
\text { Hanford Site }\end{array}$ & 2.3 & 2.0 & 2.1 & 1.8 & 1.4 & 1.1 & 0.8 & 0.8 & 1.0 & 0.8 & 52.6 & 32.2 & 26.3 & 45.9 & 44.0 & 0 & 0 & 0 & 0 & 0 \\
\hline $\begin{array}{l}\text { 1999-2003 } \\
\text { average }\end{array}$ & \multicolumn{5}{|c|}{1.9} & \multicolumn{5}{|c|}{0.9} & \multicolumn{5}{|c|}{40.2} & \multicolumn{5}{|c|}{0} \\
\hline
\end{tabular}




\subsubsection{Occupational Radiation Exposure at the Hanford Site}

DOE's Office of Safety and Health reports occupational radiation exposure data for all monitored DOE employees, contractors, subcontractors, and members of the public associated with DOE facilities. The number of workers monitored during the 5-yr period, 1999-2003, at the Hanford Site ranged from 10,048 to 11,310 , for a total of 53,090 worker-years of monitored exposure. Waste processing and management facility employees on the Hanford Site, monitored for the same period, represented approximately 12 percent of the site's monitored workers, a total of 6180 worker-years of exposure (DOE 2004b).

DOE has established dose limits in order to control radiation exposures. Doses are expressed as Total Effective Dose Equivalent (TEDE), which is defined as the sum of the dose from radiation sources internal and external to the body, reported in units of rem or mrem. The regulatory limit for an individual worker is $5000 \mathrm{mrem}$ (50 mSv) per year TEDE (10 CFR 835). A DOE Administrative Control Level (ACL) of 2000 mrem (20 mSv) per year TEDE has been established for all DOE workers to maintain doses well below the regulatory limit (DOE 1999c). There were no individual worker doses in excess of the 2000 mrem ( $20 \mathrm{mSv}$ ) per year TEDE ACL or the 5000 mrem (50 mSv) per year TEDE regulatory limit at the Hanford Site during the period 1999-2003 (DOE 2004b).

Measurable dose is used to report the dose for individuals whose TEDE is statistically greater than background measurments. Twenty-one percent of the total monitored Hanford Site employees and 28\% of the waste processing and management facility employees had measurable doses during the 1999-2003 period. The average measurable dose for all monitored waste processing and management facility employees decreased 44\% from 134 to $59 \mathrm{mrem} / \mathrm{yr}$ (1.34 to $0.59 \mathrm{mSv} / \mathrm{yr}$ ) TEDE for the period 1999 to 2001, but has increased to $93 \mathrm{mrem} / \mathrm{yr}(0.93 \mathrm{mSv} / \mathrm{yr}) \mathrm{TEDE}$ in 2003, an increase of 58\% from 2001 to 2003. The average dose for all monitored Hanford workers increased from $90 \mathrm{mrem} / \mathrm{yr}$ [0.90 mSv/yr] TEDE during 1999 to $107 \mathrm{mrem} / \mathrm{yr}$ [1.07 mSv/yr] TEDE in 2003, an increase of 19\% (Figure 4.8-2)(DOE 2004b).

Collective dose, an indicator of the overall workforce radiation exposure, is the sum of the dose received by all individual workers with measurable dose and is expressed in units of person-rem. (For example, a dose of 1 rem to each of 10 workers would result in a collective dose of 10 person-rem.) The collective dose at the Hanford Site decreased for waste processing and management facility employees from 64 to 17 person-rem/yr for the period 1999 to 2001, a 77\% decline; however, it increased to 34 person-rem/yr in 2003. The collective dose for all workers for the 1999-2003 time period increased 54\%, from 182 person-rem/yr to 281 person-rem/yr.

Radiation exposure data for the period 1999-2003 indicate the total number of individuals monitored on the Hanford Site has generally decreased, while the number of individuals with measurable dose has increased (Table 4.8-2) (DOE 2004b). The 5-yr average occupational dose for workers with measurable dose was $103 \mathrm{mrem} / \mathrm{yr}$ (10.3 mSv/yr) for all Hanford workers and $96 \mathrm{mrem} / \mathrm{yr}$ ( $9.6 \mathrm{mSv} / \mathrm{yr})$ for waste management facility workers, well below the established ACL of $2000 \mathrm{mrem} / \mathrm{yr}$ ( $20 \mathrm{mSv} / \mathrm{yr}$ ). 


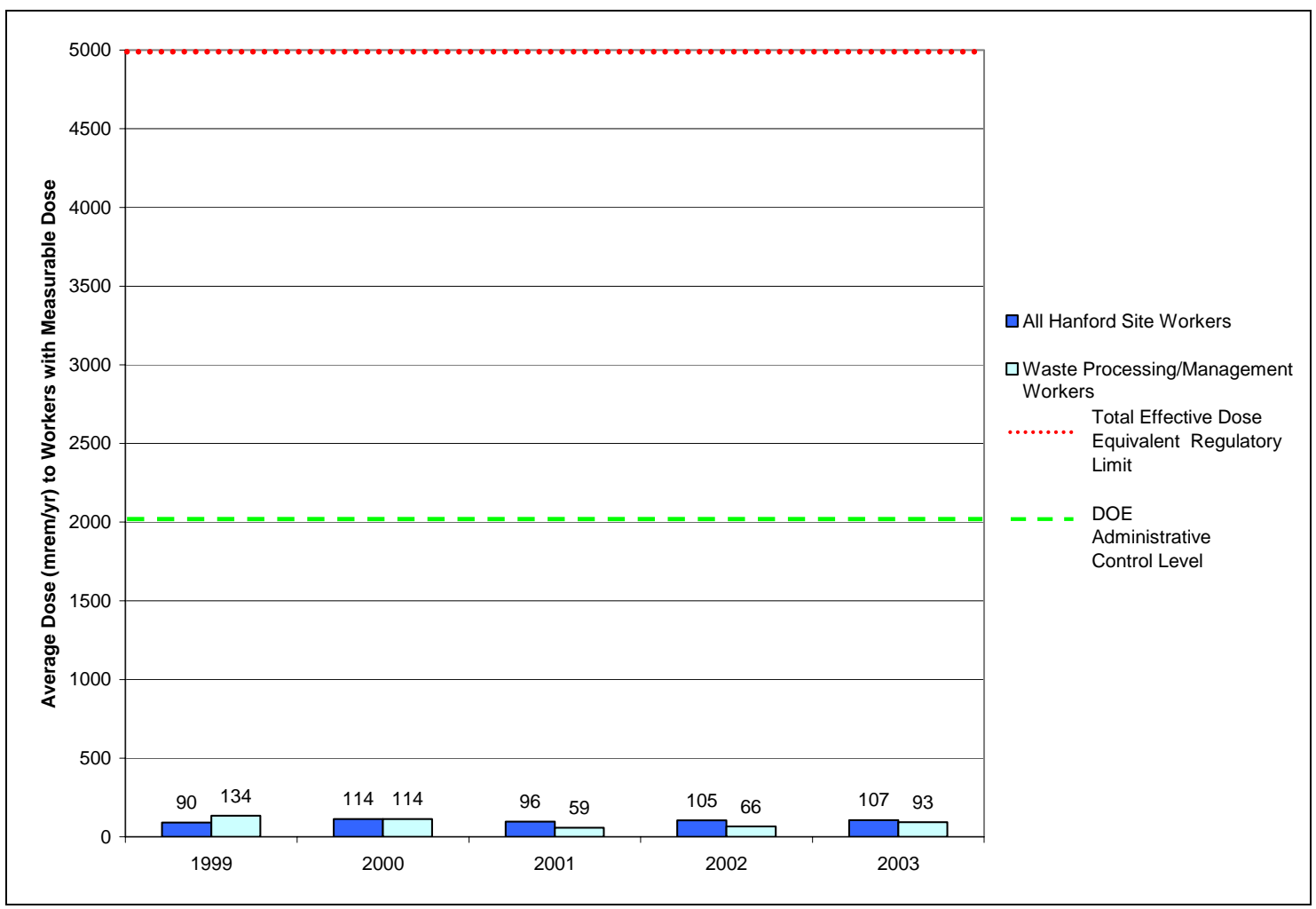

Figure 4.8-2. Average Measureable Dose (mrem/yr) to Hanford Site, Washington, 1999-2003 (DOE 2004b) $(1 \mathrm{mrem}=0.01 \mathrm{mSv})$

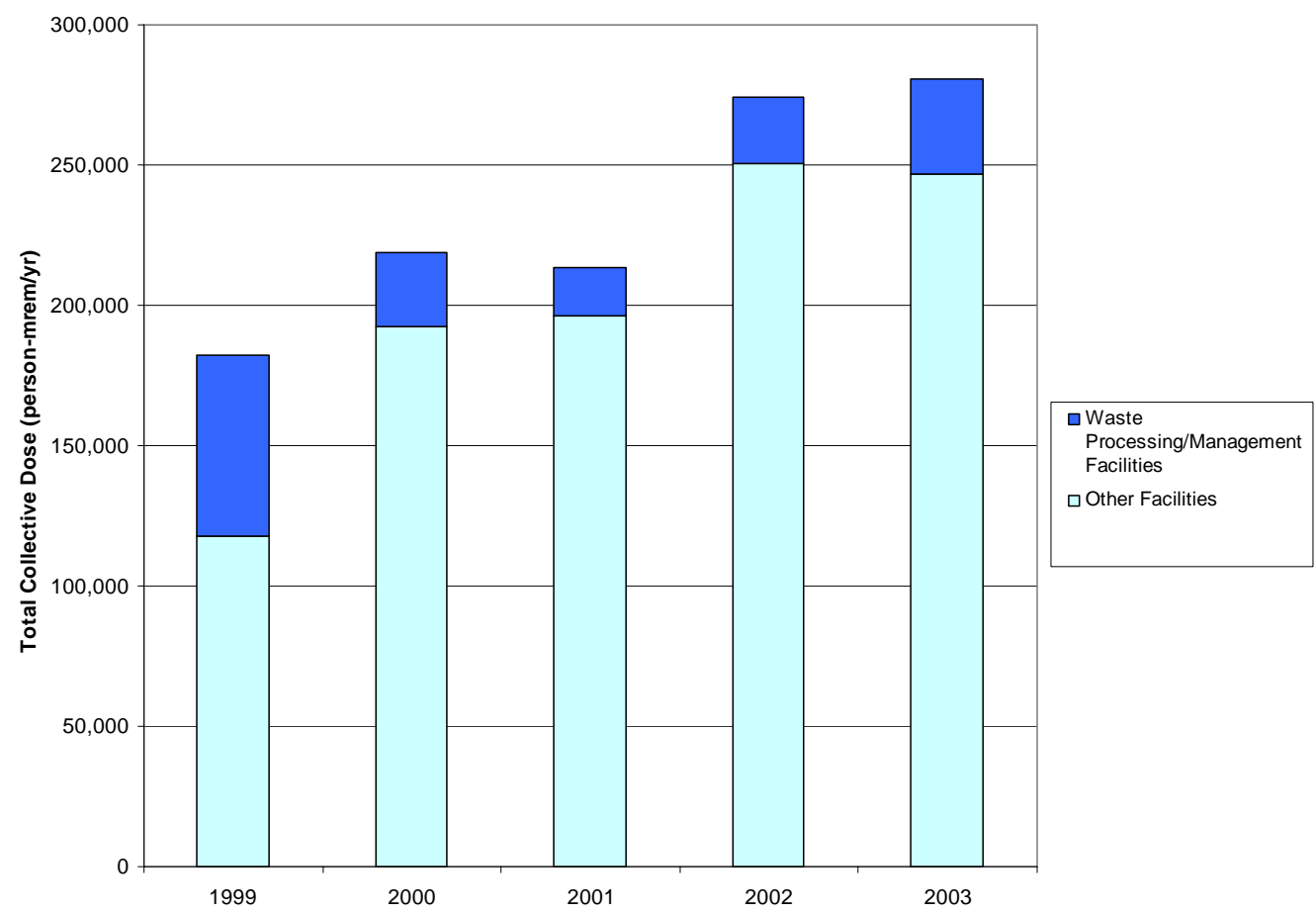

Figure 4.8-3. Collective Operational Dose (person-mrem/yr) at the Hanford Site, Washington, 1999-2003 (DOE 2004b). (1 mrem = $0.01 \mathrm{mSv})$ 
Table 4.8-2. Radiation Exposure Data for the Hanford Site, Washington, 1999-2003 (DOE 2004b) $(1 \mathrm{mrem}=0.01 \mathrm{mSv})$

\begin{tabular}{|c|c|c|c|c|c|}
\hline Year & $\begin{array}{c}\text { Total Number } \\
\text { Monitored }\end{array}$ & $\begin{array}{c}\text { Number with } \\
\text { Measured Dose }\end{array}$ & $\begin{array}{c}\text { Percent } \\
\text { with Dose } \\
>0 \\
\end{array}$ & $\begin{array}{l}\text { Total Collective } \\
\text { Dose (TEDE) } \\
\text { (Person-mrem/yr) }\end{array}$ & \begin{tabular}{|c} 
Average Dose to \\
Workers (mrem) \\
$($ Dose $>0)$
\end{tabular} \\
\hline \multicolumn{6}{|c|}{$\begin{array}{ll}\text { Hanford Site } \\
\end{array}$} \\
\hline 2003 & 10,564 & 2,626 & $25 \%$ & 280,781 & 107 \\
\hline 2002 & 10,669 & 2,611 & $24 \%$ & 274,384 & 105 \\
\hline 2001 & 10,499 & 2,219 & $21 \%$ & 213,630 & 96 \\
\hline 2000 & 10,048 & 1,923 & $19 \%$ & 219,032 & 114 \\
\hline 1999 & 11,310 & 2,013 & $18 \%$ & 182,000 & 90 \\
\hline \multicolumn{6}{|c|}{ Cumulative Totals } \\
\hline 1999-2003 & 53,090 & 11,392 & $21 \%$ & $1,169,827$ & 103 \\
\hline \multicolumn{6}{|c|}{ "Waste Processing/Management Facility } \\
\hline 2003 & 1,203 & 366 & $30 \%$ & 34,141 & 93 \\
\hline 2002 & 1,225 & 360 & $29 \%$ & 23,936 & 66 \\
\hline 2001 & 1,216 & 294 & $24 \%$ & 17,277 & 59 \\
\hline 2000 & 938 & 234 & $25 \%$ & 26,722 & 114 \\
\hline 1999 & 1,598 & 479 & $30 \%$ & 64,258 & 134 \\
\hline \multicolumn{6}{|c|}{ Cumulative Totals } \\
\hline 1999-2003 & 6,180 & 1,733 & $28 \%$ & 166,334 & 96 \\
\hline
\end{tabular}




\section{References}

10 CFR 835. Occupational Radiation Protection. U.S. Code of Federal Regulations. Online at: http://www.gpoaccess.gov/cfr/index.html.

40 CFR 50. National Primary and Secondary Ambient Air Quality Standards. U.S. Code of Federal Regulations.

40 CFR 61. National Emission Standards for Hazardous Air Pollutant. U.S. Code of Federal Regulations.

40 CFR 81.348. Designation of Areas for Air Quality Planning Purposes, Washington, Attainment Status Designations. U.S. Environmental Protection Agency.

40 CFR 81.434. Designation of Areas for Air Quality Planning Purposes, Washington, Identification of Mandatory Class I Federal Areas Where Visibility Is an Important Value. U.S. Environmental Protection Agency.

40 CFR 201-211. Subchapter G. Protection of Environment: Noise Abatement Programs. U.S. Code of Federal Regulations.

50 CFR 17. Wildlife and Fisheries. United States Fish and Wildlife Service, Department of the Interior, Endangered and Threatened Wildlife and Plants. U.S. Code of Federal Regulations.

16 USC 470, et seq. National Historic Preservation Act (NHPA) of 1966. Online at: http://www4.law.cornell.edu

16 USC 470aa, et seq. Archaeological Resources Protection Act of 1979. Online at: http://www4.law.cornell.edu

25 USC 3001, et seq. Native American Graves Protection and Repatriation Act. Online at: http://www4.law.cornell.edu

42 USC 6901, et seq. Resource Conservation and Recovery Act (RCRA) of 1976. Online at: http://www4.law.cornell.edu

42 USC 7401. Clean Air Act. U.S. Code of Federal Regulations.

42 USC 9601, et seq. Comprehensive Environmental Response, Compensation, and Liability Act (CERCLA) of 1980. Online at: http://www4.law.cornell.edu

59 FR 7629. “Executive Order 12898: Federal Actions to Address Environmental Justice in Minority Populations and Low-income Populations.” Federal Register (February 16, 1994).

64 FR 61615. "Record of Decision: Hanford Comprehensive Land-Use Plan Environmental Impact Statement (HCP EIS).” Federal Register (November 12, 1999).

65 FR 37253. “Establishment of the Hanford Reach National Monument.” Federal Register (June 9, 2000). 
66 FR 9663. “Clean Air Act Reclassification; Wallula, Washington Particulate Matter (PM-10) Nonattainment Area.” U.S. Environmental Protection Agency.

Agnew, S.F. 1997. Hanford Tank Chemical and Radionuclide Inventories: HDW Model, Rev. 4. LAUR-96-3860. Online at: http://lib-www.lanl.gov/la-pubs/00326181.pdf

American Wind Energy Association. 2003. Washington State Wind Energy Development. Online at: http://www.awea.org/projects/washington.html

Anderson, J.D. 1990. A History of the 200 Area Tank Farms. WHC-MR-0132, Westinghouse Hanford Company, Richland, Washington.

Andrefsky, Jr., W., L.L. Hale, and D.A. Harder. 1996. 1995 WSU Archaeological Block Survey of the Hanford 600 Area. Project Report No. 29. Center for Northwest Anthropology, Department of Anthropology, Washington State University, Pullman, Washington.

BAER 2000. 24 Command Fire Burn Area Emergency Rehabilitation (BAER) Plan. Northern States Burned Area Emergency Rehabilitation Team, U.S. Department of the Interior, Washington, D.C.

Baker, V.R., and R.C. Bunker. 1985. "Cataclysmic late Pleistocene flooding from glacial Lake Missoula: A review”. Quaternary Science Reviews 4:1-41.

Bard, J.C. 1997. "Ethnographic /Contact Period (Lewis and Clark 1805 - Hanford Engineer Works 1943) of the Hanford Site, Washington.” In National Register of Historic Places Multiple Property Documentation Form - Historic, Archaeological and Traditional Cultural Properties of the Hanford Site, Washington. DOE/RL-97-02. Richland, Washington.

Bauer, H.H., J.J. Vaccaro, and R.C. Lane. 1985. Maps Showing Ground-Water Levels in the Columbia River Basalt and Overlying Materials, Spring 1983, Southeastern Washington. Water Resources Investigation Report 84-4360, U.S. Geological Survey, Tacoma, Washington.

Beak Consultants Inc. 1980. Aquatic Ecological Studies Near WNP-1, 2 and 4. August 1978-March 1980. WPPSS Columbia River Ecology Studies, Vol. 7, prepared for Washington Public Power Supply System by Beak Consultants Inc., Portland, Oregon.

Becker, J.M. 1993. A Preliminary Survey of Selected Structures on the Hanford Site for Townsend's BigEared Bat (Plecotus townsendii). PNL-8916, Pacific Northwest Laboratory, Richland, Washington.

Belnap, J., J.H. Kaltenecker, R. Rosentreter, J. Williams, S. Leonard, and D. Eldrige. 2001. Biological Soil Crusts: Ecology and Management. Technical Reference 1730-2. Bureau of Land Management, Denver, Colorado.

Benton Franklin Council of Governments (BFCOG). 2003. Major Employers in Benton, Franklin and Walla Walla Counties. Benton Franklin Council of Governments, Richland, Washington. Available URL: http://www.benton-franklin.cog.wa.us/transportation.html. (Data accessed May 21,2004).

Ben Franklin Transit (BFT). 2003. Comprehensive Annual Financial Report. May 2004. Ben Franklin Transit, Richland, WA.

BFCOG (see Benton Franklin Council of Governments) 
BFT (see Ben Franklin Transit)

Bisping L.E. 2003. Hanford Site Environmental Surveillance Data Report for Calendar Year 2002. PNNL-14295 Appendix 1, Pacific Northwest National Laboratory, Richland, Washington.

Bjornstad, B.N., K.R. Fecht, and C.J. Pluhar. 2001. "Long history of Pre-Wisconsin, Ice-Age cataclysmic floods: evidence from southeastern Washington State”. Journal of Geology 109:695-713.

Brandt, C.A., C.E. Cushing, W.H. Rickard, N.A. Cadoret, and R. Mazaika. 1993. Biological Resources of the 300-FF-5 Operable Unit. WHC-SD-EN-TI-121, Westinghouse Hanford Company, Richland, Washington.

Bretz, J H., H.T.U. Smith, and G.E. Neff. 1956. “Channeled Scabland of Washington: New Data and Interpretations”. Geological Society of America Bulletin. 67:957-1049.

Brown, R.E. 1970. Interrelationships of Geologic Formations and Processes Affecting Ecology as Exposed at Rattlesnake Springs, Hanford Project. BNWL-B-29, Pacific Northwest Laboratories, Richland, Washington.

Brown, R.E. 1979. A Review of Water Well Data from the Unconfined Aquifer in the Eastern and Southern Parts of the Pasco Basin. RHO-BWI-C-56, Rockwell Hanford Operations, Richland, Washington.

Bureau of Labor Statistics (BLS). 2004. Industry Injury and Illness Data. Bureau of Labor Statistics, U.S. Department of Labor, Washington DC. Online at: http://www.bls.gov/iif/oshsum.htm

Cadwell, L.L. 1994. Wildlife Studies on the Hanford Site: 1993 Highlights Report. PNL-9380, Pacific Northwest Laboratory, Richland, Washington.

Cantrell K.J., R.J. Serne, and G.V. Last. 2002. Hanford Contaminant Distribution Coefficient Database and Users Guide. PNNL-13895, Pacific Northwest National Laboratory, Richland, Washington.

Cardenas, A., J. Lewinsohn, C. Auger, J.L. Downs, L.L. Cadwell, and R. Burrows. 1997.

Characterization of a Sagebrush (Artemisia tridentata spp. wyomingensis) Die-Off on the Hanford Site. PNNL-11673, Pacific Northwest National Laboratory, Richland, Washington.

Census (See U.S. Census Bureau).

CEQ (see Council on Environmental Quality).

Chatters, J.C. 1982. "Prehistoric Settlement and Land Use in the Dry Columbia Basin.” Northwest Anthropological Research Notes 16:125-147.

Chatters, J.C., and N.A. Cadoret. 1990. Archeological Survey of the 200-East and 200-West Areas, Hanford Site, Washington. PNL-7264, Pacific Northwest Laboratory, Richland, Washington.

Chatters, J.C., H.A. Gard, and P.E. Minthorn. 1992. Fiscal Year 1991 Report on Archaeological Surveys of the 100 Areas, Hanford Site, Washington. PNL-8143, Pacific Northwest Laboratory, Richland, Washington. 
CNSS (see Council of the National Seismic System).

Cole, C.R., M.P. Bergeron, C.J. Murray, P.D. Thorne, S.K. Wurstner, P. Rogers. 2001. Uncertainty Analysis Framework Hanford Site-Wide Groundwater Flow and Transport Model. PNNL-13641, Pacific Northwest National Laboratory, Richland, Washington.

Columbia River Inter-Tribal Fish Commission. 1994. A Fish Consumption Survey of the Umatilla, Nez Perce, Yakama, and Warm Springs Tribes of the Columbia River Basin. CRITFC Technical Report No. 94-3, Portland, Oregon.

Connelly, M.P., B.H. Ford, and J.V. Borghese. 1992a. Hydrogeologic Model for the 200 West Groundwater Aggregate Area. WHC-SD-EN-TI-014, Rev. 0, Westinghouse Hanford Company, Richland, Washington.

Connelly, M.P., B.H. Ford, J.W. Lindberg, S.J. Trent, C.D. Delaney, and J.V. Borghese. 1992b. Hydrogeologic Model for the 200 East Groundwater Aggregate Area. WHC-SD-EN-TI-019, Westinghouse Hanford Company, Richland, Washington.

Coopey, R.W. 1953. The Abundance of the Principal Crustacea of the Columbia River and the Radioactivity they Contain. HW-251, Hanford Atomic Products Operation, Richland, Washington.

Corps (see U.S. Army Corps of Engineers).

Council on Environmental Quality (CEQ). 1997. Environmental Justice. Guidance Under the National Environmental Policy Act. Executive Office of the President, Washington, D.C.

Council of the National Seismic System (CNSS). 2001. On-line Earthquake Catalog. Council of the National Seismic System. Online at: http://www.quake.geo.berkeley.edu/cnss

CRITFC (see Columbia River Inter-Tribal Fish Commission).

Cushing, C.E., Jr. 1967a. "Concentration and Transport of ${ }^{32} \mathrm{P}$ and ${ }^{65} \mathrm{Z}$ by Columbia River Plankton.” Limnology and Oceanography 12:330-332.

Cushing, C.E., Jr. 1967b. "Periphyton Productivity and Radionuclide Accumulation in the Columbia River, Washington, USA.” Hydrobiologia 29:125-139.

Cushing, C.E., and E.G. Wolf. 1982. “Organic Energy Budget of Rattlesnake Springs, Washington.” American Midland Naturalist 107(2): 404-407.

Cushing, C.E., and E.G. Wolf. 1984. "Primary Production in Rattlesnake Springs, a Cold Desert SpringStream.” Hydrobiologia 114:229-236.

Cushing, C.E., C.D. McIntire, J.R. Sedell, K.W. Cummins, G.W. Minshall, R.C. Petersen, and R.L. Vannote. 1980. "Comparative Study of Physical-Chemical Variables of Streams Using Multivariate Analyses.” Arch. Hydrobiologia 89(3):343-352.

Daubenmire, R. 1970. Steppe Vegetation of Washington. Technical Bulletin 62, Experimental Station, Washington State University, Pullman, Washington. 
Dauble, D.D., and D.G. Watson. 1990. Spawning and Abundance of Fall Chinook Salmon (Oncorhynchus tshawytscha) in the Hanford Reach of the Columbia River, 1948-1988. PNL-7289, Pacific Northwest Laboratory, Richland, Washington.

Dauble, D.D., and D.G. Watson. 1997. Status of Fall Chinook Salmon Populations in the Mid Columbia River, 1948-1992. North American Journal of Fisheries Management 17: 283-300.

Daugherty, R.D. 1952. “Archaeological Investigations of O’Sullivan Reservoir, Grant County, Washington.” American Antiquity 17: 274-278.

Davis, J.J., and C.L. Cooper. 1951. Effect of Hanford Pile Effluent upon Aquatic Invertebrates in the Columbia River. HW-20055, Hanford Works, Richland, Washington.

DOC (see U.S. Department of Commerce).

DOE (see U.S. Department of Energy).

DOI (see U.S. Department of the Interior).

DOL (see U.S. Department of Labor Employment and Training Administration).

Dorian, J.J., and V.R. Richards. 1978. Radiological Characterization of the Retired 100 Areas. UNI946, United Nuclear Industries, Inc., Richland, Washington.

Downs, J.L., W.H. Rickard, C.A. Brandt, L.L. Cadwell, C.E. Cushing, D.R. Geist, R.M. Mazaika, D.A. Neitzel, L.E. Rogers, M.R. Sackschewsky, and J.J. Nugent. 1993. Habitat Types on the Hanford Site: Wildlife and Plant Species of Concern. PNL-8942, Pacific Northwest Laboratory, Richland, Washington.

Drost, B.W., K.M. Schurr, and W.E. Lum II. 1989. Selected Ground-Water Information for the Pasco Basin and Adjacent Areas, Washington, 1986-1989. Open-File Report 89-228, U.S. Geological Survey, Tacoma, Washington.

Drucker, P. 1948. Appraisal of the Archaeological Resources of the McNary Reservoir, OregonWashington. Report on file, Columbia Basin Project, River Basin Survey, Smithsonian Institution, Washington, D.C.

Eberhardt, L.E., R.E. Anthony, and W.H. Rickard. 1989. "Survival of Juvenile Canada Geese during the Rearing Period.” Journal of Wildlife Management 53:372-377.

Ecology. (See Washington State Department of Ecology).

EIA (see Energy Information Administration)

Emery, R.M., and M.C. McShane. 1978. Comparative Ecology of Nuclear Waste Ponds and Streams on the Hanford Site. PNL-2499, Pacific Northwest Laboratory, Richland, Washington.

Emery, R.M., and M.C. McShane. 1980. "Nuclear Waste Ponds and Streams on the Hanford Site: An Ecological Search for Radiation Effects." Health Physics 38:787-809.

Energy Information Administration (EIA). 2004. Annual Energy Outlook 2004 with Projections to 2025. DOE/EIA-0383(2004), Washington, DC. January 2004. 
ERDA (see U.S. Energy Research and Development Administration).

ERTEC. 1981. Cultural Resources Survey and Exploratory Excavations for the Skagit-Hanford Nuclear Power Project. ERTEC Northwest, Seattle, Washington.

Evans, J. R., M. P. Lih, and P. W. Dunwiddie (eds.). 2003. Biodiversity Studies of the Hanford Site, Final Report: 2002-2003. Prepared for the U.S. Department of Energy and U.S. Fish and Wildlife Service, Hanford Reach National Monument, in partial fulfillment of federal grant DE-FG-0602RL14344, by The Nature Conservancy, Seattle Washington.

Fayer M.J., and J.E. Szecsody. 2004. Recharge Data Package for the 2005 Integrated Disposal Facility Performance Assessment. PNNL-14744, Pacific Northwest National Laboratory, Richland, Washington.

Fayer, M.J., and T.B. Walters. 1995. Estimated Recharge Rates at the Hanford Site. PNL-10285, Pacific Northwest National Laboratory, Richland, Washington.

Fayer M.J., G.W. Gee, M.L. Rockhold, M.D. Freshley, and T.B. Walters. 1996. "Estimating Recharge Rates for a Groundwater Model using a GIS.” Journal of Environmental Quality 25: 510-518.

Fecht, K.R., S.P. Reidel, and A.M. Tallman. 1987. Paleodrainage of the Columbia River System on the Columbia Plateau of Washington State - A Summary. Washington Division of Geology and Earth Resources Bulletin 77.

Fecht, K.R., K.A. Lindsey, B.N. Bjornstad, D.G. Horton, G.V. Last, and S.P. Reidel. 1998. An Atlas of Clastic Injection Dikes of the Pasco Basin and Vicinity. BHI-01103. Online at: http://www.erc.rl.gov/ pgs/readroom/BHI/01103/Intro.pdf

Fecht, K.R., K.A. Lindsey, B.N. Bjornstad, D.G. Horton, G.V. Last, and S.P. Reidel. 1999. Clastic Injection Dikes of the Pasco Basin and Vicinity - Geologic Atlas Series. BHI-01103, Rev. 0. Online at: http://www.erc.rl.gov/ pgs/ClasticDikes.pdf

Fitzner, R.E., and R.H. Gray. 1991. "The Status, Distribution, and Ecology of Wildlife on the U.S. DOE Hanford Site: A Historical Overview of Research Activities.” Environ. Monit. Assess. 18:173-202.

Freshley, M.D., and M.J. Graham. 1988. Estimation of Ground-Water Travel Time at the Hanford Site: Description, Past Work, and Future Needs. PNL-6328, Pacific Northwest National Laboratory, Richland, Washington.

Gaines, W.E. 1987. Secondary Production of Benthic Insects in Three Cold Desert Streams. PNL-6286, Pacific Northwest Laboratory, Richland, Washington.

Gaines, W.L., C.E. Cushing, and S.D. Smith. 1992. "Secondary Production Estimates of Benthic Insects in Three Cold Desert Streams.” Great Basin Naturalist 52(1):11-24.

Gee, G.W., M.J. Fayer, M.L. Rockhold, and M.D. Campbell. 1992. "Variations in Recharge at the Hanford Site." Northwest Science 66:237-250.

Geomatrix. 1994. Probabilistic Seismic Hazard Assessment DOE Hanford Site, Washington. Prepared for Westinghouse Hanford Company. WHC-SD-W236A-TI-002, Westinghouse Hanford Company, Richland, Washington. 
Geomatrix. 1996. Probabilistic Seismic Hazard Analysis DOE Hanford Site, Washington. Prepared for Westinghouse Hanford Company. WHC-SD-W236A-TI-002, Rev. 1, Westinghouse Hanford Company, Richland, Washington.

Gephart, R.E. 1999. A Short History of Plutonium Production and Nuclear Waste Generation, Storage, and Release at the Hanford Site. PNNL-SA-32152, Pacific Northwest National Laboratory,

Richland, Washington.

Gephart, R.E., P.A. Eddy, R.C. Arnett, and G.A. Robinson. 1976. Geohydrologic Study of the West Lake Basin. ARH-CD-775, Atlantic Richfield Hanford Company, Richland, Washington.

Gilmore, T.J., D.R. Newcomer, S.K. Wurstner, and F.A. Spane Jr. 1992. Calculation of Groundwater Discharge to the Columbia River in the 100-N Area. PNL-8057, Pacific Northwest Laboratory, Richland, Washington.

Glantz, C.S., M.N. Schwartz, K.W. Burk, R.B. Kasper, M.W. Ligotke, and P.J. Perrault. 1990.

Climatological Summary of Wind and Temperature Data for the Hanford Meteorology Monitoring

Network. PNL-7471, Pacific Northwest Laboratory, Richland, Washington.

Graham, M.J., M.D. Hall, S.R. Straight, and W.R. Brown. 1981. Hydrology of the Separations Area.

RHO-ST-42, Rockwell Hanford Operations, Richland, Washington.

Graham, M.J., G.V. Last, and K.R. Fecht. 1984. An Assessment of Aquifer Intercommunication with B Pond-Gable Mountain Pond Area of the Hanford Site. RHO-RE-ST-12P, Rockwell Hanford Operations, Richland, Washington.

Gray, R.H., and D.D. Dauble. 1977. "Checklist and Relative Abundance of Fish Species from the Hanford Reach of the Columbia River.” Northwest Science 51:208-215.

Greene, G.S. 1975. Prehistoric Utilization of the Channeled Scablands of Eastern Washington. Ph.D. Dissertation, Department of Anthropology, Washington State University, Pullman, Washington.

Greengo, R.E. 1982. Studies in Prehistory: Priest Rapids and Wanapum Reservoir Areas, Columbia River, Washington. Department of Anthropology, University of Washington, Seattle, Washington.

Hajek, B.F. 1966. Soil Survey: Hanford Project in Benton County, Washington. BNWL-243, Pacific Northwest Laboratories, Richland, Washington.

Hale, L.L., and D.W. Harvey. 2002. “8.3. Cultural Resources,” In Poston, T.M. et al. Hanford Site Environmental Report for Calendar Year 2001. PNNL-13190. Pacific Northwest National Laboratory, Richland, Washington.

Hall, J.A. (ed.). 1998. Biodiversity Inventory and Analysis of the Hanford Site, 1997 Annual Report. The Nature Conservancy of Washington, Seattle, Washington.

Hanlon, B.M. 2001. Waste Tank summary Report for Month Ending January 31, 2001. HNF-EP-0182154. Online at: http://www.doe.gov/bridge

Hanson, W.C., and R.L. Browning. 1959. "Nesting Studies of Canada Geese on the Hanford Reservation, 1953-1956.” Journal of Wildlife Management 23:129-137. 
Harris, C.M. 1991. Introduction Handbook of Acoustical Measurements and Noise Control. Third edition. Acoustical Society of America.

Harris, S.G., and B.L. Harper. 1997. “A native American Exposure Sceanrio”. Risk Analysis 17(6): 789795.

Hartman, M.J., ed. 2000. Hanford Site Groundwater: Setting, Sources, and Methods. PNNL-13080. Online at: http://hanford-site.pnl.gov/groundwater/reports/gwset99/html/start1.htm

Hartman, M.J., and K.A. Lindsey. 1993. Hydrogeology of the 100-N Area, Hanford Site, Washington. WHC-SD-EN-EV-027, Rev. 0, Westinghouse Hanford Company, Richland, Washington.

Hartman, M.J., and R.E. Peterson. 1992. Hydrologic Information Summary for the Northern Hanford Site. WHC-SD-EN-TI-023, Westinghouse Hanford Company, Richland, Washington.

Hartman, M.J., L.F. Morasch, and W.D. Webber (eds.). 2004. Hanford Site Groundwater Monitoring for Fiscal Year 2003. PNNL-14548, Pacific Northwest National Laboratory, Richland, Washington.

Hartshorn D.C., S.P. Reidel, and A.C. Rohay. 2002. Annual Hanford Seismic Report for Fiscal Year 2002. PNNL-11557-20, Pacific Northwest National Laboratory, Richland, WA.

Hays, W.H., and R.L. Schuster. 1987. Maps Showing Ground Failure Hazards in the Columbia River Valley between Richland and Priest Rapids Dam, South-Central Washington. U.S. Geological Survey.

Hewes, G.W. 1947. Aboriginal Use of Fishery Resources in Northwestern North America. Doctoral dissertation, University of California, Berkeley.

Hewes, G.W. 1973. "Indian Fisheries Productivity in Pre-Contact Time in the Pacific Salmon Area”. Northwest Anthropological Research Notes 7(2): 133-155.

Hoitink, D.J., K.W. Burk, J.V. Ramsdell, III, and W.J. Shaw. 2004. Hanford Site Climatological Data Summary 2003 with Historical Data . PNNL-14616, Pacific Northwest National Laboratory, Richland, Washington.

Hunn, E.S., and C.L. Bruneau. 1989. Estimations of Traditional Native American Diets in the Columbia Plateau. PNL-SA-17296-HEDR. Pacific Northwest Laboratory. Richland, Washington.

Jamison, J.D. 1982. Standardized Input for Hanford Environmental Impact Statements Part II: Site Descriptions. PNL-3509, Pt. 2, Pacific Northwest Laboratory, Richland, Washington.

Jenkins, O.P. 1922. Underground Water Supply of the Region About White Bluffs and Hanford. Bulletin No. 26, Division of Geology, State of Washington Department of Conservation and Development, Olympia, Washington.

Jensen, E.J. 1987. An Evaluation of Aquifer Intercommunication Between the Unconfined and Rattlesnake Ridge Aquifers on the Hanford Site. PNL-6313, Pacific Northwest Laboratory, Richland, Washington. 
Johansen, J.R., J. Ashley, and W.R. Rayburn. 1993. Effects of Rangefire on Soil Algal Crusts in Semiarid Shrub-Steppe of the Lower Columbia Basin and their Subsequent Recovery. Great Basin Naturalist 53(1): 73-88.

Johnson, V.G., F.N. Hodges, and S.P. Reidel. 1992. “Arid Environment Aquifers: An Example from South Central Washington.” Geological Society of America (ABS) 24(5):36.

Johnson, V.G., C.J. Chou, and J.W. Lindberg. 1995. Groundwater Monitoring and Assessment Plan for the 100-K Area Fuel Storage Basins. WHC-SD-EN-AP-174, Westinghouse Hanford Company, Richland, Washington.

Kast, G.V., E.J. Freeman, K.J. Cantrell, M.J. Fayer, G.W. Gee, W.E. Nichols, and B.N. Bjornstad. 2004. Vadose Zone Hydrogeology Data Package for the 2004 Composite Analysis. PNNL-14702, Rev. 0. Pacific Northwest National Laboratory, Richland, Washington.

Kincaid, C.T., M.P. Bergeron, C.R. Cole, M.D. Freshley, N.L. Hassig, V.G. Johnson, D.I. Kaplan, R.J. Serne, G.P. Streile, D.L. Strenge, P.D. Thorne, L.W. Vail, G.A. Whyatt, and S.K. Wurstner. 1998. Composite Analysis for Low-Level Waste Disposal in the 200 Areas Plateau of the Hanford Site. PNNL11800, Pacific Northwest National Laboratory, Richland, Washington.

Kincaid, C.T., F.M. Coony, D.L. Strenge, R.L. Aaberg, and P.W. Eslinger. 2001. "Appendix A. Inventory Data for Initial Assessment Performed with the System Assessment Capability (Rev. 0)”. In: Bergeron, M.P., E.J. Freeman, S.K. Wurstner. 2001. Addendum to Composite Analysis for Low-Level Waste Disposal in the 200 Area Plateau of the Hanford Site. PNNL-11800, Addendum 1. Pacific Northwest National Laboratory, Richland, Washington.

Kipp, K.L., and R.D. Mudd. 1973. Collection and Analysis of Pump Test Data for Transmissivity Values. BNWL-1709, Pacific Northwest Laboratories, Richland, Washington.

Krieger, H.W. 1928. “A Prehistoric Pithouse Village Site at Wahluke, Grant County, Washington.” Proc. U.S. Natl. Mus. 73:1-29.

Landeen, D. (ed.). 1996. Wetes pe m'e wes - I am of this land. [Wildlife of the Hanford Site]. Confluence Press, Lewiston, Idaho.

Landeen, D.S., A.R. Johnson, and R.M. Mitchell. 1992. Status of Birds at the Hanford Site in Southeastern Washington. WHC-EP-0402, Westinghouse Hanford Company, Richland, Washington.

Landeen, D.S., M.R. Sackschewsky, and S. Weiss. 1993. 100 Areas CERCLA Ecological Investigations. WHC-EP-0620, Westinghouse Hanford Company, Richland, Washington.

Last, G.V., B.N. Bjornstad, M.P. Bergeron, D.W. Wallace, D.R. Newcomer, J.A. Schremke, M.A. Chamness, C.S. Cline, S.P. Airhart, and J.S. Wilbur. 1989. Hydrogeology of the 200 Areas Low Level Burial Grounds - An Interim Report. PNL-6820, Pacific Northwest Laboratory, Richland, Washington.

Last, G.V., E.J. Freeman, K.J.Cantrell, M.J. Fayer, G.W. Gee, W. E. Nichols, and B.N. Bjornstad. 2004. Vadose Zone Hydrogeology Data Package for the 2004 Composite Analysis. PNNL-14702 Rev 0. Pacific Northwest Laboratory, Richland, Washington.

Leonhardy, F.C., and D.G. Rice. 1970. “A Proposed Culture Typology for the Lower Snake River Region, Southeastern Washington.” Northwest Anthropological Research Notes 4:1-29. 
Liikala, T.L. 1994. Hydrogeology Along the Southern Boundary of the Hanford Site Between the Yakima and Columbia Rivers, Washington. PNL-10094, Pacific Northwest National Laboratory, Richland, Washington.

Liikala, T.L., R.L. Aaberg, N.J. Aimo, D.J. Bates, T.J. Gilmore, E.J. Jensen, G.V. Last, P.L. Oberlander, K.B. Olsen, K.R. Oster, L.R. Roome, J.C. Simpson, S.S. Teel, and J. Westergard. 1988. Geohydrologic Characterization of the Area Surrounding the 183-H Solar Evaporation Basins. PNL-6728, Pacific Northwest Laboratory, Richland, Washington.

Lindberg, J.W. 1993a. Geology of the 100-B/C Area, Hanford Site, South-Central Washington. WHCSD-EN-TI-133, Westinghouse Hanford Company, Richland, Washington.

Lindberg, J.W. 1993b. Geology of the 100-K Area, Hanford Site, South-Central Washington. WHC-SDEN-TI-155, Westinghouse Hanford Company, Richland, Washington.

Lindsey, K.A. 1992. Geology of the Northern Part of the Hanford Site: An Outline of Data Sources and the Geologic Setting of the 100 Areas. WHC-SD-EN-TI-011, Rev. 0, Westinghouse Hanford Company, Richland, Washington.

Lindsey, K.A. 1995. Miocene- to Pliocene-Aged Suprabasalt Sediments of the Hanford Site, SouthCentral Washington. BHI-00184, Bechtel Hanford, Inc., Richland, Washington.

Lindsey, K.A. 1996. The Miocene to Pliocene Ringold Formation and Associated Deposits of the Ancestral Columbia River System, South-central Washington and North-central Oregon. Washington Division of Geology and Earth Resources Open File Report 96-8, Washington State Department of Natural Resources, Olympia, Washington.

Lindsey, K.A., and G.K. Jaeger. 1993. Geologic Setting of the 100-HR-3 Operable Unit, Hanford Site, South-Central Washington. WHC-SD-EN-TI-132, Westinghouse Hanford Company, Richland, Washington.

Link, S.O., B.D. Ryan, J.L. Downs, L.L. Cadwell, J.A. Soll, M.A. Hawke, and J. Ponzetti. 2000. "Lichens and Mosses on Shrub-steppe Soils in Southeastern Washington." Northwest Science, Vol. 74, No. 1.

LMEA (see Washington State Labor Market and Economic Analysis).

Malde, H.E. 1968. The Catastrophic Late Pleistocene Bonneville Flood in the Snake River Plain, Idaho. Professional Paper 596, U.S. Geological Survey, Washington, D.C.

McCormack, W.D., and J.M.V. Carlile. 1984. Investigation of Ground-Water Seepage from the Hanford Shoreline of the Columbia River. PNL-5289, Pacific Northwest Laboratory, Richland, Washington.

McMahon, W.J., and R.E. Peterson. 1992. Estimating Aquifer Hydraulic Properties Using the Ferris Method, Hanford Site, Washington. DOE/RL-92-64, U.S. Department of Energy, Richland, Washington.

Meinhardt, C.C., and J.C. Frostenson. 1979. Current Status of the 200 Area Ponds. RHO-CD-798, Rockwell Hanford Operations, Richland, Washington. 
Mize, A.L. 1993. Differential Utilization of Allochthonous and Autochthonous Carbon By Aquatic Insects of Two Shrub-Steppe Desert Spring-Streams: A Stable Carbon Isotope Analysis and Critique of the Method. PNL-8684, Pacific Northwest Laboratory, Richland, Washington.

Murray, C.J., D.G. Horton, A.L. Ward, and G.W. Gee. 2002. Hydrogeologic Influence of Clastic Dikes on Vadose Zone Transport. Sec. 3.3.4, p. 3.64-3.67, 3.82-3.86. In: Hanford Site Groundwater Monitoring for Fiscal Year 2001. PNNL-13788, Pacific Northwest National Laboratory, Richland, Washington.

Murray, C.J., A.L. Ward, and J.L. Wilson. 2003. Influence of Clastic Dikes on Vertical Migration of Contaminants in the Vadose Zone at Hanford. USDOE Environmental Management Science Final Report, Project 70193.

Napier, B.A., R.A. Peloquin, D.L. Strenge, and J.V. Ramsdell. 1998. GENII- The Hanford Environmental Radiation Dosimetry Software System. PNL-6584 (3 vols), Pacific Northwest National Laboratory, Richland, Washington.

Neitzel, D.A., T.L. Page, and R.W. Hanf, Jr. 1982a. “Mid-Columbia River Microflora.” J. Freshwater Ecology 1(5): 495-505.

Neitzel, D.A., T.L. Page, and R.W. Hanf, Jr. 1982b. “Mid-Columbia River Zooplankton.” Northwest Science 57:112-118.

Newcomb, R.C., J.R. Strand, and F.J. Frank. 1972. Geology and Ground-Water Characteristics of the Hanford Reservation of the U.S. Atomic Energy Commission, Washington. Professional Paper 717, U.S. Geological Survey, Washington, D.C.

Newcomer, D.R., K.D. Pohlod, and J.P. McDonald. 1991. Water-Table Elevations on the Hanford Site, 1990. PNL-7693, Pacific Northwest Laboratory, Richland, Washington.

NRC (see U.S. Nuclear Regulatory Commission).

O’Connor, J.E. 1993. “Hydrology, Hydraulics, and Geomorphology of the Bonneville Flood”. Geological Society of America Special Paper 274. 83 p.

O’Connor, J.E., and V.R. Baker. 1992. “Magnitudes and Implications of Peak Discharges from Glacial Lake Missoula”. Geological Society of America Bulletin 104:267-279.

Office of Financial Management (OFM). 2004a. Intercensal and Postcensal Estimates of County Population by Age and Sex, 1980-2003. Office of Financial Management, Forecasting Division, Olympia, Washington. Available URL: http://www.ofm.wa.gov/pop/coagemf/index.htm . (Data accessed May 21,2004).

Office of Financial Management (OFM). 2004b. Median Household Income by County: 1989 to 2001 and Forecast for 2003. Office of Financial Management, Forecasting Division, Olympia, Washington. Available at http://www.ofm.wa.gov/pop/poptrends/index.htm . (Data accessed May 21,2004).

Office of Financial Management (OFM). 2004c. Population of Cities, Towns and Counties: April 1, 2000 to April 1, 2003. Office of Financial Management, Forecasting Division, Olympia, Washington. Available URL: http://www.ofm.wa.gov/pop/poptrends/index.htm . (Data accessed May 21,2004). 
Office of Financial Management (OFM). 2004d. Washington State April 1 Housing Estimates for Cities, Towns, and Counties. Office of Financial Management, Forecasting Division, Olympia, Washington. Available URL: http://www.ofm.wa.gov/pop/housing/index.htm . (Data accessed May 21,2004).

Office of Superintendent of Public Instruction (OSPI). 2004. 2003-2004 Public and Private School Enrollment Summary (Report 1345A-by county, district, building, and ethnicity). Office of Superintendent of Public Instruction, Olympia, Washington. Available URL: http://www.k12.wa.us/dataadmin/. (Data accessed May 21,2004).

OFM (see Office of Financial Management).

OSPI (see Office of Superintendent of Public Instruction).

OTED (see Washington State Office of Trade and Economic Development).

Page, T.L., and D.A. Neitzel. 1978. "Columbia River Benthic Macrofauna and Microfauna Near WNP 1, 2, and 4: January through December 1977.” In Aquatic Ecological Studies Near WNP 1, 2, and 4, January through December 1977, WPPSS Columbia River Ecology Studies, Vol. 5, Section 4. Battelle, Pacific Northwest Laboratories, Richland, Washington.

Page, T.L., D.A. Neitzel, and R.W. Hanf. 1979. "Columbia River Benthic Macrofauna and Microflora Near WNP 1, 2, and 4: January through August 1978.” In Aquatic Ecological Studies Near WNP 1, 2, and 4, January through August 1978, WPPSS Columbia River Ecology Studies, Vol. 6, Section 4. Battelle, Pacific Northwest Laboratories, Richland, Washington.

Parker, M.B. 1986. Tales of Richland, White Bluffs and Hanford, 1805 - 1943: Before the Atomic Reserve. Ye Galleon Press, Fairfield, Washington.

Parker, P.L., and T.F. King. 1990. Guidelines for Evaluating and Documenting Traditional Cultural Properties. National Register Bulletin 38, National Park Service, Washington, D.C.

Perteet Engineering, Inc., Thomas/Lane and Associates, Inc., and SCM Consultants, Inc. 2001. The Impact of the Waste Treatment Plant Project on the Hanford Communities. Prepared by Perteet Engineering, Inc., Everett, Washington for the Hanford Communities, Richland, Washington.

Peterson, R.E. 1992. Hydrologic and Geologic Data Available for the Region North of Gable Mountain, Hanford Site, Washington. WHC-SD-EN-TI-006, Westinghouse Hanford Company, Richland, Washington.

Peterson, R.E., and V.G. Johnson. 1992. Riverbank Seepage of Groundwater Along the 100 Areas Shoreline, Hanford Site. WHC-EP-0609, Westinghouse Hanford Company, Richland, Washington.

Peterson, R.E., and M.P. Connelly. 2001. Zone of Interaction Between Hanford Site Groundwater and Adjacent Columbia River. PNNL-13674, Pacific Northwest National Laboratory, Richland, Washington.

Peterson, R.E., R.F. Raidl, and C.W. Denslow. 1996. Conceptual Site Models for Groundwater Contamination at 100-BC-5, 100-KR-4, 100-HR-3, and 100-FR-3 Operable Units. BHI-00917, Bechtel Hanford Incorporated, Richland, Washington.

PNNL Seismic Monitoring Team. 2001. Second and Third Quarter Hanford Seismic Report for Fiscal Year 2001. PNNL-11557-18, Pacific Northwest National Laboratory, Richland, Washington. 
Poston, T.M., K.R. Price, and D.R. Newcomer. 1991. An Evaluation of the Chemical, Radiological, and Ecological Conditions of West Lake on the Hanford Site. PNL-7662, Pacific Northwest Laboratory, Richland, Washington.

Poston, T.M., R.W. Hanf, R.L. Dirkes, and L.F. Morasch. 2003. Hanford Site Environmental Report for Calendar Year 2002. PNNL-13487, Pacific Northwest National Laboratory, Richland, Washington.

Poston, T.M., R.W. Hanf, R.L. Dirkes, and L.F. Morasch. 2004. Hanford Site Environmental Report for Calendar Year 2003. Pacific Northwest National Laboratory, Richland, Washington.

Price, K.R., J.M. Carlile, R.L. Dirkes, R.E. Jaquish, M.S. Trevathan, and R.K. Woodruff. 1986.

Environmental Monitoring at Hanford for 1984. Supplement. PNL-5407 Suppl. Pacific Northwest

Laboratory, Richland, Washington.

PSPL (see Puget Sound Power and Light Company).

Puget Sound Power and Light Company (PSPL). 1982. Preliminary Safety Analysis for Skagit/Hanford Nuclear Project. Amendment 29, Puget Sound Power and Light Company, Bellevue, Washington.

Ramsdell, J.V., and G.L. Andrews. 1986. Tornado Climatology of the Contiguous United States. NUREG/CR-4461, U.S. Nuclear Regulatory Commission, Washington, D.C.

RCW 70.107. Noise Control. Revised Code of Washington, Olympia, Washington.

Reidel, S.P., and P.R. Hooper. 1989. Volcanism and Tectonism in the Columbia River Flood-Basalt Province. Geological Society of America Special Paper 239, 30 technical papers.

Reidel, S.P., K.A. Lindsey, and K.R. Fecht. 1992. Field Trip Guide to the Hanford Site. WHC-MR0391. Westinghouse Hanford Company, Richland, Washington.

Reidel, S.P., N.P. Campbell, K.R. Fecht, and K.A. Lindsey. 1994. "Late Cenozoic Structure and Stratigraphy of South-central Washington.” In: Lasmanis, R. and E.S. Cheney, convenors, Regional Geology of Washington State. Washington Division of Geology and Earth Resources Bulletin 80: 159180.

Relander, C. 1956. Drummers and Dreamers. Caxton Printers, Caldwell, Idaho.

Rice, D.G. 1976. The Log Structure at White Bluffs Landing, Franklin County, Washington. Anthropological Research Manuscript Series No. 25, University of Idaho, Moscow, Idaho.

Rice, D.G. 1968a. Archaeological Reconnaissance: Ben Franklin Reservoir Area, 1968. Washington State University, Laboratory of Anthropology, Pullman, Washington.

Rice, D.G. 1968b. Archaeological Reconnaissance: Hanford Atomic Works. U.S. Atomic Energy Commission, National Park Service and Washington State University, Pullman, Washington.

Rice, D.G. 1980a. Overview of Cultural Resources on the Hanford Reservation in South Central Washington State. Report submitted to U.S. Department of Energy, Richland Operations, Richland, Washington. 
Rice, D.G. 1980b. Cultural Resources Assessment of the Hanford Reach of the Columbia River, State of Washington. U.S. Army Corps of Engineers, Seattle District, Seattle, Washington.

Rice, H.S., D.H. Stratton, and G.W. Lundeman. 1978. An Archaeological and Historic Survey of the 400 Area, Hanford Reservation. National Heritage, Inc., Pullman, Washington.

Rickard, W.H., and L.E. Rogers. 1983. "Industrial Land Use and the Conservation of Native Biota in the Shrub-Steppe Region of Western North America.” Environmental Conservation 10:205-211.

Rickard, W.H., R.E. Fitzner, and C.E. Cushing. 1981. "Biological Colonization of an Industrial Pond.” Environmental Conservation 8:241-247.

Rogers, L.E., and W.H. Rickard. 1977. Ecology of the 200 Area Plateau Waste Management Environs: A Status Report. PNL-2253, Pacific Northwest Laboratory, Richland, Washington.

Rohay, A.C. 1987. Earthquake Focal Mechanisms, Recurrence Rates and Deformation in the Columbia River Basalts. RHO-BW-SA-666 P, Rockwell Hanford Operations, Richland, Washington.

Rohay, A.C. 1989. "Earthquake Recurrence Rate Estimates for Eastern Washington and the Hanford Site.” In Proceedings, Second DOE Natural Phenomena Hazards Mitigation Conference, CONF8910192, October 3-5, 1989, Knoxville, Tennessee, sponsored by U.S. Department of Energy Headquarters, Office of Nuclear Safety, NTIS, Springfield, Virginia.

Rohay, V.J., K.J. Swett, and G.V. Last. 1994. 1994 Conceptual Model for the Carbon Tetrachloride Contamination in the 200 West Area at the Hanford Site. WHC-SD-EN-TI-248, Westinghouse Hanford Company, Richland, Washington.

Rokkan, D.J., Diediker, D.L. Dyekman, N.A. Homan, K. Rhoads, and L.H. Staven. 2003. Radionuclide Air Emission Report for the Hanford Site, Calendar Year 2002. DOE/RL-2003-19, Revision 0. U.S. Department of Energy, Richland, Washington.

Sackschewsky, M.R., and J.L. Downs. 2001. Vascular Plants of the Hanford Site. PNNL-13688. Pacific Northwest National Laboratory, Richland, WA.

Sackschewsky, M.R., C.A. Duberstein, and J.M. Becker. 2001. 200 Areas Ecological Data Compilation. Letter Report for CH2M Hill Hanford Company. Pacific Northwest National Laboratory, Richland, WA.

Schalla, R., R.W. Wallace, A.L. Aaberg, S.P. Arihart, D.J. Bates, J.V.M. Carlile, C.S. Cline, I. Dennison, M.D. Freshley, P.R. Heller, E.J. Jensen, K.B. Olsen, R.G. Parkhurst, J.T. Rieger, and E.J. Westergard. 1988. Interim, Characterization Report for the 300 Area Process Trenches. PNL-6716, Pacific Northwest Laboratory, Richland, Washington.

Schwab, G.E., R.M. Colpitts Jr., and D.A. Schwab. 1979. Spring Inventory of the Rattlesnake Hills. W.K. Summers and Associates, Inc., Socorro, New Mexico.

Serne R.J., and D.I. Kaplan. 2000. Geochemical Data Package for the Hanford Immobilized LowActivity Tank Waste Performance Assessment (ILAWPA). PNNL-13037, Rev. 1, Pacific Northwest National Laboratory, Richland, Washington. 
Serne, R.J., B.N. Bjornstad, H.T. Schaef, B.A. Williams, D.C. Lanigan, D.G. Horton, R.E. Clayton, A.V. Mitroshkov, V.L. LeGore, M.J. O’Hara, C.F. Brown, K.E. Parker, I.V. Kutnyokov, J.N. Serne, G.V. Last, S.C. Smith, C.W. Lindemeier, J.M. Zachara, and D.B. Burke. 2002. Characterization of Vadose Zone Sediment: Uncontaminated RCRA Borehole Core Samples and Composite Samples. PNNL-13757-1. Pacific Northwest National Laboratory, Richland, Washington.

Shaw, J., M. Munro-Stasuik, B. Sawyer, C. Beaney, J.-E. Lesemann, A. Musacchio, B. Rains, and R.R. Young. 1999. "The Channeled Scabland: Back to Bretz”. Geology 27:605-608.

Simpson, B.C., R.A. Corbin, and S.F. Agnew. 2001. Hanford Soil Inventory Model. BHI-01496, Bechtel Hanford, Inc., Richland, Washington.

Skaggs, R.L., and W.H. Walters. 1981. Flood Risk Analysis of Cold Creek Near the Hanford Site. RHO-BWI-C-120/PNL-4219, Rockwell Hanford Operations, Richland, Washington.

Slate, J.L. 1996. "Buried Carbonate Paleosols Developed in Pliocene-Pleistocene Deposits of the Pasco Basin, South-central Washington, U.S.A.” Quarternary International 34-36: 191-196. Published by Elsevier Science Ltd., Great Britain.

Soll, J.A., and C. Soper, eds. 1996. Biodiversity Inventory and Analysis of the Hanford Site, 1995 Annual Report. The Nature Conservancy of Washington, Seattle, Washington.

Soll, J.A., Hall, R. Pabst, and C. Soper. 1999. Biodiversity Inventory and Analysis of the Hanford Site Final Report 1994 - 1999. The Nature Conservancy of Washington. Seattle, Washington.

Spane, F.A., Jr. 1987. Fresh-Water Potentiometric Map and Inferred Flow Direction of Ground Water Within the Mabton Interbed, Hanford Site, Washington State - January 1987. SD-BWI-TI-335, Rockwell Hanford Operations, Richland, Washington.

Spane, F.A., Jr., and P.D. Thorne. 1995. Comparison of Constant-Rate Pumping Test and Slug Interference Test Results at the B-Pond Multi-Level Test Facility, Hanford Site. PNL-10835. Pacific Northwest National Laboratory, Richland, Washington.

Spane, F.A., Jr., and P.D. Thorne. 2000. Analysis of the Hydrologic Response Associated with Shutdown and Restart of the 200-ZP-1 Pump and Treat System. PNNL-13342. Pacific Northwest National Laboratory, Richland, Washington.

Spane, F.A., Jr., P.D. Thorne and D.R. Newcomer. 2001a. Results of Detailed Hydrologic Characterization Tests Fiscal Year 1999. PNNL-13378. Pacific Northwest National Laboratory, Richland, Washington.

Spane, F.A., Jr., P.D. Thorne and D.R. Newcomer. 2001b. Results of Detailed Hydrologic Characterization Tests Fiscal Year 2000. PNNL-13514. Pacific Northwest National Laboratory, Richland, Washington.

Spane, F.A., Jr., P.D. Thorne, and D.R. Newcomer. 2002. Results of Detailed Hydrologic Characterizaton Tests - Fiscal Year 2001. PNNL-14113, Pacific Northwest National Laboratory, Richland, WA.

Spier, L. 1936. Tribal Distribution in Washington. General Services in Anthropology No. 3, George Banta Publishing Co., Menasha, Wisconsin. 
Stroms, D.M., W.J. Okin, and F.W. Davis. 1997. Preserve Selection Modeling in the Columbia Plateau. University of California Santa, Barbara, Santa Barbara, California. Prepared for the Nature Conservancy. Available at http://www.biogeog.ucsb.edu/projects/tnc/tnc_report.html.

Stone, W.A., D.E. Jenne, and J.M. Thorp. 1972. Climatography of the Hanford Area. BNWL-1605, Pacific Northwest Laboratories, Richland, Washington.

Stone, W.A., J.M. Thorp, O.P. Gifford, and D.J. Hoitink. 1983. Climatological Summary for the Hanford Area. PNL-4622, Pacific Northwest Laboratory, Richland, Washington.

Swanson, D.A., J.L. Anderson, R.D. Bentley, V.E. Camp, J.N. Gardner, and T.L. Wright. 1979a. Reconnaissance Geologic Map of the Columbia River Basalt Group in Eastern Washington and Northern Idaho. Open-File Report 79-1363, U.S. Geological Survey, Washington, D.C.

Swanson, D.A., T.L. Wright, P.R. Hooper, and R.D. Bentley. 1979b. Revisions in Stratigraphic Nomenclature of the Columbia River Basalt Group. USGS Bulletin 1457, U.S. Geological Survey, Boulder, Colorado.

Swanson, L.C. 1992. Phase 1 Hydrogeologic Summary of the 300-FF-5 Operable Unit, 300 Area. WHC-SD-EN-TI-052, Rev. 0, Westinghouse Hanford Company, Richland, Washington.

Swanson, L.C., V.J. Rohay, and J.M. Faurote. 1999. Hydrogeologic Conceptual Model for the Carbon Tretrachloride and Uranium/Technitium Plumes in the 200 West Area: 1994 Through 1999 Update. BHI-01311, Rev. 0. Bechtel Hanford, Inc., Richland, Washington.

Tallman, A.M., J.T. Lillie, and K.R. Fecht. 1981. "Suprabasalt Sediments of the Cold Creek Syncline Area.” In: Subsurface Geology of the Cold Creek Syncline, eds. C.W. Myers and S.M. Price. RHOBW1-ST-14, Rockwell Hanford Operations, Richland, Washington.

TCAR (see Tri-City Association of Realtors).

Thorne, P.D. 2004. Groundwater Data Package for the 2004 Composite Analysis. Pacific Northwest National Laboratory, Richland, Washington.

Thorne, P.D., and D.R. Newcomer. 1992. Summary and Evaluation of Available Hydraulic Property Data for the Hanford Site Unconfined Aquifer System. PNL-8337, Pacific Northwest Laboratory, Richland, Washington.

Thorne, P.D., and D.R. Newcomer. 2002. Prototype Database and User's Guide of Saturated Zone Hydraulic Properties for the Hanford Site. PNNL-14058, Pacific Northwest National Laboratory, Richland, Washington.

Thorne, P.D., M.A. Chamness, F.A. Spane, Jr., V.R. Vermeul, and W.D. Webber. 1993. ThreeDimensional Conceptual Model for the Hanford Site Unconfined Aquifer System, FY 93 Status Report. PNL-8971, Pacific Northwest National Laboratory, Richland, Washington.

Thorne, P.D., M.A. Chamness, V.R. Vermeul, Q.C. MacDonald, and S.E. Schubert. 1994. ThreeDimensional Conceptual Model for the Hanford Site Unconfined Aquifer System: FY 1994 Status Report. PNL-10195, Pacific Northwest National Laboratory, Richland, Washington. 
Tiller, B.L., G.E. Dagle, L.L. Cadwell, T.M. Poston, and A. Oganesian. 1997. Investigation of Anatomical Anomalies in Hanford Site Mule Deer. PNL-11518, Pacific Northwest National Laboratory, Richland, Washington.

Tiller, B.L. and J.L. Downs. 2004. FY2003 Synthesis of Ecological Data Collected in the Riparian and Riverine Environments of the Hanford Reach. Draft Letter Report. Pacific Northwest National Laboratory, Richland Washington.

Treaty with the Yakama. 1855. June 9, 1855, 12 Stat. 951.

Tri-City Association of REALTORS (TCAR). 2004. Tri-City Area Housing Statistics. Tri-City Association of REALTORS, Kennewick, Washington. Available URL http://www.tricityrealtors.com/. (Data accessed May 21,2004).

Tri-City Herald. 2001. “KID Supplies Plummet,” Tri-City Herald, June 22, 2001.

U.S. Army Corps of Engineers (Corps). 1989. Water Control Manual for McNary Lock and Dam, Columbia River, Oregon and Washington. U.S. Army Corps of Engineers, Walla Walla District, Walla Walla, Washington.

USBR (see U.S. Bureau of Reclamation).

U.S. Bureau of Reclamation (USBR). 2002. Lock Island Landslide Study, White Bluffs Area, Columbia Basin Project, Washington. U.S. Bureau of Reclamation, Pacific Northwest Region.

U.S. Census Bureau (Census). 2000. Poverty 1999. Poverty Thresholds in 1999, by Size of Family and Number of Related Children Under 18 Years. Last revised September 26, 2000. U.S. Bureau of the Census, U.S. Department of Commerce, Washington, D.C. Online at: http://www.census.gov

U.S. Census Bureau (Census). 2001a. Poverty Thresholds in 2000, by Size of Family and Number of Related Children Under 18 Years. Last revised January 29, 2001. U.S. Bureau of the Census, U.S. Department of Commerce, Washington, D.C. Online at: http://www.census.gov

U.S. Census Bureau (Census). 2001b. Census 2000 Redistricting Data (P.L. 94-171) Summary FileOregon. U.S. Bureau of the Census, U.S. Department of Commerce, Washington, D.C.

U.S. Census Bureau (Census). 2001c. Census 2000 Redistricting Data (P.L. 94-171) Summary FileWashington. U.S. Bureau of the Census, U.S. Department of Commerce, Washington, D.C.

U.S. Census Bureau (Census). 2002a. Census 2000 Summary File 3 (SF 3)- Oregon. U.S. Bureau of the Census, U.S. Department of Commerce, Washington, D.C.

U.S. Census Bureau (Census). 2002b. Census 2000 Summary File 3 (SF 3) - Washington. U.S. Bureau of the Census, U.S. Department of Commerce, Washington, D.C.

U.S. Census Bureau (Census). 2003a. Table QT P-34 Poverty Status of Individuals. Census Summary File 3 (SF3) Sample Data. U.S. Bureau of the Census, U.S. Department of Commerce, Washington, D.C. Online at: http://factfinder.census.gov 
U.S. Census Bureau (Census). 2003b. Geographic Comparison Table, Washington State Counties. , Census 2000 Redistricting Data (Public Law 94-171) Summary File, Matrices PL1 and PL2. U.S. Bureau of the Census, U.S. Department of Commerce, Washington, D.C. Online at: http://factfinder.census.gov/servlet/BasicFactsTable? lang=en\& vt name=DEC 2000_PL_U_GCTPL_S T2\&_geo_id $=04000$ US53 $>$

U.S. Department of the Army. 1990. Final Environmental Impact Statement Yakima Firing Center Proposed Land Acquisition, Yakima Firing Center, Washington. Department of Army, I Corps, Fort Lewis, Washington.

U.S. Department of Commerce (DOC). 2004. Regional Economic Information System (REIS). Bureau of Economic Analysis, U.S. Department of Commerce, Washington, D.C. Available URL: http://www.bea.doc.gov/bea/regional/reis/. (Data accessed May 21,2004).

U.S. Department of Energy (DOE). 1986. Environmental Assessment, Reference Repository Location, Hanford Site, Washington. DOE/RW-0070, U.S. Department of Energy, Washington, D.C.

U.S. Department of Energy (DOE). 1987. Final Environmental Impact Statement, Disposal of Hanford Defense High-Level, Transuranic and Tank Wastes, Hanford Site, Richland, Washington. DOE/EIS0113, Vol. I-III, U.S. Department of Energy, Washington, D.C.

U.S. Department of Energy (DOE). 1988. Consultation Draft: Site Characterization Plan, Reference Repository Location, Hanford Site, Washington. DOE/RW-0164, U.S. Department of Energy, Washington, D.C.

U.S. Department of Energy (DOE). 1991. Draft Environmental Impact Statement for the Siting, Construction, and Operation of New Production Reactor Capacity. DOE/EIS-0144D, Vol. 4, Appendix E, U.S. Department of Energy, Washington, D.C.

U.S. Department of Energy (DOE). 1992a. Hanford Site Groundwater Background. DOE/RL-92-23, U.S. Department of Energy, Richland Field Office, Richland, Washington.

U.S. Department of Energy (DOE). 1992b. American Indian Tribal Government Policy. DOE 1230.2. U.S. Department of Energy, Office of Congressional and Intergovernmental Affairs.

U.S. Department of Energy (DOE). 1993a. Recommendations for the Preparation of Environmental Assessments and Environmental Impact Statements. U.S. Department of Energy, Office of NEPA Oversight, Washington, D.C.

U.S. Department of Energy (DOE). 1993b. Radiation Protection of the Public and the Environment. DOE Order 5400.5. U.S. Department of Energy, Washington, D.C.

U.S. Department of Energy (DOE). 1996a. Programmatic Agreement Among the U.S. Department of Energy Richland Operations Office, the Advisory Council on Historic Preservation, and the Washington State Historic Preservation Office for the Maintenance, Deactivation, Alteration, and Demolition of the Built Environment on the Hanford Site, Washington. DOE/RL-96-77. Online at: http://www.hanford.gov/docs/96eap154/96eap154.htm 
U.S. Department of Energy (DOE). 1996b. Tank Waste Remediation System, Hanford Site, Richland, Washington. Final Environmental Impact Statement. DOE/EIS-0189. U.S. Department of Energy, Washington, D.C.

U.S. Department of Energy (DOE). 1997a. National Register of Historic Places Multiple Property Documentation Form - Historic, Archaeological and Traditional Cultural Properties of the Hanford Site, Washington. DOE/RL-97-02. Online at: http://www.hanford.gov/doe/culres/mpd/toc.htm

U.S. Department of Energy (DOE). 1997b. Waste Site Grouping for 200 Areas Soil Investigations. DOE/RL-96-81, Rev 0. Online at: http://www.erc.rl.gov/ pgs/READROOM/DOE_RL.HTM

U.S. Department of Energy (DOE). 1997c. Hanford Site Background: Part 3, Groundwater Background. DOE/RL-96-61. U.S. Department of Energy, Richland, Washington.

U.S. Department of Energy (DOE). 1997d. N Reactor Comprehensive Treatment Report, Hanford Site, Washington. DOE/RL-96-91, Draft A, Volumes I, II, III. U.S. Department of Energy, Richland, Washington.

U.S. Department of Energy (DOE). 1998a. Screening Assessment and Requirements for a Comprehensive Assessment: Columbia River Comprehensive Impact Assessment. DOE/RL-96-16, Rev. 1, Final. Online at: http://sesp.pnl.gov/Reports/CRCIA/reports.htm

U.S. Department of Energy (DOE). 1998b. Hanford Site Manhattan Project and Cold War Era Historic District Treatment Plan. DOE/RL-97-56, Rev. 1. U.S. Department of Energy, Richland, Washington.

U.S. Department of Energy (DOE). 1998c. Hanford Facility Dangerous Waste Permit Application, General Information Portion. DOE/RL-91-28, Rev. 4. Online at: http://www.hanford.gov/docs/rl-9128/rl91-28chp 02f.htm\#f2-9

U.S. Department of Energy (DOE). 1999a. Final Hanford Comprehensive Land-Use Plan Environmental Impact Statement. DOE/EIS-0222, U.S. Department of Energy, Washington, D.C.

U. S. Department of Energy (DOE). 1999b. Groundwater/Vadose Zone Integration Project Background Information and State of Knowledge. DOE/RL.-98-48 Vol. II, Rev. 0, U.S. Department of Energy, Richland, Operations Office, Richland, Washington.

U.S. Department of Energy (DOE). 1999c. Radiological Control Standard. DOE-STD-1098-99. U.S. Department of Energy, Washington, D.C.

Online at: http://tis.eh.doe.gov/techstds/standard/std1098/std109899.pdf.

U.S. Department of Energy (DOE). 2000a. Clean Air Act General Conformity Requirements and the National Environmental Policy Act Process. Online at:

http://tis.eh.doe.gov/nepa/tools/guidance/caaguidance.pdf

U.S. Department of Energy (DOE). 2001a. Hanford Site Biological Resources Management Plan. DOE/RL-96-32, Rev. 0. U.S. Department of Energy, Richland, Washington.

U.S. Department of Energy (DOE). 2001b. Historic American Engineering Record B Reactor (105-B Building) HAER No. WA-164. DOE/RL-2001-16. U.S. Department of Energy, Richland Operations Office, Richland, Washington. 
U.S. Department of Energy (DOE). 2002a. Hanford Site Waste Management Units Report. DOE/RL-8830, Rev 11, U.S. Department of Energy, Richland, Washington. Online at:

http://www.hanford.gov/docs/rl-91-28/rl91-28chp_02.htm\#2.0

U.S. Department of Energy (DOE). 2002b. Standardized Stratigraphic Nomenclature for the PostRingold-Formation Sediments Within the Central Pasco Basin. DOE/RL-2002-39, Rev. 0, U.S. Department of Energy, Richland, Washington.

U.S. Department of Energy (DOE). 2002c. History of the Plutonium Production Facilities at the Hanford Site Historic District, 1943-1990. DOE/RL-97-1047. Hanford Cultural and Historic Resources Program, U.S. Department of Energy, Richland, Operations Office, Richland, Washington. Online at: www.hanford.gov/docs/rl-97-1047/index.htm.

U.S. Department of Energy (DOE). 2003. Hanford Cultural Resources Management Plan. DOE/RL-9810, Rev. 0. U.S. Department of Energy, Richland Operations Office, Richland, Washington.

U.S. Department of Energy (DOE). 2004a. DOE Computerized Accident/Incident reporting System (CAIRS). Online at: http://tis.eh.doe.gov/cairs (Data Downloaded May 3, 2004).

U.S. Department of Energy (DOE). 2004b. The US Department of Energy's Web Page for Information on Occupational Radiation Exposure. Online at: http://rems.eh.doe.gov (Data Downloaded June 7, 2004).

U.S. Department of the Interior (DOI). 1994. Hanford Reach of the Columbia River: Comprehensive River Conservation Study and Environmental Impact Statement - Final. Volumes II and I. U.S. Department of Interior, Washington, D.C.

U.S. Department of Labor, Employment and Training Administration (DOL). 2004. Domestic Agricultural In-Season Farm Labor Report. Monthly Farm Labor Abstracts, January-December 2002. Washington State Employment Security Department for the U.S. Department of Labor, Olympia, Washington. Available URL: http://www.workforceexplorer.com/ . (Data accessed May 21,2004).

U.S. Energy Research and Development Administration (ERDA). 1975. Final Environmental Impact Statement of Waste Management Operations, Hanford Reservation, Richland, Washington, 2 vol. ERDA-1538, U.S. Energy Research and Development Administration, Washington, D.C.

U.S. Energy Research and Development Administration (ERDA). 1976. Evaluation of Impact of Potential Flooding Criteria on the Hanford Project. RLO-76-4, U.S. Energy Research and Development Administration, Richland, Washington.

U.S. Environmental Protection Agency (EPA). 1996. EPA's Natural Events Policy for Particulate Matter, June 6, 1996. U.S. Environmental Protection Agency, Washington, D.C. Online at: http://www.epa.gov/ttn/caaa/t1/memoranda/nepol.pdf

U.S. Environmental Protection Agency (EPA). 2000. Updated Users Guide for CAP88-PC, Version 2.0. EPA 402-R-00-004, Office of Radiation and Indoor Air, U.S. Environmental Protection Agency, Washington, D.C.

U.S. Environmental Protection Agency (EPA). 2004. AIRS database. Online at: http://www.epa.gov/air/data/reports.html 
U.S. Fish and Wildlife Service (USFWS). 2004. Species List Request. Letter from Mark Miller, USFWS to Michael R. Sackschewsky, PNNL. 3 May 2004.

USFWS (see U.S. Fish and Wildlife Service).

U.S. Geological Survey (USGS). 1987. Subsurface Transport of Radionuclides in Shallow Deposits of the Hanford Nuclear Reservation, Washington - Review of Selected Previous Work and Suggestions for Further Study. USGS Open File Report 87-222, Tacoma, Washington.

U.S. Geological Survey (USGS). 1995. Nitrate Concentrations in Ground Water of the Central Columbia Plateau. Open File Report 95-445, U.S. Geological Survey, Tacoma, Washington.

U.S. Geological Survey (USGS). 1996. National Seismic-Hazard Maps: Documentation June 1996. U.S. Geological Survey Open-File Report 96-532, Denver, Colorado.

U.S. Geological Survey (USGS). 2002. Daily Streamflow for the Nation. May 2001. U.S. Geological Survey, Reston, Virginia. Online at: http://waterdata.usgs.gov/nwis/discharge

U.S. Geological Survey (USGS). 2004. Surface-Water Data for the Nation. Accessed on the Internet May 6, 2004 at http://nwis.waterdata.usgs.gov/nwis/sw. Data is updated daily.

U.S. Nuclear Regulatory Commission (NRC). 1982. Draft Environmental Statement Related to the Construction of Skagit/Hanford Nuclear Project, Units 1 and 2. Prepared by Puget Sound Power \& Light Company, Pacific Power and Light Company, the Washington Water Power Company, and Portland General Electric Company. NUREG-0894, U.S. Nuclear Regulatory Commission, Washington, D.C.

University of Washington Geophysics Program (UWGP). 2001. On-line Earthquake Catalog. University of Washington Geophysics Program, Seattle, Washington. Online at:

http://www.geophys.washington.edu/SEIS

USGS (see U.S Geological Survey)

UWGP (see University of Washington Geophysics Program).

WAC 173-60. Maximum Environmental Noise Levels. Washington Administrative Code, Olympia, Washington.

WAC 173-70. Watercraft Noise Performance Standards. Washington Administrative Code, Olympia, Washington.

WAC 173-201A. Water Quality Standards for Surface Waters of the State Of Washington. Washington Administrative Code, Olympia, Washington.

WAC 173-216. State Waste Discharge Permit Program. Washington Administrative Code, Olympia, Washington.

WAC 173-470. Ambient Air Quality Standards for Particulate Matter. Washington Administrative Code, Olympia, Washington.

WAC 173-480. Ambient Air Quality Standards and Emission Limits for Radionuclides. Washington Administrative Code, Olympia, Washington. 
WAC 173-481. Ambient Air Quality and Environmental Standards for Fluorides. Washington Administrative Code, Olympia, Washington.

WAC 246-247. Radiation protection -- Air emissions. Washington Administrative Code, Olympia, Washington.

Waitt, R.B. 1980. "About Forty Last-Glacial Lake Missoula Jokulhlaups Through Southern Washington.” Journal of Geology 88: 653-679.

Walker, D.E., Jr. 1967. Mutual cross-utilizatin of economic resources in the Plateau: An example from aboriginal Nez Perce fishing practices. Washington State University Laboratory of Anthropology, Report of Investigations, No. 41, Pullman, Washington.

Walker, D.E., Jr. 1998. Handbook of North American Indians. Volume 12:Plateau. Smithsonian Institute, Washington D.C.

Walker, D.E., Jr. and L.W. Pritchard. 1999. Estimated Radiation Doses to Yakama Tribal Fishermen: An Application of the Columbia River Dosimetry Model Developed for the Hanford Environmental Dose Reconstruction Project. Walker Research Group, Ltd. Boulder Colorado.

Ward, A. L., G. W. Gee, Z. F. Zhang, and J.M. Keller. 2002a. Vadose Zone Transport Field Study: FY 2002 Status Report. PNNL 14150 Pacific Northwest National Laboratory, Richland, Washington.

Ward, A.L., G.W. Gee and Z.F. Zhang. 2002b. Hydrologic Tests of Lateral Flow and Transport in the Hanford Vadose Zone. Appendix D.4.1 (D-223- D233), In. A. J. Knepp. Field Investigation Report for Waste Management Area B-BX-BY. RPP-10098. Rev 0, CH2MHILL Hanford Group, Inc. Richland, Washington.

Warren, J.L. 1980. Vegetation Maps of the Hanford Reach, Columbia River. Prepared for the U.S. Army Corps of Engineers, Seattle District, Seattle, Washington, by Pacific Northwest Laboratory, Richland, Washington.

Washington Center for Real Estate Research (WCRER). 2004a. Washington State Housing Market. Washington State University, Pulman, Washington. Available URL: http://www.cbe.wsu.edu/ wcrer/market/HousingMarket.asp. (Data accessed May 21,2004).

Washington Center for Real Estate Research (WCRER). 2004b. WCRER Apartment Market Survey, Fall 2002. Washington State University, Pulman, Washington. Available URL:

http://www.cbe.wsu.edu/ wcrer/market/apt_intro.htm. (Data accessed May 21,2004).

Washington Department of Fish and Wildlife. 2004. Species of Concern. Washington State Department of Fish and Wildlife. Olympia, WA. Available URL: http://wdfw.wa.gov/wlm/diversty/soc/concern.htm

Washington Natural Heritage Program. 2004. Rare Plant Species County List. Washington State Department of Natural Resources, Olympia, Washington. Available URL: http://www.wa.gov/dnr/htdocs/fr/nhp/refdesk/fsrefix.htm

Washington State Department of Ecology (Ecology). 1997. 1997 Air Quality Annual Report for Washington State. \#97-208, Washington State Department of Ecology, Olympia, Washington. 
Washington State Department of Ecology Air Quality Program (Ecology). 1999. 1998 Washington State Air Quality Report. \#98-213. Online at: http://www.wa.gov/ecology/air/98rptbea.pdf

Washington State Department of Ecology Air Quality Program (Ecology). 2000. 1998 Air Quality Data Summary. \#00-02-005. Online at: http://www.wa.gov/ecology/air/98-final1.pdf

Washington State Department of Ecology (Ecology). 2003. Columbia Plateau Windblown Dust Natural Events Action Plan. \#03-02-014. Online at: http://www.ecy.wa.gov/pubs/0302014.pdf

Washington State Labor Market and Economic Analysis (LMEA). 2004a. Washington State Labor Summaries. Olympia, Washington. Online at: http://www.workforceexplorer.com/

Washington State Labor Market and Economic Analysis (LMEA). 2004b. Total Agricultural Employment in Washington State, Statewide, and by Area, 2003.. Olympia, Washington. Available URL: http://www.workforceexplorer.com/. (Data accessed June 18, 2004).

Washington State Labor Market and Economic Analysis (LMEA). 2004c. Nonagricultural Wage and Salary Workers Employed in the Richland-Kennewick-Pasco MSA. Olympia, Washington. Available URL: http://www.workforceexplorer.com/ . (data accessed May 21,2004).

Washington State Office of Trade and Economic Development (OTED). 2004a. Washington State Travel Impacts \& Visitor Volume 1991-2003p. Washington State Tourism Division, Olympia, Washington. Available URL: http://www.experiencewashington.com/industry . (Data accessed May 21,2004).

Washington State Office of Trade and Economic Development (OTED). 2004b. A Brief Analysis of the Economic Benefits of Wind Power in Washington State. Energy Policy Division, Olympia, Washington. Online at: http://www.energy.cted.wa.gov/Papers/Wind\%20Power\%200pportunities\%20in\%20WA.pdf

Watson, D.G. 1970. Fall Chinook Salmon Spawning in the Columbia River Near Hanford 1947-1969. BNWL-1515, Pacific Northwest Laboratories, Richland, Washington.

Watson, D.G. 1973. Fall Chinook Salmon Population Census. BNWL-1750, Pacific Northwest Laboratories, Richland, Washington.

Watson, E.C., C.D. Becker, R.E. Fitzner, K.A. Gano, C.L. Imhoff, R.F. McCallum, A. Myers, T.L. Page, K.R. Price, J.V. Ramsdell, D.G. Rice, D.L. Schreiber, L.A. Skumatz, D.J. Sommer, J.J. Tawil, R.W. Wallace, and D.G. Watson. 1984. Environmental Characterization of Two Potential Locations at Hanford for a New Production Reactor. PNL-5275, Pacific Northwest Laboratory, Richland, Washington.

WCRER (see Washington Center for Real Estate Research).

Weida, K., and G. P. O’Connor. 2001. Northwest Arid Lands: An Introduction to the Columbia Basin Shrub-Steppe. Battelle Press, Columbus, Ohio.

Weiss, S.G., and R.M. Mitchell. 1992. A Synthesis of Ecological Data from the 100 Areas of the Hanford Site. WHC-EP-0601, Westinghouse Hanford Company, Richland, Washington.

Westinghouse Hanford Company (WHC). 1989. Primary Operable Units Designation Project. WHCEP-0216, Environmental Engineering Group, Westinghouse Hanford Company, Richland, Washington. 
Westinghouse Hanford Company (WHC). 1994. Traffic Data for the Comprehensive Tank Waste Remediation System, Environmental Impact Statement. Response to Memorandum 94-JE-DOE-010. Westinghouse Hanford Company, Richland, Washington.

WHC (see Westinghouse Hanford Company).

Williams, B.A., B.N. Bjornstad, R. Schalla, and W.D. Webber. 2000. "Identification of Separate Suprabasalt Aquifers and Temporal Changes in Groundwater Contaminant Preferential Flow Paths with the Hanford Site 200 East Area, Richland, Washington”. In: Hydrogeology of Washington State Symposium. Tacoma, Washington.

Williams, B.A., B.N. Bjornstad, R. Schalla, and W.D. Webber. 2002. Revised Hydrogeology for the Suprabasalt Aquifer System, 200-West Area and Vicinity, Hanford Site, Washington. PNNL-13858, Pacific Northwest National Laboratory, Richland, WA.

WNHP (see Washington Natural Heritage Program)

Wolf, E.G. 1976. "Characterization of the Benthos Community.” In Final Report on Aquatic Ecological Studies Conducted at the Hanford Generating Project, prepared by Battelle, Pacific Northwest Laboratories for United Engineers and Constructors, Inc. for Washington Public Power Supply System under Contract No. 2311201335, Richland, Washington.

Wolf, E.G., T.L. Page, and D.A. Neitzel. 1976. "Phytoplankton Community: Primary Productivity, Pigment Concentration, Species Composition and Relative Abundance of Phytoplankton and Physicochemical Analysis," Section 2. In Final Report on Aquatic Ecological Studies Conducted at the Hanford Generating Project, 1973-1974, WPPSS Columbia River Ecological Studies, Vol. 1. Prepared by Battelle, Pacific Northwest Laboratories for Washington Public Power Supply System, Richland, Washington.

Wood, M.I., R. Schalla, B.N. Bjornstad, and S.M. Narbutovskih. 2000. Subsurface Conditions Description of the B-BX-BY Waste Management Area. HNF-5507, Rev. 0. CH2MHill Hanford Group, Incorporated, Richland, Washington.

Woody, D.M. 2003. Maximizing Value of an Archaeological Database at a Federal Facility in the MidColumbia. Unpublished masters thesis, Central Washington University, Ellensburg, Washington.

Wright, M.K. 1993. Fiscal Year 1992 Report on Archaeological Surveys of the 100 Areas, Hanford Site, Washington. PNL-8819, Pacific Northwest Laboratory, Richland, Washington.

Wurstner, S.K., and M.D. Freshley. 1994. Predicted Impacts of Future Water Level Decline on Monitoring Wells Using a Ground-Water Model of the Hanford Site. PNL-10196, Pacific Northwest Laboratory, Richland, Washington.

Wydoski, R.S., and R.R. Whitney. 1979. Inland fishes of Washington. University of Washington Press, Seattle, WA

Yakama (see Treaty with the Yakama).

Zhang, Z.F., A.L. Ward and G.W. Gee. 2003. "A Tensorial Connectivity-Tortuosity Concept to Describe the Unsaturated Hydraulic Properties of Anisotropic Soils”. Vadose Zone Journal. 2: 313-321. 
Zimmerman, D.A., A.E. Reisenauer, G.D. Black, and M.A. Young. 1986. Hanford Site Water Table Changes, 1950 Through 1980 - Data Observations and Evaluation. PNL-5506, Pacific Northwest Laboratory, Richland, Washington. 
This page intentionally left blank 


\section{Appendix A}

Atmospheric Dispersion Tables 
This page intentionally left blank 


\section{Atmospheric Dispersion Tables}

\section{Definitions:}

$\mathrm{X}=$ Air Concentration in Curies per Cubic Meter $\left(\mathrm{Ci} / \mathrm{m}^{3}\right)$

$\mathrm{Q}=$ Emission Rate in Curies per Second (Ci/s)

$\mathrm{E}=95 \%$ Centerline Concentration $\left(\mathrm{Ci} / \mathrm{m}^{3}\right)$

\section{Atmospheric Stability Class:}

A - Extremely unstable

B - Moderately unstable

C - Slightly unstable

D - Neutral

E - Slightly stable

F - Moderately stable

G - Very stable

\section{Conversion Factors:}
$1 \mathrm{Ci}=37,000 \mathrm{mBq}$
$1 \mathrm{pCi}=0.037 \mathrm{~Bq}$
$1 \mathrm{Ci}=10^{12} \mathrm{pCi}$
$1 \mathrm{~m}^{3}=35.3 \mathrm{ft}^{3}$
$1.61 \mathrm{~km}=1 \mathrm{mi}$

Examples for the use of Chronic (X/Q') and Acute (E/Q') Release Tables:

\section{- $\quad$ Chronic Release (Long Term):}

Assume wind is from $100 \mathrm{~N}$ Area towards the south. To find the estimated air concentration $1 \mathrm{~km}$ downwind from a constant source (i.e. stack) with a release rate of $0.0028 \mathrm{Ci} / \mathrm{s}$, multiply the $\mathrm{X} / \mathrm{Q}$ ' value from the table $\left(3.1 \times 10^{-6} \mathrm{~s} / \mathrm{m}^{3}\right)$ by the release rate $(0.0028 \mathrm{Ci} / \mathrm{s})$ :

$$
\mathbf{X}=\left(3.1 \times 10^{-6} \mathrm{~s} / \mathrm{m}^{3}\right)(0.0028 \mathrm{Ci} / \mathrm{s})=10^{-8} \mathrm{Ci} / \mathrm{m}^{3}=10,000 \mathrm{pCi} / \mathrm{m}^{3}
$$

\section{- $\quad$ Acute Release (Short Term):}

Assume wind is from $100 \mathrm{~N}$ Area towards the south. To find the estimated maximum centerline concentration (95\%) in this direction from a ground level accidental release $(10 \mathrm{Ci}$ in $1 \mathrm{hr}=0.0028 \mathrm{Ci} / \mathrm{s})$ at a location $1 \mathrm{~km}$ downwind, multiply the E/Q' value from the table $\left(9.8 \times 10^{-4} \mathrm{~s} / \mathrm{m}^{3}\right)$ by the release rate $(0.0028 \mathrm{Ci} / \mathrm{s})$ :

$$
\mathbf{E}=\left(9.8 \times 10^{-4} \mathrm{~s} / \mathrm{m}^{3}\right)(0.0028 \mathrm{Ci} / \mathrm{s})=2.7 \times 10^{-6} \mathrm{Ci} / \mathrm{m}^{3}=2.7 \times 10^{6} \mathrm{pCi} / \mathrm{m}^{3}
$$

\section{- Maximum Emission Rate:}

Another use of the X/Q' value is to estimate a maximum allowable release rate. Assume that the maximum allowable air concentration of a radionuclide $4 \mathrm{~km}$ north of $100 \mathrm{~N}$ Area is $100 \mathrm{pCi} / \mathrm{m}^{3}$. The 
maximum allowable release rate can be estimated by dividing the X/Q' value from the table $\left(2.5 \times 10^{-7}\right.$ $\mathrm{s} / \mathrm{m}^{3}$ ) by the maximum allowable concentration:

$$
\mathbf{Q}=2.5 \times 10^{-7} \mathrm{~s} / \mathrm{m}^{3} / 100 \mathrm{pCi} / \mathrm{m}^{3}=2.5 \times 10^{-9} \mathrm{pCi} / \mathrm{s}
$$


Table A1. Joint Frequency Distributions of Atmospheric Stability, Wind Speed, and Transport Direction for the 100 Area at $9.1 \mathrm{~m}$ (30 ft) above Ground Level, Hanford Site, Washington.

Based on 1983-2002 data from the 100-N Area instrumented tower.

\begin{tabular}{|c|c|c|c|c|c|c|c|c|c|c|c|c|c|c|c|c|c|}
\hline \multirow[t]{2}{*}{$\begin{array}{l}\text { Average } \\
\text { Wind } \\
\text { Speed }\end{array}$} & \multirow{2}{*}{$\begin{array}{c}\text { Atmospheric } \\
\text { Stability } \\
\text { Class } \\
9.1 \mathrm{~m} \\
\end{array}$} & \multicolumn{16}{|c|}{ Percentage of Time Wind Blows in the $100 \mathrm{~N}$ Area toward the Direction Indicated } \\
\hline & & $\mathrm{S}$ & SSW & SW & WSW & $\mathbf{W}$ & WNW & NW & NNW & $\mathbf{N}$ & NNE & NE & ENE & $\mathbf{E}$ & ESE & SE & SSE \\
\hline \multirow{7}{*}{$\begin{array}{l}0.89 \mathrm{~m} / \mathrm{s} \\
(2 \mathrm{mph})\end{array}$} & A & 0.09 & 0.07 & 0.05 & 0.05 & 0.07 & 0.06 & 0.05 & 0.03 & 0.03 & 0.04 & 0.06 & 0.09 & 0.12 & 0.12 & 0.14 & 0.11 \\
\hline & B & 0.07 & 0.05 & 0.04 & 0.03 & 0.04 & 0.03 & 0.03 & 0.03 & 0.02 & 0.02 & 0.04 & 0.05 & 0.08 & 0.10 & 0.09 & 0.08 \\
\hline & $\mathrm{C}$ & 0.10 & 0.08 & 0.07 & 0.05 & 0.05 & 0.05 & 0.05 & 0.04 & 0.04 & 0.04 & 0.06 & 0.06 & 0.11 & 0.12 & 0.14 & 0.12 \\
\hline & $\mathrm{D}$ & 0.47 & 0.40 & 0.44 & 0.50 & 0.76 & 0.87 & 0.70 & 0.47 & 0.44 & 0.41 & 0.48 & 0.55 & 0.62 & 0.64 & 0.68 & 0.57 \\
\hline & $\mathrm{E}$ & 0.77 & 0.68 & 0.79 & 0.95 & 1.31 & 1.31 & 1.07 & 0.82 & 0.76 & 0.71 & 0.82 & 1.00 & 1.22 & 1.20 & 1.05 & 0.87 \\
\hline & F & 0.35 & 0.36 & 0.46 & 0.53 & 0.63 & 0.52 & 0.41 & 0.28 & 0.24 & 0.25 & 0.37 & 0.48 & 0.56 & 0.56 & 0.53 & 0.42 \\
\hline & G & 0.30 & 0.26 & 0.29 & 0.31 & 0.37 & 0.30 & 0.23 & 0.16 & 0.15 & 0.17 & 0.27 & 0.41 & 0.59 & 0.63 & 0.54 & 0.36 \\
\hline \multirow{7}{*}{$\begin{array}{l}2.65 \mathrm{~m} / \mathrm{s} \\
(6 \mathrm{mph})\end{array}$} & A & 0.25 & 0.23 & 0.15 & 0.07 & 0.12 & 0.12 & 0.10 & 0.07 & 0.06 & 0.08 & 0.20 & 0.30 & 0.37 & 0.33 & 0.30 & 0.27 \\
\hline & B & 0.16 & 0.17 & 0.12 & 0.06 & 0.07 & 0.07 & 0.07 & 0.04 & 0.03 & 0.04 & 0.10 & & 0.18 & 0.17 & 18 & 0.16 \\
\hline & C & 0.14 & 0.15 & 0.13 & 0.05 & 0.08 & 0.12 & 0.10 & 0.05 & 0.04 & 0.04 & 0.09 & 0.13 & 0.15 & 0.12 & 0.14 & 0.13 \\
\hline & D & 0.34 & 0.41 & 0.35 & 0.30 & 0.50 & 0.62 & 0.54 & 0.30 & 0.19 & 0.19 & 0.36 & 0.65 & 0.70 & 0.54 & 0.41 & 0.35 \\
\hline & E & 0.46 & 0.52 & 0.62 & 0.97 & 1.22 & 1.10 & 0.99 & 0.56 & 0.42 & 0.45 & 0.91 & 1.93 & 2.15 & 1.33 & 0.79 & 0.50 \\
\hline & F & 0.08 & 0.10 & 0.18 & 0.42 & 0.56 & 0.40 & 0.27 & 0.17 & 0.12 & 0.14 & 0.30 & 0.68 & 0.70 & 0.39 & 0.20 & 0.10 \\
\hline & G & 0.04 & 0.04 & 0.08 & 0.13 & 0.20 & 0.22 & 0.16 & 0.06 & 0.04 & 0.05 & 0.17 & 0.44 & 0.61 & 0.33 & 0.13 & 0.05 \\
\hline \multirow{7}{*}{$\begin{array}{c}4.7 \mathrm{~m} / \mathrm{s} \\
(10.5 \mathrm{mph})\end{array}$} & A & 0.05 & 0.15 & 0.13 & 0.02 & 0.03 & 0.03 & 0.04 & 0.02 & 0.02 & 0.05 & 0.17 & 0.21 & 0.28 & 0.26 & 0.09 & 0.04 \\
\hline & B & 0.02 & 0.05 & 0.05 & 0.01 & 0.02 & 0.02 & 0.03 & 0.01 & 0.01 & & 0.07 & 0.07 & & & 0.03 & 0.01 \\
\hline & C & 0.02 & 0.06 & 0.04 & 0.01 & 0.01 & 0.02 & 0.04 & 0.02 & 0.02 & 0.02 & 0.07 & 0.06 & 0.06 & 0.07 & 0.03 & 0.02 \\
\hline & D & 0.17 & 0.23 & 0.12 & 0.04 & 0.05 & 0.12 & 0.21 & 0.10 & 0.06 & 0.08 & 0.20 & 0.29 & 0.43 & 0.38 & 0.18 & 0.15 \\
\hline & E & 0.17 & 0.30 & 0.20 & 0.11 & 0.11 & 0.15 & 0.40 & 0.23 & 0.17 & 0.25 & 0.54 & 1.11 & 1.95 & 1.34 & 0.33 & 0.14 \\
\hline & F & 0.02 & 0.02 & 0.02 & 0.03 & 0.02 & 0.02 & 0.08 & 0.06 & 0.03 & 0.03 & 0.06 & 0.27 & 0.38 & 0.17 & 0.03 & 0.02 \\
\hline & G & 0.00 & 0.00 & 0.00 & 0.01 & 0.00 & 0.00 & 0.02 & 0.01 & 0.01 & 0.00 & 0.02 & 0.07 & 0.04 & 0.01 & 0.00 & 0.00 \\
\hline \multirow{7}{*}{$\begin{array}{c}7.2 \mathrm{~m} / \mathrm{s} \\
(16 \mathrm{mph})\end{array}$} & A & 0.02 & 0.05 & 0.04 & 0.01 & 0.00 & 0.01 & 0.01 & 0.01 & 0.00 & 0.02 & 0.11 & 0.08 & 0.11 & 0.17 & 0.06 & 0.01 \\
\hline & B & 0.01 & 0.02 & 0.01 & 0.00 & 0.00 & 0.00 & 0.01 & 0.01 & 0.00 & & 0.05 & 0.03 & 0.05 & 0.08 & 0.02 & 0.00 \\
\hline & C & 0.01 & 0.02 & 0.01 & 0.00 & 0.00 & 0.00 & 0.01 & 0.01 & 0.00 & 0.01 & 0.04 & 0.02 & 0.05 & 0.08 & 0.03 & 0.00 \\
\hline & D & 0.09 & 0.13 & 0.06 & 0.01 & 0.00 & 0.01 & 0.04 & 0.04 & 0.03 & 0.06 & 0.18 & 0.11 & 0.23 & 0.49 & 0.29 & 0.05 \\
\hline & E & 0.06 & 0.16 & 0.11 & 0.03 & 0.01 & 0.01 & 0.07 & 0.07 & 0.08 & 0.15 & 0.37 & 0.31 & 0.78 & 1.22 & 0.30 & 0.06 \\
\hline & F & 0.01 & 0.00 & 0.00 & 0.00 & 0.00 & 0.00 & 0.00 & 0.00 & 0.00 & 0.01 & 0.01 & 0.02 & 0.04 & 0.02 & 0.01 & 0.01 \\
\hline & G & 0.00 & 0.00 & 0.00 & 0.00 & 0.00 & 0.00 & 0.00 & 0.00 & 0.00 & 0.00 & 0.00 & 0.00 & 0.00 & 0.00 & 0.00 & 0.00 \\
\hline \multirow{7}{*}{$\begin{array}{c}9.8 \mathrm{~m} / \mathrm{s} \\
(22 \mathrm{mph})\end{array}$} & A & 0.00 & 0.01 & 0.01 & 0.00 & 0.00 & 0.00 & 0.00 & 0.00 & 0.00 & 0.00 & 0.04 & 0.02 & 0.02 & 0.04 & 0.02 & 0.00 \\
\hline & B & 0.00 & 0.00 & 0.00 & 0.00 & 0.00 & 0.00 & 0.00 & 0.00 & 0.00 & 0.00 & 0.02 & 0.01 & 0.01 & 0.03 & 0.01 & 0.00 \\
\hline & C & 0.00 & 0.00 & 0.01 & 0.0 & 0.0 & 0.0 & 0.00 & 0.0 & 0.00 & & 0.02 & & 0.01 & 0.04 & 0.02 & 0.00 \\
\hline & D & 0.02 & 0.04 & 0.03 & 0.01 & 0.00 & 0.00 & 0.00 & 0.00 & 0.01 & 0.04 & 0.08 & 0.05 & 0.07 & 0.27 & 0.22 & 0.00 \\
\hline & E & 0.02 & 0.05 & 0.03 & 0.01 & 0.00 & 0.00 & 0.00 & 0.01 & 0.02 & 0.09 & 0.17 & 0.08 & 0.11 & 0.36 & 0.17 & 0.01 \\
\hline & F & 0.00 & 0.00 & 0.00 & 0.00 & 0.00 & 0.00 & 0.00 & 0.00 & 0.00 & 0.01 & 0.00 & 0.00 & 0.00 & 0.00 & 0.00 & 0.00 \\
\hline & G & 0.00 & 0.00 & 0.00 & 0.00 & 0.00 & 0.00 & 0.00 & 0.00 & 0.00 & 0.00 & 0.00 & 0.00 & 0.00 & 0.00 & 0.00 & 0.00 \\
\hline \multirow{7}{*}{$\begin{array}{l}12.7 \mathrm{~m} / \mathrm{s} \\
(29 \mathrm{mph})\end{array}$} & A & 0.00 & 0.00 & 0.00 & 0.00 & 0.00 & 0.00 & 0.00 & 0.00 & 0.00 & 0.00 & 0.01 & 0.00 & 0.01 & 0.01 & 0.00 & 0.00 \\
\hline & B & 0.00 & 0.00 & 0.00 & 0.00 & & 0.00 & 0.00 & 0.00 & 0.00 & 00 & 0.00 & 00 & 0.0 & 0.00 & 0.00 & \\
\hline & C & 0.00 & 0.00 & 0.00 & 0.00 & 0.00 & 0.00 & 0.00 & 0.00 & 0.00 & 0.00 & 0.00 & 0.00 & 0.00 & 0.01 & 0.01 & 0.00 \\
\hline & D & 0.00 & 0.01 & 0.01 & 0.00 & 0.00 & 0.00 & 0.00 & 0.00 & 0.00 & 0.03 & 0.03 & 0.02 & 0.02 & 0.08 & 0.06 & 0.00 \\
\hline & E & 0.00 & 0.01 & 0.02 & 0.00 & 0.00 & 0.00 & 0.00 & 0.00 & 0.01 & 0.03 & 0.04 & 0.02 & 0.02 & 0.06 & 0.04 & 0.00 \\
\hline & F & 0.00 & 0.00 & 0.00 & 0.00 & 0.00 & 0.00 & 0.00 & 0.00 & 0.00 & 0.00 & 0.00 & 0.00 & 0.00 & 0.00 & 0.00 & 0.00 \\
\hline & G & 0.00 & 0.00 & 0.00 & 0.00 & 0.00 & 0.00 & 0.00 & 0.00 & 0.00 & 0.00 & 0.00 & 0.00 & 0.00 & 0.00 & 0.00 & 0.00 \\
\hline \multirow{7}{*}{$\begin{array}{l}15.6 \mathrm{~m} / \mathrm{s} \\
(35 \mathrm{mph})\end{array}$} & A & & 0.00 & & & & & & & 0.00 & 0.00 & 0.00 & 0.00 & 0.00 & 0.00 & 0.00 & \\
\hline & B & 0.00 & 0.00 & 0.00 & 0.00 & 0.00 & 0.00 & 0.00 & 0.00 & 0.00 & 0.00 & 0.00 & 0.00 & 0.00 & 0.00 & 0.00 & 0.00 \\
\hline & C & 0.00 & 0.00 & 0.00 & 0.00 & 0.00 & 0.00 & 0.00 & 0.00 & 0.00 & 0.00 & 0.00 & 0.00 & 0.00 & 0.00 & 0.00 & 0.00 \\
\hline & D & 0.00 & 0.00 & 0.00 & 0.00 & 0.00 & 0.00 & 0.00 & 0.00 & 0.00 & 0.00 & 0.00 & 0.00 & 0.00 & 0.00 & 0.01 & 0.00 \\
\hline & E & 0.00 & 0.00 & 0.00 & 0.00 & 0.00 & 0.00 & 0.00 & 0.00 & 0.00 & 0.00 & 0.00 & 0.00 & 0.00 & 0.00 & 0.00 & 0.00 \\
\hline & F & 0.00 & 0.00 & 0.00 & 0.00 & 0.00 & 0.00 & 0.00 & 0.00 & 0.00 & 0.00 & 0.00 & 0.00 & 0.00 & 0.00 & 0.00 & 0.00 \\
\hline & G & 0.00 & 0.00 & 0.00 & 0.00 & 0.00 & 0.00 & 0.00 & 0.00 & 0.00 & 0.00 & 0.00 & 0.00 & 0.00 & 0.00 & 0.00 & 0.00 \\
\hline \multirow{7}{*}{$\begin{array}{c}19 \mathrm{~m} / \mathrm{s} \\
(43 \mathrm{mph})\end{array}$} & A & 0.00 & 0.00 & 0.00 & 0.00 & 0.00 & 0.00 & 0.00 & 0.00 & 0.00 & 0.00 & 0.00 & 0.00 & 0.00 & 0.00 & 0.00 & 0.00 \\
\hline & B & 0.00 & 0.00 & 0.00 & 0.00 & 0.00 & 0.00 & 0.00 & 0.00 & 0.00 & 0.00 & 0.00 & 0.00 & 0.00 & 0.00 & 0.00 & 0.00 \\
\hline & C & 0.00 & 0.00 & 0.00 & 0.00 & 0.00 & 0.00 & 0.00 & 0.00 & 0.00 & 0.00 & 0.00 & 0.00 & 0.00 & 0.00 & 0.00 & 0.00 \\
\hline & D & 0.00 & 0.00 & 0.00 & 0.00 & 0.00 & 0.00 & 0.00 & 0.00 & 0.00 & 0.00 & 0.00 & 0.00 & 0.00 & 0.00 & 0.00 & 0.00 \\
\hline & E & 0.00 & 0.00 & 0.00 & 0.00 & 0.00 & 0.00 & 0.00 & 0.00 & 0.00 & 0.00 & 0.00 & 0.00 & 0.00 & 0.00 & 0.00 & 0.00 \\
\hline & F & 0.00 & 0.00 & 0.00 & 0.00 & 0.00 & 0.00 & 0.00 & 0.00 & 0.00 & 0.00 & 0.00 & 0.00 & 0.00 & 0.00 & 0.00 & 0.00 \\
\hline & G & 0.00 & 0.00 & 0.00 & 0.00 & 0.00 & 0.00 & 0.00 & 0.00 & 0.00 & 0.00 & 0.00 & 0.00 & 0.00 & 0.00 & 0.00 & 0.00 \\
\hline
\end{tabular}


Table A2. Joint Frequency Distributions of Atmospheric Stability, Wind Speed, and Transport Direction for the 100 Area at $60 \mathrm{~m}(197 \mathrm{ft})$ above Ground Level, Hanford Site, Washington.

Based on 1986-2002 data from the 100-N Area instrumented tower.

\begin{tabular}{|c|c|c|c|c|c|c|c|c|c|c|c|c|c|c|c|c|c|}
\hline \multirow[t]{2}{*}{$\begin{array}{l}\text { Average } \\
\text { Wind } \\
\text { Speed }\end{array}$} & \multirow{2}{*}{$\begin{array}{c}\text { Atmospheric } \\
\text { Stability } \\
\text { Class } \\
60 \mathrm{~m} \\
\end{array}$} & \multicolumn{16}{|c|}{ Percentage of Time Wind Blows in the $100 \mathrm{~N}$ Area toward the Direction Indicated } \\
\hline & & S & SSW & SW & WSW & W & WNW & NW & NNW & $\mathbf{N}$ & NNE & $\mathrm{NE}$ & ENE & $\mathbf{E}$ & ESE & SE & SSE \\
\hline \multirow{7}{*}{$\begin{array}{l}0.89 \mathrm{~m} / \mathrm{s} \\
(2 \mathrm{mph})\end{array}$} & A & 0.05 & 0.04 & 0.03 & 0.03 & 0.03 & 0.03 & 0.02 & 0.02 & 0.02 & 0.02 & 0.03 & 0.05 & 0.05 & 0.05 & 0.07 & 0.07 \\
\hline & B & 0.07 & 0.04 & 0.03 & 0.02 & 0.02 & 0.02 & 0.01 & 0.01 & 0.01 & 0.02 & 0.02 & 0.04 & 0.05 & 0.08 & 0.09 & 0.09 \\
\hline & $\mathrm{C}$ & 0.13 & 0.08 & 0.06 & 0.04 & 0.04 & 0.03 & 0.04 & 0.03 & 0.03 & 0.02 & 0.04 & 0.06 & 0.11 & 0.12 & 0.13 & 0.13 \\
\hline & $\mathrm{D}$ & 0.40 & 0.37 & 0.39 & 0.47 & 0.71 & 0.81 & 0.68 & 0.48 & 0.38 & 0.33 & 0.35 & 0.45 & 0.54 & 0.54 & 0.46 & 0.43 \\
\hline & E & 0.71 & 0.66 & 0.69 & 0.86 & 1.12 & 1.11 & 0.90 & 0.69 & 0.57 & 0.52 & 0.55 & 0.58 & 0.68 & 0.67 & 0.66 & 0.59 \\
\hline & F & 0.20 & 0.21 & 0.31 & 0.45 & 0.69 & 0.58 & 0.41 & 0.26 & 0.22 & 0.18 & 0.20 & 0.19 & 0.26 & 0.24 & 0.23 & 0.21 \\
\hline & G & 0.23 & 0.23 & 0.32 & 0.43 & 0.59 & 0.46 & 0.37 & 0.24 & 0.19 & 0.16 & 0.14 & 0.19 & 0.23 & 0.31 & 0.30 & 0.25 \\
\hline \multirow{7}{*}{$\begin{array}{l}2.65 \mathrm{~m} / \mathrm{s} \\
(6 \mathrm{mph})\end{array}$} & A & 0.21 & 0.19 & 0.11 & 0.05 & 0.07 & 0.09 & 0.06 & 0.05 & 0.04 & 0.05 & 0.11 & 0.22 & 0.24 & 0.18 & 0.16 & 0.17 \\
\hline & B & 0.17 & 0.20 & 0.13 & 0.05 & 0.07 & 0.07 & 0.07 & 0.05 & 0.03 & 0.04 & 0.10 & 0.15 & 0.19 & 0.14 & 0.11 & 0.11 \\
\hline & $\mathrm{C}$ & 0.14 & 0.21 & 0.13 & 0.06 & 0.09 & 0.14 & 0.11 & 0.06 & 0.04 & 0.04 & 0.10 & 0.15 & 0.14 & 0.10 & 0.07 & 0.07 \\
\hline & D & 0.31 & 0.37 & 0.34 & 0.30 & 0.53 & 0.67 & 0.63 & 0.36 & 0.20 & 0.17 & 0.26 & 0.39 & 0.52 & 0.45 & 0.30 & 0.23 \\
\hline & E & 0.68 & 0.71 & 0.61 & 0.72 & 1.27 & 1.30 & 1.04 & 0.61 & 0.44 & 0.34 & 0.51 & 0.76 & 1.23 & 1.25 & 0.83 & 0.56 \\
\hline & F & 0.10 & 0.09 & 0.15 & 0.38 & 0.73 & 0.63 & 0.41 & 0.20 & 0.12 & 0.10 & 0.13 & 0.22 & 0.40 & 0.53 & 0.34 & 0.14 \\
\hline & $\mathrm{G}$ & 0.10 & 0.09 & 0.12 & 0.22 & 0.31 & 0.27 & 0.27 & 0.16 & 0.07 & 0.06 & 0.06 & 0.11 & 0.29 & 0.48 & 0.36 & 0.15 \\
\hline \multirow{7}{*}{$\begin{array}{c}4.7 \mathrm{~m} / \mathrm{s} \\
(10.5 \mathrm{mph})\end{array}$} & A & 0.03 & 0.13 & 0.12 & 0.02 & 0.03 & 0.04 & 0.04 & 0.02 & 0.02 & 0.04 & 0.16 & 0.19 & 0.23 & 0.15 & 0.04 & 0.02 \\
\hline & B & 0.02 & 0.07 & 0.06 & 0.01 & 0.02 & 0.03 & 0.04 & 0.02 & 0.01 & 0.02 & 0.09 & 0.08 & 0.10 & 0.05 & 0.02 & 0.02 \\
\hline & $\mathrm{C}$ & 0.02 & 0.06 & 0.06 & 0.01 & 0.01 & 0.03 & 0.04 & 0.02 & 0.02 & 0.02 & 0.08 & 0.07 & 0.05 & 0.06 & 0.03 & 0.02 \\
\hline & D & 0.21 & 0.25 & 0.14 & 0.07 & 0.06 & 0.13 & 0.25 & 0.10 & 0.06 & 0.07 & 0.13 & 0.17 & 0.28 & 0.23 & 0.15 & 0.16 \\
\hline & $\mathrm{E}$ & 0.33 & 0.43 & 0.31 & 0.25 & 0.29 & 0.37 & 0.59 & 0.32 & 0.26 & 0.27 & 0.43 & 0.66 & 1.50 & 1.29 & 0.47 & 0.29 \\
\hline & F & 0.04 & 0.05 & 0.05 & 0.05 & 0.06 & 0.10 & 0.19 & 0.12 & 0.06 & 0.06 & 0.08 & 0.15 & 0.40 & 0.51 & 0.13 & 0.03 \\
\hline & G & 0.03 & 0.03 & 0.02 & 0.02 & 0.02 & 0.02 & 0.06 & 0.03 & 0.02 & 0.01 & 0.02 & 0.03 & 0.10 & 0.27 & 0.10 & 0.02 \\
\hline \multirow{7}{*}{$\begin{array}{c}7.2 \mathrm{~m} / \mathrm{s} \\
(16 \mathrm{mph})\end{array}$} & A & 0.01 & 0.10 & 0.05 & 0.01 & 0.00 & 0.00 & 0.01 & 0.00 & 0.01 & 0.01 & 0.10 & 0.07 & 0.16 & 0.16 & 0.02 & 0.01 \\
\hline & B & 0.01 & 0.03 & 0.01 & 0.01 & 0.00 & 0.00 & 0.01 & 0.00 & 0.00 & 0.01 & 0.05 & 0.03 & 0.06 & 0.06 & 0.01 & 0.00 \\
\hline & $\mathrm{C}$ & 0.01 & 0.03 & 0.02 & 0.00 & 0.00 & 0.00 & 0.02 & 0.01 & 0.01 & 0.01 & 0.05 & 0.03 & 0.05 & 0.06 & 0.02 & 0.00 \\
\hline & $\mathrm{D}$ & 0.14 & 0.16 & 0.06 & 0.01 & 0.01 & 0.01 & 0.09 & 0.08 & 0.05 & 0.06 & 0.13 & 0.12 & 0.26 & 0.36 & 0.18 & 0.05 \\
\hline & $\mathrm{E}$ & 0.19 & 0.28 & 0.19 & 0.13 & 0.13 & 0.14 & 0.30 & 0.24 & 0.17 & 0.24 & 0.46 & 0.55 & 1.63 & 1.79 & 0.38 & 0.12 \\
\hline & F & 0.02 & 0.02 & 0.02 & 0.01 & 0.01 & 0.01 & 0.05 & 0.06 & 0.03 & 0.03 & 0.04 & 0.07 & 0.37 & 0.48 & 0.05 & 0.01 \\
\hline & G & 0.01 & 0.01 & 0.01 & 0.00 & 0.00 & 0.00 & 0.01 & 0.01 & 0.01 & 0.01 & 0.00 & 0.01 & 0.04 & 0.09 & 0.01 & 0.00 \\
\hline \multirow{7}{*}{$\begin{array}{c}9.8 \mathrm{~m} / \mathrm{s} \\
(22 \mathrm{mph})\end{array}$} & A & 0.00 & 0.02 & 0.02 & 0.00 & 0.00 & 0.00 & 0.00 & 0.00 & 0.00 & 0.01 & 0.06 & 0.03 & 0.05 & 0.08 & 0.01 & 0.00 \\
\hline & B & 0.00 & 0.01 & 0.01 & 0.00 & 0.00 & 0.00 & 0.00 & 0.00 & 0.00 & 0.01 & 0.02 & 0.01 & 0.02 & 0.04 & 0.01 & 0.00 \\
\hline & $\mathrm{C}$ & 0.01 & 0.01 & 0.01 & 0.00 & 0.00 & 0.00 & 0.00 & 0.00 & 0.00 & 0.00 & 0.02 & 0.01 & 0.03 & 0.05 & 0.01 & 0.00 \\
\hline & $\mathrm{D}$ & 0.07 & 0.08 & 0.05 & 0.01 & 0.00 & 0.00 & 0.01 & 0.02 & 0.02 & 0.05 & 0.13 & 0.09 & 0.16 & 0.39 & 0.23 & 0.01 \\
\hline & $\mathrm{E}$ & 0.13 & 0.18 & 0.12 & 0.06 & 0.08 & 0.07 & 0.10 & 0.09 & 0.10 & 0.14 & 0.28 & 0.26 & 0.69 & 1.27 & 0.30 & 0.07 \\
\hline & $\mathrm{F}$ & 0.00 & 0.01 & 0.00 & 0.00 & 0.00 & 0.00 & 0.01 & 0.01 & 0.01 & 0.01 & 0.01 & 0.01 & 0.05 & 0.09 & 0.01 & 0.00 \\
\hline & G & 0.00 & 0.00 & 0.00 & 0.00 & 0.00 & 0.00 & 0.00 & 0.00 & 0.00 & 0.00 & 0.00 & 0.00 & 0.01 & 0.01 & 0.00 & 0.00 \\
\hline \multirow{7}{*}{$\begin{array}{c}12.7 \mathrm{~m} / \mathrm{s} \\
(29 \mathrm{mph})\end{array}$} & A & 0.00 & 0.00 & 0.00 & 0.00 & 0.00 & 0.00 & 0.00 & 0.00 & 0.00 & 0.00 & 0.03 & 0.01 & 0.01 & 0.02 & 0.01 & 0.00 \\
\hline & B & 0.00 & 0.00 & 0.00 & 0.00 & 0.00 & 0.00 & 0.00 & 0.00 & 0.00 & 0.00 & 0.01 & 0.01 & 0.01 & 0.01 & 0.00 & 0.00 \\
\hline & $\mathrm{C}$ & 0.00 & 0.00 & 0.00 & 0.00 & 0.00 & 0.00 & 0.00 & 0.00 & 0.00 & 0.00 & 0.01 & 0.01 & 0.01 & 0.03 & 0.01 & 0.00 \\
\hline & D & 0.02 & 0.03 & 0.03 & 0.01 & 0.00 & 0.00 & 0.00 & 0.00 & 0.01 & 0.05 & 0.07 & 0.05 & 0.07 & 0.19 & 0.16 & 0.00 \\
\hline & $\mathrm{E}$ & 0.05 & 0.10 & 0.08 & 0.02 & 0.02 & 0.02 & 0.03 & 0.04 & 0.04 & 0.10 & 0.17 & 0.11 & 0.22 & 0.44 & 0.15 & 0.03 \\
\hline & F & 0.00 & 0.00 & 0.00 & 0.00 & 0.00 & 0.00 & 0.00 & 0.00 & 0.00 & 0.01 & 0.00 & 0.01 & 0.00 & 0.00 & 0.00 & 0.00 \\
\hline & $\mathrm{G}$ & 0.00 & 0.00 & 0.00 & 0.00 & 0.00 & 0.00 & 0.00 & 0.00 & 0.00 & 0.00 & 0.00 & 0.00 & 0.00 & 0.00 & 0.00 & 0.00 \\
\hline \multirow{7}{*}{$\begin{array}{l}15.6 \mathrm{~m} / \mathrm{s} \\
(35 \mathrm{mph})\end{array}$} & A & 0.00 & 0.00 & 0.00 & 0.00 & 0.00 & 0.00 & 0.00 & 0.00 & 0.00 & 0.00 & 0.01 & 0.00 & 0.00 & 0.01 & 0.00 & 0.00 \\
\hline & B & 0.00 & 0.00 & 0.00 & 0.00 & 0.00 & 0.00 & 0.00 & 0.00 & 0.00 & 0.00 & 0.00 & 0.00 & 0.00 & 0.00 & 0.00 & 0.00 \\
\hline & $\mathrm{C}$ & 0.00 & 0.00 & 0.00 & 0.00 & 0.00 & 0.00 & 0.00 & 0.00 & 0.00 & 0.00 & 0.00 & 0.00 & 0.00 & 0.01 & 0.00 & 0.00 \\
\hline & $\mathrm{D}$ & 0.00 & 0.00 & 0.00 & 0.00 & 0.00 & 0.00 & 0.00 & 0.00 & 0.00 & 0.03 & 0.03 & 0.02 & 0.02 & 0.05 & 0.03 & 0.00 \\
\hline & E & 0.01 & 0.02 & 0.02 & 0.00 & 0.00 & 0.00 & 0.00 & 0.00 & 0.01 & 0.04 & 0.05 & 0.03 & 0.04 & 0.08 & 0.04 & 0.01 \\
\hline & F & 0.00 & 0.00 & 0.00 & 0.00 & 0.00 & 0.00 & 0.00 & 0.00 & 0.00 & 0.00 & 0.00 & 0.00 & 0.00 & 0.00 & 0.00 & 0.00 \\
\hline & $\mathrm{G}$ & 0.00 & 0.00 & 0.00 & 0.00 & 0.00 & 0.00 & 0.00 & 0.00 & 0.00 & 0.00 & 0.00 & 0.00 & 0.00 & 0.00 & 0.00 & 0.00 \\
\hline \multirow{7}{*}{$\begin{array}{c}19 \mathrm{~m} / \mathrm{s} \\
(43 \mathrm{mph})\end{array}$} & A & 0.00 & 0.00 & 0.00 & 0.00 & 0.00 & 0.00 & 0.00 & 0.00 & 0.00 & 0.00 & 0.00 & 0.00 & 0.00 & 0.00 & 0.00 & 0.00 \\
\hline & B & 0.00 & 0.00 & 0.00 & 0.00 & 0.00 & 0.00 & 0.00 & 0.00 & 0.00 & 0.00 & 0.00 & 0.00 & 0.00 & 0.00 & 0.00 & 0.00 \\
\hline & $\mathrm{C}$ & 0.00 & 0.00 & 0.00 & 0.00 & 0.00 & 0.00 & 0.00 & 0.00 & 0.00 & 0.00 & 0.00 & 0.00 & 0.00 & 0.00 & 0.00 & 0.00 \\
\hline & D & 0.00 & 0.00 & 0.00 & 0.00 & 0.00 & 0.00 & 0.00 & 0.00 & 0.00 & 0.01 & 0.00 & 0.00 & 0.00 & 0.00 & 0.01 & 0.00 \\
\hline & E & 0.00 & 0.00 & 0.00 & 0.00 & 0.00 & 0.00 & 0.00 & 0.00 & 0.00 & 0.03 & 0.01 & 0.00 & 0.01 & 0.03 & 0.01 & 0.00 \\
\hline & $\mathrm{F}$ & 0.00 & 0.00 & 0.00 & 0.00 & 0.00 & 0.00 & 0.00 & 0.00 & 0.00 & 0.00 & 0.00 & 0.00 & 0.00 & 0.00 & 0.00 & 0.00 \\
\hline & G & 0.00 & 0.00 & 0.00 & 0.00 & 0.00 & 0.00 & 0.00 & 0.00 & 0.00 & 0.00 & 0.00 & 0.00 & 0.00 & 0.00 & 0.00 & 0.00 \\
\hline
\end{tabular}


Table A3. Joint Frequency Distributions of Atmospheric Stability, Wind Speed, and Transport Direction for the 200 Areas at $9.1 \mathrm{~m}$ (30 ft) above Ground Level, Hanford Site, Washington.

Based on 1983-2002 data from the Hanford Meteorology Station instrumented tower.

\begin{tabular}{|c|c|c|c|c|c|c|c|c|c|c|c|c|c|c|c|c|c|}
\hline \multirow{2}{*}{$\begin{array}{l}\text { Average } \\
\text { Wind } \\
\text { Speed }\end{array}$} & \multirow{2}{*}{$\begin{array}{c}\text { Atmospheric } \\
\text { Stability Class } \\
9.1 \mathrm{~m} \\
\end{array}$} & \multicolumn{16}{|c|}{ Percentage of Time Wind Blows in the 200 Areas toward the Direction Indicated } \\
\hline & & $\mathbf{S}$ & SSW & SW & WSW & $\mathbf{W}$ & WNW & NW & NNW & $\mathbf{N}$ & NNE & NE & ENE & E & ESE & SE & SSE \\
\hline \multirow{7}{*}{$\begin{array}{l}0.89 \mathrm{~m} / \mathrm{s} \\
(2 \mathrm{mph})\end{array}$} & A & 0.32 & 0.36 & 0.39 & 0.29 & 0.29 & 0.27 & 0.21 & 0.16 & 0.14 & 0.12 & 0.11 & 0.10 & 0.11 & 0.13 & 0.19 & 0.25 \\
\hline & B & 0.15 & 0.14 & 0.16 & 0.11 & 0.10 & 0.10 & 0.09 & 0.05 & 0.06 & 0.05 & 0.05 & 0.04 & 0.06 & 0.07 & 0.10 & 0.12 \\
\hline & $\mathrm{C}$ & 0.13 & 0.13 & 0.13 & 0.09 & 0.08 & 0.08 & 0.08 & 0.06 & 0.04 & 0.04 & 0.05 & 0.04 & 0.05 & 0.06 & 0.08 & 0.12 \\
\hline & $\mathrm{D}$ & 0.76 & 0.65 & 0.62 & 0.49 & 0.52 & 0.55 & 0.57 & 0.40 & 0.34 & 0.29 & 0.32 & 0.35 & 0.44 & 0.52 & 0.69 & 0.73 \\
\hline & $\mathrm{E}$ & 0.37 & 0.28 & 0.26 & 0.24 & 0.28 & 0.33 & 0.44 & 0.38 & 0.34 & 0.33 & 0.45 & 0.48 & 0.54 & 0.59 & 0.58 & 0.50 \\
\hline & $\mathrm{F}$ & 0.24 & 0.16 & 0.15 & 0.14 & 0.16 & 0.19 & 0.25 & 0.24 & 0.26 & 0.29 & 0.34 & 0.34 & 0.40 & 0.42 & 0.39 & 0.30 \\
\hline & G & 0.10 & 0.08 & 0.10 & 0.08 & 0.08 & 0.07 & 0.10 & 0.09 & 0.10 & 0.10 & 0.12 & 0.10 & 0.12 & 0.14 & 0.15 & 0.13 \\
\hline \multirow{7}{*}{$\begin{array}{l}2.65 \mathrm{~m} / \mathrm{s} \\
(6 \mathrm{mph})\end{array}$} & $A$ & 0.75 & 0.53 & 0.42 & 0.37 & 0.44 & 0.46 & 0.42 & 0.28 & 0.23 & 0.25 & 0.33 & 0.25 & 0.21 & 0.31 & 0.71 & 0.83 \\
\hline & B & 0.24 & 0.16 & 0.11 & 0.10 & 0.10 & 0.12 & 0.10 & 0.07 & 0.07 & 0.06 & 0.08 & 0.07 & 0.08 & 0.15 & 0.31 & \\
\hline & $\mathrm{C}$ & 0.18 & 0.11 & 0.08 & 0.07 & 0.07 & 0.08 & 0.08 & 0.05 & 0.04 & 0.05 & 0.05 & 0.05 & 0.05 & 0.09 & 0.23 & 0.25 \\
\hline & $\mathrm{D}$ & 0.58 & 0.39 & 0.27 & 0.24 & 0.30 & 0.31 & 0.38 & 0.28 & 0.21 & 0.21 & 0.28 & 0.38 & 0.55 & 1.02 & 1.60 & 1.02 \\
\hline & $\mathrm{E}$ & 0.28 & 0.15 & 0.12 & 0.12 & 0.21 & 0.27 & 0.33 & 0.39 & 0.32 & 0.30 & 0.55 & 1.01 & 1.78 & 2.11 & 1.69 & 0.71 \\
\hline & $\mathrm{F}$ & 0.14 & 0.07 & 0.05 & 0.06 & 0.08 & 0.12 & 0.27 & 0.35 & 0.33 & 0.41 & 0.71 & 1.33 & 1.79 & 1.89 & 1.54 & 0.56 \\
\hline & G & 0.04 & 0.03 & 0.02 & 0.03 & 0.03 & 0.03 & 0.11 & 0.17 & 0.18 & 0.20 & 0.31 & 0.63 & 0.64 & 0.71 & 0.64 & 0.17 \\
\hline \multirow{7}{*}{$\begin{array}{c}4.7 \mathrm{~m} / \mathrm{s} \\
(10.5 \mathrm{mph})\end{array}$} & $\mathrm{A}$ & 0.22 & 0.24 & 0.14 & 0.05 & 0.06 & 0.04 & 0.03 & 0.05 & 0.06 & 0.15 & 0.33 & 0.42 & 0.24 & 0.31 & 0.75 & 0.33 \\
\hline & B & 0.04 & 0.04 & 0.03 & 0.01 & 0.01 & 0.01 & 0.01 & 0.01 & 0.01 & & & & 08 & & 0.23 & 0.08 \\
\hline & C & 0.03 & 0.02 & 0.01 & 0.01 & 0.01 & 0.00 & 0.01 & 0.01 & 0.02 & 0.03 & 0.05 & 0.07 & 0.06 & 0. & 0.18 & 0.07 \\
\hline & D & 0.13 & 0.12 & 0.06 & 0.03 & 0.04 & 0.03 & 0.05 & 0.09 & 0.11 & 0.19 & 0.34 & 0.50 & 60 & 1.23 & 1.46 & 0.31 \\
\hline & $\mathrm{E}$ & 0.06 & 0.05 & 0.04 & 0.02 & 0.02 & 0.02 & 0.05 & 0.10 & 0.12 & 0.16 & 0.38 & 0.72 & 1.10 & 2.00 & 1.70 & 0.21 \\
\hline & $\mathrm{F}$ & 0.01 & 0.01 & 0.01 & 0.01 & 0.01 & 0.01 & 0.03 & 0.09 & 0.04 & 0.03 & 0.10 & 0.35 & 0.33 & 0.55 & 0.68 & 0.09 \\
\hline & G & 0.00 & 0.00 & 0.00 & 0.00 & 0.00 & 0.00 & 0.02 & 0.03 & 0.01 & 0.02 & 0.05 & 0.21 & 0.09 & 0.18 & 0.30 & 0.02 \\
\hline \multirow{7}{*}{$\begin{array}{c}7.2 \mathrm{~m} / \mathrm{s} \\
(16 \mathrm{mph})\end{array}$} & $\mathrm{A}$ & 0.03 & 0.06 & 0.04 & 0.01 & 0.00 & 0.00 & 0.00 & 0.01 & 0.02 & 0.06 & 0.26 & 0.37 & 0.15 & 0.2 & 0.52 & 0.11 \\
\hline & B & 0.01 & 0.01 & 0.01 & 0.00 & 0.00 & & & 0.00 & 0.01 & & 0.06 & & 0.03 & 0.05 & 0.13 & 0.02 \\
\hline & C & 0.01 & 0.01 & 0.01 & 0.00 & 0.00 & 0.00 & 0.00 & 0.00 & 0.01 & 0.02 & 0.04 & 0.0 & 0.03 & 0.04 & 0.09 & 0.01 \\
\hline & $\mathrm{D}$ & 0.02 & 0.04 & 0.03 & 0.01 & 0.00 & 0.00 & 0.01 & 0.03 & 0.08 & 0.19 & 0.41 & 0.36 & 0.24 & 0.72 & 0.93 & 0.08 \\
\hline & $\mathrm{E}$ & 0.01 & 0.04 & 0.02 & 0.00 & 0.00 & 0.00 & 0.00 & 0.03 & 0.08 & 0.14 & 0.28 & 0.24 & 0.15 & 0.43 & 0.81 & 0.04 \\
\hline & $\mathrm{F}$ & 0.00 & 0.00 & 0.00 & 0.00 & 0.00 & 0.00 & 0.00 & 0.01 & 0.00 & 0.00 & 0.01 & 0.02 & 0.01 & 0.01 & 0.01 & 0.00 \\
\hline & G & 0.00 & 0.00 & 0.00 & 0.00 & 0.00 & 0.00 & 0.00 & 0.00 & 0.00 & 0.00 & 0.00 & 0.00 & 0.00 & 0.00 & 0.00 & 0.00 \\
\hline \multirow{7}{*}{$\begin{array}{c}9.8 \mathrm{~m} / \mathrm{s} \\
(22 \mathrm{mph})\end{array}$} & A & 0.00 & 0.01 & 0.01 & 0.00 & 0.00 & 0.00 & 0.00 & 0.00 & 0.00 & 0.02 & 0.11 & 0.14 & 0.04 & 0.04 & 0.18 & 0.01 \\
\hline & B & 0.00 & 0.01 & 0.00 & 0.0 & 0.00 & 0.00 & 0.00 & 0.00 & 0.00 & 0.00 & 0.04 & 0.03 & 0.01 & 0.01 & 0.05 & 0.00 \\
\hline & C & 0.00 & 0.00 & 0.00 & 0.00 & 0.00 & 0.00 & 0.00 & 0.00 & 0.00 & 0.01 & 0.02 & 0.01 & 0.01 & 0.01 & 0.03 & 0.00 \\
\hline & $\mathrm{D}$ & 0.00 & 0.01 & 0.01 & 0.00 & 0.00 & 0.00 & 0.00 & 0.00 & 0.02 & 0.10 & 0.19 & 0.10 & 0.03 & 0.12 & 0.27 & 0.01 \\
\hline & $\mathrm{E}$ & 0.00 & 0.01 & 0.01 & 0.00 & 0.00 & 0.00 & 0.00 & 0.01 & 0.01 & 0.05 & 0.07 & 0.04 & 0.01 & 0.05 & 0.15 & 0.00 \\
\hline & $\mathrm{F}$ & 0.00 & 0.00 & 0.00 & 0.00 & 0.00 & 0.00 & 0.00 & 0.00 & 0.00 & 0.00 & 0.00 & 0.00 & 0.00 & 0.00 & 0.00 & 0.00 \\
\hline & G & 0.00 & 0.00 & 0.00 & 0.00 & 0.00 & 0.00 & 0.00 & 0.00 & 0.00 & 0.00 & 0.00 & 0.00 & 0.00 & 0.00 & 0.00 & 0.00 \\
\hline \multirow{7}{*}{$\begin{array}{c}12.7 \mathrm{~m} / \mathrm{s} \\
(29 \mathrm{mph})\end{array}$} & A & 0.00 & 0.00 & 0.00 & 0.00 & 0.00 & 0.00 & 0.00 & 0.00 & 0.00 & 0.00 & 0.02 & 0.02 & 0.00 & 0.00 & 0.01 & 0.00 \\
\hline & B & & 0.00 & 0.0 & $0 . C$ & 0.1 & & 0.0 & 0.0 & 0.0 & & 0.0 & 0. & 0.00 & & 0.00 & 0.00 \\
\hline & $\mathrm{C}$ & 0.00 & 0.00 & 0.00 & 0.00 & 0.00 & 0.00 & 0.00 & 0.00 & 0.00 & 0.00 & 0.01 & 0.00 & 0.00 & 0.00 & 0.00 & 0.00 \\
\hline & $\mathrm{D}$ & 0.00 & 0.00 & 0.00 & 0.00 & 0.00 & 0.00 & 0.00 & 0.00 & 0.00 & 0.03 & 0.04 & 0.03 & 0.01 & 0.01 & 0.01 & 0.00 \\
\hline & $\mathrm{E}$ & 0.00 & 0.00 & 0.00 & 0.00 & 0.00 & 0.00 & 0.00 & 0.00 & 0.00 & 0.02 & 0.01 & 0.01 & 0.00 & 0.00 & 0.01 & 0.00 \\
\hline & $\mathrm{F}$ & 0.00 & 0.00 & 0.00 & 0.00 & 0.00 & 0.00 & 0.00 & 0.00 & 0.00 & 0.00 & 0.00 & 0.00 & 0.00 & 0.00 & 0.00 & 0.00 \\
\hline & $\mathrm{G}$ & 0.00 & 0.00 & 0.00 & 0.00 & 0.00 & 0.00 & 0.00 & 0.00 & 0.00 & 0.00 & 0.00 & 0.00 & 0.00 & 0.00 & 0.00 & 0.00 \\
\hline \multirow{7}{*}{$\begin{array}{l}15.6 \mathrm{~m} / \mathrm{s} \\
(35 \mathrm{mph})\end{array}$} & A & & 0.00 & 0.00 & 0.00 & 0.00 & 0.00 & 0.00 & & 0.00 & 0.00 & 0.00 & 0.00 & 0.00 & 0. & 0.00 & 0.00 \\
\hline & B & 0.00 & 0.00 & 0.00 & 0.00 & 0.00 & 0.00 & 0.00 & 0.00 & 0.00 & 0.00 & 0.00 & 0.00 & 0.00 & 0.00 & 0.00 & 0.00 \\
\hline & $\mathrm{C}$ & 0.00 & 0.00 & 0.00 & 0.00 & 0.00 & 0.00 & 0.00 & 0.00 & 0.00 & 0.00 & 0.00 & 0.00 & 0.00 & 0.00 & 0.00 & 0.00 \\
\hline & $\mathrm{D}$ & 0.00 & 0.00 & 0.00 & 0.00 & 0.00 & 0.00 & 0.00 & 0.00 & 0.00 & 0.00 & 0.00 & 0.00 & 0.00 & 0.00 & 0.00 & 0.00 \\
\hline & $\mathrm{E}$ & 0.00 & 0.00 & 0.00 & 0.00 & 0.00 & 0.00 & 0.00 & 0.00 & 0.00 & 0.00 & 0.00 & 0.00 & 0.00 & 0.00 & 0.00 & 0.00 \\
\hline & F & 0.00 & 0.00 & 0.00 & 0.00 & 0.00 & 0.00 & 0.00 & 0.00 & 0.00 & 0.00 & 0.00 & 0.00 & 0.00 & 0.00 & 0.00 & 0.00 \\
\hline & $\mathrm{G}$ & 0.00 & 0.00 & 0.00 & 0.00 & 0.00 & 0.00 & 0.00 & 0.00 & 0.00 & 0.00 & 0.00 & 0.00 & 0.00 & 0.00 & 0.00 & 0.00 \\
\hline \multirow{7}{*}{$\begin{array}{c}19 \mathrm{~m} / \mathrm{s} \\
(43 \mathrm{mph})\end{array}$} & A & 0.00 & 0.00 & 0.00 & 0.00 & 0.00 & 0.00 & 0.00 & 0.00 & 0.00 & 0.00 & 0.00 & 0.00 & 0.00 & 0.00 & 0.00 & 0.00 \\
\hline & B & 0.00 & 0.00 & 0.00 & 0.00 & 0.00 & 0.00 & 0.00 & 0.00 & 0.00 & 0.00 & 0.00 & 0.00 & 0.00 & 0.00 & 0.00 & 0.00 \\
\hline & $\mathrm{C}$ & 0.00 & 0.00 & 0.00 & 0.00 & 0.00 & 0.00 & 0.00 & 0.00 & 0.00 & 0.00 & 0.00 & 0.00 & 0.00 & 0.00 & 0.00 & 0.00 \\
\hline & $\mathrm{D}$ & 0.00 & 0.00 & 0.00 & 0.00 & 0.00 & 0.00 & 0.00 & 0.00 & 0.00 & 0.00 & 0.00 & 0.00 & 0.00 & 0.00 & 0.00 & 0.00 \\
\hline & $\mathrm{E}$ & 0.00 & 0.00 & 0.00 & 0.00 & 0.00 & 0.00 & 0.00 & 0.00 & 0.00 & 0.00 & 0.00 & 0.00 & 0.00 & 0.00 & 0.00 & 0.00 \\
\hline & $\mathrm{F}$ & 0.00 & 0.00 & 0.00 & 0.00 & 0.00 & 0.00 & 0.00 & 0.00 & 0.00 & 0.00 & 0.00 & 0.00 & 0.00 & 0.00 & 0.00 & 0.00 \\
\hline & G & 0.00 & 0.00 & 0.00 & 0.00 & 0.00 & 0.00 & 0.00 & 0.00 & 0.00 & 0.00 & 0.00 & 0.00 & 0.00 & 0.00 & 0.00 & 0.00 \\
\hline
\end{tabular}


Table A4. Joint Frequency Distributions of Atmospheric Stability, Wind Speed, and Transport Direction for the 200 Areas at $60 \mathrm{~m}(197 \mathrm{ft})$ above Ground Level, Hanford Site, Washington.

Based on 1983-2002 data from the Hanford Meteorology Station instrumented tower.

\begin{tabular}{|c|c|c|c|c|c|c|c|c|c|c|c|c|c|c|c|c|c|}
\hline \multirow[t]{2}{*}{$\begin{array}{l}\text { Average } \\
\text { Wind } \\
\text { Speed }\end{array}$} & \multirow{2}{*}{$\begin{array}{c}\text { Atmospheric } \\
\text { Stability } \\
\text { Class } \\
60 \mathrm{~m} \\
\end{array}$} & \multicolumn{16}{|c|}{ Percentage of Time Wind Blows in the 200 Areas toward the Direction Indicated } \\
\hline & & $\mathbf{S}$ & SSW & SW & WSW & $\mathbf{W}$ & WNW & NW & NNW & $\mathbf{N}$ & NNE & NE & ENE & $\mathbf{E}$ & ESE & SE & SSE \\
\hline \multirow{7}{*}{$\begin{array}{c}0.89 \mathrm{~m} / \mathrm{s} \\
(2 \mathrm{mph})\end{array}$} & $\mathrm{A}$ & 0.11 & 0.15 & 0.16 & 0.12 & 0.13 & 0.13 & 0.08 & 0.07 & 0.05 & 0.04 & 0.05 & 0.04 & 0.05 & 0.04 & 0.06 & 0.09 \\
\hline & B & 0.08 & 0.08 & 0.08 & 0.07 & 0.07 & 0.06 & 0.06 & 0.04 & 0.02 & 0.03 & 0.02 & 0.02 & 0.03 & 0.03 & 0.05 & 0.07 \\
\hline & $\mathrm{C}$ & 0.08 & 0.07 & 0.09 & 0.07 & 0.05 & 0.06 & 0.06 & 0.04 & 0.02 & 0.02 & 0.02 & 0.02 & 0.03 & 0.03 & 0.04 & 0.07 \\
\hline & $\mathrm{D}$ & 0.49 & 0.46 & 0.42 & 0.38 & 0.40 & 0.39 & 0.46 & 0.33 & 0.22 & 0.20 & 0.20 & 0.19 & 0.24 & 0.30 & 0.39 & 0.48 \\
\hline & $\mathrm{E}$ & 0.25 & 0.20 & 0.18 & 0.17 & 0.21 & 0.24 & 0.31 & 0.23 & 0.16 & 0.15 & 0.16 & 0.16 & 0.21 & 0.23 & 0.27 & 0.28 \\
\hline & F & 0.18 & 0.13 & 0.11 & 0.11 & 0.13 & 0.13 & 0.18 & 0.15 & 0.12 & 0.12 & 0.13 & 0.12 & 0.16 & 0.18 & 0.21 & 0.20 \\
\hline & G & 0.06 & 0.04 & 0.05 & 0.05 & 0.06 & 0.06 & 0.08 & 0.07 & 0.08 & 0.07 & 0.07 & 0.08 & 0.08 & 0.10 & 0.11 & 0.09 \\
\hline \multirow{7}{*}{$\begin{array}{l}2.65 \mathrm{~m} / \mathrm{s} \\
(6 \mathrm{mph})\end{array}$} & $\mathrm{A}$ & 0.67 & 0.62 & 0.54 & 0.49 & 0.58 & 0.45 & 0.51 & 0.42 & 0.26 & 0.24 & 0.24 & 0.19 & 0.16 & 0.22 & 0.52 & 0.74 \\
\hline & B & 0.22 & 0.19 & 0.15 & 0.12 & 0.14 & 0.12 & 0.12 & 0.10 & 0.08 & 0.07 & 0.07 & 0.06 & 0.07 & 0.11 & 0.24 & 0.28 \\
\hline & $\mathrm{C}$ & 0.19 & 0.13 & 0.11 & 0.08 & 0.08 & 0.08 & 0.10 & 0.07 & 0.05 & & 0.06 & 0.04 & 0.04 & 0.07 & 0.19 & \\
\hline & $\mathrm{D}$ & 0.68 & 0.50 & 0.36 & 0.31 & 0.36 & 0.31 & 0.44 & 0.32 & 0.20 & 0.20 & 0.22 & 0.24 & 0.34 & 0.58 & 1.19 & 1.01 \\
\hline & $\mathrm{E}$ & 0.34 & 0.23 & 0.18 & 0.16 & 0.23 & 0.23 & 0.34 & 0.33 & 0.18 & 0.18 & 0.25 & 0.34 & 0.52 & 0.78 & 0.90 & 0.61 \\
\hline & $\mathrm{F}$ & 0.28 & 0.13 & 0.12 & 0.08 & 0.12 & 0.12 & 0.24 & 0.25 & 0.19 & 0.18 & 0.23 & 0.33 & 0.55 & 0.79 & 0.83 & 0.59 \\
\hline & $\mathrm{G}$ & 0.08 & 0.05 & 0.04 & 0.03 & 0.05 & 0.03 & 0.07 & 0.12 & 0.09 & 0.10 & 0.14 & 0.19 & 0.32 & 0.37 & 0.30 & 0.20 \\
\hline \multirow{7}{*}{$\begin{array}{c}4.7 \mathrm{~m} / \mathrm{s} \\
(10.5 \mathrm{mph})\end{array}$} & $\mathrm{A}$ & 0.35 & 0.33 & 0.21 & 0.10 & 0.12 & 0.08 & 0.10 & 0.09 & 0.10 & 0.19 & 0.32 & 0.32 & 0.16 & 0.25 & 0.76 & 0.48 \\
\hline & B & 0.08 & 0.07 & 0.03 & 0.02 & 0.03 & 0.02 & 0.02 & 0.03 & 0.03 & 0.04 & 0.08 & 0.09 & 0.06 & 0.11 & 0.29 & 0.13 \\
\hline & C & 0.05 & 0.04 & 0.03 & 0.01 & 0.01 & 0.01 & 0.02 & 0.01 & 0.02 & 0.03 & 0.05 & 06 & 0.04 & & 0.21 & 0.11 \\
\hline & $\mathrm{D}$ & 0.18 & 0.14 & 0.08 & 0.06 & 0.09 & 0.07 & 0.11 & 0.13 & 0.10 & 0.15 & 0.24 & 0.30 & 0.32 & 0.83 & 1.47 & 0.42 \\
\hline & E & 0.19 & 0.10 & 0.10 & 0.07 & 0.11 & 0.09 & 0.13 & 0.20 & 0.12 & 0.14 & 0.27 & 0.54 & 0.98 & 1.76 & 1.52 & 0.42 \\
\hline & $\mathrm{F}$ & 0.12 & 0.06 & 0.03 & 0.02 & 0.04 & 0.03 & 0.08 & 0.20 & 0.08 & 0.06 & 0.16 & 0.38 & 0.81 & 1.37 & 1.39 & 0.46 \\
\hline & $\mathrm{G}$ & 0.03 & 0.01 & 0.00 & 0.00 & 0.01 & 0.00 & 0.02 & 0.04 & 0.03 & 0.03 & 0.06 & 0.15 & 0.34 & 0.46 & 0.59 & 0.23 \\
\hline \multirow{7}{*}{$\begin{array}{c}7.2 \mathrm{~m} / \mathrm{s} \\
(16 \mathrm{mph})\end{array}$} & $\mathrm{A}$ & 0.06 & 0.13 & 0.08 & 0.02 & 0.01 & 0.01 & 0.01 & 0.02 & 0.03 & 0.11 & 0.31 & 0.40 & 0.14 & 0.21 & 0.56 & 0.12 \\
\hline & B & 0.01 & 0.02 & 0.01 & 0.01 & 0.00 & 0.00 & 0.00 & 0.01 & 0.01 & 0.03 & 0.05 & 0.09 & 0.04 & 0.08 & 0.14 & 0.03 \\
\hline & C & 0.01 & 0.01 & 0.01 & 0.00 & 0.00 & 0.00 & 0.00 & 0.01 & 0.01 & 0.02 & 0.04 & 06 & 0.03 & .05 & 0.11 & 0.01 \\
\hline & $\mathrm{D}$ & 0.06 & 0.08 & 0.04 & 0.02 & & 0.01 & 0.03 & 0.08 & 0.09 & 0.16 & 0.34 & 0.44 & 0.40 & 0.98 & 1.17 & 0.12 \\
\hline & E & 0.06 & 0.05 & 0.04 & 0.02 & 0.02 & 0.01 & 0.04 & 0.10 & 0.10 & 0.14 & 0.33 & 0.66 & 0.90 & 2.18 & 1.69 & 0.14 \\
\hline & $\mathrm{F}$ & 0.04 & 0.02 & 0.02 & 0.01 & 0.01 & 0.00 & 0.03 & 0.08 & 0.03 & 0.03 & 0.06 & 0.24 & 0.39 & 0.92 & 1.26 & 0.14 \\
\hline & G & 0.00 & 0.00 & 0.00 & 0.00 & 0.00 & 0.00 & 0.01 & 0.03 & 0.01 & 0.00 & 0.01 & 0.05 & 0.08 & 0.18 & 0.59 & 0.09 \\
\hline \multirow{7}{*}{$\begin{array}{c}9.8 \mathrm{~m} / \mathrm{s} \\
(22 \mathrm{mph})\end{array}$} & A & 0.01 & 0.02 & 0.03 & 0.01 & 0.00 & 0.00 & 0.00 & 0.00 & 0.01 & 0.04 & 0.18 & 0.23 & 0.06 & 0.12 & 0.37 & 0.03 \\
\hline & B & 0.00 & 0.01 & 0.00 & 0.00 & 0.00 & 0.00 & 0.00 & 0.00 & 0.00 & 0.01 & 0.05 & 0.05 & 0.01 & 0.03 & 0.08 & 0.01 \\
\hline & C & 0.00 & 0.00 & 0.00 & 0.00 & & 0.00 & 0.00 & 0.00 & 0.00 & 0.01 & 0.03 & 0.04 & 0.01 & 0.03 & 0.06 & 0.00 \\
\hline & D & & 0.0 & 0.02 & 0.01 & & & 0.00 & 0.0 & & 0. & 0.3 & 0.27 & 0.15 & 0.6 & 0.73 & 0.03 \\
\hline & E & 0.01 & 0.04 & 0.03 & 0.00 & 0.00 & 0.00 & 0.01 & 0.03 & 0.06 & 0.12 & 0.27 & 0.29 & 0.19 & 0.75 & 0.95 & 0.03 \\
\hline & $\mathrm{F}$ & 0.00 & 0.00 & 0.00 & 0.00 & 0.00 & 0.00 & 0.00 & 0.01 & 0.01 & 0.00 & 0.02 & 0.03 & 0.04 & 0.08 & 0.18 & 0.01 \\
\hline & G & 0.00 & 0.00 & 0.00 & 0.00 & 0.00 & 0.00 & 0.00 & 0.00 & 0.00 & 0.00 & 0.00 & 0.00 & 0.00 & 0.03 & 0.08 & 0.00 \\
\hline \multirow{7}{*}{$\begin{array}{l}12.7 \mathrm{~m} / \mathrm{s} \\
(29 \mathrm{mph})\end{array}$} & $\mathrm{A}$ & 0.00 & 0.00 & 0.01 & 0.00 & 0.00 & 0.00 & 0.00 & 0.00 & 0.00 & 0.02 & 0.11 & 0.11 & 0.02 & 0.03 & 0.19 & 0.01 \\
\hline & B & 0.00 & 0.01 & 0.00 & 0.00 & 0.00 & 0.00 & 0.00 & 0.00 & 0.00 & 0.01 & 0.04 & 0.03 & 0.01 & 0.01 & 0.05 & 0.00 \\
\hline & C & 0.00 & 0.00 & 0.00 & 0.00 & 0.00 & 0.00 & 0.00 & 0.00 & 0.00 & 0.01 & 0.02 & 0.02 & 0.00 & 0.01 & 0.04 & 0.00 \\
\hline & D & 0.01 & 0.01 & 0.01 & 0.01 & 0.00 & 0.00 & 0.00 & 0.01 & 0.03 & 0.13 & 0.26 & 0.13 & 0.04 & 0.29 & 0.52 & 0.01 \\
\hline & $\mathrm{E}$ & 0.00 & 0.01 & 0.01 & 0.00 & 0.00 & 0.00 & 0.00 & 0.01 & 0.03 & 0.08 & 0.13 & 0.08 & 0.03 & 0.17 & 0.31 & 0.00 \\
\hline & $\mathrm{F}$ & 0.00 & 0.00 & 0.00 & 0.00 & 0.00 & 0.00 & 0.00 & 0.00 & 0.00 & 0.00 & 0.00 & 0.01 & 0.00 & 0.00 & 0.00 & 0.00 \\
\hline & $\mathrm{G}$ & 0.00 & 0.00 & 0.00 & 0.00 & 0.00 & 0.00 & 0.00 & 0.00 & 0.00 & 0.00 & 0.00 & 0.00 & 0.00 & 0.00 & 0.00 & 0.00 \\
\hline \multirow{7}{*}{$\begin{array}{l}15.6 \mathrm{~m} / \mathrm{s} \\
(35 \mathrm{mph})\end{array}$} & A & 0.00 & 0.00 & 0.00 & 0.00 & 0.00 & 0.00 & 0.00 & 0.00 & 0.00 & 0.01 & 0.03 & 0.02 & 0.00 & 0.00 & 0.02 & 0.00 \\
\hline & B & 0.00 & 0.0 & 0.00 & 0.00 & & 0.00 & 0.00 & 0.0 & 0.00 & 00 & 0.01 & 0.01 & 0.00 & 0.00 & 0.01 & 0.00 \\
\hline & C & 0.00 & & & & & 0.00 & & 0.00 & 00 & 00 & 0.01 & 01 & 0.00 & 0.00 & 0.01 & 0.00 \\
\hline & D & 0.00 & 0.00 & 0.00 & 0.00 & 0.00 & 0.00 & 0.00 & 0.00 & 0.01 & 0.06 & 0.09 & 0.03 & 0.01 & 0.03 & 0.06 & 0.00 \\
\hline & $\mathrm{E}$ & 0.00 & 0.00 & 0.00 & 0.00 & 0.00 & 0.00 & 0.00 & 0.00 & 0.00 & 0.03 & 0.04 & 0.01 & 0.01 & 0.02 & 0.05 & 0.00 \\
\hline & $\mathrm{F}$ & 0.00 & 0.00 & 0.00 & 0.00 & 0.00 & 0.00 & 0.00 & 0.00 & 0.00 & 0.00 & 0.00 & 0.00 & 0.00 & 0.00 & 0.00 & 0.00 \\
\hline & $\mathrm{G}$ & 0.00 & 0.00 & 0.00 & 0.00 & 0.00 & 0.00 & 0.00 & 0.00 & 0.00 & 0.00 & 0.00 & 0.00 & 0.00 & 0.00 & 0.00 & 0.00 \\
\hline \multirow{7}{*}{$\begin{array}{c}19 \mathrm{~m} / \mathrm{s} \\
(43 \mathrm{mph})\end{array}$} & A & 0.00 & 0.00 & 0.00 & & 0.00 & 0.00 & 0.00 & 0.00 & 0.00 & 0.00 & 0.01 & 0.00 & 0.00 & 0.00 & 0.00 & 0.00 \\
\hline & B & 0.00 & 0.00 & 0.00 & 0.00 & 0.00 & 0.00 & 0.00 & 0.00 & 0.00 & 0.00 & 0.00 & 0.00 & 0.00 & 0.00 & 0.00 & 0.00 \\
\hline & C & 0.00 & 0.00 & 0.00 & 0.00 & 0.00 & 0.00 & 0.00 & 0.00 & 0.00 & 0.00 & 0.00 & 0.00 & 0.00 & 0.00 & 0.00 & 0.00 \\
\hline & D & 0.00 & 0.00 & 0.00 & 0.00 & 0.00 & 0.00 & 0.00 & 0.00 & 0.00 & 0.02 & 0.03 & 0.02 & 0.00 & 0.00 & 0.00 & 0.00 \\
\hline & $\mathrm{E}$ & 0.00 & 0.00 & 0.00 & 0.00 & 0.00 & 0.00 & 0.00 & 0.00 & 0.00 & 0.01 & 0.01 & 0.01 & 0.00 & 0.00 & 0.00 & 0.00 \\
\hline & $\mathrm{F}$ & 0.00 & 0.00 & 0.00 & 0.00 & 0.00 & 0.00 & 0.00 & 0.00 & 0.00 & 0.00 & 0.00 & 0.00 & 0.00 & 0.00 & 0.00 & 0.00 \\
\hline & G & 0.00 & 0.00 & 0.00 & 0.00 & 0.00 & 0.00 & 0.00 & 0.00 & 0.00 & 0.00 & 0.00 & 0.00 & 0.00 & 0.00 & 0.00 & 0.00 \\
\hline
\end{tabular}


Table A5. Joint Frequency Distributions of Atmospheric Stability, Wind Speed, and Transport Direction for the 300 Area at $9.1 \mathrm{~m}$ (30 ft) above Ground Level, Hanford Site, Washington.

Based on 1983-2002 data from the 300 Area instrumented tower.

\begin{tabular}{|c|c|c|c|c|c|c|c|c|c|c|c|c|c|c|c|c|c|}
\hline \multirow[t]{2}{*}{$\begin{array}{l}\text { Average } \\
\text { Wind } \\
\text { Speed }\end{array}$} & \multirow{2}{*}{$\begin{array}{c}\text { Atmospheric } \\
\text { Stability } \\
\text { Class } \\
9.1 \mathrm{~m} \\
\end{array}$} & \multicolumn{16}{|c|}{ Percentage of Time Wind Blows in the 300 Area toward the Direction Indicated } \\
\hline & & $\mathbf{S}$ & SSW & SW & WSW & $\mathbf{W}$ & WNW & NW & NNW & $\mathbf{N}$ & NNE & NE & ENE & $\mathbf{E}$ & ESE & SE & SSE \\
\hline \multirow{7}{*}{$\begin{array}{l}0.89 \mathrm{~m} / \mathrm{s} \\
(2 \mathrm{mph})\end{array}$} & A & 0.01 & 0.01 & 0.01 & 0.01 & 0.01 & 0.01 & 0.01 & 0.01 & 0.01 & 0.00 & 0.01 & 0.01 & 0.01 & 0.00 & 0.00 & 0.01 \\
\hline & B & 0.01 & 0.01 & 0.00 & 0.00 & 0.01 & 0.00 & 0.01 & 0.00 & 0.00 & 0.01 & 0.01 & 0.00 & 0.00 & 0.00 & 0.00 & 0.01 \\
\hline & $\mathrm{C}$ & 0.00 & 0.00 & 0.01 & 0.01 & 0.01 & 0.02 & 0.02 & 0.02 & 0.01 & 0.01 & 0.00 & 0.01 & 0.01 & 0.00 & 0.00 & 0.01 \\
\hline & D & 0.29 & 0.21 & 0.21 & 0.22 & 0.26 & 0.37 & 0.38 & 0.33 & 0.28 & 0.24 & 0.25 & 0.20 & 0.22 & 0.20 & 0.28 & 0.34 \\
\hline & E & 0.56 & 0.33 & 0.25 & 0.24 & 0.34 & 0.54 & 0.76 & 0.82 & 0.83 & 0.68 & 0.63 & 0.57 & 0.58 & 0.65 & 0.79 & 0.82 \\
\hline & $\mathrm{F}$ & 0.19 & 0.10 & 0.08 & 0.07 & 0.12 & 0.20 & 0.36 & 0.37 & 0.34 & 0.26 & 0.26 & 0.21 & 0.25 & 0.27 & 0.35 & 0.28 \\
\hline & G & 0.22 & 0.10 & 0.06 & 0.06 & 0.08 & 0.13 & 0.24 & 0.30 & 0.27 & 0.20 & 0.20 & 0.18 & 0.19 & 0.25 & 0.36 & 0.32 \\
\hline \multirow{7}{*}{$\begin{array}{l}2.65 \mathrm{~m} / \mathrm{s} \\
(6 \mathrm{mph})\end{array}$} & A & 0.03 & 0.04 & 0.04 & 0.04 & 0.07 & 0.07 & 0.07 & 0.04 & 0.04 & 0.04 & 0.05 & 0.02 & 0.01 & 0.01 & 0.01 & 0.02 \\
\hline & B & 0.01 & 0.01 & 0.03 & 0.02 & 0.03 & 0.04 & 0.05 & 0.05 & 0.04 & 0.05 & 0.04 & 0.01 & 0.00 & 0.00 & 0.00 & 0.01 \\
\hline & C & 0.02 & 0.05 & 0.12 & 0.13 & 0.10 & 0.10 & 0.09 & 0.06 & 0.05 & 0.08 & 0.07 & 0.03 & 0.01 & 0.01 & 0.01 & 0.02 \\
\hline & D & 0.87 & 0.63 & 0.50 & 0.60 & 0.85 & 1.11 & 1.36 & 0.68 & 0.65 & 0.72 & 0.58 & 0.29 & 0.17 & 0.16 & 0.45 & 0.90 \\
\hline & $\mathrm{E}$ & 1.64 & 0.71 & 0.33 & 0.35 & 0.65 & 1.78 & 2.96 & 1.88 & 1.67 & 1.22 & 0.91 & 0.63 & 0.49 & 0.52 & 0.94 & 1.77 \\
\hline & $\mathrm{F}$ & 0.52 & 0.12 & 0.03 & 0.03 & 0.13 & 0.97 & 1.60 & 0.65 & 0.44 & 0.30 & 0.22 & 0.16 & 0.15 & 0.17 & 0.32 & 0.62 \\
\hline & G & 0.41 & 0.07 & 0.01 & 0.00 & 0.03 & 0.33 & 0.72 & 0.33 & 0.16 & 0.09 & 0.05 & 0.04 & 0.05 & 0.10 & 0.34 & 0.61 \\
\hline \multirow{7}{*}{$\begin{array}{c}4.7 \mathrm{~m} / \mathrm{s} \\
(10.5 \mathrm{mph})\end{array}$} & A & 0.04 & 0.07 & 0.04 & 0.01 & 0.02 & 0.04 & 0.03 & 0.02 & 0.03 & 0.12 & 0.10 & 0.05 & 0.02 & 0.01 & 0.01 & 0.02 \\
\hline & B & 0.02 & 0.09 & 0.07 & 0.00 & 0.01 & 0.02 & 0.04 & 0.02 & 0.04 & 0.11 & 0.11 & 0.04 & 0.01 & 0.01 & 0.01 & 0.01 \\
\hline & $\mathrm{C}$ & 0.08 & 0.19 & 0.17 & 0.03 & 0.02 & 0.05 & 0.06 & 0.03 & 0.05 & 0.18 & 0.23 & 0.07 & 0.02 & 0.01 & 0.02 & 0.04 \\
\hline & D & 0.70 & 0.59 & 0.30 & 0.13 & 0.17 & 0.35 & 0.48 & 0.25 & 0.42 & 0.98 & 0.97 & 0.47 & 0.15 & 0.11 & 0.31 & 0.71 \\
\hline & E & 1.62 & 0.75 & 0.24 & 0.09 & 0.13 & 0.40 & 0.68 & 0.47 & 0.97 & 1.53 & 1.55 & 0.86 & 0.33 & 0.25 & 0.63 & 1.24 \\
\hline & F & 0.64 & 0.18 & 0.01 & 0.01 & 0.02 & 0.24 & 0.26 & 0.06 & 0.11 & 0.21 & 0.26 & 0.12 & 0.05 & 0.04 & 0.10 & 0.31 \\
\hline & G & 0.38 & 0.07 & 0.00 & 0.00 & 0.01 & 0.14 & 0.14 & 0.01 & 0.01 & 0.03 & 0.03 & 0.02 & 0.01 & 0.01 & 0.03 & 0.23 \\
\hline \multirow{7}{*}{$\begin{array}{c}7.2 \mathrm{~m} / \mathrm{s} \\
(16 \mathrm{mph})\end{array}$} & A & 0.02 & 0.04 & 0.01 & 0.00 & 0.00 & 0.00 & 0.00 & 0.00 & 0.01 & 0.07 & 0.13 & 0.08 & 0.01 & 0.01 & 0.01 & 0.02 \\
\hline & B & 0.02 & 0.05 & 0.01 & 0.00 & 0.00 & 0.00 & 0.00 & 0.00 & 0.01 & 0.08 & 0.13 & 0.09 & 0.02 & 0.01 & 0.02 & 0.00 \\
\hline & C & 0.04 & 0.06 & 0.01 & 0.00 & 0.00 & 0.00 & 0.01 & 0.00 & 0.02 & 0.11 & 0.17 & 0.11 & 0.02 & 0.01 & 0.02 & 0.02 \\
\hline & $\mathrm{D}$ & 0.18 & 0.14 & 0.04 & 0.01 & 0.00 & 0.01 & 0.03 & 0.03 & 0.10 & 0.49 & 0.72 & 0.4 & 0.15 & 0.08 & 0.26 & 0.34 \\
\hline & E & 0.24 & 0.15 & 0.06 & 0.03 & 0.01 & 0.01 & 0.07 & 0.07 & 0.22 & 0.68 & 1.18 & 0.57 & 0.20 & 0.10 & 0.51 & 0.49 \\
\hline & F & 0.04 & 0.02 & 0.01 & 0.01 & 0.00 & 0.00 & 0.01 & 0.00 & 0.01 & 0.05 & 0.07 & 0.03 & 0.00 & 0.01 & 0.03 & 0.03 \\
\hline & G & 0.03 & 0.01 & 0.00 & 0.00 & 0.00 & 0.00 & 0.00 & 0.00 & 0.00 & 0.00 & 0.01 & 0.00 & 0.00 & 0.00 & 0.00 & 0.01 \\
\hline \multirow{7}{*}{$\begin{array}{c}9.8 \mathrm{~m} / \mathrm{s} \\
(22 \mathrm{mph})\end{array}$} & A & 0.00 & 0.01 & 0.00 & 0.00 & 0.00 & 0.00 & 0.00 & 0.00 & 0.00 & 0.02 & 0.04 & 0.04 & 0.01 & 0.00 & 0.01 & 0.01 \\
\hline & B & 0.00 & 0.00 & 0.00 & 0.00 & 0.00 & 0.00 & 0.00 & 0. & 0.00 & 0.02 & 0.04 & 0.04 & 0.01 & 0.00 & 0.01 & 0.00 \\
\hline & $\mathrm{C}$ & 0.01 & 0.01 & 0.00 & 0.00 & 0.00 & 0.00 & 0.00 & 0.00 & 0.00 & 0.02 & 0.04 & 0.05 & 0.02 & 0.01 & 0.01 & 0.00 \\
\hline & D & 0.02 & 0.03 & 0.01 & 0.00 & 0.00 & 0.00 & 0.00 & 0.00 & 0.01 & 0.11 & 0.25 & 0.16 & 0.09 & 0.02 & 0.14 & 0.08 \\
\hline & $\mathrm{E}$ & 0.02 & 0.04 & 0.02 & 0.00 & 0.00 & 0.00 & 0.01 & 0.02 & 0.05 & 0.22 & 0.50 & 0.17 & 0.07 & 0.02 & 0.16 & 0.07 \\
\hline & F & 0.00 & 0.00 & 0.00 & 0.00 & 0.00 & 0.00 & 0.00 & 0.00 & 0.00 & 0.01 & 0.01 & 0.00 & 0.00 & 0.00 & 0.00 & 0.00 \\
\hline & G & 0.00 & 0.00 & 0.00 & 0.00 & 0.00 & 0.00 & 0.00 & 0.00 & 0.00 & 0.00 & 0.00 & 0.00 & 0.00 & 0.00 & 0.00 & 0.00 \\
\hline \multirow{7}{*}{$\begin{array}{c}12.7 \mathrm{~m} / \mathrm{s} \\
(29 \mathrm{mph})\end{array}$} & A & 0.00 & 0.00 & 0.00 & 0.00 & 0.00 & 0.00 & 0.00 & 0.00 & 0.00 & 0.00 & 0.01 & 0.01 & 0.00 & 0.00 & 0.00 & 0.00 \\
\hline & B & 0.00 & 0.00 & 0.0 & 0.00 & $0 . C$ & 0.0 & 0.00 & & 0. & 0.00 & 0.01 & 0.01 & 0.01 & 0.00 & 0.00 & 0.00 \\
\hline & $\mathrm{C}$ & 0.00 & 0.00 & 0.00 & 0.00 & 0.00 & 0.00 & 0.00 & 0.00 & 0.00 & 0.00 & 0.01 & 0.01 & 0.01 & 0.00 & 0.00 & 0.00 \\
\hline & $\mathrm{D}$ & 0.01 & 0.01 & 0.00 & 0.00 & 0.00 & 0.00 & 0.00 & 0.00 & 0.00 & 0.03 & 0.11 & 0.03 & 0.02 & 0.01 & 0.03 & 0.01 \\
\hline & E & 0.00 & 0.01 & 0.00 & 0.00 & 0.00 & 0.00 & 0.00 & 0.00 & 0.01 & 0.08 & 0.25 & 0.05 & 0.02 & 0.00 & 0.02 & 0.01 \\
\hline & F & 0.00 & 0.00 & 0.00 & 0.00 & 0.00 & 0.00 & 0.00 & 0.00 & 0.00 & 0.00 & 0.00 & 0.00 & 0.00 & 0.00 & 0.00 & 0.00 \\
\hline & G & 0.00 & 0.00 & 0.00 & 0.00 & 0.00 & 0.00 & 0.00 & 0.00 & 0.00 & 0.00 & 0.00 & 0.00 & 0.00 & 0.00 & 0.00 & 0.00 \\
\hline \multirow{7}{*}{$\begin{array}{l}15.6 \mathrm{~m} / \mathrm{s} \\
(35 \mathrm{mph})\end{array}$} & A & & 0.00 & 0.00 & 0.00 & 0.00 & 0.00 & 0.00 & & 0.00 & 0.00 & 0.00 & 0.00 & 0.00 & 0. & 0.00 & 0.00 \\
\hline & B & 0.00 & 0.00 & 0.00 & 0.00 & 0.00 & 0.00 & 0.00 & 0.00 & 0.00 & 0.00 & 0.00 & 0.00 & 0.00 & 0.00 & 0.00 & 0.00 \\
\hline & $\mathrm{C}$ & 0.00 & 0.00 & 0.00 & 0.00 & 0.00 & 0.00 & 0.00 & 0.00 & 0.00 & 0.00 & 0.00 & 0.00 & 0.00 & 0.00 & 0.00 & 0.00 \\
\hline & $\mathrm{D}$ & 0.00 & 0.00 & 0.00 & 0.00 & 0.00 & 0.00 & 0.00 & 0.00 & 0.00 & 0.01 & 0.02 & 0.00 & 0.00 & 0.00 & 0.00 & 0.00 \\
\hline & E & 0.00 & 0.00 & 0.00 & 0.00 & 0.00 & 0.00 & 0.00 & 0.00 & 0.00 & 0.02 & 0.07 & 0.01 & 0.00 & 0.00 & 0.00 & 0.00 \\
\hline & F & 0.00 & 0.00 & 0.00 & 0.00 & 0.00 & 0.00 & 0.00 & 0.00 & 0.00 & 0.00 & 0.00 & 0.00 & 0.00 & 0.00 & 0.00 & 0.00 \\
\hline & G & 0.00 & 0.00 & 0.00 & 0.00 & 0.00 & 0.00 & 0.00 & 0.00 & 0.00 & 0.00 & 0.00 & 0.00 & 0.00 & 0.00 & 0.00 & 0.00 \\
\hline \multirow{7}{*}{$\begin{array}{c}19 \mathrm{~m} / \mathrm{s} \\
(43 \mathrm{mph})\end{array}$} & A & 0.00 & 0.00 & 0.00 & 0.00 & 0.00 & 0.00 & 0.00 & 0.00 & 0.00 & 0.00 & 0.00 & 0.00 & 0.00 & 0.00 & 0.00 & 0.00 \\
\hline & B & 0.00 & 0.00 & 0.00 & 0.00 & 0.00 & 0.00 & 0.00 & 0.00 & 0.00 & 0.00 & 0.00 & 0.00 & 0.00 & 0.00 & 0.00 & 0.00 \\
\hline & C & 0.00 & 0.00 & 0.00 & 0.00 & 0.00 & 0.00 & 0.00 & 0.00 & 0.00 & 0.00 & 0.00 & 0.00 & 0.00 & 0.00 & 0.00 & 0.00 \\
\hline & D & 0.00 & 0.00 & 0.00 & 0.00 & 0.00 & 0.00 & 0.00 & 0.00 & 0.00 & 0.00 & 0.00 & 0.00 & 0.00 & 0.00 & 0.00 & 0.00 \\
\hline & E & 0.00 & 0.00 & 0.00 & 0.00 & 0.00 & 0.00 & 0.00 & 0.00 & 0.00 & 0.01 & 0.01 & 0.00 & 0.00 & 0.00 & 0.00 & 0.00 \\
\hline & F & 0.00 & 0.00 & 0.00 & 0.00 & 0.00 & 0.00 & 0.00 & 0.00 & 0.00 & 0.00 & 0.00 & 0.00 & 0.00 & 0.00 & 0.00 & 0.00 \\
\hline & $\mathrm{G}$ & 0.00 & 0.00 & 0.00 & 0.00 & 0.00 & 0.00 & 0.00 & 0.00 & 0.00 & 0.00 & 0.00 & 0.00 & 0.00 & 0.00 & 0.00 & 0.00 \\
\hline
\end{tabular}


Table A6. Joint Frequency Distributions of Atmospheric Stability, Wind Speed, and Transport Direction for the 300 Area at $60 \mathrm{~m}(197 \mathrm{ft})$ above Ground Level, Hanford Site, Washington.

Based on 1986-2002 data from the 300 Area instrumented tower.

\begin{tabular}{|c|c|c|c|c|c|c|c|c|c|c|c|c|c|c|c|c|c|}
\hline \multirow[t]{2}{*}{$\begin{array}{l}\text { Average } \\
\text { Wind } \\
\text { Speed }\end{array}$} & \multirow{2}{*}{$\begin{array}{c}\text { Atmospheric } \\
\text { Stability Class } \\
60 \mathrm{~m}\end{array}$} & \multicolumn{16}{|c|}{ Percentage of Time Wind Blows in the 300 Area toward the Direction Indicated } \\
\hline & & $\mathbf{S}$ & SSW & SW & WSW & W & WNW & NW & NNW & $\mathbf{N}$ & NNE & NE & ENE & $\mathbf{E}$ & ESE & SE & SSE \\
\hline \multirow{7}{*}{$\begin{array}{l}0.89 \mathrm{~m} / \mathrm{s} \\
(2 \mathrm{mph})\end{array}$} & $\mathrm{A}$ & 0.00 & 0.00 & 0.00 & 0.00 & 0.00 & 0.01 & 0.01 & 0.01 & 0.00 & 0.00 & 0.00 & 0.00 & 0.00 & 0.00 & 0.00 & 0.00 \\
\hline & B & 0.00 & 0.00 & 0.00 & 0.00 & 0.00 & 0.00 & 0.00 & 0.00 & 0.00 & 0.00 & 0.00 & 0.00 & 0.00 & 0.00 & 0.00 & 0.00 \\
\hline & $\mathrm{C}$ & 0.00 & 0.01 & 0.01 & 0.01 & 0.01 & 0.01 & 0.01 & 0.01 & 0.00 & 0.01 & 0.01 & 0.00 & 0.00 & 0.00 & 0.00 & 0.00 \\
\hline & $\mathrm{D}$ & 0.26 & 0.22 & 0.21 & 0.22 & 0.28 & 0.37 & 0.37 & 0.30 & 0.25 & 0.19 & 0.16 & 0.16 & 0.16 & 0.18 & 0.24 & 0.30 \\
\hline & $\mathrm{E}$ & 0.43 & 0.33 & 0.25 & 0.23 & 0.29 & 0.40 & 0.47 & 0.51 & 0.51 & 0.40 & 0.36 & 0.30 & 0.32 & 0.35 & 0.39 & 0.4 \\
\hline & $\mathrm{F}$ & 0.19 & 0.12 & 0.12 & 0.10 & 0.12 & 0.17 & 0.24 & 0.21 & 0.22 & 0.18 & 0.14 & 0.12 & 0.12 & 0.12 & 0.14 & 0.16 \\
\hline & G & 0.15 & 0.12 & 0.13 & 0.10 & 0.12 & 0.17 & 0.20 & 0.19 & 0.18 & 0.13 & 0.14 & 0.11 & 0.12 & 0.15 & 0.18 & 0.18 \\
\hline \multirow{7}{*}{$\begin{array}{c}2.65 \mathrm{~m} / \mathrm{s} \\
(6 \mathrm{mph})\end{array}$} & A & 0.01 & 0.01 & 0.01 & 0.02 & 0.03 & 0.03 & 0.04 & 0.02 & 0.02 & 0.02 & 0.01 & 0.01 & 0.00 & 0.00 & 0.00 & 0.01 \\
\hline & B & 0.01 & 0.00 & 0.02 & 0.01 & 0.02 & 0.03 & 0.03 & 0.03 & 0.03 & 0.04 & 0.02 & 0.01 & 0.00 & 0.00 & 0.00 & 0.01 \\
\hline & $\mathrm{C}$ & 0.01 & 0.04 & 0.12 & 0.11 & 0.11 & 0.10 & 0.08 & 0.05 & 0.05 & 0.06 & 0.06 & 0.03 & 0.01 & 0.01 & 0.01 & 0.01 \\
\hline & $\mathrm{D}$ & 0.80 & 0.64 & 0.57 & 0.66 & 0.90 & 1.09 & 1.33 & 0.70 & 0.60 & 0.66 & 0.51 & 0.28 & 0.16 & 0.13 & 0.34 & 0.7 \\
\hline & $\mathrm{E}$ & 1.19 & 0.65 & 0.35 & 0.30 & 0.54 & 0.96 & 1.61 & 1.29 & 1.26 & 1.16 & 0.98 & 0.62 & 0.46 & 0.44 & 0.61 & 1.0 \\
\hline & $\mathrm{F}$ & 0.40 & 0.20 & 0.06 & 0.05 & 0.11 & 0.37 & 0.67 & 0.69 & 0.66 & 0.44 & 0.30 & 0.23 & 0.18 & 0.14 & 0.18 & 0.32 \\
\hline & G & 0.44 & 0.23 & 0.05 & 0.03 & 0.06 & 0.28 & 0.51 & 0.38 & 0.26 & 0.13 & 0.08 & 0.08 & 0.08 & 0.08 & 0.19 & 0.33 \\
\hline \multirow{7}{*}{$\begin{array}{c}4.7 \mathrm{~m} / \mathrm{s} \\
(10.5 \mathrm{mph})\end{array}$} & A & 0.02 & 0.03 & 0.02 & 0.02 & 0.02 & 0.04 & 0.03 & & 0.03 & & 0.05 & & 0.01 & & & 0.01 \\
\hline & B & 0.02 & 0.09 & 0.05 & 0.01 & 0.01 & 0.02 & 0.05 & 0.02 & 0.04 & 0.10 & 0.10 & 0.03 & 0.01 & 0.00 & 0.01 & 0.00 \\
\hline & $\mathrm{C}$ & 0.05 & 0.22 & 0.17 & 0.04 & 0.02 & 0.06 & 0.08 & 0.03 & 0.05 & 0.18 & 0.20 & 0.06 & 0.02 & 0.01 & 0.02 & 0.02 \\
\hline & D & 0.71 & 0.68 & 0.43 & 0.18 & 0.15 & 0.35 & 0.59 & 0.30 & 0.41 & 1.04 & 0.97 & 0.42 & 0.13 & 0.12 & 0.28 & 0.6 \\
\hline & $\mathrm{E}$ & 1.44 & 0.64 & 0.22 & 0.12 & 0.16 & 0.49 & 1.06 & 0.62 & 1.01 & 1.75 & 1.56 & 0.84 & 0.41 & 0.33 & 0.65 & 1.32 \\
\hline & $\mathrm{F}$ & 0.54 & 0.16 & 0.02 & 0.02 & 0.04 & 0.23 & 0.64 & 0.31 & 0.32 & 0.30 & 0.36 & 0.25 & 0.14 & 0.09 & 0.15 & 0.41 \\
\hline & $\mathrm{G}$ & 0.56 & 0.24 & 0.01 & 0.00 & 0.01 & 0.08 & 0.26 & 0.15 & 0.09 & 0.05 & 0.06 & 0.06 & 0.04 & 0.02 & 0.04 & 0.20 \\
\hline \multirow{7}{*}{$\begin{array}{c}7.2 \mathrm{~m} / \mathrm{s} \\
(16 \mathrm{mph})\end{array}$} & $\mathrm{A}$ & & 0.05 & 0.02 & 0.00 & 0.00 & 0.00 & 0.00 & & 0.01 & 0.07 & 0.11 & & 0.01 & 0.01 & 0.01 & 0.01 \\
\hline & B & 0.02 & 0.07 & 0.01 & 0.00 & 0.00 & 0.00 & 0.00 & 0.00 & 0.01 & 0.07 & 0.13 & 0.08 & 0.02 & 0.01 & 0.01 & 0.01 \\
\hline & $\mathrm{C}$ & 0.06 & 0.11 & 0.02 & 0.00 & 0.00 & 0.00 & 0.01 & 0.00 & 0.02 & 0.13 & 0.21 & 0.12 & 0.02 & 0.02 & 0.02 & 0.03 \\
\hline & $\mathrm{D}$ & 0.28 & 0.23 & 0.05 & 0.01 & 0.01 & 0.01 & 0.05 & 0.05 & 0.13 & 0.57 & 0.79 & 0.48 & 0.15 & 0.11 & 0.27 & 0.3 \\
\hline & $\mathrm{E}$ & 0.78 & 0.29 & 0.07 & 0.03 & 0.02 & 0.09 & 0.22 & 0.17 & 0.33 & 1.06 & 1.69 & 0.93 & 0.33 & 0.23 & 0.68 & 1.0 \\
\hline & $\mathrm{F}$ & 0.36 & 0.08 & 0.01 & 0.02 & 0.01 & 0.05 & 0.11 & 0.04 & 0.03 & 0.11 & 0.30 & 0.21 & 0.06 & 0.05 & 0.12 & 0.36 \\
\hline & G & 0.30 & 0.09 & 0.00 & 0.00 & 0.00 & 0.02 & 0.05 & 0.01 & 0.01 & 0.01 & 0.03 & 0.02 & 0.01 & 0.00 & 0.03 & \\
\hline \multirow{7}{*}{$\begin{array}{c}9.8 \mathrm{~m} / \mathrm{s} \\
(22 \mathrm{mph})\end{array}$} & $\mathrm{A}$ & & 0.01 & 0.00 & 0.00 & & 0.00 & 0.00 & & 0.00 & 0.03 & 0.03 & 0.06 & 0.01 & 0.00 & 0. & 0.01 \\
\hline & B & 0.00 & 0. & 0.00 & 0. & 0.00 & 0. & 0. & & 0.00 & 0. & 0.06 & 0. & 0.02 & 0.00 & 0.01 & 0.0 \\
\hline & $\mathrm{C}$ & 0.01 & 0.01 & 0.00 & 0.00 & 0.00 & 0.00 & 0.00 & 0.00 & 0.01 & 0.03 & 0.06 & 0.06 & 0.03 & 0.01 & 0.01 & 0.00 \\
\hline & $\mathrm{D}$ & 0.07 & 0.04 & 0.03 & 0.01 & 0.00 & 0.00 & 0.01 & 0.01 & 0.03 & 0.18 & 0.31 & 0.23 & 0.10 & 0.06 & 0.20 & 0.12 \\
\hline & $\mathrm{E}$ & 0.09 & 0.08 & 0.04 & 0.03 & 0.01 & 0.01 & 0.03 & 0.04 & 0.08 & 0.37 & 0.95 & 0.44 & 0.15 & 0.09 & 0.46 & 0.25 \\
\hline & $\mathrm{F}$ & 0.02 & 0.00 & 0.01 & 0.01 & 0.00 & 0.01 & 0.01 & 0.01 & 0.00 & 0.03 & 0.07 & 0.05 & 0.01 & 0.01 & 0.04 & 0.03 \\
\hline & G & 0.02 & 0.01 & 0.00 & 0.00 & 0.00 & 0.00 & 0.00 & 0.00 & 0.00 & 0.00 & 0.00 & 0.00 & 0.00 & 0.00 & 0.00 & 0.01 \\
\hline \multirow{7}{*}{$\begin{array}{l}12.7 \mathrm{~m} / \mathrm{s} \\
(29 \mathrm{mph})\end{array}$} & A & & & 0.00 & & & & 0.00 & & 0.00 & 0.01 & 0.02 & 0.02 & 0.01 & 0.00 & 0. & 0.01 \\
\hline & B & & 0.00 & 0.00 & 0.00 & 0.00 & 0.00 & 0.00 & 0.00 & 0.00 & 0.01 & 0.02 & 0.03 & 0.01 & 0.00 & 0.00 & 0.0 \\
\hline & C & 0.00 & 0.00 & 0.00 & 0.00 & 0.00 & 0.00 & 0.00 & 0.00 & 0.00 & 0.01 & 0.03 & 0.02 & 0.01 & 0.00 & 0.01 & 0.0 \\
\hline & $\mathrm{D}$ & 0.01 & 0.03 & 0.01 & 0.00 & 0.00 & 0.00 & 0.00 & 0.00 & 0.01 & 0.06 & 0.17 & 0.09 & 0.05 & 0.01 & 0.09 & 0.02 \\
\hline & $\mathrm{E}$ & 0.01 & 0.03 & 0.02 & 0.02 & 0.00 & 0.00 & 0.01 & 0.01 & 0.03 & 0.16 & 0.54 & 0.16 & 0.06 & 0.03 & 0.13 & 0.0 \\
\hline & $\mathrm{F}$ & 0.00 & 0.00 & 0.00 & 0.00 & 0.00 & 0.00 & 0.00 & 0.00 & 0.00 & 0.01 & 0.02 & 0.01 & 0.00 & 0.00 & 0.00 & 0.00 \\
\hline & $\mathrm{G}$ & 0.00 & 0.00 & 0.00 & 0.00 & 0.00 & 0.00 & 0.00 & 0.00 & 0.00 & 0.00 & 0.00 & 0.00 & 0.00 & 0.00 & 0.00 & 0.00 \\
\hline \multirow{7}{*}{$\begin{array}{l}15.6 \mathrm{~m} / \mathrm{s} \\
(35 \mathrm{mph})\end{array}$} & $\mathrm{A}$ & & 0.00 & 0.00 & 0.00 & 0.00 & 0.00 & 0.00 & 0.00 & 0.00 & & 0.01 & & 0.00 & & 0.00 & \\
\hline & B & 0.00 & 0.00 & 0.00 & 0.00 & 0.00 & 0.00 & 0.00 & 0.00 & 0.00 & 0.00 & 0.00 & 0.00 & 0.00 & 0.00 & 0.00 & 0.0 \\
\hline & $\mathrm{C}$ & 0.00 & 0.00 & 0.00 & 0.00 & 0.00 & 0.00 & 0.00 & 0.00 & 0.00 & 0.00 & 0.00 & 0.00 & 0.00 & 0.00 & 0.00 & 0.00 \\
\hline & $\mathrm{D}$ & 0.00 & 0.01 & 0.00 & 0.00 & 0.00 & 0.00 & 0.00 & 0.00 & 0.00 & 0.02 & 0.07 & 0.02 & 0.01 & 0.00 & 0.01 & 0.0 \\
\hline & $\mathrm{E}$ & 0.00 & 0.01 & 0.01 & 0.00 & 0.00 & 0.00 & 0.00 & 0.00 & 0.00 & 0.05 & 0.21 & 0.03 & 0.01 & 0.00 & 0.01 & 0.0 \\
\hline & $\mathrm{F}$ & 0.00 & 0.00 & 0.00 & 0.00 & 0.00 & 0.00 & 0.00 & 0.00 & 0.00 & 0.00 & 0.00 & 0.00 & 0.00 & 0.00 & 0.00 & 0.0 \\
\hline & $\mathrm{G}$ & 0.00 & 0.00 & 0.00 & 0.00 & 0.00 & 0.00 & 0.00 & 0.00 & 0.00 & 0.00 & 0.00 & 0.00 & 0.00 & 0.00 & 0.00 & \\
\hline \multirow{7}{*}{$\begin{array}{c}19 \mathrm{~m} / \mathrm{s} \\
(43 \mathrm{mph})\end{array}$} & $\mathrm{A}$ & 0.00 & 0.00 & 0.00 & 0.00 & 0.00 & 0.00 & 0.00 & 0.00 & 0.00 & 0.00 & 0.00 & 0.00 & 0.00 & 0.00 & 0.00 & \\
\hline & B & 0.00 & 0.00 & 0.00 & 0.00 & 0.00 & 0.00 & 0.00 & 0.00 & 0.00 & 0.00 & 0.00 & 0.00 & 0.00 & 0.00 & 0.00 & 0.0 \\
\hline & C & 0.00 & 0.00 & 0.00 & 0.00 & 0.00 & 0.00 & 0.00 & 0.00 & 0.00 & 0.00 & 0.00 & 0.00 & 0.00 & 0.00 & 0.00 & 0.0 \\
\hline & $\mathrm{D}$ & 0.00 & 0.00 & 0.00 & 0.00 & 0.00 & 0.00 & 0.00 & 0.00 & 0.00 & 0.00 & 0.03 & 0.01 & 0.01 & 0.00 & 0.00 & 0.0 \\
\hline & $\mathrm{E}$ & 0.00 & 0.00 & 0.01 & 0.00 & 0.00 & 0.00 & 0.00 & 0.00 & 0.00 & 0.02 & 0.13 & 0.02 & 0.00 & 0.00 & 0.00 & 0.00 \\
\hline & $\mathrm{F}$ & 0.00 & 0.00 & 0.00 & 0.00 & 0.00 & 0.00 & 0.00 & 0.00 & 0.00 & 0.00 & 0.00 & 0.00 & 0.00 & 0.00 & 0.00 & 0.0 \\
\hline & G & 0.00 & 0.00 & 0.00 & 0.00 & 0.00 & 0.00 & 0.00 & 0.00 & 0.00 & 0.00 & 0.00 & 0.00 & 0.00 & 0.00 & 0.00 & \\
\hline
\end{tabular}


Table A7. Joint Frequency Distributions of Atmospheric Stability, Wind Speed, and Transport Direction for the 400 Area at $9.1 \mathrm{~m}$ (30 ft) above Ground Level, Hanford Site, Washington.

Based on 1983-2002 data from the Fast Flux Test Facility (FFTF) instrumented tower.

\begin{tabular}{|c|c|c|c|c|c|c|c|c|c|c|c|c|c|c|c|c|c|}
\hline \multirow[t]{2}{*}{$\begin{array}{l}\text { Average } \\
\text { Wind } \\
\text { Speed }\end{array}$} & \multirow{2}{*}{$\begin{array}{c}\text { Atmospheric } \\
\text { Stability } \\
\text { Class } \\
\mathbf{9 . 1} \mathbf{~ m} \\
\end{array}$} & \multicolumn{16}{|c|}{ Percentage of Time Wind Blows at FFTF toward the Direction Indicated } \\
\hline & & $\mathbf{S}$ & SSW & SW & WSW & $\mathbf{W}$ & WNW & NW & NNW & $\mathbf{N}$ & NNE & NE & ENE & $\mathbf{E}$ & ESE & SE & SSE \\
\hline \multirow{7}{*}{$\begin{array}{c}0.89 \mathrm{~m} / \mathrm{s} \\
(2 \mathrm{mph})\end{array}$} & A & 0.03 & 0.03 & 0.02 & 0.03 & 0.03 & 0.04 & 0.03 & 0.02 & 0.03 & 0.02 & 0.01 & 0.01 & 0.01 & 0.02 & 0.02 & 0.02 \\
\hline & B & 0.01 & 0.03 & 0.03 & 0.02 & 0.03 & 0.02 & 0.02 & 0.02 & 0.02 & 0.02 & 0.02 & 0.01 & 0.01 & 0.01 & 0.02 & 0.01 \\
\hline & C & 0.04 & 0.04 & 0.04 & 0.04 & 0.04 & 0.04 & 0.04 & 0.03 & 0.03 & 0.04 & 0.03 & 0.02 & 0.02 & 0.02 & 0.02 & 0.04 \\
\hline & $\mathrm{D}$ & 0.28 & 0.29 & 0.28 & 0.23 & 0.24 & 0.30 & 0.31 & 0.28 & 0.26 & 0.24 & 0.21 & 0.15 & 0.17 & 0.20 & 0.27 & 0.30 \\
\hline & $\mathrm{E}$ & 0.51 & 0.44 & 0.39 & 0.34 & 0.37 & 0.42 & 0.46 & 0.48 & 0.57 & 0.52 & 0.55 & 0.45 & 0.47 & 0.53 & 0.60 & 0.56 \\
\hline & F & 0.19 & 0.17 & 0.14 & 0.11 & 0.13 & 0.13 & 0.17 & 0.18 & 0.24 & 0.26 & 0.24 & 0.19 & 0.19 & 0.20 & 0.23 & 0.21 \\
\hline & G & 0.14 & 0.10 & 0.07 & 0.06 & 0.06 & 0.06 & 0.07 & 0.08 & 0.14 & 0.16 & 0.13 & 0.14 & 0.16 & 0.14 & 0.16 & 0.13 \\
\hline \multirow{7}{*}{$\begin{array}{l}2.65 \mathrm{~m} / \mathrm{s} \\
(6 \mathrm{mph})\end{array}$} & A & 0.10 & 0.15 & 0.14 & 0.11 & 0.12 & 0.16 & 0.16 & 0.14 & 0.20 & 0.15 & 0.07 & 0.05 & 0.04 & 0.05 & 0.05 & 0.06 \\
\hline & B & 0.11 & 0.12 & 0.10 & 0.09 & 0.10 & 0.10 & 0.12 & 0.13 & 0.17 & 0.13 & 0.05 & 0.04 & 0.03 & 0.03 & 0.04 & 0.07 \\
\hline & $\mathrm{C}$ & 0.14 & 0.15 & 0.11 & 0.09 & 0.09 & 0.11 & 0.13 & 0.16 & 0.16 & 0.12 & 0.08 & 0.03 & 0.05 & 0.04 & 0.08 & 0.09 \\
\hline & $\mathrm{D}$ & 0.69 & 0.57 & 0.42 & 0.24 & 0.29 & 0.34 & 0.64 & 0.72 & 0.67 & 0.49 & 0.29 & 0.18 & 0.21 & 0.36 & 0.70 & 0.81 \\
\hline & E & 1.00 & 0.91 & 0.74 & 0.46 & 0.40 & 0.52 & 1.14 & 1.63 & 1.62 & 1.31 & 0.82 & 0.58 & 0.65 & 0.90 & 1.49 & 1.29 \\
\hline & F & 0.50 & 0.43 & 0.25 & 0.10 & 0.10 & 0.15 & 0.37 & 0.70 & 0.81 & 0.72 & 0.43 & 0.23 & 0.23 & 0.31 & 0.57 & 0.58 \\
\hline & $\mathrm{G}$ & 0.30 & 0.36 & 0.17 & 0.05 & 0.04 & 0.05 & 0.15 & 0.36 & 0.56 & 0.65 & 0.29 & 0.13 & 0.14 & 0.26 & 0.55 & 0.38 \\
\hline \multirow{7}{*}{$\begin{array}{c}4.7 \mathrm{~m} / \mathrm{s} \\
(10.5 \mathrm{mph})\end{array}$} & A & 0.12 & 0.19 & 0.11 & 0.02 & 0.03 & 0.04 & 0.06 & 0.07 & 0.32 & 0.37 & 0.15 & 0.07 & 0.07 & 0.06 & 0.07 & 0.06 \\
\hline & B & 0.10 & 0.12 & 0.06 & 0.02 & 0.02 & 0.03 & 0.03 & 0.05 & 0.20 & 0.20 & 0.08 & 0.05 & 0.04 & 0.03 & 0.04 & 0.05 \\
\hline & $\mathrm{C}$ & 0.13 & 0.11 & 0.06 & 0.02 & 0.02 & 0.02 & 0.05 & 0.05 & 0.15 & 0.22 & 0.09 & 0.05 & 0.06 & 0.05 & 0.08 & 0.09 \\
\hline & D & 0.42 & 0.27 & 0.13 & 0.05 & 0.04 & 0.06 & 0.21 & 0.37 & 0.69 & 0.88 & 0.32 & 0.17 & 0.16 & 0.33 & 0.70 & 0.66 \\
\hline & E & 0.43 & 0.48 & 0.25 & 0.09 & 0.06 & 0.09 & 0.52 & 1.34 & 1.54 & 1.70 & 0.77 & 0.40 & 0.42 & 0.93 & 2.04 & 1.05 \\
\hline & F & 0.12 & 0.08 & 0.04 & 0.01 & 0.00 & 0.01 & 0.23 & 0.86 & 0.65 & 0.59 & 0.22 & 0.06 & 0.07 & 0.22 & 0.62 & 0.48 \\
\hline & G & 0.09 & 0.10 & 0.05 & 0.00 & 0.00 & 0.00 & 0.11 & 0.48 & 0.33 & 0.31 & 0.08 & 0.01 & 0.01 & 0.05 & 0.45 & 0.36 \\
\hline \multirow{7}{*}{$\begin{array}{c}7.2 \mathrm{~m} / \mathrm{s} \\
(16 \mathrm{mph})\end{array}$} & A & 0.04 & 0.07 & 0.04 & 0.00 & 0.00 & 0.00 & 0.00 & 0.01 & 0.09 & 0.40 & 0.21 & 0.10 & 0.07 & 0.06 & 0.08 & 0.03 \\
\hline & B & 0.02 & 0.03 & 0.02 & 0.00 & 0.00 & 0.00 & 0.00 & 0.00 & 0.04 & 0.17 & 0.10 & 0.06 & 0.04 & 0.04 & 0.06 & 0.01 \\
\hline & C & 0.03 & 0.02 & 0.01 & 0.00 & 0.00 & 0.00 & 0.01 & 0.01 & 0.05 & 0.17 & 0.11 & 0.05 & 0.04 & 0.03 & 0.07 & 0.03 \\
\hline & D & 0.10 & 0.06 & 0.03 & 0.01 & 0.00 & 0.01 & 0.03 & 0.04 & 0.17 & 0.62 & 0.37 & 0.18 & 0.13 & 0.18 & 0.52 & 0.21 \\
\hline & E & 0.07 & 0.12 & 0.06 & 0.01 & 0.00 & 0.01 & 0.05 & 0.14 & 0.43 & 1.25 & 0.87 & 0.34 & 0.19 & 0.48 & 0.92 & 0.21 \\
\hline & F & 0.00 & 0.01 & 0.00 & 0.00 & 0.00 & 0.00 & 0.01 & 0.05 & 0.11 & 0.25 & 0.09 & 0.02 & 0.01 & 0.03 & 0.07 & 0.02 \\
\hline & G & 0.00 & 0.00 & 0.00 & 0.00 & 0.00 & 0.00 & 0.01 & 0.07 & 0.03 & 0.06 & 0.01 & 0.00 & 0.00 & 0.00 & 0.01 & 0.00 \\
\hline \multirow{7}{*}{$\begin{array}{c}9.8 \mathrm{~m} / \mathrm{s} \\
(22 \mathrm{mph})\end{array}$} & A & 0.01 & 0.01 & 0.01 & 0.00 & 0.00 & 0.00 & 0.00 & 0.00 & 0.01 & 0.07 & 0.07 & 0.07 & 0.04 & 0.02 & 0.04 & 0.01 \\
\hline & B & 0.00 & 0.00 & 0.00 & 0.00 & 0.00 & 0.00 & 0.00 & 0.00 & 0.00 & 0.02 & 0.05 & 0.03 & 0.02 & 0.01 & 0.03 & 0.00 \\
\hline & C & 0.00 & 0.00 & 0.00 & 0.00 & 0.00 & 0.00 & 0.00 & 0.00 & 0.00 & 0.03 & 0.04 & 0.03 & 0.02 & 0.01 & 0.04 & 0.01 \\
\hline & D & 0.01 & 0.02 & 0.01 & 0.00 & 0.00 & 0.00 & 0.00 & 0.00 & 0.01 & 0.12 & 0.19 & 0.10 & 0.04 & 0.05 & 0.21 & 0.02 \\
\hline & E & 0.01 & 0.06 & 0.03 & 0.00 & 0.00 & 0.00 & 0.00 & 0.01 & 0.04 & 0.29 & 0.43 & 0.15 & 0.06 & 0.10 & 0.16 & 0.01 \\
\hline & F & 0.00 & 0.00 & 0.00 & 0.00 & 0.00 & 0.00 & 0.00 & 0.00 & 0.00 & 0.03 & 0.03 & 0.00 & 0.00 & 0.00 & 0.00 & 0.00 \\
\hline & G & 0.00 & 0.00 & 0.00 & 0.00 & 0.00 & 0.00 & 0.00 & 0.00 & 0.00 & 0.01 & 0.00 & 0.00 & 0.00 & 0.00 & 0.00 & 0.00 \\
\hline \multirow{7}{*}{$\begin{array}{l}12.7 \mathrm{~m} / \mathrm{s} \\
(29 \mathrm{mph})\end{array}$} & A & 0.00 & 0.00 & 0.00 & 0.00 & 0.00 & 0.00 & 0.00 & 0.00 & 0.00 & 0.01 & 0.02 & 0.03 & 0.01 & 0.00 & 0.02 & 0.00 \\
\hline & B & 0.00 & 0.00 & 0.00 & 0.00 & 0.00 & 0.00 & 0.00 & 0.00 & 0.00 & 0.01 & 0.01 & 0.01 & 0.00 & 0.00 & 0.01 & 0.00 \\
\hline & C & 0.00 & 0.00 & 0.00 & 0.00 & 0.00 & 0.00 & 0.00 & 0.00 & 0.00 & 0.00 & 0.01 & 0.01 & 0.00 & 0.00 & 0.01 & 0.00 \\
\hline & D & 0.00 & 0.01 & 0.00 & 0.00 & 0.00 & 0.00 & 0.00 & 0.00 & 0.00 & 0.03 & 0.09 & 0.02 & 0.01 & 0.01 & 0.03 & 0.00 \\
\hline & E & 0.00 & 0.01 & 0.01 & 0.00 & 0.00 & 0.00 & 0.00 & 0.00 & 0.01 & 0.09 & 0.19 & 0.04 & 0.01 & 0.02 & 0.02 & 0.00 \\
\hline & F & 0.00 & 0.00 & 0.00 & 0.00 & 0.00 & 0.00 & 0.00 & 0.00 & 0.00 & 0.00 & 0.00 & 0.00 & 0.00 & 0.00 & 0.00 & 0.00 \\
\hline & G & 0.00 & 0.00 & 0.00 & 0.00 & 0.00 & 0.00 & 0.00 & 0.00 & 0.00 & 0.00 & 0.00 & 0.00 & 0.00 & 0.00 & 0.00 & 0.00 \\
\hline \multirow{7}{*}{$\begin{array}{l}15.6 \mathrm{~m} / \mathrm{s} \\
(35 \mathrm{mph})\end{array}$} & A & 0.00 & 0.00 & 0.00 & 0.00 & 0.00 & 0.00 & 0.00 & 0.00 & 0.00 & 0.00 & 0.00 & 0.00 & 0.00 & 0.00 & 0.00 & 0.00 \\
\hline & B & 0.00 & 0.00 & 0.00 & 0.00 & 0.00 & 0.00 & 0.00 & 0.00 & 0.00 & 0.00 & 0.00 & 0.00 & 0.00 & 0.00 & 0.00 & 0.00 \\
\hline & C & 0.00 & 0.00 & 0.00 & 0.00 & 0.00 & 0.00 & 0.00 & 0.00 & 0.00 & 0.00 & 0.00 & 0.00 & 0.00 & 0.00 & 0.00 & 0.00 \\
\hline & $\mathrm{D}$ & 0.00 & 0.00 & 0.00 & 0.00 & 0.00 & 0.00 & 0.00 & 0.00 & 0.00 & 0.00 & 0.02 & 0.01 & 0.01 & 0.00 & 0.00 & 0.00 \\
\hline & E & 0.00 & 0.00 & 0.00 & 0.00 & 0.00 & 0.00 & 0.00 & 0.00 & 0.00 & 0.03 & 0.06 & 0.01 & 0.00 & 0.00 & 0.00 & 0.00 \\
\hline & F & 0.00 & 0.00 & 0.00 & 0.00 & 0.00 & 0.00 & 0.00 & 0.00 & 0.00 & 0.00 & 0.00 & 0.00 & 0.00 & 0.00 & 0.00 & 0.00 \\
\hline & $\mathrm{G}$ & 0.00 & 0.00 & 0.00 & 0.00 & 0.00 & 0.00 & 0.00 & 0.00 & 0.00 & 0.00 & 0.00 & 0.00 & 0.00 & 0.00 & 0.00 & 0.00 \\
\hline \multirow{7}{*}{$\begin{array}{c}19 \mathrm{~m} / \mathrm{s} \\
(43 \mathrm{mph})\end{array}$} & A & 0.00 & 0.00 & 0.00 & 0.00 & 0.00 & 0.00 & 0.00 & 0.00 & 0.00 & 0.00 & 0.00 & 0.00 & 0.00 & 0.00 & 0.00 & 0.00 \\
\hline & B & 0.00 & 0.00 & 0.00 & 0.00 & 0.00 & 0.00 & 0.00 & 0.00 & 0.00 & 0.00 & 0.00 & 0.00 & 0.00 & 0.00 & 0.00 & 0.00 \\
\hline & C & 0.00 & 0.00 & 0.00 & 0.00 & 0.00 & 0.00 & 0.00 & 0.00 & 0.00 & 0.00 & 0.00 & 0.00 & 0.00 & 0.00 & 0.00 & 0.00 \\
\hline & D & 0.00 & 0.00 & 0.00 & 0.00 & 0.00 & 0.00 & 0.00 & 0.00 & 0.00 & 0.00 & 0.00 & 0.00 & 0.00 & 0.00 & 0.00 & 0.00 \\
\hline & E & 0.00 & 0.00 & 0.00 & 0.00 & 0.00 & 0.00 & 0.00 & 0.00 & 0.00 & 0.00 & 0.01 & 0.00 & 0.00 & 0.00 & 0.00 & 0.00 \\
\hline & F & 0.00 & 0.00 & 0.00 & 0.00 & 0.00 & 0.00 & 0.00 & 0.00 & 0.00 & 0.00 & 0.00 & 0.00 & 0.00 & 0.00 & 0.00 & 0.00 \\
\hline & G & 0.00 & 0.00 & 0.00 & 0.00 & 0.00 & 0.00 & 0.00 & 0.00 & 0.00 & 0.00 & 0.00 & 0.00 & 0.00 & 0.00 & 0.00 & 0.00 \\
\hline
\end{tabular}


Table A8. Joint Frequency Distributions of Atmospheric Stability, Wind Speed, and Transport Direction for the 400 Area at $60 \mathrm{~m} \mathrm{(197} \mathrm{ft)} \mathrm{above} \mathrm{Ground} \mathrm{Level,} \mathrm{Hanford} \mathrm{Site,} \mathrm{Washington.}$

Based on 1986-2002 data from the Fast Flux Test Facility (FFTF) instrumented tower.

\begin{tabular}{|c|c|c|c|c|c|c|c|c|c|c|c|c|c|c|c|c|c|}
\hline \multirow{2}{*}{$\begin{array}{l}\text { Average } \\
\text { Wind } \\
\text { Speed }\end{array}$} & \multirow{2}{*}{$\begin{array}{c}\text { Atmospheric } \\
\text { Stability } \\
\text { Class } \\
60 \mathrm{~m} \\
\end{array}$} & \multicolumn{16}{|c|}{ Percentage of Time Wind Blows at FFTF toward the Direction Indicated } \\
\hline & & $\mathbf{S}$ & SSW & SW & WSW & W & WNW & NW & NNW & $\mathbf{N}$ & NNE & NE & ENE & $\mathbf{E}$ & ESE & SE & SSE \\
\hline \multirow{7}{*}{$\begin{array}{l}0.89 \mathrm{~m} / \mathrm{s} \\
(2 \mathrm{mph})\end{array}$} & $\mathrm{A}$ & 0.01 & 0.01 & 0.01 & 0.01 & 0.01 & 0.01 & 0.01 & 0.01 & 0.01 & 0.01 & 0.01 & 0.01 & 0.01 & 0.01 & 0.01 & 0.01 \\
\hline & B & 0.02 & 0.01 & 0.02 & 0.01 & 0.02 & 0.01 & 0.02 & 0.01 & 0.01 & 0.01 & 0.01 & 0.01 & 0.00 & 0.01 & 0.01 & 0.01 \\
\hline & C & 0.03 & 0.04 & 0.03 & 0.02 & 0.03 & 0.03 & 0.03 & 0.03 & 0.02 & 0.03 & 0.02 & 0.02 & 0.01 & 0.02 & 0.03 & 0.02 \\
\hline & $\mathrm{D}$ & 0.21 & 0.21 & 0.22 & 0.18 & 0.23 & 0.26 & 0.27 & 0.23 & 0.20 & 0.15 & 0.16 & 0.12 & 0.12 & 0.14 & 0.19 & 0.20 \\
\hline & $\mathrm{E}$ & 0.34 & 0.32 & 0.29 & 0.26 & 0.31 & 0.32 & 0.41 & 0.41 & 0.40 & 0.34 & 0.34 & 0.28 & 0.32 & 0.31 & 0.35 & 0.34 \\
\hline & $\mathrm{F}$ & 0.14 & 0.11 & 0.09 & 0.10 & 0.10 & 0.12 & 0.15 & 0.17 & 0.18 & 0.15 & 0.13 & 0.13 & 0.12 & 0.10 & 0.11 & 0.13 \\
\hline & G & 0.09 & 0.07 & 0.05 & 0.06 & 0.07 & 0.08 & 0.09 & 0.11 & 0.12 & 0.11 & 0.12 & 0.11 & 0.11 & 0.08 & 0.08 & 0.09 \\
\hline \multirow{7}{*}{$\begin{array}{l}2.65 \mathrm{~m} / \mathrm{s} \\
(6 \mathrm{mph})\end{array}$} & A & 0.03 & 0.06 & 0.07 & 0.06 & 0.07 & 0.07 & 0.07 & 0.06 & 0.08 & 0.05 & 0.02 & 0.01 & 0.01 & 0.02 & 0.02 & 0.02 \\
\hline & B & 0.08 & 0.09 & 0.11 & 0.09 & 0.09 & 0.09 & 0.10 & 0.11 & 0.15 & 0.10 & 0.04 & 0.03 & 0.03 & 0.03 & 0.02 & 0.05 \\
\hline & $\mathrm{C}$ & 0.12 & 0.15 & 0.11 & 0.10 & 0.10 & 0.12 & 0.12 & 0.15 & 0.16 & 0.12 & 0.07 & 0.04 & 0.04 & 0.04 & 0.06 & 0.09 \\
\hline & $\mathrm{D}$ & 0.58 & 0.49 & 0.38 & 0.24 & 0.28 & 0.35 & 0.53 & 0.62 & 0.53 & 0.40 & 0.23 & 0.17 & 0.16 & 0.25 & 0.53 & 0.60 \\
\hline & E & 0.76 & 0.74 & 0.62 & 0.42 & 0.40 & 0.51 & 0.78 & 1.10 & 1.13 & 0.87 & 0.61 & 0.47 & 0.57 & 0.73 & 0.93 & .91 \\
\hline & $\mathrm{F}$ & 0.34 & 0.28 & 0.15 & 0.08 & 0.09 & 0.11 & 0.24 & 0.45 & 0.57 & 0.40 & 0.28 & 0.26 & 0.24 & 0.21 & 0.29 & 0.31 \\
\hline & G & 0.24 & 0.20 & 0.14 & 0.07 & 0.03 & 0.04 & 0.15 & 0.30 & 0.35 & 0.35 & 0.35 & 0.20 & 0.16 & 0.14 & 0.24 & 0.25 \\
\hline \multirow{7}{*}{$\begin{array}{c}4.7 \mathrm{~m} / \mathrm{s} \\
(10.5 \mathrm{mph})\end{array}$} & A & 0.07 & 0.16 & 0.10 & 0.02 & 0.03 & 0.03 & 0.06 & 0.06 & 0.23 & 0.20 & 0.07 & 0.03 & 0.03 & 0.03 & 0.03 & 0.02 \\
\hline & B & 0.12 & 0.13 & 0.07 & 0.03 & 0.03 & 0.03 & 0.05 & 0.07 & 0.21 & 0.18 & 0.07 & 0.03 & 0.03 & 0.04 & 0.04 & 0.05 \\
\hline & $\mathrm{C}$ & 0.15 & 0.13 & 0.08 & 0.03 & 0.02 & 0.03 & 0.05 & 0.07 & 0.17 & 0.20 & 0.08 & 0.05 & 0.05 & 0.04 & 0.06 & 0.09 \\
\hline & $\mathrm{D}$ & 0.46 & 0.31 & 0.19 & 0.08 & 0.06 & 0.07 & 0.27 & 0.35 & 0.61 & 0.74 & 0.27 & 0.13 & 0.12 & 0.21 & 0.63 & 0.60 \\
\hline & $\mathrm{E}$ & 0.67 & 0.63 & 0.44 & 0.15 & 0.11 & 0.15 & 0.60 & 1.03 & 1.35 & 1.38 & 0.85 & 0.43 & 0.45 & 0.75 & 1.43 & .08 \\
\hline & $\mathrm{F}$ & 0.25 & 0.20 & 0.09 & 0.04 & 0.03 & 0.03 & 0.21 & 0.46 & 0.61 & 0.60 & 0.38 & 0.13 & 0.15 & 0.27 & 0.42 & 0.47 \\
\hline & G & 0.20 & 0.13 & 0.08 & 0.02 & 0.00 & 0.00 & 0.10 & 0.28 & 0.32 & 0.36 & 0.34 & 0.09 & 0.07 & 0.10 & 0.35 & 0.37 \\
\hline \multirow{7}{*}{$\begin{array}{c}7.2 \mathrm{~m} / \mathrm{s} \\
(16 \mathrm{mph})\end{array}$} & A & 0.05 & 0.08 & 0.04 & 0.00 & 0.00 & 0.00 & 0.01 & 0.00 & 0.11 & 0.36 & 0.15 & 0.06 & 0.04 & 0.04 & 0.04 & 0.01 \\
\hline & B & 0.04 & 0.05 & 0.02 & 0.00 & 0.00 & 0.00 & 0.00 & 0.01 & 0.05 & 0.16 & 0.10 & 0.06 & 0.03 & 0.03 & 0.04 & 0.02 \\
\hline & $\mathrm{C}$ & 0.05 & 0.04 & 0.01 & 0.00 & 0.00 & 0.00 & 0.01 & 0.01 & 0.05 & 0.19 & 0.11 & 0.04 & 0.04 & 0.04 & 0.06 & 0.05 \\
\hline & $\mathrm{D}$ & 0.17 & 0.09 & 0.03 & 0.01 & 0.00 & 0.01 & 0.06 & 0.08 & 0.24 & 0.64 & 0.32 & 0.14 & 0.11 & 0.15 & 0.51 & 0.34 \\
\hline & $\mathrm{E}$ & 0.28 & 0.25 & 0.11 & 0.03 & 0.02 & 0.02 & 0.25 & 0.39 & 0.74 & 1.65 & 1.18 & 0.43 & 0.30 & 0.83 & 1.93 & 0.72 \\
\hline & $\mathrm{F}$ & 0.07 & 0.05 & 0.05 & 0.01 & 0.00 & 0.01 & 0.12 & 0.21 & 0.26 & 0.53 & 0.36 & 0.05 & 0.05 & 0.29 & 0.62 & 0.33 \\
\hline & $\mathrm{G}$ & 0.06 & 0.01 & 0.02 & 0.01 & 0.00 & 0.00 & 0.03 & 0.10 & 0.14 & 0.18 & 0.16 & 0.01 & 0.01 & 0.12 & 0.49 & 0.29 \\
\hline \multirow{7}{*}{$\begin{array}{c}9.8 \mathrm{~m} / \mathrm{s} \\
(22 \mathrm{mph})\end{array}$} & A & 0.00 & 0.03 & 0.01 & 0.00 & 0.00 & 0.00 & 0.00 & 0.00 & 0.02 & 0.09 & 0.09 & 0.07 & 0.04 & 0.03 & 0.04 & 0.01 \\
\hline & B & 0.00 & 0.01 & 0.01 & 0.00 & 0.00 & 0.00 & 0.00 & 0.00 & 0.01 & 0.04 & 0.06 & 0.03 & 0.03 & 0.02 & 0.04 & 0.00 \\
\hline & $\mathrm{C}$ & 0.00 & 0.01 & 0.01 & 0.00 & 0.00 & 0.00 & 0.00 & 0.00 & 0.01 & 0.05 & 0.06 & 0.03 & 0.03 & 0.02 & 0.05 & 0.01 \\
\hline & $\mathrm{D}$ & 0.03 & 0.03 & 0.01 & 0.00 & 0.00 & 0.00 & 0.00 & 0.01 & 0.03 & 0.20 & 0.23 & 0.12 & 0.07 & 0.09 & 0.38 & 0.07 \\
\hline & $\mathrm{E}$ & 0.07 & 0.11 & 0.07 & 0.02 & 0.02 & 0.02 & 0.06 & 0.08 & 0.21 & 0.80 & 0.85 & 0.29 & 0.15 & 0.52 & 1.24 & 0.20 \\
\hline & $\mathrm{F}$ & 0.01 & 0.00 & 0.01 & 0.00 & 0.00 & 0.00 & 0.01 & 0.01 & 0.04 & 0.16 & 0.13 & 0.02 & 0.01 & 0.16 & 0.28 & 0.04 \\
\hline & G & 0.00 & 0.00 & 0.01 & 0.00 & 0.00 & 0.00 & 0.00 & 0.00 & 0.01 & 0.03 & 0.02 & 0.00 & 0.00 & 0.07 & 0.17 & 0.02 \\
\hline \multirow{7}{*}{$\begin{array}{l}12.7 \mathrm{~m} / \mathrm{s} \\
(29 \mathrm{mph})\end{array}$} & A & 0.00 & 0.00 & 0.01 & 0.00 & 0.00 & 0.00 & 0.00 & 0.00 & 0.00 & 0.01 & 0.03 & 0.04 & 0.02 & 0.01 & 0.03 & 0.00 \\
\hline & B & 0.00 & 0.00 & 0.00 & 0.00 & 0.00 & 0.00 & 0.00 & 0.00 & 0.00 & 0.01 & 0.02 & 0.02 & 0.01 & 0.01 & 0.02 & 0.00 \\
\hline & $\mathrm{C}$ & 0.00 & 0.00 & 0.00 & 0.00 & 0.00 & 0.00 & 0.00 & 0.00 & 0.00 & 0.01 & 0.02 & 0.02 & 0.01 & 0.00 & 0.03 & 0.00 \\
\hline & $\mathrm{D}$ & 0.00 & 0.02 & 0.01 & 0.00 & 0.00 & 0.00 & 0.00 & 0.00 & 0.00 & 0.05 & 0.13 & 0.07 & 0.03 & 0.04 & 0.20 & 0.01 \\
\hline & $\mathrm{E}$ & 0.02 & 0.06 & 0.03 & 0.01 & 0.00 & 0.01 & 0.03 & 0.03 & 0.05 & 0.28 & 0.50 & 0.17 & 0.07 & 0.13 & 0.33 & 0.06 \\
\hline & $\mathrm{F}$ & 0.00 & 0.01 & 0.00 & 0.00 & 0.00 & 0.00 & 0.00 & 0.00 & 0.00 & 0.04 & 0.04 & 0.00 & 0.00 & 0.01 & 0.01 & 0.00 \\
\hline & $\mathrm{G}$ & 0.00 & 0.00 & 0.00 & 0.00 & 0.00 & 0.00 & 0.00 & 0.00 & 0.00 & 0.00 & 0.00 & 0.00 & 0.00 & 0.00 & 0.00 & 0.00 \\
\hline \multirow{7}{*}{$\begin{array}{l}15.6 \mathrm{~m} / \mathrm{s} \\
(35 \mathrm{mph})\end{array}$} & A & & 0.00 & 0.00 & 0.00 & 0.00 & 0.00 & 0.00 & 0.00 & 0.00 & 0.00 & 0.01 & 0.02 & 0.00 & 0.00 & 0.01 & 0.00 \\
\hline & B & 0.00 & 0.00 & 0.00 & 0.00 & 0.00 & 0.00 & 0.00 & 0.00 & 0.00 & 0.00 & 0.01 & 0.00 & 0.00 & 0.00 & 0.01 & 0.00 \\
\hline & $\mathrm{C}$ & 0.00 & 0.00 & 0.00 & 0.00 & 0.00 & 0.00 & 0.00 & 0.00 & 0.00 & 0.00 & 0.00 & 0.00 & 0.00 & 0.00 & 0.01 & 0.00 \\
\hline & $\mathrm{D}$ & 0.00 & 0.00 & 0.00 & 0.00 & 0.00 & 0.00 & 0.00 & 0.00 & 0.00 & 0.02 & 0.04 & 0.02 & 0.01 & 0.01 & 0.03 & 0.00 \\
\hline & $\mathrm{E}$ & 0.00 & 0.01 & 0.01 & 0.00 & 0.00 & 0.00 & 0.00 & 0.01 & 0.01 & 0.12 & 0.22 & 0.06 & 0.01 & 0.01 & 0.04 & 0.02 \\
\hline & $\mathrm{F}$ & 0.00 & 0.00 & 0.00 & 0.00 & 0.00 & 0.00 & 0.00 & 0.00 & 0.00 & 0.01 & 0.01 & 0.00 & 0.00 & 0.00 & 0.00 & 0.00 \\
\hline & $\mathrm{G}$ & 0.00 & 0.00 & 0.00 & 0.00 & 0.00 & 0.00 & 0.00 & 0.00 & 0.00 & 0.00 & 0.00 & 0.00 & 0.00 & 0.00 & 0.00 & 0.00 \\
\hline \multirow{7}{*}{$\begin{array}{c}19 \mathrm{~m} / \mathrm{s} \\
(43 \mathrm{mph})\end{array}$} & $\mathrm{A}$ & 0.00 & 0.00 & 0.00 & 0.00 & 0.00 & 0.00 & 0.00 & 0.00 & 0.00 & 0.00 & 0.00 & 0.00 & 0.00 & 0.00 & 0.00 & 0.00 \\
\hline & B & 0.00 & 0.00 & 0.00 & 0.00 & 0.00 & 0.00 & 0.00 & 0.00 & 0.00 & 0.00 & 0.00 & 0.00 & 0.00 & 0.00 & 0.00 & 0.00 \\
\hline & $\mathrm{C}$ & 0.00 & 0.00 & 0.00 & 0.00 & 0.00 & 0.00 & 0.00 & 0.00 & 0.00 & 0.00 & 0.00 & 0.00 & 0.00 & 0.00 & 0.00 & 0.00 \\
\hline & $\mathrm{D}$ & 0.00 & 0.00 & 0.00 & 0.00 & 0.00 & 0.00 & 0.00 & 0.00 & 0.00 & 0.01 & 0.03 & 0.01 & 0.01 & 0.00 & 0.00 & 0.00 \\
\hline & $\mathrm{E}$ & 0.00 & 0.00 & 0.01 & 0.00 & 0.00 & 0.00 & 0.00 & 0.00 & 0.00 & 0.06 & 0.11 & 0.01 & 0.01 & 0.00 & 0.00 & 0.00 \\
\hline & $\mathrm{F}$ & 0.00 & 0.00 & 0.00 & 0.00 & 0.00 & 0.00 & 0.00 & 0.00 & 0.00 & 0.00 & 0.00 & 0.00 & 0.00 & 0.00 & 0.00 & 0.00 \\
\hline & G & 0.00 & 0.00 & 0.00 & 0.00 & 0.00 & 0.00 & 0.00 & 0.00 & 0.00 & 0.00 & 0.00 & 0.00 & 0.00 & 0.00 & 0.00 & 0.00 \\
\hline
\end{tabular}


Table A9. X/Q' Values $\left(\mathrm{s} \mathrm{m}^{-3}\right.$ ) for Chronic Ground-Level Releases from 100-N Area Based on 1983 through 2002 Meteorological Information, Hanford Site, Washington

Distance Sector (Wind from 100-N toward Direction Indicated)

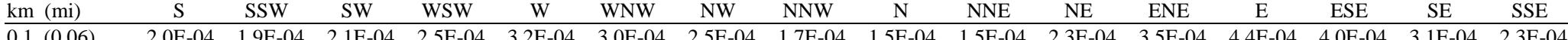

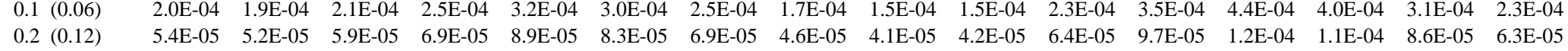

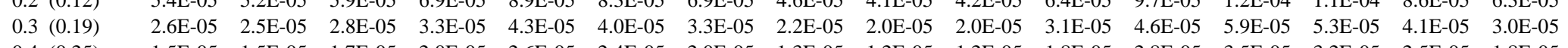

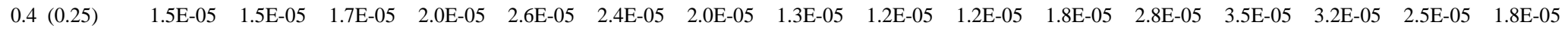

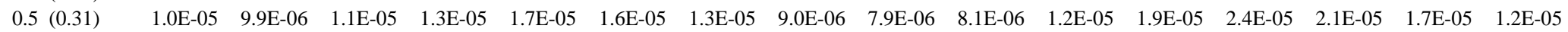

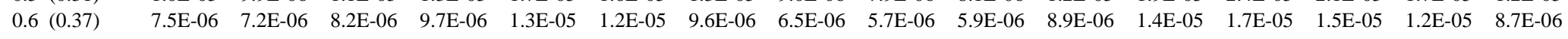

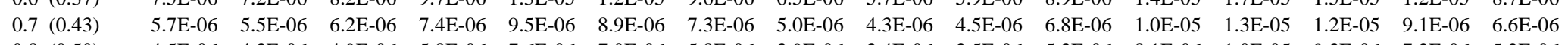

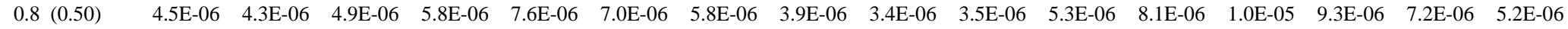

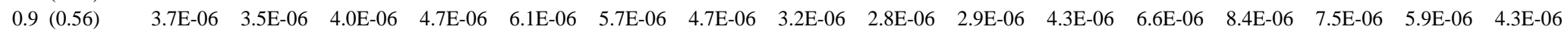

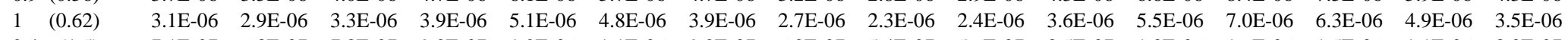

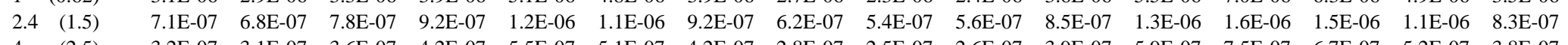

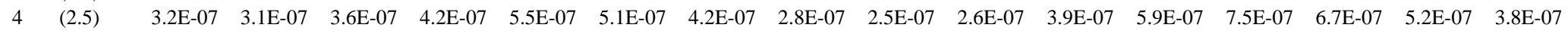

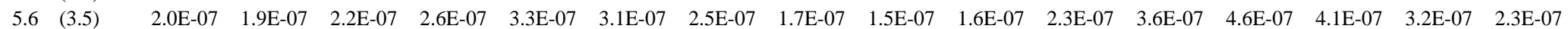

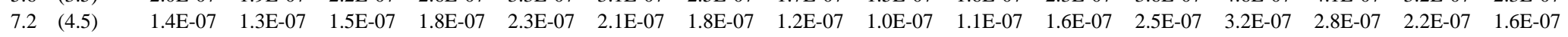

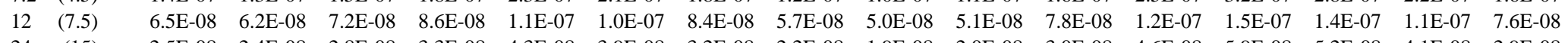

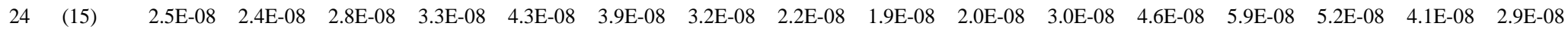

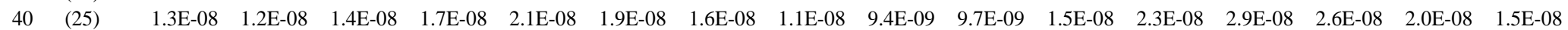

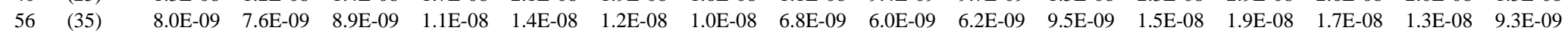

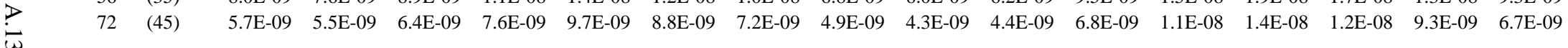

Table A10. X/Q' Values $\left(\mathrm{s} \mathrm{m}^{-3}\right.$ ) for Chronic 60-m Stack Releases from 100-N Area Based on 1986 through 2002 Meteorological Information, Hanford Site, Washington

\begin{tabular}{|c|c|c|c|c|c|c|c|c|c|c|c|c|c|c|c|c|}
\hline \multirow{2}{*}{$\begin{array}{l}\text { Distance } \\
\text { km (mi) }\end{array}$} & \multicolumn{16}{|c|}{ Sector (Wind from 100-N toward Direction Indicated) } \\
\hline & $\mathrm{S}$ & SSW & SW & WSW & $\mathrm{W}$ & WNW & NW & NNW & $\mathrm{N}$ & NNE & NE & ENE & $\mathrm{E}$ & ESE & SE & SSE \\
\hline $0.1(0.06)$ & $2.3 \mathrm{E}-10$ & $2.5 \mathrm{E}-10$ & $1.7 \mathrm{E}-10$ & 9.3E-11 & $1.1 \mathrm{E}-10$ & $1.2 \mathrm{E}-10$ & 8.7E-11 & $7.2 \mathrm{E}-11$ & $6.9 \mathrm{E}-11$ & 8.3E-11 & $2.1 \mathrm{E}-10$ & $3.1 \mathrm{E}-10$ & $3.6 \mathrm{E}-10$ & $3.0 \mathrm{E}-10$ & $2.4 \mathrm{E}-10$ & $E$ \\
\hline ( 017 & & & 5E-08 & 4E-08 & & & & & & & & 7.7E-08 & & & & \\
\hline & & & & $4 \mathrm{E}$ & & & & & & & & & & & & \\
\hline (1) & & & & & & & & & & & & & & & & \\
\hline-1031 & & & & & & & & & & & & & & & & \\
\hline $5(0.37)$ & & & & & & & & & & & & & & & & \\
\hline $7(0.4$ & & & & & & & & & & & & & & & & \\
\hline $.8(0.50$ & & & & & & & & & & & & & & & & \\
\hline $0.9(0.56$ & & & & & & & & & & & & & & & & \\
\hline $1 \quad(0.62)$ & & & & & & & & & & & & & & & & \\
\hline $2.4 \quad(1.5)$ & & & & & & & & & & & & & & & & \\
\hline 4 & & & & & & & & & & & & & & & & \\
\hline $5.6 \quad(3.5)$ & & & & & & & & & & & & & & & & \\
\hline $7.2 \quad(4.5)$ & & & & & & & & & & & & & & & & \\
\hline $12 \quad(7.5)$ & & 3. & 3 & & & & & & 2.6E-08 & & & & & & & \\
\hline (15) & & & & & & & & & $2 \mathrm{E}-08$ & & & & & & & \\
\hline (25) & & 19 & $8 \mathrm{E}-$ & & & & & & & & & & & & & \\
\hline (35) & & $3 E-09$ & $6.0 \mathrm{E}-$ & & & & & & & & & & & & & \\
\hline (45) & $3.9 \mathrm{E}-09$ & 3.9E-09 & 4.4E-09 & 5.8E-09 & 8.4E-09 & 7.8E-09 & 6.4E-09 & 4.2E-09 & 3.2E-09 & 2.9E-09 & 3.3E-09 & 4.1E-09 & 6.3E-09 & 7.1E-09 & 5.0E-09 & $0.1 \mathrm{~L}$ \\
\hline
\end{tabular}


Table A11. X/Q' Values $\left(\mathrm{s} \mathrm{m}^{-3}\right.$ ) for Chronic Ground-Level Releases from 200 Areas Based on 1983 through 2002 Meteorological Information, Hanford Site, Washington

\begin{tabular}{|c|c|c|c|c|c|c|c|c|c|c|c|c|c|c|c|c|}
\hline \multirow{2}{*}{$\begin{array}{l}\text { Distance } \\
\mathrm{km}(\mathrm{mi})\end{array}$} & \multicolumn{16}{|c|}{ Sector (Wind from 200 Areas toward Direction Indicated) } \\
\hline & $\mathrm{S}$ & SSW & SW & WSW & W & WNW & NW & NNW & $\mathrm{N}$ & NNE & $\mathrm{NE}$ & ENE & E & ESE & SE & SSE \\
\hline $0.1(0.06)$ & $1.5 \mathrm{E}-04$ & $1.2 \mathrm{E}-04$ & $1.1 \mathrm{E}-04$ & $9.2 \mathrm{E}-05$ & $1.0 \mathrm{E}-04$ & $1.1 \mathrm{E}-04$ & $1.4 \mathrm{E}-04$ & $1.3 \mathrm{E}-04$ & $1.3 \mathrm{E}-04$ & $1.3 \mathrm{E}-04$ & $1.9 \mathrm{E}-04$ & 2.5E-04 & $3.0 \mathrm{E}-04$ & 3.7E-04 & $3.8 \mathrm{E}-04$ & 2.1E-04 \\
\hline $0.2(0.12)$ & 4.1E-05 & 3.1E-05 & $3.0 \mathrm{E}-05$ & 2.5E-05 & 2.8E-05 & $3.0 \mathrm{E}-05$ & 3.9E-05 & 3.7E-05 & 3.5E-05 & 3.7E-05 & 5.1E-05 & 7.0E-05 & 8.4E-05 & $1.0 \mathrm{E}-04$ & $1.1 \mathrm{E}-04$ & $5.8 \mathrm{E}-05$ \\
\hline $0.3(0.19)$ & $1.9 \mathrm{E}-05$ & $1.5 \mathrm{E}-05$ & $1.4 \mathrm{E}-05$ & $1.2 \mathrm{E}-05$ & $1.3 \mathrm{E}-05$ & $1.4 \mathrm{E}-05$ & $1.9 \mathrm{E}-05$ & $1.7 \mathrm{E}-05$ & $1.7 \mathrm{E}-05$ & $1.8 \mathrm{E}-05$ & 2.5E-05 & 3.3E-05 & 4.0E-05 & 4.9E-05 & $5.0 \mathrm{E}-05$ & 2.8E-05 \\
\hline $0.4(0.25)$ & $1.1 \mathrm{E}-05$ & 8.6E-06 & $8.2 \mathrm{E}-06$ & $6.9 \mathrm{E}-06$ & 7.7E-06 & 8.4E-06 & $1.1 \mathrm{E}-05$ & $1.0 \mathrm{E}-05$ & 9.9E-06 & $1.0 \mathrm{E}-05$ & $1.5 \mathrm{E}-05$ & 2.0E-05 & 2.4E-05 & 2.9E-05 & $3.0 \mathrm{E}-05$ & 1.6E-05 \\
\hline $0.5(0.31)$ & 7.5E-06 & 5.7E-06 & $5.4 \mathrm{E}-06$ & 4.6E-06 & 5.1E-06 & 5.6E-06 & 7.4E-06 & 6.9E-06 & 6.6E-06 & 7.0E-06 & $9.8 \mathrm{E}-06$ & 1.3E-05 & 1.6E-05 & 2.0E-05 & 2.0E-05 & $1.1 \mathrm{E}-05$ \\
\hline $0.6(0.37)$ & $5.4 \mathrm{E}-06$ & 4.1E-06 & $3.9 \mathrm{E}-06$ & 3.3E-06 & 3.7E-06 & 4.0E-06 & 5.3E-06 & $5.0 \mathrm{E}-06$ & $4.8 \mathrm{E}-06$ & 5.1E-06 & 7.1E-06 & 9.7E-06 & $1.2 \mathrm{E}-05$ & $1.4 \mathrm{E}-05$ & $1.5 \mathrm{E}-05$ & 7.9E-06 \\
\hline $0.7(0.43)$ & 4.1E-06 & $3.1 \mathrm{E}-06$ & 2.9E-06 & 2.5E-06 & $2.8 \mathrm{E}-06$ & $3.1 \mathrm{E}-06$ & 4.0E-06 & $3.8 \mathrm{E}-06$ & $3.7 \mathrm{E}-06$ & $3.9 \mathrm{E}-06$ & $5.4 \mathrm{E}-06$ & 7.4E-06 & 8.9E-06 & $1.1 \mathrm{E}-05$ & $1.1 \mathrm{E}-05$ & $6.0 \mathrm{E}-06$ \\
\hline $0.8(0.50)$ & 3.2E-06 & 2.4E-06 & 2.3E-06 & $2.0 \mathrm{E}-06$ & 2.2E-06 & 2.4E-06 & $3.2 \mathrm{E}-06$ & $3.0 \mathrm{E}-06$ & $2.9 \mathrm{E}-06$ & $3.0 \mathrm{E}-06$ & 4.3E-06 & $5.8 \mathrm{E}-06$ & 7.1E-06 & 8.6E-06 & 8.7E-06 & 4.7E-06 \\
\hline $0.9(0.56)$ & 2.6E-06 & $2.0 \mathrm{E}-06$ & $1.9 \mathrm{E}-06$ & $1.6 \mathrm{E}-06$ & $1.8 \mathrm{E}-06$ & 2.0E-06 & 2.6E-06 & $2.4 \mathrm{E}-06$ & 2.3E-06 & 2.5E-06 & 3.5E-06 & 4.7E-06 & 5.7E-06 & $7.0 \mathrm{E}-06$ & 7.1E-06 & 3.8E-06 \\
\hline $1 \quad(0.62)$ & 2.2E-06 & $1.6 \mathrm{E}-06$ & $1.6 \mathrm{E}-06$ & $1.3 \mathrm{E}-06$ & $1.5 \mathrm{E}-06$ & $1.6 \mathrm{E}-06$ & 2.1E-06 & $2.0 \mathrm{E}-06$ & $1.9 \mathrm{E}-06$ & 2.1E-06 & 2.9E-06 & $3.9 \mathrm{E}-06$ & $4.8 \mathrm{E}-06$ & 5.8E-06 & 5.9E-06 & $3.2 \mathrm{E}-06$ \\
\hline $2.4 \quad(1.5)$ & $4.9 \mathrm{E}-07$ & 3.8E-07 & 3.6E-07 & $3.0 \mathrm{E}-07$ & $3.4 \mathrm{E}-07$ & 3.7E-07 & $5.0 \mathrm{E}-07$ & 4.7E-07 & 4.5E-07 & 4.8E-07 & 6.7E-07 & $9.2 \mathrm{E}-07$ & $1.1 \mathrm{E}-06$ & $1.4 \mathrm{E}-06$ & $1.4 \mathrm{E}-06$ & 7.3E-07 \\
\hline (2.5) & 2.2E-07 & $1.7 \mathrm{E}-07$ & $1.6 \mathrm{E}-07$ & $1.4 \mathrm{E}-07$ & $1.5 \mathrm{E}-07$ & $1.7 \mathrm{E}-07$ & 2.3E-07 & 2.2E-07 & $2.1 \mathrm{E}-07$ & 2.2E-07 & 3.1E-07 & 4.2E-07 & $5.1 \mathrm{E}-07$ & $6.2 \mathrm{E}-07$ & 6.3E-07 & 3.3E-07 \\
\hline (3.5) & $1.3 \mathrm{E}-07$ & $1.0 \mathrm{E}-07$ & 9.7E-08 & 8.3E-08 & $9.3 \mathrm{E}-08$ & $1.0 \mathrm{E}-07$ & $1.4 \mathrm{E}-07$ & $1.3 \mathrm{E}-07$ & $1.3 \mathrm{E}-07$ & $1.3 \mathrm{E}-07$ & $1.9 \mathrm{E}-07$ & 2.6E-07 & $3.1 \mathrm{E}-07$ & 3.8E-07 & 3.8E-07 & $2.0 \mathrm{E}-07$ \\
\hline (4.5) & 9.3E-08 & $7.0 \mathrm{E}-08$ & 6.7E-08 & 5.7E-08 & $6.4 \mathrm{E}-08$ & $7.0 \mathrm{E}-08$ & $9.5 \mathrm{E}-08$ & $9.1 \mathrm{E}-08$ & $8.8 \mathrm{E}-08$ & 9.3E-08 & $1.3 \mathrm{E}-07$ & $1.8 \mathrm{E}-07$ & 2.2E-07 & 2.6E-07 & 2.6E-07 & $1.4 \mathrm{E}-07$ \\
\hline (7.5) & $4.4 \mathrm{E}-08$ & 3.3E-08 & $3.1 \mathrm{E}-08$ & 2.7E-08 & $3.0 \mathrm{E}-08$ & 3.3E-08 & 4.5E-08 & 4.3E-08 & $4.2 \mathrm{E}-08$ & $4.5 \mathrm{E}-08$ & 6.3E-08 & $8.6 \mathrm{E}-08$ & $1.0 \mathrm{E}-07$ & 1.3E-07 & $1.3 \mathrm{E}-07$ & $6.6 \mathrm{E}-08$ \\
\hline (15) & $1.7 \mathrm{E}-08$ & $1.2 \mathrm{E}-08$ & $1.2 \mathrm{E}-08$ & $1.0 \mathrm{E}-08$ & $1.2 \mathrm{E}-08$ & $1.3 \mathrm{E}-08$ & $1.7 \mathrm{E}-08$ & $1.7 \mathrm{E}-08$ & $1.6 \mathrm{E}-08$ & $1.7 \mathrm{E}-08$ & 2.4E-08 & 3.3E-08 & $4.0 \mathrm{E}-08$ & 4.9E-08 & $4.8 \mathrm{E}-08$ & $2.5 \mathrm{E}-08$ \\
\hline (25) & 8.2E-09 & $6.2 \mathrm{E}-09$ & $5.9 \mathrm{E}-09$ & 5.1E-09 & 5.7E-09 & 6.3E-09 & 8.6E-09 & 8.4E-09 & $8.1 \mathrm{E}-09$ & 8.6E-09 & $1.2 \mathrm{E}-08$ & $1.7 \mathrm{E}-08$ & $2.0 \mathrm{E}-08$ & $2.4 \mathrm{E}-08$ & 2.4E-08 & $1.2 \mathrm{E}-08$ \\
\hline (35) & $5.2 \mathrm{E}-09$ & $3.9 \mathrm{E}-09$ & 3.8E-09 & 3.3E-09 & 3.7E-09 & 4.0E-09 & 5.5E-09 & 5.3E-09 & $5.2 \mathrm{E}-09$ & 5.5E-09 & 7.8E-09 & $1.1 \mathrm{E}-08$ & $1.3 \mathrm{E}-08$ & $1.5 \mathrm{E}-08$ & $1.5 \mathrm{E}-08$ & $8.0 \mathrm{E}-09$ \\
\hline (45) & 3.7E-09 & 2.8E-09 & 2.7E-09 & 2.3E-09 & 2.6E-09 & 2.9E-09 & 3.9E-09 & 3.8E-09 & 3.7E-09 & 4.0E-09 & $5.6 \mathrm{E}-09$ & 7.7E-09 & 9.3E-09 & $1.1 \mathrm{E}-08$ & $1.1 \mathrm{E}-08$ & $5.7 \mathrm{E}-09$ \\
\hline
\end{tabular}

Table A12. X/Q' Values $\left(\mathrm{s} \mathrm{m}^{-3}\right.$ ) for Chronic 60-m Stack Releases from 200 Areas Based on 1983 through 2002 Meteorological Information, Hanford Site, Washington

\begin{tabular}{|c|c|c|c|c|c|c|c|c|c|c|c|c|c|c|c|c|}
\hline \multirow{2}{*}{$\begin{array}{l}\text { Distance } \\
\text { km (mi) }\end{array}$} & \multicolumn{16}{|c|}{200 Areas toward D } \\
\hline & $\mathrm{S}$ & SSW & SW & WSW & $\mathrm{W}$ & WNW & NW & NNW & $\mathrm{N}$ & NNE & $\mathrm{NE}$ & ENE & $\mathrm{E}$ & ESE & SE & SSE \\
\hline $0.1(0.06)$ & $.3 \mathrm{E}-10$ & $7.8 \mathrm{E}-10$ & $7.0 \mathrm{E}-10$ & $5.5 \mathrm{E}-10$ & $2 \mathrm{E}-10$ & & $4.8 \mathrm{E}-10$ & $4.1 \mathrm{E}-10$ & & & $4.6 \mathrm{E}-10$ & 4.4E-10 & $8 \mathrm{E}-10$ & $3.6 \mathrm{E}-10$ & & \\
\hline $0.2(0.12$ & & ЭЕ-07 & 7E-07 & & & & & & & & & & & & & \\
\hline $3(0$ & & $8 \mathrm{E}$ & $4 \mathrm{E}-$ & $7 \mathrm{E}$ & & & & & & & $1 \mathrm{E}-07$ & & & & & \\
\hline $4(C$ & & $2 \mathrm{E}$ & $9 \mathrm{E}$ & & & & & & & & $8 \mathrm{E}-07$ & & & & & \\
\hline 5( & & $5 \mathrm{E}$ & $3 \mathrm{E}$ & & & & & & & & 3E-07 & & & & & \\
\hline 6( & & 15 & & & & & & & & & IE-07 & & & & & \\
\hline 7 ( & & & & & & & & & & & & & & & & \\
\hline 0.8 & & & & & & & & & & & $9.3 \mathrm{E}$ & & & & & -07 \\
\hline 0.9 & & & & & & & & & & & $9.2 \mathrm{E}$ & & & & & -07 \\
\hline $1 \quad(C$ & & & & & & & & & & & 9.3E-08 & & & & & -07 \\
\hline $2.4 \quad(1$ & & & & & & & & & & & 08 & & & & & -07 \\
\hline 4 & & & 5 & & & & & & & & $5.4 \mathrm{E}-08$ & & & & & $1.1 \mathrm{E}-07$ \\
\hline 5.6 & & & & & & & & & & & & & & & & $7.6 \mathrm{E}-08$ \\
\hline 7.2 & & & & & & & & & & & & & & & & $5.8 \mathrm{E}-08$ \\
\hline (7.5) & & & & & & & & & & & & & & & & 3.3E-08 \\
\hline 24 & & & & & & & & & & & & & & & & $1.5 \mathrm{E}-08$ \\
\hline (25) & & & 3.6E-09 & & & & & & & & & & & & & $8.2 \mathrm{E}-09$ \\
\hline (35) & 3.7E-09 & 2.7E-09 & 2.4E-09 & $2.1 \mathrm{E}-09$ & 2.6E-09 & & & & & & $3.0 \mathrm{E}-09$ & & & 8.4E-09 & $9.8 \mathrm{E}$ & $5.5 \mathrm{E}-09$ \\
\hline (45) & 2.7E-09 & 2.0E-09 & $1.8 \mathrm{E}-09$ & $1.6 \mathrm{E}-09$ & $1.9 \mathrm{E}-09$ & 1.9E-09 & 2.6E-09 & $2.4 \mathrm{E}-09$ & 1.7E-09 & 1.7E-09 & 2.2E-09 & 2.8E-09 & 4.1E-09 & $6.2 \mathrm{E}-09$ & 7.2E-09 & 4.1E-09 \\
\hline
\end{tabular}


Table A13. X/Q' Values ( $\mathrm{s} \mathrm{m}^{-3}$ ) for Chronic Ground-Level Releases from 300 Area Based on 1983 through 2002 Meteorological Information, Hanford Site, Washington

\begin{tabular}{|c|c|c|c|c|c|c|c|c|c|c|c|c|c|c|c|c|}
\hline \multirow{2}{*}{$\begin{array}{l}\text { Distance } \\
\text { km (mi) }\end{array}$} & \multicolumn{16}{|c|}{ Sector (Wind from 300 Area toward Direction Indicated) } \\
\hline & $\mathrm{S}$ & SSW & SW & WSW & $\mathrm{W}$ & WNW & NW & NNW & $\mathrm{N}$ & NNE & $\mathrm{NE}$ & ENE & E & ESE & SE & SSE \\
\hline $0.1(0.06)$ & $2.6 \mathrm{E}-04$ & $1.2 \mathrm{E}-04$ & 7.3E-05 & $6.8 \mathrm{E}-05$ & $1.0 \mathrm{E}-04$ & $2.3 \mathrm{E}-04$ & $3.6 \mathrm{E}-04$ & $2.6 \mathrm{E}-04$ & $2.4 \mathrm{E}-04$ & $2.2 \mathrm{E}-04$ & $2.1 \mathrm{E}-04$ & $1.6 \mathrm{E}-04$ & $1.4 \mathrm{E}-04$ & $1.5 \mathrm{E}-04$ & $2.4 \mathrm{E}-04$ & $3.1 \mathrm{E}-04$ \\
\hline $0.2(0.12)$ & 7.1E-05 & 3.3E-05 & $2.0 \mathrm{E}-05$ & $1.9 \mathrm{E}-05$ & $2.8 \mathrm{E}-05$ & $6.2 \mathrm{E}-05$ & $9.8 \mathrm{E}-05$ & 7.3E-05 & 6.7E-05 & $6.1 \mathrm{E}-05$ & $5.9 \mathrm{E}-05$ & 4.3E-05 & 3.9E-05 & 4.3E-05 & $6.7 \mathrm{E}-05$ & 8.5E-05 \\
\hline $0.3(0.19)$ & 3.4E-05 & $1.6 \mathrm{E}-05$ & $9.5 \mathrm{E}-06$ & 8.9E-06 & 1.3E-05 & 3.0E-05 & 4.7E-05 & 3.5E-05 & 3.2E-05 & 2.9E-05 & 2.8E-05 & 2.1E-05 & 1.9E-05 & $2.1 \mathrm{E}-05$ & 3.2E-05 & 4.1E-05 \\
\hline $0.4(0.25)$ & 2.0E-05 & $9.4 \mathrm{E}-06$ & 5.7E-06 & 5.3E-06 & 8.0E-06 & $1.8 \mathrm{E}-05$ & 2.8E-05 & $2.1 \mathrm{E}-05$ & $1.9 \mathrm{E}-05$ & $1.7 \mathrm{E}-05$ & $1.7 \mathrm{E}-05$ & $1.2 \mathrm{E}-05$ & $1.1 \mathrm{E}-05$ & $1.2 \mathrm{E}-05$ & $1.9 \mathrm{E}-05$ & 2.4E-05 \\
\hline $0.5(0.31)$ & $1.4 \mathrm{E}-05$ & 6.4E-06 & 3.8E-06 & 3.6E-06 & $5.4 \mathrm{E}-06$ & $1.2 \mathrm{E}-05$ & $1.9 \mathrm{E}-05$ & $1.4 \mathrm{E}-05$ & 1.3E-05 & $1.2 \mathrm{E}-05$ & $1.1 \mathrm{E}-05$ & 8.3E-06 & 7.5E-06 & $8.4 \mathrm{E}-06$ & 1.3E-05 & $1.6 \mathrm{E}-05$ \\
\hline $0.6(0.37)$ & $1.0 \mathrm{E}-05$ & 4.6E-06 & 2.8E-06 & 2.6E-06 & 3.9E-06 & 8.7E-06 & $1.4 \mathrm{E}-05$ & $1.0 \mathrm{E}-05$ & $9.5 \mathrm{E}-06$ & 8.5E-06 & 8.3E-06 & $6.0 \mathrm{E}-06$ & 5.4E-06 & $6.1 \mathrm{E}-06$ & $9.5 \mathrm{E}-06$ & $1.2 \mathrm{E}-05$ \\
\hline $0.7(0.43)$ & 7.6E-06 & 3.5E-06 & 2.1E-06 & $2.0 \mathrm{E}-06$ & 3.0E-06 & 6.7E-06 & $1.1 \mathrm{E}-05$ & 7.9E-06 & 7.2E-06 & $6.5 \mathrm{E}-06$ & 6.3E-06 & 4.6E-06 & 4.1E-06 & 4.6E-06 & 7.2E-06 & $9.1 \mathrm{E}-06$ \\
\hline $0.8(0.50)$ & $6.0 \mathrm{E}-06$ & 2.8E-06 & $1.7 \mathrm{E}-06$ & $1.6 \mathrm{E}-06$ & 2.3E-06 & 5.3E-06 & 8.3E-06 & $6.2 \mathrm{E}-06$ & 5.7E-06 & $5.1 \mathrm{E}-06$ & $5.0 \mathrm{E}-06$ & $3.6 \mathrm{E}-06$ & 3.3E-06 & 3.7E-06 & 5.7E-06 & 7.2E-06 \\
\hline $0.9(0.56)$ & 4.9E-06 & 2.3E-06 & $1.4 \mathrm{E}-06$ & $1.3 \mathrm{E}-06$ & $1.9 \mathrm{E}-06$ & 4.3E-06 & $6.8 \mathrm{E}-06$ & $5.1 \mathrm{E}-06$ & 4.7E-06 & 4.2E-06 & $4.1 \mathrm{E}-06$ & $3.0 \mathrm{E}-06$ & 2.7E-06 & $3.0 \mathrm{E}-06$ & 4.6E-06 & $5.9 \mathrm{E}-06$ \\
\hline $1 \quad(0.62)$ & $4.1 \mathrm{E}-06$ & $1.9 \mathrm{E}-06$ & $1.1 \mathrm{E}-06$ & $1.0 \mathrm{E}-06$ & $1.6 \mathrm{E}-06$ & $3.6 \mathrm{E}-06$ & 5.6E-06 & $4.2 \mathrm{E}-06$ & 3.9E-06 & $3.5 \mathrm{E}-06$ & $3.4 \mathrm{E}-06$ & $2.5 \mathrm{E}-06$ & 2.2E-06 & $2.5 \mathrm{E}-06$ & 3.9E-06 & $4.9 \mathrm{E}-06$ \\
\hline $2.4 \quad(1.5)$ & $9.6 \mathrm{E}-07$ & 4.4E-07 & 2.6E-07 & $2.4 \mathrm{E}-07$ & 3.7E-07 & $8.4 \mathrm{E}-07$ & $1.3 \mathrm{E}-06$ & 9.9E-07 & $9.1 \mathrm{E}-07$ & $8.1 \mathrm{E}-07$ & 7.9E-07 & $5.8 \mathrm{E}-07$ & $5.2 \mathrm{E}-07$ & $5.8 \mathrm{E}-07$ & $9.1 \mathrm{E}-07$ & $1.1 \mathrm{E}-06$ \\
\hline (2.5) & $4.4 \mathrm{E}-07$ & $2.0 \mathrm{E}-07$ & $1.2 \mathrm{E}-07$ & $1.1 \mathrm{E}-07$ & $1.7 \mathrm{E}-07$ & 3.8E-07 & $6.1 \mathrm{E}-07$ & 4.5E-07 & 4.2E-07 & 3.7E-07 & $3.6 \mathrm{E}-07$ & 2.6E-07 & 2.4E-07 & 2.7E-07 & $4.2 \mathrm{E}-07$ & 5.3E-07 \\
\hline (3.5) & 2.7E-07 & $1.2 \mathrm{E}-07$ & 7.1E-08 & $6.6 \mathrm{E}-08$ & $1.0 \mathrm{E}-07$ & 2.3E-07 & 3.7E-07 & $2.8 \mathrm{E}-07$ & $2.5 \mathrm{E}-07$ & 2.2E-07 & 2.2E-07 & $1.6 \mathrm{E}-07$ & $1.5 \mathrm{E}-07$ & $1.6 \mathrm{E}-07$ & 2.5E-07 & 3.2E-07 \\
\hline (4.5) & $1.8 \mathrm{E}-07$ & 8.3E-08 & 4.9E-08 & 4.6E-08 & 7.0E-08 & $1.6 \mathrm{E}-07$ & 2.6E-07 & $1.9 \mathrm{E}-07$ & $1.8 \mathrm{E}-07$ & $1.6 \mathrm{E}-07$ & $1.5 \mathrm{E}-07$ & $1.1 \mathrm{E}-07$ & $1.0 \mathrm{E}-07$ & $1.1 \mathrm{E}-07$ & $1.8 \mathrm{E}-07$ & 2.2E-07 \\
\hline (7.5) & 8.8E-08 & $3.9 \mathrm{E}-08$ & 2.3E-08 & $2.1 \mathrm{E}-08$ & 3.3E-08 & 7.7E-08 & $1.2 \mathrm{E}-07$ & $9.2 \mathrm{E}-08$ & 8.4E-08 & 7.4E-08 & 7.2E-08 & 5.3E-08 & $4.8 \mathrm{E}-08$ & $5.5 \mathrm{E}-08$ & $8.5 \mathrm{E}-08$ & $1.1 \mathrm{E}-07$ \\
\hline (15) & $3.4 \mathrm{E}-08$ & $1.5 \mathrm{E}-08$ & 8.6E-09 & 8.0E-09 & $1.2 \mathrm{E}-08$ & 2.9E-08 & 4.7E-08 & 3.5E-08 & $3.2 \mathrm{E}-08$ & $2.8 \mathrm{E}-08$ & 2.7E-08 & $2.0 \mathrm{E}-08$ & $1.9 \mathrm{E}-08$ & $2.1 \mathrm{E}-08$ & 3.3E-08 & 4.1E-08 \\
\hline (25) & $1.7 \mathrm{E}-08$ & 7.4E-09 & 4.2E-09 & 3.9E-09 & $6.1 \mathrm{E}-09$ & $1.5 \mathrm{E}-08$ & $2.4 \mathrm{E}-08$ & $1.8 \mathrm{E}-08$ & $1.6 \mathrm{E}-08$ & $1.4 \mathrm{E}-08$ & $1.4 \mathrm{E}-08$ & $1.0 \mathrm{E}-08$ & 9.3E-09 & $1.1 \mathrm{E}-08$ & $1.6 \mathrm{E}-08$ & $2.0 \mathrm{E}-08$ \\
\hline (35) & $1.1 \mathrm{E}-08$ & 4.7E-09 & 2.7E-09 & 2.5E-09 & 3.9E-09 & 9.3E-09 & $1.5 \mathrm{E}-08$ & $1.1 \mathrm{E}-08$ & $1.0 \mathrm{E}-08$ & 8.9E-09 & 8.6E-09 & 6.4E-09 & 5.9E-09 & 6.7E-09 & $1.0 \mathrm{E}-08$ & $1.3 \mathrm{E}-08$ \\
\hline (45) & 7.7E-09 & 3.3E-09 & $1.9 \mathrm{E}-09$ & $1.8 \mathrm{E}-09$ & 2.7E-09 & 6.6E-09 & $1.1 \mathrm{E}-08$ & 8.1E-09 & 7.3E-09 & 6.3E-09 & $6.1 \mathrm{E}-09$ & 4.6E-09 & 4.2E-09 & 4.8E-09 & 7.5E-09 & 9.3E-09 \\
\hline
\end{tabular}

Table A14. X/Q' Values $\left(\mathrm{s} \mathrm{m}^{-3}\right)$ for Chronic 60-m Stack Releases from 300 Area Based on 1986 through 2002 Meteorological Information, Hanford Site, Washington

\begin{tabular}{|c|c|c|c|c|c|c|c|c|c|c|c|c|c|c|c|c|}
\hline \multirow{2}{*}{$\begin{array}{l}\text { Distance } \\
\text { km (mi) }\end{array}$} & \multicolumn{16}{|c|}{ Sector (Wind from 300 Area toward Direction Indicated) } \\
\hline & $\mathrm{S}$ & SSW & SW & WSW & $\mathrm{W}$ & WNW & NW & NNW & $\mathrm{N}$ & NNE & $\mathrm{NE}$ & ENE & E & ESE & SE & SSE \\
\hline $0.1(0.06)$ & $1.7 \mathrm{E}-11$ & $3.0 \mathrm{E}-11$ & $1.7 \mathrm{E}-11$ & $1.9 \mathrm{E}-11$ & $2.5 \mathrm{E}-11$ & 4.9E-11 & 5.2E-11 & 3.3E-11 & $2.4 \mathrm{E}-11$ & 6.1E-11 & 5.6E-11 & $3.8 \mathrm{E}-11$ & $8.5 \mathrm{E}-12$ & $2.2 \mathrm{E}-12$ & $1.0 \mathrm{E}-11$ & $.4 \mathrm{E}-$ \\
\hline $2(0.12)$ & & 5E-09 & 0E-09 & 6E-09 & & & & & & & & & & & & \\
\hline 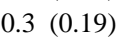 & & & & & & & & & & & & & & & & \\
\hline 1 (1) & & & & & & & & & & & & & & & & \\
\hline 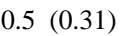 & & & & & & & & & & & & & & & & \\
\hline $5(0.37)$ & & & & & & & & & & & & & & & & \\
\hline $7(0.4$ & & & & & & & & & & & & & & & & \\
\hline $0.8(0.50)$ & & 8 & 8 & & & & & & & & & & & & & \\
\hline $0.9(0.56)$ & & & & & & & & & & & & & & & & \\
\hline $1 \quad(0.62)$ & & & & & & & & & & & & & & & & \\
\hline $2.4 \quad(1.5)$ & & & & & & & & & & & & & & & & \\
\hline (2.5) & & & & & & & & & & & & & & & & \\
\hline $5.6 \quad(3.5)$ & & & 4 & & & & & & & & & & & & & \\
\hline $7.2 \quad(4.5)$ & & & & & & & & & & & & & & & & \\
\hline $12 \quad(7.5)$ & & 2. & $1.7 \mathrm{E}$ & & & & 4.7E & & & & & & -08 & & & \\
\hline (15) & & 1. & $7.6 \mathrm{E}$ & & $8.8 \mathrm{E}-$ & & $2.2 \mathrm{E}$ & & & & & & $8.7 \mathrm{E}$ & & & \\
\hline (25) & & $4 \mathrm{E}-\mathrm{C}$ & 4.1E- & & $4.7 \mathrm{E}$ & & $1.2 \mathrm{E}$ & & & & & & & & & \\
\hline (35) & & $3 E-09$ & & & & & & & & & & & & & & \\
\hline (45) & $5.4 \mathrm{E}-09$ & 3.2E-09 & 2.0E-09 & 1.7E-09 & 2.3E-09 & 3.9E-09 & 5.9E-09 & 4.9E-09 & 4.8E-09 & 4.6E-09 & 4.5E-09 & 3.1E-09 & 2.4E-09 & 2.3E-09 & 3.3E-09 & 4.01 \\
\hline
\end{tabular}


Table A15. X/Q' Values ( $\mathrm{s} \mathrm{m}^{-3}$ ) for Chronic Ground-Level Releases from 400 Area Based on 1983 through 2002 Meteorological Information, Hanford Site, Washington

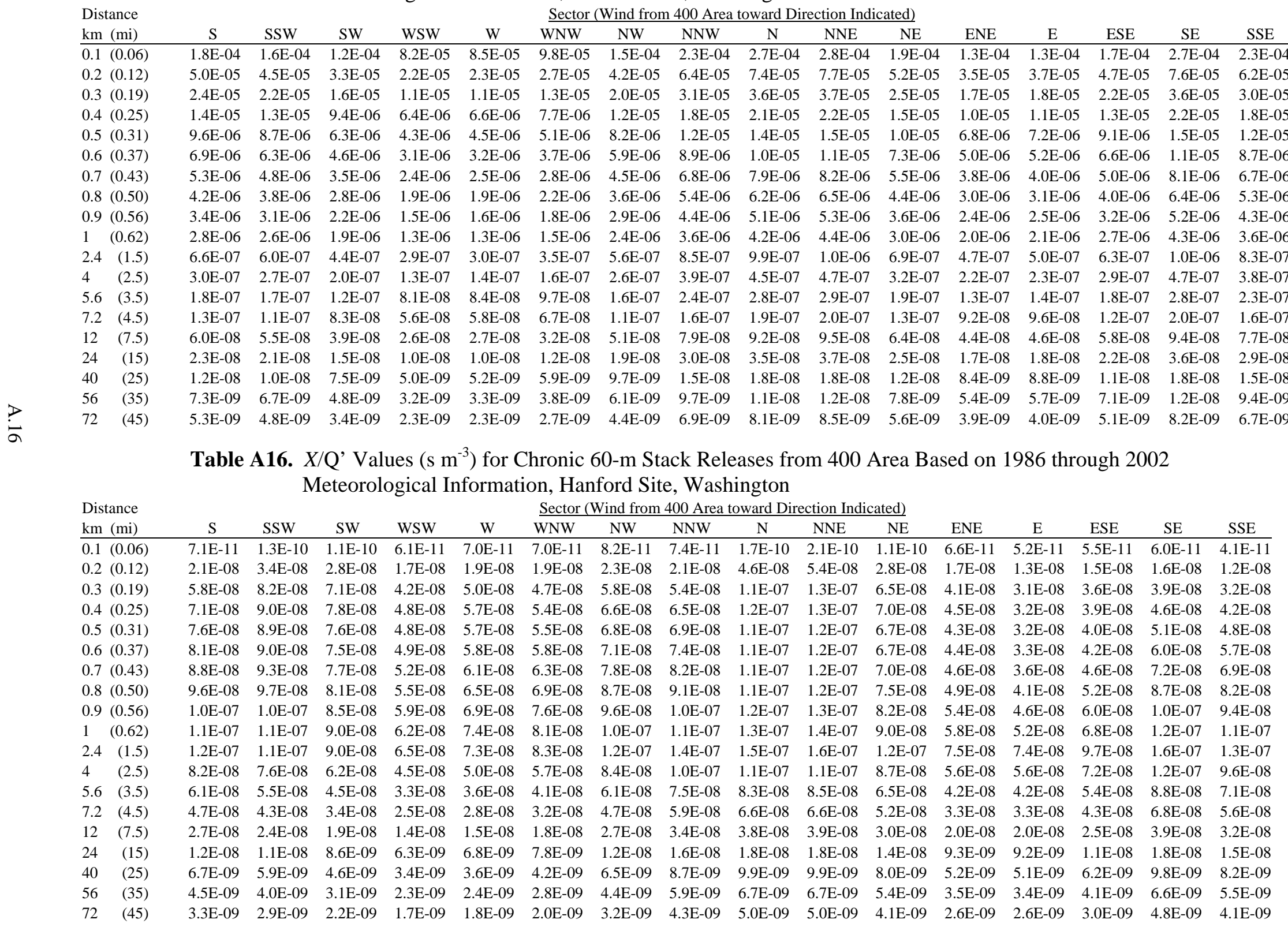


Table A17. 95th Percentile E/Q Values $\left(\mathrm{s} \mathrm{m}^{-3}\right.$ ) for Acute Ground Level Releases from 100-N Area Based on 1983 through 2002 Meteorological Information, Hanford Site, Washington

\begin{tabular}{|c|c|c|c|c|c|c|c|c|c|c|c|c|c|c|c|c|}
\hline \multirow{2}{*}{$\begin{array}{l}\text { Distance } \\
\text { km (mi) }\end{array}$} & \multicolumn{16}{|c|}{ Sector (Wind from 100-N toward Direction Indicated) } \\
\hline & $\mathrm{S}$ & SSW & SW & WSW & $\mathrm{W}$ & WNW & NW & NNW & $\mathrm{N}$ & NNE & NE & ENE & E & ESE & SE & SSE \\
\hline $0.1(0.06)$ & $4.9 \mathrm{E}-02$ & $3.8 \mathrm{E}-02$ & 4.4E-02 & 4.7E-02 & 4.2E-02 & 3.4E-02 & $3.4 \mathrm{E}-02$ & 3.4E-02 & $3.4 \mathrm{E}-02$ & 3.4E-02 & $3.4 \mathrm{E}-02$ & 3.3E-02 & $3.4 \mathrm{E}-02$ & 3.7E-02 & 5.1E-02 & 5.3E-02 \\
\hline $0.2(0.12)$ & $1.5 \mathrm{E}-02$ & $1.1 \mathrm{E}-02$ & 1.3E-02 & $1.4 \mathrm{E}-02$ & 1.3E-02 & $1.0 \mathrm{E}-02$ & $1.0 \mathrm{E}-02$ & $1.0 \mathrm{E}-02$ & $1.0 \mathrm{E}-02$ & $1.0 \mathrm{E}-02$ & $1.0 \mathrm{E}-02$ & $1.0 \mathrm{E}-02$ & $1.0 \mathrm{E}-02$ & $1.1 \mathrm{E}-02$ & $1.5 \mathrm{E}-02$ & 1.6E-02 \\
\hline 0.3 (0.19) & 7.4E-03 & $5.8 \mathrm{E}-03$ & 6.7E-03 & 7.1E-03 & $6.4 \mathrm{E}-03$ & $5.2 \mathrm{E}-03$ & $5.1 \mathrm{E}-03$ & $5.1 \mathrm{E}-03$ & $5.2 \mathrm{E}-03$ & $5.2 \mathrm{E}-03$ & $5.1 \mathrm{E}-03$ & $5.1 \mathrm{E}-03$ & $5.1 \mathrm{E}-03$ & 5.7E-03 & 7.7E-03 & 8.0E-03 \\
\hline $0.4(0.25)$ & 4.5E-03 & 3.5E-03 & $4.1 \mathrm{E}-03$ & 4.3E-03 & $4.0 \mathrm{E}-03$ & 3.2E-03 & 3.1E-03 & 3.2E-03 & $3.2 \mathrm{E}-03$ & $3.2 \mathrm{E}-03$ & 3.1E-03 & 3.1E-03 & $3.2 \mathrm{E}-03$ & 3.5E-03 & 4.8E-03 & 4.9E-03 \\
\hline $0.5(0.31)$ & $3.1 \mathrm{E}-03$ & 2.4E-03 & $2.8 \mathrm{E}-03$ & 3.0E-03 & 2.7E-03 & 2.2E-03 & 2.2E-03 & 2.2E-03 & $2.2 \mathrm{E}-03$ & 2.2E-03 & 2.2E-03 & $2.1 \mathrm{E}-03$ & 2.2E-03 & 2.4E-03 & 3.3E-03 & 3.4E-03 \\
\hline $0.6(0.37)$ & 2.3E-03 & $1.8 \mathrm{E}-03$ & $2.1 \mathrm{E}-03$ & 2.2E-03 & $2.0 \mathrm{E}-03$ & $1.6 \mathrm{E}-03$ & $1.6 \mathrm{E}-03$ & $1.6 \mathrm{E}-03$ & $1.6 \mathrm{E}-03$ & $1.6 \mathrm{E}-03$ & $1.6 \mathrm{E}-03$ & $1.6 \mathrm{E}-03$ & $1.6 \mathrm{E}-03$ & $1.8 \mathrm{E}-03$ & $2.4 \mathrm{E}-03$ & 2.5E-03 \\
\hline $0.7(0.43)$ & $1.8 \mathrm{E}-03$ & $1.4 \mathrm{E}-03$ & $1.6 \mathrm{E}-03$ & 1.7E-03 & $1.6 \mathrm{E}-03$ & 1.3E-03 & $1.2 \mathrm{E}-03$ & $1.2 \mathrm{E}-03$ & $1.3 \mathrm{E}-03$ & $1.3 \mathrm{E}-03$ & $1.2 \mathrm{E}-03$ & $1.2 \mathrm{E}-03$ & $1.2 \mathrm{E}-03$ & $1.4 \mathrm{E}-03$ & $1.9 \mathrm{E}-03$ & $1.9 \mathrm{E}-03$ \\
\hline $0.8(0.50)$ & $1.4 \mathrm{E}-03$ & $1.1 \mathrm{E}-03$ & $1.3 \mathrm{E}-03$ & $1.4 \mathrm{E}-03$ & $1.2 \mathrm{E}-03$ & $1.0 \mathrm{E}-03$ & $9.8 \mathrm{E}-04$ & $9.9 \mathrm{E}-04$ & $1.0 \mathrm{E}-03$ & $1.0 \mathrm{E}-03$ & $9.8 \mathrm{E}-04$ & $9.8 \mathrm{E}-04$ & $9.9 \mathrm{E}-04$ & $1.1 \mathrm{E}-03$ & $1.5 \mathrm{E}-03$ & $1.5 \mathrm{E}-03$ \\
\hline $0.9(0.56)$ & $1.2 \mathrm{E}-03$ & $9.2 \mathrm{E}-04$ & $1.1 \mathrm{E}-03$ & $1.1 \mathrm{E}-03$ & $1.0 \mathrm{E}-03$ & 8.3E-04 & 8.1E-04 & $8.2 \mathrm{E}-04$ & 8.3E-04 & $8.2 \mathrm{E}-04$ & 8.1E-04 & 8.1E-04 & 8.1E-04 & $9.0 \mathrm{E}-04$ & $1.2 \mathrm{E}-03$ & $1.3 \mathrm{E}-03$ \\
\hline $1 \quad(0.62)$ & $9.8 \mathrm{E}-04$ & 7.7E-04 & $9.0 \mathrm{E}-04$ & $9.4 \mathrm{E}-04$ & 8.6E-04 & $6.9 \mathrm{E}-04$ & $6.8 \mathrm{E}-04$ & $6.8 \mathrm{E}-04$ & $6.9 \mathrm{E}-04$ & $6.9 \mathrm{E}-04$ & $6.8 \mathrm{E}-04$ & $6.8 \mathrm{E}-04$ & $6.8 \mathrm{E}-04$ & 7.6E-04 & $1.0 \mathrm{E}-03$ & $1.1 \mathrm{E}-03$ \\
\hline $2.4 \quad(1.5)$ & $2.5 \mathrm{E}-04$ & $2.0 \mathrm{E}-04$ & 2.3E-04 & $2.4 \mathrm{E}-04$ & 2.2E-04 & $1.8 \mathrm{E}-04$ & $1.7 \mathrm{E}-04$ & $1.8 \mathrm{E}-04$ & $1.8 \mathrm{E}-04$ & $1.8 \mathrm{E}-04$ & $1.7 \mathrm{E}-04$ & $1.7 \mathrm{E}-04$ & $1.8 \mathrm{E}-04$ & $1.9 \mathrm{E}-04$ & 2.7E-04 & 2.7E-04 \\
\hline (2.5) & $1.2 \mathrm{E}-04$ & 9.7E-05 & $1.1 \mathrm{E}-04$ & $1.2 \mathrm{E}-04$ & $1.1 \mathrm{E}-04$ & 8.7E-05 & 8.5E-05 & 8.6E-05 & 8.7E-05 & 8.7E-05 & 8.5E-05 & 8.5E-05 & 8.6E-05 & 9.5E-05 & $1.3 \mathrm{E}-04$ & $1.3 \mathrm{E}-04$ \\
\hline (3.5) & 7.9E-05 & $6.2 \mathrm{E}-05$ & 7.2E-05 & 7.6E-05 & $6.9 \mathrm{E}-05$ & 5.5E-05 & $5.4 \mathrm{E}-05$ & 5.5E-05 & $5.5 \mathrm{E}-05$ & 5.5E-05 & $5.4 \mathrm{E}-05$ & $5.4 \mathrm{E}-05$ & 5.5E-05 & $6.1 \mathrm{E}-05$ & 8.3E-05 & 8.6E-05 \\
\hline (4.5) & 5.7E-05 & 4.4E-05 & $5.2 \mathrm{E}-05$ & $5.4 \mathrm{E}-05$ & $5.0 \mathrm{E}-05$ & 4.0E-05 & 3.9E-05 & $3.9 \mathrm{E}-05$ & $4.0 \mathrm{E}-05$ & 4.0E-05 & $3.9 \mathrm{E}-05$ & 3.9E-05 & 3.9E-05 & 4.4E-05 & $6.0 \mathrm{E}-05$ & $6.2 \mathrm{E}-05$ \\
\hline (7.5) & 2.9E-05 & 2.3E-05 & 2.7E-05 & 2.8E-05 & 2.5E-05 & 2.1E-05 & 2.0E-05 & 2.0E-05 & 2.1E-05 & 2.1E-05 & 2.0E-05 & $2.0 \mathrm{E}-05$ & 2.0E-05 & 2.2E-05 & 3.1E-05 & $3.2 \mathrm{E}-05$ \\
\hline (15) & $1.2 \mathrm{E}-05$ & $9.7 \mathrm{E}-06$ & $1.1 \mathrm{E}-05$ & $1.2 \mathrm{E}-05$ & $1.1 \mathrm{E}-05$ & 8.7E-06 & 8.6E-06 & 8.6E-06 & 8.7E-06 & 8.7E-06 & 8.5E-06 & $8.5 \mathrm{E}-06$ & 8.6E-06 & 9.5E-06 & $1.3 \mathrm{E}-05$ & $1.4 \mathrm{E}-05$ \\
\hline (25) & $6.7 \mathrm{E}-06$ & $5.2 \mathrm{E}-06$ & 6.1E-06 & $6.4 \mathrm{E}-06$ & $5.8 \mathrm{E}-06$ & 4.7E-06 & 4.6E-06 & 4.6E-06 & 4.7E-06 & 4.7E-06 & 4.6E-06 & 4.6E-06 & 4.6E-06 & 5.1E-06 & 7.0E-06 & 7.2E-06 \\
\hline (35) & 4.5E-06 & $3.5 \mathrm{E}-06$ & 4.1E-06 & 4.3E-06 & 3.9E-06 & $3.1 \mathrm{E}-06$ & 3.1E-06 & $3.1 \mathrm{E}-06$ & $3.1 \mathrm{E}-06$ & $3.1 \mathrm{E}-06$ & $3.1 \mathrm{E}-06$ & $3.1 \mathrm{E}-06$ & $3.1 \mathrm{E}-06$ & $3.4 \mathrm{E}-06$ & 4.7E-06 & $4.8 \mathrm{E}-06$ \\
\hline (45) & 3.3E-06 & $2.6 \mathrm{E}-06$ & $3.0 \mathrm{E}-06$ & $3.2 \mathrm{E}-06$ & 2.9E-06 & 2.3E-06 & 2.3E-06 & 2.3E-06 & 2.3E-06 & 2.3E-06 & 2.3E-06 & 2.3E-06 & 2.3E-06 & 2.5E-06 & $3.5 \mathrm{E}-06$ & $3.6 \mathrm{E}-06$ \\
\hline
\end{tabular}

Table A18. 95th Percentile E/Q Values $\left(\mathrm{s} \mathrm{m}^{-3}\right)$ for Acute 60-m Stack Releases from 100-N Area Based on 1986 through 2002 Meteorological Information, Hanford Site, Washington

\begin{tabular}{|c|c|c|c|c|c|c|c|c|c|c|c|c|c|c|c|c|}
\hline \multirow{2}{*}{$\begin{array}{l}\text { Distance } \\
\mathrm{km} \text { (mi) }\end{array}$} & \multicolumn{16}{|c|}{ rection Indicated) } \\
\hline & $\mathrm{S}$ & SSW & SW & WSW & $\mathrm{W}$ & WNW & NW & NNW & $\mathrm{N}$ & NNE & $\mathrm{NE}$ & ENE & $\mathrm{E}$ & ESE & SE & SSE \\
\hline $0.1(0.06)$ & $4 \mathrm{E}-08$ & & $1.6 \mathrm{E}-08$ & & & & $3.9 \mathrm{E}-18$ & & & & & & $3 \mathrm{E}-08$ & & & $2.6 \mathrm{E}-08$ \\
\hline $0.2(0.12)$ & & & & & & & & & & & & & & & & \\
\hline 3( & & & & & & & & & & & & & & & & \\
\hline 4 & & & & & & & & & & & & & & & & \\
\hline 5( & & & & & & & & & & & & & & & & \\
\hline 6( & & & & & & & & & & & & & & & & \\
\hline 7( & & & & & & & & & & & & & & & & \\
\hline 8( & & & & & & & & & & & & & & & & \\
\hline $0.9(0.5$ & & & & & & & & & & & & & & & & \\
\hline $1 \quad(0.62$ & & & & & & & & & & & & & & & & \\
\hline $2.4 \quad(1$. & & & & & & & & & & & & & & & & \\
\hline $4 \quad($ & & & & & & & & & & & & & & & & \\
\hline 5.6 & & & & & & & & & & & & & & & & -05 \\
\hline 7.2( & & & & & & & & & & & & & & & & E-05 \\
\hline$(7.5$ & & & 06 & & & & & & & & & & & & & $6.5 \mathrm{E}-06$ \\
\hline (15) & & 8E-06 & $5.5 \mathrm{E}-06$ & & & & & & & & $3.8 \mathrm{E}-06$ & 3.7E-06 & 2.8E-06 & 2.7E-06 & 5.0E-06 & 5.5E-06 \\
\hline (25) & E-06 & 2.9E-06 & 3.6E-06 & $3.8 \mathrm{E}-06$ & 3.8E-06 & 3.6E-06 & & $3.4 \mathrm{E}-06$ & & & $2.2 \mathrm{E}-06$ & 2.1E-06 & $1.6 \mathrm{E}-06$ & $1.6 \mathrm{E}-06$ & $3.0 \mathrm{E}-06$ & 3.5E-06 \\
\hline (35) & 3E-06 & $2.1 \mathrm{E}-06$ & 2.6E-06 & 2.9E-06 & 2.8E-06 & 2.6E-06 & $2.5 \mathrm{E}-06$ & 2.5E-06 & 2.5E-06 & 2.3E-06 & $1.6 \mathrm{E}-06$ & $1.5 \mathrm{E}-06$ & $1.1 \mathrm{E}-06$ & $1.2 \mathrm{E}-06$ & 2.2E-06 & 2.6E-06 \\
\hline (45) & $1.8 \mathrm{E}-06$ & $1.6 \mathrm{E}-06$ & $2.1 \mathrm{E}-06$ & 2.3E-06 & 2.3E-06 & $2.1 \mathrm{E}-06$ & $1.9 \mathrm{E}-06$ & $1.9 \mathrm{E}-06$ & $2.0 \mathrm{E}-06$ & $1.8 \mathrm{E}-06$ & $1.3 \mathrm{E}-06$ & $1.2 \mathrm{E}-06$ & $9.2 \mathrm{E}-07$ & 9.3E-07 & $1.7 \mathrm{E}-06$ & $2.0 \mathrm{~L}-\mathrm{U}$ \\
\hline
\end{tabular}


Table A19. 95th Percentile E/Q Values ( $\mathrm{s} \mathrm{m}^{-3}$ ) for Acute Ground-Level Releases from 200 Areas Based on 1983 through 2002 Meteorological Information, Hanford Site, Washington

\begin{tabular}{|c|c|c|c|c|c|c|c|c|c|c|c|c|c|c|c|c|}
\hline \multirow{2}{*}{$\begin{array}{l}\text { Distance } \\
\mathrm{km} \text { (mi) }\end{array}$} & \multicolumn{16}{|c|}{ Sector (Wind from 200 Areas toward Direction Indicated) } \\
\hline & $\mathrm{S}$ & SSW & SW & WSW & W & WNW & NW & NNW & $\mathrm{N}$ & NNE & NE & ENE & E & ESE & SE & SSE \\
\hline $0.1(0.06)$ & $3.1 \mathrm{E}-02$ & $3.0 \mathrm{E}-02$ & $3.2 \mathrm{E}-02$ & $3.2 \mathrm{E}-02$ & $3.2 \mathrm{E}-02$ & $3.2 \mathrm{E}-02$ & $3.3 \mathrm{E}-02$ & $3.2 \mathrm{E}-02$ & 3.3E-02 & $3.2 \mathrm{E}-02$ & $3.1 \mathrm{E}-02$ & $2.8 \mathrm{E}-02$ & $.9 \mathrm{E}-02$ & $2.6 \mathrm{E}-02$ & $2.2 \mathrm{E}-02$ & 3.0E-02 \\
\hline $0.2(0.12)$ & & $1 \mathrm{E}-03$ & $6 \mathrm{E}-03$ & & & & & & & & & & & & $6.7 \mathrm{E}-03$ & \\
\hline $0.3(0.1$ & & & & & & & & & & & & & & & & \\
\hline $4(0$. & & & & & & & & & & & & & & & & \\
\hline $5(0.3$ & & & & & & & & & & & & & & & & \\
\hline $6(0$. & & & & & & & & & & & & & & & & \\
\hline $.7(0$. & & & & & & & & & & & & & & & & \\
\hline $0.8(0.5$ & & & 94 & & & & & & & & & & & & & \\
\hline $0.9(0.5$ & & 3E-04 & 04 & & & & & & & & & & & & & \\
\hline $1 \quad(0.62)$ & & 1E-04 & $6.4 \mathrm{E}-04$ & & 04 & & & & & & & & & & & \\
\hline $2.4 \quad(1.5)$ & & & 1.7E-04 & & & & & & & & & & & & & \\
\hline $4 \quad(2.5)$ & & $.7 \mathrm{E}-05$ & 8.1E-05 & & 2E-05 & & & & & & & & & & & \\
\hline 5.6 & & 4.9E-05 & $5.2 \mathrm{E}-05$ & & 2505 & & & & & & $5.0 \mathrm{E}-05$ & & & & & 4.9E-05 \\
\hline 7.2 & & 3.5E-05 & 3.7E-05 & & .7E-05 & & & & & & 3.6E-05 & & & & & 3.5E-05 \\
\hline 12 & & 8E-05 & $1.9 \mathrm{E}-05$ & & & & & & & & & & & & & $1.8 \mathrm{E}-05$ \\
\hline 24 & & & $8.2 \mathrm{E}$ & & & & & & & & & & & & & 7.6E-06 \\
\hline (25) & & & & & & & & & & & & & & & & \\
\hline 56 & & & & & & & & & & & & & & & & \\
\hline (45) & $2.1 \mathrm{E}-06$ & $2.1 \mathrm{E}-06$ & 2.2E-06 & $2.2 \mathrm{E}-06$ & $2 \mathrm{E}-06$ & $2.2 \mathrm{E}-06$ & $2.2 \mathrm{E}-06$ & 2.2E-06 & 2.2E-06 & 2.2E-06 & $2.1 \mathrm{E}-06$ & $1.9 \mathrm{E}-06$ & $2.0 \mathrm{E}-06$ & $1.8 \mathrm{E}-06$ & $1.5 \mathrm{E}-06$ & $2.0 \mathrm{E}-1$ \\
\hline
\end{tabular}

Table A20. 95th Percentile E/Q Values ( $\mathrm{s} \mathrm{m}^{-3}$ ) for Acute 60-m Stack Releases from 200 Areas Based on 1983 through 2002 Meteorological Information, Hanford Site, Washington

\begin{tabular}{|c|c|c|c|c|c|c|c|c|c|c|c|c|c|c|c|c|}
\hline \multirow{2}{*}{$\begin{array}{l}\text { Distance } \\
\mathrm{km} \text { (mi) }\end{array}$} & \multicolumn{16}{|c|}{$\underline{\text { Sector (Wind from } 200 \text { Areas toward Direction Indicated) }}$} \\
\hline & $\mathrm{S}$ & SSW & SW & WSW & $\mathrm{W}$ & WNW & NW & NNW & $\mathrm{N}$ & NNE & $\mathrm{NE}$ & ENE & $\mathrm{E}$ & ESE & SE & SSE \\
\hline $0.1(0.06)$ & $3.6 \mathrm{E}-08$ & $3.8 \mathrm{E}-08$ & $4.0 \mathrm{E}-08$ & $4.0 \mathrm{E}-08$ & $3.9 \mathrm{E}-08$ & $4.0 \mathrm{E}-08$ & 3.7E-08 & $3.5 \mathrm{E}-08$ & $3.4 \mathrm{E}-08$ & $3.0 \mathrm{E}-08$ & $2.3 \mathrm{E}-08$ & $1.9 \mathrm{E}-08$ & $1.4 \mathrm{E}-08$ & 9.7E-09 & $1.8 \mathrm{E}-08$ & 3 3E-0 \\
\hline $0.2(0.12)$ & & $4 \mathrm{E}-06$ & 8E-06 & 7E-06 & & & & & & & & & & & & \\
\hline $0.3(0.1 \mathrm{~s}$ & & 2E-05 & & & & & & & & & & & & $4 \mathrm{E}-06$ & & \\
\hline $4(0.25$ & & 3E-05 & & & & & & & & & & & & 06 & & -0 \\
\hline $5(0.3$ & & -05 & & & & & & & & & -06 & & & 06 & & $3 \mathrm{E}-0$ \\
\hline 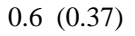 & & -05 & & & & & & & & & E-06 & & & & & $.3 \mathrm{E}-0$ \\
\hline 7( & & & & & & & & & & & E-06 & & & & & $1 \mathrm{E}-05$ \\
\hline 0.8( & & & & & & & & & & & E-06 & & & & & $.4 \mathrm{E}-0 \mathrm{5}$ \\
\hline 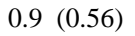 & & & & & & & & & & & E-06 & & & & & $1.6 \mathrm{E}-05$ \\
\hline$(0.6$ & & & & & & & & & & & E-06 & & & & & $2.1 \mathrm{E}-0 \mathrm{5}$ \\
\hline $2.4 \quad(1$. & & & & & & & & & & & E-05 & & & & & $1.9 \mathrm{E}-05$ \\
\hline 4 & & & & & & & & & & & -05 & & & & & $1.3 \mathrm{E}-05$ \\
\hline 5.6 & & & & & & & & & & & 8-06 & & & & & $1.1 \mathrm{E}-05$ \\
\hline 7.2 & & 06 & & & & & & & & & & & & & & 7.6E-06 \\
\hline 12 & & & & & & & & & & & & & & & & $6.3 \mathrm{E}-06$ \\
\hline 24 & & & & & & & & & & & & & & & & $2.5 \mathrm{E}-06$ \\
\hline 40 & & & & & & & & & & & & & & & & $1.5 \mathrm{E}-06$ \\
\hline 56 & & & & & & & & & & & & & & & & $1.1 \mathrm{E}-06$ \\
\hline (45) & $9.6 \mathrm{E}-07$ & $8.2 \mathrm{E}-07$ & 9.4E-07 & $1.2 \mathrm{E}-06$ & $1.2 \mathrm{E}-06$ & $1.3 \mathrm{E}-06$ & 1.3E-06 & $1.2 \mathrm{E}-06$ & $1.4 \mathrm{E}-06$ & $1.1 \mathrm{E}-06$ & 8.4E-07 & $8.0 \mathrm{E}-07$ & $8.8 \mathrm{E}-07$ & $6.8 \mathrm{E}-07$ & $6.0 \mathrm{E}-07$ & $8.7 \mathrm{E}-0$ \\
\hline
\end{tabular}


Table A21. 95th Percentile E/Q Values $\left(\mathrm{s} \mathrm{m}^{-3}\right.$ ) for Acute Ground-Level Releases from 300 Area Based on 1983 through 2002 Meteorological Information, Hanford Site, Washington

\begin{tabular}{|c|c|c|c|c|c|c|c|c|c|c|c|c|c|c|c|c|}
\hline \multirow{2}{*}{$\begin{array}{l}\text { Distance } \\
\mathrm{km} \text { (mi) }\end{array}$} & \multicolumn{16}{|c|}{ Sector (Wind from 300 Area toward Direction Indicated) } \\
\hline & $\mathrm{S}$ & SSW & SW & WSW & $\mathrm{W}$ & WNW & NW & NNW & $\mathrm{N}$ & NNE & $\mathrm{NE}$ & ENE & $\mathrm{E}$ & ESE & SE & SSE \\
\hline $0.1(0.06)$ & $2.8 \mathrm{E}-02$ & $2.1 \mathrm{E}-02$ & $2.9 \mathrm{E}-02$ & $2.2 \mathrm{E}-02$ & $3.1 \mathrm{E}-02$ & $2.8 \mathrm{E}-02$ & $3.0 \mathrm{E}-02$ & $3.4 \mathrm{E}-02$ & 3.3E-02 & $2.9 \mathrm{E}-02$ & $1.6 \mathrm{E}-02$ & $3.1 \mathrm{E}-02$ & $4.0 \mathrm{E}-02$ & 5.4E-02 & $4.2 \mathrm{E}-02$ & $3.1 \mathrm{E}-02$ \\
\hline $0.2(0.12)$ & & $2 \mathrm{E}-03$ & $8 \mathrm{E}-03$ & & & & & & & & & & & $1.6 \mathrm{E}-02$ & & \\
\hline $.3(0.19$ & & & & & & & & & & & & & & & & \\
\hline $4(0.2$ & & & 3 & & & & & & & & & & & & & \\
\hline $5(0.3$ & & & & & & & & & & & & & & & & \\
\hline $6(0$. & & & & & & & & & & & & & & & & \\
\hline $0.7(0$. & & & & & & & & & & & & & & & & \\
\hline $0.8(0.5$ & & & 4 & & & & & & & & & & & & & \\
\hline $0.9(0.5$ & & & $O F$ & & & & & & & & & & & & & \\
\hline $1 \quad(0.62)$ & & & $59 \mathrm{~F}$ & & & & & & & & & & & & & \\
\hline $2.4 \quad(1.5)$ & & & & & & & & & & & & & & & & \\
\hline $4 \quad(2.5)$ & & & $7.4 \mathrm{E}-$ & & & & & & & & $4.1 \mathrm{E}-05$ & & & $1.4 \mathrm{E}-04$ & & \\
\hline 5.6 & & & & & & & & & & & & & & & & \\
\hline 7.2 & & & & & & & & & & & & & & & & \\
\hline 12 & & & & & & & & & & & & & & & & \\
\hline 24 & & & & & & & & & & & & & & & & \\
\hline 40 & & & $4.0 \mathrm{~F}$ & & & & & & & & & & & & & \\
\hline 56 & & & & & & & & & & & & & & & & \\
\hline (45) & $1.9 \mathrm{E}-06$ & $1.4 \mathrm{E}-06$ & $.0 E-U 6$ & $1.4 \mathrm{E}-06$ & 2.1E-06 & $1.9 \mathrm{E}-06$ & 2.0E-06 & 2.3E-06 & 2.3E-06 & $2.0 \mathrm{E}-06$ & 1.1E-06 & 2.1E-06 & 2.7E-06 & 3.7E-06 & 2.8E-06 & $2.1 \mathrm{E}-06$ \\
\hline
\end{tabular}

Table A22. 95th Percentile E/Q Values $\left(\mathrm{s} \mathrm{m}^{-3}\right.$ ) for Acute 60-m Stack Releases from 300 Area Based on 1986 through 2002 Meteorological Information, Hanford Site, Washington

\begin{tabular}{|c|c|c|c|c|c|c|c|c|c|c|c|c|c|c|c|c|}
\hline \multirow{2}{*}{$\begin{array}{l}\text { Distance } \\
\mathrm{km} \text { (mi) }\end{array}$} & \multicolumn{16}{|c|}{ dicated) } \\
\hline & $\mathrm{S}$ & SSW & SW & WSW & W & WNW & NW & NNW & $\mathrm{N}$ & NNE & $\mathrm{NE}$ & ENE & E & ESE & SE & SSE \\
\hline$\overline{0.1}$ & $1 \mathrm{E}-42$ & & 4.4E-18 & & & & E-41 & & & & $6 \mathrm{E}-18$ & & & 1.1E-41 & & \\
\hline 0.2 & & & & & & & & & & & E-08 & & & & & \\
\hline 0.3 & & & & & & & & & & & 4 E-06 & & & & & \\
\hline 0.4 & & & & & & & & & & & E-06 & & & & & \\
\hline 0.5 & & & & & & & & & & & E-06 & & & & & \\
\hline 6 & & & & & & & & & & & $.9 \mathrm{E}-06$ & & & & & $.9 \mathrm{E}-06$ \\
\hline 7 & & & & & & & & & & & & & & & & \\
\hline 8 & & & & & & & & & & & & & & & & \\
\hline $0.9(0.5$ & & & & & & & & & & & & & & & & \\
\hline $1 \quad(0.62$ & & & & & & & & & & & & & & & & \\
\hline 2.4 & & & & & & & & & & & & & & & & \\
\hline 4 & & & & & & & & & & & & & & & & 1.4E-05 \\
\hline 5.6 & & & & & & & & & & & & & & & & $1.4 \mathrm{E}-05$ \\
\hline 7.2 & & & & & & & & & & & E-06 & & & & & $8.2 \mathrm{E}-06$ \\
\hline (7.5) & & 3E-06 & & & & & & & & & E-06 & & & & 6.3E-06 & $6.3 \mathrm{E}-06$ \\
\hline (15) & & $2.8 \mathrm{E}-06$ & $.9 \mathrm{E}-06$ & & 4.7E-06 & & & & & & $2.0 \mathrm{E}-06$ & 2.5E-06 & 4.3E-06 & $5.5 \mathrm{E}-06$ & 3.6E-06 & 2.7E-06 \\
\hline (25) & & $1.6 \mathrm{E}-06$ & $2.9 \mathrm{E}-06$ & 3.0E-06 & $2.8 \mathrm{E}-06$ & & & & & & $1.5 \mathrm{E}-06$ & $1.5 \mathrm{E}-06$ & $2.5 \mathrm{E}-06$ & $3.4 \mathrm{E}-06$ & $2.1 \mathrm{E}-06$ & $1.6 \mathrm{E}-06$ \\
\hline (35) & 2E-06 & $1.2 \mathrm{E}-06$ & $2.1 \mathrm{E}-06$ & 2.2E-06 & $2.0 \mathrm{E}-06$ & $1.7 \mathrm{E}-06$ & $1.2 \mathrm{E}-06$ & $1.7 \mathrm{E}-06$ & & $1.0 \mathrm{E}-06$ & $8.8 \mathrm{E}-07$ & $1.0 \mathrm{E}-06$ & $1.8 \mathrm{E}-06$ & $2.4 \mathrm{E}-06$ & $1.5 \mathrm{E}-06$ & $1.2 \mathrm{E}-06$ \\
\hline (45) & $9.2 \mathrm{E}-07$ & $9.4 \mathrm{E}-07$ & $1.6 \mathrm{E}-06$ & $1.7 \mathrm{E}-06$ & $1.6 \mathrm{E}-06$ & $1.3 \mathrm{E}-06$ & $9.9 \mathrm{E}-07$ & $1.4 \mathrm{E}-06$ & $1.2 \mathrm{E}-06$ & 7.5E-07 & $6.6 \mathrm{E}-07$ & 7.5E-07 & $1.5 \mathrm{E}-06$ & $1.9 \mathrm{E}-06$ & $1.2 \mathrm{E}-06$ & 9.3E-07 \\
\hline
\end{tabular}


Table A23. 95th Percentile E/Q Values $\left(\mathrm{s} \mathrm{m}^{-3}\right.$ ) for Acute Ground-Level Releases from 400 Area Based on 1983 through 2002 Meteorological Information, Hanford Site, Washington

\begin{tabular}{|c|c|c|c|c|c|c|c|c|c|c|c|c|c|c|c|c|}
\hline \multirow{2}{*}{$\begin{array}{l}\text { Distance } \\
\text { km (mi) }\end{array}$} & \multicolumn{16}{|c|}{ Sector (Wind from 400 Area toward Direction Indicated) } \\
\hline & $\mathrm{S}$ & SSW & SW & WSW & W & WNW & NW & NNW & $\mathrm{N}$ & NNE & NE & ENE & $\mathrm{E}$ & ESE & SE & SSE \\
\hline $0.1(0.06)$ & $3.0 \mathrm{E}-02$ & $2.8 \mathrm{E}-02$ & $2.9 \mathrm{E}-02$ & $3.2 \mathrm{E}-02$ & $3.2 \mathrm{E}-02$ & $3.1 \mathrm{E}-02$ & $2.7 \mathrm{E}-02$ & $2.3 \mathrm{E}-02$ & $2.6 \mathrm{E}-02$ & $2.5 \mathrm{E}-02$ & $2.8 \mathrm{E}-02$ & $3.2 \mathrm{E}-02$ & $3.3 \mathrm{E}-02$ & $3.0 \mathrm{E}-02$ & $2.5 \mathrm{E}-02$ & $2.7 \mathrm{E}-02$ \\
\hline $0.2(0.12)$ & $.0 \mathrm{E}-03$ & $.6 \mathrm{E}-03$ & $.9 \mathrm{E}-03$ & 9.6E-03 & $9.7 \mathrm{E}-03$ & & & & $.7 E-03$ & & 8.3E-03 & .7E-03 & $1.0 \mathrm{E}-02$ & $.1 \mathrm{E}-03$ & 7.5E-03 & 8.1E-03 \\
\hline 0.3 (0.19) & & .3E-03 & $.5 \mathrm{E}-03$ & $.8 \mathrm{E}-03$ & $.9 \mathrm{E}-03$ & & & & & & 2E-03 & & & & 3.8E-03 & \\
\hline $0.4(0.25)$ & E-03 & 2.6E-03 & 2.7E-03 & 3.0E-03 & $3.0 \mathrm{E}$ & & & & & & & & & & & \\
\hline $0.5(0.31)$ & & $1.8 \mathrm{E}$ & $1.9 \mathrm{E}-03$ & -03 & $2.1 \mathrm{E}$ & & & & & & & & & & & \\
\hline $0.6(0.37)$ & 03 & $1.3 \mathrm{E}$ & $1.4 \mathrm{E}$ & $1.5 \mathrm{E}-03$ & $1.5 \mathrm{~F}$ & & & & & & & & & & & \\
\hline $0.7(0.43)$ & -03 & $1.0 \mathrm{E}-$ & $1.1 \mathrm{E}-03$ & $.2 \mathrm{E}-03$ & $1.2 \mathrm{E}$ & & & & 04 & & & & & & & \\
\hline $0.8(0.50)$ & 3E-04 & 8.3E-04 & 8.6E-04 & 9.3E-04 & $9.4 \mathrm{E}$ & & $8.0 \mathrm{E}$ & & 7.5E-04 & & & & & & & \\
\hline $0.9(0.56)$ & 2E-04 & $6.8 \mathrm{E}-04$ & 7.1E-04 & 7.7E-04 & $7.7 \mathrm{E}$ & -04 & $6.6 \mathrm{E}$ & & $6.2 \mathrm{E}-04$ & & E-04 & & & & & \\
\hline $1 \quad(0.62)$ & 1E-04 & 5.7E-04 & $5.9 \mathrm{E}-04$ & $6.4 \mathrm{E}-04$ & $6.5 \mathrm{E}$ & 6.3E-04 & $5.5 \mathrm{E}-$ & & $5.2 \mathrm{E}-04$ & & E-04 & & & & & \\
\hline $2.4 \quad(1.5)$ & & $1.5 \mathrm{E}-04$ & $1.5 \mathrm{E}-04$ & & $1.7 \mathrm{E}$ & & & & $1.3 \mathrm{E}-04$ & & $1.4 \mathrm{E}-04$ & & & & & $1.4 \mathrm{E}-04$ \\
\hline $4 \quad(2.5)$ & 7E-05 & 7.3E-05 & 7.5E-05 & $8.1 \mathrm{E}-05$ & $8.2 \mathrm{E}-05$ & 7.9E-05 & $7.0 \mathrm{E}-05$ & 59505 & $6.6 \mathrm{E}-05$ & 6.3E-05 & 7.1E-05 & & $8.5 \mathrm{E}-05$ & 7.7E-05 & $6.4 \mathrm{E}-05$ & $6.9 \mathrm{E}-05$ \\
\hline (3.5) & & & 4.8E-05 & & $5.2 \mathrm{E}-05$ & & 4.5E-05 & & 4.2E-05 & & 4.5E-05 & & 5.4E-05 & & 4.1E-05 & 4.4E-05 \\
\hline (4.5) & E-05 & 3.3E-05 & 3.5E-05 & 3.7E-05 & $3.8 \mathrm{E}$ & & $3.2 \mathrm{E}$ & & 3.0E-05 & 2.9E-05 & 3.2E-05 & & 3.9E-05 & & 2.9E-05 & $3.2 \mathrm{E}-05$ \\
\hline (7.5) & 3E-05 & & $1.8 \mathrm{E}-05$ & $1.9 \mathrm{E}-05$ & $1.9 \mathrm{E}$ & & & & & & & & & & $1.5 \mathrm{E}-05$ & $1.6 \mathrm{E}-05$ \\
\hline (15) & & & 7.6E-06 & & $8.2 \mathrm{E}$ & & & & & & & & & & 6.4E-06 & $6.9 \mathrm{E}-06$ \\
\hline (25) & & & & & $4.4 \mathrm{E}$ & & & & & & & & & & & \\
\hline (35) & 3E-06 & & & & & & & & & & & & & & & \\
\hline (45) & $2.0 \mathrm{E}-06$ & $1.9 \mathrm{E}-06$ & $2.0 \mathrm{E}-06$ & 2.2E-06 & 2.2E-06 & $2.1 \mathrm{E}-06$ & $1.9 \mathrm{E}-06$ & $1.6 \mathrm{E}-06$ & $1.8 \mathrm{E}-06$ & $1.7 \mathrm{E}-06$ & $1.9 \mathrm{E}-06$ & $2.2 \mathrm{E}-06$ & 2.3E-06 & 2.1E-06 & 1.7E-06 & $1.8 \mathrm{E}-06$ \\
\hline
\end{tabular}

Table A24. 95th Percentile E/Q Values $\left(\mathrm{s} \mathrm{m}^{-3}\right.$ ) for Acute 60-m Stack Releases from 400 Area Based on 1986 through 2002 Meteorological Information, Hanford Site, Washington

\begin{tabular}{|c|c|c|c|c|c|c|c|c|c|c|c|c|c|c|c|c|}
\hline \multirow{2}{*}{$\begin{array}{l}\text { Distance } \\
\mathrm{km} \text { (mi) }\end{array}$} & \multicolumn{16}{|c|}{ Sector (Wind from 400 Area toward Direction Indicated) } \\
\hline & $\mathrm{S}$ & SSW & SW & WSW & $\mathrm{W}$ & WNW & NW & NNW & $\mathrm{N}$ & NNE & $\mathrm{NE}$ & ENE & E & ESE & SE & SSE \\
\hline $0.1(0.06)$ & $.0 \mathrm{E}-11$ & 3E-08 & 4E-08 & 3E-11 & $1 \mathrm{E}-09$ & & & & & 1E-08 & 4.3E-11 & 5E-09 & & 4.3E-18 & $.7 \mathrm{E}-19$ & $1.8 \mathrm{E}-18$ \\
\hline $0.2(0.12)$ & & & & & & & & & & & & & & & & \\
\hline $0.3(0.1$ & & $2 \mathrm{~F}_{-} \mathrm{C}$ & & & & & & & & & & & & & & E-07 \\
\hline $4(0$. & & & & & & & & & & & & & & & & $.0 \mathrm{E}-06$ \\
\hline $5(0$. & & & & & & & & & & & & & & & & $.8 \mathrm{E}-06$ \\
\hline $6(\mathrm{C}$ & & & & & & & & & & & & & & & & \\
\hline 7( & & & & & & & & & & & & & & & & \\
\hline 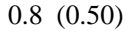 & & & & & & & & & & & & & & & & \\
\hline $0.9(0.5$ & & & & & & & & & & & & & & & & \\
\hline 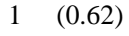 & & & & & & & & & & & & & & & & \\
\hline 2.4 & & & & & & & & & & & & & & & & $\mathrm{E}-05$ \\
\hline 4 & & & & & & & & & & & & & & & & $\mathrm{E}-05$ \\
\hline 5.6 & & & & & & & & & & & & & & & & E-05 \\
\hline $7.2 \quad(4.5)$ & & 8.7E-06 & & & & & & & & & & & & & & $.3 \mathrm{E}-06$ \\
\hline (7.5) & & $6.3 \mathrm{E}-06$ & 6.3E-06 & & & & $6.4 \mathrm{E}-06$ & & & & E-06 & & & & & $.2 \mathrm{E}-06$ \\
\hline (15) & E-06 & $2.6 \mathrm{E}-06$ & $.7 \mathrm{E}-06$ & & & & 2.9E-06 & 2.7E-06 & & & 2.3E-06 & & 3.7E-06 & $2.5 \mathrm{E}-06$ & $1.9 \mathrm{E}$ & $.4 \mathrm{E}-06$ \\
\hline (25) & E-06 & $1.6 \mathrm{E}-06$ & $1.6 \mathrm{E}-06$ & $2.5 \mathrm{E}-06$ & 2.7E-06 & 2.6E-06 & $1.6 \mathrm{E}-06$ & $1.6 \mathrm{E}-06$ & & $1.5 \mathrm{E}-06$ & $1.5 \mathrm{E}-06$ & $1.7 \mathrm{E}-06$ & $2.1 \mathrm{E}-06$ & $1.5 \mathrm{E}-06$ & $1.4 \mathrm{E}-06$ & $1.5 \mathrm{E}-06$ \\
\hline (35) & 2E-06 & $1.1 \mathrm{E}-06$ & $1.1 \mathrm{E}-06$ & $1.8 \mathrm{E}-06$ & $1.9 \mathrm{E}-06$ & $1.9 \mathrm{E}-06$ & $1.2 \mathrm{E}-06$ & $1.2 \mathrm{E}-06$ & $1.1 \mathrm{E}-06$ & $1.0 \mathrm{E}-06$ & $1.1 \mathrm{E}-06$ & $1.3 \mathrm{E}-06$ & $1.5 \mathrm{E}-06$ & $1.1 \mathrm{E}-06$ & $9.1 \mathrm{E}-07$ & $1.1 \mathrm{E}-06$ \\
\hline (45) & $9.3 \mathrm{E}-07$ & 8.9E-07 & $9.1 \mathrm{E}-07$ & $1.4 \mathrm{E}-06$ & $1.5 \mathrm{E}-06$ & $1.5 \mathrm{E}-06$ & $9.8 \mathrm{E}-07$ & 9.3E-07 & $8.8 \mathrm{E}-07$ & 7.6E-07 & 8.5E-07 & $1.1 \mathrm{E}-06$ & $1.2 \mathrm{E}-06$ & 7.9E-07 & $6.8 \mathrm{E}-07$ & $0 . \Delta \mathrm{L}-\mathrm{U}$ \\
\hline
\end{tabular}




\section{Appendix B}

\section{Hanford Site Species Lists}

This appendix contains five tables that list species of vascular plants, mammals, birds, reptiles and amphibians, and fish that have been sighted on the Hanford Site. The lists are for those species likely to be encountered on the site and are not intended to represent a complete listing of all species. When appropriate, more comprehensive listings have been identified. 
This page intentionally left blank 
Table B-1. Common Vascular Plants on the Hanford Site, Washington (Taxonomy follows Hitchcock and Cronquist 1973). See Sackschewsky and Downs (2001) for a complete listing of Hanford Site vascular plants

\begin{tabular}{|c|c|}
\hline A. Shrub-Steppe Species & Scientific Name \\
\hline \multicolumn{2}{|l|}{ Shrub } \\
\hline big sagebrush & Artemisia tridentata \\
\hline bitterbrush & Purshia tridentata \\
\hline gray rabbitbrush & Chrysothamnus nauseosus \\
\hline green rabbitbrush & Chrysothamnus viscidiflorus \\
\hline snow buckwheat & Eriogonum niveum \\
\hline spiny hopsage & Grayia (Atriplex) spinosa \\
\hline threetip sagebrush & Artemisia tripartita \\
\hline \multicolumn{2}{|l|}{ Perennial Grasses } \\
\hline bluebunch wheatgrass & Agropyron spicatum \\
\hline bottlebrush squirreltail & Sitanion hystrix \\
\hline crested wheatgrass & Agropyron desertorum (cristatum) ${ }^{(a)}$ \\
\hline Indian ricegrass & Oryzopsis hymenoides \\
\hline needle-and-thread grass & Stipa comata \\
\hline prairie junegrass & Koeleria cristata \\
\hline sand dropseed & Sporobolus cryptandrus \\
\hline Sandberg’s bluegrass & Poa sandbergii (secunda) \\
\hline thickspike wheatgrass & Agropyron dasytachyum \\
\hline \multicolumn{2}{|l|}{ Biennial/Perennial Forbs } \\
\hline bastard toad flax & Comandra umbellata \\
\hline buckwheat milkvetch & Astragalus caricinus \\
\hline carey’s balsamroot & Balsamorhiza careyana \\
\hline Cusick’s sunflower & Helianthus cusickii \\
\hline Cutleaf ladysfoot mustard & Thelypodium laciniatum \\
\hline Douglas’ clusterlily & Brodiaea douglasii \\
\hline dune scurfpea & Psoralea lanceolata \\
\hline Franklin’s sandwort & Arenaria franklinii \\
\hline Gray’s desertparsley & Lomatium grayi \\
\hline hoary aster & Machaeranthera canescens \\
\hline hoary falseyarrow & Chaenactis douglasii \\
\hline longleaf phlox & Phlox longifolia \\
\hline Munro’s globemallow & Sphaeralcea munroana \\
\hline pale eveningprimrose & Oenothera pallida \\
\hline rough wallflower & Erysimum asperum \\
\hline sand beardtongue & Penstemon acuminatus \\
\hline
\end{tabular}




\begin{tabular}{|c|c|}
\hline A. Shrub-Steppe Species (cont'd.) & Scientific Name \\
\hline slender hawksbeard & Crepis atrabarba \\
\hline stalked-pod milkvetch & Astragalus sclerocarpus \\
\hline threadleaf fleabane & Erigeron filifolius \\
\hline turpentine spring parsley & Cymopteris terebinthinus \\
\hline winged dock & Rumex venosus \\
\hline yarrow & Achillea millefolium \\
\hline yellow bell & Fritillaria pudica \\
\hline yellow salsify & Tragopogon dubius ${ }^{(\mathrm{a})}$ \\
\hline \multicolumn{2}{|l|}{ Annual Forbs } \\
\hline annual Jacob’s ladder & Polemonium micranthum \\
\hline blue mustard & Chorispora tenella $^{(\mathrm{a})}$ \\
\hline bur ragweed & Ambrosia acanthicarpa \\
\hline clasping pepperweed & Lepidium perfoliatum \\
\hline Indian wheat & Plantago patagonica \\
\hline jagged chickweed & Holosteum umbellatum ${ }^{(a)}$ \\
\hline Jim Hill's tumblemustard & Sisymbrium altissimum ${ }^{(a)}$ \\
\hline matted cryptantha & Cryptantha circumscissa \\
\hline pink microsteris & Microsteris gracilis \\
\hline prickly lettuce & Lactuca serriola $^{(\mathrm{a})}$ \\
\hline Russian thistle (tumbleweed) & Salsola kali ${ }^{(\mathrm{a})}$ \\
\hline spring whitlowgrass & Draba verna ${ }^{(a)}$ \\
\hline storksbill & Erodium cicutarium $^{(\mathrm{a})}$ \\
\hline tall willowherb & Epilobium paniculatum \\
\hline tarweed fiddleneck & Amsinckia lycopsoides \\
\hline threadleaf scorpion weed & Phacelia linearis \\
\hline Western tansymustard & Descurainia pinnata \\
\hline white cupseed & Plectritis macrocera \\
\hline whitestem stickleaf & Mentzelia albicaulis \\
\hline winged cryptantha & Cryptantha pterocarya \\
\hline \multicolumn{2}{|l|}{ Annual Grasses } \\
\hline cheatgrass & Bromus tectorum $^{(\mathrm{a})}$ \\
\hline slender sixweeks & Festuca octoflora \\
\hline small sixweeks & Festuca microstachys \\
\hline B. Riparian Species & Scientific Name \\
\hline \multicolumn{2}{|l|}{ Trees and Shrubs } \\
\hline black cottonwood & Populus trichocarpa \\
\hline black locust & Robinia pseudo-acacia \\
\hline coyote willow & Salix exigua \\
\hline peach, apricot, cherry & Prunus spp. \\
\hline peachleaf willow & Salix amygdaloides ${ }^{(a)}$ \\
\hline
\end{tabular}




\begin{tabular}{|c|c|}
\hline $\begin{array}{l}\text { Trees and Shrubs (cont'd) } \\
\text { willow } \\
\text { white mulberry }\end{array}$ & $\begin{array}{l}\text { Salix spp. } \\
\text { Morus alba }^{(a)}\end{array}$ \\
\hline $\begin{array}{l}\text { Perennial Grasses and Forbs } \\
\text { bentgrass } \\
\text { blanket flower } \\
\text { bulrushes } \\
\text { cattail } \\
\text { Columbia River gumweed } \\
\text { dogbane } \\
\text { hairy golden aster } \\
\text { heartweed } \\
\text { horsetails } \\
\text { horseweed tickseed } \\
\text { lovegrass } \\
\text { lupine } \\
\text { meadow foxtail } \\
\text { Pacific sage } \\
\text { prairie sagebrush } \\
\text { reed canary grass } \\
\text { rushes } \\
\text { Russian knapweed } \\
\text { sedge } \\
\text { water speedwell } \\
\text { western goldenrod } \\
\text { wild onion } \\
\text { wiregrass spikerush }\end{array}$ & 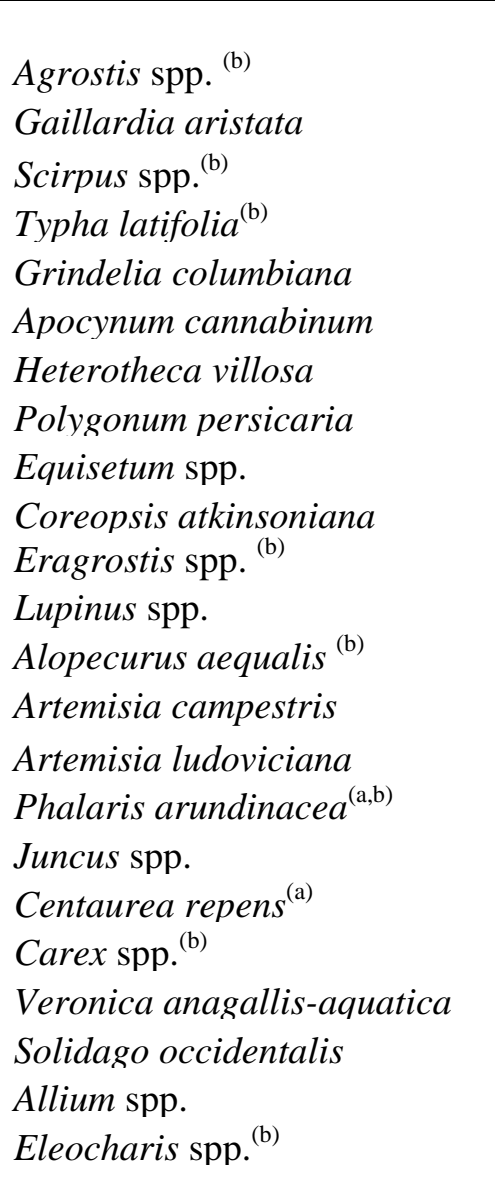 \\
\hline $\begin{array}{l}\text { C. Aquatic Vascular Species } \\
\text { Canadian waterweed } \\
\text { duckweed } \\
\text { pondweed } \\
\text { spiked water milfoil } \\
\text { watercress } \\
\end{array}$ & $\begin{array}{l}\text { Scientific Name } \\
\text { Elodea canadensis } \\
\text { Lemna minor } \\
\text { Potamogeton spp. } \\
\text { Myriophyllum spicatum } \\
\text { Rorippa nasturtium-aquaticum }\end{array}$ \\
\hline $\begin{array}{l}\text { (a) Introduced } \\
\text { (b) Perennial grasses and graminoids. }\end{array}$ & \\
\hline
\end{tabular}


Table B-2. Mammals that Have Been Observed on the Hanford Site, Washington

\begin{tabular}{|c|c|}
\hline Species & Scientific Name \\
\hline badger & Taxidea taxus \\
\hline beaver & Castor canadensis \\
\hline big brown bat & Eptesicus fuscus \\
\hline black-tailed jackrabbit & Lepus californicus \\
\hline bobcat & Lynx rufus \\
\hline bushytail woodrat & Neotoma cinerea \\
\hline California myotis & Myotis californicus \\
\hline coyote & Canis latrans \\
\hline deer mouse & Peromyscus maniculatus \\
\hline elk & Cervus elaphus \\
\hline Great Basin pocket mouse & Perognathus parvus \\
\hline hoary bat & Lasiurus cinereus \\
\hline house mouse & Mus musculus \\
\hline least chipmunk & Eutamius minimus \\
\hline little brown myotis & Myotis lucifugus \\
\hline long-legged myotis & Myotis volans \\
\hline longtail weasel & Mustela frenata \\
\hline meadow vole & Microtus pennsylvanicus \\
\hline merriam shrew & Sorex merriami \\
\hline $\operatorname{mink}$ & Mustela vison \\
\hline mountain cottontail & Sylvilagus nutalli \\
\hline mountain lion & Felis concolor \\
\hline mule deer & Odocoileus hemionus \\
\hline muskrat & Ondatra zibethica \\
\hline northern grasshopper mouse & Onychomys leucogaster \\
\hline northern pocket gopher & Thomomys talpoides \\
\hline pallid bat & Antrozous pallidus \\
\hline porcupine & Erithizon dorsatum \\
\hline raccoon & Procyon lotor \\
\hline river otter & Lutra canadensis \\
\hline sagebrush vole & Lagurus curtatus \\
\hline shorttail weasel & Mustela erminea \\
\hline silver-haired bat & Lasionycteris octivagans \\
\hline small-footed myotis & Myotis subulatus \\
\hline striped skunk & Mephitis mephitis \\
\hline townsend ground squirrel & Citellus townsendi \\
\hline vagrant shrew & Sorex vagrans \\
\hline Washington ground squirrel & Citellus washingtoni \\
\hline western harvest mouse & Riethrodontonomys megalotis \\
\hline western pipistrel & Pipistrellus hesperus \\
\hline white-tailed deer & Odocoileus virginianus \\
\hline white-tailed jackrabbit & Lepus townsendi \\
\hline yellowbelly marmot & Marmota flaviventris \\
\hline yuma myotis & Myotis yumanensis \\
\hline
\end{tabular}


Table B-3. Common Bird Species Known to Occur on the Hanford Site, Washington (Fitzner and Gray 1991, Landeen et al. 1992, Duberstein 1997). Season Code: Yr = all year, $\mathrm{W}=$ winter, $\mathrm{B}=$ Breeding, $\mathrm{M}=$ Migration

\begin{tabular}{|c|c|c|}
\hline Common Name & Scientific Name & $\begin{array}{c}\text { Season of } \\
\text { highest } \\
\text { abundance }\end{array}$ \\
\hline \multicolumn{3}{|l|}{ Gaviiformes - Loons or divers } \\
\hline common loon & Gavia immer & $\mathrm{Yr}$ \\
\hline \multicolumn{3}{|l|}{ Podicipediformes - Grebes } \\
\hline eared grebe & Podiceps nigricollis & $\mathrm{W}$ \\
\hline horned grebe & Podiceps auritus & W \\
\hline pied-billed grebe & Podilymbus podiceps & $\mathrm{Yr}$ \\
\hline western grebe & Aechmophorus occidentalis & $\mathrm{W}$ \\
\hline \multicolumn{3}{|c|}{ Pelecaniformes - Pelicans and allies } \\
\hline $\begin{array}{l}\text { American white pelican } \\
\text { double-crested cormorant }\end{array}$ & $\begin{array}{l}\text { Pelecanus erythrorhynchos } \\
\text { Phalacrocorax auritus }\end{array}$ & $\begin{array}{l}\mathrm{Yr} \\
\mathrm{Yr}\end{array}$ \\
\hline \multicolumn{3}{|l|}{ Anseriformes - Waterfowl } \\
\hline American green-winged teal & Anas crecca & Yr \\
\hline American wigeon & Anas americana & W \\
\hline Barrow's goldeneye & Bucephala islandica & $\mathrm{W}$ \\
\hline blue-winged teal & Anas discors & B \\
\hline bufflehead & Bucephala albeola & $\mathrm{W}$ \\
\hline cinnamon teal & Anas cyanoptera & B \\
\hline Canada goose & Branta canadensis & Yr \\
\hline common goldeneye & Bucephala clangula & $\mathrm{W}$ \\
\hline common merganser & Mergus merganser & $\mathrm{Yr}$ \\
\hline gadwall & Anas strepera & $\mathrm{Yr}$ \\
\hline hooded merganser & Lophodytes cucullatus & W \\
\hline mallard & Anas platyrhynchos & $\mathrm{Yr}$ \\
\hline northern pintail & Anas acuta & $\mathrm{Yr}$ \\
\hline northern shoveler & Anas clypeata & Yr \\
\hline redhead & Aythya americana & W \\
\hline ruddy duck & Oxyura jamaicensis & Yr \\
\hline \multicolumn{3}{|c|}{ Gruiformes - Cranes, rails, and allies } \\
\hline American coot & Fulica americana & $\mathrm{Yr}$ \\
\hline sora & Porzana carolina & B \\
\hline Virginia rail & Rallus limicola & $\mathrm{B}$ \\
\hline \multicolumn{3}{|c|}{$\begin{array}{l}\text { Charadriiformes - Shorebirds and } \\
\text { allies }\end{array}$} \\
\hline California gull & Larus californicus & $\mathrm{Yr}$ \\
\hline Forster's tern & Sterna forsteri & $\mathrm{B}$ \\
\hline
\end{tabular}


Table B-3 (cont'd)

\begin{tabular}{|c|c|c|}
\hline Common Name & Scientific Name & $\begin{array}{c}\text { Season of } \\
\text { Highest } \\
\text { Abundance }\end{array}$ \\
\hline \multicolumn{3}{|c|}{$\begin{array}{l}\text { Charadriiformes - Shorebirds and } \\
\text { allies (cont'd) }\end{array}$} \\
\hline American avocet & Recurvirostra americana & B \\
\hline black-crowned night-heron & Nycticorax nycticorax & B \\
\hline Caspian tern & Sterna caspia & B \\
\hline common snipe & Gallinago gallinago & B \\
\hline dunlin & Calidris alpinis & M \\
\hline glaucous-winged gull & Larus glaucescens & $\mathrm{Yr}$ \\
\hline great blue heron & Ardea herodias & $\mathrm{Yr}$ \\
\hline great egret & Casmerodius albus & B \\
\hline greater yellowlegs & Tringa melanoleuca & M \\
\hline herring gull & Larus argentatus & $\mathrm{W}$ \\
\hline killdeer & Charadrius viociferus & B \\
\hline lesser yellowlegs & Tringa flavipes & M \\
\hline long-billed curlew & Numenius americanus & B \\
\hline long-billed dowitcher & Limnodromus scolopaceus & M \\
\hline red-necked phalarope & Phalaropus lobatus & M \\
\hline ring-billed gull & Larus delawarensis & Yr \\
\hline sandhill crane & Grus canadensis & M \\
\hline spotted sandpiper & Actitis macularia & $\mathrm{B}$ \\
\hline solitary sandpiper & Tringa solitaria & M \\
\hline western sandpiper & Calidris mauri & $\mathrm{M}$ \\
\hline \multicolumn{3}{|c|}{ Galliformes - Chicken-like birds } \\
\hline California quail & Callipepla californica & $\mathrm{Yr}$ \\
\hline chukar & Alectoris chukar & $\mathrm{Yr}$ \\
\hline grey partridge & Perdix perdix & $\mathrm{Yr}$ \\
\hline ring-necked pheasant & Phasianus colchicus & Yr \\
\hline \multicolumn{3}{|c|}{ Falconiformes - Diurnal birds of prey } \\
\hline American kestrel & Falco sparverius & $\mathrm{Yr}$ \\
\hline bald eagle & Haliaeetus leucocephalus & $\mathrm{W}$ \\
\hline Cooper's hawk & Accipiter cooperii & $\mathrm{W}$ \\
\hline ferruginous hawk & Buteo regalis & B \\
\hline golden eagle & Aquila chrysaetos & $\mathrm{Yr}$ \\
\hline merlin & Falco columbarius & M \\
\hline northern harrier & Circus cyaneus & $\mathrm{Yr}$ \\
\hline northern rough-legged hawk & Buteo lagopus & W \\
\hline osprey & Pandion haliaetus & $\mathrm{B}$ \\
\hline prairie falcon & Falco mexicanus & $\mathrm{Yr}$ \\
\hline red-tailed hawk & Buteo jamaicensis & $\mathrm{Yr}$ \\
\hline sharp-shinned hawk & Accipiter striatus & W \\
\hline Swainson's hawk & Buteo swainsoni & $\mathrm{B}$ \\
\hline
\end{tabular}


Table B-3 (cont'd)

\begin{tabular}{|c|c|c|}
\hline Common Name & Scientific Name & $\begin{array}{c}\text { Season of } \\
\text { Highest } \\
\text { Abundance }\end{array}$ \\
\hline \multicolumn{3}{|l|}{ Strigiformes - Owls } \\
\hline burrowing owl & Athene cunicularia & B \\
\hline common barn-owl & Tyto alba & $\mathrm{Yr}$ \\
\hline great horned owl & Bubo virginianus & $\mathrm{Yr}$ \\
\hline long-eared owl & Asio otus & $\mathrm{Yr}$ \\
\hline short-eared owl & Asio flammeus & $\mathrm{Yr}$ \\
\hline \multicolumn{3}{|c|}{ Coraciiformes - Rollers and allies } \\
\hline belted kingfisher & Cerle alcyon & $\mathrm{Yr}$ \\
\hline \multicolumn{3}{|c|}{$\underline{\text { Columbiformes - Pigeons }}$} \\
\hline mourning dove & Zenaida macroura & Yr \\
\hline rock dove & Columba livia & $\mathrm{Yr}$ \\
\hline \multicolumn{3}{|c|}{$\begin{array}{l}\text { Caprimulgiformes - Nightjars and } \\
\text { allies }\end{array}$} \\
\hline common nighthawk & Chordeiles minor & B \\
\hline common poorwill & Pahalaenoptilus nuttallii & $\mathrm{B}$ \\
\hline \multicolumn{3}{|c|}{ Apodiformes - Hummingbirds, swifts } \\
\hline rufous hummingbird & Selasphorus rufus & M \\
\hline \multicolumn{3}{|c|}{ Piciformes - Woodpeckers and allies } \\
\hline Northern flicker & Colaptes auratus & $\mathrm{Yr}$ \\
\hline \multicolumn{3}{|c|}{ Passeriformes - Perching birds } \\
\hline American crow & Corvus brachyrhynchos & $\mathrm{Yr}$ \\
\hline American goldfinch & Carduelis tristis & $\mathrm{Yr}$ \\
\hline American robin & Turdus migratorius & $\mathrm{Yr}$ \\
\hline bank swallow & Riparia riparia & B \\
\hline barn swallow & Hirundo rustica & $\mathrm{B}$ \\
\hline Bewick's wren & Thryomanes bewickii & B \\
\hline black-billed magpie & Pica pica & $\mathrm{Yr}$ \\
\hline black-headed grosbeak & Pheucticus melanocephalus & $\mathrm{B}$ \\
\hline Brewer's blackbird & Euphagus cyanocephalus & B \\
\hline Brewer's sparrow & Spizella breweri & B \\
\hline brown-headed cowbird & Molothrus ater & B \\
\hline Bullock's oriole & Icterus galbula & B \\
\hline canyon wren & Catherpes mexicanus & B \\
\hline cedar waxwing & Bombycilla cedrorum & M \\
\hline chipping sparrow & Spizella passerina & M \\
\hline cliff swallow & Hirundo pyrrhonota & B \\
\hline common raven & Corvus corax & $\mathrm{Yr}$ \\
\hline
\end{tabular}


Table B-3 (cont'd)

\begin{tabular}{|c|c|c|}
\hline Common Name & Scientific Name & $\begin{array}{c}\text { Season of } \\
\text { Highest } \\
\text { Abundance }\end{array}$ \\
\hline \multicolumn{3}{|l|}{$\frac{\text { Passeriformes - Perching birds }}{\text { (cont'd) }}$} \\
\hline dark-eyed junco & Junco hyemalis & $\mathrm{Yr}$ \\
\hline Eastern kingbird & Tyrannus tyrannus & $\mathrm{B}$ \\
\hline European starling & Sturnus vulgaris & $\mathrm{Yr}$ \\
\hline golden-crowned kinglet & Regulus satrapa & M \\
\hline golden-crowned sparrow & Zonotrichia atricapilla & M \\
\hline grasshopper sparrow & Ammodramus savannarum & $\mathrm{B}$ \\
\hline Hammond's flycatcher & Empidonax hammondii & M \\
\hline horned lark & Eremophila alpestris & $\mathrm{Yr}$ \\
\hline house finch & Carpodacus mexicanus & $\mathrm{Yr}$ \\
\hline house sparrow & Passer domesticus & $\mathrm{Yr}$ \\
\hline house wren & Troglodytes aedon & $\mathrm{B}$ \\
\hline lark sparrow & Chondestes grammacus & $\mathrm{B}$ \\
\hline lazuli bunting & Passerina amoena & $\mathrm{B}$ \\
\hline Lincoln's sparrow & Melospiza lincolnii & M \\
\hline loggerhead shrike & Lanius ludovicianus & $\mathrm{Yr}$ \\
\hline MacGillivray's warbler & Oporornis tolmiei & $\mathrm{B}$ \\
\hline marsh wren & Cistothorus palustris & $\mathrm{B}$ \\
\hline Nashville warbler & Vermivora ruficapilla & M \\
\hline Northern rough-winged swallow & Stelgidopteryx serripennis & $\mathrm{B}$ \\
\hline orange-crowned warbler & Vermivora celata & $\mathrm{M}$ \\
\hline Pacific-slope flycatcher & Empidonax difficilis & M \\
\hline red-breasted nuthatch & Sitta canadensis & $\mathrm{W}$ \\
\hline red-winged blackbird & Agelaius phoeniceus & $\mathrm{B}$ \\
\hline rock wren & Salpinctes obsoletus & $\mathrm{B}$ \\
\hline rosy finch & Leucosticte arctoa & M \\
\hline ruby-crowned kinglet & Regulus calendula & M \\
\hline rufous-sided towhee & Pipilo erythrophthalmus & $\mathrm{B}$ \\
\hline sage sparrow & Amphispiza belli & $\mathrm{B}$ \\
\hline sage thrasher & Oreoscoptes montanus & $\mathrm{B}$ \\
\hline Savannah sparrow & Passerculus sandwichensis & $\mathrm{B}$ \\
\hline Say's phoebe & Sayornis saya & $\mathrm{B}$ \\
\hline solitary vireo & Vireo solitarius & M \\
\hline song sparrow & Melospiza melodia & Yr \\
\hline Townsend's solitaire & Myadestes townsendi & M \\
\hline Townsend's warbler & Dendroica townsendi & M \\
\hline tree swallow & Tachycineta bicolor & M \\
\hline varied thrush & Ixoreus naevius & $\mathrm{W}$ \\
\hline vesper sparrow & Pooecetes gramineus & $\mathrm{B}$ \\
\hline violet-green swallow & Tachycineta thalassina & M \\
\hline warbling vireo & Vireo gilvus & M \\
\hline western kingbird & Tyrannus verticalis & B \\
\hline western meadowlark & Sturnella neglecta & $\mathrm{Yr}$ \\
\hline
\end{tabular}


Table B-3 (cont'd)

\begin{tabular}{|c|c|c|}
\hline Common Name & Scientific Name & $\begin{array}{c}\text { Season of } \\
\text { Highest } \\
\text { Abundance }\end{array}$ \\
\hline \multicolumn{3}{|c|}{$\begin{array}{l}\text { Passeriformes - Perching birds } \\
\text { (cont'd) }\end{array}$} \\
\hline white-crowned sparrow & Zonotrichia leucophrys & W \\
\hline western tanager & Piranga ludoviciana & $\mathrm{M}$ \\
\hline western wood-pewee & Contopus sordidulus & M \\
\hline Wilson's warbler & Wilsonia pusilla & M \\
\hline winter wren & Troglodytes troglodytes & W \\
\hline yellow-breasted chat & Icteria virens & $\mathrm{B}$ \\
\hline yellow-rumped warbler & Dendroica coronata & M \\
\hline yellow warbler & Dendroica petechia & M \\
\hline yellow-headed blackbird & Xanthocephalus xanthocephalus & $\mathrm{B}$ \\
\hline
\end{tabular}


Table B-4. Reptiles and Amphibians Found on the Hanford Site, Washington

\begin{tabular}{|ll|}
\hline Common Name & Scientific Name \\
\hline$\underline{\text { Reptiles }}$ & \\
common garter snake & Thamnophis sirtalis \\
Great Basin gopher snake & Pituiphis melanoleucus \\
night snake & Hupsiglena torquata \\
northern sagebrush lizard & Sceloporus graciosus \\
painted turtle & Chrysemys picta \\
short-horned lizard & Phrynosoma douglassii \\
side-blotched lizard & Uta stansburiana \\
striped whipsnake & Masticophis taeniatus \\
Rocky Mountain rubber boa & Charina bottae \\
western rattlesnake & Crotalus viridis \\
western yellow-bellied racer & Coluber constrictor \\
\hline & \\
Amphibians & \\
bullfrog & Rana catesbeiana \\
Great Basin spadefoot & Scaphiopus intermontanus \\
Pacific Treefrog & Hyla regilla \\
tiger Salamander & Ambystoma tigrinum \\
woodhouse toad & Bufo woodhousei \\
\hline
\end{tabular}


Table B-5. Fish Species in the Hanford Reach, Washington, Region of the Columbia River

\begin{tabular}{|c|c|}
\hline Common Name & Scientific Name \\
\hline American shad & Alosa sapidissima \\
\hline black bullhead & Ameiurus melas \\
\hline black crappie & Pomoxis nigromaculatus \\
\hline bluegill & Lepomis macrochirus \\
\hline bridgelip sucker & Catostomus columbianus \\
\hline brown bullhead & Ictalurus nebulosus \\
\hline burbot & Lota lota \\
\hline carp & Cyprinus carpio \\
\hline channel catfish & Ictalurus punctatus \\
\hline Chinook salmon & Oncorhynchus tshawytscha \\
\hline chiselmouth & Acrocheilus alutaceus \\
\hline coho salmon & Oncorhynchus kisutch \\
\hline cutthroat trout & Oncorhynchus clarki \\
\hline Dolly Varden & Salvelinus malma \\
\hline lake whitefish & Coregonus clupeaformis \\
\hline largemouth bass & Micropterus salmoides \\
\hline largescale sucker & Catostomus macrocheilus \\
\hline leopard dace & Rhinichthys falcatus \\
\hline longnose dace & Rhinichthys cataractae \\
\hline mottled sculpin & Cottus bairdi \\
\hline mountain sucker & Catostomus platyrhynchus \\
\hline mountain whitefish & Prosopium williamsoni \\
\hline northern pikeminnow (aka squawfish) & Ptychocheilus oregonensis \\
\hline Pacific lamprey & Entosphenus tridentatus \\
\hline peamouth & Mylocheilus caurinus \\
\hline Paiute sculpin & Cottus beldingi \\
\hline prickley sculpin & Cottus asper \\
\hline pumpkinseed & Lepomis gibbosus \\
\hline rainbow trout (steelhead) & Oncorhynchus mykiss \\
\hline redside shiner & Richardsonius balteatus \\
\hline reticulate sculpin & Cottus perplexus \\
\hline river lamprey & Lampetra ayresi \\
\hline sandroller & Percopsis transmontana \\
\hline smallmouth bass & Micropterus dolomieui \\
\hline sockeye salmon & Oncorhynchus nerka \\
\hline speckled dace & Rhinichthys osculus \\
\hline tench & Tinca tinca \\
\hline threespine stickleback & Gasterosteus aculeatus \\
\hline torrent sculpin & Cottus rotheus \\
\hline walleye & Stizostedion vitreum \\
\hline white crappie & Pomoxis annularis \\
\hline white sturgeon & Acipenser transmontanus \\
\hline yellow perch & Perca flavescens \\
\hline yellow bullhead & Ameiuruss natalis \\
\hline
\end{tabular}




\section{Appendix B References}

Duberstein, C.A. 1997. Use of Riparian Habitats by Spring Migrant Landbirds in the Shrub Steppe of Washington. M.S. Thesis. Washington State University, Pullman, WA.

Fitzner, R.E., and R.H. Gray. 1991. "The Status, Distribution, and Ecology of Wildlife on the U.S. DOE Hanford Site: A Historical Overview of Research Activities.” Environ. Monit. Assess. 18:173-202.

Hitchcock, C.L., and A. Cronquist. 1973. Flora of the Pacific Northwest. University of Washington Press, Seattle, Washington.

Landeen, D.S., A.R. Johnson, and R.M. Mitchell. 1992. Status of Birds at the Hanford Site in Southeastern Washington. WHC-EP-0402, Westinghouse Hanford Company, Richland, Washington.

Sackschewsky, M.R., and J.L. Downs. 2001. Vascular Plants of the Hanford Site. PNNL-13688, Pacific Northwest National Laboratory, Richland, Washington. 
Appendix C - Vegetation Maps 
This page intentionally left blank 


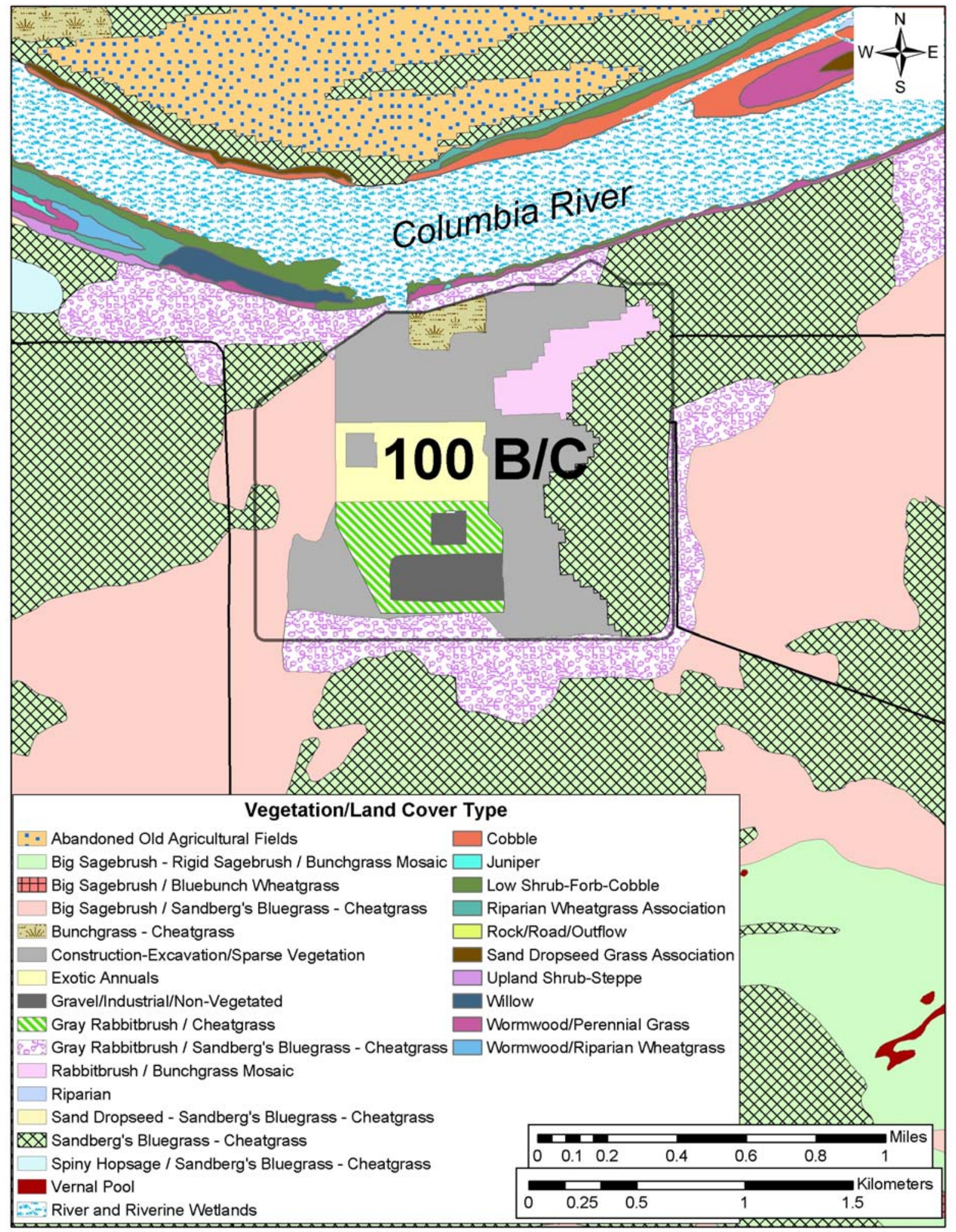

Figure C-1. Vegetation/Land Coverage Map for the 100-B/C Area, Hanford Site, Washington 


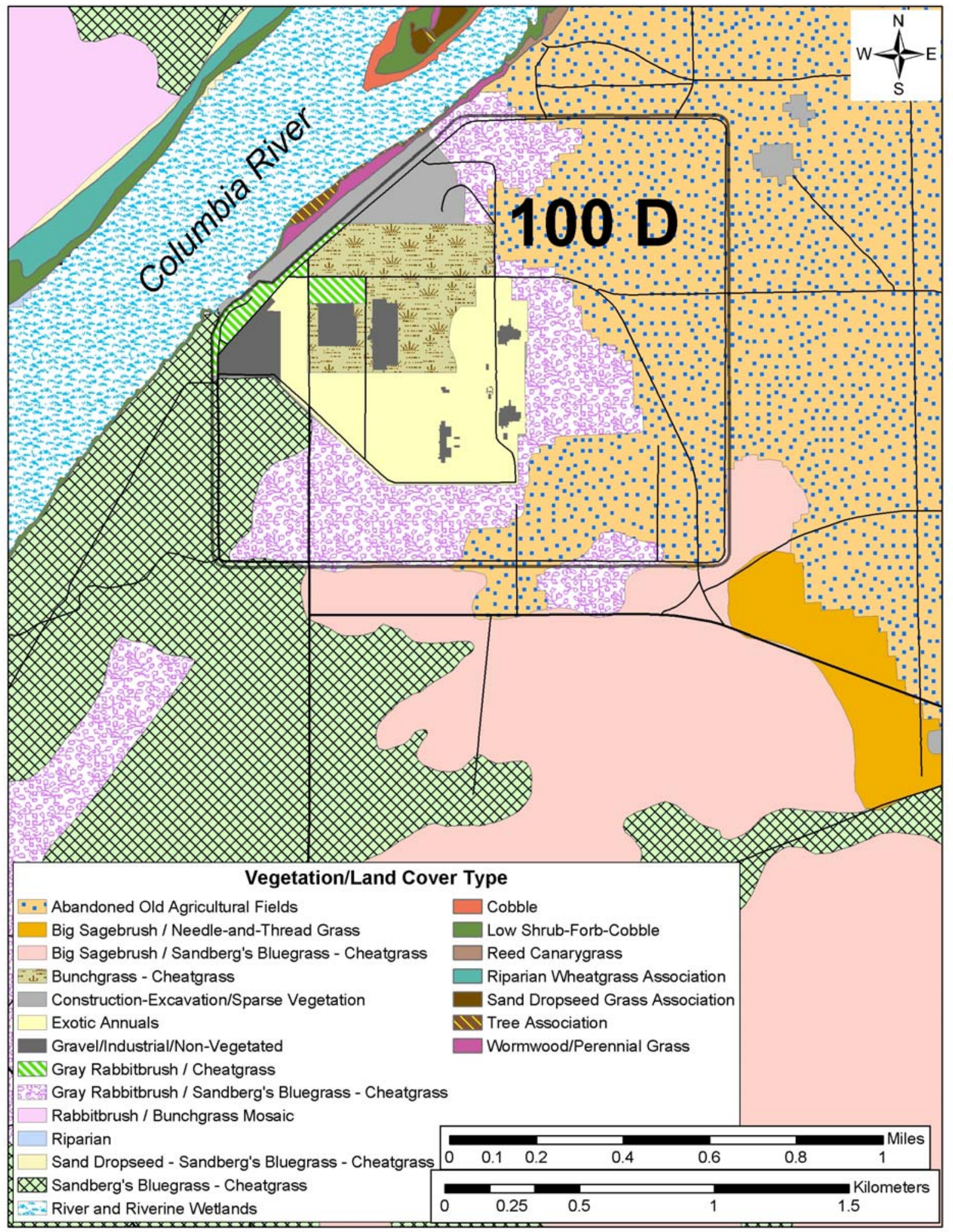

Figure C-2. Vegetation/Land Coverage Map for the 100-D Area, Hanford Site, Washington 


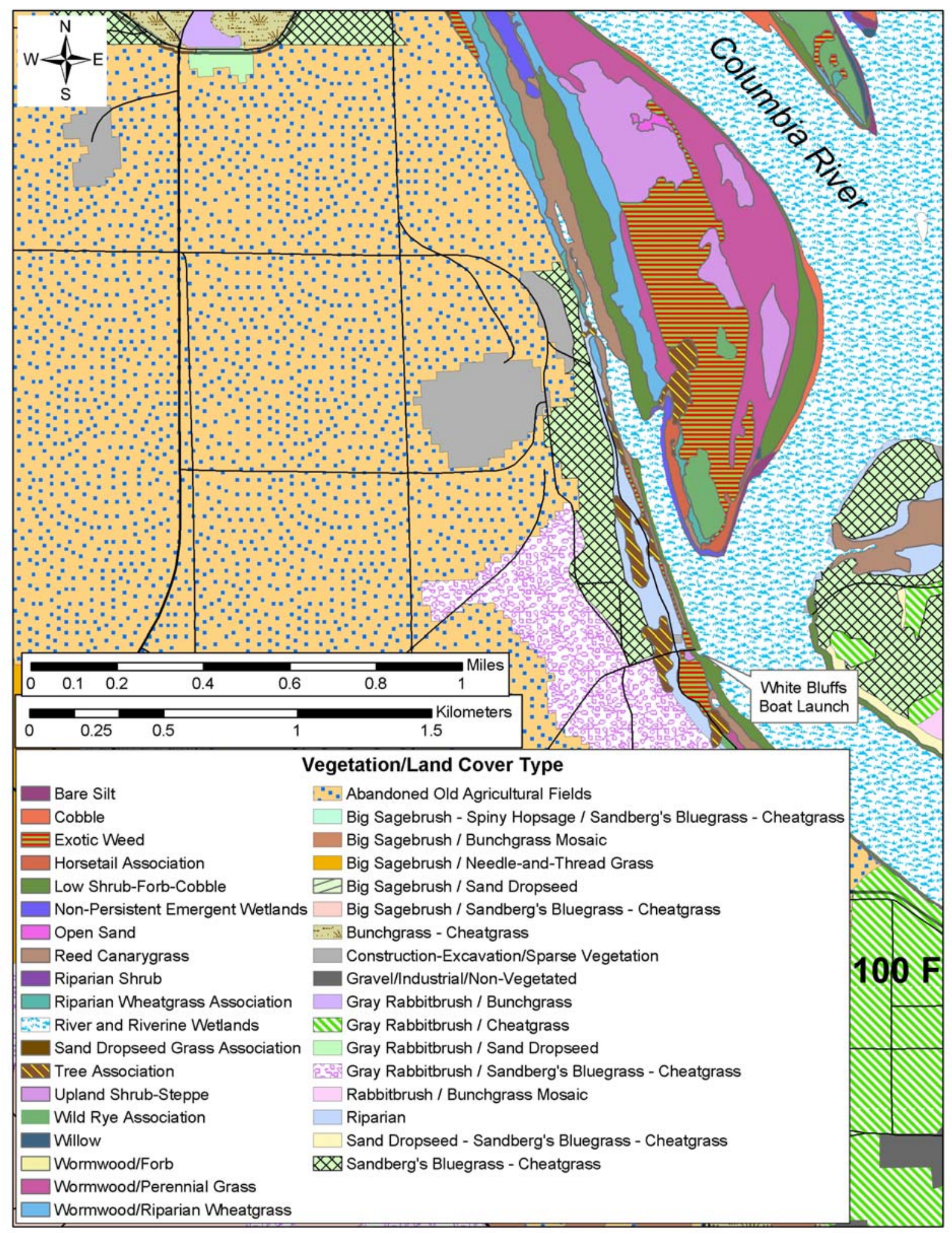

Figure C-3. Vegetation/Land Coverage Map for the White Bluffs Boat Launch Vicinity, Hanford Site, Washington 


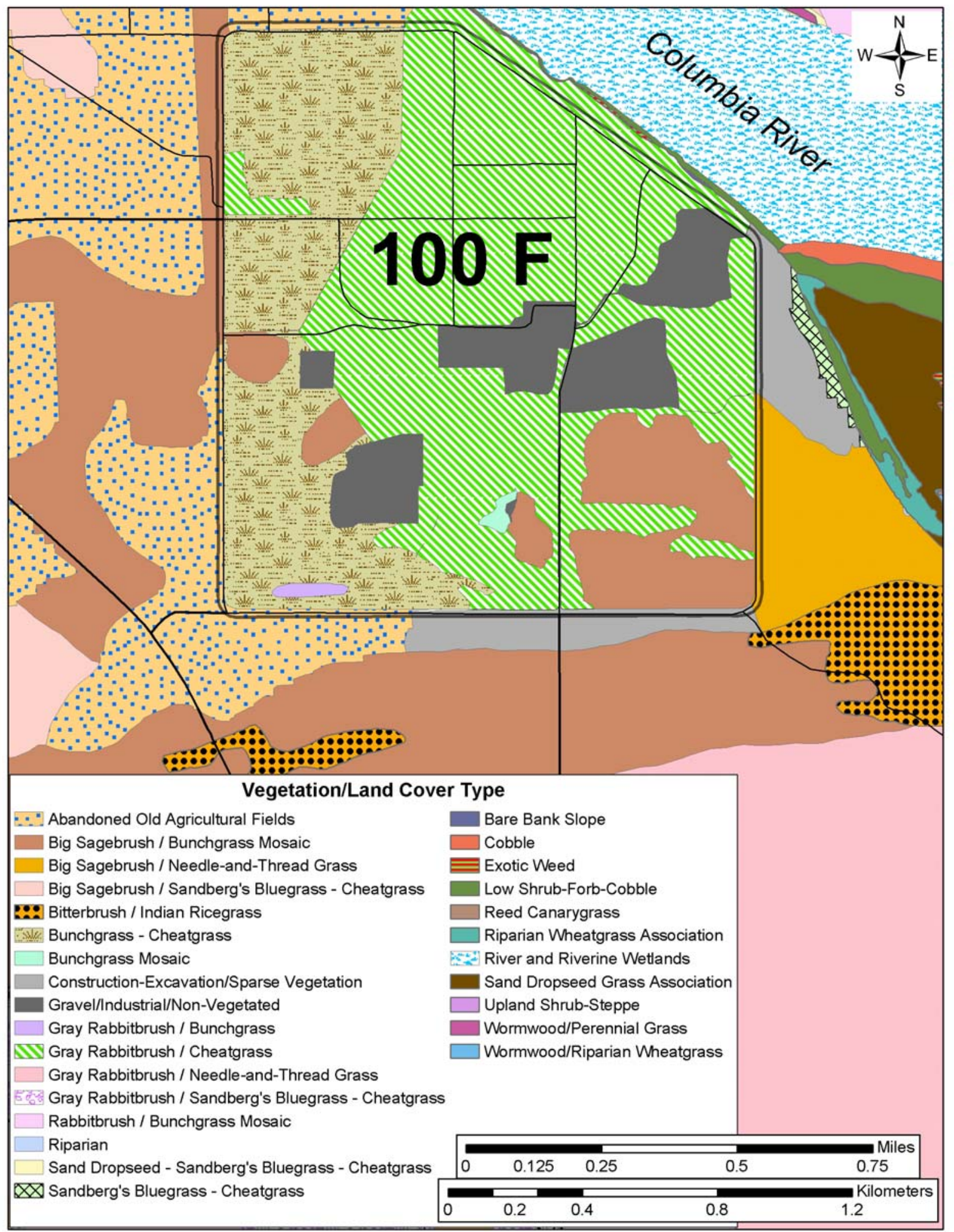

Figure C-4. Vegetation/Land Coverage Map for the 100-F Area, Hanford Site, Washington 


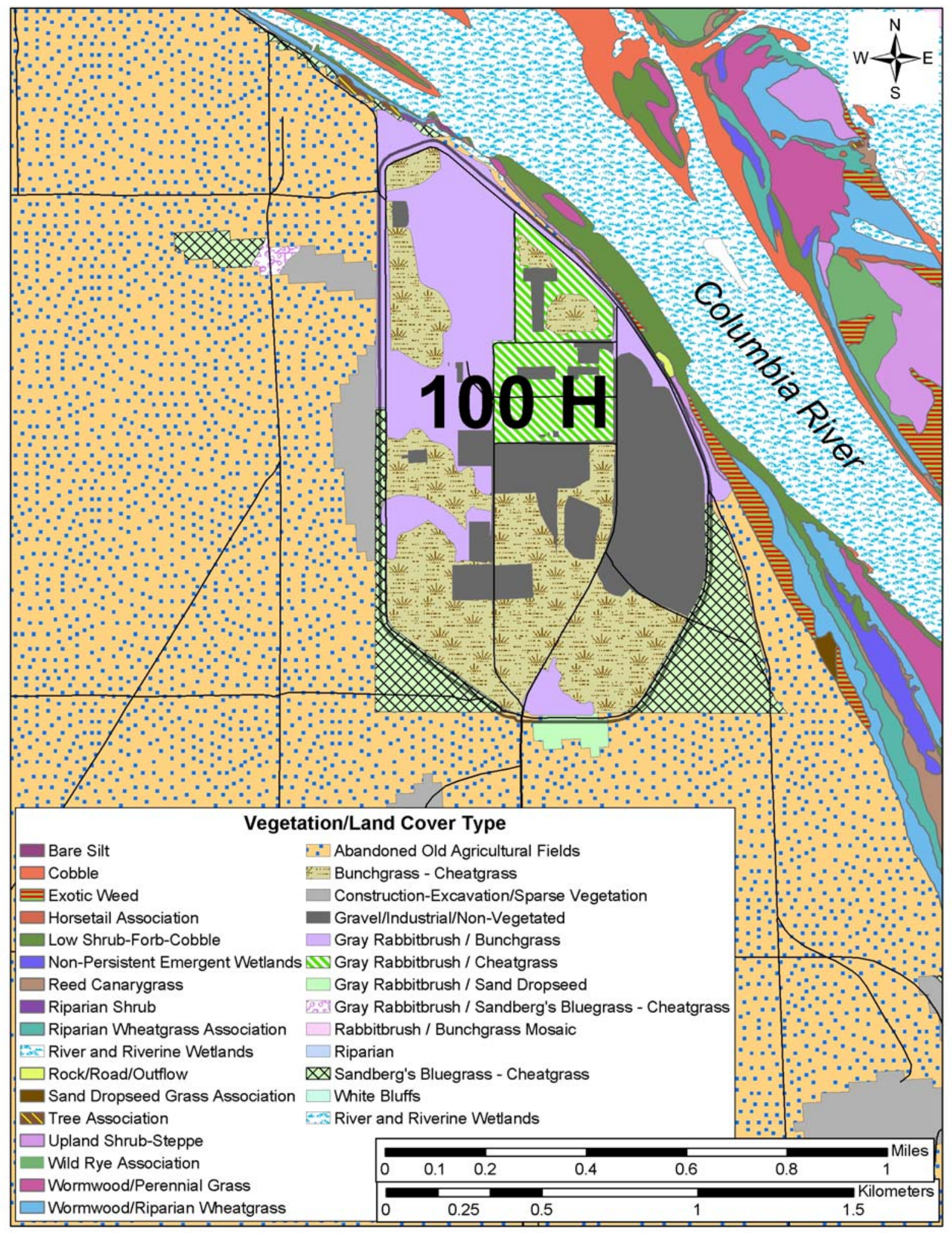

Figure C-5. Vegetation/Land Coverage Map for the 100-H Area, Hanford Site, Washington 


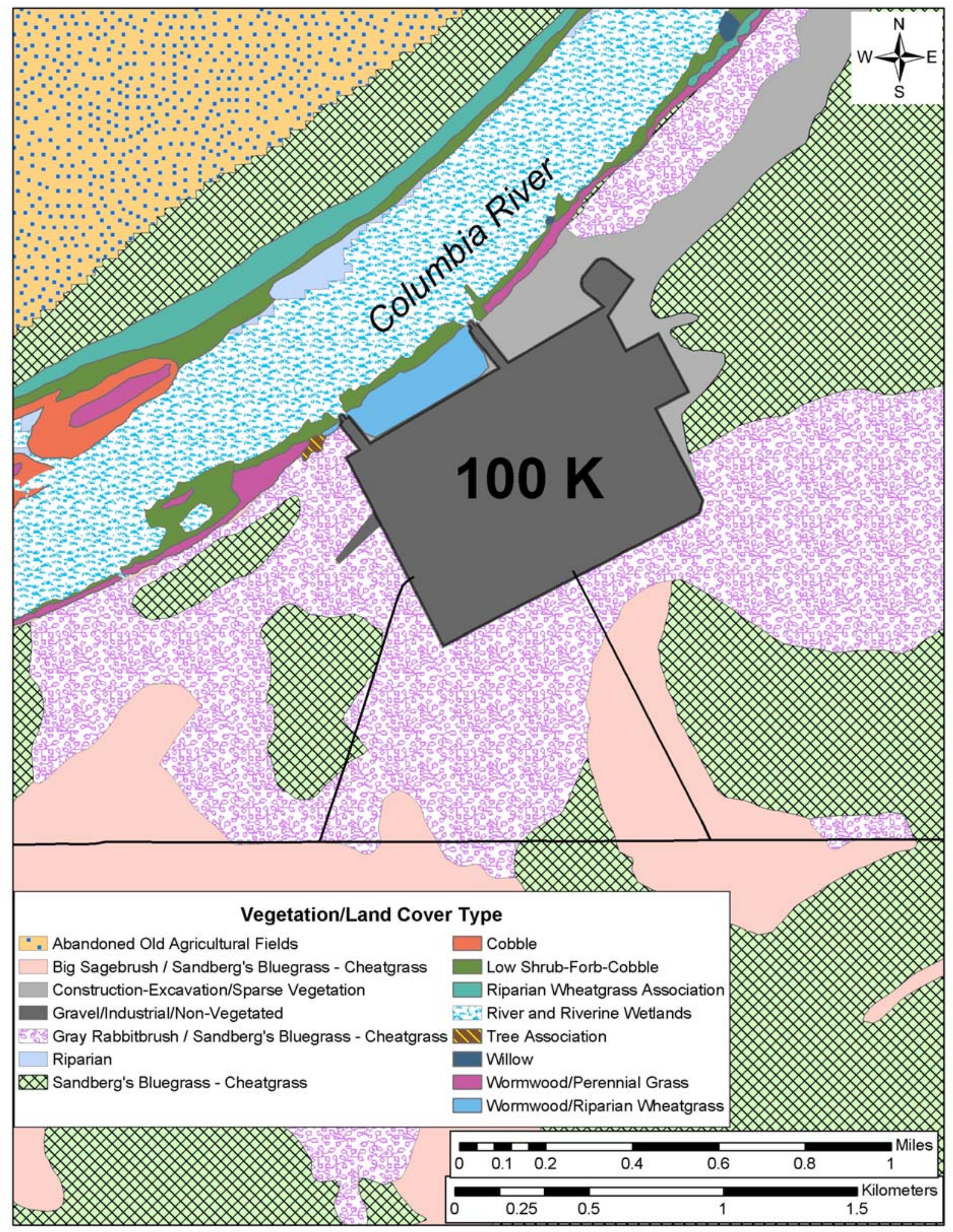

Figure C-6. Vegetation/Land Coverage Map for the 100-K Area, Hanford Site, Washington 


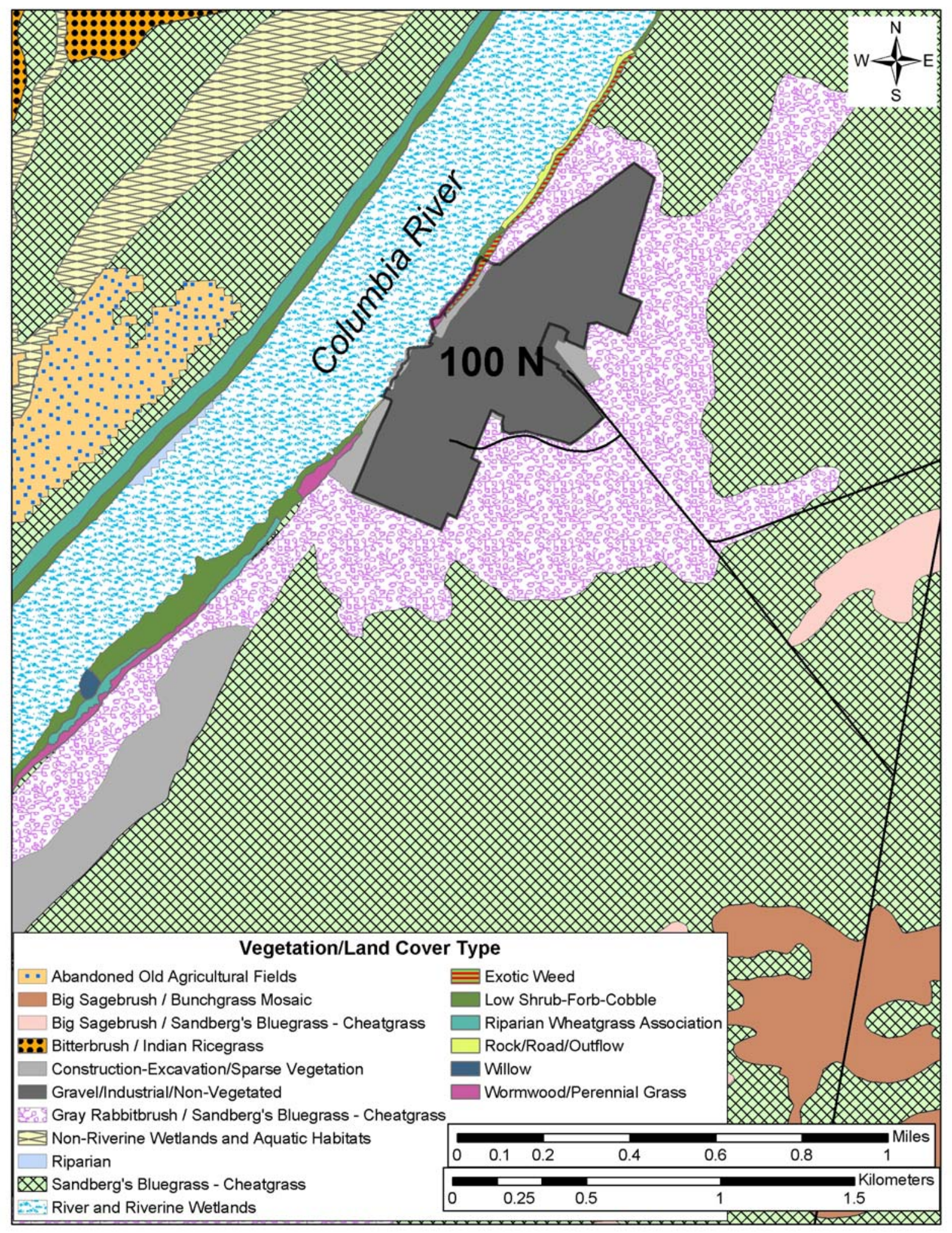

Figure C-7. Vegetation/Land Coverage Map for the 100-N Area, Hanford Site, Washington 


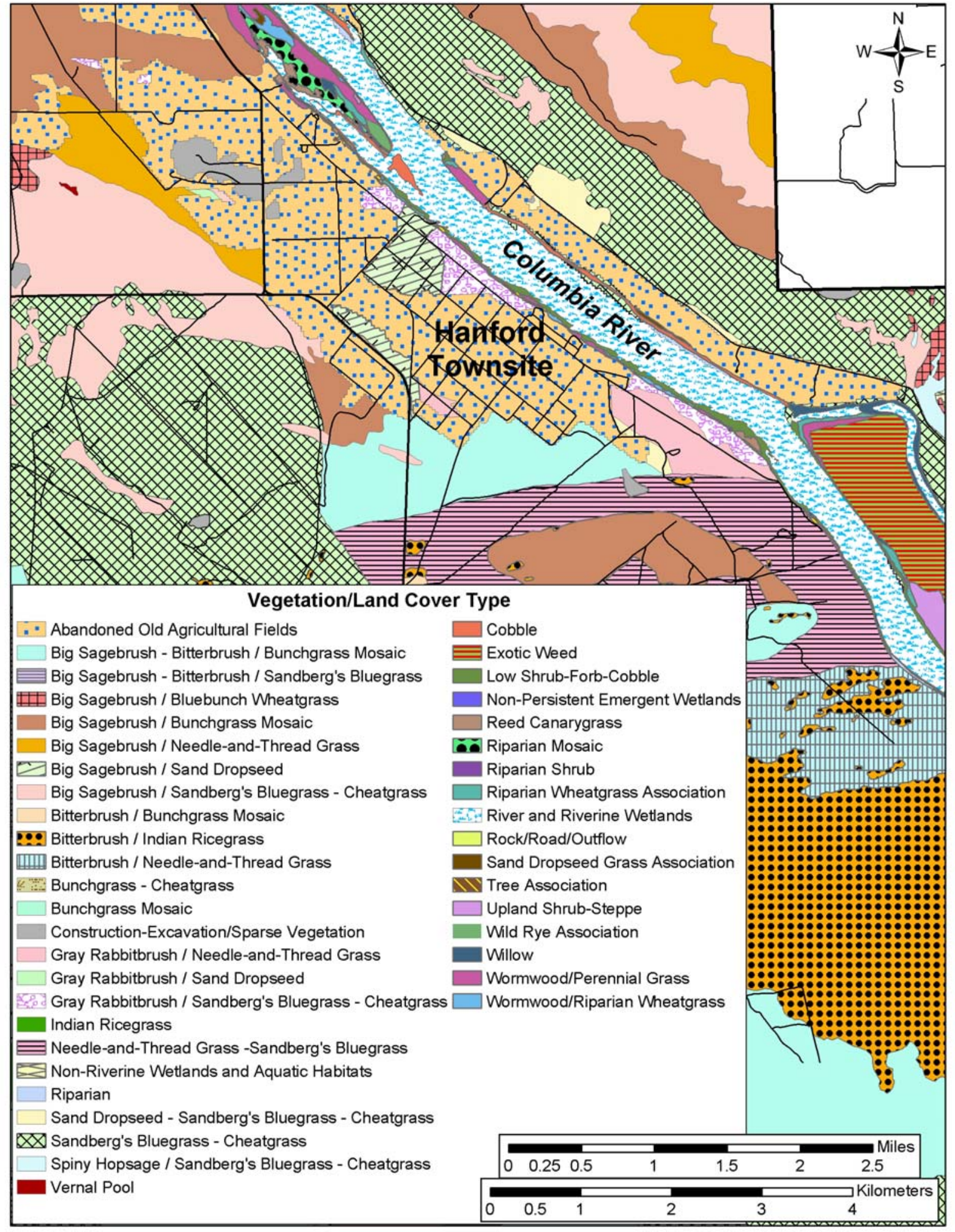

Figure C-8. Vegetation/Land Coverage Map for the Hanford Townsite Vicinity, Hanford Site, Washington 


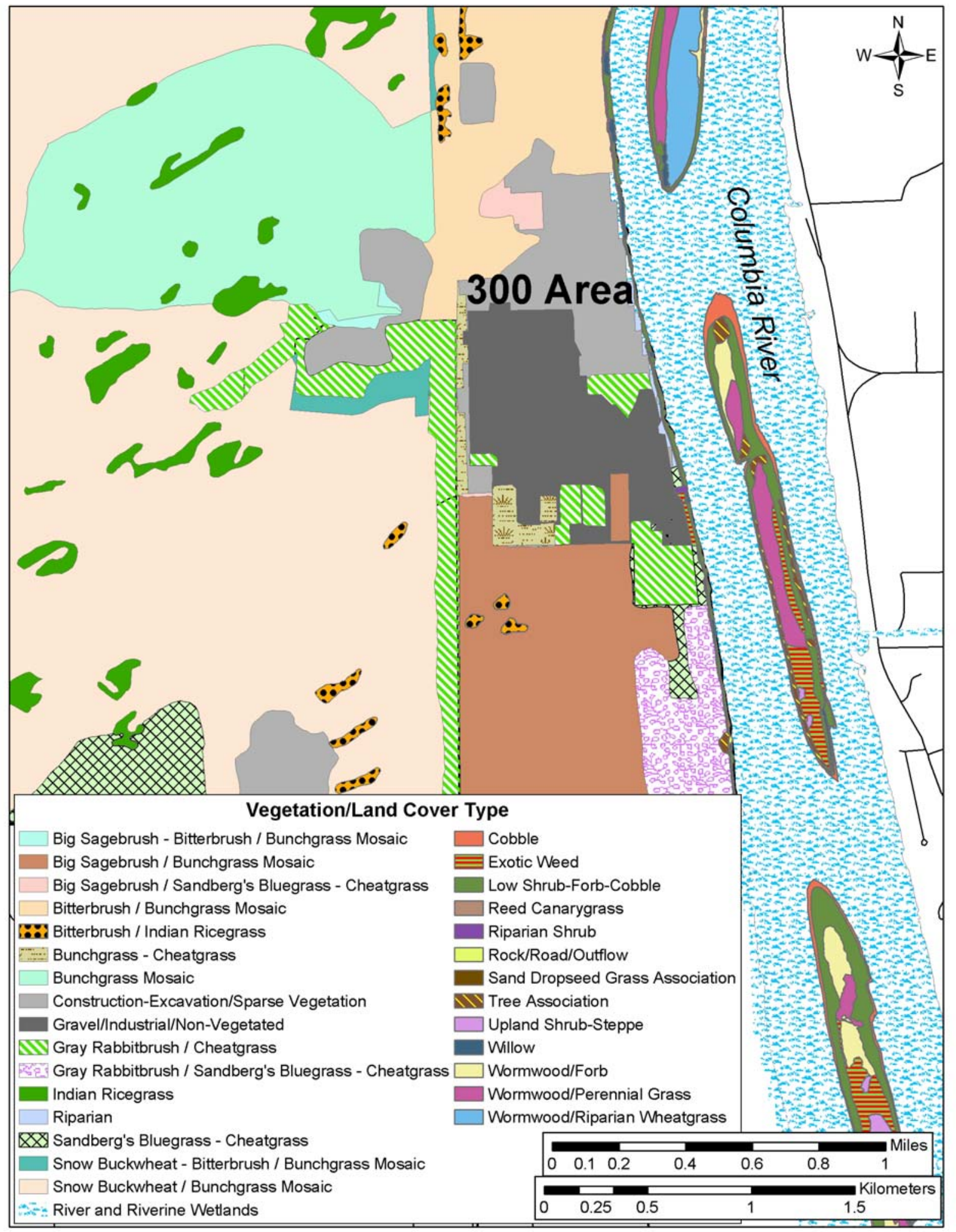

Figure C-9. Vegetation/Land Coverage Map for the 300 Area, Hanford Site, Washington 
This page intentionally left blank 


\title{
6.0 Statutory and Regulatory Requirements
}

\author{
P.L. Hendrickson
}

The Hanford Site is owned by the U.S. Government and is managed by the U.S. Department of Energy (DOE). It is the policy of the DOE to carry out its operations in compliance with all applicable federal, state, and local laws and regulations, presidential executive orders, DOE directives, and treaty rights. Environmental regulatory authority over the Hanford Site is vested both in federal agencies, primarily the U.S. Environmental Protection Agency (EPA), and in Washington State agencies, primarily the Washington State Department of Ecology (Ecology) and the Washington State Department of Health (DOH). In addition, the Benton Clean Air Authority (BCAA) has certain regulatory authority over Hanford activities, including open burning, asbestos removal, and fugitive dust control. Significant environmental laws, regulations, and other requirements are discussed in this chapter in the following order:

- Major federal environmental laws

- Significant applicable federal and state regulations

- Presidential executive orders

- DOE directives

- Treaties, statutes, and policies relating to Indian Tribes of the Hanford region

- Existing environmental permits covering activities at the Hanford Site.

There are a number of sources of information available concerning statutory and regulatory requirements as they relate to the National Environmental Policy Act (NEPA) process. Sources available over the Internet include the following:

- Links to Hanford NEPA documents at: http://www.hanford.gov/rl/resource.asp

- DOE's NEPA web site at: http://www.eh.doe.gov/nepa/

- Council on Environmental Quality’s (CEQ’s) web site at: http://www.whitehouse.gov/ceq/

- EPA's NEPA web site at: http://epa.gov/compliance/nepa/index.html.

The National Environmental Policy Act Compliance Guide (DOE 1998) issued by the DOE Office of Environment, Safety, and Health, contains useful information including regulations, DOE and CEQ guidance, and copies of relevant executive orders, as well as other preparation assistance documents such as checklists.

(The following introduction [boxed text] is intended to be explanatory for persons writing the chapter of a Hanford Site environmental impact statement [EIS] or environmental assessment [EA] covering regulatory requirements, but is not intended to be included in the EIS or EA.) The material following the boxed text can be adapted, as appropriate, for use in an EIS or EA at the discretion of the authors. Additional specificity should be added to the material to reflect the particular circumstances and facts that are the subject of the EIS or EA. An EIS will normally contain more detail than an EA. 


\section{Introduction}

The CEQ regulations in the Code of Federal Regulations (CFR) at 40 CFR 1500-1508 implement NEPA and set forth requirements for the preparation of environmental documentation by federal agencies that satisfies NEPA. DOE has adopted the CEQ regulations as part of its NEPA implementing procedures (10 CFR 1021.103). The CEQ regulations identify the types of actions proposed by a federal agency that require preparation of an EIS, prescribe the content of an EIS, and identify actions and other environmental reviews that must or should be undertaken by the federal agency in preparing and circulating an EIS. In general, an EIS must be prepared by a federal agency for any major federal action significantly affecting the quality of the human environment (40 CFR 1502.3). The regulations also state reasons why an agency may want to prepare an EA instead of an EIS (40 CFR 1508.9).

A specific requirement in the CEQ regulations (40 CFR 1502.25) is that the draft EIS must list "all federal permits, licenses, and other entitlements which must be obtained in implementing the proposal.” If it is uncertain whether a federal permit or license is needed, the draft EIS is to so indicate. There is, however, no requirement in the CEQ regulations or in the DOE NEPA implementing procedures at 10 CFR Part 1021 that the EIS must list or discuss applicable environmental laws and regulations. Nevertheless, applicable environmental laws and regulations (federal, state, and local) have been discussed in recent Hanford Site EISs and EAs in a chapter usually captioned "Statutory and Regulatory Requirements." The discussion below assumes this chapter is chapter 6 of the EIS or EA, but another chapter number is possible.

Chapter 6 of Hanford Site EISs and EAs should include the list called for by 40 CFR 1502.25(b). The list should also include significant permits that will be needed from federal, state, and local government agencies. Chapter 6 should not normally include information on environmental impacts associated with any of the requirements. For example, Executive Order (E.O.) 12962 requires federal agencies to evaluate the effects of their actions on aquatic systems and recreational fisheries. Although E.O. 12962 should be mentioned in Chapter 6 in appropriate cases, the actual impacts of the alternatives on aquatic systems and recreational fisheries should be discussed in the Environmental Consequences chapter (normally Chapter 5) of the EIS or EA and any recreational fisheries aspects of the affected environment should be discussed in the Affected Environment chapter (normally Chapter 4) of the EIS or EA. Chapter 6 can refer the reader to the portion of the EIS or EA where the environmental impacts associated with a particular environmental requirement are discussed.

A summary of prior EAs and EISs prepared for activities at the Hanford Site is in National Environmental Policy Act Source Guide for the Hanford Site (Fluor Hanford 2002).

The purpose, then, of Chapter 6 in this document is to present a "reference" that can be used as the basis for the preparation of future Hanford Site EISs and EAs. The intent is to present a reasonably complete discussion of federal, state, and local environmental laws, regulations, and permit requirements that are applicable to activities at the Hanford Site. The information in this chapter can then be adapted to any future Hanford Site EIS/EA by deleting irrelevant parts and by adding some specificity with respect to the proposed action and the alternatives being considered.

It should be noted that environmental standards and permit requirements usually appear in regulations and not in the laws themselves. Thus, more emphasis is placed on regulations and less on laws in this chapter. 


\section{Federal and State Environmental Laws}

Federal law governs environmental regulation of federal facilities. Most major federal environmental laws now include provisions for regulation of federal activities that impact the environment. The activity to be regulated is usually an activity being carried out by an agency of the executive branch. The federal environmental law will also typically designate a specific agency, such as EPA or the U.S. Nuclear Regulatory Commission (NRC), as the regulator. In addition, federal laws may provide for the delegation of the environmental regulation of federal facilities to the states or may directly authorize the environmental regulation of federal facilities by the states through waivers of sovereign immunity. At Hanford, all these situations apply in varying degrees. EPA has regulatory authority over Hanford facilities and has delegated regulatory authority to, shares regulatory authority with, or is in the process of delegating regulatory authority to the State of Washington. The State of Washington also asserts its own independent regulatory authority over Hanford facilities under federal waivers of sovereign immunity and state legislation. The Washington State Department of Ecology has also delegated various air compliance responsibilities to the BCAA.

As a legal matter at Hanford, applicable federal and state environmental standards must be met. As a practical matter, differences in language between federal and state laws and regulations may result in some differences in applicability and interpretation. Guidance on specific applicability should be obtained from the Office of Chief Counsel of the DOE Richland Operations Office (DOE/RL) or the Office of River Protection (DOE-ORP).

\section{Citation of Laws and Regulations}

Laws and regulations may be cited both by their common name and by their location in the appropriate document. Federal laws are most often cited by their common name (e.g., Clean Water Act [CWA]), by their public law (Pub. L. or PL) number, or by their location in the United States Code (USC). Section numbers differ between laws as enacted and as codified in the USC, so it must be understood which is being cited. Federal regulations appear in the CFR. Washington State laws are most often cited by their location in the Revised Code of Washington (RCW). Washington State regulations are cited by their location in the Washington Administrative Code (WAC). Links to the RCW and WAC are available at http://slc.leg.wa.gov/. Announcements of proposed and final federal regulations appear in the Federal Register (FR). Announcements of proposed and final Washington State regulations appear in the Washington State Register.

\section{Specific Federal Laws Cited in the CEQ Regulations}

Four federal laws are specifically cited in the CEQ regulations [40 CFR 1502.25(a) and 1504.1(b)]:

- Section 309 of the Clean Air Act (CAA) (42 USC 7609)

- Fish and Wildlife Coordination Act (16 USC 661 et seq.)

- National Historic Preservation Act (NHPA) (16 USC 470 et seq.)

- $\quad$ Endangered Species Act (ESA) (16 USC 1531 et seq.). 
Section 309 of the CAA directs EPA to review and comment in writing on the environmental impacts of any matter relating to EPA's authority contained in proposed legislation, federal construction projects, other federal actions requiring EISs, and new regulations. In addition to commenting on EISs, EPA rates every draft EIS prepared by a federal agency under its Section 309 authority. Ratings are made for the environmental impact of the proposed action and the adequacy of the impact statement. Rating categories for environmental impact are: LO - lack of objections, EC environmental concerns, EO - environmental objections, and EU - environmentally unsatisfactory. Rating categories for adequacy are: Category 1 - adequate, Category 2 - insufficient information, and Category 3 - inadequate. A summary of EPA rating definitions is available at:

http://www.epa.gov/compliance/nepa/comments/ratings.html. Responses to EPA's comments on a draft EIS are included in the final EIS.

The CEQ regulations (40 CFR 1502.25[a]) direct federal agencies to prepare draft EISs concurrently with and integrated with environmental impact analyses and related surveys required by the Fish and Wildlife Coordination Act, the NHPA, the ESA, and other environmental review laws and executive orders. The three preceding statutes should be cited in Chapter 6 of a draft EIS. Environmental impacts associated with the laws should be discussed in Chapter 5. 


\subsection{Federal Environmental Laws}

Significant federal environmental laws potentially applicable to the Hanford Site include the following:

- $\quad$ Antiquities Act (16 USC 431 et seq.)

- American Indian Religious Freedom Act (42 USC 1996)

- Archaeological and Historic Preservation Act (16 USC 469 et seq.)

- Archaeological Resources Protection Act (ARPA) (16 USC 470aa et seq.)

- $\quad$ Bald and Golden Eagle Protection Act (16 USC 668 et seq.)

- Clean Air Act (CAA) (42 USC 7401 et seq.)

- Clean Water Act (CWA) (33 USC 1251 et seq.) (The CWA is also known as the Federal Water Pollution Control Act)

- Comprehensive Environmental Response, Compensation, and Liability Act (CERCLA) as amended by the Superfund Amendments and Reauthorization Act (SARA) (42 USC 9601 et seq.)

- Emergency Planning and Community Right-to-Know Act (EPCRA) (42 USC 11001 et seq.)

- $\quad$ Endangered Species Act (16 USC 1531 et seq.)

- $\quad$ Farmland Protection Policy Act of 1981 (7 USC 4201 et seq.)

- $\quad$ Fish and Wildlife Coordination Act (16 USC 661 et seq.)

- Hanford Reach Study Act (PL 100-605), as amended by PL 104-333

- Hazardous Materials Transportation Act (49 USC 5101 et seq.)

- $\quad$ Migratory Bird Treaty Act (16 USC 703 et seq.)

- National Historic Preservation Act (NHPA) (16 USC 470 et seq.)

- Native American Graves Protection and Repatriation Act (25 USC 3001 et seq.)

- National Environmental Policy Act (NEPA) (42 USC 4321 et seq.)

- $\quad$ Noise Control Act (42 USC 4901 et seq.)

- Pollution Prevention Act (42 USC 13101 et seq.) 
- Resource Conservation and Recovery Act (RCRA) of 1976 as amended by the Hazardous and Solid Waste Amendments (42 USC 6901 et seq.) of 1984

- Safe Drinking Water Act (SDWA) (42 USC 300f et seq.)

- Toxic Substances Control Act (TSCA) (15 USC 2601 et seq.).

In addition, the Atomic Energy Act (AEA) (42 USC 2011 et seq.), the Low-Level Radioactive Waste Policy Act (LLWPA) (42 USC 2021b et seq.), and the Nuclear Waste Policy Act (NWPA) (42 USC 10101 et seq.), while not environmental laws per se, contain provisions under which environmental regulations applicable to the Hanford Site may be or have been promulgated. Brief descriptions of most of the preceding statutes are in Section 6.1 of the Hanford Solid (Radioactive and Hazardous) Waste Program Environmental Impact Statement (DOE 2004). 


\subsection{Federal and State Environmental Regulations}

Under the Supremacy Clause of the U.S. Constitution (Article VI, Clause 2), activities of the federal government are ordinarily not subject to regulation by the states unless Congress creates specific exceptions. Congress has created exceptions with respect to environmental regulation and provisions in several federal laws giving specific authority to the states to regulate federal activities affecting the environment. These waivers (or partial waivers) of sovereign immunity appear in Section 118 of the CAA, Section 313 of the CWA, Section 1447 of the SDWA, Section 6001 of RCRA, and Section 120 of CERCLA/SARA. The Federal Facilities Compliance Act is an amendment to RCRA that makes the RCRA waiver of sovereign immunity more explicit. Many Washington State programs, with respect to the environmental regulation of Hanford Site facilities under the preceding statutes, are coordinated with the U.S. Environmental Protection Agency (EPA) Region 10 office.

Federal and state environmental regulations that may apply to operations at the Hanford Site have been promulgated under the CAA, CWA, SDWA, RCRA, CERCLA, SARA, AEA, LLWPA, NWPA, under other federal statutes, and under relevant state statutes.

Several of the more important existing federal and state environmental regulations are discussed briefly below. These regulations are grouped according to environmental media.

\subsubsection{Air Quality}

The federal Clean Air Act and the Washington Clean Air Act (Revised Code of Washington [RCW] 70.94) provide the statutory basis for air quality regulation of Hanford Site activities. The federal CAA establishes a floor or minimum level of requirements. State requirements can exceed, i.e., be more stringent than, federal requirements.

- 40 Code of Federal Regulations (CFR) 50, "National Primary and Secondary Ambient Air Quality Standards.” EPA regulations in 40 CFR 50 set national ambient air quality standards for sulfur oxides, particulate matter, carbon monoxide, ozone, nitrogen dioxide, and lead. The standards are not directly enforceable, but other enforceable regulations are based on the standards. Washington's ambient air standards are at Washington Administrative Code (WAC) 173-470 through 173-481 and include standards for radionuclides and fluorides. The Hanford Site is within an area that is in attainment with or is unclassifiable for all national ambient air quality standards (40 CFR 81.348).

- 40 CFR 51-52, State Implementation Plans (SIPs). EPA regulations in 40 CFR 51-52 establish the requirements for SIPs and record the approved plans. The SIPs are directed at the control of emissions for which federal ambient air standards exist. Information on the Washington SIP is available at: http://yosemite.epa.gov/r10/airpage.nsf/webpage/SIP+$+\mathrm{WA}+$ Table+of+Contents?OpenDocument.

- 40 CFR 60, "Standards of Performance for New Stationary Sources.” EPA regulations in 40 CFR 60 provide standards for the control of the emission of pollutants to the atmosphere. Construction or modification of an emissions source in an attainment area such as Hanford can require a prevention of significant deterioration (PSD) of air quality permit under 40 CFR 52.21 and WAC 173-400-141. 
- 40 CFR 61, "National Emission Standards for Hazardous Air Pollutants” (NESHAP); 40 CFR 63, "National Emission Standards for Hazardous Air Pollutants for Source Categories." EPA hazardous emission standards in 40 CFR 61 provide for the control of the emission of hazardous pollutants to the atmosphere. Standards in 40 CFR 61 Subpart H apply specifically to the emission of radionuclides from DOE facilities. Emissions of radionuclides (other than radon-220 and radon-222) to the ambient air from DOE facilities are not to exceed those amounts that would cause any member of the public to receive in any year an effective dose equivalent of $10 \mathrm{mrem} / \mathrm{yr}$ (0.1 mSv/yr) (40 CFR 61.92). Standards in 40 CFR 61 Subpart Q apply to the emission of radon from DOE facilities. No source at a DOE facility is to emit more than 20 picocuries per square meter per second $\left(\mathrm{pCi} /\left(\mathrm{m}^{2}-\mathrm{s}\right)\right)\left(1.9 \mathrm{pCi} /\left(\mathrm{ft}^{2}-\mathrm{s}\right)\right)$ of radon-222 as an average for the entire source into the air (40 CFR 61.192). Approval to construct a new facility or to modify an existing one may be required under 40 CFR 61.07. Emission standards for sources of hazardous air pollutants designated in the 1990 CAA amendments appear at 40 CFR 63.

- 40 CFR 70, "State Operating Permit Programs.” These regulations provide for the establishment of comprehensive state air quality permitting programs. All major sources of air pollutants including hazardous air pollutants are covered. Washington's operating permit regulations appear at WAC 173-401.

- 40 CFR 93 Subpart B, "Determining Conformity of General Federal Actions to State or Federal Implementation Plans." The general conformity requirements require that actions of federal agencies are to comply with state implementation plans designed to achieve national ambient air quality standards.

- WAC 173-400 through 173-495, Washington State Air Pollution Control Regulations. Ecology air pollution control regulations, promulgated under the Washington CAA appear in WAC 173400 through 173-495 and are available at http://www.ecy.wa.gov/laws-rules/ecywac.html\#air. These regulations include emission standards, ambient air quality standards, and the standards in WAC 173-460, "Controls for New Sources of Toxic Air Pollutants.” The State of Washington has delegated much of its authority under the Washington CAA to the BCAA. However, except for certain air pollution sources (e.g., asbestos removal, fugitive dust, and open burning) administered by the BCAA, Ecology continues to administer air pollution control requirements for the Hanford Site.

- WAC 246-247, "Radiation Protection--Air Emissions.” Washington DOH regulations in WAC 246-247 contain standards and permit requirements for the emission of radionuclides to the atmosphere.

- Regulation 1 of the Benton Clean Air Authority can be accessed at: http://www.bcaa.net/RegPol.htm.

\subsubsection{Water Quality}

The CWA and the Washington Water Pollution Control Act provide the statutory basis for the regulation of water quality in Washington State. The CWA established the National Pollutant Discharge Elimination System (NPDES) to limit the amount of pollutants that could be discharged.

- 40 CFR 121, "State Certification of Activities Requiring a Federal License or Permit.” These regulations provide for state certification that any activity requiring a federal water permit, i.e., a 
NPDES permit or a discharge of dredged or fill material permit, will not violate state water quality standards.

- 40 CFR 122, "EPA Administered Permit Programs: The National Pollutant Discharge Elimination System.” EPA regulations in 40 CFR 122 (and also in 40 CFR 125 and 129) apply to the discharge of pollutants from any point source into waters of the United States. These regulations also apply to the discharge of storm waters (40 CFR 122.26) and the discharge of runoff waters from construction areas over $0.02 \mathrm{~km}^{2}\left(0.008 \mathrm{mi}^{2}\right)$ in size into waters of the United States. NPDES permits may be required by 40 CFR 122. EPA has not delegated to the State of Washington the authority to issue NPDES permits at the Hanford Site.

- 40 CFR 141, "National Primary Drinking Water Regulations.” EPA drinking water standards in 40 CFR 141 apply to Columbia River water at community water supply intakes downstream of the Hanford Site. Standards in 40 CFR 141.16 apply indirectly to releases of radionuclides from DOE facilities (and also non-DOE facilities) to the extent that the releases impact community water systems. The average annual concentration of beta particle and photon radioactivity from man-made radionuclides in drinking water are not to produce an annual dose equivalent to the body or any internal organ greater than $4 \mathrm{mrem}(0.04 \mathrm{mSv})$ in a year. Maximum contaminant levels in community water systems of $5 \mathrm{pCi} / \mathrm{L}(0.18 \mathrm{~Bq} / \mathrm{L})$ of combined radium-226 and radium$228 ; 15 \mathrm{pCi} / \mathrm{L}(0.56 \mathrm{~Bq} / \mathrm{L})$ of gross alpha particle activity, including radium-226 but excluding radon and uranium; and $30 \mu \mathrm{g} / \mathrm{L}$ for uranium are specified in 40 CFR 141.66. The average annual concentration of beta particle and photon radioactivity from man-made radionuclides in drinking water must not produce an annual dose equivalent to the total body or any internal organ greater than $4 \mathrm{mrem} / \mathrm{yr}(0.04 \mathrm{mSv} / \mathrm{yr})$ [40 CFR 141.66(d)].

- 40 CFR 144-147, Underground Injection Control Program. EPA regulations in 40 CFR 144-147 apply to the underground injection of liquids and wastes and may require a permit for any underground injection. In Washington State, EPA has approved Ecology regulations in WAC 173-218, “Underground Injection Control Program,” to operate in lieu of the EPA program. The Ecology regulations provide standards and permit requirements for the disposal of fluids by well injection.

- 10 CFR 1022, “Compliance with Floodplain/Wetlands Environmental Review Requirements.” DOE regulations in 10 CFR 1022 implement Executive Orders 11988 and 11990 and apply to DOE activities that are proposed to take place either in wetlands or in floodplains.

- 33 CFR 322-323, 40 CFR 230-233. Construction or placement of structures in the Columbia River and work in the Columbia River, as well as the discharge of dredged or fill material into the Columbia River, require permits under these U.S. Army Corps of Engineers and EPA regulations.

- WAC 173-160. Under WAC 173-160, DOE provides notification to Ecology for water-well drilling on the Hanford Site.

- WAC 173-216, “State Waste Discharge Permit Program.” Ecology regulations in WAC 173-216 establish a state permit program for the discharge of waste materials from industrial, commercial, and municipal operations into ground and surface waters of the state. Discharges covered by NPDES or WAC 173-218 permits are excluded from the WAC 173-216 program. DOE has agreed to meet the requirements of this program at the Hanford Site for discharges of liquids to the ground. 
- WAC 332-30, “Aquatic Land Management.” Where applicable, DOE will obtain an aquatic land use lease or permit from the Washington Department of Natural Resources for the placement of structures in the Columbia River on lands owned by the State of Washington. The U.S. Government owns most of the riverbed along the Hanford Site to the line of navigation.

- WAC 246-272-08001 and 246-272-09001. These regulations, administered by the Washington $\mathrm{DOH}$, contain permit requirements for onsite sewage systems.

- WAC 246-290. These regulations, administered by the Washington DOH, contain requirements applicable to water systems providing piped water for human consumption.

\subsubsection{Hazardous Waste Management}

Regulation of hazardous wastes at Hanford is conducted under RCRA, CERCLA, the Tri-Party Agreement, and the Washington State Hazardous Waste Management Act.

- 40 CFR 300, "National Oil and Hazardous Substances Pollution Contingency Plan.” EPA CERCLA regulations in 40 CFR 300 apply to the cleanup of inactive hazardous waste disposal sites, the cleanup of hazardous substances released into the environment, the reporting of hazardous substances released into the environment, and natural resource damage assessments. Four areas of the Hanford Site $(100,200,300$, and 1100) were listed on the EPA's National Priorities List (NPL) in November 1989. The 1100 Area was subsequently delisted. Placement on the list requires DOE, in consultation with EPA and Washington State, to conduct remedial investigations and feasibility studies leading to a Record of Decision (ROD) on the cleanup of inactive waste disposal sites at Hanford. Standards for cleanup under CERCLA are "applicable or relevant and appropriate requirements" (ARARs), which may include both federal and state laws and regulations. In anticipation of Hanford's being placed on the NPL, DOE, EPA, and Ecology signed the Hanford Federal Facility Agreement and Consent Order (Tri-Party Agreement) on May 15, 1989. This agreement describes the cleanup responsibilities and authorities of the three parties under CERCLA (and RCRA), and also provides for permitting of the treatment, storage, and disposal of hazardous wastes under RCRA. The Tri-Party Agreement has been amended a number of times (http://www.hanford.gov/tpa/tpahome.htm).

- 40 CFR 260-268 and 270-272, Hazardous Waste Management. EPA RCRA regulations in 40 CFR 260-268 and 270-272 apply to the generation, transport, treatment, storage, and disposal of hazardous wastes (but not to source, by-product, or special nuclear material [i.e., not in general to radioactive wastes]), and apply to the hazardous component of hazardous radioactive mixed wastes (but not to the radioactive component) owned by DOE. RCRA regulations (40 CFR 268) require treatment of many hazardous wastes before they can be disposed of in landfills (land disposal restrictions). RCRA permits are required for the treatment, storage, or disposal of hazardous wastes. The regulations also require cleanup (corrective action) of any RCRA facility from which there is an unauthorized release before a RCRA permit is granted. Ecology has been authorized by EPA to administer the RCRA program within Washington. Ecology has oversight authority for RCRA corrective actions at Hanford under the Tri-Party Agreement.

- 40 CFR 280-281, Underground Storage Tanks. EPA has regulations in 40 CFR 280-281 issued under RCRA Subtitle IX that apply to new and existing underground storage tanks containing petroleum or substances regulated under CERCLA (except for hazardous wastes regulated under RCRA). New tanks must meet strict design and operating standards. Owners of new tanks must notify the applicable regulatory agency and certify compliance with the regulations. The 
regulations require the reporting, investigation, and cleanup of releases from underground tanks. EPA has authorized Washington State to administer the underground storage tank program.

Washington's requirements are in RCW 90.76 and WAC 173-360.

- WAC 173-303, "Dangerous Waste Regulations.” EPA has authorized the State of Washington through Ecology to conduct its own dangerous waste regulation program in lieu of major portions of the RCRA interim and final permit program for the treatment, storage, and disposal of hazardous wastes. Ecology is also authorized to conduct its own program for the hazardous portion of radioactive - mixed wastes. The state regulations include both standards and permit requirements, as well as a larger universe of covered materials than the federal hazardous waste program.

\subsubsection{Species Protection}

- 50 CFR 10-24, 222, 402, and 450-453, Species Protection Regulations. Regulations under the Endangered Species Act, the Bald and Golden Eagle Protection Act, and the Migratory Bird Treaty Act in 50 CFR 10-24 apply to the protection of plant and animal species on the Hanford Site. Regulations in 50 CFR 17, 81, 222, 223, 402, and 450-453 apply to endangered or threatened species. Section 7 of the Endangered Species Act (16 USC 1536) requires that federal agencies 1) utilize their authority in furtherance of the purposes of the Act by carrying out programs for the conservation of listed endangered and threatened species, and 2) consult with appropriate federal agencies to ensure that any action carried out is not likely to jeopardize the continued existence of any endangered or threatened species or result in the destruction or adverse modification of critical habitat for such species. The Fish and Wildlife Coordination Act [16 USC 662(a, h)] requires that a federal agency consult with the U.S. Fish and Wildlife Service and the state agency exercising administration over wildlife if any body of water over $0.04 \mathrm{~km}^{2}$ $\left(0.016 \mathrm{mi}^{2}\right)$ in size is to be modified by a federal agency, or a licensee or permitee of the agency, for any purpose. The purpose of this consultation is to prevent loss and damage to wildlife resources.

\subsubsection{Historic and Cultural Resource Preservation}

The DOE policy on management of cultural resources (DOE 2001a) provides that:

DOE will uphold [the NHPA, the Archaeological Resources Protection Act, and the Native American Graves Protection and Repatriation Act] by preserving, protecting, and perpetuating cultural resources for future generations in a spirit of stewardship to the extent feasible given the agency's mission and mandates. To do this, DOE will implement management accountability for compliance with federal statutes, executive orders, treaties, DOE orders, and implementation guidance. The Department also ensures that DOE contractors are obligated to implement DOE programs and projects in a manner that is consistent with this Policy and that reflects this commitment in site management contracts.

The background statement in "Management of Cultural Resources at Department of Energy Facilities” (DOE 2001b) further states that:

DOE recognizes the cultural and scientific value of the resources that may exist on the properties under its management or over which it has direct or indirect control. Therefore, DOE has implemented a program to protect these resources and ensure that all DOE facilities and programs comply with all existing cultural resource executive orders, laws, and regulations. 
The DOE management document (DOE 2001b) defines cultural resources to include "historic properties" as defined in the NHPA, "archaeological resources" as defined in the Archaeological Resources Protection Act of 1979, and "cultural items” as defined in the Native American Graves Protection and Repatriation Act.

The NHPA authorizes the Secretary of the Interior to maintain a National Register of Historic Places (16 USC 470a[a][1]). Federal agencies are to consider the effect of their actions on properties included in or eligible for inclusion in the Register and afford the Advisory Council on Historic Preservation a reasonable opportunity to comment on such actions (16 USC 470f).

The Archaeological Resources Protection Act of 1979 prohibits the excavation of material remains of past human life that have archaeological interest and are at least 100 years old without a permit from the appropriate federal land manager or an exemption (16 USC 470bb, 470ee).

The Native American Graves Protection and Repatriation Act prohibits the intentional excavation or removal of human remains or cultural items without a written permit, and prescribes protective measures and repatriative actions to be taken in the event that human remains or cultural items are discovered inadvertently (25 USC 3001 et seq.).

Additional information is available by contacting the Department of Energy, Richland Operations Office, Hanford Cultural and Historic Resources Program or by accessing the Hanford website at http://www.hanford.gov/doe/culres/index.htm.

\subsubsection{Land Use}

The Hanford Reach National Monument was created on June 9, 2000, by a proclamation (65 FR 37253) signed by President Clinton under the authority of the Antiquities Act. The Monument includes $792.6 \mathrm{~km}^{2}\left(306 \mathrm{mi}^{2}\right)$ of federally owned land making up a portion of the Hanford Site. The principal components of the Monument are:

- the Fitzner-Eberhardt Arid Lands Ecology Reserve Unit,

- the McGee Ranch and Riverlands Unit,

- the Saddle Mountain National Wildlife Refuge Unit,

- $\quad$ the quarter-mile study strip along the south and west sides of the Columbia River corridor as designated by the Hanford Reach Study Act (Hanford Reach Study Act [1988] as amended by Public Law 104-333),

- the federally owned islands within the portion of the Columbia River included in the Monument,

- $\quad$ and the Hanford Sand Dune Field Unit.

The U.S. Fish and Wildlife Service (USFWS) manages approximately 67,000 ha (166,000 ac) of Monument lands that are within the Fitzner-Eberhardt Arid Lands Ecology Reserve Unit and the Wahluke Slope (Wahluke Unit and Saddle Mountain Unit) under permit from DOE. DOE manages the remainder of the Monument. The June 9, 2000, proclamation does not affect the responsibilities and authority of 
DOE on Hanford Site lands nor does it affect DOE activities on lands not included within the Monument boundaries. In a separate memorandum ${ }^{(a)}$ to the Secretary of Energy, DOE was directed by the President to protect the natural values of the Hanford Site land not included within the Monument. DOE and USFWS signed a Memorandum of Understanding on June 14, 2001, covering management responsibilities for the Monument. USFWS issued a Notice of Intent to prepare a comprehensive conservation plan and associated EIS for the Monument in June 2002 (67 FR 40333).

In September 1999, DOE issued the Final Hanford Comprehensive Land-Use Plan Environmental Impact Statement (DOE 1999). The ROD issued in November 1999 (64 FR 61615) states that the purpose of the land-use plan and its implementing policies is to facilitate decision making about the Hanford Site's uses and facilities over at least the next 50 years. The ROD adopts the Preferred Alternative land-use maps, designations, policies, and implementing procedures as described in the 1999 EIS and designates the Central Plateau (200 Areas) for Industrial-Exclusive use. In November 1999, USFWS signed a Record of Decision documenting USFWS's adoption of the DOE's Final Comprehensive Land Use Plan.

\subsubsection{Other}

- 40 CFR 191, "Environmental Radiation Protection Standards for Management and Disposal of Spent Nuclear Fuel, High-Level and Transuranic Radioactive Wastes.” EPA regulations in 40 CFR 191 provide environmental standards for the management, storage, and disposal of spent nuclear fuel, high-level radioactive wastes, and transuranic radioactive wastes at high-level or transuranic waste disposal sites.

- 40 CFR 355, 370, and 372. These regulations implement the federal Emergency Planning and Community Right-to-Know Act (EPCRA). EPCRA was signed into law in October 1986 as part of the Superfund Amendments and Reauthorization Act.

- 40 CFR 700-799, TSCA Regulations. EPA's regulations in 40 CFR 700-799 implement TSCA and, in particular, regulate polychlorinated biphenyls (PCBs) and dioxins and partially regulate asbestos.

- 40 CFR 1500-1508, Council on Environmental Quality. The CEQ regulations in 40 CFR 1500 to 1508 implement NEPA.

- 10 CFR 830, “Nuclear Safety Management.” Part 830 contains nuclear safety management requirements applicable to DOE contractors.

- 10 CFR 835, “Occupational Radiation Protection.” These DOE rules establish radiation protection standards, limits, and program requirements for protecting individuals from ionizing radiation resulting from DOE activities.

- 10 CFR 1021, “National Environmental Policy Act Implementing Procedures.” DOE regulations in 10 CFR 1021 set out procedures that DOE uses to comply with section 102(2) of NEPA and the CEQ regulations for implementing the procedural provisions of NEPA (40 CFR parts 15001508). The DOE regulations supplement, and are to be used in conjunction with, the CEQ regulations.

(a) The memorandum is available at http://clinton6.nara.gov/2000/06/2000-06-09-memorandum-on-hanford-reachnational-monument.html. 
- 49 CFR 171-179, Hazardous Materials Regulations. These Department of Transportation regulations apply to the handling, packaging, labeling, and shipment of hazardous materials offsite, including radioactive materials and wastes.

- WAC 173-60, "Maximum Environmental Noise Levels.” These regulations contain maximum permissible environmental noise levels in Washington. Additionally, the Occupational Safety and Health Administration has regulations covering noise exposure of occupational workers at 29 CFR 1910.95. 


\subsection{Executive Orders}

DOE is subject to a number of presidential executive orders (E.O.s) concerning environmental matters. Some of these orders may be appropriately considered in a Hanford EIS or EA. Potentially relevant E.O.s include:

E.O. 11514 Protection and Enhancement of Environmental Quality

E.O. 11593 Protection and Enhancement of the Cultural Environment

E.O. 11738 Providing for Administration of the Clean Air Act and the Federal Water Pollution Control Act with Respect to Federal Contracts, Grants, or Loans

E.O. $11988 \quad$ Floodplain Management

E.O. $11990 \quad$ Protection of Wetlands

E.O. 12088 Federal Compliance with Pollution Control Standards

E.O. 12114 Environmental Effects Abroad of Major Federal Actions

E.O. 12196 Occupational Safety and Health Programs for Federal Employees

E.O. $12580 \quad$ Superfund Implementation

E.O. 12898 Federal Actions to Address Environmental Justice in Minority Populations and LowIncome Populations

E.O. $12962 \quad$ Recreational Fisheries

E.O. 13007 Indian Sacred Sites

E.O. 13045 Protection of Children from Environmental Health Risks and Safety Risks (as amended by E.O. 13296)

E.O. 13101 Greening the Government through Waste Prevention, Recycling, and Federal Acquisition

E.O. 13112 Invasive Species

E.O. 13123 Greening the Government through Energy Efficient Management

E.O. 13134 Developing and Promoting Biobased Products and Bioenergy

E.O. 13148 Greening the Government through Leadership in Environmental Management

E.O. 13149 Greening the Government through Federal Fleet and Transportation Efficiency 
E.O. $13150 \quad$ Federal Workforce Transportation

E.O. 13175 Consultation and Coordination with Indian Tribal Governments

E.O. 13186 Responsibilities of Federal Agencies to Protect Migratory Birds

E.O. 13195 Trails for America in the $21^{\text {st }}$ Century

E.O. $13287 \quad$ Preserve America 


\subsection{DOE Directives}

Categories of DOE directives include orders, policy statements, standards, notices, manuals, and contractor requirements documents.

DOE directives can be accessed at: http://www.directives.doe.gov/.

Directives with particular application to DOE's environmental activities are found in the 400 series of the new series directives and the 5000 series (particularly the 5400 and 5800 series) under the old series directives.

Topics covered in DOE directives include environmental protection, safety, and health protection standards; hazardous and radioactive-mixed waste management; cleanup of retired facilities; safety requirements for the packaging and transportation of hazardous materials; safety of nuclear facilities; radiation protection; and other standards for the safety and protection of workers and the public. Regulations and standards of other federal agencies and standard setting entities are incorporated by reference into some DOE directives. 
This page intentionally left blank 


\subsection{Treaties, Statutes, and Policies Relating to Indian Tribes of the Hanford Region}

DOE's relationship with American Indians is based on treaties, statutes, Executive Orders, and DOE policy statements. Representatives of the United States negotiated treaties with leaders of various Columbia Plateau American Tribes and Bands in June 1855 at Camp Stevens in the Walla Walla Valley. The negotiations resulted in three treaties, one with the 14 tribes and bands of the group that would become the Confederated Tribes and Bands of the Yakama Nation, one with the three tribes that would become the Confederated Tribes of the Umatilla Reservation, and one with the Nez Perce Tribe of Idaho. The U.S. Senate ratified the treaties in 1859. The three treaties are included in Appendix A of the Final Hanford Comprehensive Land-Use Plan EIS (DOE 1999). The negotiated treaties are as follows:

1. Treaty with the Walla Walla, Cayuse, etc. (June 9, 1855; 12 Stats. 945)

2. Treaty with the Yakama (June 9, 1855; 12 Stats. 951)

3. Treaty with the Nez Perce (June 11, 1855; 12 Stats. 957).

The Confederated Tribes and Bands of the Yakama Nation, Washington; the Confederated Tribes of the Umatilla Reservation, Oregon; and the Nez Perce Tribe of Idaho are federally recognized tribes that are eligible for funding and services from the U.S. Bureau of Indian Affairs by virtue of their status as Indian tribes (68 FR 68180, December 5, 2003 ).

The terms of the three preceding treaties are similar. Each of the three tribal organizations agreed to cede large blocks of land to the United States. The Hanford Site is within the ceded lands of the Confederated Tribes and Bands of the Yakama Nation and the Confederated Tribes of the Umatilla Reservation. The treaties reserved to the Tribes certain lands for their exclusive use (the three reservations). The treaties also secured to the Tribes certain rights and privileges to continue traditional activities outside the reservations. These included 1) the right to fish at usual and accustomed places in common with citizens of the United States, and 2) the privileges of hunting, gathering roots and berries, and pasturing horses and cattle on open and unclaimed lands.

The U.S. Department of Energy American Indian and Alaska Native Tribal Government Policy (DOE 2000) states, in part, that DOE

- $\quad$ Recognizes the federal trust relationship with American Indians and Alaska Native Nations and will fulfill its trust responsibilities to them

- $\quad$ Recognizes and commits to a government-to-government relationship and will institute appropriate protocols and procedures for program and policy implementation

- Complies with applicable federal cultural resource protection and other laws and executive orders will assist in preservation and protection of historic and cultural sites and traditional religious practices.

The American Indian Religious Freedom Act (42 USC 1996) establishes that U.S. policy is to protect and preserve for American Indians their inherent rights of freedom to believe, express, and exercise their 
traditional religions, including access to sites, use and possession of sacred objects, and the freedom to worship through ceremonies and traditional rites.

The Native American Graves Protection and Repatriation Act establishes the right of lineal descendants, Indian Tribes, and Native Hawaiian organizations to certain Native American human remains, funerary objects, sacred objects, or objects of cultural patrimony discovered on federal lands after November 16, 1990 (25 USC 3002). When discovered during an activity on federal lands, the activity is to cease and appropriate tribal governments are to be notified. Work on the activity may resume, if the activity is otherwise lawful, 30 days after the receipt of certification that tribal governments have received the notice.

Executive Order 13007 “Indian Sacred Sites,” (61 FR 26771, May 29, 1996) directs federal agencies, to the extent practicable, permitted by law, and not clearly inconsistent with essential agency functions, to 1) accommodate access to and ceremonial use of American Indian sacred sites by their religious practitioners, and 2) avoid adversely affecting the physical integrity of such sacred sites. Where appropriate, agencies are to maintain the confidentiality of sacred sites.

DOE/RL interacts and consults regularly and directly with the three federally recognized tribes affected by Hanford operations; that is, the Nez Perce Tribe of Idaho; the Confederated Tribes of the Umatilla Reservation, Oregon; and the Confederated Tribes and Bands of the Yakama Nation, Washington. In addition, the Wanapum, who still live adjacent to the Hanford Site, are a non-federally recognized tribe that has strong cultural ties to the Site. The Hanford area was also used by groups whose descendants are now enrolled members of the Confederated Tribes of the Colville Reservation. The Wanapum and the Confederated Tribes of the Colville Reservation are also consulted on cultural resource issues in accordance with DOE policy and relevant legislation. 


\subsection{Permits}

Information on the status of environmental permits at Hanford is included in the Annual Hanford Site Environmental Permitting Status Report (DOE 2003). The report includes information on environmental permitting under RCRA; TSCA; CAA; CWA; the State Waste Discharge, Hydraulic Permit, and Underground Injection Control Programs; the Onsite Sewage System Program; and the Petroleum Underground Storage Tank Program.

The Hanford Site RCRA permit is in two portions, one portion issued by EPA Region 10 and the other portion issued by Ecology. The EPA portion of the RCRA permit covers the Hazardous and Solid Waste Amendments portion of the RCRA permit (EPA 1994). The Ecology portion of the Hanford Site RCRA permit covers compliance with Ecology's dangerous waste regulations (Ecology 2001a). The Ecology portion of the permit includes standard conditions, general facility conditions, and specific conditions for individual operating Treatment, Storage, and/or Disposal (TSD) units, TSD units undergoing corrective action, and TSD units undergoing closure.

Clean Air Act compliance requires both facility and sitewide compliance. The Annual Hanford Site Environmental Permitting Status Report (DOE 2003) identifies existing facility-specific and sitewide CAA compliance activities. The air operating permit for the Hanford Site issued by Ecology became effective in July 2001 (Ecology 2001b).

The Hanford Site National Pollutant Discharge Elimination System Permit (WA-002591-7) governs liquid process effluent discharges to the Columbia River (DOE 2003).

DOE has asserted a federally reserved water withdrawal right with respect to its Hanford operations. Current Hanford activities use water withdrawn under the DOE's federally reserved water rights. 
This page intentionally left blank 


\section{References}

10 CFR 830. “Nuclear Safety Management.” U.S. Code of Federal Regulations. Online at: http://www.gpoaccess.gov/cfr/index.html.

10 CFR 835. “Occupational Radiation Protection.” U.S. Code of Federal Regulations. Online at: http://www.gpoaccess.gov/cfr/index.html.

10 CFR 1021. “DOE National Environmental Policy Act Implementing Procedures.” U.S. Code of Federal Regulations. Online at: http://www.gpoaccess.gov/cfr/index.html.

10 CFR 1022. “Compliance with Floodplain/Wetlands Environmental Review Requirements.” U.S. Code of Federal Regulations. Online at: http://www.access.gpo.gov/nara/cfr/index.html.

29 CFR 1910. “Occupational Safety and Health Standards.” U.S. Code of Federal Regulations. Online at: http://www.gpoaccess.gov/cfr/index.html.

33 CFR 322. "Permits for Structures or Work in or Affecting Navigable Waters of the United States." U.S. Code of Federal Regulations. Online at: http://www.access.gpo.gov/nara/cfr/index.html.

33 CFR 323. "Permits for Discharges of Dredged or Fill Material Into Waters of the United States.” U.S. Code of Federal Regulations. Online at: http://www.access.gpo.gov/nara/cfr/index.html.

40 CFR 50. “National Primary and Secondary Ambient Air Quality Standards.” U.S. Code of Federal Regulations. Online at: http://www.gpoaccess.gov/cfr/index.html.

40 CFR 51. "Requirements for Preparation, Adoption, and Submittal of Implementation Plans.” U.S. Code of Federal Regulations. Online at: http://www.gpoaccess.gov/cfr/index.html.

40 CFR 52. “Approval and Promulgation of Implementation Plans.” U.S. Code of Federal Regulations. Online at: http://www.gpoaccess.gov/cfr/index.html.

40 CFR 60. "Standards of Performance for New Stationary Sources.” Online at: http://www.gpoaccess.gov/cfr/index.html.

40 CFR 61. "National Emission Standards for Hazardous Air Pollutants.” U.S. Code of Federal Regulations. Online at: http://www.gpoaccess.gov/cfr/index.html.

40 CFR 63. "National Emissions Standards for Hazardous Air Pollutants for Source Categories." U.S. Code of Federal Regulations. Online at: http://www.gpoaccess.gov/cfr/index.html.

40 CFR 70. “State Operating Permit Programs.” U.S. Code of Federal Regulations. Online at: http://www.gpoaccess.gov/cfr/index.html.

40 CFR 81. "Designation of Areas for Air Quality Planning Purposes.” U.S. Code of Federal Regulations. Online at: http://www.gpoaccess.gov/cfr/index.html.

40 CFR 93 Subpart B. "Determining Conformity of Federal Actions to State and Federal Implementation Plans.” U.S. Code of Federal Regulations. Online at: http://www.gpoaccess.gov/cfr/index.html. 
40 CFR 121. “State Certification of Activities Requiring a Federal License or Permit.” U.S. Code of Federal Regulations. Online at: http://www.gpoaccess.gov/cfr/index.html.

40 CFR 122. "EPA Administered Permit Programs: The National Pollutant Discharge Elimination System.” U.S. Code of Federal Regulations. Online at: http://www.gpoaccess.gov/cfr/index.html.

40 CFR 141. "National Primary Drinking Water Regulations.” U.S. Code of Federal Regulations. Online at: http://www.gpoaccess.gov/cfr/index.html.

40 CFR 144. “Underground Injection Control Program.” U.S. Code of Federal Regulations. Online at: http://www.gpoaccess.gov/cfr/index.html.

40 CFR 191. "Environmental Radiation Protection Standards for Management and Disposal of Spent Nuclear Fuel, High-Level and Transuranic Radioactive Wastes.” U.S. Code of Federal Regulations. Online at: http://www.gpoaccess.gov/cfr/index.html.

40 CFR 230. "Section 404(b)(1) Guidelines for Specification of Disposal Sites for Dredged or Fill Material.” U.S. Code of Federal Regulations. Online at: http://www.gpoaccess.gov/cfr/index.html.

40 CFR 260-282. "Resource Conservation and Recovery Act.” U.S. Code of Federal Regulations. Online at: http://www.gpoaccess.gov/cfr/index.html.

40 CFR 300. "National Oil and Hazardous Substances Pollution Contingency Plan.” U.S. Code of Federal Regulations. Online at: http://www.access.gpo.gov/nara/cfr/waisidx 02/40cfr300 02.html.

40 CFR 350 - 374. “Emergency Planning and Community Right-to-Know Act regulations.” U.S. Code of Federal Regulations. Online at: http://www.gpoaccess.gov/cfr/index.html.

40 CFR 700-799. “Toxic Substances Control Act.” U.S. Code of Federal Regulations. Online at: http://www.gpoaccess.gov/cfr/index.html.

40 CFR 761. "Polychlorinated Biphenyls (PCBs) Manufacturing, Processing, Distribution in Commerce, and Use Prohibitions.” U.S. Code of Federal Regulations. Online at:

http://www.gpoaccess.gov/cfr/index.html.

40 CFR 1500-1508. “Council on Environmental Quality Regulations for Implementing the Procedural Provision of the National Environmental Policy Act.” U.S. Code of Federal Regulations. Online at: http://www.gpoaccess.gov/cfr/index.html.

49 CFR 105-180. "Subtitle B--Other Regulations Relating to Transportation. Chapter I. Research and Special Programs Administration.” U.S. Code of Federal Regulations. Online at: http://www.gpoaccess.gov/cfr/index.html.

49 CFR 397. “Transportation of Hazardous Materials: Driving and Parking Rules.” U.S. Code of Federal Regulations. Online at: http://www.access.gpo.gov/nara/cfr/index.html.

50 CFR. "Wildlife and Fisheries.” U.S. Code of Federal Regulations. Online at: http://www.access.gpo.gov/nara/cfr/index.html. 
64 FR 61615. "Record of Decision: Hanford Comprehensive Land-Use Plan Environmental Impact Statement.” Federal Register (November 12, 1999). Online at: http://www.gpoaccess.gov/fr/index.html.

65 FR 37253. "Establishment of the Hanford Reach National Monument.” Proclamation 7319 of June 9, 2000 by the President of the United States of America. Federal Register (June 9, 2000). Online at: http://www.gpoaccess.gov/fr/index.html.

67 FR 40333. "Notice of Intent to Prepare a Comprehensive Conservation Plan and Associated Environmental Impact Statement for Hanford Reach National Monument/Saddle Mountain National Wildlife Refuge.” Federal Register (June 12, 2002). Online at: http://www.gpoaccess.gov/fr/index.html.

68 FR 68180. "Indian Entities Recognized and Eligible to Receive Services from the United States Bureau of Indian Affairs.” Federal Register (December 5, 2003 ). Online at:

http://www.gpoaccess.gov/fr/index.html.

15 USC 2601, et seq., Toxic Substances Control Act. Online at: http://www.gpoaccess.gov/uscode/index.html.

16 USC 431, et seq. Antiquities Act of 1906 (American Antiquities Preservation Act). Online at: http://www.gpoaccess.gov/uscode/index.html.

16 USC 469 et seq. Archaeological and Historic Preservation Act. Online at: http://www.gpoaccess.gov/uscode/index.html.

16 USC 470aa et seq. Archaeological Resources Protection Act of 1979. Online at: http://www.gpoaccess.gov/uscode/index.html.

16 USC 470, et seq. National Historic Preservation Act. Online at: http://www.gpoaccess.gov/uscode/index.html.

16 USC 661, et seq. Fish and Wildlife Coordination Act. Online at: http://www.gpoaccess.gov/uscode/index.html.

16 USC 668, et seq. Bald and Golden Eagle Protection Act. Online at: http://www.gpoaccess.gov/uscode/index.html.

16 USC 703, et seq. Migratory Bird Treaty Act. Online at: http://www.gpoaccess.gov/uscode/index.html.

16 USC 1531, et seq. Endangered Species Act. Online at: http://www.gpoaccess.gov/uscode/index.html 25 USC 3001, et seq. Native American Graves Protection and Repatriation Act. Online at: http://www.gpoaccess.gov/uscode/index.html.

33 USC 1251, et seq. Clean Water Act. Online at: http://www.gpoaccess.gov/uscode/index.html.

42 USC 300f, et seq. Safe Drinking Water Act. Online at: http://www.gpoaccess.gov/uscode/index.html.

42 USC 1996. American Indian Religious Freedom Act. Online at: http://www.gpoaccess.gov/uscode/index.html. 
42 USC 2011, et seq. Atomic Energy Act. Online at: http://www.gpoaccess.gov/uscode/index.html.

42 USC 2021b, et seq. Low-Level Radioactive Waste Policy Act. Online at: http://www.gpoaccess.gov/uscode/index.html.

42 USC 4321, et seq. National Environmental Policy Act. Online at: http://www.gpoaccess.gov/uscode/index.html.

42 USC 4901, et seq. Noise Control Act. Online at: http://www.gpoaccess.gov/uscode/index.html.

42 USC 6901, et seq. Resource Conservation and Recovery Act of 1976. Online at: http://www.gpoaccess.gov/uscode/index.html.

42 USC 7401, et seq. Clean Air Act. Online at: http://www.gpoaccess.gov/uscode/index.html.

42 USC 9601, et seq. Comprehensive Environmental Response, Compensation, and Liability Act as amended by the Superfund Amendments and Reauthorization Act. Online at:

http://www.gpoaccess.gov/uscode/index.html.

42 USC 10101, et seq. Nuclear Waste Policy Act. Online at:

http://www.gpoaccess.gov/uscode/index.html.

42 USC 11001, et seq. Emergency Planning and Community Right-to-Know Act. Online at: http://www.gpoaccess.gov/uscode/index.html.

42 USC 13101, et seq. Pollution Prevention Act. Online at:

http://www.gpoaccess.gov/uscode/index.html.

49 USC 5101, et seq. Hazardous Materials Transportation Act. Online at:

http://www.gpoaccess.gov/uscode/index.html.

Ecology (see Washington State Department of Ecology)

Ecology, EPA, and DOE. 1989. Hanford Federal Facility Agreement and Consent Order. 89-10 (as amended). Washington State Department of Ecology, U.S. Environmental Protection Agency, U.S. Department of Energy. Online at: http://www.hanford.gov/tpa/tpahome.htm.

Executive Order 11514. "Protection and Enhancement of Environmental Quality.” Online at: http://www.archives.gov/federal_register/executive_orders/disposition_tables.html.

Executive Order 11593. "Protection and Enhancement of the Cultural Environment.” Online at: http://www.archives.gov/federal_register/executive_orders/disposition_tables.html.

Executive Order 11738. "Providing for Administration of the Clean Air Act and the Federal Water Pollution Control Act with Respect to Federal Contracts, Grants, or Loans.” Online at: http://www.archives.gov/federal_register/executive_orders/disposition tables.html.

Executive Order 11988. “Floodplain Management.” Online at: http://www.archives.gov/federal_register/executive_orders/disposition_tables.html. 
Executive Order 11990. "Protection of Wetlands.” Online at:

http://www.archives.gov/federal_register/executive_orders/disposition_tables.html.

Executive Order 12088. "Federal Compliance with Pollution Control Standards.” Online at: http://www.archives.gov/federal_register/executive_orders/disposition_tables.html.

Executive Order 12114. “Environmental Effects Abroad of Major Federal Actions.” Online at: http://www.archives.gov/federal_register/executive_orders/disposition_tables.html.

Executive Order 12196. “Occupational Safety and Health Programs for Federal Employees.”

Executive Order 12580. "Superfund Implementation.” Online at:

http://www.archives.gov/federal_register/executive_orders/disposition_tables.html.

Executive Order 12898. "Federal Actions to Address Environmental Justice in Minority Populations and Low-Income Populations.” Online at: http://www.archives.gov/federal_register/executive_orders/disposition_tables.html.

Executive Order 12962. "Recreational Fisheries.” Online at:

http://www.archives.gov/federal register/executive_orders/disposition tables.html.

Executive Order 13007. "Indian Sacred Sites.” Online at:

http://www.archives.gov/federal register/executive orders/disposition tables.html.

Executive Order 13045. "Protection of Children from Environmental Health Risks and Safety Risks."

Online at: http://www.archives.gov/federal_register/executive_orders/disposition_tables.html.

Executive Order 13101. "Greening the Government through Waste Prevention, Recycling, and Federal Acquisition.” Online at:

http://www.archives.gov/federal_register/executive_orders/disposition_tables.html.

Executive Order 13112. “Invasive Species.” Online at:

http://www.archives.gov/federal_register/executive_orders/disposition_tables.html.

Executive Order 13123. “Greening the Government through Energy Efficient Management. Online at: http://www.archives.gov/federal_register/executive_orders/disposition_tables.html.

Executive Order 13134. "Developing and Promoting Biobased Products and Bioenergy." Online at: http://www.archives.gov/federal_register/executive_orders/disposition_tables.html.

Executive Order 13148. “Greening the Government through Leadership in Environmental Management.” Online at: http://www.archives.gov/federal_register/executive_orders/disposition_tables.html.

Executive Order 13149. “Greening the Government through Federal Fleet and Transportation Efficiency.” Online at:

http://www.archives.gov/federal_register/executive_orders/disposition_tables.html.

Executive Order 13150. “Federal Workforce Transportation.” Online at:

http://www.archives.gov/federal register/executive orders/disposition tables.html. 
Executive Order 13175. “Consultation and Coordination with Indian Tribal Governments.” Online at: http://www.archives.gov/federal_register/executive_orders/disposition_tables.html.

Executive Order 13186. "Responsibilities of Federal Agencies to Protect Migratory Birds.” Online at: http://www.archives.gov/federal_register/executive_orders/disposition_tables.html.

Executive Order 13195. “Trails for America in the $21^{\text {st }}$ Century.” Online at:

http://www.archives.gov/federal_register/executive_orders/disposition_tables.html.

Executive Order 13287. "Preserve America.” Online at:

http://www.archives.gov/federal_register/executive orders/disposition tables.html.

Fluor Hanford. 2002. National Environmental Policy Act Source Guide for the Hanford Site. HNF-SP0903 Revision 9.

Hanford Reach Study Act. 1988. Public Law No. 100-605 as amended by Public Law 104-333. Online at: http://206.61.210.104/pl/iap/html/body_apx-a.htm.

RCW 70.94. Washington State Clean Air Act. Online at:

http://www.leg.wa.gov/rcw/index.cfm\#RCW by Title.

Treaty with the Walla Walla, Cayuse and Umatilla. 1855. June 9, 1855, 12 Stat. 945.

Treaty with the Yakama. 1855. June 9, 1855, 12 Stat. 951.

Treaty with the Nez Perces. 1855. June 11, 1855, 12 Stat. 957.

U.S. Department of Energy (DOE). 1998. National Environmental Policy Act Compliance Guide. Washington, D.C. Online at: http://www.eh.doe.gov/nepa/guidance.html.

U.S. Department of Energy (DOE). 1999. Final Hanford Comprehensive Land-Use Plan Environmental Impact Statement. DOE/EIS-0222-F. U.S. Department of Energy, Richland, Washington. Online at: http://www.hanford.gov/eis/hraeis/maintoc.htm.

U.S. Department of Energy (DOE). 2000. U.S. Department of Energy American Indian and Alaska Native Tribal Government Policy. Online at: http://www.ci.doe.gov/indianbk.pdf.

U.S. Department of Energy (DOE). 2001a. Department of Energy Management of Cultural Resources. DOE P 141.1, Washington, D.C. Online at: http://www.directives.doe.gov.

U.S. Department of Energy (DOE). 2001b. “Management of Cultural Resources at Department of Energy Facilities.” DOE/EH-412/0005r (revised July 2001). U.S. Department of Energy, Washington, D.C. Online at: http://homer.ornl.gov/oepa/guidance/cultural/culturalresourcemgt.pdf.

U.S. Department of Energy (DOE). 2003. Annual Hanford Site Environmental Permitting Status Report. DOE/RL-96-63, Revision 7, U.S. Department of Energy, Richland, Washington.

U.S. Department of Energy (DOE). 2004. Hanford Site Solid (Radioactive and Hazardous) Waste Program Environmental Impact Statement. DOE/EIS-0286F. U.S. Department of Energy, Richland, Washington. Online at: http://www.hanford.gov/eis/eis-0286D2/2003_FINAL.cfm. 
U.S. Environmental Protection Agency (EPA). 1994. "Hazardous and Solid Waste Amendments Portion of the Resource Conservation and Recovery Act Permit for the Treatment, Storage, and Disposal of Hazardous Waste”. September 1994. U.S. Environmental Protection Agency, Region 10, Seattle, Washington. Online at: http://yosemite.epa.gov/R10/OWCM.NSF/ed6c817875102d2d8825650f00714a59/771ea51111ea0a9e882 56ddd0076ecd3/\$FILE/hswa-per.pdf.

WAC 173-60. “Maximum Environmental Noise Levels.” Washington Administrative Code. Online at: http://www.leg.wa.gov/wac/index.cfm?fuseaction=chapterdigest\&chapter=173-60.

WAC 173-160. “Minimum Standards for Construction and Maintenance of Wells.” Washington Administrative Code. Online at: http://www.leg.wa.gov/wac/index.cfm?fuseaction=chapterdigest\&chapter=173-160.

WAC 173-216. “State Waste Discharge Permit Program.” Washington Administrative Code. Online at: http://www.leg.wa.gov/wac/index.cfm?fuseaction=chapterdigest\&chapter=173-216.

WAC 173-218. “Underground Injection Control Program.” Washington Administrative Code. Online at: http://www.leg.wa.gov/wac/index.cfm?fuseaction=chapterdigest\&chapter=173-218.

WAC 173-303. "Dangerous Waste Regulations.” Washington Administrative Code. Online at: http://www.leg.wa.gov/wac/index.cfm?fuseaction=chapterdigest\&chapter=173-303.

WAC 173-400. “General Regulations for Air Pollution Sources.” Washington Administrative Code. Online at: http://www.leg.wa.gov/wac/index.cfm?fuseaction=chapterdigest\&chapter=173-400.

WAC 173-460. “Controls for New Sources of Toxic Air Pollutants.” Washington Administrative Code. Online at: http://www.leg.wa.gov/wac/index.cfm?fuseaction=chapterdigest\&chapter=173-460.

WAC 173-470. “Ambient Air Quality Standards for Particulate Matter.” Washington Administrative Code. Online at: http://www.leg.wa.gov/wac/index.cfm?fuseaction=title\&title=173

WAC 173-474. “Ambient Air Quality Standards for Sulfur Oxides.” Washington Administrative Code. Online at: http://www.leg.wa.gov/wac/index.cfm?fuseaction=title\&title=173

WAC 173-475. “Ambient Air Quality Standards for Carbon Monoxide, Ozone, and Nitrogen Dioxide.” Washington Administrative Code. Online at:

http://www.leg.wa.gov/wac/index.cfm?fuseaction=title\&title=173

WAC 173-480. “Ambient Air Quality Standards and Emission Limits for Radionuclides.” Washington Administrative Code. Online at:

http://www.leg.wa.gov/wac/index.cfm?fuseaction=chapterdigest\&chapter=173-480.

WAC 173-481. “Ambient Air Quality Standards for Fluorides.” Washington Administrative Code. Online at: http://www.leg.wa.gov/wac/index.cfm?fuseaction=title\&title=173

WAC 220-110. “Hydraulic Code Rules.” Washington Administrative Code. Online at: http://www.leg.wa.gov/wac/index.cfm?fuseaction=chapterdigest\&chapter=220-110. 
WAC 246-247. "Radiation Protection - Air Emissions.” Washington Administrative Code. Online at: http://www.leg.wa.gov/wac/index.cfm?fuseaction=chapterdigest\&chapter=246-247.

WAC 246-272. “On-Site Sewage Systems.” Washington Administrative Code. Online at: http://www.leg.wa.gov/wac/index.cfm?fuseaction=chapterdigest\&chapter=246-272.

WAC 246-290. "Public Water Supplies.” Washington Administrative Code. Online at: http://www.leg.wa.gov/wac/index.cfm?fuseaction=chapterdigest\&chapter=246-290.

WAC 332-30. “Aquatic Land Management.” Washington Administrative Code. Online at: http://www.leg.wa.gov/wac/index.cfm?fuseaction=chapterdigest\&chapter=332-30.

Washington State Department of Ecology (Ecology). 2001a. Dangerous Waste Portion of the Resource Conservation and Recovery Act Permit for the Treatment, Storage, and Disposal of Dangerous Waste, Revision 7. Washington State Department of Ecology Publication Number 94-05-001. Permit Number: WA7890008967. Olympia, Washington. Online at: http://www.ecy.wa.gov/programs/nwp/pdf/permitrev7.pdf.

Washington State Department of Ecology (Ecology). 2001b. Hanford Air Operating Permit. Washington State Department of Ecology Publication Number 00-05-006. Olympia, Washington. Online at: http://www.ecy.wa.gov/pubs/0005006.pdf. 


\section{Distribution}

No. of

$\underline{\text { Copies }}$

\section{$\underline{\text { OFFSITE }}$}

2 Gary Ballew

Sustainable Development Manager

Benton County Planning Dept.

P.O. Box 910

Prosser, WA 99350

1

C. Borgstrom

U.S. Department of Energy (EH-42)

1000 Independence Avenue SW

Washington, D.C. 20585-0119

1

A. J. Dvorak

Environmental Assessment Division

Argonne National Laboratory

9700 S. Cass Avenue, Bldg 900

Argonne, IL 60439-4832

$1 \quad$ S. Frank

U.S. Department of Energy (EM-20)

1000 Independence Avenue SW

Washington, D.C. 20585

1 C. Hickey

NEPA Compliance Officer

U.S. Department of Energy

Office of Science (SC-83)

19901 Germantown Road

Germantown, MD 20874-1290

7 G. Hughes

U.S. Fish and Wildlife Service 3250 Port of Benton Blvd

Richland, WA 99352

6 C. L. Johnson

SAIC

3250 Port of Benton Blvd

Richland, WA 99352
No. of

$\underline{\text { Copies }}$

$1 \quad$ J. E. Loving

U.S. Department of Energy (EH-42)

Office Of NEPA Policy \&Compliance

1000 Independence Avenue SW

Washington, D.C. 20585

$1 \quad$ Lloyd Lorenzi

NEPA Compliance Officer

National Energy Technology Lab

P.O. Box 10940

Pittsburgh, PA 15236

1 David Rice

US Corps of Engineers

P.O. Box 3755

Seattle, WA 98124-3755

1 R. Sharma

NEPA Compliance Officer

U.S. Department of Energy (NE-47)

19901 Germantown Road

Germantown, MD 20874-1290

1 Laurie Vigue

Washington Dept of Fish \& Wildlife

600 Capitol Way N

Olympia, WA 98501-1091

$\underline{\text { Native American Tribes }}$

3 Mr. Stuart Harris (2)

Mr. Jeff Van Pelt

Confederated Tribes of the Umatilla

Indian Reservation

P.O. Box 638

Pendleton, OR 97801

2 Mr. Russell Jim, Manager

Environmental Restoration/

Waste Management Program

Yakama Nation

2808 Main Street

Union Gap, WA 98903 
No. of

$\underline{\text { Copies }}$

2 Mr. Patrick Sobotta

Environmental Restoration and

Waste Management

Nez Perce Tribe

P.O. Box 365

Lapwai, ID 83540

2 Ms. Leanora Seelatsee

Wanapum

Grant County P.U.D.

30 "C" Street, S.W.

P.O. Box 878

Ephrata, WA 98823

$1 \quad$ Ms. Camille Pleasants

Colville Tribal Historic Preservation

Officer

P.O. Box 150

Nespelem WA 99155

\section{ONSITE}

$47 \quad$ DOE Richland Operations

Office/Office of River Protection

T. L. Aldridge, PNSO

K8-50

D. W. Bowser, ORP

H6-60

M. E. Burandt, ORP

H6-60

B. F. Burton, OOD

$\mathrm{N} 2-36$

R. M. Carosino, OCC

A4-52

D. H. Chapin, FFTF

A3-04

R. Christiansen, PNSO

K8-50

C. E. Clark, OES

A5-15

S. S. Clark, PMO

K. V. Clarke, COM

M. S. Collins, AMCP

P. F. Dunigan, OES (20)

T. W. Ferns, OES

H. B. Hathaway, AMRC

J. B. Hebdon, OES

R. D. Hildebrand, AMCP

E. V. Hiskes, OCC

L. A. Huffman, ORP

R. R. McNulty, ORP

G. M. Neath, ORP

J. E. Rasmussen, ORP

A. L. Rodriguez, OES

W. Russell, ORP

A7-75

A5-15

A5-15

A2-17

A5-15

A6-38

A4-52

H6-60

H6-60

H6-60

H6-60

A5-15

H6-60
No. of

$\underline{\text { Copies }}$

DOE Richland Operations Office/ Office of River Protection (cont.)

C. V. Smith, OCC

D. C. Ward, AMRC

A4-52

D. Wilcox, OCC

A2-17

A4-52

B. D. Williamson, OCC A4-52

J. H. Zeisloft, AMRC

A3-04

$4 \quad$ CH2M HILL Hanford Group, Inc.

L. Borneman

T6-16

M. Jarayssi

H6-03

F. M. Mann

E6-35

F. R. Miera

H6-03

2 CH2M Hill Hanford, Inc.

L. M. Johnson

H9-01

R. W. Ovink

H9-01

1 Bechtel National, Inc.

B.G. Erlandson

H4-20

11 Bechtel Hanford, Inc.

R. A. Carlson

X0-17

K. R. Fecht

H9-01

G. E. Fitzgibbon

H9-04

K. A. Gano

$\mathrm{H} 0-23$

R. J. Landon

H9-03

T. J. Lazarski

H9-03

T. E. Marceau

$\mathrm{H} 0-23$

D. D. Teel

B. L. Vedder

H0-23
S. G. Weiss

J. G. Woolard

$\mathrm{H} 0-23$

H9-03

11 Fluor Hanford, Inc.

G. D. Cummins

H8-12

D. P. Demitruk

S3-96

B. J. Dixon

R3-32

R. H. Engelmann

H8-12

K. A. Hadley

T3-10

A. M. Hopkins

H8-25

M. T. Jansky

H8-40

Distr. 2 
No. of

$\underline{\text { Copies }}$

$\underline{\text { Fluor Hanford, Inc. (cont'd) }}$

B. B. Nelson-Maki
F. A. Ruck, III
D. J. Watson
K. R. Welsch

R3-32

H8-40

X3-79

H8-12

1 Fluor Federal Services, Inc.

P. D. Rittmann

E6-17

$1 \quad$ Washington State University

R. G. Schreckhise

H2-52

$2 \quad$ Duratek Federal Services Northwest

Operations

J. J. Dorian

H1-11

R. M. Mitchell

H1-11

78

Pacific Northwest National Laboratory

E. J. Antonio

M. P. Bergeron

K3-54

G. R. Bilyard

B. N. Bjornstad

C. A. Brandt

R. W. Bryce

A. L. Bunn

K. W. Burk

S. D. Cannon

C. R. Cole

P. J. Cowley

P. M. Daling

D. D. Dauble

R. L. Dirkes (5)

J. L. Downs

J. P. Duncan (15)

T. O. Eschbach

M. J. Fayer

R. A. Fowler

B. G. Fritz

S. W. Gajewski

D. R. Geist

T. L. Gilbride

D. L. Hadley

K9-36

J7-22

J2-38

K6-75

K6-85

K6-85

K3-54

K9-33

K6-05

K6-75

K9-18

K6-85

BPO

K5-16
No. of

Copies

$\underline{\text { Pacific NW Natl. Laboratory (cont'd) }}$

J. C. Hail

K5-16

R. W. Hanf

K6-75

D. W. Harvey

K6-75

P. L. Hendrickson K6-50

D. J. Hoitink

K9-30

D. G. Horton K6-81

D. J. Hostick K6-05

U. P. Jenquin K8-34

R. A. Kennedy

K7-63

C. T. Kincaid

K9-33

W. W. Laity

K7-84

G. V. Last K6-81

D. K. Lutter

P8-08

B. A. Napier K3-54

D. A. Neitzel (5) K6-85

W. E. Nichols K9-33

G. P. O’Connor K6-86

T. L. Page K9-02

T. M. Poston K6-75

E. Prendergast-Kennedy K6-75

J. V. Ramsdell, Jr. K3-54

K. Rhoads K3-54

S. P. Reidel K6-81

A. C. Rohay K6-81

M. R. Sackschewsky K6-85

M. J. Scott K6-05

D.C. Stapp K6-75

D. L. Strenge K3-54

P. D. Thorne K9-33

K. M. Tominey K6-52

M. D. White K9-36

R. S. Weeks K3-75 